Historic, Archive Document

Do not assume content reflects current scientific knowledge, policies, or practices. 



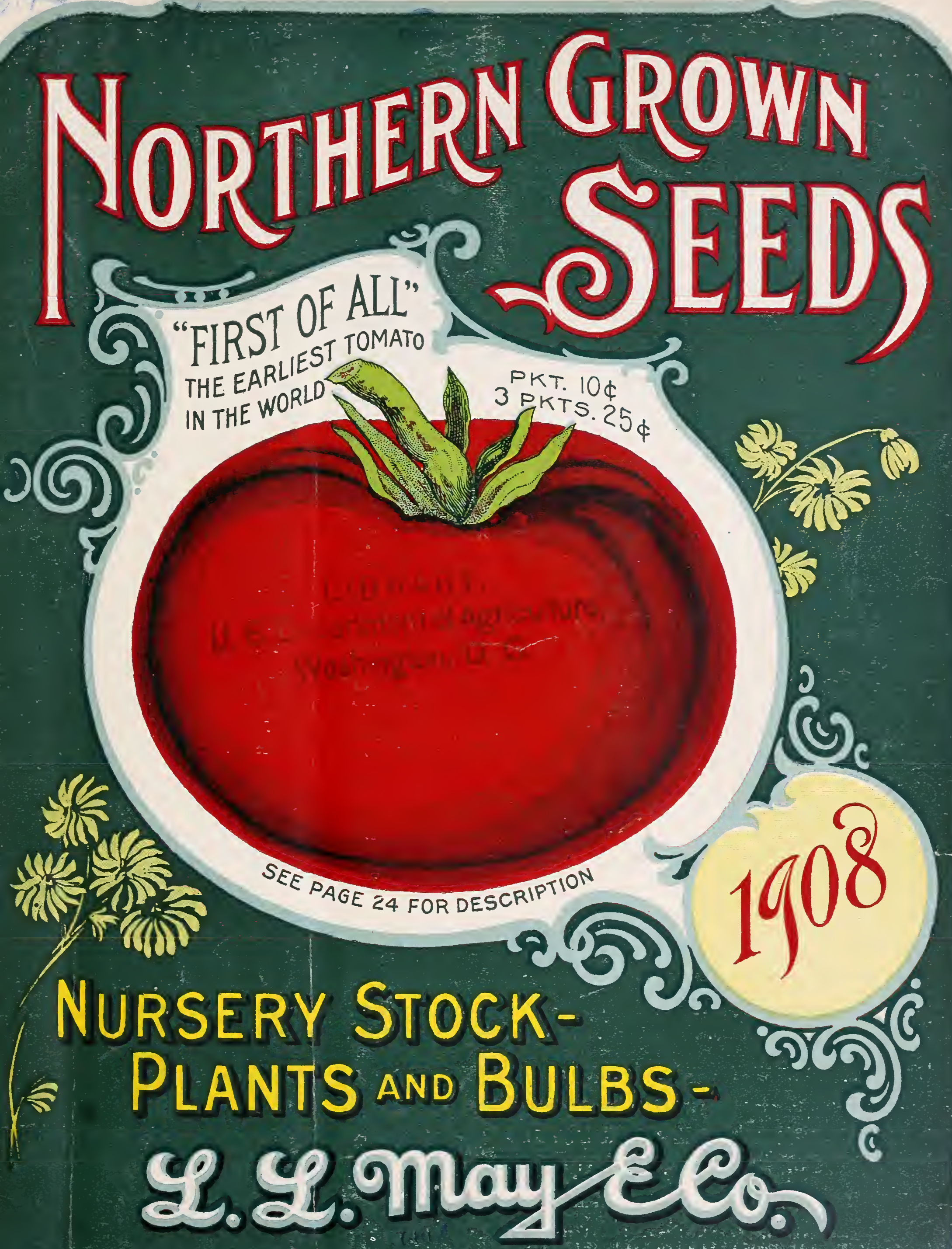



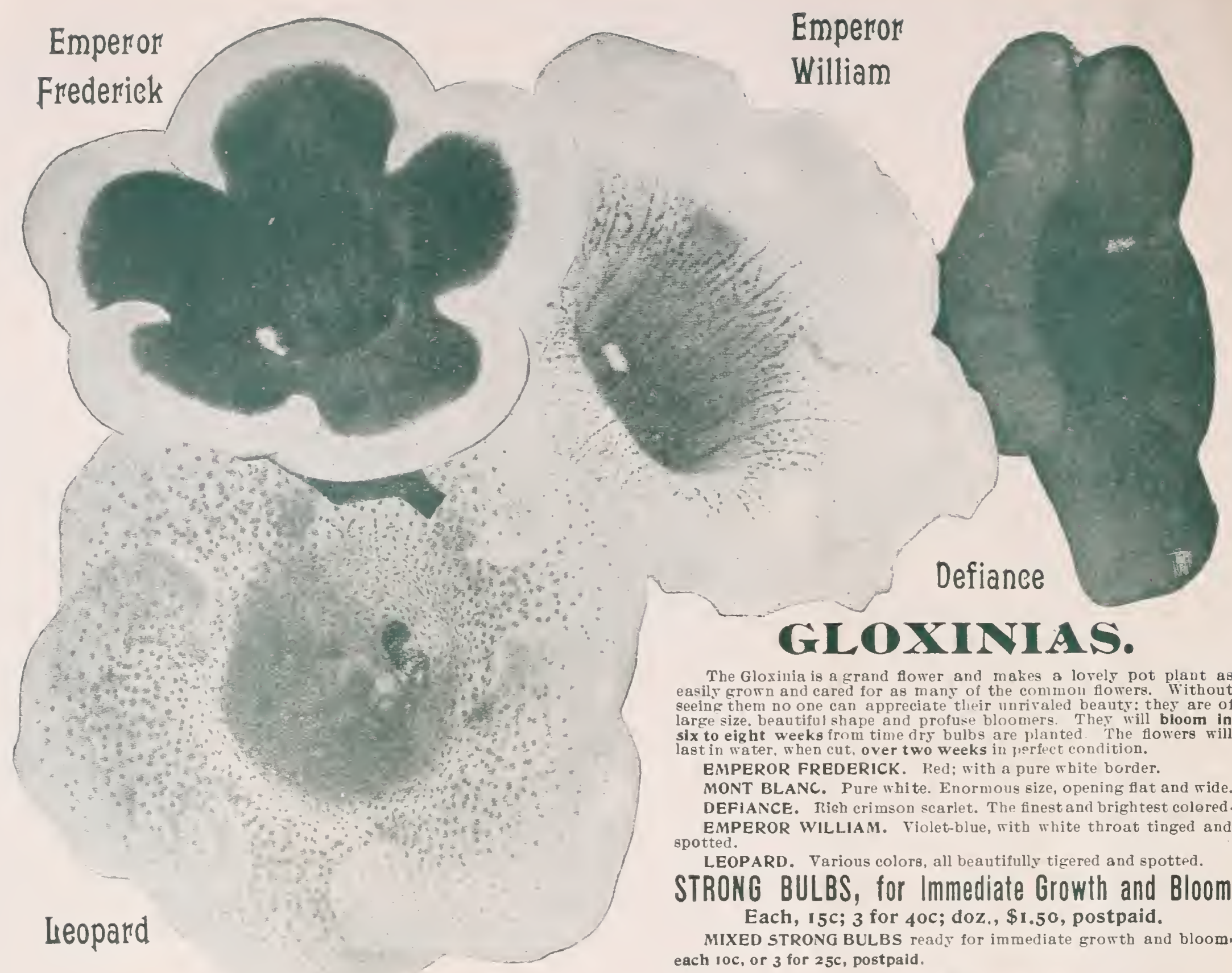

The Gloxinia is a grand flower and makes a lovely pot plant a easily cromn and cared for as many of the commoul flowers. Without seein them ano care for large size beautiful shape and tuse bloomers. Ther will bloom in six to eight weeks from time dry bulbs are planted. The flowers rill last in water, when cut, over two weeks in porfect condition.

EMPEROR FREDERICK. Red; with a pure white border.

MONT BLANC. Pure white. Enormous size, opening flat and ride.

DEFiANCE. Rich crimson scarlet. The finest and brightest colored

EMPEROR WILLIAM. Violet-blue, with white throat tinged and

LEOPARD. Various colors, all beautifully tigered and spotted.

STRONG BULBS, for Immediate Growth and Bloom

Each, I5c; 3 for $40 c$; doz., \$I.50, postpaid.

MIXED STRONG BULBS readr for immediate growth and bloom. each roc, or 3 for 25 , postpaid.

\section{TUBEROUS-ROOTED BEGONIAS.}

This grand flower is a rival to the Gloxinias as a summer window or conservatory plant, and as strong a rival to the Geranium and Verbena as an ontdoor bedding plant. The enor mous size and in tense brilliancr of the florers astonish those who hare nerer seen an but the ordinary house Begonia The bulbs can be started from March to June and rill soon be in full bloom. Thes will succeed in any rich, well drained soil, and prefer a position where ther will be protected from the direct rass of the sun during the hottest part of the day. Ther also make fine pot plants for the conservators or window garden. Ther mas be had in both single and double sorts in the folloring colors:

SINGLE SORTS.. White, Scarlet, Yellow, Pink, each, $7 \mathrm{c} ; 4$ for $25 \mathrm{c} ;$ doz., $70 \mathrm{c}$; postpaid.

SINGLE MIIXED COLORS=-each, 5c; 4 for 20c; doz., 50c, postpaid.

DOUBLE SORTS--White, Scariet, Yellow, Pink, each, I2c; 4 for $45 \mathrm{c}$; doz. $\$ 1.25$, postpaid.

DOUBLE MIXED COLORS-=each, Ioc; 4 for 35c; doz., \$1.00, postpaid.

\section{NEW TUBEROUS BEGOYIAS.}

Bertini,-Grows from 10 to 12 inches high; single flowering, elongated petals, rermiliou color. The flowers are produced on graceful stems well abore the foliage, and for brillianey of color cannot be surpassed. Each 25c, postpaid.

Cristata.-Curious strain of Single Begonias with flowers of good size bearing on each petal a crest or beard composed of curiously twisted threads which gives florers an interesting appearance. Each $20 c$ postpald.

Cardinal.-Splendid ner rariety has proren to be one of the best sun resisting Begonias in existence. Flowers are siugle, of a dark rosy scarlet, and measure $21 / 2$ to 3 iuches in diameter. Plants gror from 12 to 15 inches in height, are of strong rigorous habit, and extremely free flowering. Each $25 \mathrm{c}$, postpald.

Duke Zeppelin.-This is one of the most gorgeous and bright of the summer-flowering tuberous-rooted begonias. A profuse and continuous bloomer. It has bloomed in the open ground from Mar until October. The waxy flowers are glowing scarlet, and as double as camellias. Each 25 c postpaid.

Giant Tree.-A fine ner rariety of Mexican origin, as beautiful as it is norel. It attains a height of $11 / 2$ to 2 feet, and bears grand single fluters of riont carmine rose. It is a prolific bloomer, lasting well into flumers of bright carmine rose.

Lafayette.-A splendid bedding rariety. Flowers are of a most brilliant fiers scarlet. double and borne upright on their stalks. One of th best for bedding as it blooms all summer. Each $30 \mathrm{c}$, postpaid.

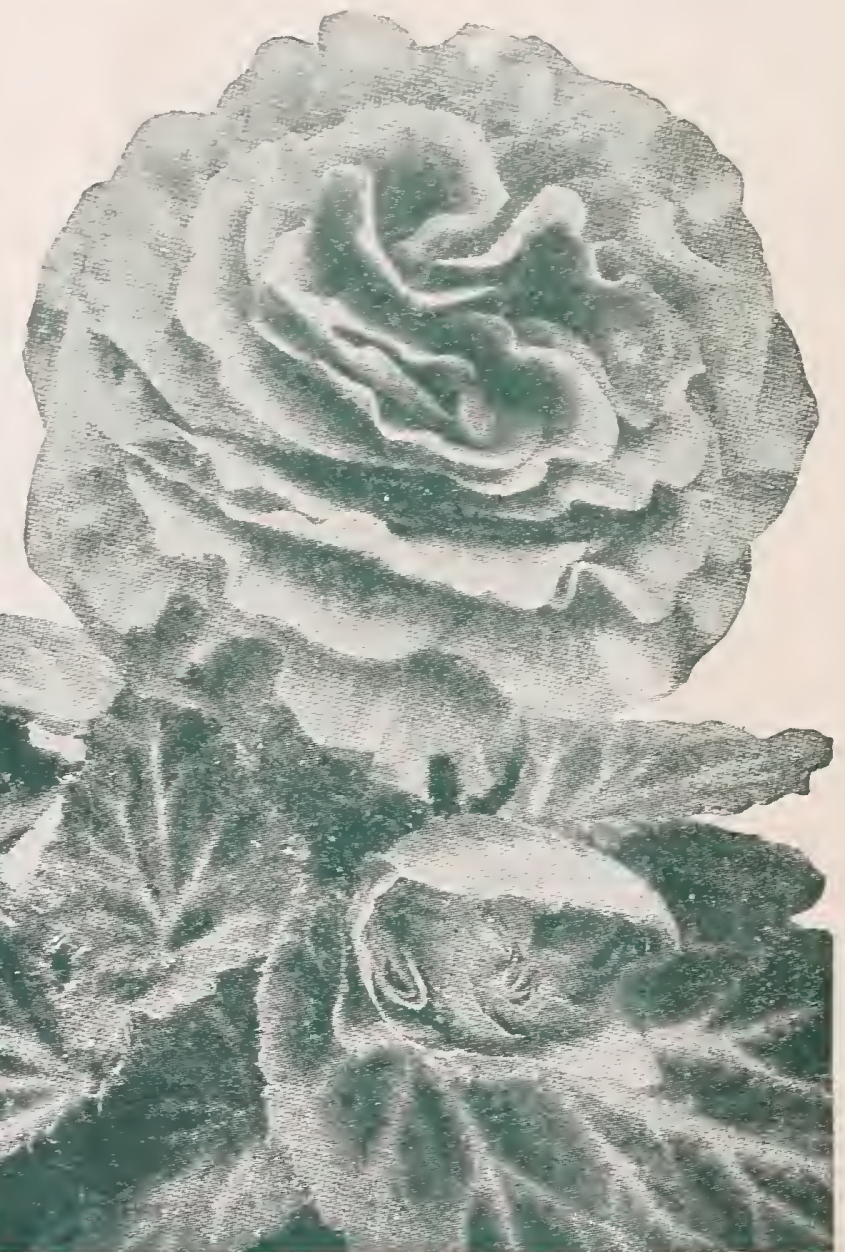




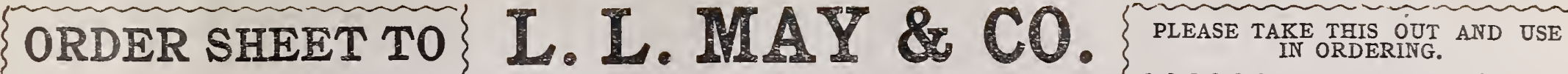

ST. PAUL, MINNN.

VERY IMPORTANT. Write your name very plainly, and give your Post Office, County and State in full every time.

Your Name

\section{(VERY PLAIN.)}

Post Office

County

State.

Street

$\left\{\begin{array}{l}\text { R. F. D. } \\ \text { P. O. Box }\end{array}\right.$

Express Office $\left\{\begin{array}{l}\text { If Different } \\ \text { from P. O. }\end{array}\right\}$

Gentlemen:

Enclosed find \$

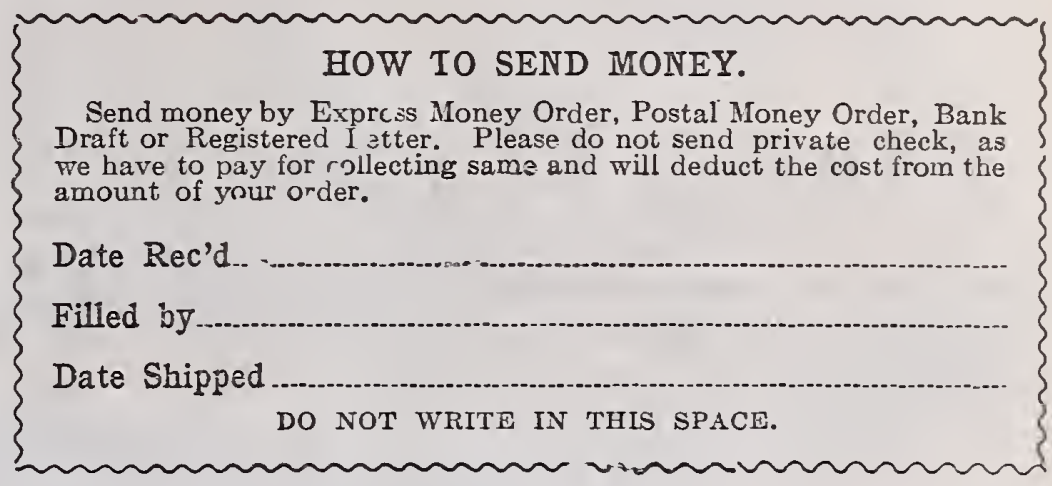

Date for which please send me the following:

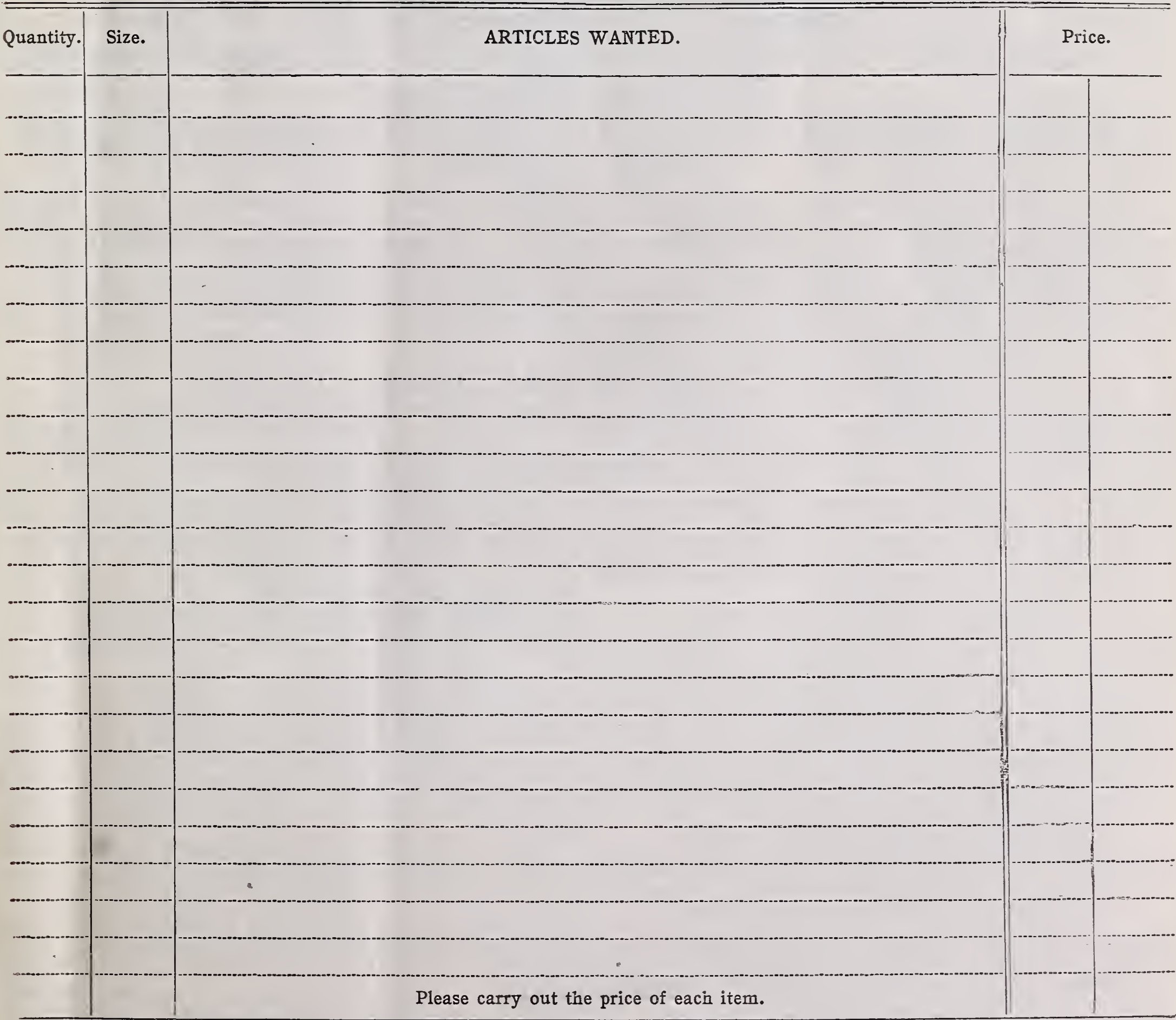




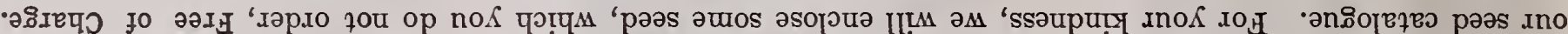
uәप7 puəs of पsț SHSSAYG

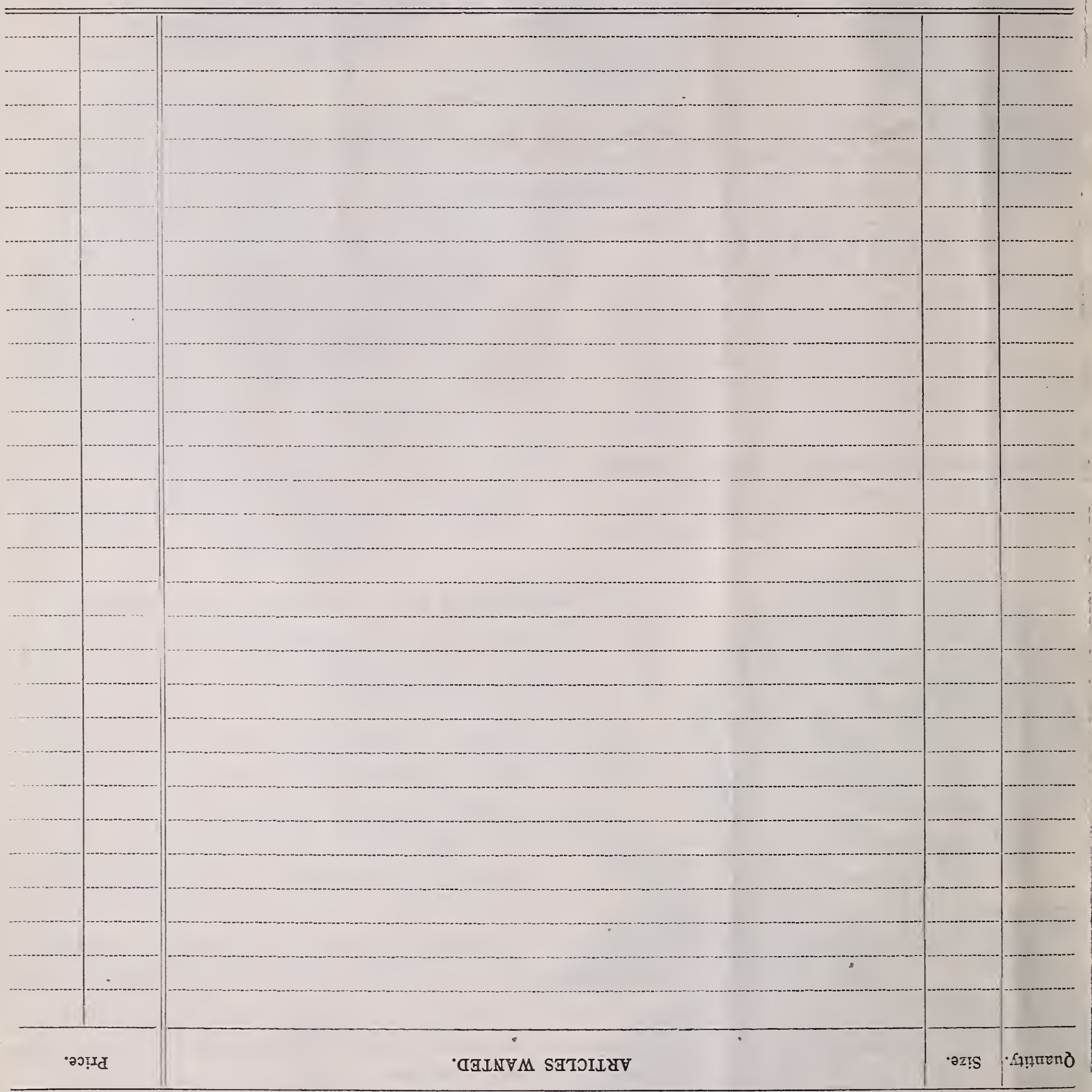




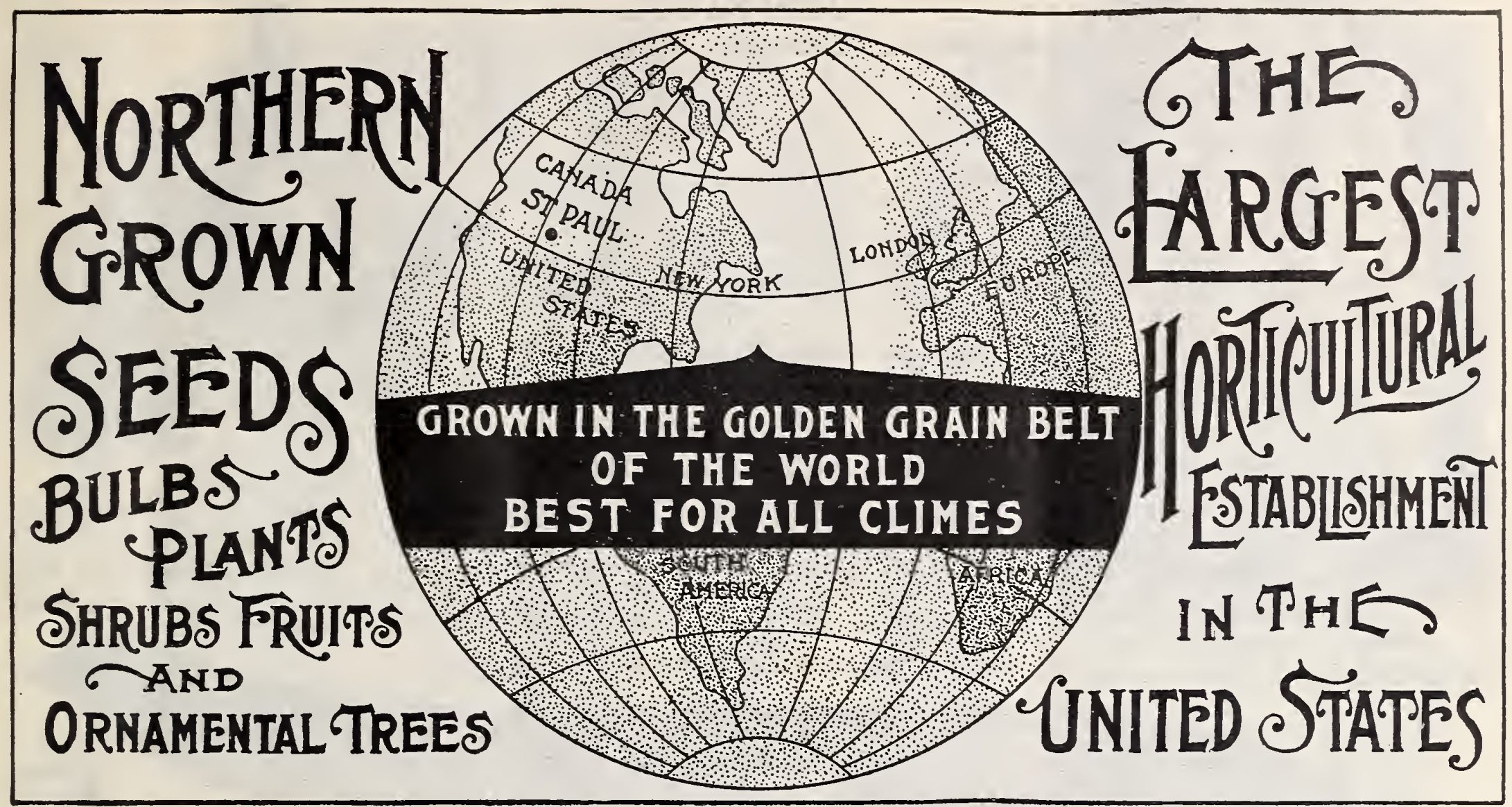

WI GROW, List and describe only the best Known and Standard Varieties of Seeds, Bulbs, Plants, Shrubs, of Real Worth and Merit, all thoroughly tested, cultivated, selected and improved on our own farms, until they have reached the highest mark of perfection, and our patrons can make their selections with the assurance that they will receive the best and choicest NORTHERN GROWN STOCKS, for unquestionably they are THE BEST for ALL CLIMATES. They are Earlier, more Hardy, more Vigorous and more Productive than those grown in Lower Latitudes.

\section{HOW TO ORDER AND I}

We Deliver Free all seeds by the packet, ounce, quarter paid, at the prices quoted in this catalogue.

On Seeds in Larger Quantities, by bushel and peck, to pay charges on receipt of the goods by express or freight. Also all plants, bulbs, fruits, trees, fertilizers, implements, machinery, etc, priced by express or freight, the purchaser pays the transportation charges. You can deduct 8 cents per pound from postage prices on seeds you wish sent by express or freight, and 7 cents per pint and 15 cents per quart, from cents per quart, from postpaid prices on Corn.

C. O. D. Shipments. OUR TERMS ARE STRICTIY CASH WITH THE ORDER. We ship goods C. O. D. unless the purchaser remits in advance sufficient money to pay transportation charges and cost of packing, etc., or at least one-third the amount of
the order. How to Send Money. Money can be sent safely either press order or registered letter. If your, order amounts to press order or registered letter. If your order amounts to If local checks are used they must be certified. We receive postage stamps the same as cash, Canadian included.

Name, Address, Etc. When ordering, give name and full every season in which the adress. Many orders reach us ing. It is, of course, impossible to fill these orders until they are identified.

Your Order, no matter how large or small, will alway Order Early. We earnestly request all customers to place ly in getting everything out promptly.

Use the Order Sheet in this book. If you wish to order on a separate sheet of paper and do not mix it up in the body of a letter. This will assist us greatly in flling your
order. Blank order sheets will be sent at any time upon request. In Ordering Goods forwarded by freight or express be or freight office, county and state in full, giving the express or railroad company you prefer to have them sent by. This save
line.

\section{TERMS OF BUSINESS.}

Prepaid Stations. Many small railroad stations are preaccept freight for such points unless charges are fully prepaid. It will save delay if you ascertain if your station is a prepaid one before sending your order and include enough If Shipments Do Not Arrive promptly and we will have them traced at once our plant and fruit departments are entirely separate. Often the seeds or plants balance of order is filled. If only part of order is received, please wait two or three days for balance before writing

\section{OUR SEED DEPARTMENT.}

We Are Seed Growers. By this we mean we do not ket, as do many firms, but grow them ourselves.

strictly fresh growth and to have shown with us
minative test, still crops are contingent upon so
tions of soil and weather, time and manner of plan tions of soil and weather, time and manner of plantich be responsible for the product, and gire no warranty, ductiveness of any seeds, plants or bulbs

\section{OUR PLANT DEPARTMENT.}

At Our Green Houses most extensive

\section{OUR NURSERY DEPARTMENT.}

\section{Our Nursery,}

and built up our imme

in discarding

offered,

A certificate of inspection from the State Inspector of $N$ ur series, showing our stock to be free from San Jose Scale and all other injurious insects and diseases, will accompany each shipment. 


\section{कृ MAY'S NORTHERN GROWN SEEDS BEST FOR AIL CLIMES S}

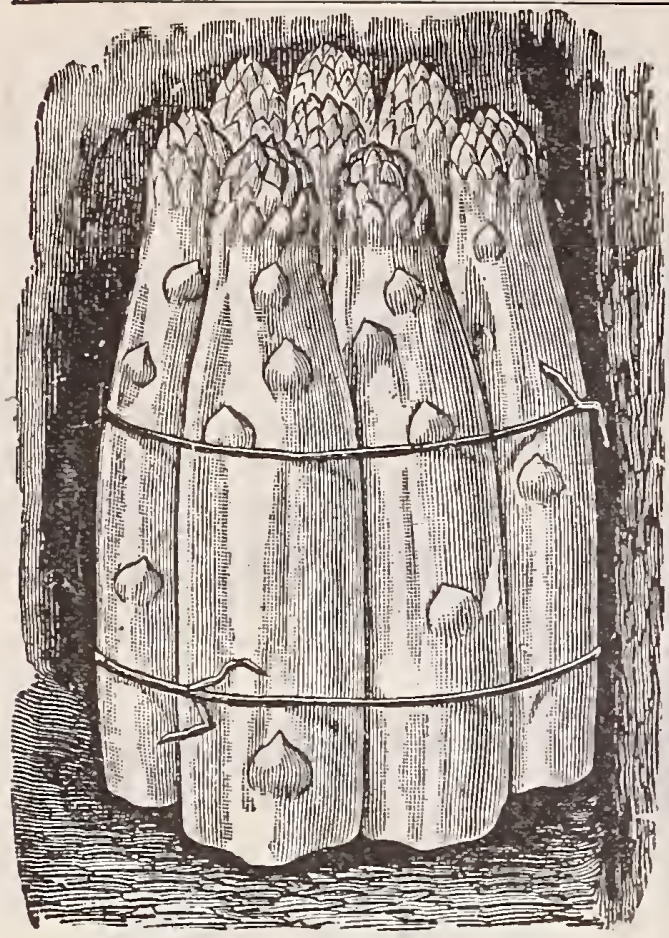

Asparagus, Mammoth white.
ASPARAGUS.

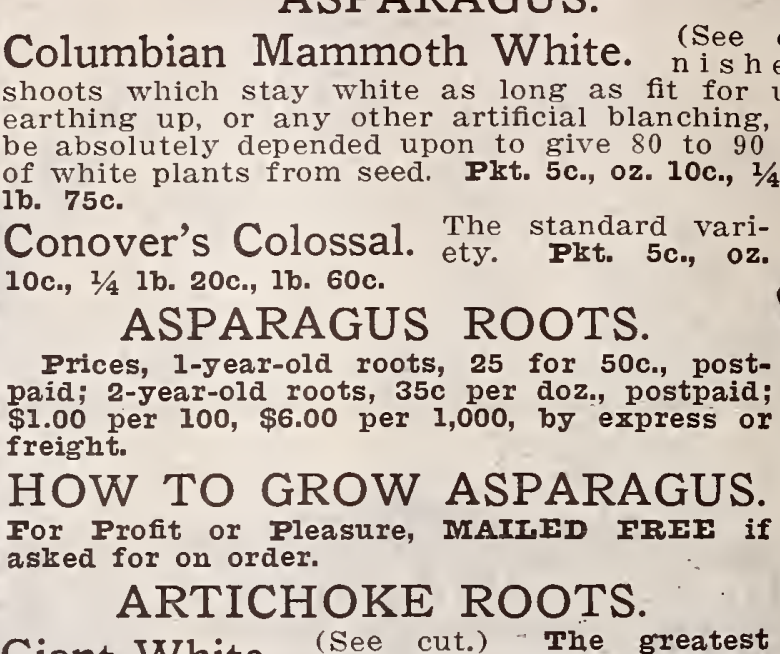

Giant White. (See cut.) The greatest

much attention on account of their great fat- Artichoke Roots. them. They are also said to be a preventive of hog cholera and other dis an apart, and 2 feet apart in the row, and cover about 2 inches deep. Ib. 35 c., 3 lbs. $\$ 1.00$, by mail postpaid; pk. $\$ 1.00$, bu. $\$ 3.00$, bbl. of $3 \mathrm{bu}$. (enough for acre), $\$ 7.50$.

Artichoke Seed. Pit. 10c., oz. 30c. BEANS-DWARF OR BUSH.

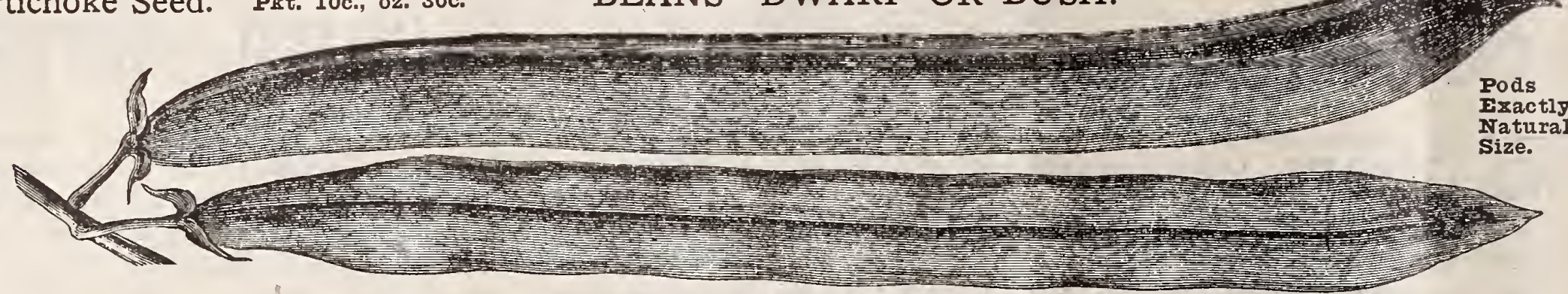

Giant Stringless Green Pod Bean.

Stringless Green Pod. New and desirable, an extra ear- Giant Stringless Bean. This should not be confounded about two

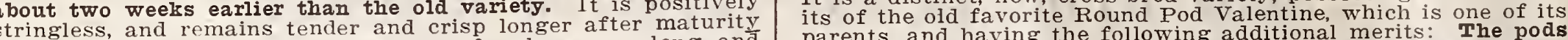
of the green podded varieties. A valuable marke

Sort. Prt. 10c., pt. 25c., qt. $45 c_{\text {. }}$ pound $\$ 1.75$,

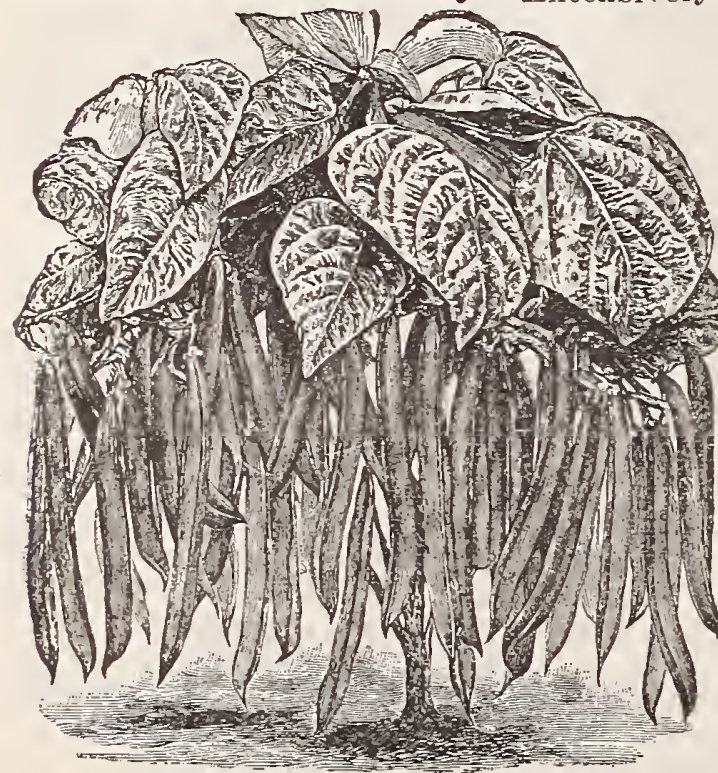

Valentine Round Pod Bean.
Plit. 10c., pt. 20c., qt. $35 \mathrm{c}$. pk. $\$ 1.25$, bu. $\$ 4.25$.

New Hodson GreenPod. This is an exact New Hodson Wax-Pod in dom from rust and blight Pkt. $10 \mathrm{c} .$, pt. $30 \mathrm{c} .$,
pls. $\$ 2.00$, bu. $\$ 7.50$.

The Kaiser. podded variety; the pods are exceedingly attractive. They are large, measure 5
to 6 inches in length, halfof a delicious flavor. Pkt. 10c.s pt. 40c., qt. 65c., pk. Early Mohawk. Large, dark green pods, 5 to 6 pt. 20c., qt. 35 c., pls. $\$ 1.25$, bu. $\$ 4.00$.

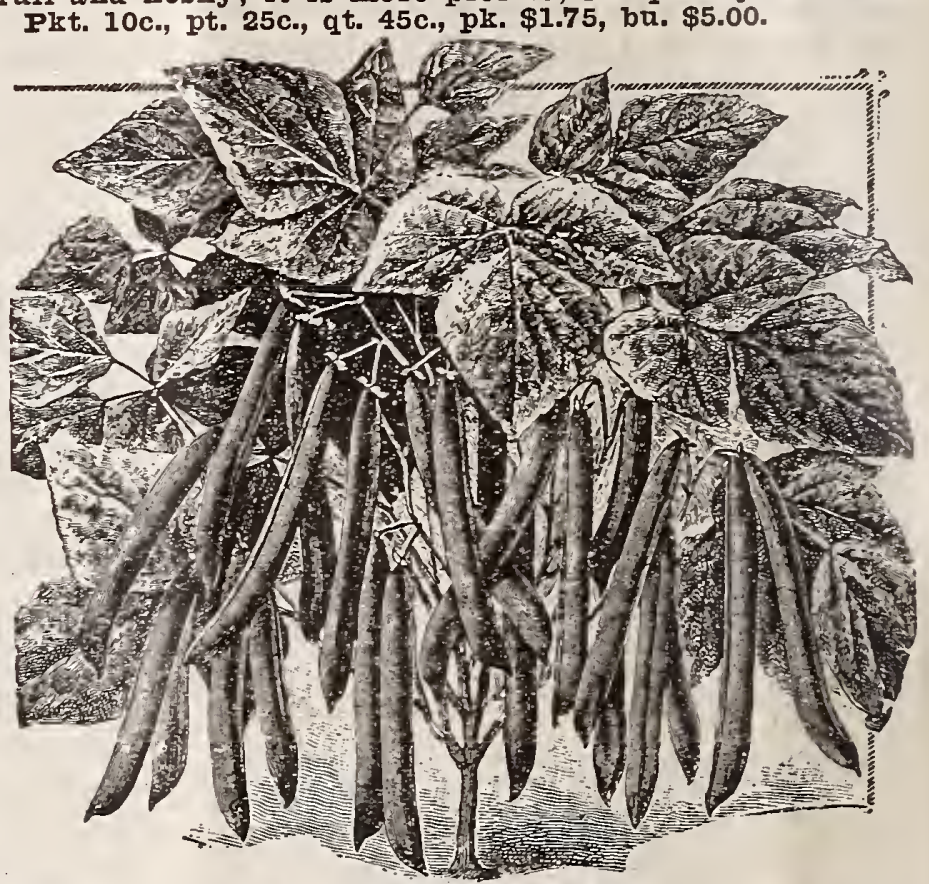

Hodson Green Pod Bean. Early Yellow Six Weeks. The pods are flat, 6 inches long, light gren in color, very little flesh, which soon becomes

Extra Early Refugee. A very, early green podded kind, furnishing an oval, fleshy pod of fine quality, ripening long before Dwarf Horticultural. Pods are of medium length, slightly curved, and when nearly developed are freely splashed with cellent soup or baking beans for winter. Plkt. 10c., pt. 20c., qt. 35c., pk. $\$ 1.50$, bu. $\$ 5.00$.

White Navy. White, seeded, fine for baking. Pkt. 10c., pt. 20c., qt. 35c., pk. 75c. (Write for prices on bushel 1ots.) 

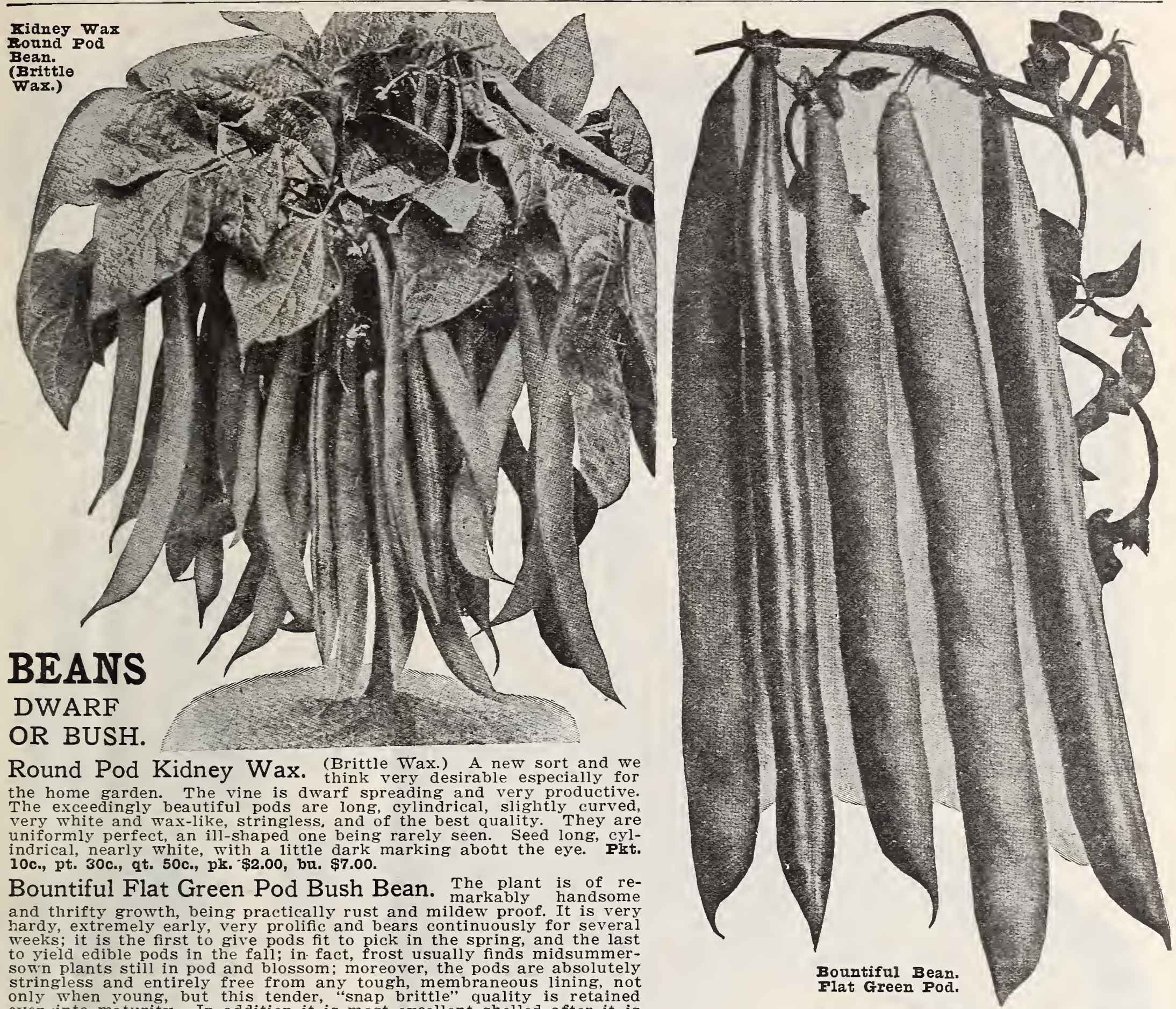

OR BUSH.

Round Pod Kidney Wax. (Brittle Wax.) A new sort and we the home garden. The vine is dwarf spreading and very productive. The exceedingly beautiful pods are long, cylindrical, slightly curved, uniformly perfect an ill-shaped one and of the best quality. They are indrical, nearly white, with a little dark marking abott the eye. Plkt. 10c., pt. 30c., qt. 50c., pk. $\$ 2.00$, bu. $\$ 7.00$.

Bountiful Flat Green Pod Bush Bean. The plant is of reand thrifty growth, being practically rust and mildew proof. It is very hardy, extremely early, very prolific and bears continuously for several weeks; it is the first to give pods fit to pick in the spring, and the last to yield edible pods in the fall; in fact, frost usually finds midsummerstringless and entirely free from any tough, membraneous lining, not only when young, but this tender, "snap brittle" quality is retained even into maturity. In addition it is most excellent shelled after it is ripe for winter use. This variety, while unrivalled in its class for the home garden, is also coming into great demand among the truckers. Pkt. 10c., pt. 20c., qt. 35c., pk. $\$ 1.25$, bu. $\$ 4.50$.

Davis' Kidney Wax. This is the most hardy and productive pods are invariably long, white, straight and handsome. The vine is rustless and very vigorous, bearing its pods near the center in clusters. shaped, clear white and excellent for baking. One of the best for shipping as snap beans and of the greatest value as a market variety. The white seed make this one of the best for canners. It is just what they want, a long, straight, clear white pod which does not discolor in canning. Plit. 10c., pt. 25c., qt. $45 \mathrm{c}$., pk. $\$ 1.60$, bu. $\$ 6.00$.

New Hodson Wax Pod. A very sturdy grower; productive; loaded with long, handsome, straight pods, averaging 7 inches in length; color of a clean light yellow. When picked young they are tinctly a market gardener's bean on account of its great vigor. Plst, 10c., pt. 30c., qt. 50c., pk. \$2.00., bu. \$7.50.

Wardwell's Kidney Wax. Strong, upright bush growth, 15 Pods straight, flat, 5 inches in length and $1 / 2$ inch broad pk. yellow, brittle, and entirely stringless. Prt. 10c., pt. 25c., qt. 45c., pk. $\$ 1.75$, bu. $\$ 6.00$

Golden Wax. (Reeney's Rustless.) Golden pods, flat and stringBlack Wax Imp. Prolific. This bean originated from the old to its parent. It is much more productive and the pods are longer, straighter and rounder. Pkt. 10c., pt. 20 c., qt. 35 c., pk. $\$ 1.60$, bu. $\$ 6.00$.

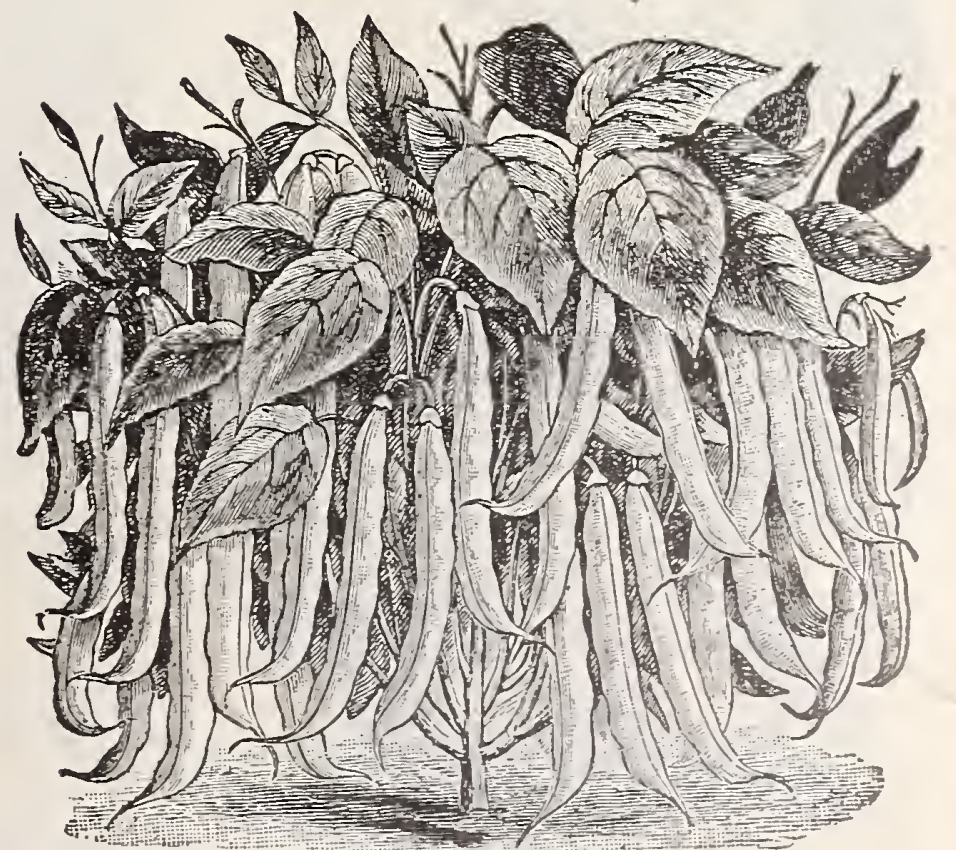

Hodson War Pod Bean. 


\section{MAY'S NORTHERN GROWN SEEDS BEST FOR ALL CLMES \&}

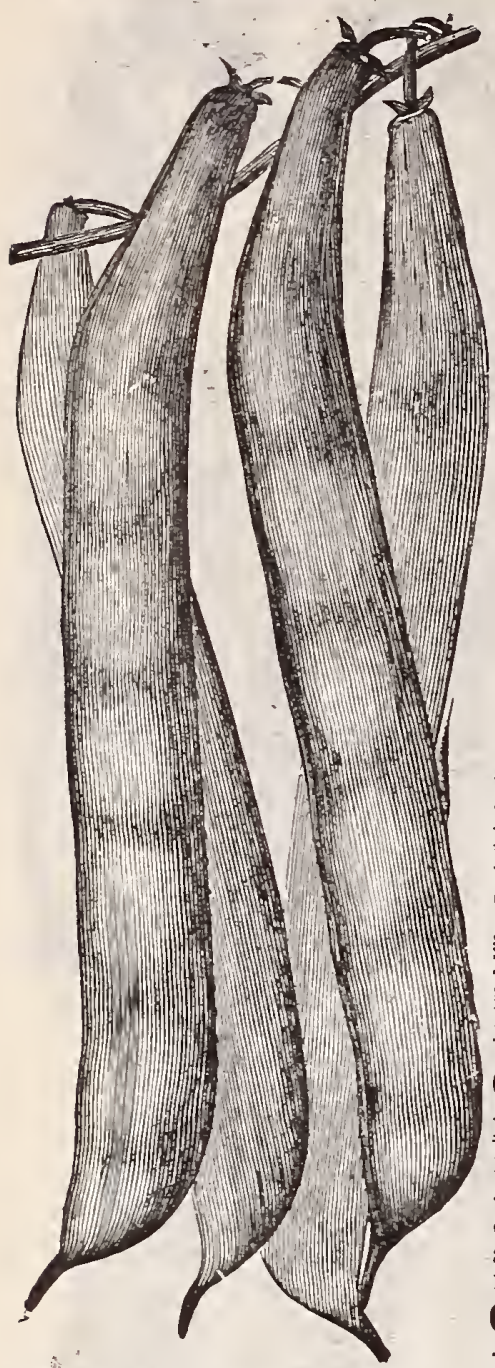

Bean, Kentucky Wonder

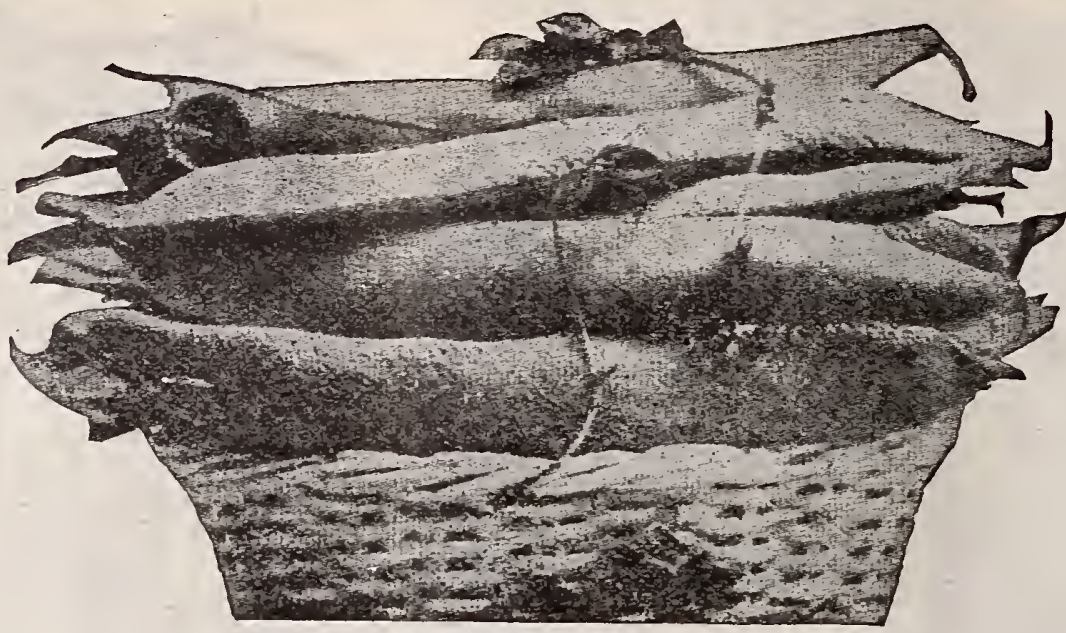

Golden Cluster Beans.

\section{BEANS--Pole or Running.}

Kentucky Wonder. (Old Homestead, Green Pod.) Very early

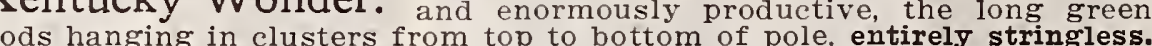
Pods of a silvery green color. Pkt. 10c., pt. 25c., qt. 45c., pls. $\$ 1.75$.

Golden Cluster. The Everlasting Pole Bean. A magnificent varicusters of 3 to 6 rods of rich golden color. in length, exceedingly tender and entirely stringless, retaining their plumpness and tenderness long after they until frost. Plt. 10c., pt. 35c., qt. 55c., pk. \$2.00. Golden Carmine. or when young; as they develop, the pods are mottled and streaked with an unusually bright carmine on the Mammoth Podded Horticultural. The mammoth pods are exceedingly brilliant crimson. The beans, when in andition for wise are of immense size, of the finest quality and when dry are colored and marked in the same way as the pods. Pkt. 10c., pt. 35c., qt. 60c., pk. \$2. Creasback White. Long, round, stringless pods. Plt. 10c., pt.

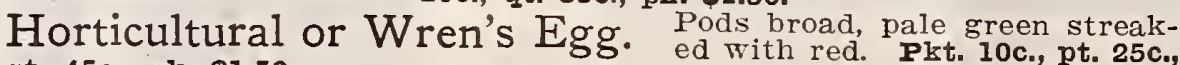
qt. $45 \mathrm{c}$., pk. $\$ 1.50$.

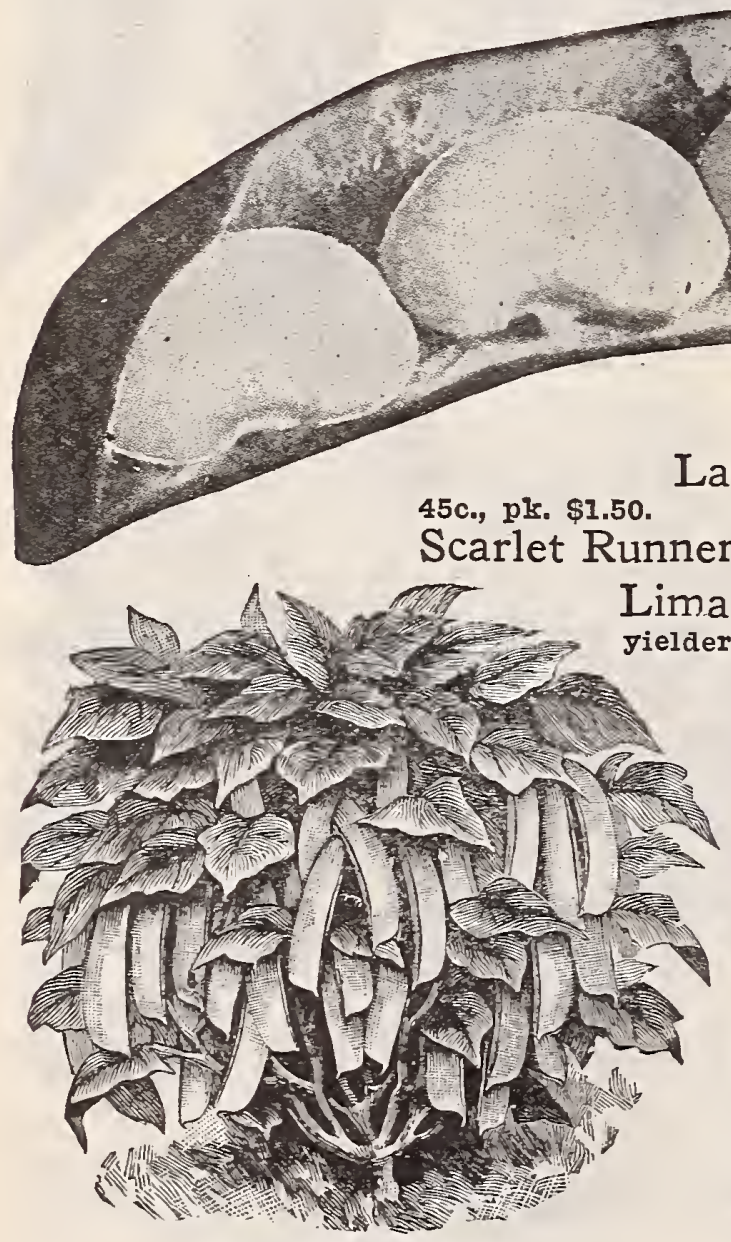

Lazy. Wife. Long green pods of good quality, exceedingBeans, May's Champion Iima. pods are of enormous size, orten measuring 8 to

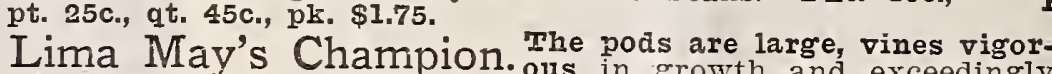
productive. Pit. 100., pt. 25c., qt. 45c., pk. $\$ 2.00$. Burpee's Bush Lima. A dwarf form of the large White high upricht branching out and forming tom to 20 inches plant, bearing large pods well filled with large, delicious beans. Pltt. 10c., pt. 20c., qt. 35 c., pk. $\$ 1.75$.

\section{BROCCOLI.}

Purple Cape. The best variety for our climate, large heads Plt. 10c., oz. 30c.

\section{BRUSSELS SPROUTS.}

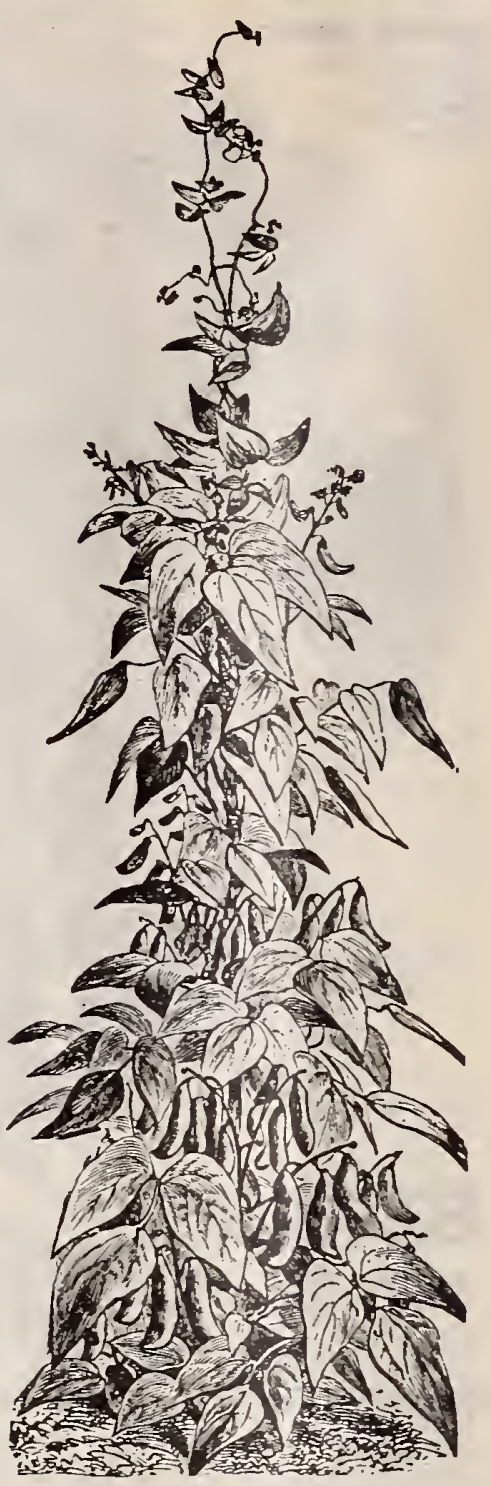

Bean, Scarlet Runner.

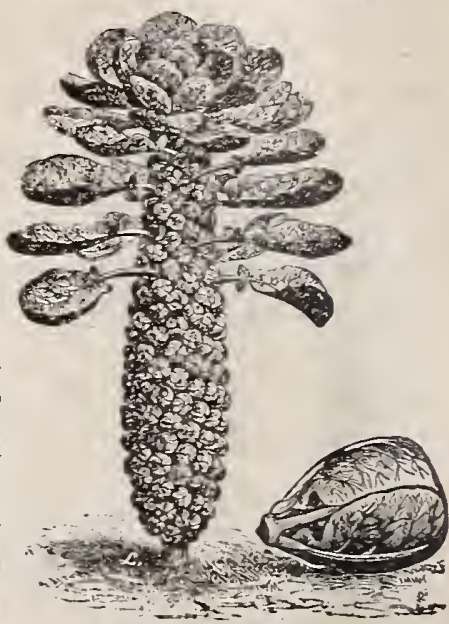

Brussels Sprouts.

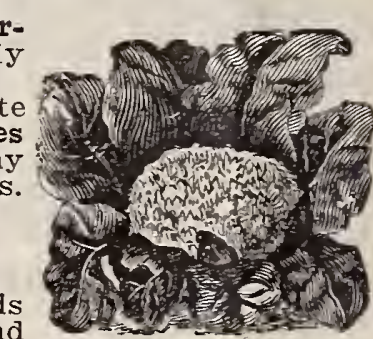

Broccoli.

Bean, Bush Iima.

May's Exhibition. The small heads which grow along the stem are the eatable stewed with cream like cauliflower, are very tender and delicious. Pkt. 10c., oz. 25c. 

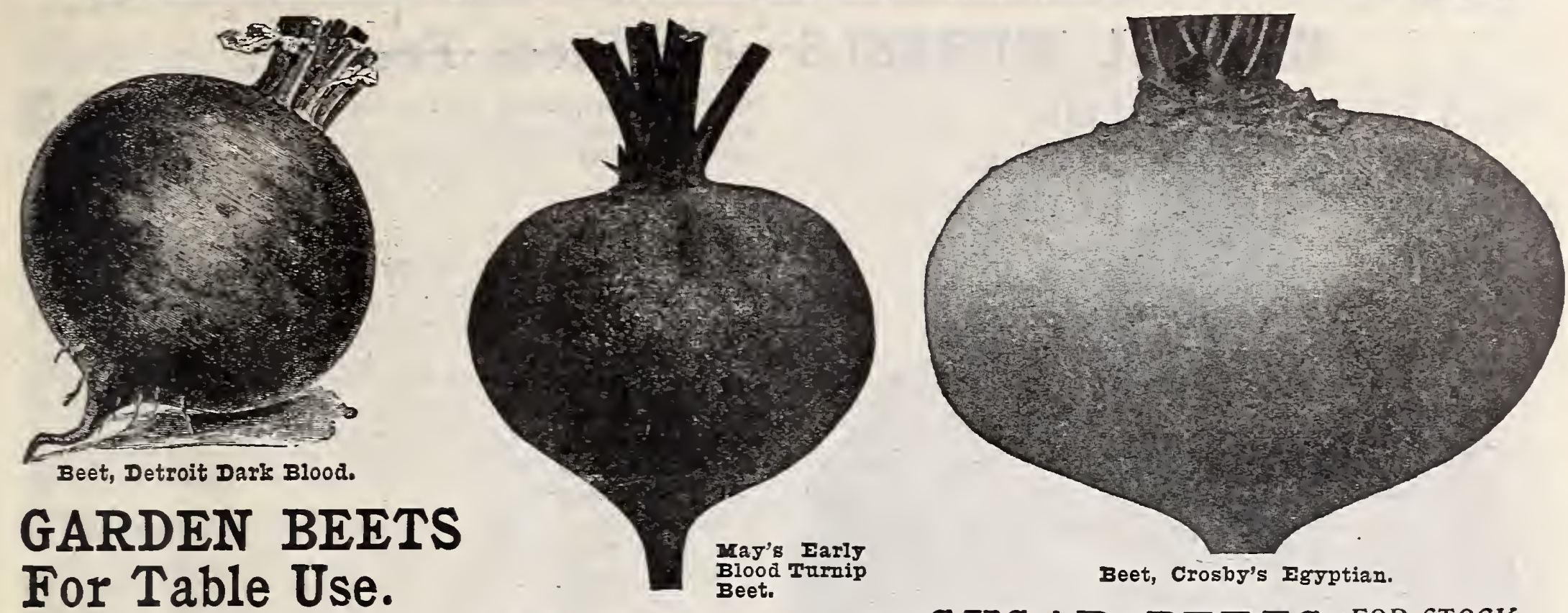

May's Early Blood Turnip. The standard of fully selected and improved strain of Blood Turnip. It is -very early, nearly as early as Egyptian. The color is a rich, dark red, the shape globular. It is free from side or fibrous roots, being always smooth. . Excellent for forcing, for a main spring or summer crop, or for use in winter, it is a fine keeper. Cooks sweet, tender and crisp, and is in every waj a standard sort for market or the home garden Pkt. 5c., oz. 10c., 1/4 1b. 20c., Ib. $70 \mathrm{c}$.

Early Blood Turnip. Pkt. 5c., oz. 10c., 1/4 Detroit Dark Blood. A most excellent It grows to a large size, is of most handsome appearance, and is rery productive in all stems and veins are dark red, blade green, roots globular, perfectly smooth, dark blood red. Flesh bright red, zoned with a darker shade, rery crisp, tender and sweet, re$1 / 4$ 1b. $15 \mathrm{c}$., $1 \mathrm{~b} .60 \mathrm{c}$.

May's Market Gardener. An extra riety. Color, deep red throughout, fine grained, tender and sweet. Valuable for market gardeners or private use. Pkt. 5c., oz. 10c., $1 / 4$ 1b. 20c., 1b. $70 \mathrm{c}$.

Crosby's Improved Egyptian.

The finest and truest strain of Crosby Egyptian to be had. This variety is probably sown more than any other for an early Beet, as it reaches the desired size in much shorter time. Pkt. 5c., 0z. 10c., $1 / 4$ Ib. 20c., 1b. $70 \mathrm{c}$.

Edmund's Early Turnip. On e of uniform of all turnip shaped beets; tops
small. flesh dark red, very tender and sweet Plt. 5c., 0z. 10c., 1/4 Ib. 15c., 1b. $65 \mathrm{c}$.

Early Eclipse. Extra early, round, 5c., 0z. 10c., 1/4 1b. 15c., 1b. 65c.

Early Dewings. Color blood red, an exceloz. 10c., 1/4 1b. 15c., 1b. 65 c.

Crimson Globe. This is an extremely handBood Trrnip Beet.

Beet, Crosbj's Egyptian.

\section{SUGAR BEETS FOR STOCK}

THE GREAT VALUE OF SUGAR BEFTS FOR STOCK FEEDING cannot be overestimated, analysis having demonstrated the fact that 400 pounds of Sugar Beets are equivalent to 100 pounds of the best hay. They are not as heary yielders as Mangels, but contain a much larger percentage nf sac-
charine matter. Sow 12 to 15 pounds to the acre

Giant Feeding Sugar. This unites the large Tize of the Mangel 列 The roots are almays regular and uniform, broad at the top, with a full and slightly tapering shoulder. Pkt. 5c., oz.'10c., $1 / 4$ Ib. 15c., 1b. 35c.

Improved Kleinwanzlebener. This is growing variety that is highly recommended in the Sugar Beet section. About 15 per cent of sugar can be obtained from this oz. 10c., $1 / 4$ lb. $15 \mathrm{c}$., $1 \mathrm{~b} .35 \mathrm{c}$.

Imperial Sugar. A long variety that largely grown than any other Sugar Beet for feeding to stock. It will yield as much as Mangels and contains a large per cent of sugar. Pkt. 5c., oz. 10c., $1 / 4$ 1b. 15c., 1b. 35c.

Wath Wandeben Bugh Btat?

Vilmorin's Improved. A hea $r y$ all kinds of soil. Pkt. 5c., oz. 10c., 1/4 Ib. $15 \mathrm{c} ., 1 \mathrm{~b} .35 \mathrm{c}$.

White French Sugar. One that is many parts of France in preference to any other variety. Plt. $5 \mathrm{c} ., 0 z .10 \mathrm{c}, 1 / 4$ Ib. $15 \mathrm{c} ., 1 \mathrm{~b}, 35 \mathrm{c}$.

Victrix Sugar. The heaviest jielding, cultivation. Produces from Sugar Beet in more sugar per ton than any other variety. The roots are very uniform an

produce more tons per acre than

ety. In addition to this they yield from 18 to 20 should investigate its merits. Plt. $5 \mathrm{c} .$, oz. $10 \mathrm{c}$, $1 / 4$ Ib. 15c., Ib. 35c.

Note We can supply any of the above varieties lots 20c. per lb., 10 lbs. at $18 \mathrm{c}$, 100 1bs. at 15c.s bags included. In ordering, state variety wanted.

The Cheapest Food For All Live Stock.

Any land that will grom a

produce a good crop of Man

crop pays

with good

They make

men claim that

Swiss Chard, White or Yellow. Grown for its stalk. Pkt. 5c., 0z. 10c., 1/4 Ib. 15c., 1b. $40 \mathrm{c}$. 


\section{MANGEL WURZELS-For Stock Feeding.}

\section{THIS IS 17 FOR \\ MONEY $>$ BREEDERS CROP \\ STOCK \\ May's Mammoth Long Red. This we consider the Long Red ever offered. It is truly a mammoth, a single root often weighing from 30 to 50 pounds. Enormously productive, yielding 30 to 40 tons to the acre. They grow well above ground and are easily harvested. Pkt. 5c., 0z. 10c., 1/4 1b. 15c., 1b. 35c. \\ Giant Golden. This is an entirely distinct type of Man- duced. In England it is largely grown by dairymen and sheep raisers; the former prize it not only for its rield, but for the rich character of the milk it produces, while the latter claim sheep fed on it thrive better and appear in much finer condi- tion. Its wonderful yield recommends it to every stock grow- er. Flesh is a light yellow and fine grained. Pkt. 5c., oz. 10c., $1 / 4$ lb. 20c., 1b. 50c. By express or freight, $10 \mathrm{lb}$. lots 35c. per lb. Champion Yellow Globe. Large and productive; keeps stock; easily harvested. Plit. 5c., oz. 10c., $1 / 4$ ib. 15c., 1b. 35c. Golden Tankard. Flesh a rich golden, and of great milk $1 / 4$ 1b. 15c., 1b. 35c. \\ Red Globe A large, red, oval variety, keeps well and is Red Globe. especially adapted to low soils. Prt. 5c., oz. 10c., $1 / 4$ lb. 15c., 1b. 35c. \\ Yellow Intermediate. Root ovoid, intermediate between solid, nearly white, zoned with yellow; hardy, vigorous and productive. Prt. 5c., oz. 10c., $1 / 4 \mathrm{lb}$. 15c., $1 \mathrm{~b}$. 35c. \\ Note. Any of the above varieties offered at $35 \mathrm{c}$. per $1 \mathrm{~b}$. lots for $\$ 2.00 ; 100-1 b$. lots for $\$ 18.00$.}

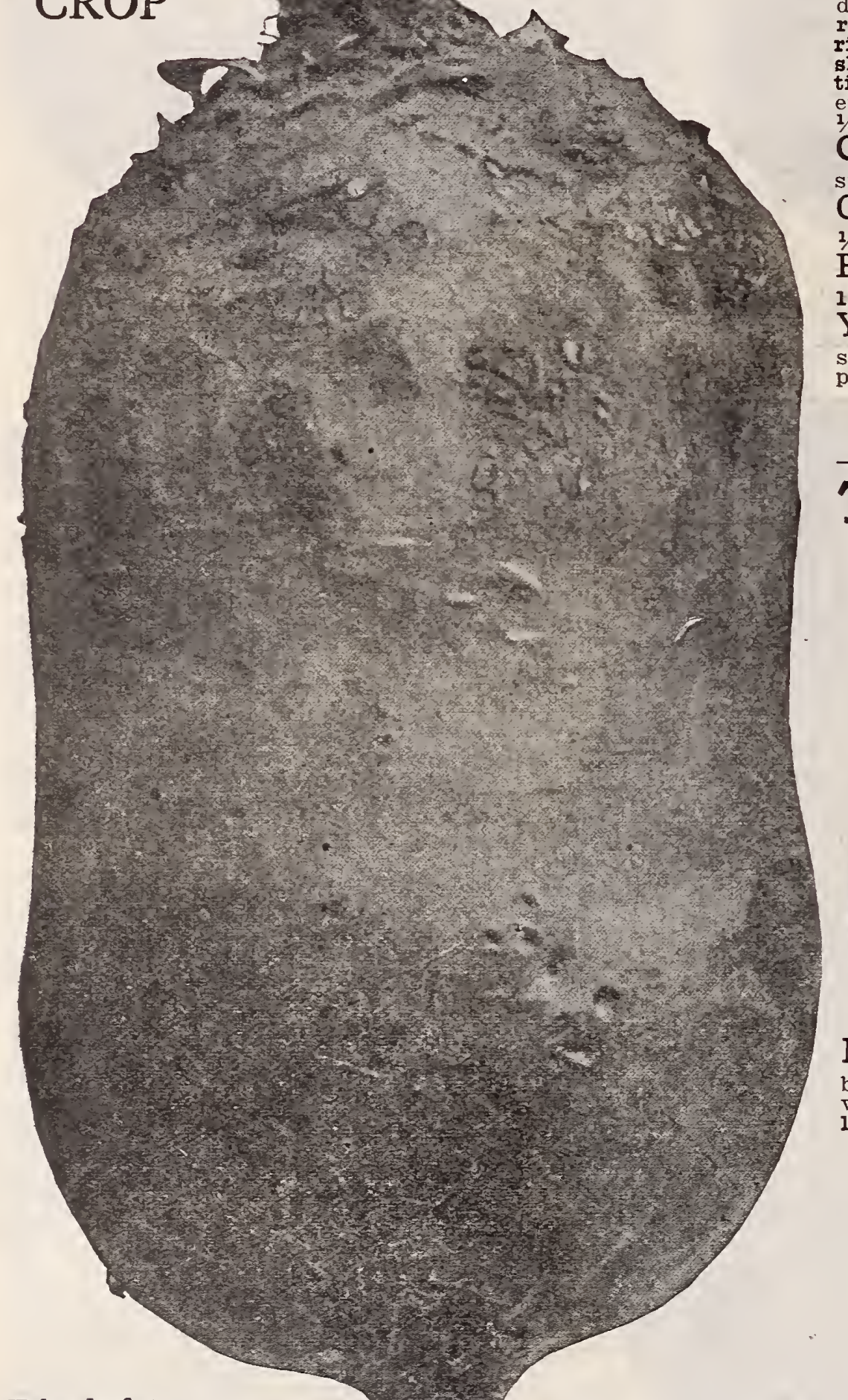

Fckendorfer

Giant Red Mangel.

The Cheapest Food For All Live Stock Eckendorfer Giant Red. One of the best and most prolific indric shape, and solid flesh of the highest nutritive value. It gives the largest yield of all Mangels; the roots are of very large size, but the larges harvested, growing partly above the ground. Pkt. 5c., oz. $10 \mathrm{c}$., $1 / 4$ 1b. $20 \mathrm{c}$., $1 \mathrm{~b}$. $45 \mathrm{c}$.

Eckendorfer Giant Yellow. Same as above except in color. $45 \mathrm{c}$.

\section{TWO DESIRABLE CABBAGE}

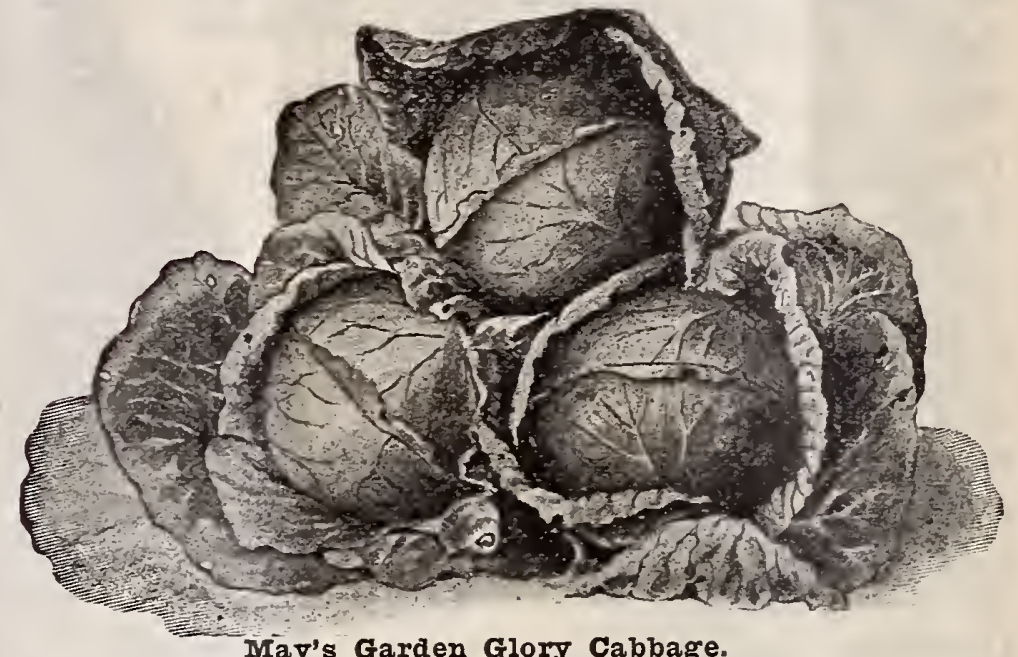

May's Garden Glory. Five to six days earlier than ble the size, better flavor and keep longer; heads ball-shaped, with very few outside leaves. Pkt. 10c., 0z. 25 c., 1/4 lb. 75c., 1b. $\$ 2.50$.

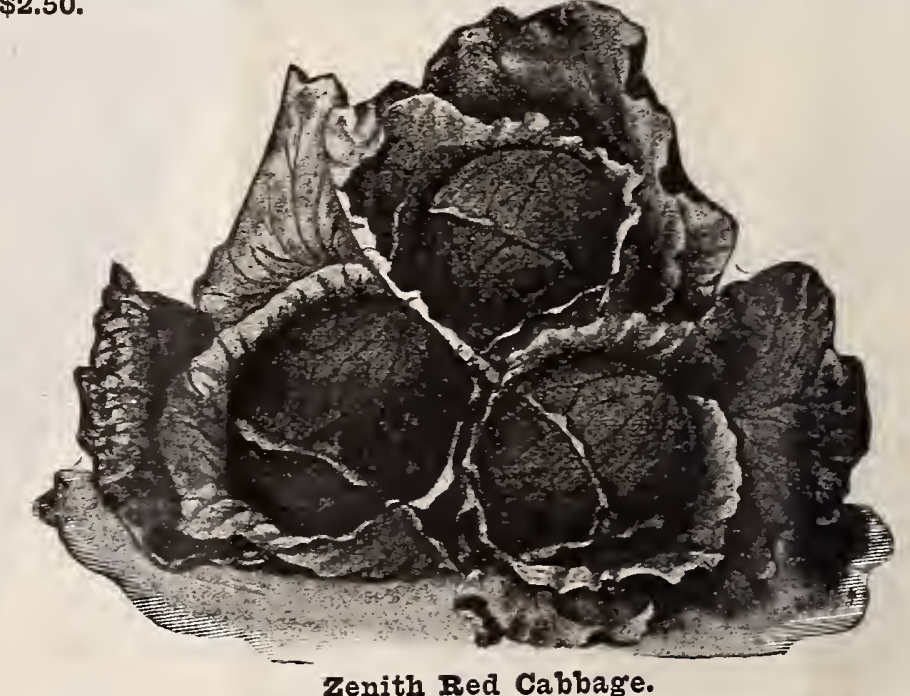

Zenith. This is a new red variety of German origin. The color a fine, deep, purplish red. The heades of medium size, and very solid, with but lew outer leave early is very crisp, tender. mila valuable for market gardeners. Pkt. 10c., 0z. 25c., 1/4 1b. 75c., 1b. \$2.50. 


\section{Northern Grown Cabbage Seed.}

Fxercising, as we do, the utmost care in the growth and selection of our seed stocks, we know that the Cabbage seed which we offer is unsurpassed in quality.

Minnesota Earliest.

shaped, hard headed, Extra Early never fails to satisfy. We hare tested all the Extra Early cans and know that none can equal sons arinnesota Earliest either for earliness, yield or quality. It will produce good sized, marketable heads 70 days from time of sowing. Pkt. 10c., Oz. 25c., 1/4 1b. 75c., 1b.

May's Early Surprise. (s u t.)

The market gardener's favorite round variety for early use. Never fails to head up even under the most adverse circumstances. The Early Surprise is unquestionable the near est approach to a thoroughbred cabbage of any variety yet introduced, both as regards size and uni 0z. 25c., $1 / 4$ 1b. 75c., 1b. $\$ 2.50$.

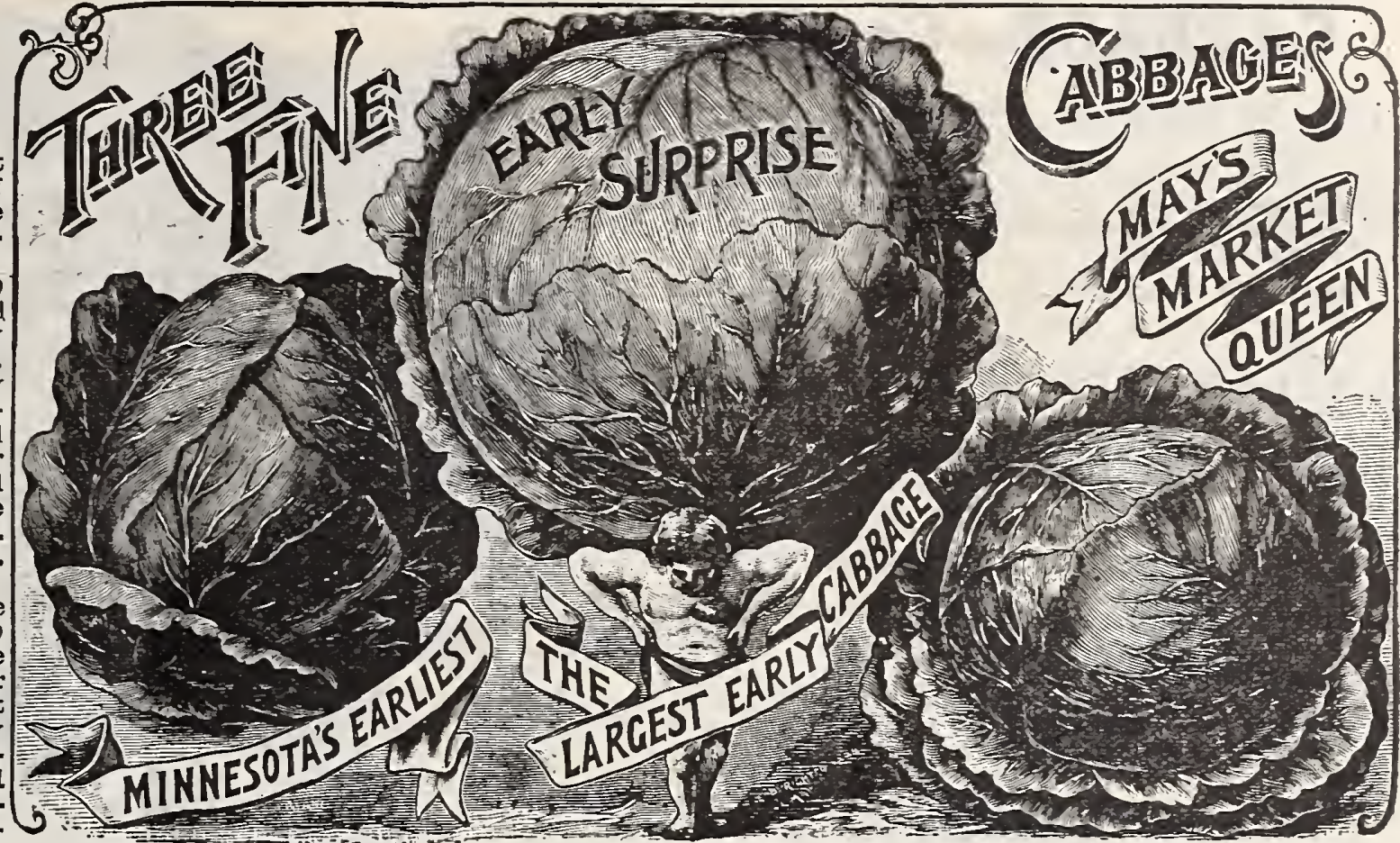
Market Queen.

enormous size and of the very best guality In sweetness, tenderness and richness of fla
$85 \mathrm{c} ., 1 \mathrm{~b}$. $\$ 2.50$.

Early Jersey Wakefield. The heads are uniformly hard and solid. pointed at the end, with but few outside leaves. The outer leaves are unusually thick and heary, and it is thereby enabled to stand more cold weather without injury when carried through the winter either in the open ground in the south or

Charleston Wakefield An improved strain of Wakefield, few days later than the Wakefield. Pkt. 5c., oz. 20c., 1/4 1b. 50c., 1b. $\$ 2.00$.

Extra Early Express. Wonderfully early conical-shaped heads. Extra Early Etampes. Extremely early and of good qualit. Early Winningstadt. A sure header, keeps better than most 50c., 1b. \$1.75.

Early Dwarf Flat Dutch. Popular variety, fine for forcing. All Head. Heads flat, hard, well folded, deep through, most uniAll Seasons. Heads round, large, solid; quality the best; with02. 15c., $1 / 4$ 1b. 50c., 1b. \$1.75.

Succession. (True Stock.) A medium early round headed sort, the Early Summer. Pkt. 5c., 0z. 15c., 1/4 1b. 50c., lb. $\$ 1.75$.

Fottler's Brunswick. Large, flat heads, of the best quality, exoz. 15c., $1 / 4$ 1b. 50c., 1b. $\$ 1.75$.

Stonemason Drumhead. Heads of good size, round and and tender. Pkt. 5c., oz. 15c., 1/4 1b. 50c., 1b. $\$ 1.75$.

Surehead. (Selected Stock.) The heads are

ing nearly all a solid, compact head. Flavor sweet, keeps well and is a good shipper. Pirt. 5c., oz. 15c., $1 / 4 \mathrm{lb}$. 50c., 1b. $\$ 2.00$.

Hollander or Danish Ball. Head.

solid and deep, a veraging 8 lbs. Their

they keep better than any other sort, the hea 65c., $1 \mathrm{~b}$. $\$ 2.25$.

Autumn King. This is an extremely large and solid heading tirely distinct and the best, well suited for fall and winter, enof that desirable bluish green shade. It

leaves that it can be planted closer than the

and it can be relied acre than any other variety. Pkt. 5c., oz. 20 c., 1/4 1b. 50c., 1b. \$2. Premium Late Flat Dutch. (Sabbage for fall and winter use. It is a sure header, wonderfully solid and of excellent flavor. The heads are large, oval in shape and flattened. Well grown heads of ten measure 12 to 15 inches across. No cabbage is so universally grown as this, because the seed may be sown in \begin{tabular}{l} 
hot beds. Prt. 5c., 0z. 15c., 1/4 1b. 45c., 1b. $\$ 1.75$. \\
\hline
\end{tabular}
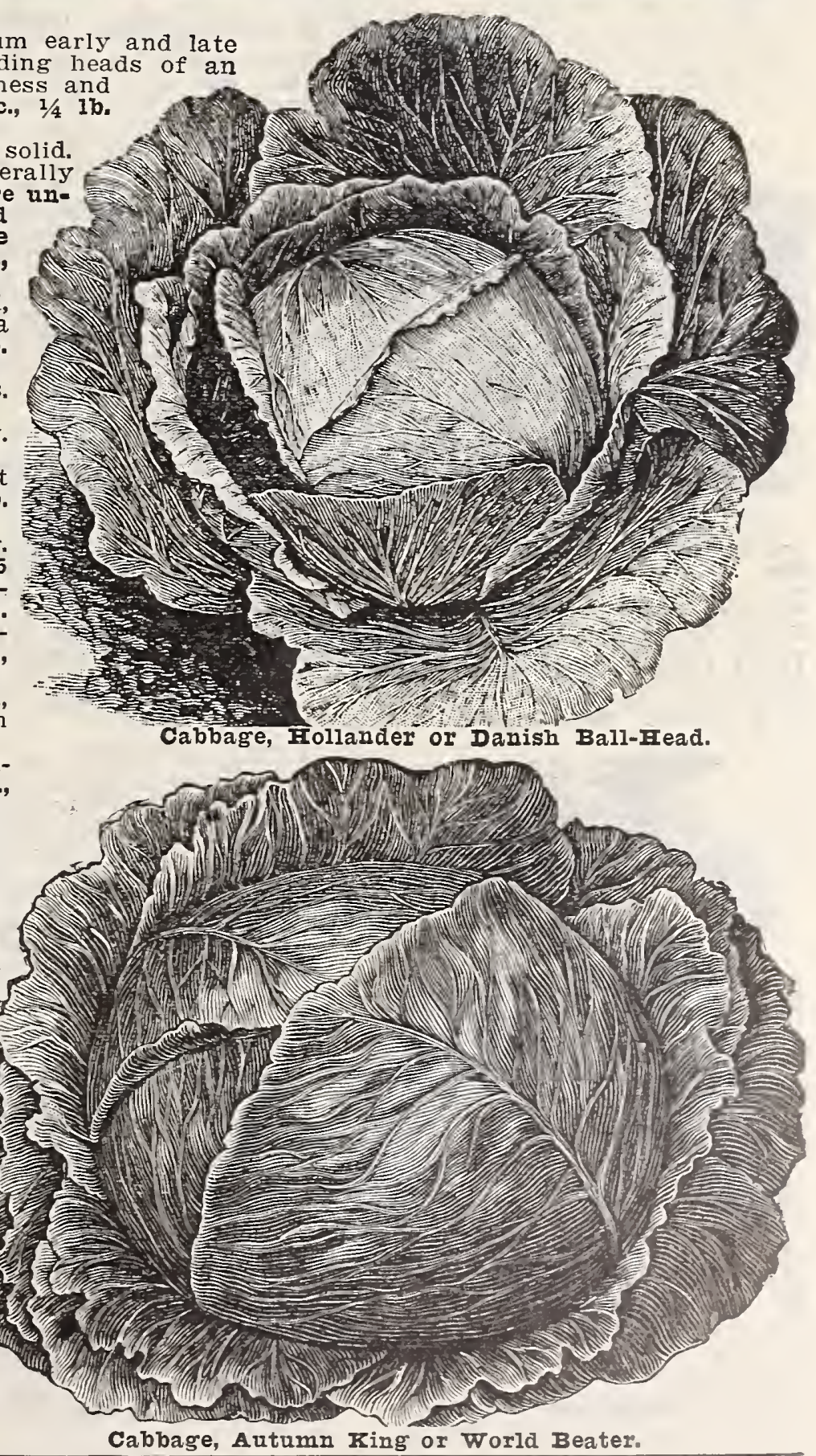


\section{G MAY'S NORTHERN GROWN SEEDS BEST FOR ALL CLMES \&o}

\section{CABBAGE-Continued.}

Hundred Weight. (May's.) The largest of all the ing been known to weigh over 40 pounds each. The truest type are excellent, and it is therefore a valuable sort for gardeners growing for dast
$1 / 4$ 1b., 65 c., 1b. $\$ 2.00$.

Mammoth Red Rock. Heads large, deep weigh 12 lbs. each. Pkt. 5c., oz. $15 c$., $1 / 4$ lb. 50c., 1b. $\$ 1.75$.

Red Dutch. Heads of a deep red or purple. $\$ 1.75$.

\section{SAVOY CABBAGE.}

列 tered, are far superior in flavor to the ordinary or dishes is stuffed Savoy cabbage served with cream

Drumhead Savoy. The largest heading Savoy; of exite with market gardeners and truckers. Pkt. 5c., oz. 10c., $1 / 4$ 1b. 35c., 1b. $\$ 1.30$.

Early Dwarf Ulm Savoy. A dwarf variety, very early and oz. 10c., 1/4 1b. 35c., 1b. $\$ 1.30$.

\section{CARROTS.}

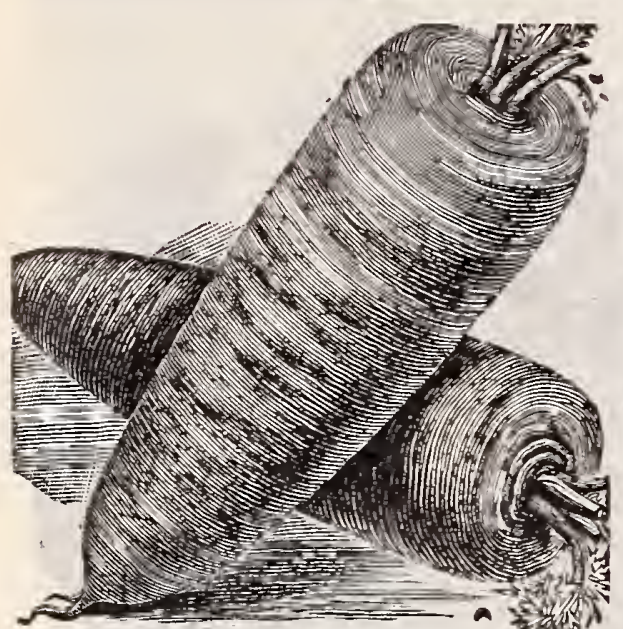

Table Queen Carrots.

grained and of splendid quality. Pkt. 5c., oz. 10c., $1 / 4$ 1b. 25c., 1b.

Early Scarlet Horn Forcing. Extra early; tops small Ready for market in 40 days. Pkt. 5c., oz. 10c., 1/4 1b. 20c., 1b. 75 c Half Long Danvers. Improved stock; one of the most progrown in all sections on account of its enormous yield Flesh deep orange. Plit. 5c., 0z. 10c., $1 / 4$ 1b. 20c., 1b. 75c.

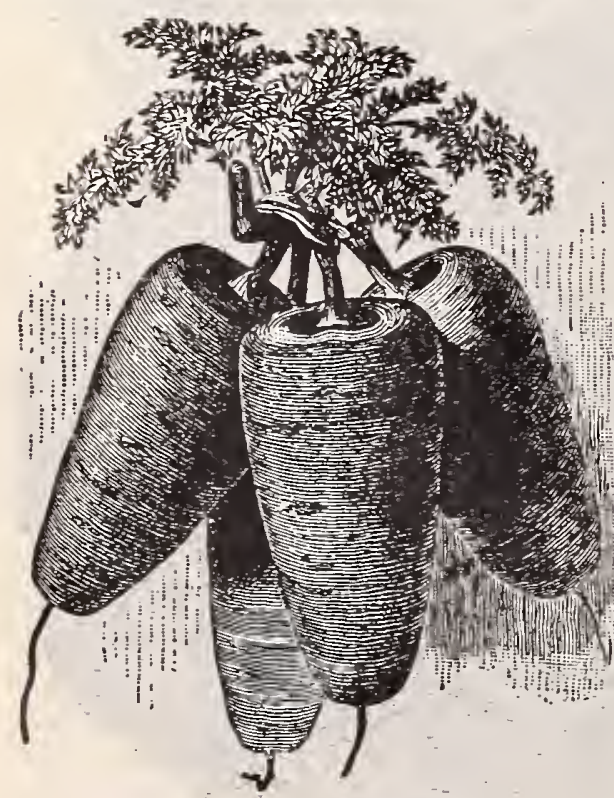

Chantenay Carrot.
Long Orange. $\mathrm{T} h \mathrm{~h}$ popular of the older sorts. The roots are long, thickest near the crown, tapering or, deep orange; yields Guerande or Oxand stiff for the longer growing sorts. The tops of the roots, which are com attain a diameter of 6 inch$20 \mathrm{c}$., $1 \mathrm{~b}$. $75 \mathrm{c}$. se this is considered parrots have attained such a uniformity that they are almost duplicates of each othsize, The tops are of medium pering slightly but uniformy, stump rooted. Pkt. $5 c$.
oz. 10c., $1 / 4$ lb. 20 c., 1 b. $75 c$. . Heart. A desirable vari paratively short, but often

Chantenay. (See cut.)
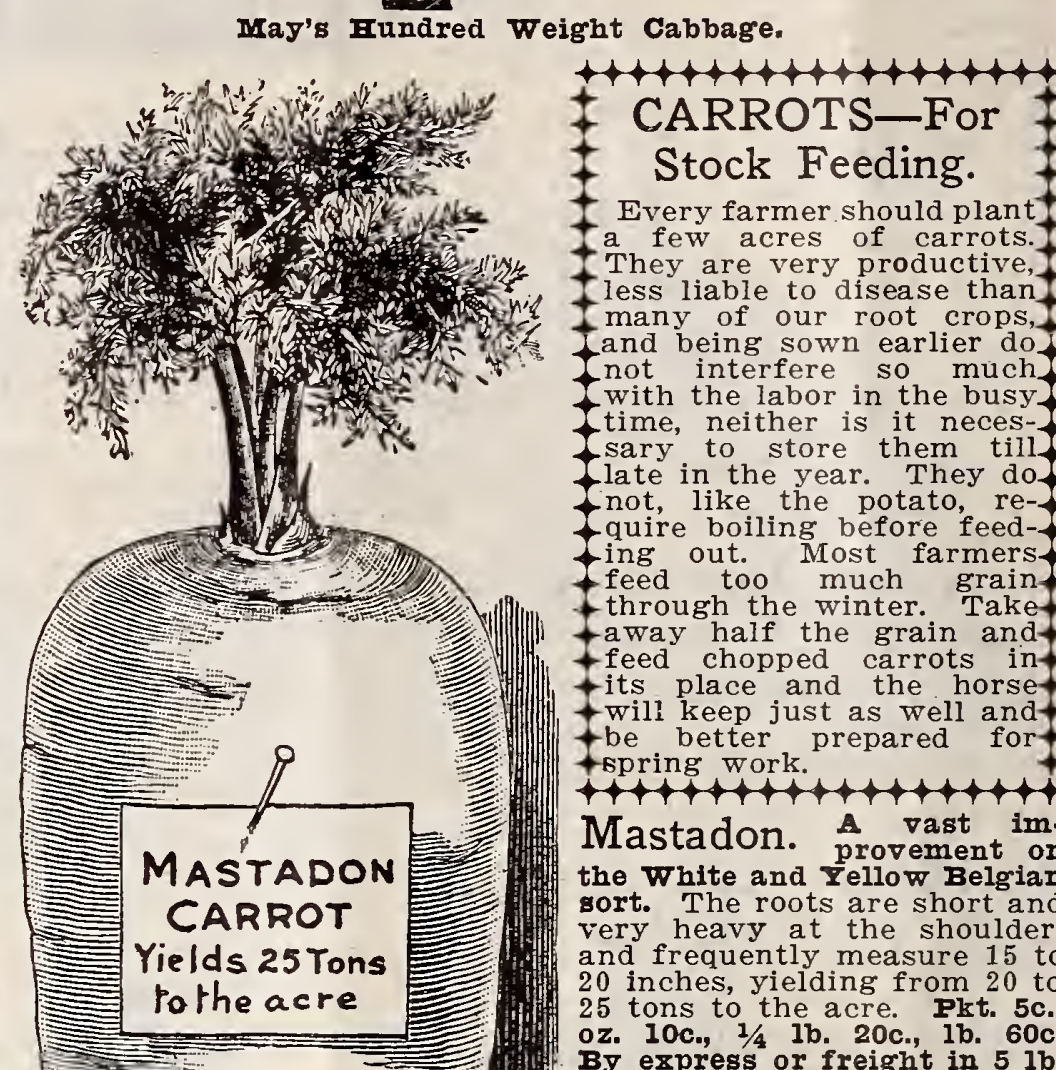

CARROTS-For + Stock Feeding.

Every farmer should plant + They are very productive, less liable to disease than many of our root crops, not interfere so much with the labor in the busy sary to store them till late in the year. They do not, like the potato, reing out Most farmerfeed too much farmers feed to huch grainf through the winter. Take taway half the grain and reed chopped carrots in its place and the horse -will keep just as well and t be better prepared for $+1+t+1+t+1+t+1+t$

Mastadon. A vast imthe White and provement on sort. The roots are short and very heavy at the shoulder. and frequently measure 15 to 20 inches, yielding from 20 to 25 tons to the acre. Pkt. 5c., oz. 10c., $1 / 4$ lb. 20c., 1b. 60c. By express or freight in $5 \mathrm{lb}$. lots or over, 45c per $1 b$.

Victoria The roots are remarkably firm, o light oran e color. Pkt. 5c., By express or freight in $5 \mathrm{lb}$. lots or over, $45 \mathrm{c}$ per 1b.

Belgian Large White. Root large. Pkt. 5c., oz. 10c., $1 / 4$ 1b. 15c., 1b. 50c. BY express or freight, 5 lbs. or over, 35c. per $1 \mathrm{~b}$.

Belgian Yellow. Differ-

from the above only in Plkt. 5c., oz. 10c., 1/4 1b. 15c., 1b. 50c. By express or freight, 5 lbs. or over, 35c. per $1 \mathrm{~b}$.

Vosges Large White.

Voils. Plt 5c. $0 z^{2} 10 \mathrm{c}, 1 / \mathrm{b}, 20 \mathrm{c}$ lb

50c. By express or freight, 5 lbs. or over, 35c per 1b. Improved Short White

Pkt. 5c., oz. 10c., 1/4 1b. 20c., 1b. 60c. By express or freight, in 5 lb. lots or over, $45 \mathrm{c}$. per $1 \mathrm{~b}$. 


\section{GGOWN IN THE GOLDEN GRA IN BELT OF THE WORLD}

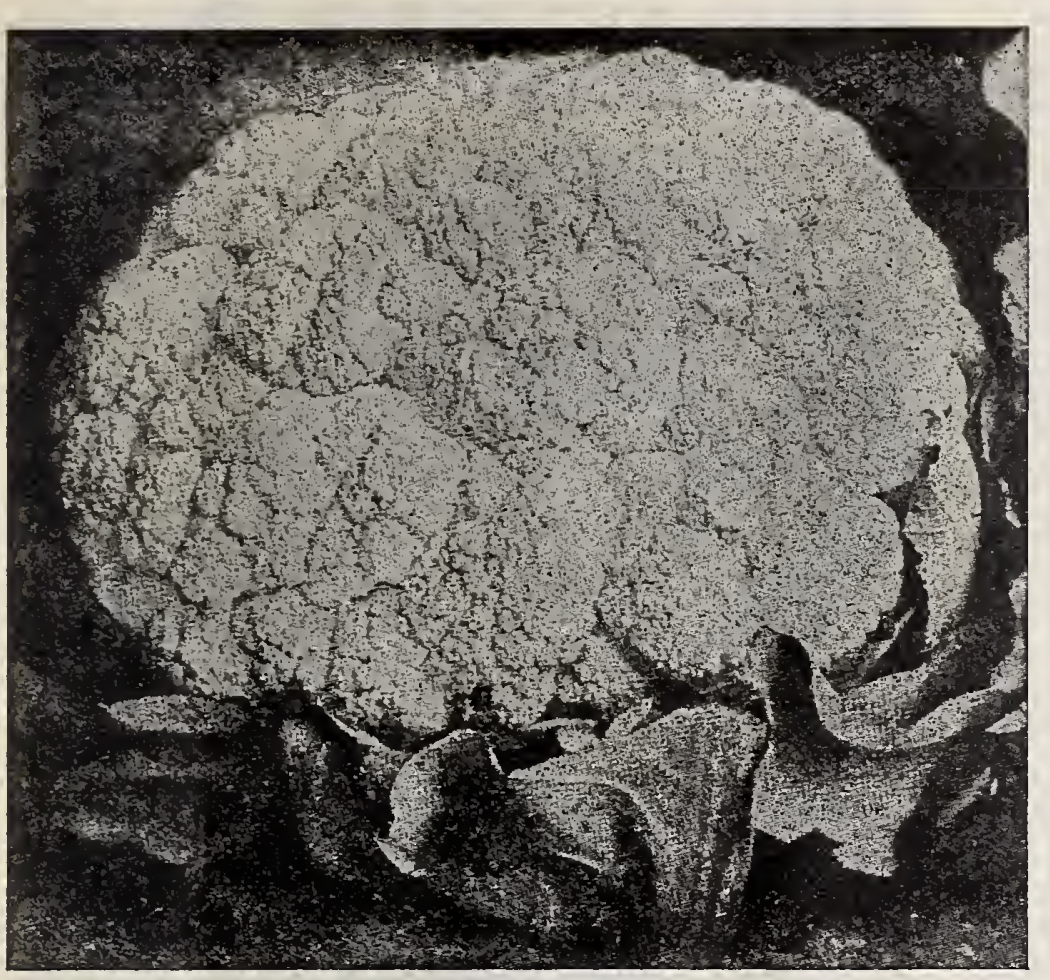

Cauliflower, Extra Early Danish.

\section{SOME CHOICE CELERIES.}

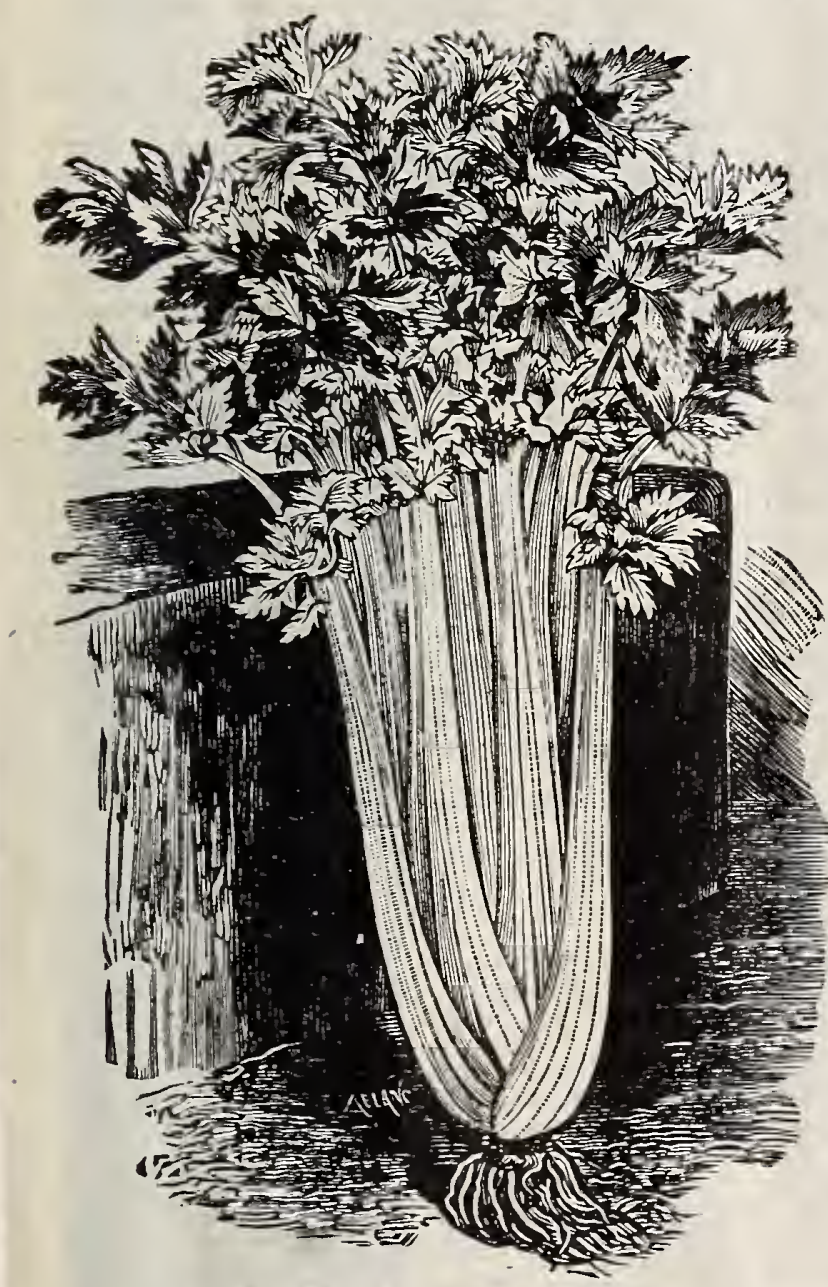

Golden Self-Blanching Celery.

Golden Self-Blanching. The best of all early "selfblanching" varieties. The leading variety in all markets as an early celery. Stalks are much broader and heavier than the White Plume, and greatly superior in quality. It is ready for use nearly as early, producing dwarfer and much larger bunches of broad, heavy stalks, blanching to a deep golden yellow. Genuine strain French grown. Pkt. 10c., oz. 35c., $1 / 4$ lb. $\$ 1.00$, 1b. $\$ 3.50$.

White Plume. It is almost ing. Valuable for fall and winter use. A good keeper. Pkt. 5c., oz. 20c., $1 / 4$ lb. 60c., $1 \mathrm{~b}$. $\$ 2.00$.

American White Solid. The best of the large growing sorts. Grows to a height, under good cultivation, of 3 feet. It is remarkably tender and keeps the rich flavor longer $5 \mathrm{c} ., 0 \mathrm{Oz}$. 15c., $1 / 4$ 1b. 40c., $1 \mathrm{~b}$. $\$ 1.40$.

Giant Pascal or Winter King. The leading celery for are remarkably large, thick, are remarkably large, thick, It is a very vigorous grower. the heart is a rich, bright yel-
low, even without blanching. low, even without blanching.
It blanches very easily, requiring only 5 or 6 days earthing up when the outer stalks present a beautiful clean white appearance. Pkt. Evans' Triumph. This splendid Celery, with large, solid stalks of the finThe stalks are of the finest texture, crisp, brittle, tender, and almost nutty in flavor. Market gardeners everywhere concede this to be one of the very best late sorts. It requires highly enriched soil and the entire season to grow it to perfection. So grown it retains its superb quality a long time. Pkt. 5c., oz.
porte perfection. So grown it

\section{CAULIFLOWER.}

Extra Early Danish. The earliest sure heading Cauliflower ety, and we have procured our seed direct from one of the largest flower reaches the lighest state of perfection. It is of dwarf, The heads are of good size and a beautiful snowy white. Pkt. 20c., $1 / 2$ oz. $\$ 1.75$, oz. $\$ 3.00$. Early Snowball. (Selected Stock.) The plants are compact, the leading market gardeners in this section claim it is by far the best variety for marketing, owing to the fact that it may be ground space. We offer a carefully selected strain of this variety. $\$ 1.00$, oz. $\$ 1.75$.

Extra Early Erfurt Selected. Plants very dwarf, with Alanted in rich soil early in the spring, heads 8 varieties Largely grown for fall . use, producing large, fine heads. Popular with mar-

( prt. 5c., $1 / 2$ oz. 20c., oz. 35c. oist or wet seasons, making: heads equal to the
dry seasons that its merits appear to best adg the effect of droughts better than any known
variety. Pkt. 10c., $1 / 2$ oz. $\$ 1.50$, oz. $\$ 2.50$.

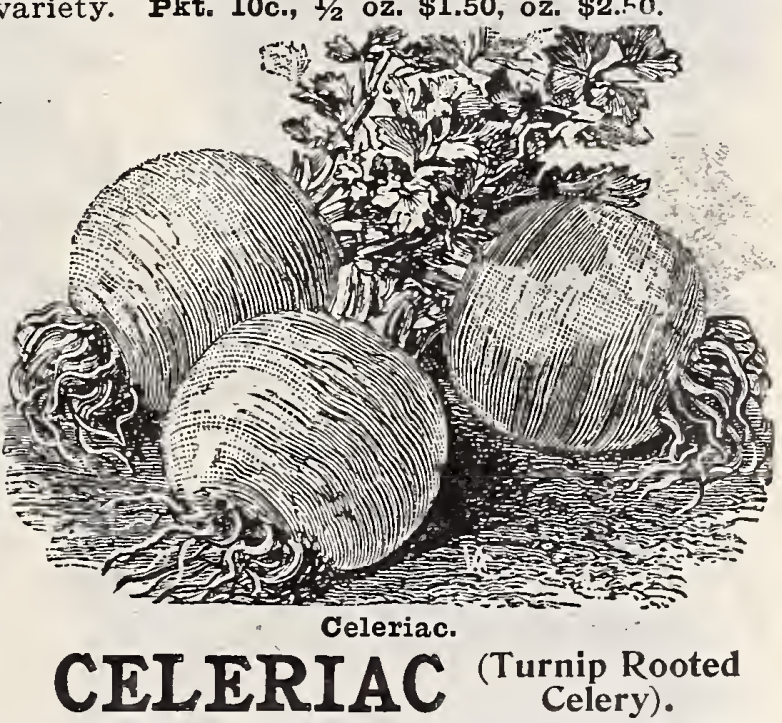

Forms a large round bulb at the roots, which is used instead of the stalks as in other celery. Cultivation same as celery.

Apple. Roots shaped like an apple. Make.s

with agreeable flavor. Prt. 5c., oz. 20c., 1/4 1b. 35c.

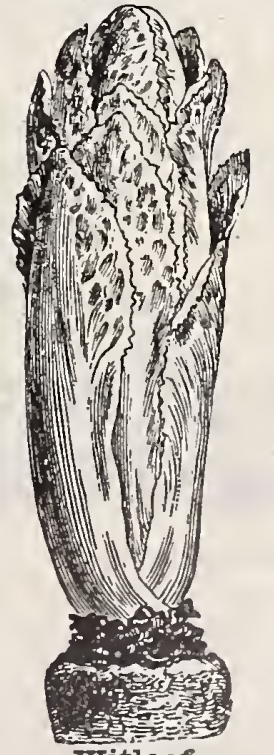

Witloof Chicory.
Large Erfurt.

sliced and used Plt. 5c., oz. 10c., $1 / 41 \mathrm{~b}$. $35 \mathrm{c}$

\section{CHICORY.}

Witloof. 


\section{${ }^{10}$ G MAYS NORTHERN GROWIN SEEDS BEST FOR ALL CLMES \&}

\section{COLLARDS.}

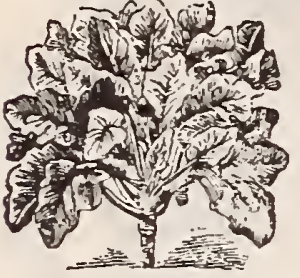

True Southern or Creole. The varicty so extensively used in the South, where it furnishes an abundance of food for both head. Pkt. 5c., oz. 10c., 1/4 1b. 30c.

Georgia. $75 \mathrm{c}$.
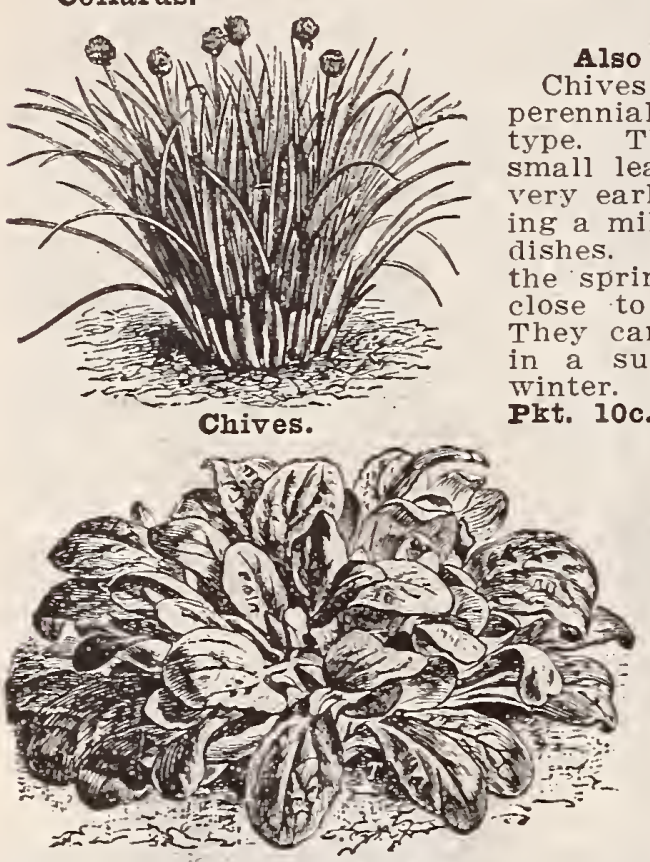

Corn Salad.

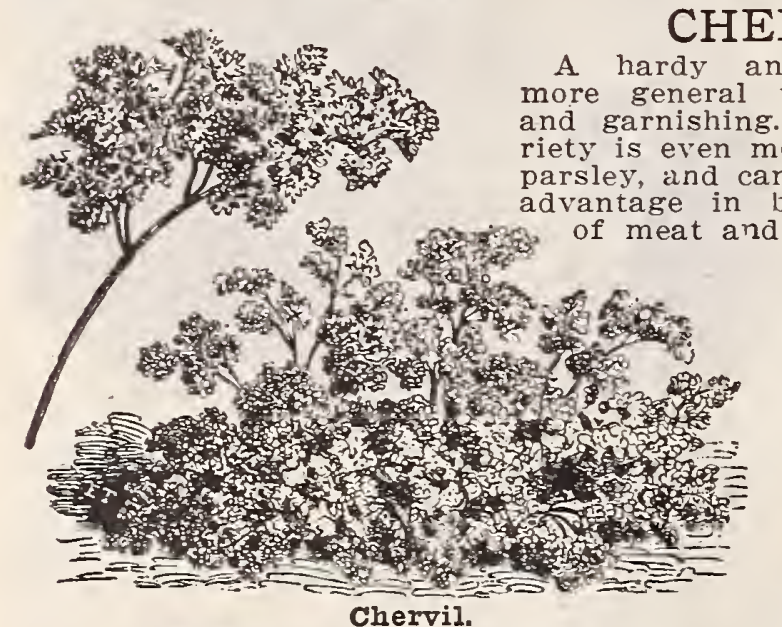

\section{Curled.}

plain variet

ing earlier, mor

having fully, as

flavor. Prt. 5c.

CRESS.

Fine Curled. (Pepper Grass.)

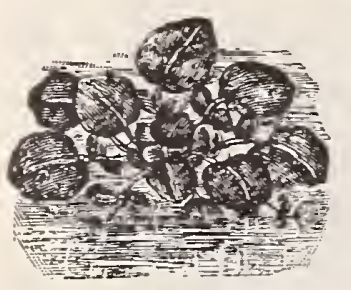

parsley. growing dwart and compact.

ing. Plt. 5c., oz. 10c., 1/4 1b. 20c., 1b. 55c.

Water Cress. Highly esteemed as a

and fall. Also used as a garnish for meats readily in pans or boxes of very moist
earth, and the young plants transplanted

True water Cress. \$1.00.
GARDEN HUCKLEBERRY.

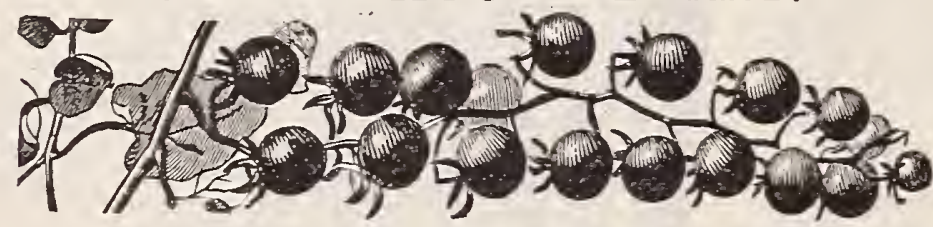

Garden Euckleberry.

Solanum Nigrum. This new fruit can be grown from seed the large as an average size gooseberry. The color is jet black, and when cooked is as palatable, and can scarcely be discerned in
taste from the real huckleberry. The berries make better pies,
jelly jelly and sauces than the common wild huckleberry, but do not
eat them green. Plant seed in a box or pan in early spring, and when danger of frost is over plant out $2 \times 4$ feet. Cultivate same

\section{MAY'S NORTHERN GROWN SWEET OR SUGAR CORN.}

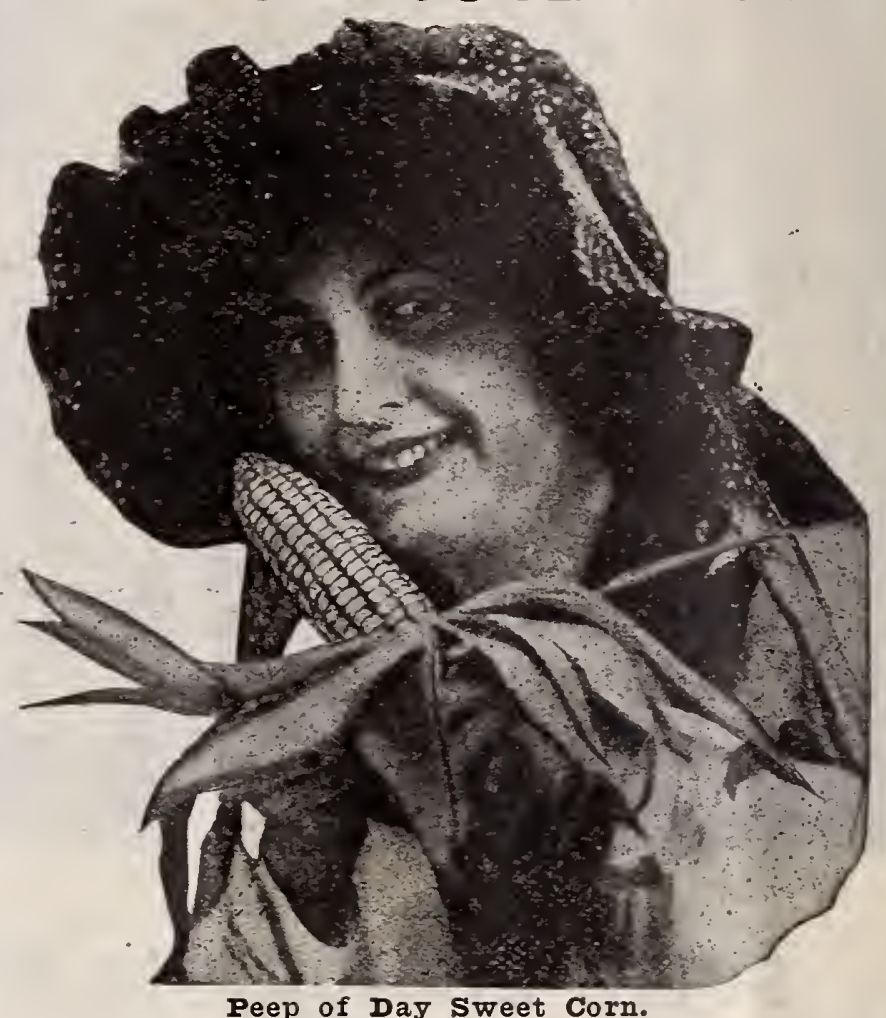

Peep of Day. This most valuable sort is of Minnesota the best. The stalks grow from three to four feet high. Ears verage from five to six inches in length and are of perfect form. Plt. 1ac., pt. 20c., qt. 35 c., ple. $\$ 1.00$, bu. $\$ 3.50$. Early Windsor. The earliest of all sugar corns. Very can be grown. Plt. 10c., pt. 25c., qt. 40c., pk. $\$ 1.25$, bu. $\$ 4.00$. Premo An extremely early variety, usually fit to use in Premo. fifty days from time of planting. It is not only ery early, but is one of the sweetest and best. This variety combines all the good qualities of the later sorts, is much hardier, and may be planted some days earlier without danger of rotting. It is a vigorous grower,
stalks about 5 feet high. Plst. 10c., pt. 20 c., qt. 30 c., pls. $85 \mathrm{c}$., bu. $\$ 3.00$.

Red-Cob Cory. This popular exshort, cool, and moist. Ears six inches in length, with eight rows of white, broad grains. The cob is red. Pkt. 10 c., pt. 20c., qt. 35c., pk. 85c., bu. $\$ 3.00$. Adam's Extra Early. Not sweet nor quite so early as Cory, but decidedly more hardv. It is not a true sweet the table if pulled promptly after reaching maturity. Pkt. 10c., pt. 20c., qt. $30 \mathrm{c}$., pk. 85c., bu. $\$ 3.00$.

Minnesota Early. One of the best ular of the older varieties, both for Stall market and private gardener. eight-rowed, very sweet and tender. Plt. 10c., pt. $20 \mathrm{c}$., qt. $35 \mathrm{c}$., pls. 85c, bu. $\$ 3.00$

White Mexican A new white vathe good quality of sweetness and flavor of the old dark type. It is one of the earliest to mature, furnishing edible ears from 4 to 6 days atead of the Cory. Plt. 10 .,
qt. 40 c., pk. $\$ 1.25$, bu. $\$ 4.00$. Golden Bantam. of extreme harplanted earlier than any .other true sweet corn, and will then produce the
earliest supply of ears for the table. Plkt. 10c., pt. 25c., qt. $40 \mathrm{c}$., pk. $\$ 1.25$, bu. $\$ 4.00$.'

Perry's Hybrid. A large early about same time as Minnesota. Pkt. $\$ 3.50$.

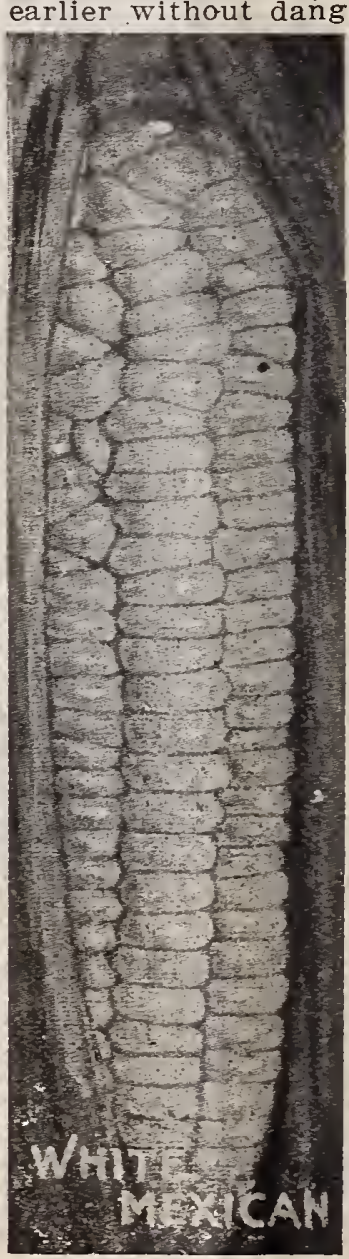




\section{GôOWN IN THE, GOLDEN GRAIN BELI OF THE WORLD ?}

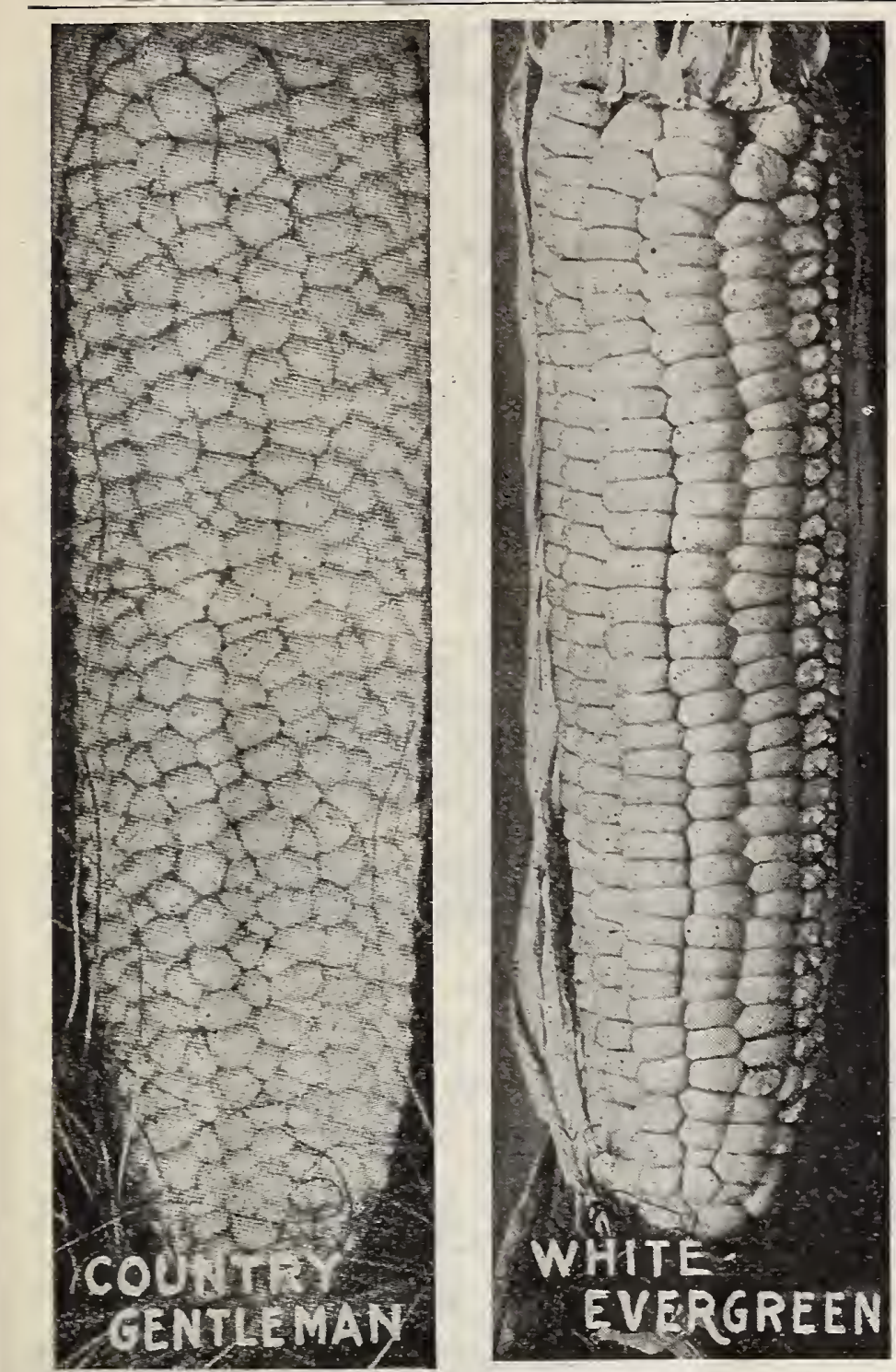

\section{SWEET OR SUGAR CORN-Cont.}

Early Mammoth Sugar. An early variety, producany sweet corn. One ear has been known to weight three pounds. Sweet, tender and

Crosby's. This is a favorite second-early variety, with

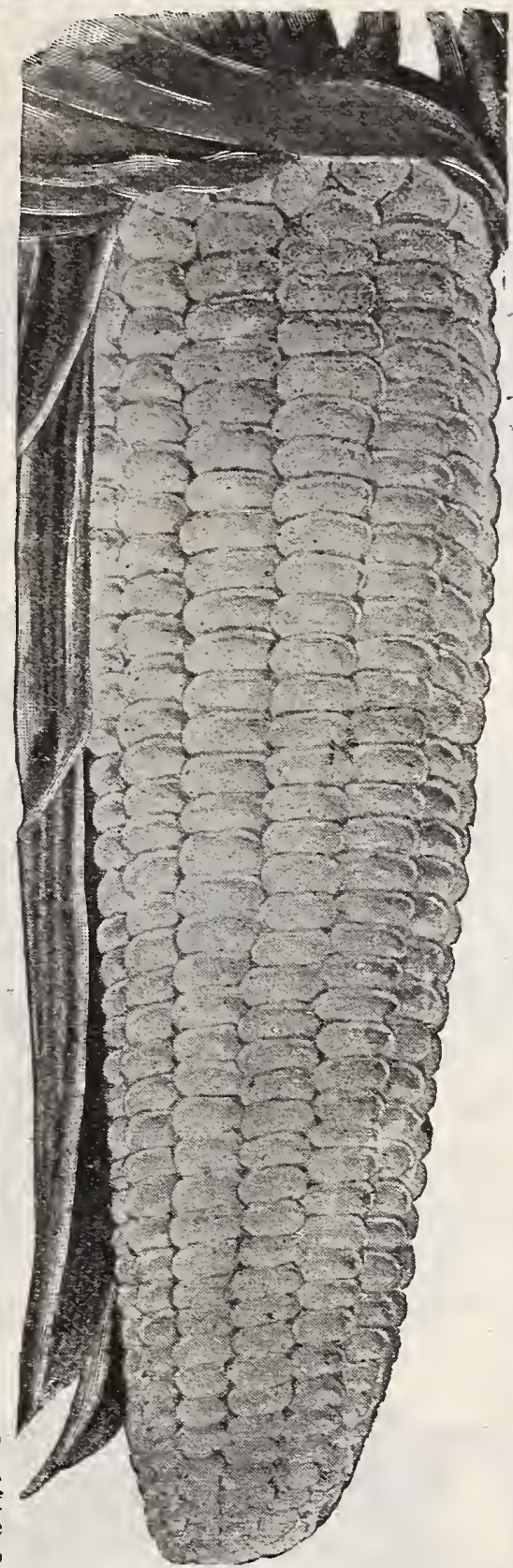

Premo Sweet Corn.

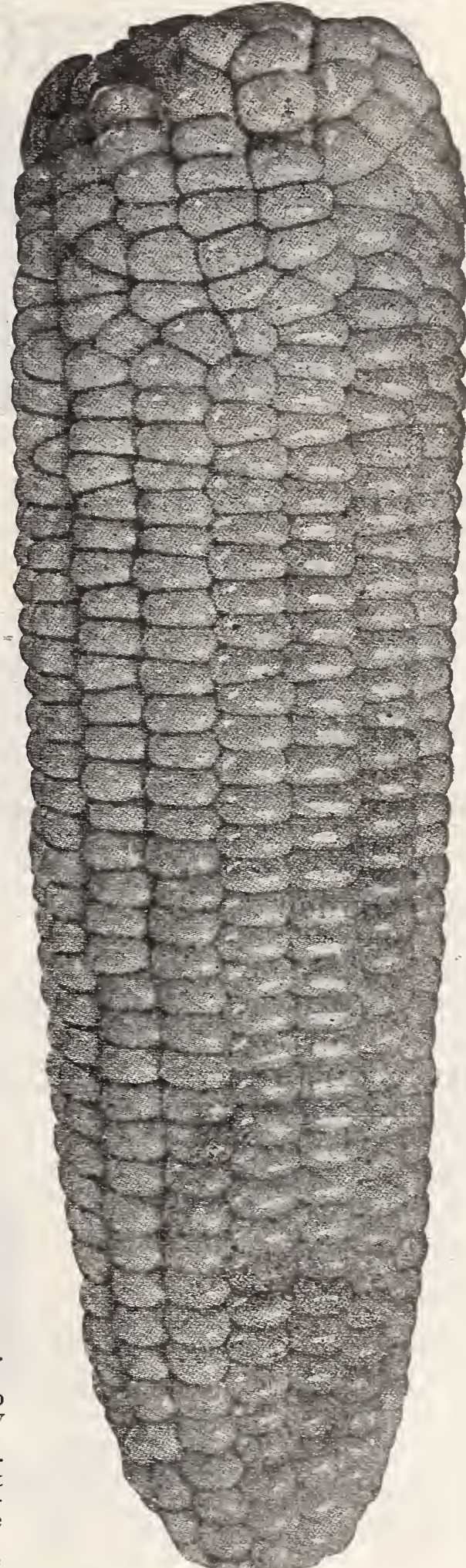

guality. The to the any other variety. Pkt. 10c., pt. 20c., qt. 30c., pli. 85c., bu. $\$ 3.00$.

May's Acme. A valuable sort for market men. Ears large, generally 12-rowed and 8 to other variety. Plit. 10c., pt. $25 \mathrm{c}$., qt. $40 \mathrm{c}$., pr. $\$ 1.25$, bu. $\$ 4.00$.

Early Evergreen One of the best sugar corns in existence, possesing every good qualshory shorter, and that it will mature in 80 days, or fully 10 days earlier. The ears are like stowell's, very large, with about 18 rows of very large grains. There is no better corn than

Black Mexican. One of the most sugary and delicious of Sweet Corns. Grains white 30c., pr. 85c., bu. $\$ 3.00$.

Mammoth Lte Extra large ears, usually 14 to 18-rowed; cob white and well filled, deep kernels of good quality. Pkt. 10crs , $30 \mathrm{c}$, pk. $85 \mathrm{c}$. , bu, $\$ 3.00$.

Country Gentleman. The most delicious of all Sweet Corns and also one of the most productive sorts. The ears are of bearing 3 to 4 ears. Pkt. $10 \mathrm{c}$, pt 20c, qt. 35 c., pla. $\$ 1.00$, bu. $\$ 3.50$.

Improved White Evergreen. The cobs and kernels are at all stages of edibility beautifully white. The getting rid of th a great gain, as it fits this variety for extensive use in canneries. Plt. 10c., pt. $25 \mathrm{c}$., qt. $40 \mathrm{cos}$., pk. $\$ 1.25$, bu. $\$ 4.00$.

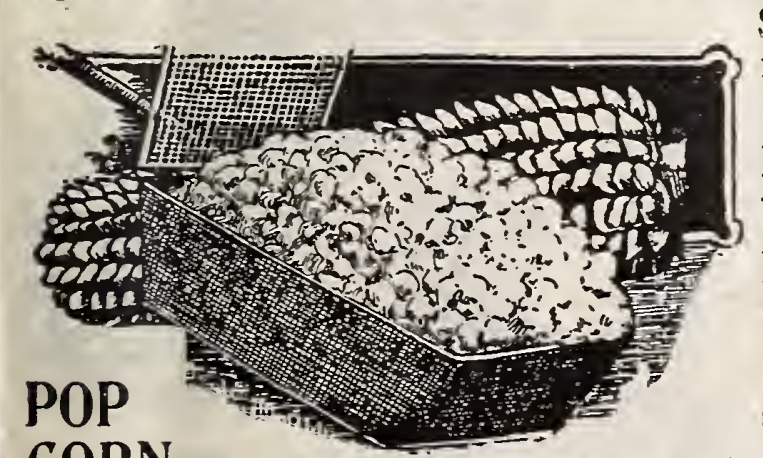

Stowell's Evergreen. Frtra selected. This is the leading standard rariety for pk. $\$ 1.00$, bu. $\$ 3.50$.

THE BEST VARIETIES OF POP CORN.

Rice. A very productive vapping sort, and the

White Pearl.

Mapledale.

Golden Queen.

Pop corn should be found in every garden, especially if there are child it auring the long winter evenings, which bring young people together for social amusement. ART OF THE ABOVE POP CORN: PKt. 10c., pt. 20c., qt. 35c., postpaid. 


\section{2 g MAY'S NORTHERN GROWN SEEDS BEST FOR ALL CUMES 8 के MAY'S CHOICE SEED OF CUCUMBERS.}

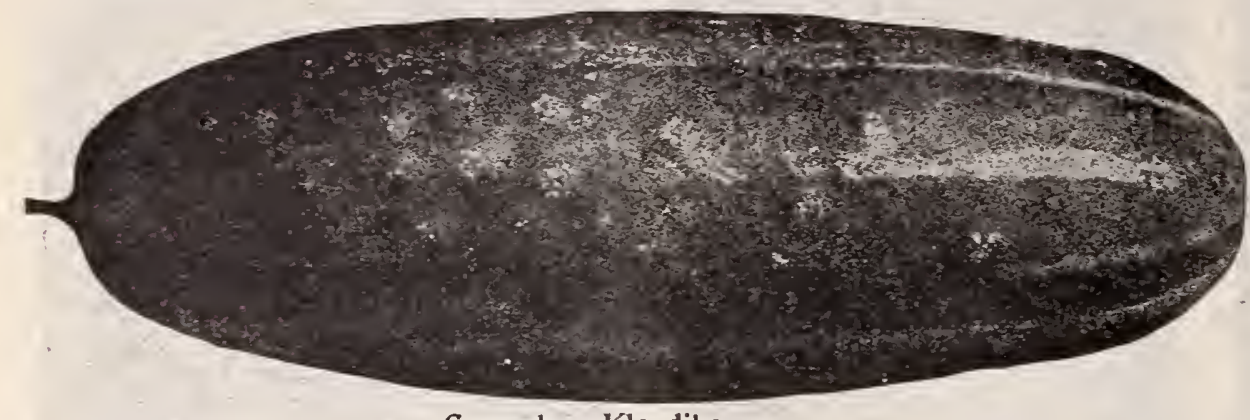

Cucumber, Klondike.

Early Prize Cucumber. The finest cumber. Extra early, a prolific bearer, a vigorous grower and of splendid shape and quality. It is a most excellent sort for either pickling
Pkt. 10c., 0z. 20c., $1 / 4$ lb. 60 c., lb. $\$ 2.00$.

May's Garden Gem. The finest cucumsurpasses all other kinds for beauty flavor and shape, being quite long, thick through, has a fine flesh and few seeds. For general crop to come in after our great forcing variety, "Early Prize," it is
undoubtedly the most desirable sort. Pkt. 10c., oz. 20 c., $1 / 4$ lb. 60 c., lb. $\$ 2.00$.

Improved Long Green. Produces ing from ten to twelve inches in length. Skin a deep This extra selected strain of the original be depended upon to produce the true long, dark green fruits - excellent alike for slicing and pickling. kt. 5c., oz. 10c., $1 / 4$ lb. 25c., lb. 80c.

Giant Pera. The cucumbers are long, smooth Unlike most sorts, they are fit to eat at any stage. Pkt. 5 c., oz. 15 c., $1 / 4 / 4$ lb. 35 c., $1 \mathrm{~b}$. $\$ 1.25$.

New Cumberland. A variety pickles

Tre

except on the extreme stem end. During

the whole period of growth, from the time exceptionally straight and symmetrical, making them as choice for a slicing variety as for pickles. The flesh is firm, very erisp
and tender at all stages. Pkt. 5c., oz. 10 c., $1 / 41 \mathrm{~b} .25 \mathrm{c}$., $1 \mathrm{~b}$. $80 \mathrm{c}$.

\section{Early Cluster.}

ty usually producing the butk of near the root and in clusters. It is a good
table variety and excellent for pickling purposes. Fruit short, dark green.
Pkt. 5c., oz. 10c., 1/4 1b. 25c., lb. 75c. May's Favorite Pickling. In form it is solid and rather thick, flesh is crisp and exceedingly tender.

all together it is about as near perfection

Pkt. 5c., oz. $15 c$., $1 / 4$ lb. $40 \mathrm{c}$., $1 \mathrm{~b}$. $\$ 1.25$.

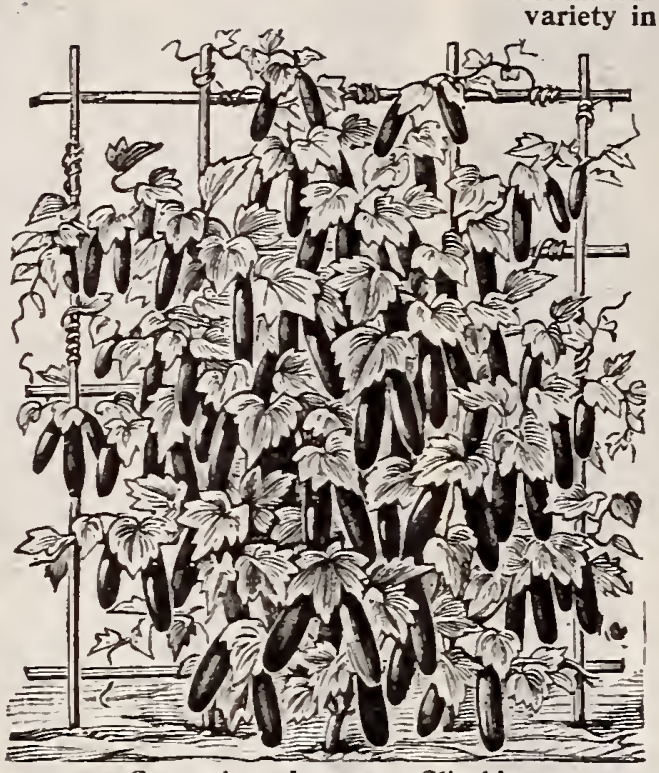
Early Frame. Fruit medium size, fine for table use. Plst. 5c.,
oz. 10c., 1/4 1b. 25c., 1b. 75c. in a in length, of a beautiful green color. Pkt. 5c., oz. $15 c ., 1 / 4 \mathrm{lb}$. 35c., lb. $\$ 1.25$.

Davis Perfect. By using this variety gardoors cucumbers that will deners can produce out of house forcing varieties. The shape is ideal. It is almost seedless one third of its length from the It is and the few seeds that are contained in its blossom end when in eating condition are so small and tender that they are hardly noticeable. Pkt. 10c., 0z. 25c., $1 / 4$ b. 75 c., lb. $\$ 250$.

White Spine Improved. Very uniform productive, crisp and fine flavor. Pkt. ${ }^{\circ} c_{.}, 0 z .10 \mathrm{c}$ $1 / 4 \mathrm{lb} .25 \mathrm{c}$., $1 \mathrm{~b} .80 \mathrm{c}$.

White Spine Extra Long. A fine, and well shaped sort a little later than the above. Arling. Pkt a v or ite. $1 / 4 \mathrm{lb} .25 \mathrm{c}$., ib. $80 \mathrm{c}$

Aksarben. A selected strain of the ArlingAksarben. ton White Spine. Pkt. 5c.,

Klondike Famous. For flavor, uniform size, color lutely unequaled. In addition to this productiveness it is absoearly, continuing right through the season until killed by frost. Always straight-never turning yellow. Best for the table, for market and for pickling. It is a hybrid of the White Spine type, averages 6 to 7 inches long, the ends are quite square, anders it is growing rapidly. The fruit is firm and hard and keeps in prime condition a long time after picking. Pkt. $5 \mathrm{c}$., oz. $15 \mathrm{c}$.

Japanese Climbing. A marvelous climbing variety vines are strong growing and immensely productive, it being cimes as much as any other

Boston Pickling. Extensively

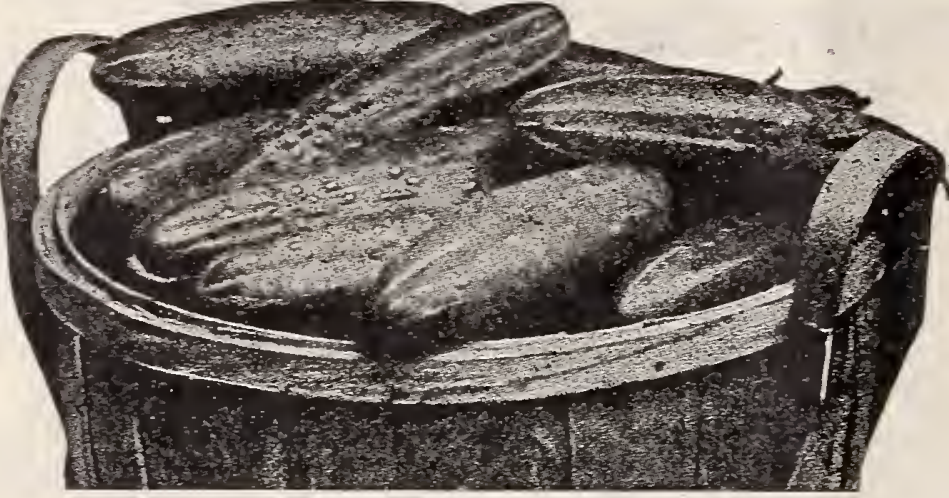

The New Davis Perfect Cucumber. pickling purposes. Color bright green. Green Prolific. One of the best or dark green. Pkt. 5c., oz. 10c., $1 / 4$ lb. $25 c ., 1 b .75 c$.

Emerald. Makes excellent pickles 5c., oz. 10c., 1/4 lb. 25c., lb. 75c. Jersey Pickling. A long, slenfor pickling. Pkt. 5c., oz. 10c., $1 / 4 / 4$ lb. West India Gherkins. Small shaped; grown extensively for pickles

\section{EGG PLANT.}

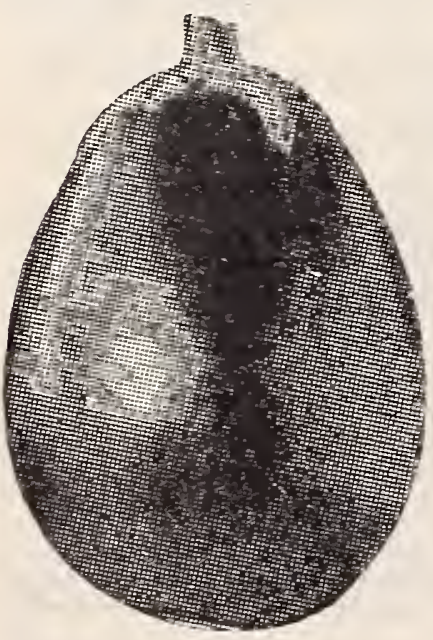

igg Plant, Black Beauty. $60 \mathrm{c} ., 1 \mathrm{~b} . \$ 2.00$.
Black Beauty.

large fruited variety, fully ten days to $t w o$

Weeks earlier than the mproved

ground and grow in well rounded bushes.

The fruit is large, thick and attractive.

fruit sets most freely and develops re-

markably quick, so that the entire crop a frost Pkt, $10 \mathrm{c}$, $1 / 2 \mathrm{z}, 25 \mathrm{c}, 0 \mathrm{z}, 40 \mathrm{c}$. $1 / 4 \mathrm{lb}, \$ 1.25, \mathrm{lb} . \$ 4.00$.

New York Improved. Large, dark purple. Pkt. 10c., 0z. 30c., 1/4 lb. $\$ 1.00,1 \mathrm{~b} . \$ 3.00$.

Black Pekin.

Black. f i n e delicate flavor, Pkt. 10c., oz. 20c., $1 / 4 \mathrm{lb}$.

Early Long Purple. v e ry Fruit long dark rich purple. Pkt. 5c. Fruit long, dark rich purpl
oz. $20 \mathrm{c}$., $-1 / 2 \mathrm{l}$ lb. $60 \mathrm{c}$., $\mathrm{lb} . \$ 2.00$.
ENDIVE.

This plant furnishes an attractive and appetizing salad for the fall and winter months, or by repeated nearly all the year round.

Green Curled. Leaves cut or laciniated, giving the plant a rich mossy appearance which is greatly enhanced when the centers are nicely blanched. Pkt. $5 c$.
oz. 15 c., $1 / 4$ lb. 40c., 1 b. $\$ 1.25$.

White Curled. T $\mathrm{h}$ i $\mathrm{s}$ tiful variety does not need blanching to prepare it for use. Pkt. 5 c., oz. $15 \mathrm{c}$., $1 / 4 \mathrm{lb}$. $40 \mathrm{c}$., lb. $\$ 1.25$.

Batavian. Formslarge broad, thick leaves. Pkt. 5c.,
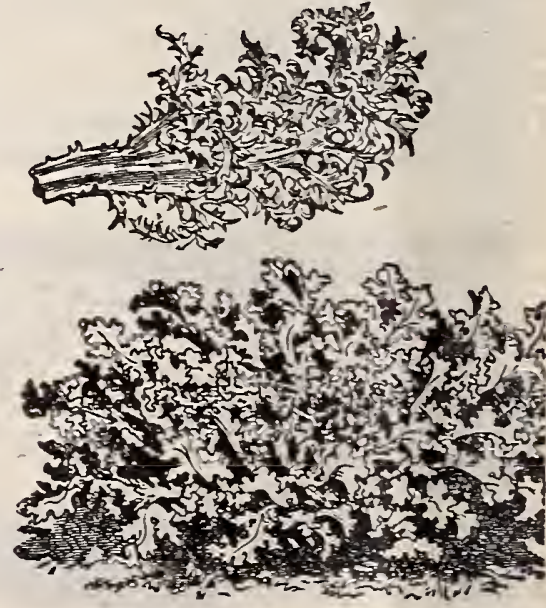

Endive, White Curled. 


\section{GROWN IN THE GOLDEN GRAIN BELT OF THE WORLD}

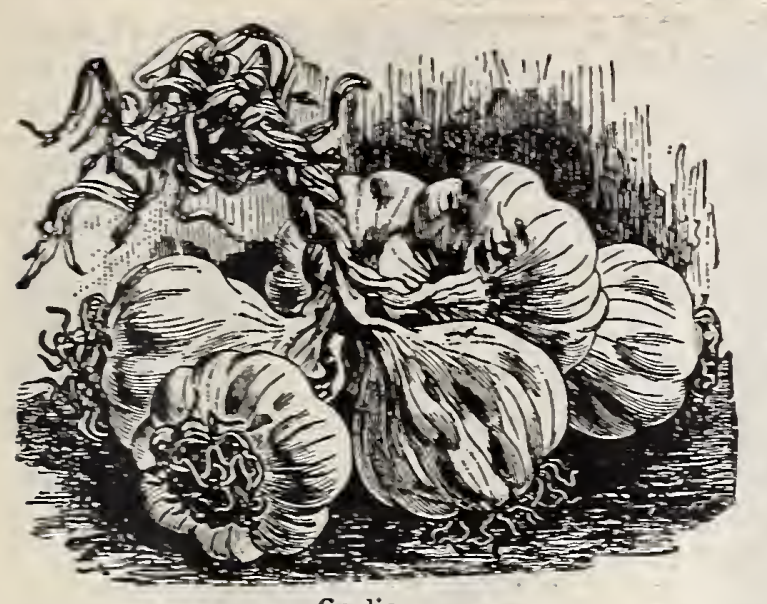

GARLIC.

The Garlic is the

most pungent in

taste and has the

strongest odor of

It is largely used

in the south of

esteemed for flavor-

ing soups, stews,

bulb is root or

of many $\mathrm{smal}$

bulbs, c alled

are planted in the

spring. Bulbs, per

lb. 30c., postpaid.

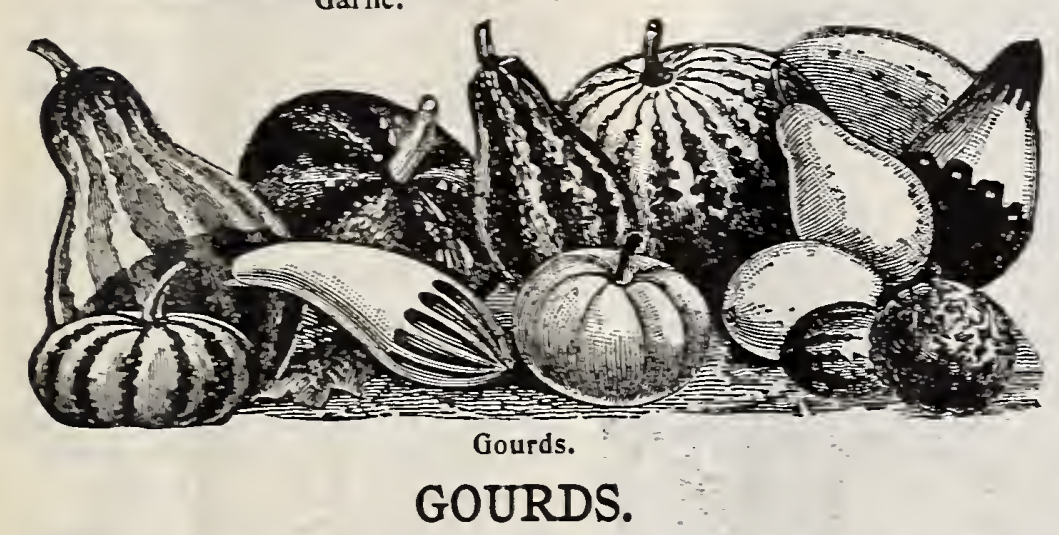

Japanese Nest Egg. These exactly resemble the eggs of ior to glass eggs, as they do not break. The plant is a rapid growing climber. Pkt. $10 \mathrm{c}$., oz. $25 \mathrm{c}$., $1 / 1 \mathrm{lb}$. $75 \mathrm{c}$.

Sugar Trough. Very useful for baskets, dishes, buckets, etc. and capable of holding from two to ten gallons each. Pkt. 10c., oz. 20c.

Dipper. Named for its resemblance to a dipper. The capacity varies long. They are convenient for dipping hot liquids, etc. Pkt. $10 \mathrm{c}$., oz. 20c. Dishcloth, or Luffa. A natural dishcloth, and a most adlining of this fruit, which is sponge-like, porous, elastic, and durable. They are also useful in the bath in place of sponges. Pkt. 10c., 0z. 35c.

Fine Mixed Ornamental. A collection of the most ornatled and striped, as shown in above cut. Pkt. 10c., 3 pkts. 25c., 0z, 40c.

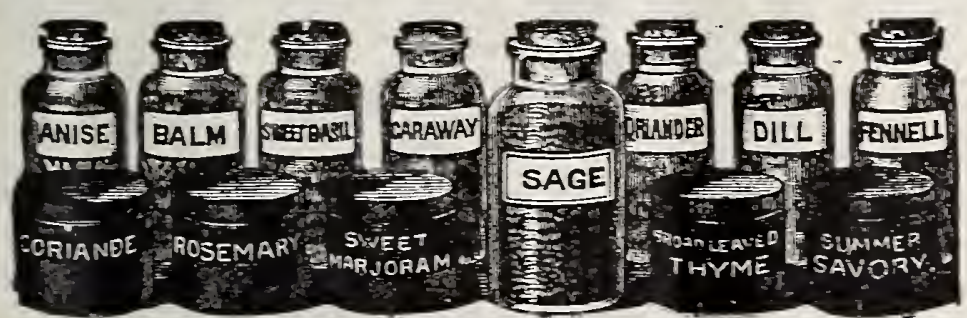

\section{HERBS, Pot, Sweet and Medicinal}

Save a corner of the garden for a few aromatic herbs. They thrive nicely along the sunny side of the garden fence, and they will require a deep and fairly rich soil. Thyme, Summer Sayory and Sage are great additions to sunny day, tie them in bunches and hang them up to dry.

\begin{tabular}{|c|c|c|}
\hline & Pkt & \\
\hline 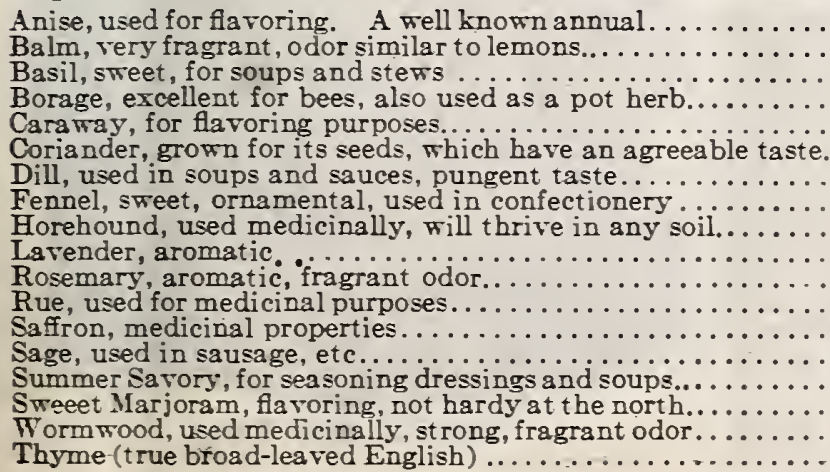 & $\begin{array}{r}\$ 0.05 \\
.05 \\
.05 \\
.05 \\
.05 \\
.05 \\
.05 \\
.05 \\
.05 \\
.05 \\
.05 \\
.05 \\
.05 \\
.05 \\
.05 \\
.05 \\
.05 \\
.05\end{array}$ & $\begin{array}{r}\$ 0.15 \\
.50 \\
.40 \\
.20 \\
.10 \\
.15 \\
.15 \\
.15 \\
.50 \\
.50 \\
.50 \\
.25 \\
.15 \\
.20 \\
.25 \\
.25 \\
.50 \\
.50\end{array}$ \\
\hline
\end{tabular}

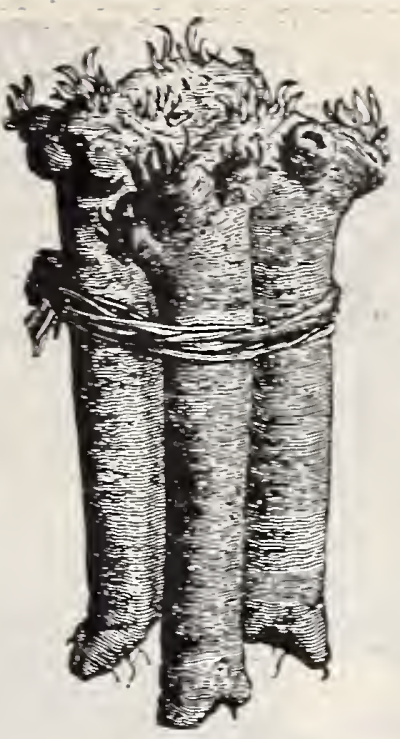

HORSE-RADISH. Dwarf German.

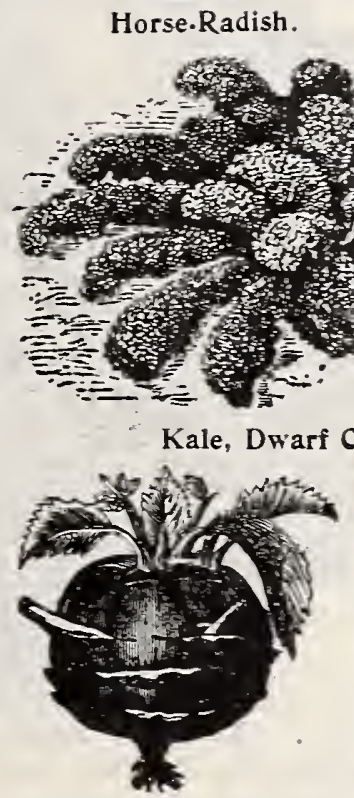

Kohl.Rabi.

Large Green

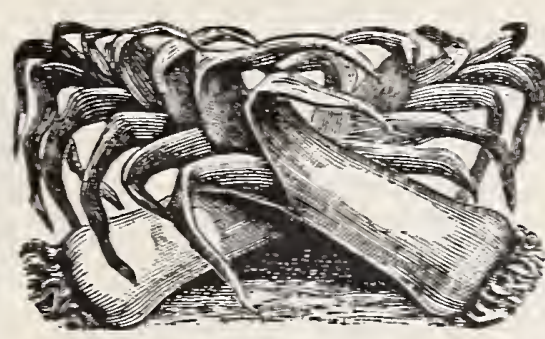

Leek, Exhibition.

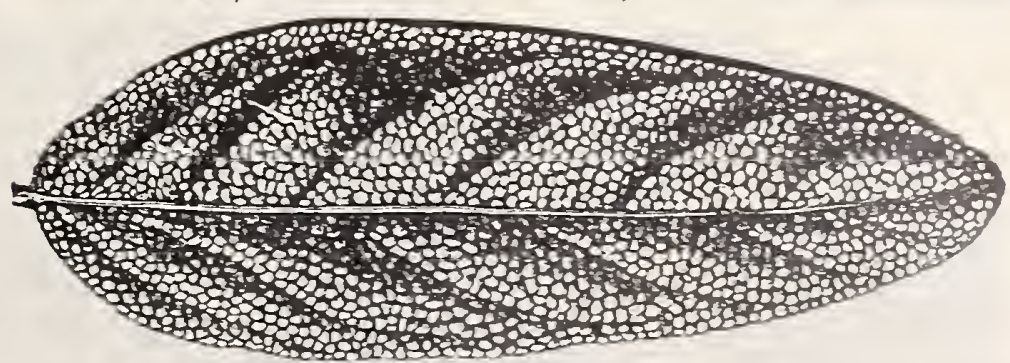

Sage, Holt's Mammoth.

HOLT'S MAMMOTH SAGE.

\section{KALE, or BORECOLE.}

Thales are more hardy than cabbage, the oz. 10c., $1 / 4 \mathrm{lb} .25 \mathrm{c}$

Dwarf Curled Scotch. Usually sorn green. Pkt. 5 c. oz, 10c., $1 / 2$ b. $25 \mathrm{c}, 1 \mathrm{~b}, 75 \mathrm{c}$. Tall Scotch. Folideeply fringed, color rich green, grows about 30 $10 \mathrm{c}$., $1 / 4 \mathrm{lb} .25 \mathrm{c}$., $1 \mathrm{~b} .75 \mathrm{c}$.

KOHL-RABI.

Kohl-rabi is grown for its turnip-shaped bulb, of the stem. The bulb should be used while
young and tender, as age detracts from its good

Early White Vienna. oz. 20c., 1/4.1b. $50 c_{1}$. Early Purple. Very similar to the late variety, largely gro

\section{LEEKS.}

May's Exhibition. Broad Flag. The gar-

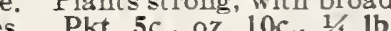
$30 \mathrm{c}$., lb. $\$ 1.00$
The illustrati
growling, the frst season attaining thee feet in diameter.
(he soll, keeping the
even in New England, and attains still larger growt
$25 \mathrm{c}$., postpaid. By express, 50c. per dozen.
THE GREAT CURIOSITV 


\section{C? MAY'S NORTHERN GROWN SEEDS BEST FOR ALL CLMES \&}

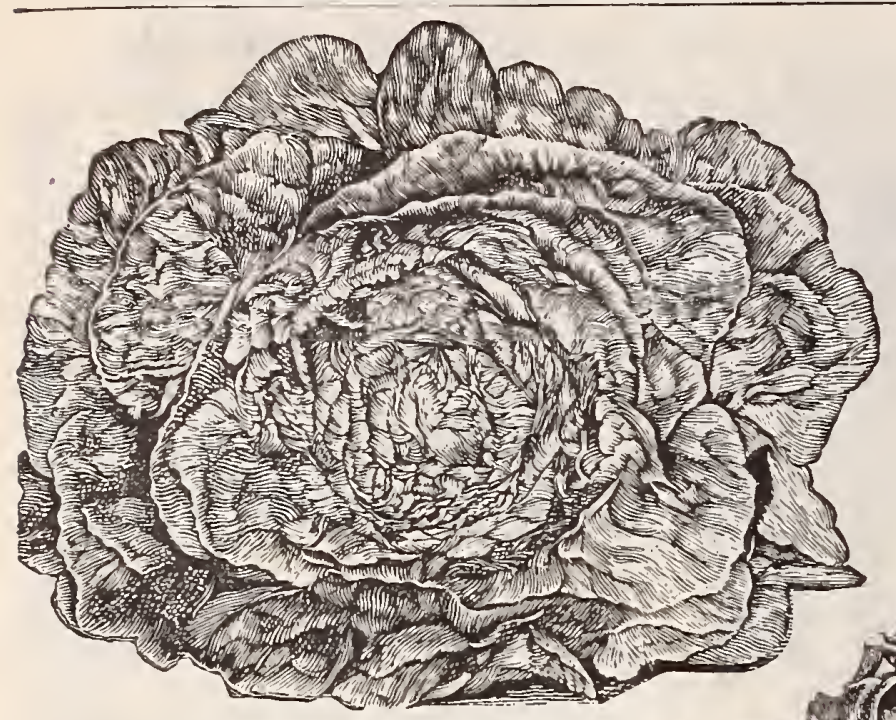

Iettuce, Nansen's North Pole. Axte

LATTUCT THE MOST USED OF ALL SALADS. Nansen's North Pole. ing nicely balanced, crisp, buttery lettuce round, or in cold frames; also desirall supply. Equally as sure lar quality, but fully a week to 10 days earlier. The plants are compact, producing solid, well folded heads 6 inches in diameter. The leaves are crisp, tender and of a mild, sweet flavor. Prt. 5c., oz. 10c., 1/4 1b. 30c., 1b. $\$ 1$. Maximum. A wonderfully heat-resisting Lettuce, remaining a long 政 the plants are of strong, vigorous growth, the large globular head. Pirt. 5c., oz. 10c., $1 / 4$ 1b. 30c., $1 \mathrm{~b}$. $\$ 1.00$.

Early Challenge. (See cut.) A splendid head variety for home garden or marketing. As a head lettuce this is is one of mense heads of a beautiful apple green shade. It matures quickly and is

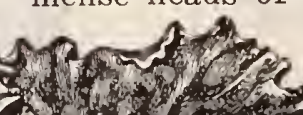
Wonderful.

to 3 poun Prt. 5c., oz. 10c., $1 / 4$ 1b. 25c., 1b. $90 \mathrm{c}$ Butter Cup.

round distinct variety. Pirt. 5c., oz. 10c., $1 / 4$ May's Market Gardener. other kinds. A variety that is unusual for size and solidity of head, and seed. Blanches itself naturally, is always free from bitterness. Outside inside a yellowish white. Prt. 10c. LETTUCE-STANDARD LIST.

AII CREAM-H DETROIT MARKET-

GOIDEN GATE-

HANSON'S-Very large,

NEW YORK IMPROVID-

PHILADEIPHIA BUTTER

PRIZE HEAD-La

SIMPSON-

SIMPSON-

TENNIS BAII

TENINIS BAIT

MAMMOTE BUTTER-F

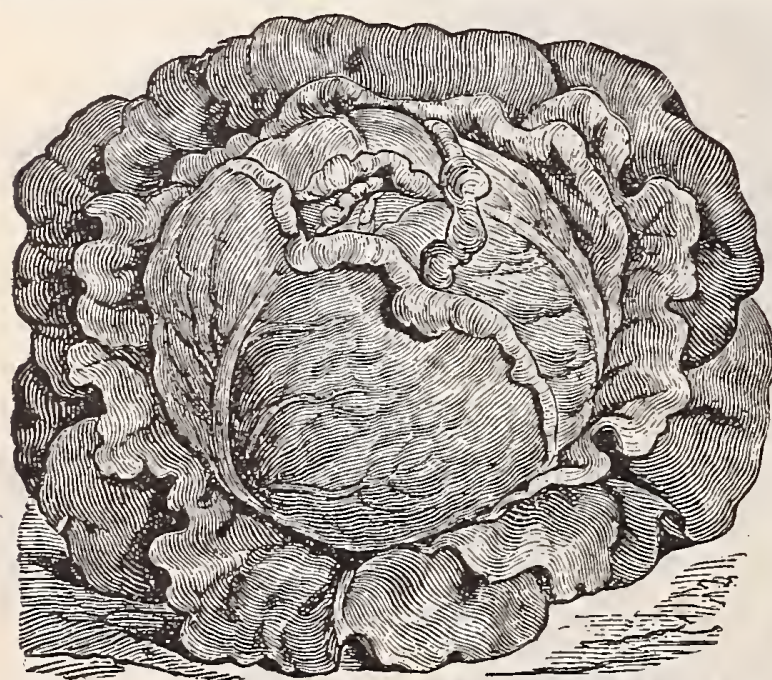

Iettuce, Big Boston.
Big Boston. Fine forcing variety for ter months; produces heads of very large size, often 12 inches across, and succeeds better in a cooler temperature than most quality. It heads well also in the open and fall, and is very popular in the seeds is an extra selected strain. Plrt. May King. A recent variety of great planting in the open ground it is unequaled. Extremely hardy, it is very ly folded that the plant is practically all head. Of rich, buttery substance, outer with brown; inner leaves are bright yelvor. The round compact heads are very solid, so that they will carry well to Plt. 10c., 0z. 25c., 1/4 1b. 60c., 1b. \$2.00. it retains its bright, fresh appearance longer than almost any other less or bitter with a ge. Plat. 10c., oz. 15c., $1 / 4$ 1b. 30c., 1 b. $\$ 1.00$. Denver Market. Large conicfinest quality; leaves light golden green, beautifully savoyed. Pkt. Grand Rapids. Does not form makes large compact bunches of light leaves with fringed edges: its delicious quality and handscme appearance make it most popul in winter markets prt. 5c., oz. 15c., 1/4 lb. 40c., 1b. \$1.25. COS LETTUCE.

Early White Self-Folding. Grows to very large size, producing long, pointed, cuinpact bunchTrianon. The first of all the blanched are stiff like leaves, wh en and can be eaten in the same manner Plit. 5c., oz. 10c., $1 / 4$ 1b. 35c., 1b. \$1.25.

Iettuce, May's Early Challenge.

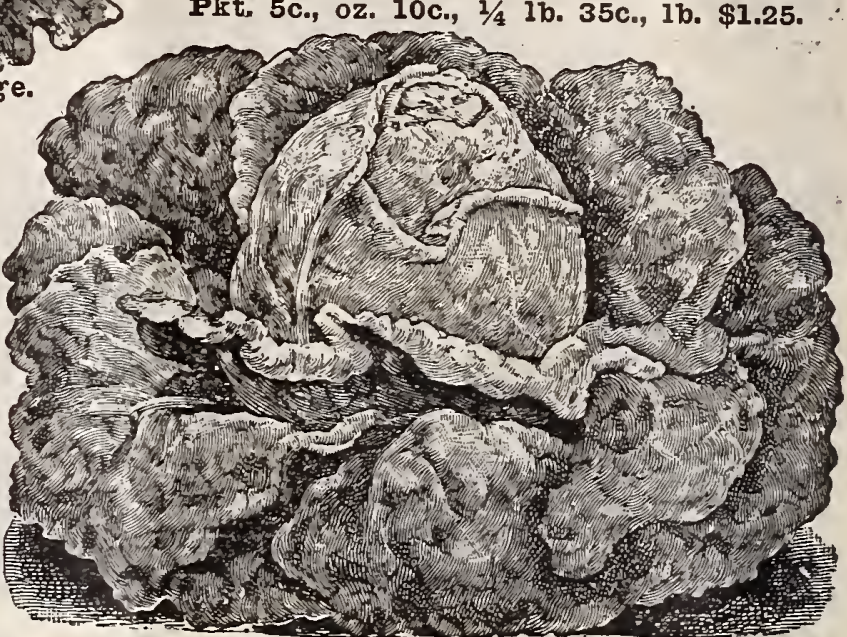

ILaximum I ettuce.

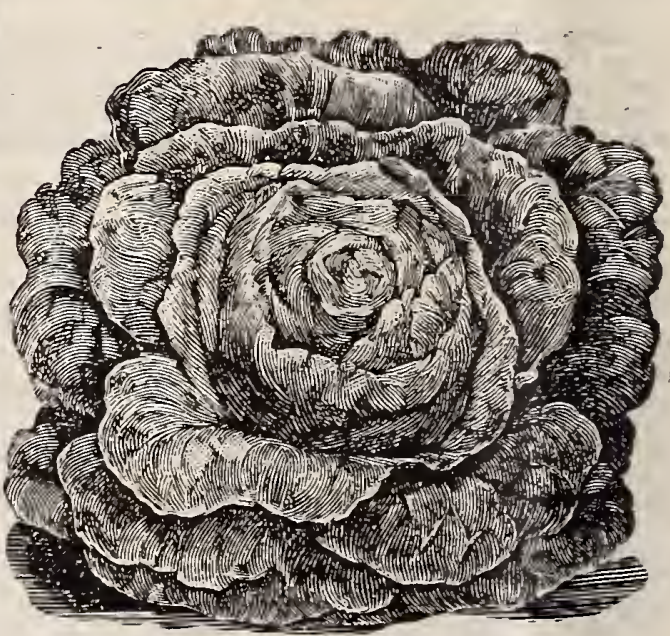

Iettuce, May King. 


\section{GROWN IN THE GOLDEN GRA IN BELT OF THE WORLD}

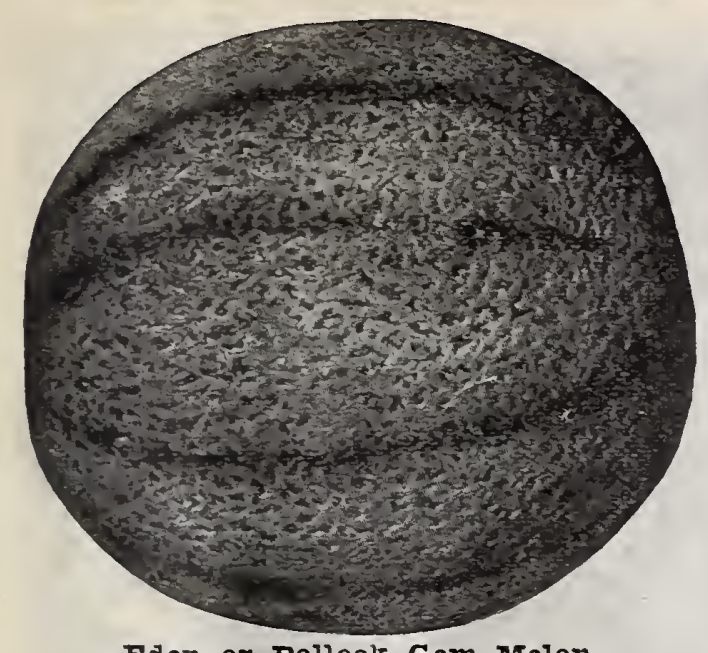

Eden or Pollock Gem Melon.

\section{MUSK MELONS.}

Cream List.

Eden or Pollock Gem. Originated at Rockyford. It is the best of all the different strains of Tetted Gem Canteloupes grown in Rockyford. The flesh is light green in color, ripens close to the rind and surpasses all in quality and fla-
vor. A splendid shipper. Plit. 10c., oz. 20c., 1/4 lb. 60c., 1b. \$2.00.

Rocky Ford. A sweet, luscious melworld famous for its captivating flavor. nutmeg is prominent, and light in color: the flesh is very deep, ripening clear to the rind, and it has a rery small seed atmost care in selecting our seed of this variety, looking well to shape, size, solidity, depth of flesh, seed cavity, color of flesh and qual-

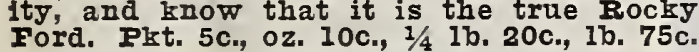
Rocky Ford (Yellow Flesh).

Plst. 10c., oz. 30c. 1// 1b. $\$ 1.00,1 b . \$ 3.00$. May's Netted Gem. They ripen extra early, and grow to flesh is thick, sweet, juicy, fine grained and of a light green, and heavily ribbed and netted. Plit. 5 c., oz. 15 c., $1 / 4$ 1b. 35c., 1b. $\$ 1.25$.

The Grand. A splendid melon, 10 to 14 dars Muskthan the Osage or Hybrid under the same conditions flesh salmon colored, and in flavor and quality equals any variety; grows more uniform than any other sort in size, flator, color and depth of eraging about 6 inches in diameter. Pkt. 10c., 0z. 25c., $1 / 4$ Ib. 75 c., $1 \mathrm{~b} . \$ 2.50$.

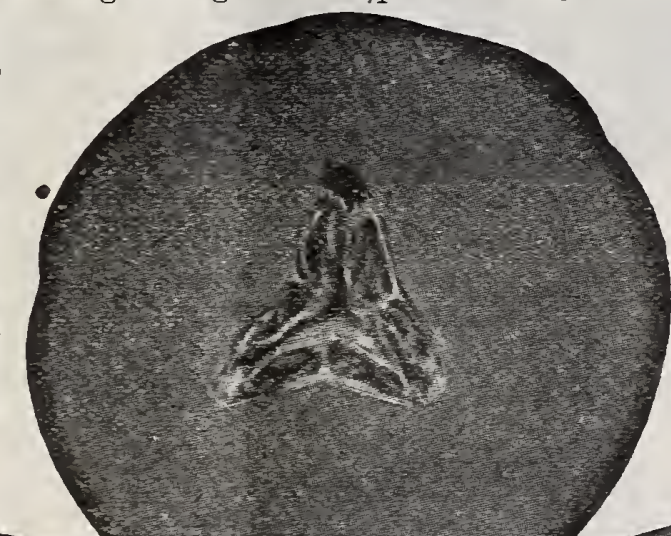

MUSK I BANOUBi.

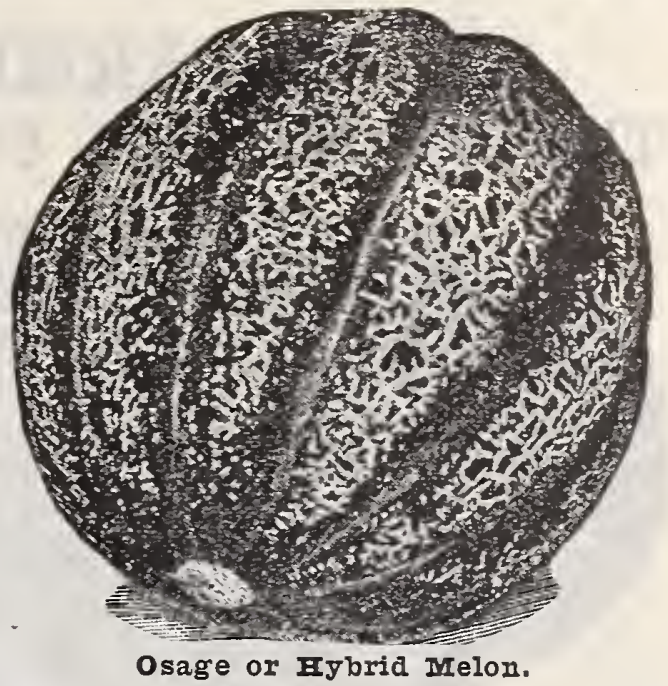

Lewis Perfection Shape nearly blossom end as on the side: erage weight 15 lbs.' Pkt. 10c., 0z. 20c., 1/4 1b. $60 \mathrm{c}$

Osage or Hybrid. One of the most ties, both for the market and home garden. Fruits are of good size, the skin is dark green, banded with lighter streaks. The flesh is of orange color, thick, firm 5c., oz. $10 \mathrm{c} ., 1 / 4 \mathrm{lb}$. 30c., $1 \mathrm{~b}$. $\$ 1.00$. Yellow Meated Japan. The flesh fine-grained rich deep yellow and of the highest flavor. Very popular with marhigh price on the market. Pkt. 5c., oz.

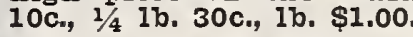
extensively grown of all Musk Melons. Flesh green, rich and sugary. This is a selection of the popular Hackensack, ripening fully 10 days earlier. Melons of $\operatorname{lin}_{1 / 4}$ 1b. 30c., 1b. $\$ 1.00$. green until it begins to ripen, when it ket gardeners, as it always commands a

Hackensack, Extra Early. Th $\mathrm{h}$ o good size, hearily ribbed and netted, makMLLONS---Standard List. ACME or BAITIMOR CITRON. Flesh a rich salmon.......... 10

DFFry Extra early, green.

DARIY GREFY NUTMEG.

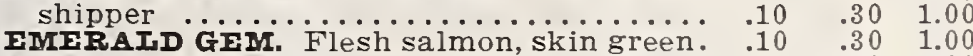
NORFOIK BUTTON. Green flesh, early.. $\quad .10 \quad .30 \quad 1.00$ PAUL ROSE OY PETOSKEY. MONTREAI NUTMEG. Large, grien flesh WINTER PINEAPPIE. LOngest keeper. WHE MIELON PEACF or MANGO

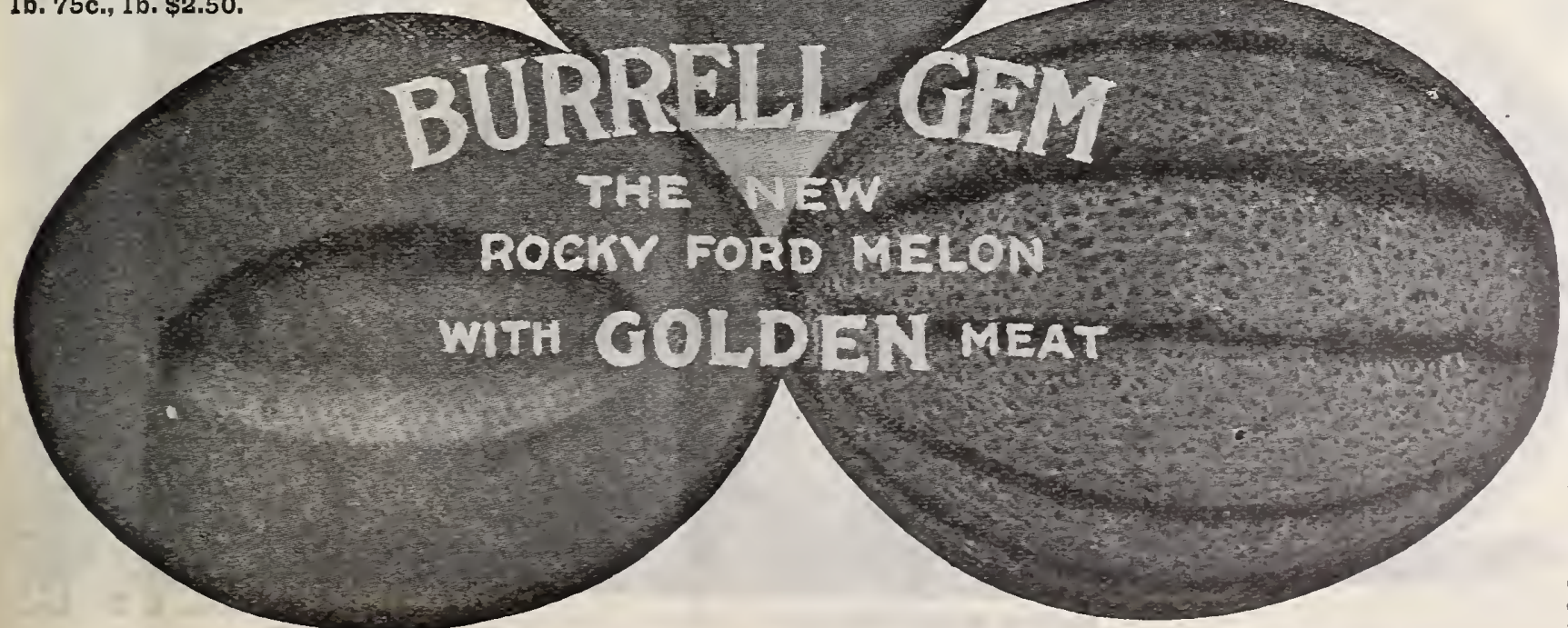
Burrell Gem. i d An market $\mathrm{Telon}$, shape

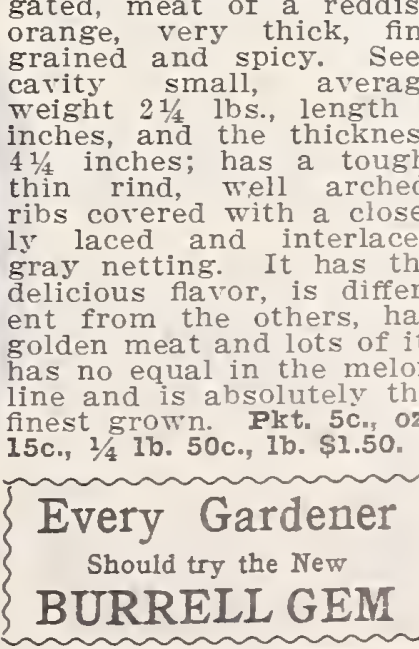




\section{6 乌 MAY'S NORTHERN GROWN SEEDS BEST FOR ALL CLMES Eु}

\section{WATERMELON.}

The Best New and Standard Varieties.

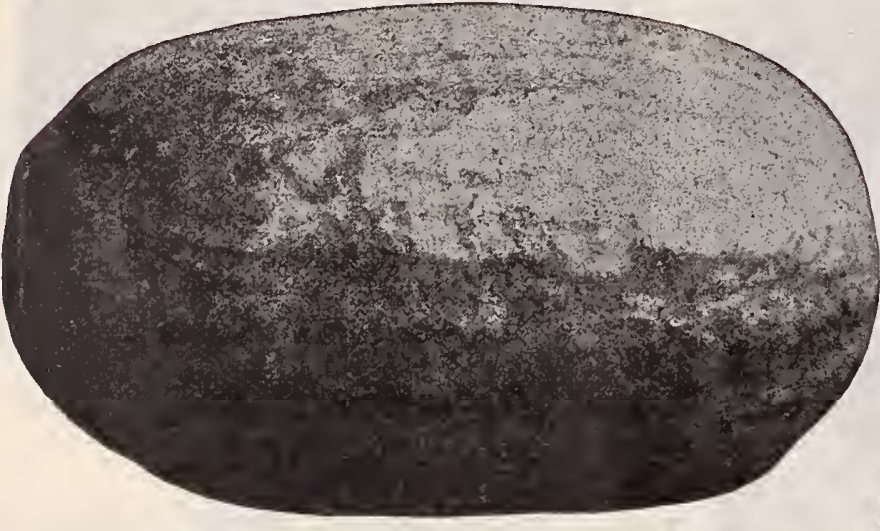

Watermelon, Snow Bound.

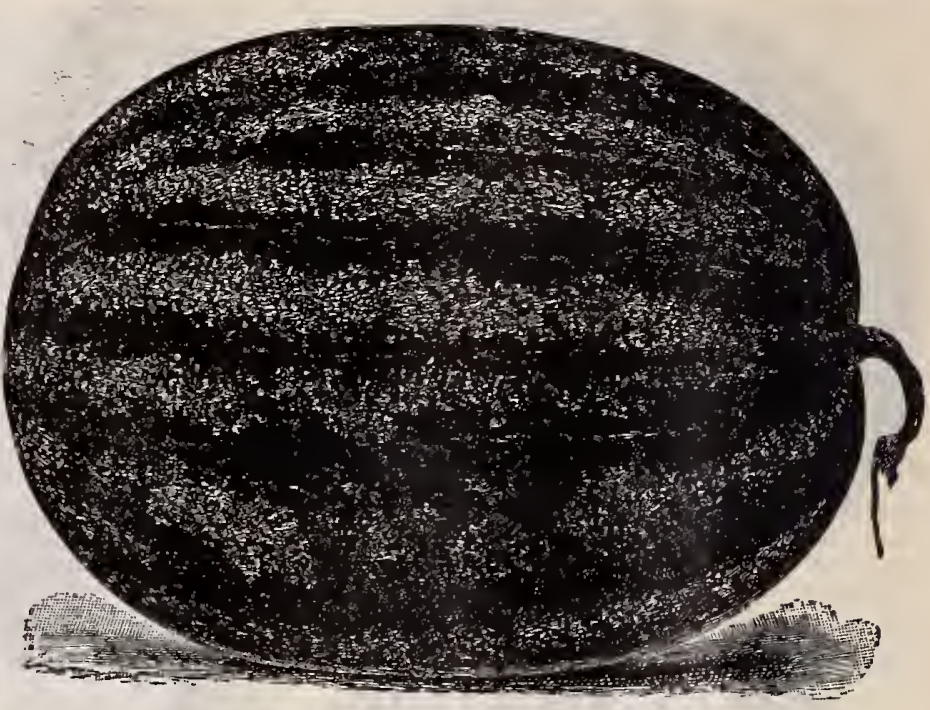

May's Ice King Watermelon.
Snow Bound. So named because it is like Whittier's of all. A very 50 pounds each Skin gray or a light green color, flesh deep red, tender and sweet. Pit. 10c., oz. 15c., 1/4 1b. 35c., 1b. $\$ 1.00$.

Black Diamond. A cross between Hoosier King. No melon ever yet pro proached it in productiveness. Melons weighing from $\mathbf{7 5}$ to 90 pounds are frequent. Color, rich, dark green, almost black. Symmetrical in shape, round$25 c$., $1 b$. 75c.

Fordhook Early. The fruits are rather short and blockey in form, with large diameter. The skin is dark green. The flesh is bright red, crisp, sweet and of splendid quality Rind quite thin, but skin tough, making an. oz. 10c., $1 / 4$ 1b. 25c., 1b. $75 \mathrm{c}$

Halbert Honey. One of the finest the home garden, fully equal in delicious flavor to the celebrated Kleckley in color and shape, being free from any green, flesh beautiful crimson. Pkt. 5c., oz. 10c., $1 / 4$ 1b. 25c., 1b. $75 c$.

Safeguard. The earliest large vari-

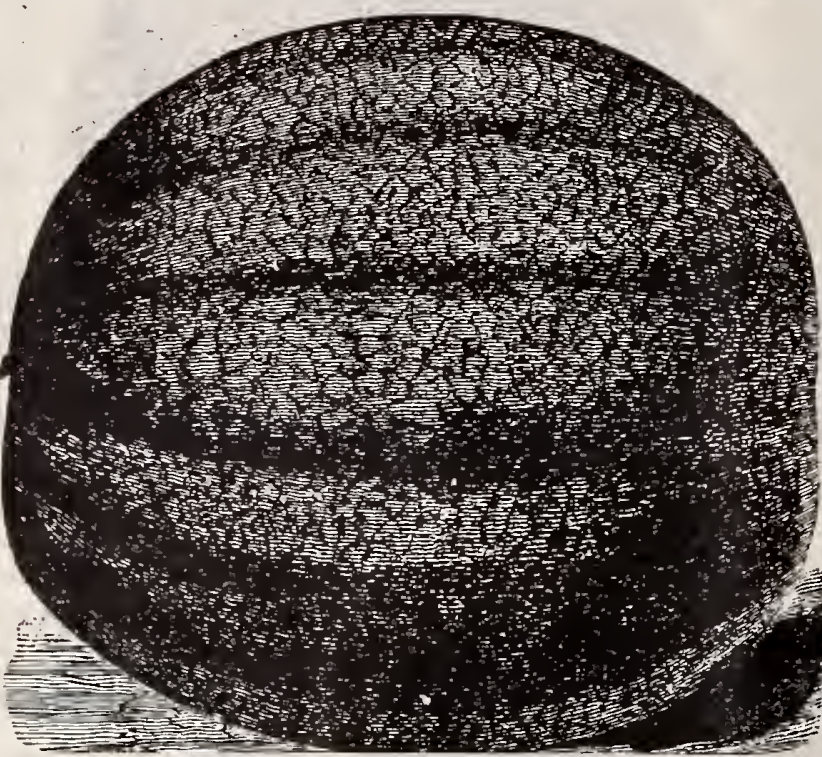

Water Melon, Fordhools Early
May's Ice King. (See cut.) The best flavored variety ever The best shipper and most productive variety ever offered. Will stand almost any amount of rough usage, and therefore valuPkt. 10c., 0z. 15c., 1/4 Sweetheart Vine vigorous and its fruit productive, ripening heavy, uniformly mottled, light and dark green, rind thin but firm flesh bright red, firm and solid, but very tender, melting and sweet. Pkt. 5c. oz. 10c., $1 / 4$ 1b. 25c., 1b. 75c.

Kentucky Wonder. Large, obgreen, beautifully marked, crisp, rich, sugary. Plkt. 5c., oz. 10c., 1/4 1b. 25c.,

True Ice Cream. The great has too thin a shipping. Few, if any, surpass a rrue Ice Cream for quality and productiveness. Flesh bright scarlet, solid to center, melting and delicious. Pkt. 5c., oz. 10c., $1 / 4$ 1b. 25c., $1 \mathrm{~b}$. $75 \mathrm{c}$.

Florida Favorite. A splendid obdays earlier than Kolb's Gem; flesh red, of fine flavor and quality. Pkt. 5c., oz. 10c., 1/4 1b. 25c., 1b. 75c.

Alabama Sweets. A grand new equal to Icing. Kleckley and Florida favorite in Iuscious quality. shape long: dark green, continuous bearer. Pkt. 5c., oz. 10c., 1/4 1b. 25c., 1b. 75 c.

Sugar or McIver. Medium size, with striped or variewer flesh and

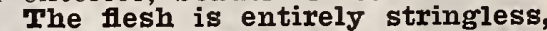
and of perfect quality as to texture and sweetness. The vines are strong, thrifty and prolific and well adapted to withstand either wet weather or drought: either wet weather or drought; extensively grown in the North and South; best results in all sec1b. $75 \mathrm{c}$.

Kleckley's Sweet. I a rge melon, 20 inches in inches in diameter. The skin is dark green, flesh bright scarlet, rind $1 / 2$ inch in thickness. The scarlet flesh is sweet and sugary; leaves no strings of pulp whatever in eatpulp whatever in eating. We the table melon the best table melon today. Pkt. 5c., oz. 10c., $1 / 4$ 1b. 25c., 1b. $75 \mathrm{c}$. Citron. $\mathbf{P}$ o 1 o $\mathbf{x}$ a do Makes beautiful, nearly transparent preserves of unsurpassed flavor; superior to the ordinary preserving citron in quality. Pkt. 1b. $75 \mathrm{c}$. 


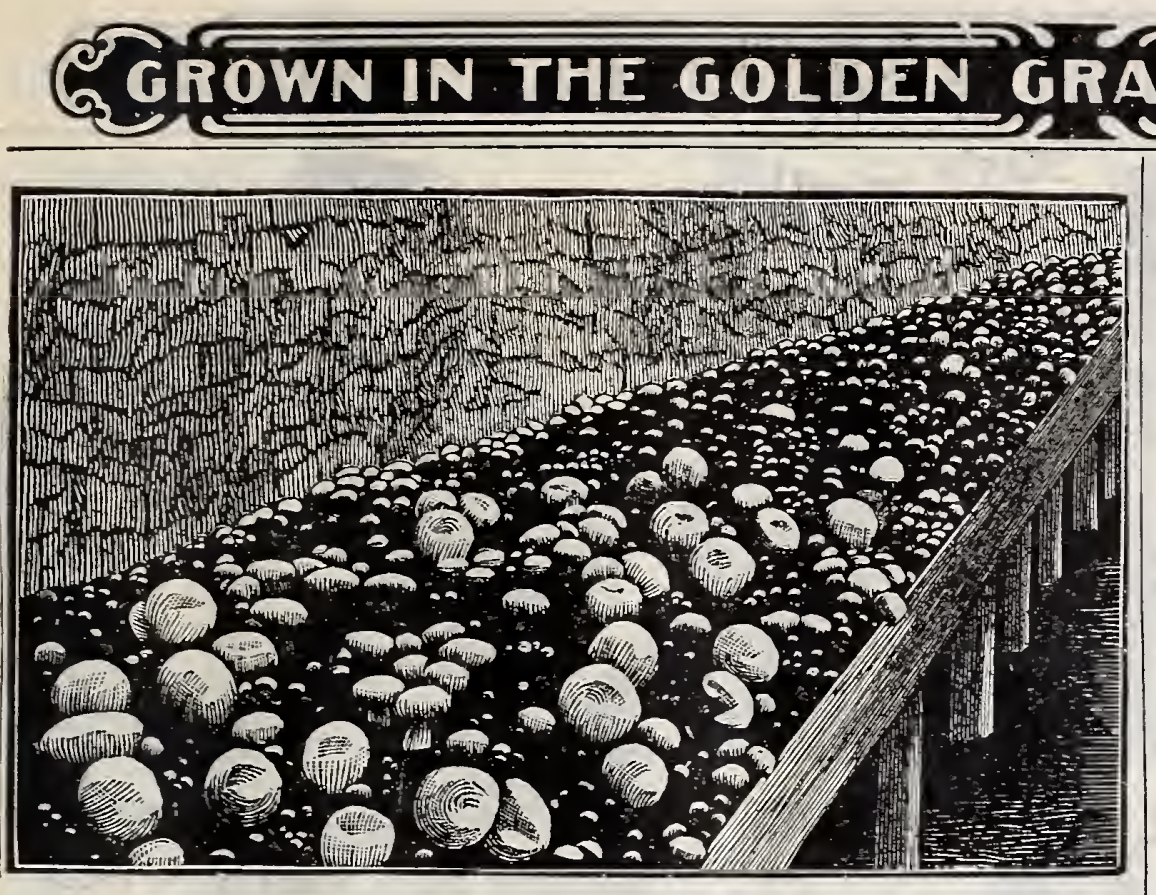

\section{MUSHROOMS.}

Pure Culture Mushroom Spawn. This is prepared by an and is far more productive than the English and French Spawn. By a scientific selection of large mushrooms for propagating purposes a mew type has been developed, possessing the following points of flavor is finer; they are more productive and come to maturity earlier. Spawn usually sold has been prepared for months, much of its vitality being spent before it is planted. This spawn, however, is if cultural instructions are followed. This spawn comes in bricks Weighing 18 to 20 ounces each. Price per brick by mail, postpaid, bricks \$4.25. Prices on larger lots quoted on application. customers on request. Do not fail to ask for it.

\section{ONION SEED-SELECTED STRAINS.}

Prizetaker. (American grown.) The large, nearly globe-shaped Onions, with thin skin of bright straw color, are of immense MUSTARD. $\mathrm{N}$ e w Chinese. A giant curled varible the size of the or10c., $1 / 4$ Plk. $25 \mathrm{c}$., $1 \mathrm{bz}$. White Leaves are mild and tender when young.
$100 ., 1 / 4$
$1 \mathrm{~b}$. Brown or Black. More pungent in fla Plit. 5c., oz. 10c., $1 / 4$ 1b. 15c., 1b. 40 c.

Southern Giant Curled. Very highly esteemed in a salad. Seeds brown in color. Produces plants ab. 60c.

\section{OKRA, or GUMBO.}

White Velvet. Of tall growth, with
are perfectly round, smooth, and which
velvety white coloring. Plyt. 5c., oz . $1 / 4$ 1b. 20c., 1b. 60c.

Mammoth Green Pod.

Pikt. 5c., oz. 10c., 1/4 1b. 20c., 1b. 60c.

Dwarf Green.

5c., oz. 10c., $1 / 4$ lb. 20 c., $1 \mathrm{~b}$. $50 \mathrm{c}$.

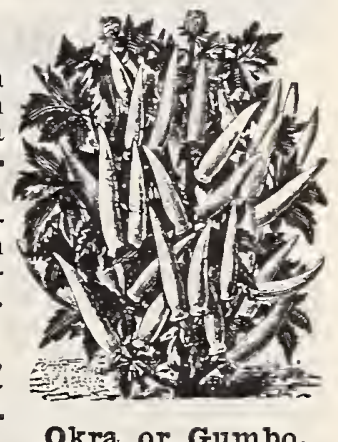

Okra or Gumbo.

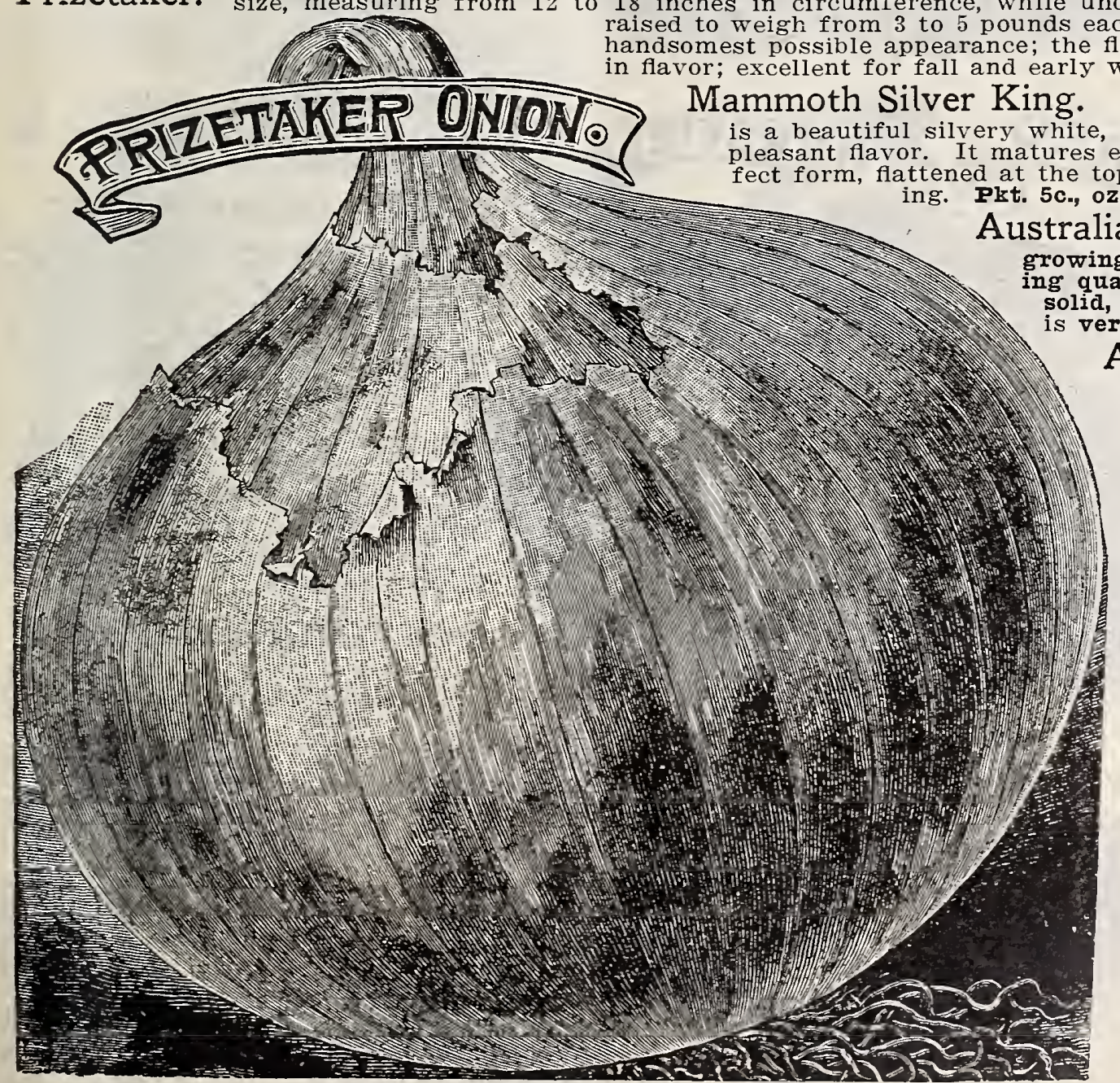




\section{'8 MAY'S NORTHERN GROWN SEEDS BEST FOR ALL CLIMES \&}

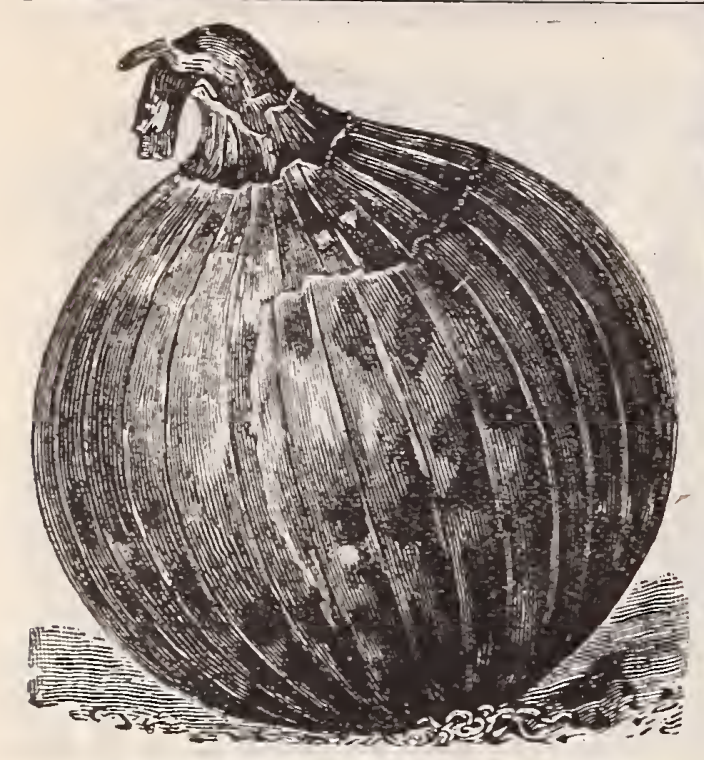

Southport Iarge Red Globo Onion.

\section{May's}

Minnesota Grown

\section{ONION SEED.}

The wide popularity of Onions grown from this seed is well proven by the largely increased sales with which we are favored jear after jear.

table life is dereloped the stronger, haris especially true regarding Onions grown from our Minnesota seed. They are earlier, hardier, finer flavored, better co

firmer and in every way superior. Tre results. In no vegetable does the value of the crop raised depend more directly on the QUAIITY of seed than the Onion.

$+1+1+1+1+1+1+1+1+1+1+1+1+1+1+1$

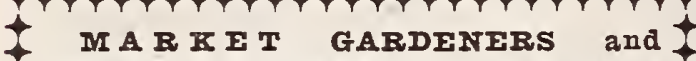
$\succ$ ONION GROWERS who use large quantities of Onion Seed will please trite for WHOIESAII PRICES.

$+1+t+1+t+1+t+1+t+1+t+1$

Red Wethersfield,. May's

Selected. We confidentiy recomfavorite Onion as the very best. Pkt. 5c., 0z。20c., 1/4 1b. 70c., 1b. $\$ 2.50$.

May's Red Wonder. I m strain that by actual tests has weeks ahead of Red Wethersfield. it to the large growers, but in adare many others, such as fine shape, good flavor and wonderful keeping 70c., 1b. $\$ 2.50$.

Red Flat. $65 \mathrm{c}$. $1 \mathrm{~b}$. $\$ 2.40$.

Red Globe, Southport. P r oduces globe-shaped bulbs of handsome appearis probably no other red variety which exceedingly attractive. The flesh is solid,
fine grained, mild and tender. In addition the 5c. oz 25 ., $1 / 4$ 1b. 90c., $1 \mathrm{~b}$. $\$ 3.00$.

White Globe Southport. This strain duce handsome, globe-shaped, white bulbs 5 c., oz. $40 \mathrm{c}$., $1 / 4 \mathrm{lb}$. $\$ 1.40$, 1b. $\$ 5.00$.
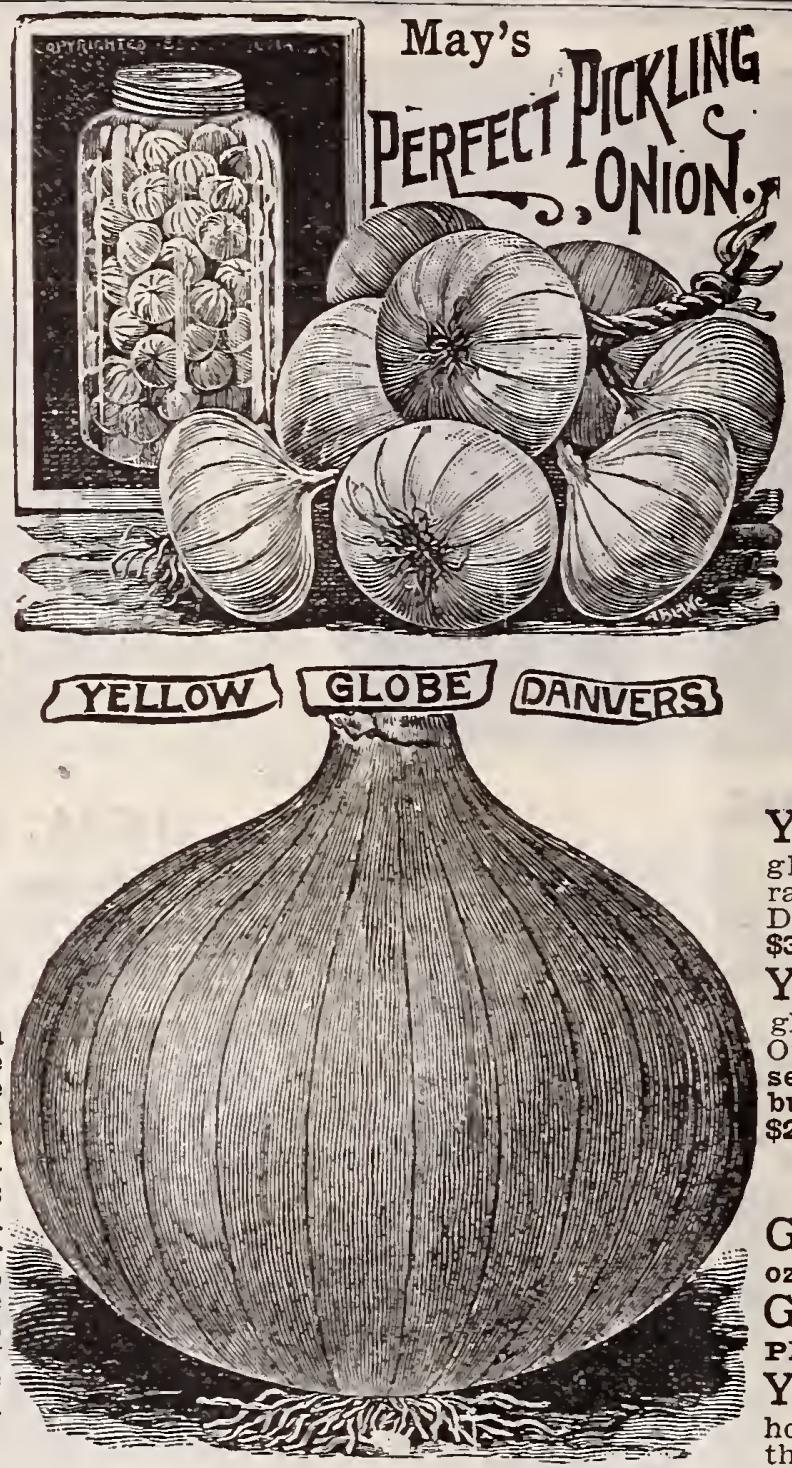

Southport Iarge White Globe Onion.

Yellow Globe Southport. M a kes globe-shaped bulbs, larger in size and rather lighter in color than the Globe Danvers. Pkt. 5c., 0z. 25c., 1/4 1b. 90c., 1b. Yellow Globe Danvers. I a r g e globe-shaped small neck a first-class Onion for either home or market use our seed is carefully saved from selected bulbs. Plat. 5c., oz. $25 \mathrm{c}$., $1 / 4 \mathrm{Ib}$. 75c., $1 \mathrm{~b}$. $\$ 2.75$.

Michigan, or Ohio Yellow

Globe. A large, pale-yellow onion of $0 z$. 25c., $1 / 4$ 1b. 90c., 1b. $\$ 3.00$.

Golden Globe. The earliest of all Globe-shaped onions. Pkt. 5c., 0z. 25c., $1 / 4$ Ib. 90c., 1b. $\$ 3.00$.

Yellows Danvers' Flat. A good home or market use. A trifle flatter than the XYellow Globe Danyers. Pkt. 5c., oz.

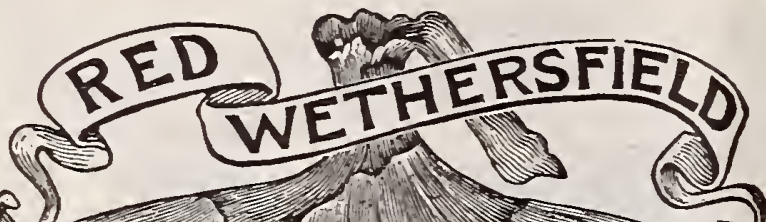
(3)

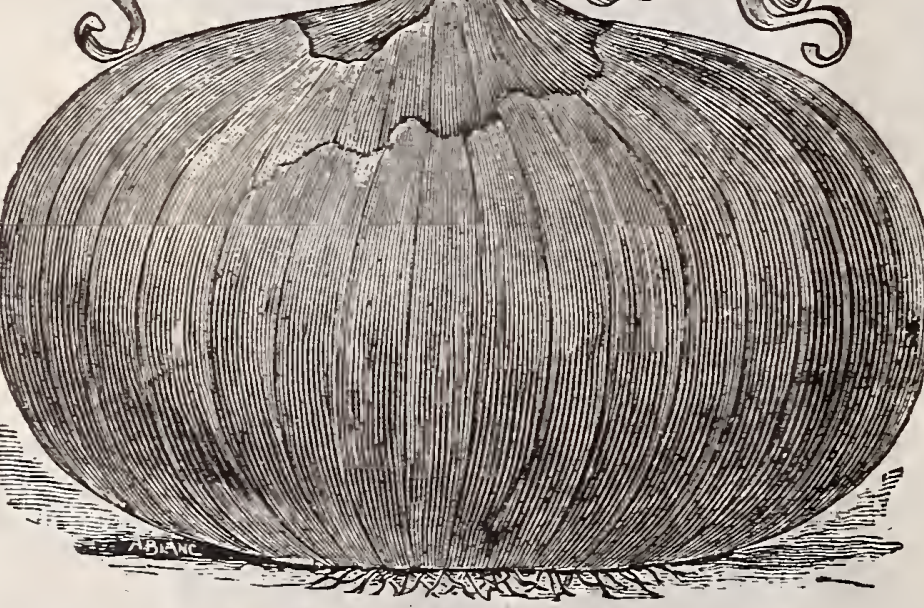

Yellow Strasburg. One of the varieties. Pkt. 5c., 0z. 25c., $1 / 4$ 1b. 75c., 1b. $\$ 2.75$.

May's Perfect Pickling.

Without doubt the best for pickling purposes. It grows rapidly, but remains small and is of the mildest slightly flattended and exceedingly bunching. Pkt. 10c., oz. 20c., $1 / 4$ 1b. 0c., 1b. $\$ 1.75$

White Portugal. L a r g ely pickling purposes when young. Pkt. 5c., oz. 40 c., $1 / 41$ b. $\$ 1.10$, 1b. $\$ 4.00$. White Pearl. Extra early. of mild flavor. Pkt. 5c., oz. $20 \mathrm{c}$., $1 / 4$ 1b. 50c., 1b. $\$ 1.75$.

BOTTOM ONION SETS.

These are the product of seed and are used for "Green Onions" or to

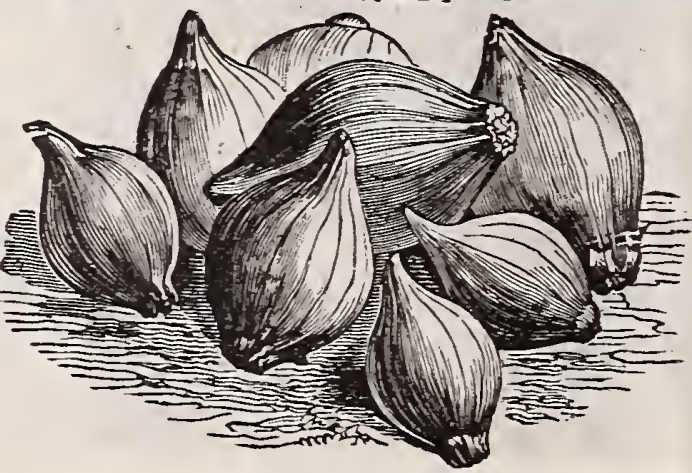

Bottom Onion Sets. produce larger Onions, which they slant Bottom onion Sets for first Treen Onions for table use. They produce grere from four to six weeks earlier than can be done by sowing seed.

Quart. Peck. Bush.

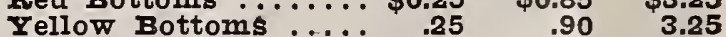
White Bottoms ....... $\quad .30 \quad 1.00 \quad 4.00$ Quarts sent by mail, postpaid; pecks and Notice-Prices by the bushel are subject to fluctuation of the market but the prices quoted on quarts, postpaid, will hold good throughout the season, or as long as ou 


\section{GGOWN IN THE GOLDEN GRAIN BELT OF THE WORLD}
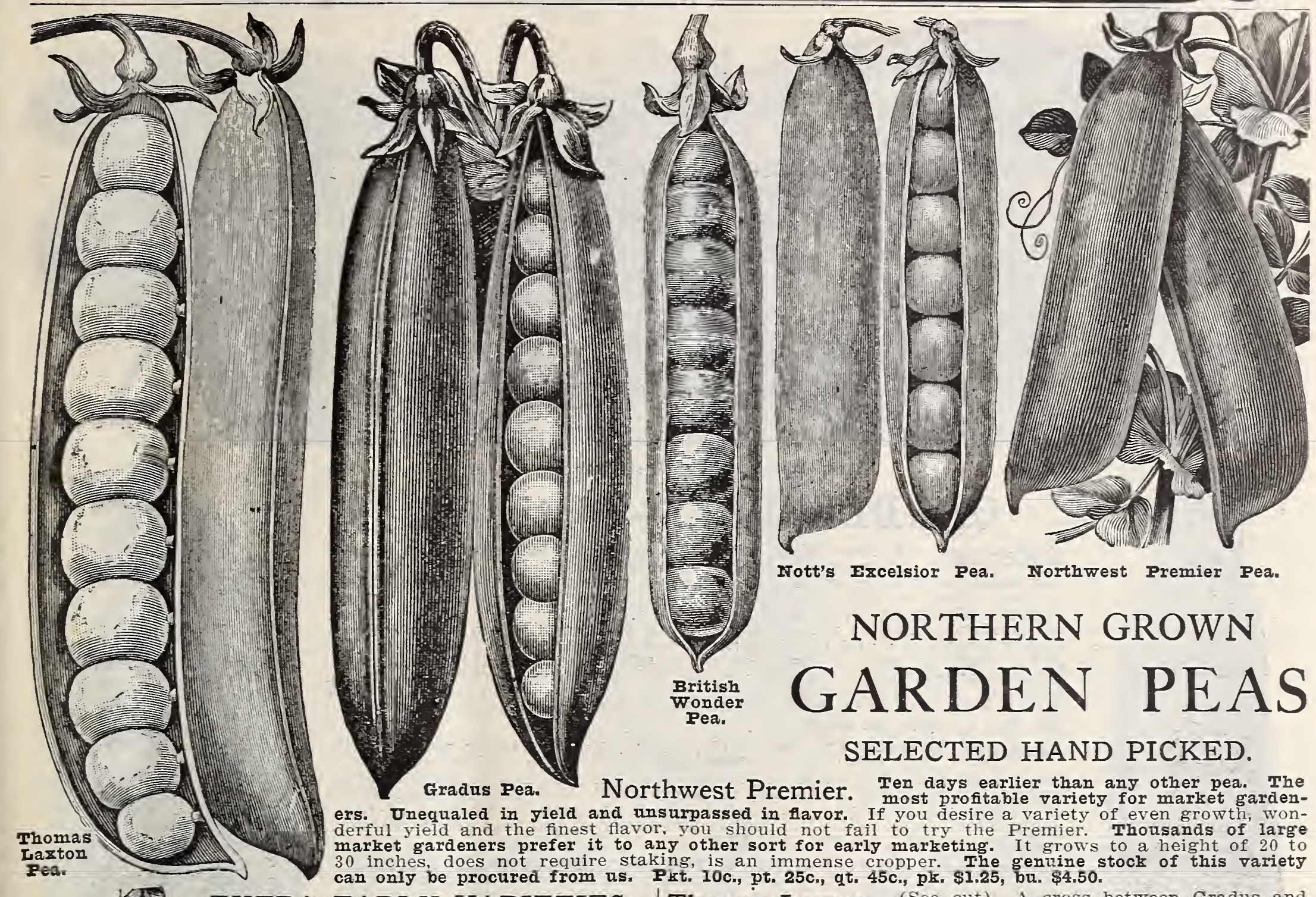

Nott's Excelsior Pea.

Northwest Premier Pea.

\section{NORTHERN GROWN}
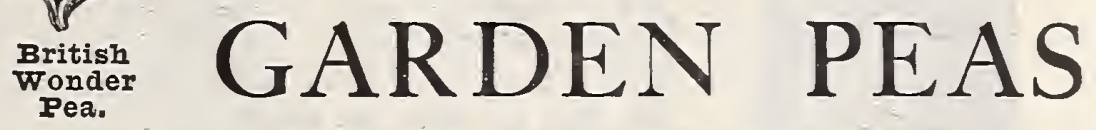

\section{SELECTED HAND PICKED.}

Northwest Premier. Ten days earlier than any other pea. The rs. Unost profitable variety for market gardenderful yield and the finest flavor, you should not fail to try the Premier. Thousands of large market gardeners prefer it to any other sort for early marketing. It grows to a height of 20 to 30 inches, does not require staking, is an immense cropper. The genuine stock of this variety can only be procured from us. Prt. 10c., pt. 25c., qt. $45 \mathrm{c}$., pk. $\$ 1.25$, bu. $\$ 4.50$.

EXTRA EARLY VARIETIES. Alaska. Extra early. 2 to $2 \frac{1 / 2}{2}$ feet in pods filled with medium sized peas. Plit. 10c., pt. 20 c., qt. 35 c., pk. $\$ 1.25$, bu. $\$ 4.50$.

First and Best. A vigorous grower, hardy grows about $21 \frac{1}{2}$ feet high. Plit. 10c., pt. 20c., qt. 35c., pk. \$1.00, bu. $\$ 3.50$.

\section{EARLY DWARF SORTS.}

American Wonder. Dwarf habit, only growing about 10 or fusion of well filled pods of the richest flavor: a great farorite for both market and home bu. $\$ 6.25$.

Tom Thumb. Very dwarf, height 9 inchround. Pkt. 10c., pt. 25c., qt. 45c., pk. \$1.60, bu. $\$ 5.75$.

McLean's Little Gem. The market gargrows about 15 inches high. the pods are large, and peas very sweet. Plrt. 10c., pt. 25c., qt. $45 \mathrm{c}$., pk. $\$ 1.35$, bu. $\$ 5.50$.

Nott's Excelsior. Grows 15 inches high, wrinkled sort ever introduced to be the best strong in growth, producing pods of large size. Plkt. 10c., pt. 25c., ๙t. 45 c., pl. $\$ 1.75$, bu. $\$ 6.50$. Premium Gem. A popular sort; grows very productive; pods large, well filled. Plrt. very productive; pods large, well pul. 25 c., qt. 45 c., pt. $\$ 1.35$, bu. $\$ 5.50$.

Surprise or Eclipse. One of the best of Peas. The vine grows 20 to 24 inches high,

Improved Tel- requin for the gardeners to grow. Plit. 10c., pt.
ephone.

Improved Tel- sorts for the gardeners to grow. Pkt. 10c., pt.
ephone. ephone.

Gradus. (See cut.) The pods are of large size and resemble of the finest flavor Telephone in shape, always well filled with peas soon as fit for use.
Thomas Laxton (See cut) A cross between Gradus and large containine from one of the extra early sorts. Pods are flavor. Pkt. 10c., pt. 25 c., qt. 45 c., pk. $\$ 2.25$, bu. $\$ 7.50$.

British Wonder Even sweeter in flavor than either Gradus Pritish Wonder. or Thomas Iaxton. It is a sure cropper. The vines grow from 15 to 18 inches high. The pods are progreen peas. Pkt. 10c., pt. 25c., qt. 45c., pk. $\$ 1.60$.

\section{MEDIUM AND LATE SORTS.}

Mayfield. The best main crop variety, grows 3 to $31 / 2$ feet quality and flavor. Pkt. $10 \mathrm{c.s}$ pt. $30 \mathrm{c}$., qt. $50 \mathrm{c}$., pk. $\$ 2.50$.

May's Midsummer. This variety should be planted by all season. Pkt. 10c., pt. $25 \mathrm{c} .$, qt. $45 \mathrm{c} .$, pk. $\$ 2.00$.

Horsford's Market Garden.

bearing pods in pairs. A very des

McLean's Advancer. A fine early market

of green wrinkled peas of delicious fiavor. It is also known as Dwarf Champion. Vines
$45 \mathrm{c}$. pk. $\$ 1.60$, bu. $\$ 6.00$.

Champion of England.

pt. 25 c., qt. 40 c., pk. $\$ 1.50$, bu. $\$ 5.00$.

Bliss' Everbearing.

of large, well-filled pods; peas of
25 c., qt. $40 c$., pk. $\$ 1.50$, bu. $\$ 5.00$.

Telephone.

flavor It is decidedly a market par

ket quicker than any other variets
$25 \mathrm{c}$., qt. $45 \mathrm{c}$., pk. $\$ 1.60$, bu. $\$ 6.00$.

Telephone Improved.

pk. $\$ 1.60$, bu. $\$ 6.00$. 


\section{${ }^{20}$ के MAY'S NORTHERN GROWN SEEDS BEST FOR ALL CLMES \&}
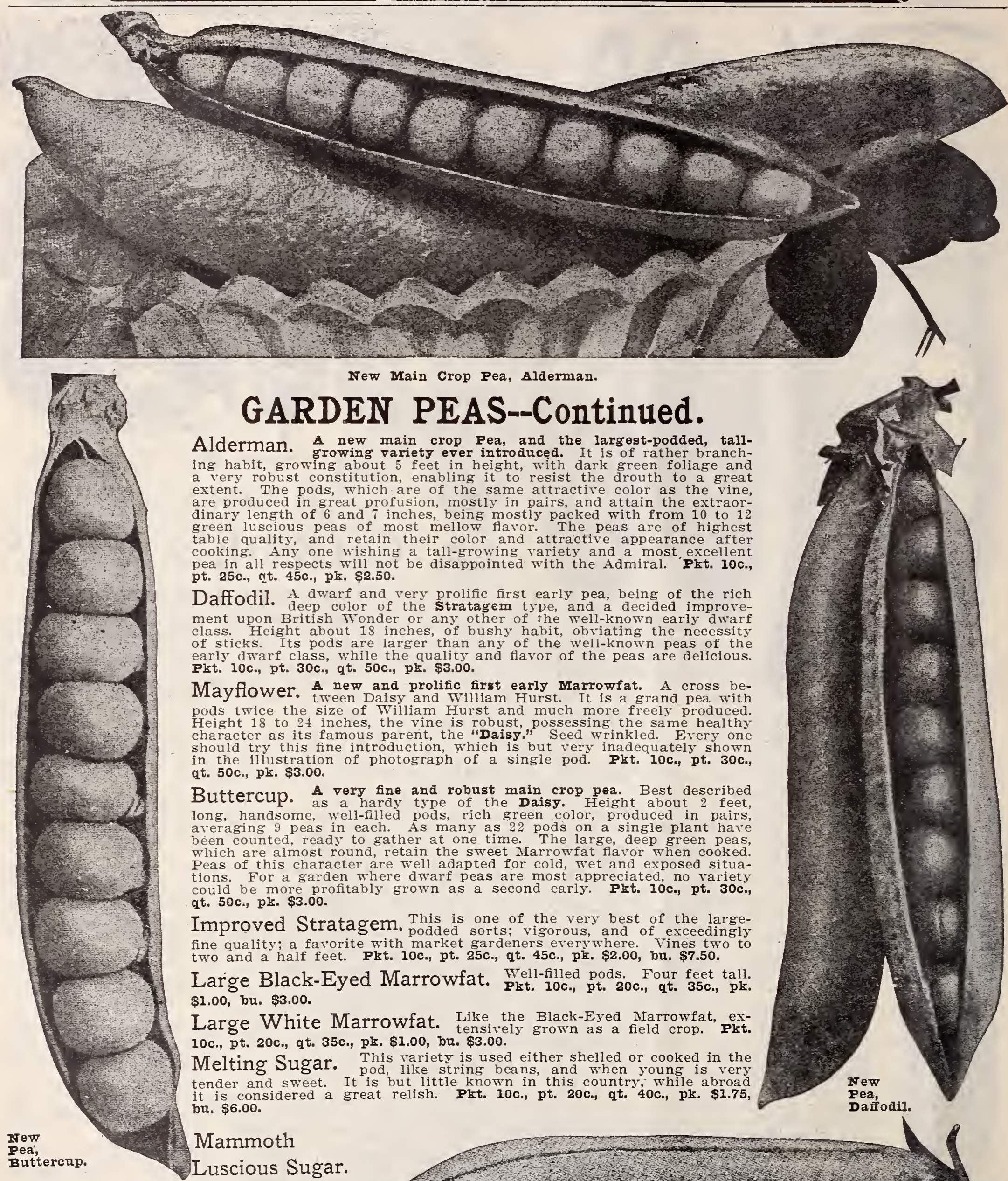

New Main Crop Pea, Alderman.

\section{GARDEN PEAS--Continued.}

Alderman. A new main crop Pea, and the largest-podded, talling habit, growing ang variety ever introduced. It is of rather branching habit, growing about 5 feet in height, with dark green foliage and a very robust constitution, enabling it to resist the drouth to a great
extent. The pods, which are of the same attractive color as the vine, are produced in great profusion, mostly in pairs, and attain the extraordinary length of 6 and 7 inches, being mostly packed with from 10 to 12 green luscious peas of most mellow flavor. The peas are of highest table quality, and retain their color and attractive appearance after cooking. Any one wishing a tall-growing variety and a most, excellent pt. 25 c., ot. $45 c .$, pk. $\$ 2.50$

Daffodil. A dwarf and very prolific first early pea, being of the rich ment upon British Wonder or any other of the well-known early dwarf habit, obviating the necessit of sticks. Its pods are larger than any of the well-known peas of the Plt. 10c., pt. 30c., qt. 50c., pl. \$3.00.

Mayflower. A new and prolific first earls Marrowfat. A cross bepods twice the size of William Hurst and much more freely produced character as its famous parent, the "Daisy." Seed wrinkled. Every one should try this fine introduction, which is but very inadequately shown in the illustration of photograph of a single pod. Prt. 10c., pt. 30c., qt. 50c., pk. $\$ 3.00$.

Buttercup. A very fine and robust main crop pea. Best described long han as a hardy type of the Daisy. Height about 2 feet

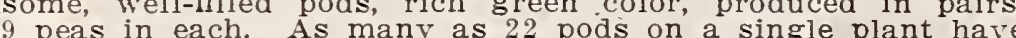
been counted, ready to gather at one time. The large, deep green peas,

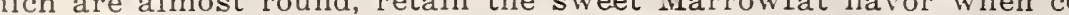
Peas of this character are well adapted for cold, wet and exposed situacould be more profitably grown as a second early. Plit. 10c., pt. 30c. qt. 50c., pr. $\$ 3.00$.

Improved Stratagem. This is one of the very best of the largefine quality: a favorite with market gardeners every where, vines two two and a half feet. Pkt. 10c., pt. 25c., qt. 45c., pk. \$2.00, bu. \$7.50.

Large Black-Eyed Marrowfat. Well-filled pods. Four feet tall. $\$ 1.00, \mathrm{bu} . \$ 3.00$.

Large White Marrowfat Like the Black-Eyed Marrowfat, ex10c., pt. 20c., qt. 35c., pk. $\$ 1.00$, bu. $\$ 3.00$.

Melting Sugar. This variety is used either shelled or cooked in the

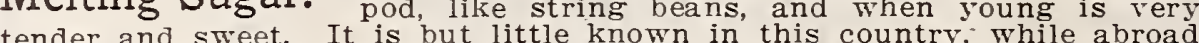
it is considered a great relish. Prt. 10c., pt. 20c., qt. 40c., pl. \$1.75, bu. $\$ 6.00$.

Mammoth

Luscious Sugar.

The pods grow 6 to 7 inches long and $1 \frac{1 / 2}{2}$ inches broad. In addition to its value as an edible-podded pea, the peas, when shelled and used as ordinaryin peas, are be used either as an edible-poded pea or as rieties. Plt. 10c., pt. 25 c., qt. 45c., pk. $\$ 2.50$.

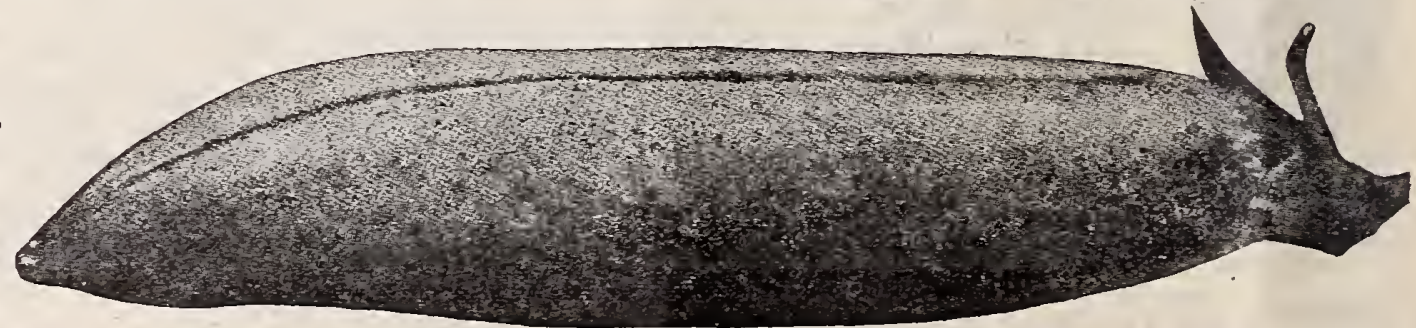

New Mayflower Pea. 


\section{* GROWN IN THE GOLDEN GRAIN BELT OF THE WORLD}

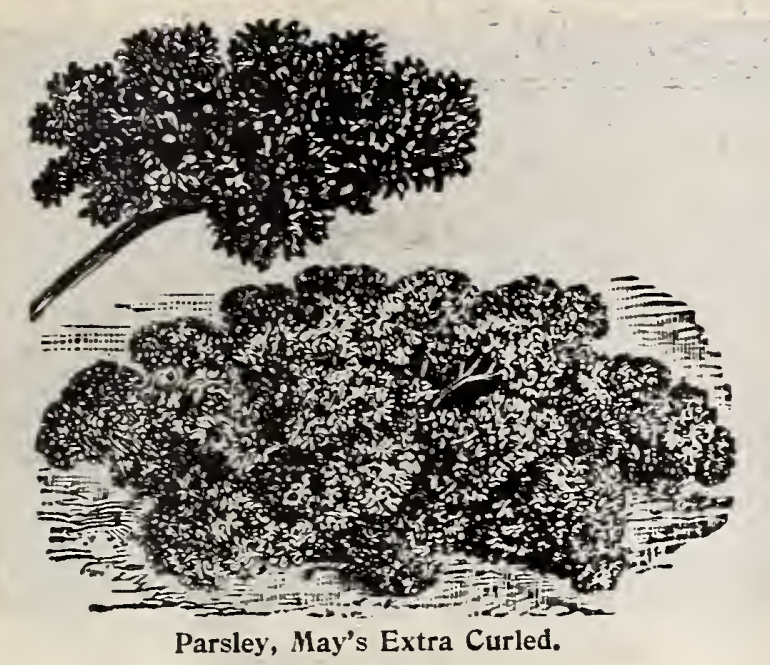

PARSLEY.

May's Extra Curled. (Siee Cut.) A most deriety of medium size, with handsome, bright, pale green leaves that are exceedingly showy. For garnishing and 5c., oz. 10c., $1 / 4$ lb. 25 c., 1b. 80c.

Champion Moss Curled. $\begin{gathered}\text { Leaves } b \text { e a u- } \\ \text { tifully curled and }\end{gathered}$ crimped. Pkt. 5c., oz. 10c., 1/4 lb. 20c., lb. $75 \mathrm{c}$.

Hamburg. The fleshy root resembles a parsnip, and 5c., oz. 10c., 1/4 lb. 20c., 1b. 60c.

Fern Leaved. This beautiful variety is perfect best for garnishing purposes and table decoration. It is of the finest curled type and stands the winter if covered of the finest curled type and stands the winter if cove $1 / 4$ lb. 20c., lb. $75 \mathrm{c}$.
before frost. Pkt. 5c., oz. 10c.,

Plain or Single. Plain leaves of excellent flavor. lb. 50c.

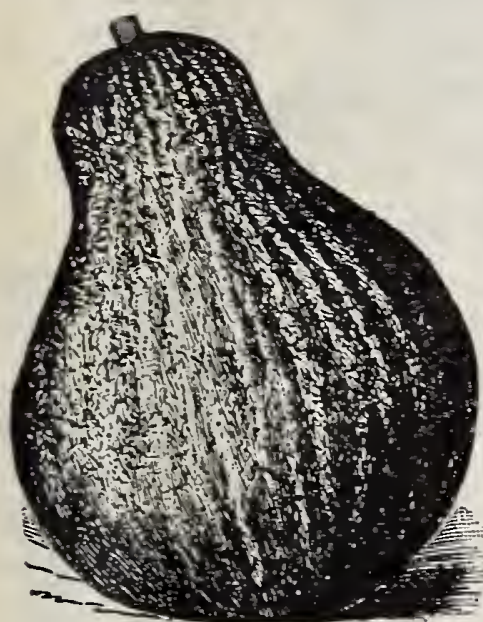

Pumpkin, Sweet Potato. 20c., lb. 50c. 10c., $1 / 4$ lb. 20c., lb. 50c. $10 \mathrm{c.,}, 1 / 4 \mathrm{lb}$. 15c., 1b. 50c.

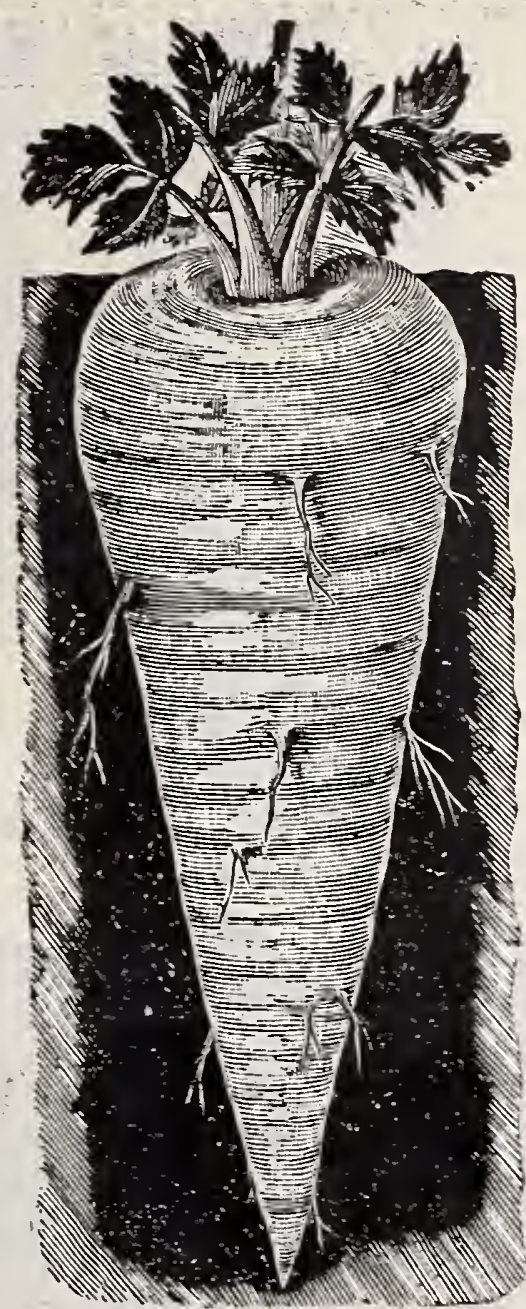

Parsnip, Magnum Bonum.

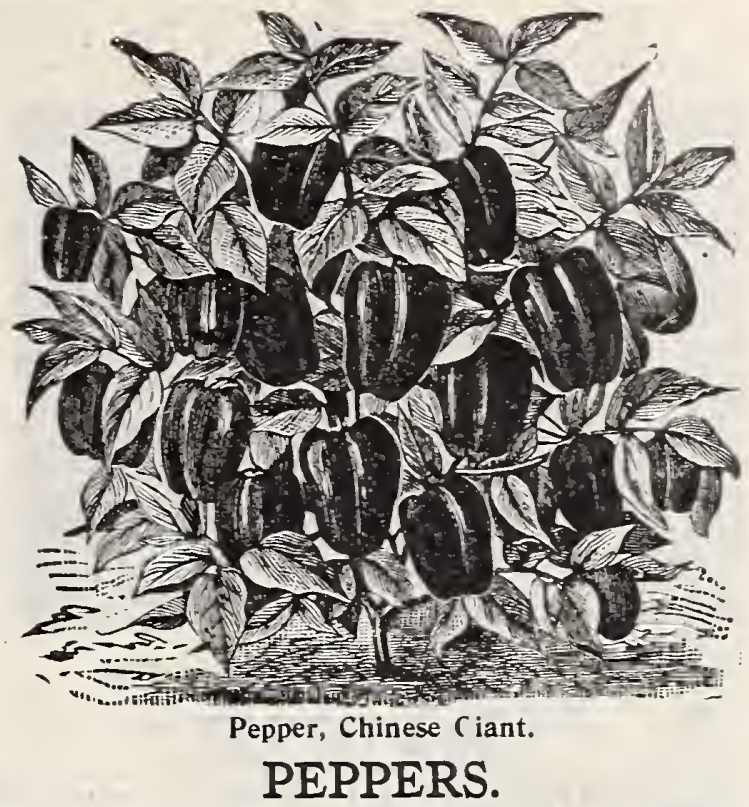

Chinese Giant. (See Cut.) A very large, fine,

immensely productive for so large a pepper, but its enormous size and magnificent appearance make it sell most branched and thickly set with enormous fruits. Fruits blocky, 4 to 5 inches broad, color brilliant scarlet. Pkt. 10c., oz. 40c., $1 / 4$ lb. $\$ 1.50,1 b$. $\$ 5.00$.

Tobasco. Of tall, bush-like growth, producing small, color vivid scarlet. Pkt. 5c. oz. 45c. Bull-Nose, OR IMPROVED LARGE BELL. The Pkt. 5c., oz. 20c., $1 / 4$ lb. 60c., lb. $\$ 2.00$. CHILI SMALL-Very pungent ..... $.05 \quad .20 .602 .00$ GOLDEN QUEEN-Large bright red. $\quad .10 \quad .20 \quad .60 \quad 2.00$

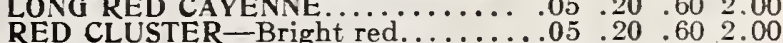

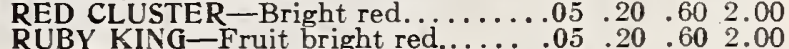
$\begin{array}{llllll}\text { SWEET MOUNTAIN-inild flavor... } & .05 & .10 & .60 & 2.00\end{array}$

\section{PARSNIPS.}

While highly appreciated for the table, the great value of the parsnip for stock feeding is but little known. The roots are very rich in saccharine food, adding to the richness of the milk when freshly dug and fed to cows.

Magnum Bonum. (See Cut.) A most exfrom Europe. The roots are oblong and grow mostly below the surface. The flesh is simply delicious, being solid, tender and very sweet. Pkt. 5c., oz. 10c., 1/4 lb. 20c., lb. 60c. Hollow Crown. The best variety; roots long, sugary, and of excellent flavor. Pkt. 5c., oz. 10c., 1/4 lb. Improved Guernsey. A good half-long vaEarly Round French. Roots broad and

\section{PUMPKINS.}

Tennessee Sweet Potato. The best variety for home gardens. They are almost ribbed and the skin is of a creamy white. The flesh is thick, of a creamy white color, dry, fine grained and of a sweetish flavor. Pkt. 5c., oz. 10c., 1/4 lb. 20c., lb. 75c.

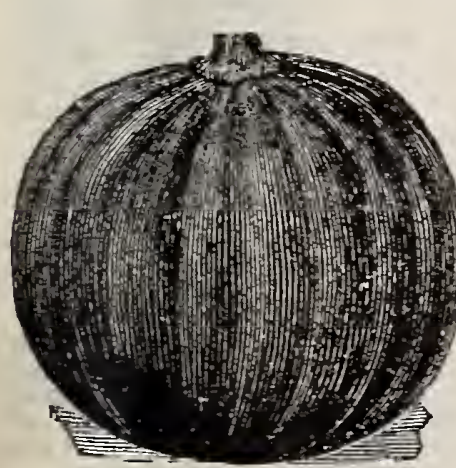

Pumpkin, Sugar.
New Golden Ribbed Oblong. Color $\mathrm{rich}$ ange with no green ends. Flesh yellow, of rich and extra fine quality; fruits a verage 14 to 20 inches in length; good keeper. Pkt. 5c., oz. 10c., 1/4 lb. 35c., lb, \$1.00.

Mammoth King. Fruits grow to enormous size, more in diameter and from 100 to 200 pounds: in weight. Salmon orange skin, very thick, bright yellow flesh, which is fine grained, tender and of excelle
$\overline{\mathbf{s}}$., $0 \mathrm{z}, 15 \mathrm{c} ., 1 / 4 \mathrm{lb}, 40 \mathrm{c}$., $1 \mathrm{~b}$. $\$ 1.50$.

French Prize. (See Cut.) A giant variety, introFrench Prize. duced in this country from France. Just the variety to grow if you want to take First Prize a your County or State Fair this coming season. It grows to $300 \mathrm{lbs}$. We have obtained our seed direct from large growers and are headquarters for it in America. Pkt. 10c., oz. 15c., $1 / 4 \mathrm{lb}$. 30c., lb. $\$ 1.00$

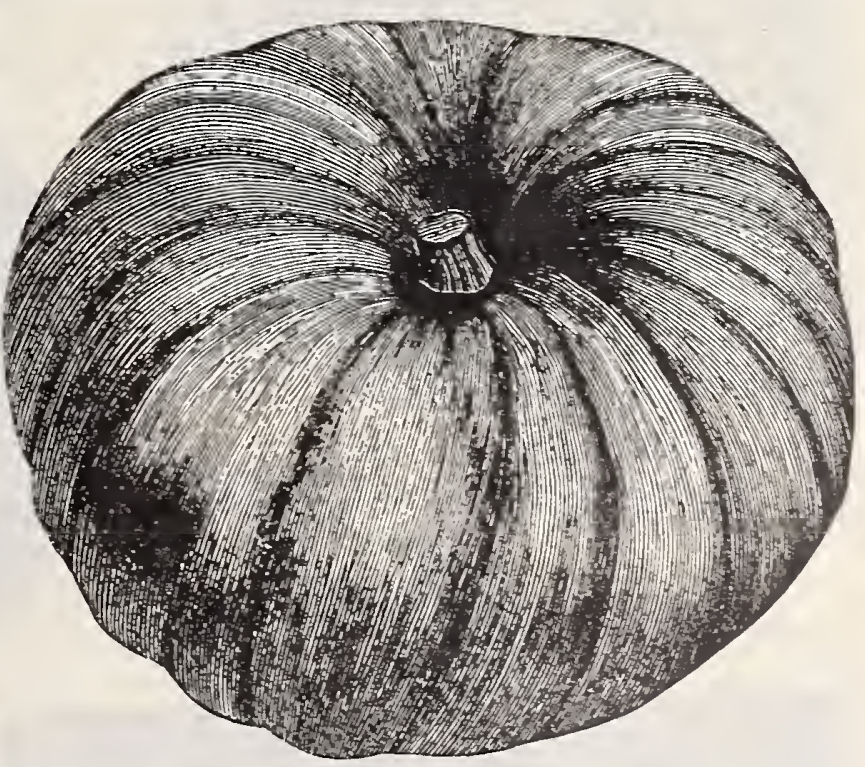

Pumpkin, French Prize.

Sugar A handsome, prolific variety; fruits of small size, cellent keeping qualities. Pkt. $5 c_{\text {. }}$, oz. $10 c_{0}, 1 / 41 \mathrm{~b}$. $20 \mathrm{c}_{\text {。, }} 1 \mathrm{~b}$ 70c.

King of the Field. (May's.) This is particularly desirable for stock feeding. It a
size, the flesh is fine grained, a rich yellow an
quality. Pkt. 5 c., oz. $10 \mathrm{c}$., $1 / 4 \mathbf{l b}$. $15 \mathrm{c}$., $1 \mathrm{~b}$. $50 \mathrm{c}$.

quality. Pkt. 5c., oz. 10c., 1/4 1b. 15c., Pkt.

Sort CAWH - Crook neck, very popular

ETAMPES RED-Large flat shape

GOLDEN OBLONG-Flesh light yellow.

LARGE CHEESE OR KENTUCKY FIĖLD

MAMMOTH TOURS-Flesh thick and

NEGRO OR NÄÁTUCKET-Yankee

05

.05 


\section{G MAY'S NORTHERN GROWN SEEDS BEST FOR ALI CLMES \&}

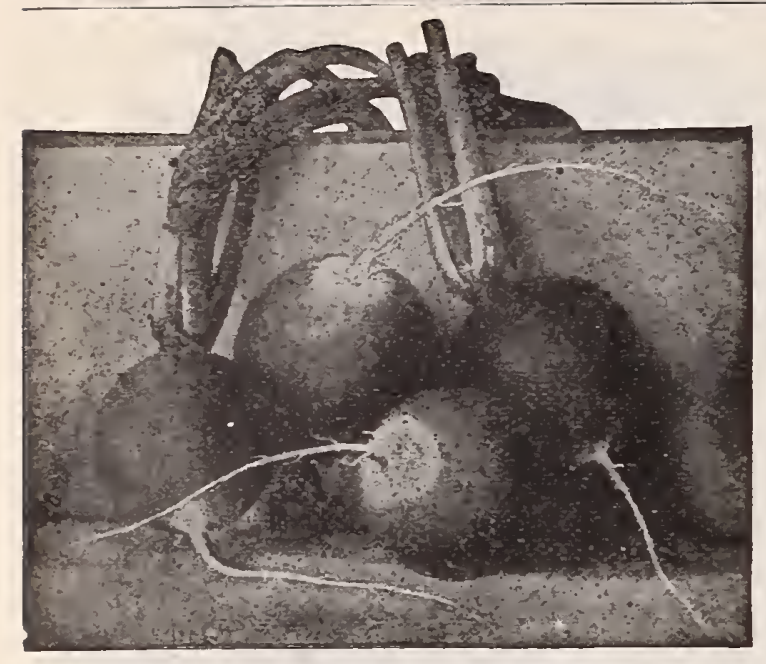

Radish, Scarlet Turnip, White Tip.

\section{RADISH.}

Scarlet Turnip, White Tip. An extremegrowing sort; bright scarlet, with a white tip; Radish, White Delicacy. Pkt. 5c., oz. 10c., $1 / 4$ 1b. 25c., 1b. 75c. Queen of the Market. turnip radish in the market; matures in 20 days. A rapid grower, being ready for use a week or ten days
ahead of the Early Scarlet Turnip.
Pkt. 5c., oz. 10c., 1/4 1b. 25c., 1b. 75c. Rosy Queen. It ripens almost as the Market and has a very small top, so that it may be planted very close. Pkt. 5c., oz. 10c., 1/4 1b. 25c., 1b. 75c.

French Breakfast. O $\mathrm{b} 1 \mathrm{l} \mathrm{n}$ glowth, very mild and tender, beauPkt. 5c., oz. 10c., 1/4 1b. 20c., 1b. $70 \mathrm{c}$. Crimson Giant. Deep crimson color crisp and mild flavor. Pkt. 5c., oz. 10c., $1 / 4$ 1b. 25c., 1b. 85c.

White Delicacy. An improvement on burg, being earlier, more evenly shaped, and smaller top; grows into full size and per5c., 0z. 10c., $1 / 4$ 1b. 25c., 1b. $75 \mathrm{c}$.

Scarlet Globe. One of the earliest; and tender. It forms a small top and will stand a great amount of heat without becoming pithy. Pkt. 5c., oz. 10c., 1/4 1b. 25c.,
1b. 75c.

White Olive-Shaped. Wuite e a r l y, skin; crisp and of mild flavor. Pkt. 5c., oz. 10c., $1 / 4$ 1b. 20c., 1b. $70 \mathrm{c}$.

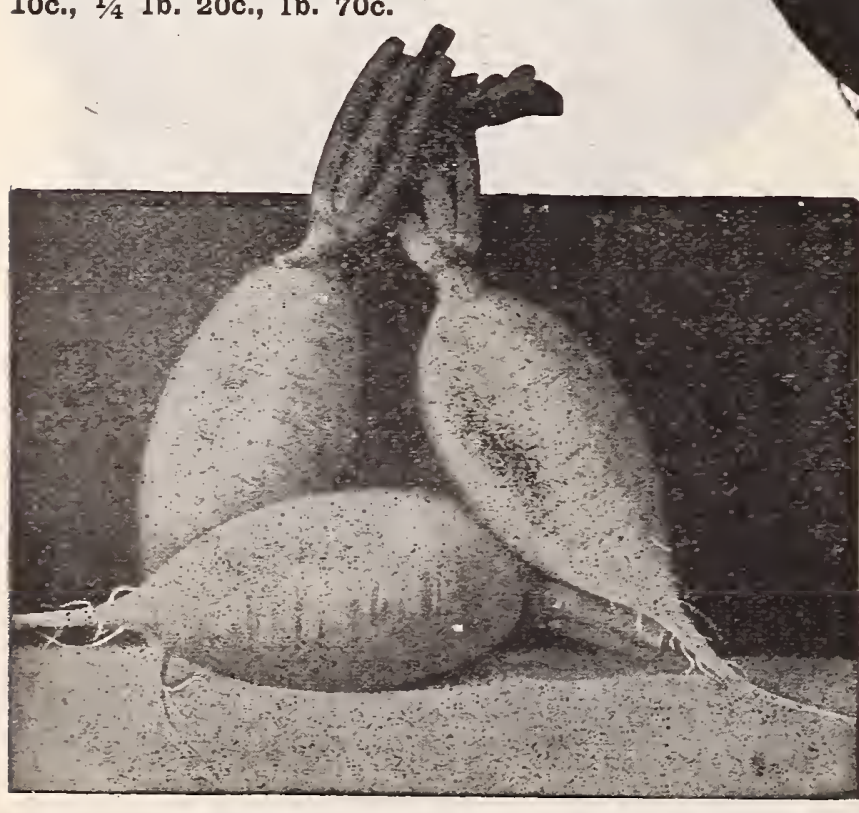

Radish, Olive-Shaped White.

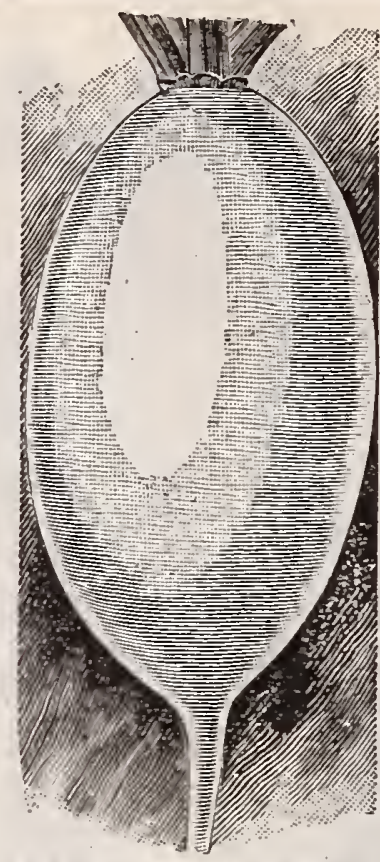
a quick grower.

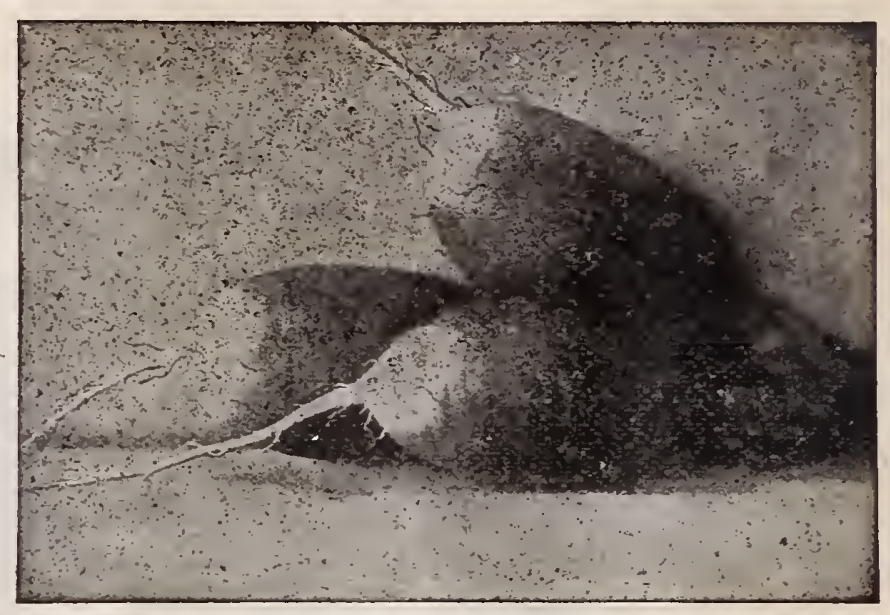

Radish, French Breakfast.

Icicle. It is long, slender. The young radishes are sowing the seed, and are fresh, crisp and tender. Pkt 5c., 0z. 10c., 1/4 1b. 25c., 1b. 75c.

Long Scarlet Short Top. Root long, growing partly, above smooth, rich, scarlet; very crisp and
Pkt. 5c., oz. 10c., 1/41b. 20c., 1b. 70c. Chartiers White Tip. $\mathrm{s}$ o ngoth red above and shading to white at tip; large, both brittle and tender. Pkt. 5c., oz. 10c., 1/4 1b. 20c., 1b. 70c.

Turnip Shaped Sorts.

$\begin{array}{lcccc}\text { Deep Scarlet .. Pkt. } & \text { Oz. } & 1 / 4 \text { Lb. } & \text { Lb. } \\ \text { Scarlet Turmip. } & .05 & .10 & .25 & .75 \\ \text { White Turnip } & .05 & .20 & .70 \\ \text { Non Plus Ultra. } & .05 & .10 & .20 & .70 \\ \text { Phil. White Box } & .05 & .10 & .25 & .75 \\ \text { Triumph Forc- } & .10 & .20 & .70 \\ \text { ing .......... } & .05 & .10 & .20 & .70\end{array}$

Radish, Queen of the Market.

Olive Shaped Sorts.

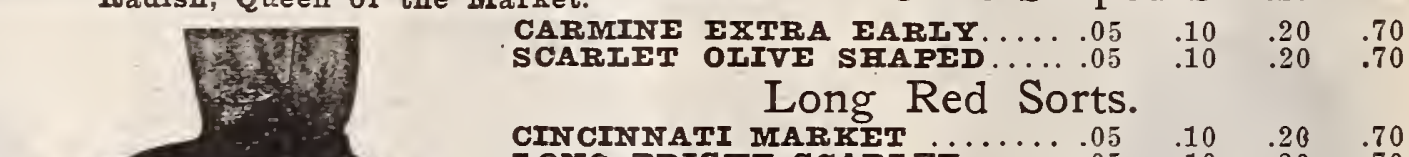
$\begin{array}{llllll}\text { CINCINNATI MARKET } & \ldots \ldots & .05 & .10 & .20 & .70 \\ \text { IONG BRIGHT SCARIET } \ldots \ldots & .05 & .10 & .20 & .70\end{array}$ PARIS BEAUTY $\ldots \ldots \ldots \ldots \ldots . .05 \quad .10 \quad .20 \quad .70$ Long White Sorts.

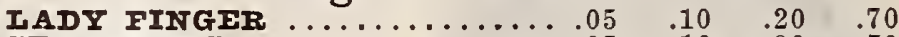
$\begin{array}{llllll}\text { STRASBURG } & \ldots \ldots \ldots \ldots \ldots \ldots \ldots & .05 & .10 & .20 & .70 \\ \text { STUTTGART } & .70 & .70\end{array}$

Winter Sorts. $\begin{array}{llllll}\text { BLACK } & \text { SPANISH } \text { LONG } \ldots \ldots & .05 & .10 & .20 & .70 \\ \text { BIACK } & .70 & .20 & .70\end{array}$

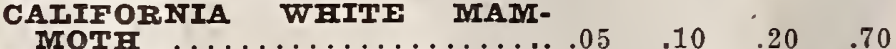

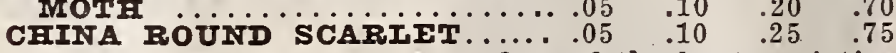
Chinese Rose Winter. One of the best varieties did keeper. Pkt. 5c., 0z. 10c., 1/4 1b. 25c., 1b. 75c.

\section{RHUBARB.}

s.

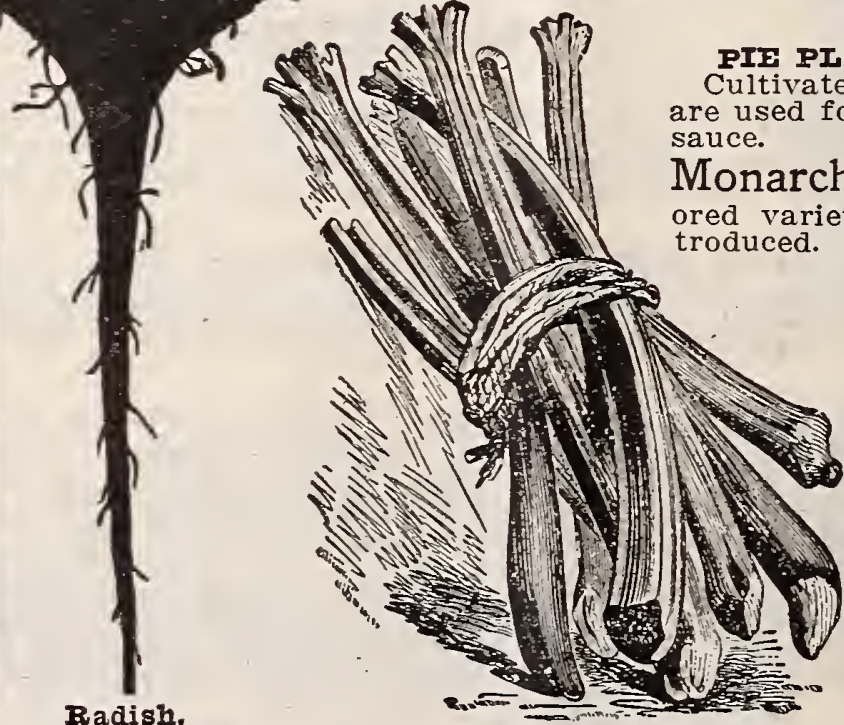

Rhubarb.
ANT or WINE PIANT.

PIE PLANT or WIN TLANT. are used for tarts and pies, also as a The largest, strongest growing and best flavthat has ever been in75c., 1b. $\$ 2.00$. Victoria. A good marstalks red, very large. Stalks red, very large. 50c., 1b. $\$ 1.50$. Linnaeus. Very protender and very fine. Pkt. 5c., oz. 15c., 1/4 1b. 50c., Ib. $\$ 1.50$.

Rhubarb Roots.

We have a fine stock. Mail size, 10c. each, 3 for 25c., 6 for 45c., postpaid. Large clump, express or freight, 20c., doz. $\$ 1.50$ 


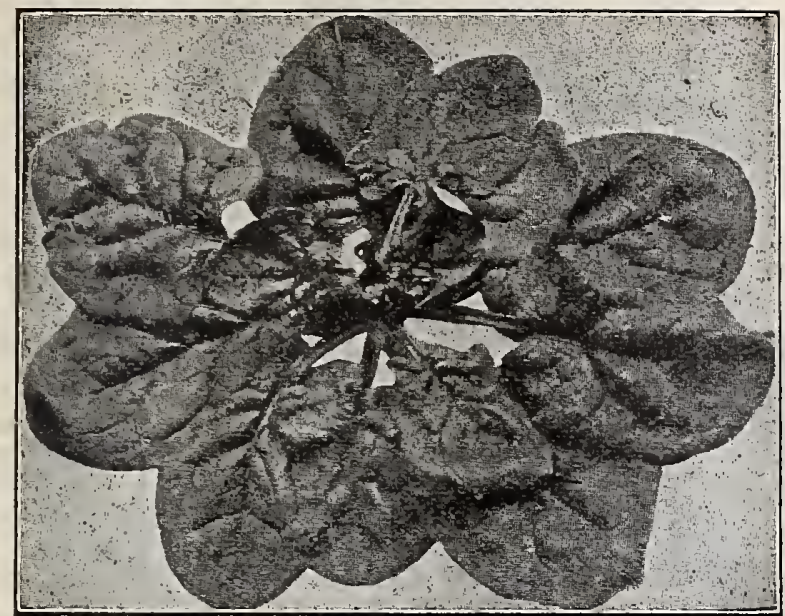

Spinach, Perfection Curled.

Spinach is a very hardy plant, extremely wholesome and very palatable, and furnishes a delicious dish of greens, available at a season when it is especially welcome.

May's Perfection Curled. (See Cut.) A splendid variety, jeaves produced in large numbers. Pkt. 5c., oz. 10c., 1/4 lb. 25c., lb. 75c. Curled Bloomsdale. Large, curled and wrinkled; leaves tender. Long Standing. Dark green, leaves large and thick, fine for spring Round Thick Leaf. Leaves large, dark green, for fall or spring

SALSIFY, OR VEGETABLE OYSTER.

We esteem this to be a much better root for table use than either the parsnip or carrot. Some have been skeptical as to their poslike the parsnip, they have been well frosted. But if dug up during spells in winter, and early in the spring, and boiled like carrots or parsnips, or half boiled or grated fine, made into balls, dipped in a batter and fried like oysters, they are a very excellent substitute for Long White. $1 / 4$ lb. 25c., lb. 80c.

Mammoth Sandwich Island. Grows uniformly to averaging fully double the size and weight of roots of the old variety. Thality, notwithstanding their enormous size, are of very superio it exclusively. The Salsify is one of the most delicious and nutritious of vegetables, and should be more generally cnltivated for use in winter, when the supply of really good vegetables is so limited Pkt. 5c., 0z. 10c., 1/4 lb. 35c., lb. $\$ 1.00$.
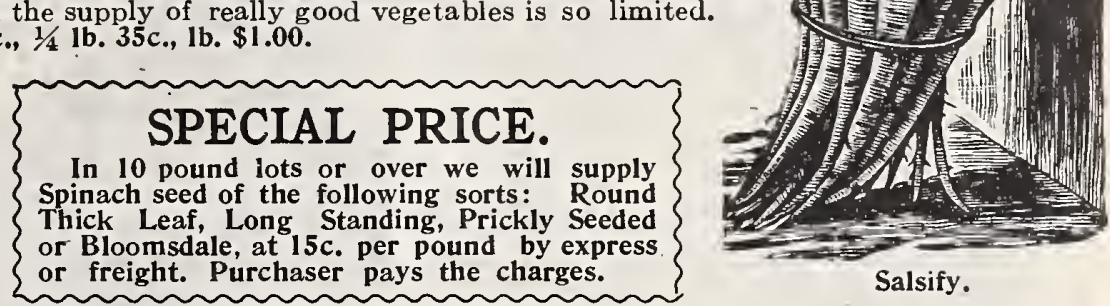

Victoria. Extra dark, black green leaves of "true savory appearance

Viroflay. The favorite market gardeners' sort. Pkt. 5c., oz. 10c.; New Zealand. Produces large quantities of leaves throughout the oz. 10c., $1 / 4 \mathrm{lb}$. 20c., lb. 60c.

Summer Varieties.

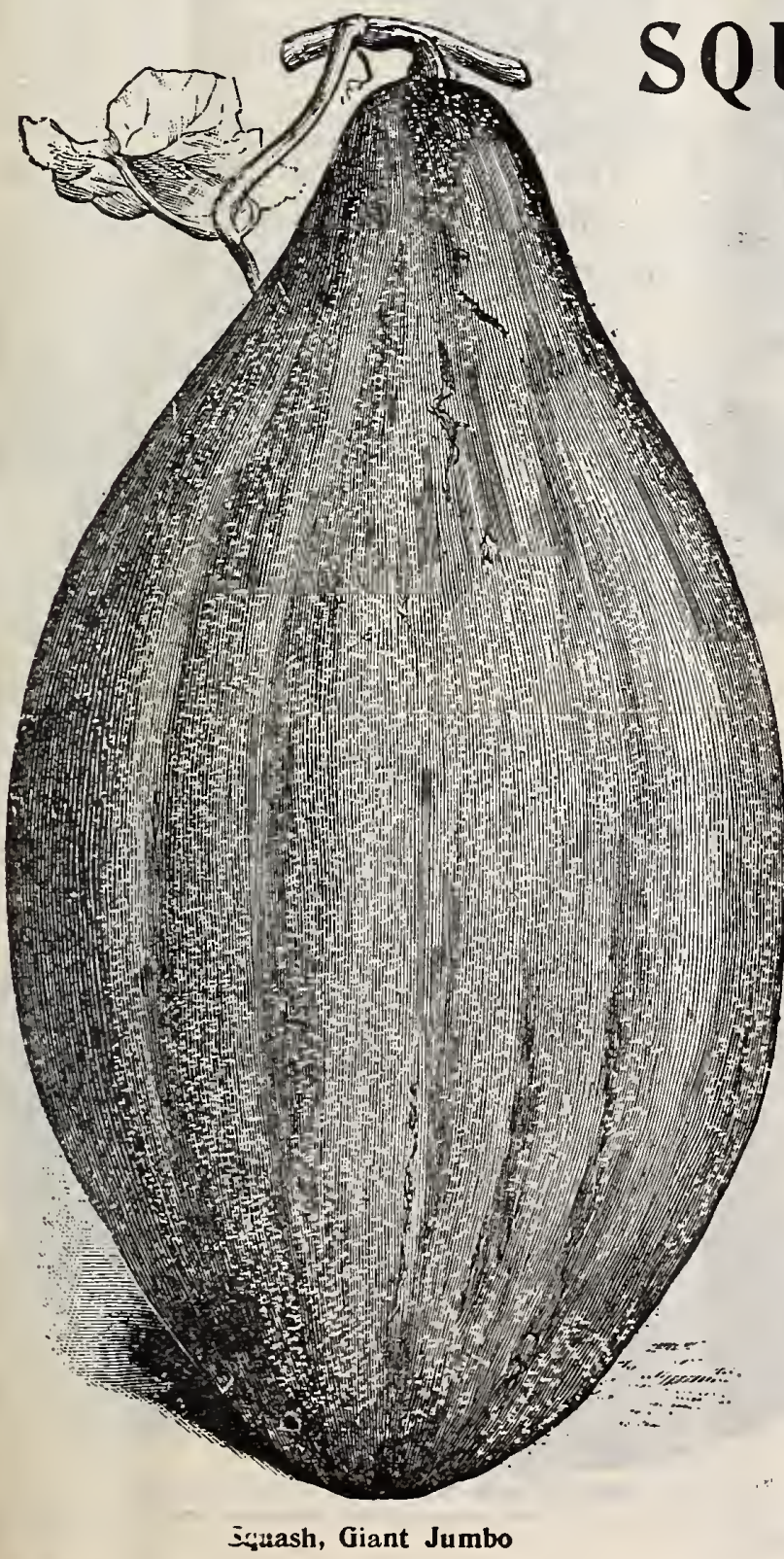

Crookneck Yellow. Pf truts bush growth, very early fruiting and productive. The squashes are of the popular crookneck type, rich golden

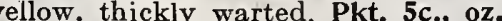
10c., $1 / 4$ lb. 25c., lb. 75c. White Bush SCALLOPED white Pattypan or "Cymling" of the South The plants are of true bush South. The plants are of true bush use very early in the summer. Pkt. 5c., oz. 10c., 1/4 lb. 25c., lb. 75c. Yellow Bush. SCALLOPED. ty Pan."). This is similar in growth and fruit to preceding, but has skin of a deep orange. Pkt. 5c., oz. 10c.

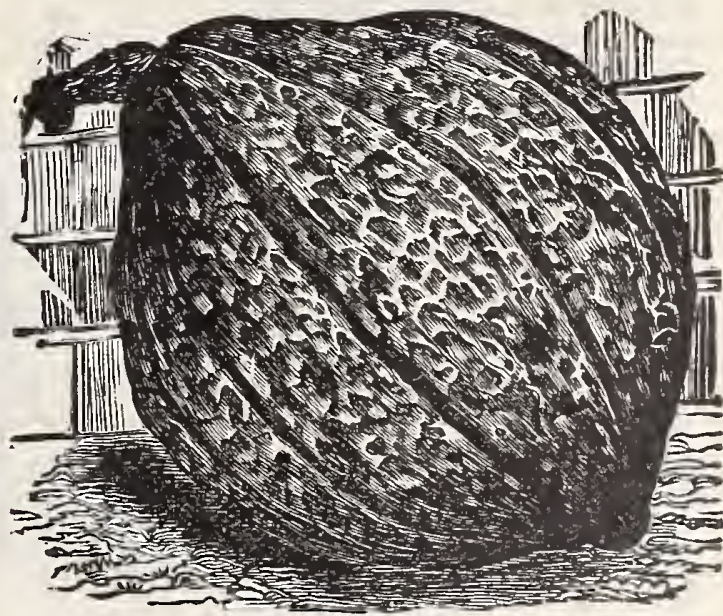

Squash, Delicious.

Squash, Delicata. A small fruited variety suitable for both summer and winter use striped with dark green. Flesh thick and solid. Cooks dry and is of a rich flavor. Pkt, 5c., oz 10c., $1 / 4$ lb. 30c., $1 \mathrm{~b}$. $90 \mathrm{c}$

\section{SQUASH.--Winter Varieties.}

Golden Hubbard. The best fall and winter squash. This is a perfect type of the green and attractive. The fruits are uniform in size, weighing from 6 to 8 pounds and in shape are lik the green Hubbard The flesh is deep orange, very dry, fine grained, and of excellent flavor. Vre vigorous, productive. Pkt. $5 c_{\text {., }}$, oz. $10 \mathrm{c}$., $1 / 4 \mathrm{lb}, 25 \mathrm{c}$., 1b. $75 \mathrm{c}$.

True Hubbard. This is the well known winter squash, now grown so largely throughou with dark green skin and very rich flesh. Pkt. 5 c., oz. 10 c., $1 / 4 \mathrm{lb} .25 \mathrm{c}$., $1 \mathrm{lb}$. $75 \mathrm{c}$.

Warted Hubbard. This is similar in size and quality to the well known Hubbard, warted. Very handsome in appearance, an excellent keeper and of splendid quality. Pkt. oz. 10c., $1 / 4 \mathrm{lb} .25 \mathrm{c}$., 1b. $75 \mathrm{c}$

Mammoth Chili.

Boston Marrow

Sibley, or Pike's Peak. Popular late sort. Skin smooth. color pale

Delicious. One of the thickest meated and very best in qual

bard although at any time excellent, does not acquire its best quality un

$1 / 4$ lb. 30c., lb. $\$ 1.00$.

Giant Jumbo

the a lishter tinger

more than one hundred pounds in weight. Flesh firm and solid, excellent quality.
$50 \mathrm{c} ., \mathrm{lb}$. $\$ 1.75$. 


\section{${ }^{24}$ o MAY'S NORTHERN GROWN SEEDS BEST FOR ALL CLMES \&}

\section{TOMATO SEED.}

May's First of All. See front cover all by a week or ten days. It is equally desirable for both market and home invariably brings the highest prices in the market. The tomatoes are of good size, smooth, solid and of the finest class extra early variety for general our patrons who desire an extra early monials regarding this tomato. Pkt. $10 \mathrm{c} ., 3$ plets. $25 \mathrm{c.}$., oz. $40 \mathrm{c}$., $1 / 4 \mathrm{lb}$. $\$ 1.00$, 1b. $\$ 3.00$

June Pink A true pink colored size, Pink. Atrain, fruit of medium shaped, without cracks or any green The tomatoes will reasonably tough so that it is excellent for shipping purposes. It ripens fully Burpee's Earliest Pink Pkt. 10c., Az. $\$ 1.00$, Matchless. A bright red, main crop er and shipper. Less liable to crack 5c., oz. 20c., $1 / 4$ 1b. 75c., 1b. \$2.50. Chalk's Early Jewell. An extremeriety of brightest scarlet color, deep of excelent flavor. Fery few seeds and $1 / 4$ 1b. 75 c., 1b. $\$ 2.50$. Earliana. Very early. Remarkable wonderful productiveness.
oz. $25 \mathrm{c}$., $1 / 4 \mathrm{lb}$. 85c., 1b. $\$ 3.00$. New Stone. Grown more extenfor a main crop variety, especially by market gardeners. Very large, smoot heavy yielder. Prtt. 5c., oz. 25c., $1 / 4$ lb. 75c., 1b. \$2.50.

New Globe. Among the very first to size. Very smooth, firm fleshed, few glossy ripens evenly; color a beautiful glossy rose, tinged purple. It has been tested with Atlantic Prize, kind claiming earliness, and beats them tomato should fail to secure the First to 1 inches in diameter, and from desirable for private use. Plrt. 10c., oz. handsome shape, bright red color and Acme. An or variety of delicious Plt. 5c., oz. 25 c., $1 / 4$ lb. 60c., 1b. $\$ 2.00$.

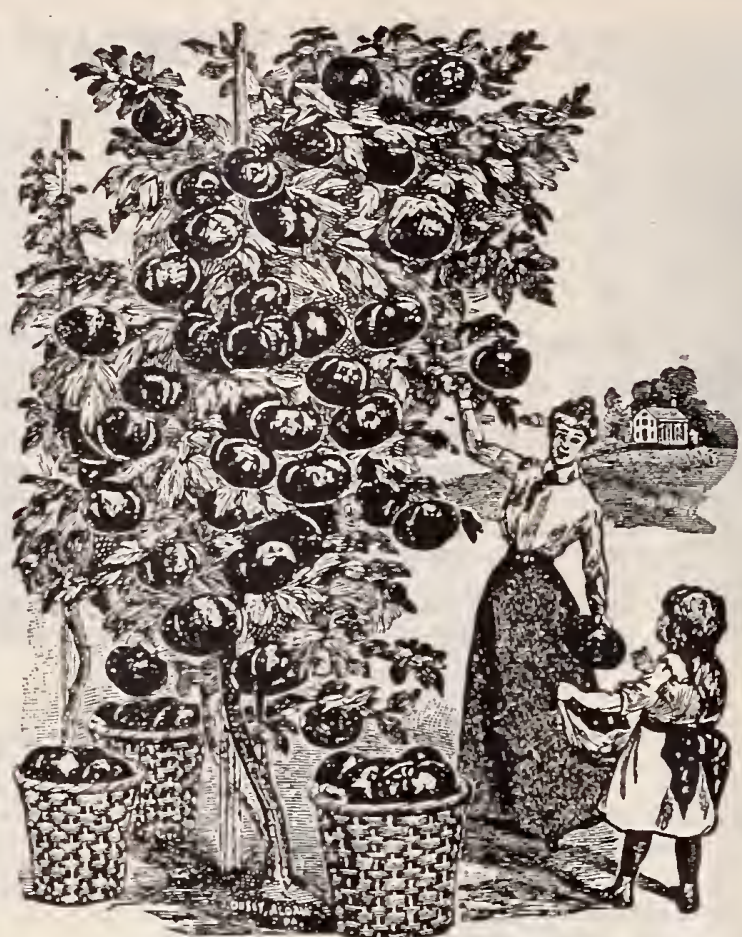

Giant Tree Tomato.

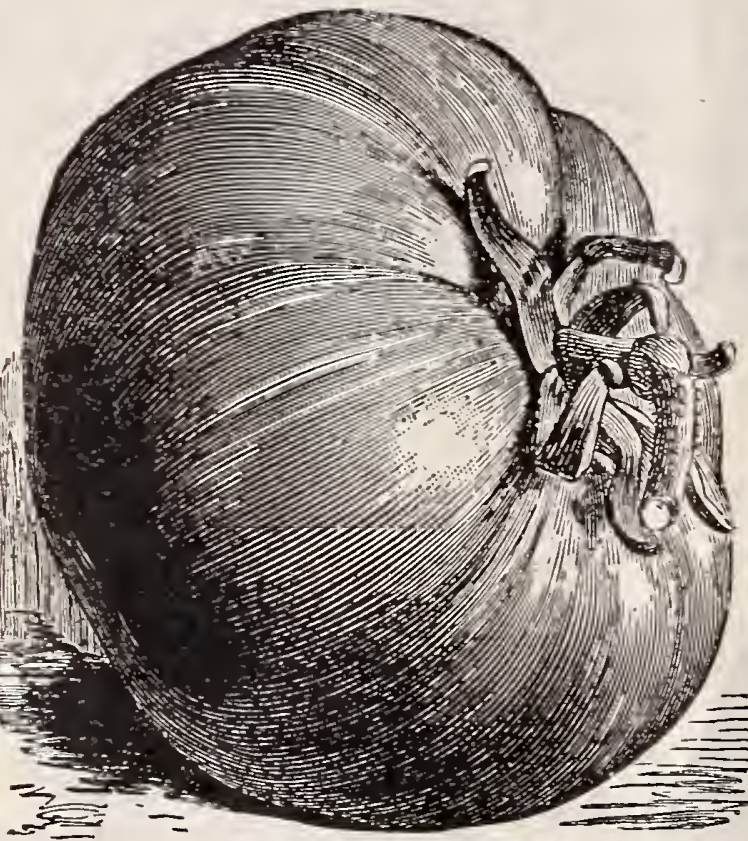

Tomato, June Pink.
Beauty. One of the best pink-skinned tough skin, making it an excellent variety for shipping. Pkt. 5c., oz. 25c., $1 / 4$ 1b. 60c., 1b. $\$ 2.00$.

Giant Tree This wonderful variety was Iree. introduced by us several years ago and immediately sprang into great favor wherever grown. It is not an untried novelty, but has stood the test. Irowg from 10 to 15 feet in height, and if planted early will begin to ripen by July 4th and bears its heavy loads of firm and solid, almost seedless, fine grained and of the most delicious flavor ever found in a tomato. It is the largest tomato we have ever seen; the fruit weighs from to 24 ounces, and specimens have been pkts. 25c.

Extra Early Tree. A splendid tomasmooth medium size Another point that particularly recommends it is the fact that it requires no support even when laden with fruit, the stiff branches holding the tomatoes far above the ground. Prt. 10c., oz. 20c., 1/4 1b. 75c., 1b. \$2.25.

Peach. This is a distinct and very ateating from the hand or table preserving, sembles a peach in shape, size and color and is covered with a delicate bloom, which makes the resemblance more striking; flesh tender and of good flavor. Pkt. 5c., oz. 20c., $1 / 4$ Ib. 65c., 1b. $\$ 2.50$.

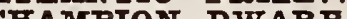

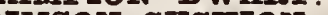
CRIMSON CUSHION.. $.10 \quad .25 \quad .85 \quad 3.00$

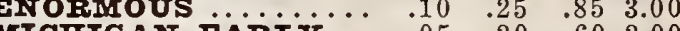
MICEIGAN EARIY... $\quad .05 \quad .20 \quad .602 .00$ MINESOTA QUEEN... $\quad .05 \quad .20 \quad .75 \quad 2.50$ $\begin{array}{llllll}\text { NEW CENTURY..... } & .05 & .20 & .60 & 2.00\end{array}$

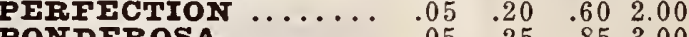

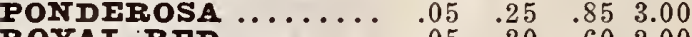
ROYAI RED. . . . . . . . . .05 $\quad .20 \quad .602 .00$

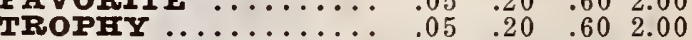
TRUCKER'S 'تAVORITE $\ldots \ldots \ldots \ldots \ldots \ldots \ldots$. . $05 \quad .20 \quad .602 .00$ SMALL FRUITED SORTS.

Strawberry or Husk. Plan ts of growth, and immensely productive. The small yellow fruits are each enclosed in a husk or covering. When ripe the fruits low, and of very sweet flavor, highly es. Pkt. 10c., oz. 20c., $1 / 4$ 1b. 65c., 1b. $\$ 2.50$. CHERRY RED ........... $.05 \quad .20 \quad .652 .50$ CHERRY YEIIOWW... PEAR RED $\cdots \cdots \cdots \cdots \cdots, .05 \quad .20 \quad .652 .50$ $\begin{array}{llllll}\text { PEAR YELIOW } \ldots \ldots & .05 & .20 & .65 & 2.50\end{array}$ $\begin{array}{llllll}\text { PIUIM RED........ } & .05 & .20 & .65 & 2.50 \\ \text { PIUIM YEIIOW..... } & 05 & .20 & .65 & 2.50\end{array}$
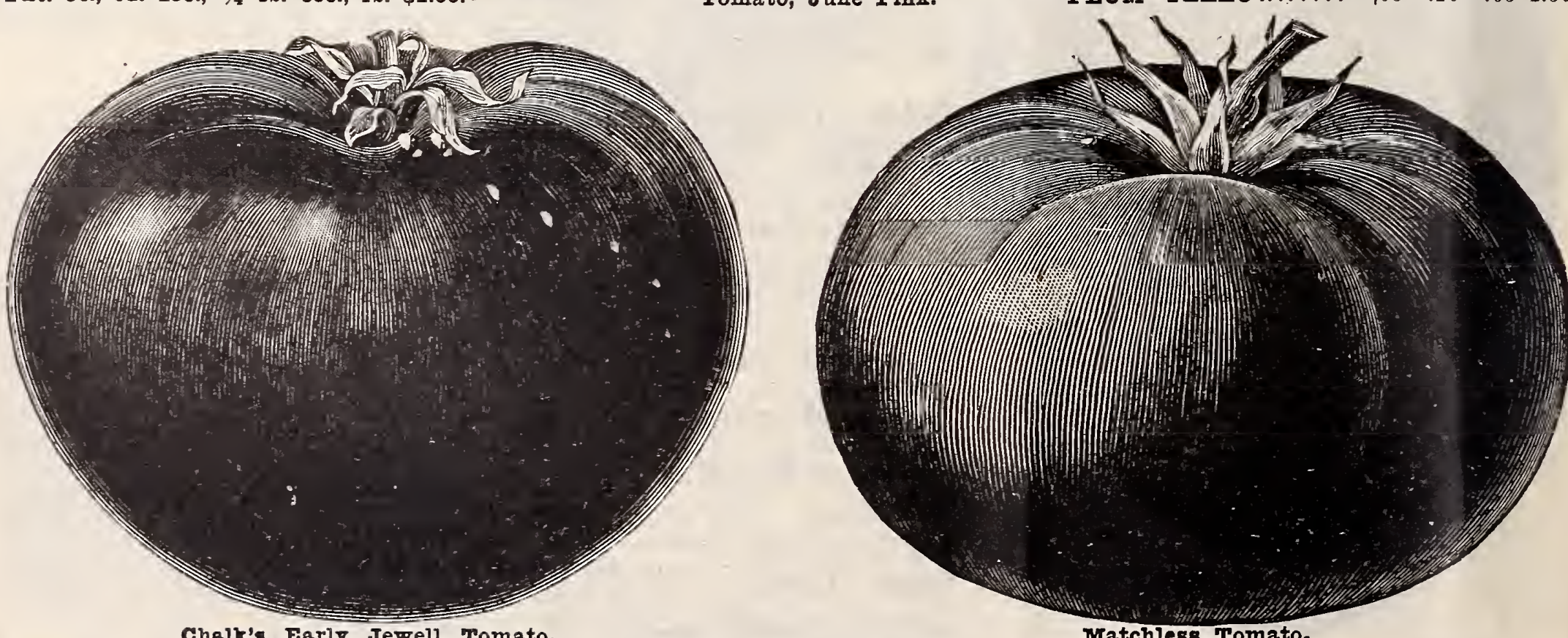

Matchless Tomato. 


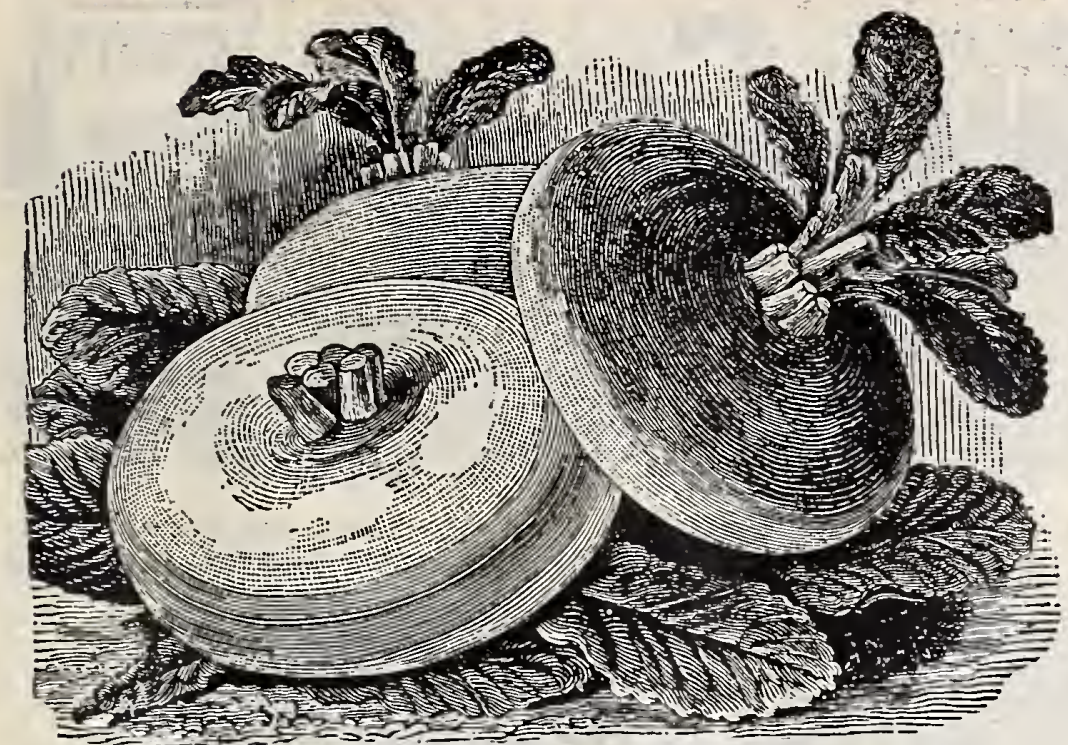

Turnips. Early White Flat Dutch and Purple Top Strap Leaf.

GARDEN TURNIPS.

Purple Top Strap Leaf Flat. This is an early variety and a great fat like a broad disk, and of medium size; color purple or dark red above ground. Wat like a broad disk, and of medium size; color purple or dark red above ground. offer is saved from carefully selected bulbs. Pkt. 5c., oz. 10c., 1/4 lb. 15c, lb. 40c.

Early White Flat Dutch. Strap leaved. A most excellent early, southern states. = Root medium sized, flat; color white; very early, sweet and tender. It is desirable for table use, but, like other early sorts, is spongy and inferior when overgrown Pkt. 5c., oz. 10c., $1 / 4 \mathrm{lb}$. 20c., lb. $50 \mathrm{c}$.

Extra Early Purple Top Milan. The earliest in"cultivation, two Strap Leaf. The bulb is flat, of medium size, quite smooth, with a purple top. Flesh white, hard and of finest quality; it is an extra good keeper. Pkt. 5c., oz. 10c., $1 / 4 \mathrm{lb}$. 20c., ib. 60c.

Model White. Flesh white, solid, fine grained and entirely free from the loc., oz. 15c., 1/4 lb. 25c., lb. 75c.

Crystal Thite. The best variety ever introduced for table use. Flesh is In ordinary seasons it will mature in six weeks. If you wish a splendid table turnip. you will find the Crystal White all that can be desired. Pkt. 5c., oz. 20c., 1/4 lb. 40c., lb. 60c.

Purple Top White Globe. A variety that originated from the Purple as large as the Pomeranian White Globe, of beautiful appearance, of most excellent quality and equally desirable for table or stock. It keeps well and is a fine market sort. Pkt. 5c., oz. 10c., $1 / 4$ lb. 20c., lb. 50c.

Snowball or Six Weeks. A very rapid growing, small variety that seed. Flesh sweet and tender. Pkt. 5c., oz. 10c., 1/4 lb. 15c., lb. 50c.

Golden Ball. Rapid grower, globe shaped, bright yellow, good keeper, super-

By express deduct 10 cents per pound. Oz. $1 / 4 \mathrm{lb} . \mathrm{lb}$. EXTRA EARLY WHITE MILAN

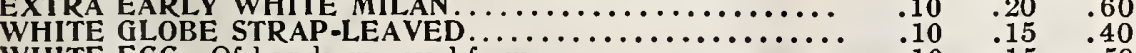
WHITE EGG-Of handsome oval form.................... $\quad .10 \quad .15 \quad .50$ LONG WHITE OR COW HORN........................ $.10 \quad .15 \quad .40$ POMERANIAN WHITE GLOBE

LARGE YELLOW, OR AMBER GiLOBE

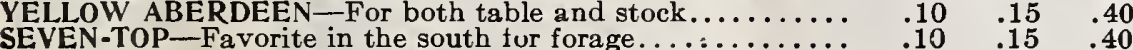
Each variety 5 cents per packet.

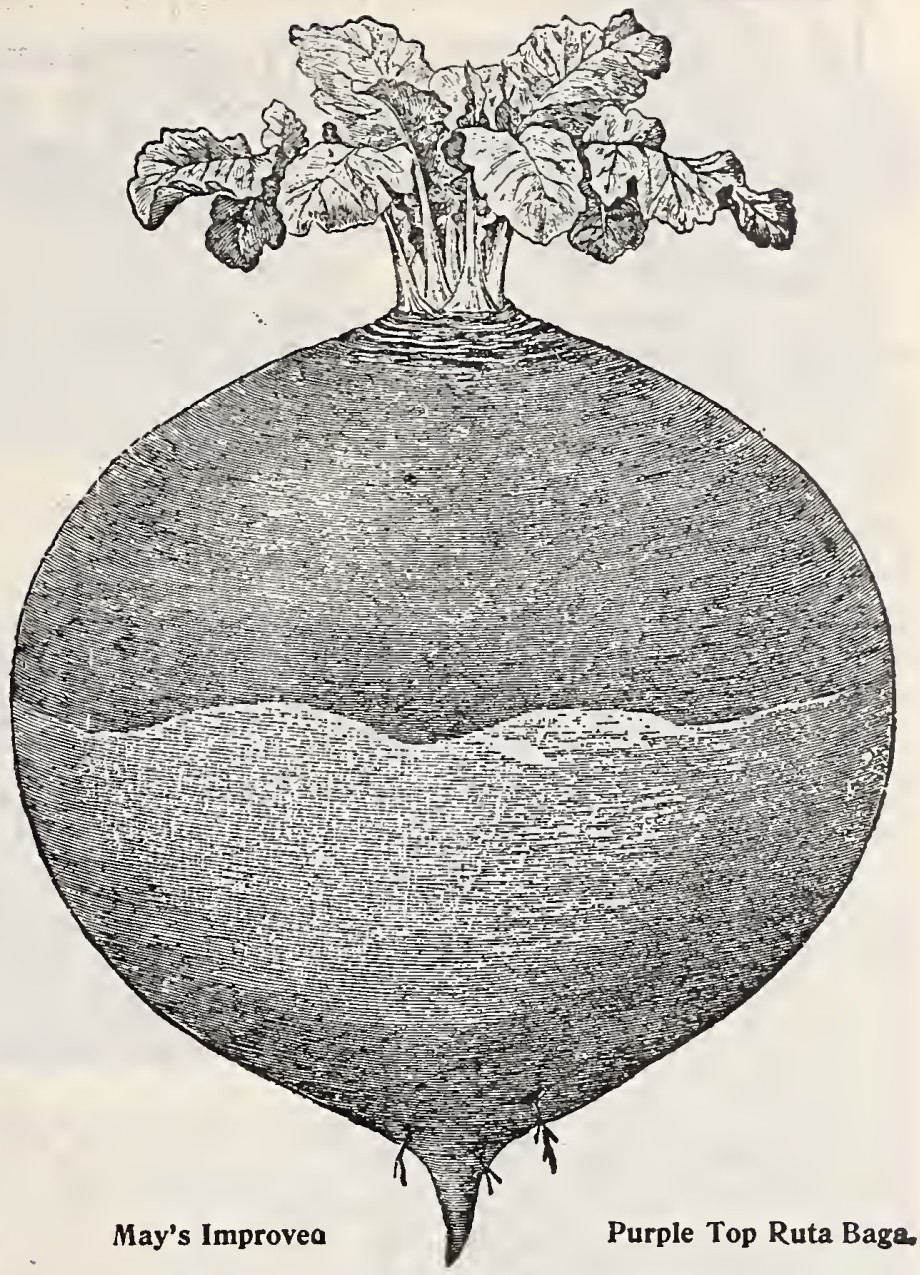

\section{RUTA BAGAS or SWEDES.}

If sown the last of July or the first of August, Ruta Bagas make an excellent pasture for sheep during the fall months, and the turnip will furnish a rich food for them all winter. All kinds of stock relish turnips, and thrive upon them when in combination with hay. May's Improved Purple Top. It is the hardiest, nutritious variety Flesh yellow, of solid texture, sweet and well flavored; shape slightly oblong; terminating abruptly; color deep purple above and bright yellow under ground. Pkt. 5c., oz. 10c., 1/4 purple above and

Monarch Swede. The largest and heaviest yielding yellow feeding, keeping qualities unsurpassed. It produces large, ovalshaped'roots; flesh very solid, fine grained, and will keep solid and hard much longer than the small varieties. Pkt. 5c., oz. 10c., 1/4 lb. hard much lo

Imperial Hardy. The well-known standard strain. The comparatively small top, with a single slender tapering root. The skin is a rich purple above the surface, deep yellow below; CARTER'S HARDY - Purple top, yellow flesh. .

SIVEET GERMAN-Grows large, flesh whit

LAING'S PURPLE TOP-Earliest yellow.

SKIRVING'S PURPLE TOP-Heavy cropper...

WHITE FRENCH--Large, productive, flesh hard

MAY'S ELEPHANT-A large, heavy yielder. .
Pkt. 5c.s ib. 15 c b. $40 \mathrm{c}$.

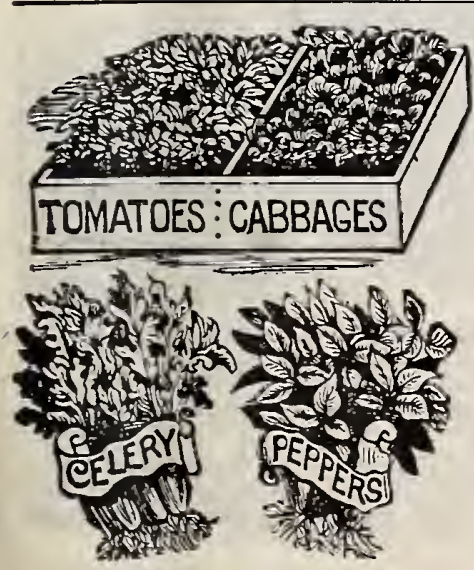

Vegetable Plants.

\section{VEGETABLE PLANTS.}

All orders for vegetable plants will be filled in season when plants are in right condition, and at the right time, See dates below when different varieties are ready for shipment.

We Can Supply in Any Quantity IN THEIR PROPER SEASON ALL VEGETABLE PLANTS HERE MENTIONED, AND SHIP DIRECTLY FROM THE BEDS, WELL PACKED, ON THE SHORTEST NOTICE. IF WE SHOULD FOR ANY REASON BE OUT OF ANY VARIETY ORDERED, WE WILL SEND SOME OTHER SIMILAR VARIETY IN PLACE OF IT UNLESS REQUESTED TO THE CONTRARY.

Our Field Grown Plants

OF CABBAGE, CELERY AND TOMATOES, ETC., WE CAN FILL ORDERS FOR ALMOST ANY QUANTITY, MAKING LIBERAL REDUCTIONS ON LARGE LOTS. WRITE FOR SPECIAL PRICES.
At Prices Quoted . They are sent by express at wanted by mail, add 6 cents per dozen and 20 cents per 100 . Cabbage Plants. Early. The leading varieties Doz. 15 c., 10050 c., $1,000 \$ 4.00$.

Cabbage Plants. Late. S S t a n d a r d varieties. $10040 c$., $1,000 \$ 3.50$.

Cauliflower Plants. Ready in Ma

Celery Plants. Ready July 1st. Doz

Egg Plants. Ready in M $100 \$ 2.00$.

Pepper Plants. Ready in $25 \mathrm{c}$., 100

Tomato Plants. Ready in May

$\$ 1.00,1,000 \$ 7.00$
$50 \mathrm{c} ., 1,000 \$ 3.00$. 
${ }_{26}$ G MAY'S NORTHERN GROWN SEEDS BEST FOR ALL CLIMES \&

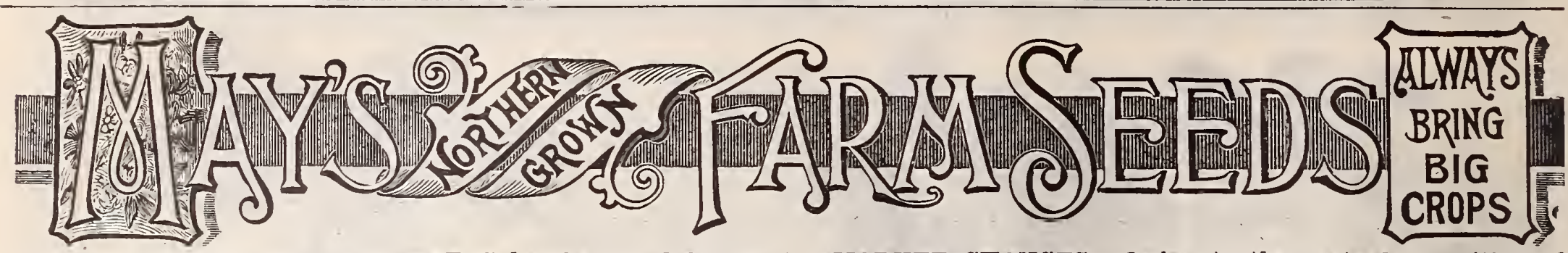

PRICES QUOTED ON FARM SEEDS by the pound include the prepayment of postage. IARGER QUANTITIES WE DO NOT DELIVER FREE, but send BY EXPRESS OR FREIGHT AT PURCHASTR'S EXPENSE, making no charge for packpress office in St. Paul.

NORTHERN STHD CORN The stocks we offer have been especially grown for seed, and every variety G ROW N L L catalogue has been properly cured and caretully selected for seed stocks

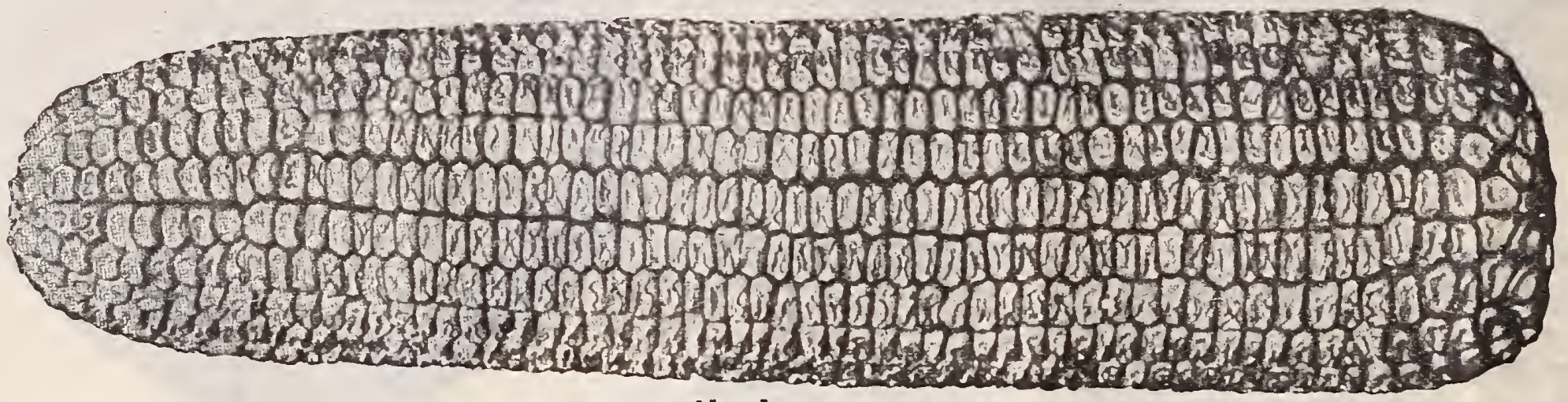

Abundance.

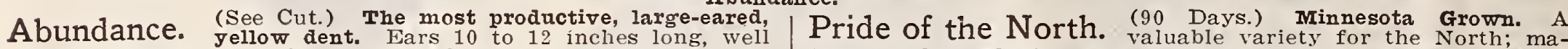
MARKET CHANGES. Owing to the unsteady condition of the markets, prices are constantly changing. The prices given here are those ruling at the time when this catalogue was pulblished; January 1st. Should our prices on any iten seem high, we would consider it a favor if our customers in making up their order for Farm Seeds in large quantities would write us, and we will be pleased to quote prices.

filled to the tip with from 14 to 18 row

tures early. Planted as late as July 4th it has matured by Even in the extreme North, if planted in May, it will mature color. Stalks 6 to 8 feet. Ib. 25c., pk. 60c., bu. \$2.00, bag bu.) $\$ 4.75$. $\left(2 \frac{1}{2}\right.$ bu. $) \$ 4.75$.

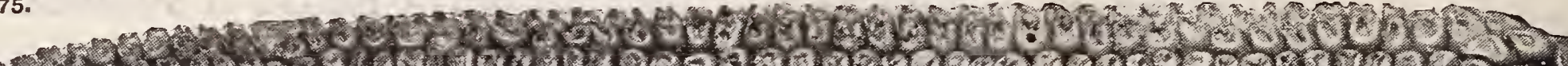

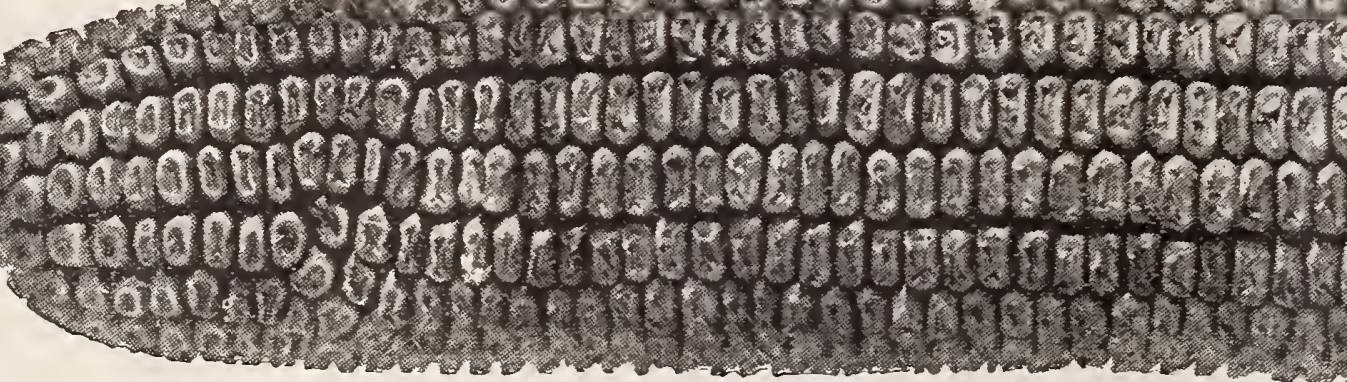

Extra Early Dakota Queen. (See Cut.) Fira Faris Dalota Queen. riety for the Northern States. Ripens in about 85 days from rank, quick, and makes ten-rowed sort. Grows strong, Planting. It is beyond doubt the earliest Dent Corn ever introduced. It is of a bright.yellow color, small ear and cob, with bu.) $\$ 4.75$. Ib. $25 \mathrm{c}$., pk. o0c., bu. $\$ 2.00$, bag

pro 75c., bu. $\$ 2.25$, bag ( $21 / 2$ bu. $) \$ 5.50$.

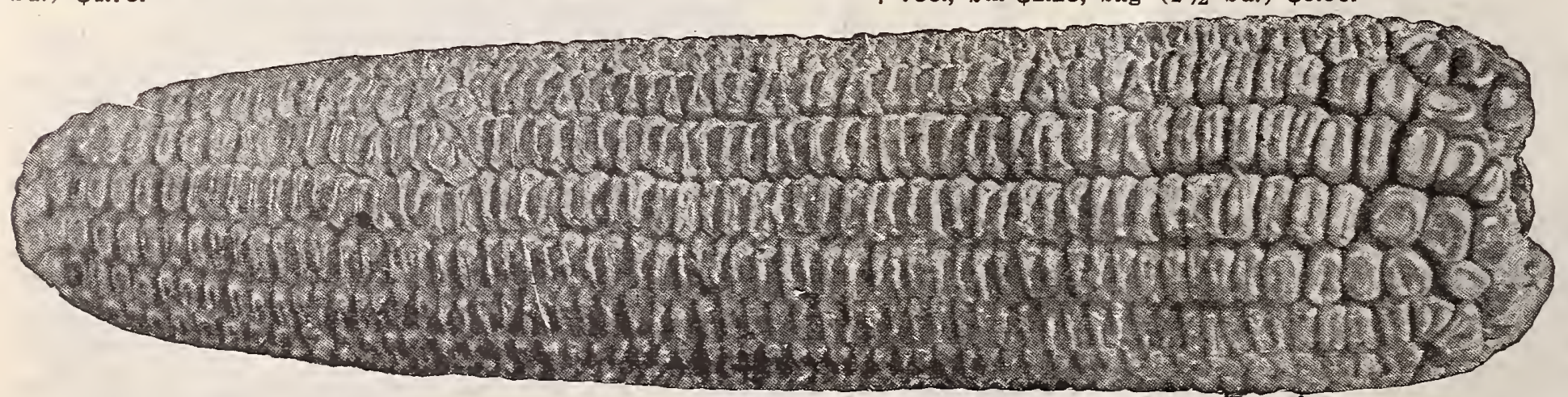
Ib. 25c., pk.

\begin{tabular}{|c|}
\hline See \\
Inside cover \\
for \\
Illustration \\
and Price \\
of \\
Sure \\
Crop \\
Corn \\
\hline
\end{tabular}

\section{Minnesota Number 13. Minnesota Number 13.}

Minnesota Number 13. Minnesota Grown. The Number $\mid$ King of the Earliest. (85 Days.) Minnesota grown. Ears ist of introduced by Prof. Hays, the widely known agriculturthis variety for the past few years, never failing to secure a on the cob, well filled from tip to butt. Will ri par
$\mathbf{I}$ b. 25 c., pls. 75 c., bu. $\$ 2.25$, bag $(21 / 2$ bu. $) \$ 5.50$. the grain and small red cob. 12 to 16 rowed. valuable for Huron Dent Extra Early. (90 Days.) Minnesota grown. large, while the cob is very small. Ib. 25c., pk. 60c., bu. \$2.00, bag $(21 / 2$ bu. $) \$ 4.75$. 


\title{
SEED CORN-Continued.
}

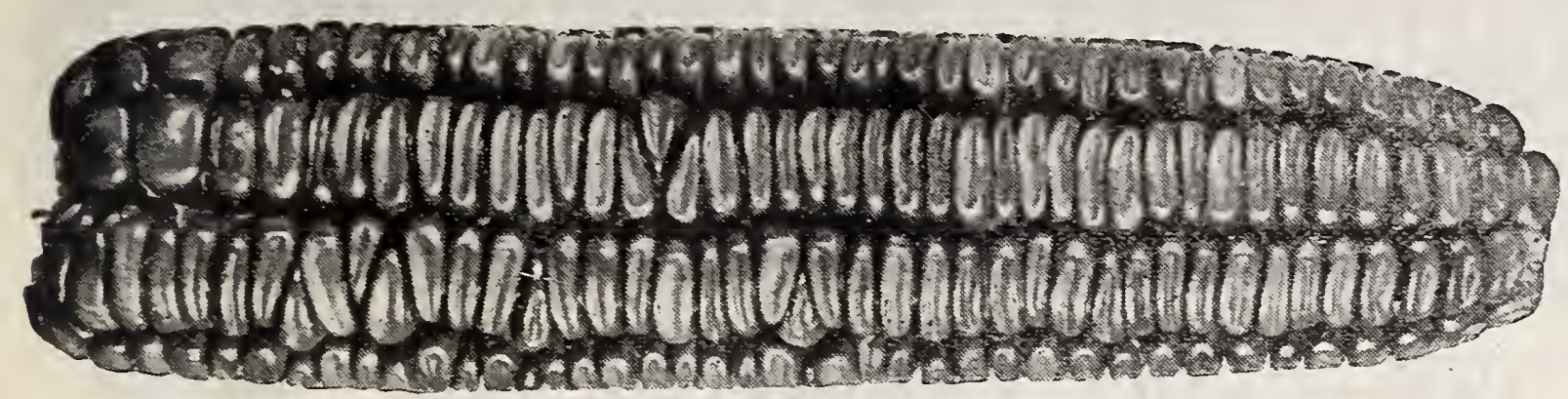

Minnesota King.

\begin{abstract}
Minnesota King. Minnesota grown. A rowed corn. This was introduced a number
of years ago and has steadily increased in favor since its introduction, and we consider for the Northern states.

as much as Minnesota King, tliere are very Ib. 25c., pk. $60 \mathrm{c}$, bu. $\$ 2.00$, bag (21/2 bu.) $\$ 4.75$ White Cap Yellow Dent Min ne sot a corn for thin soils and drought stricken sections. Ears large, 16 to 18 rowed. Stalks stout, 6 to 7 feet high, with abundant foliage. small. I b. 25c., pk. 60c., bu. \$2.00.

Iowa Gold Mine. (90 Days.) A medium that is valuable for parts of Iowa and the yellow color, ears of good size, cob small.
\end{abstract} I b. 25 .

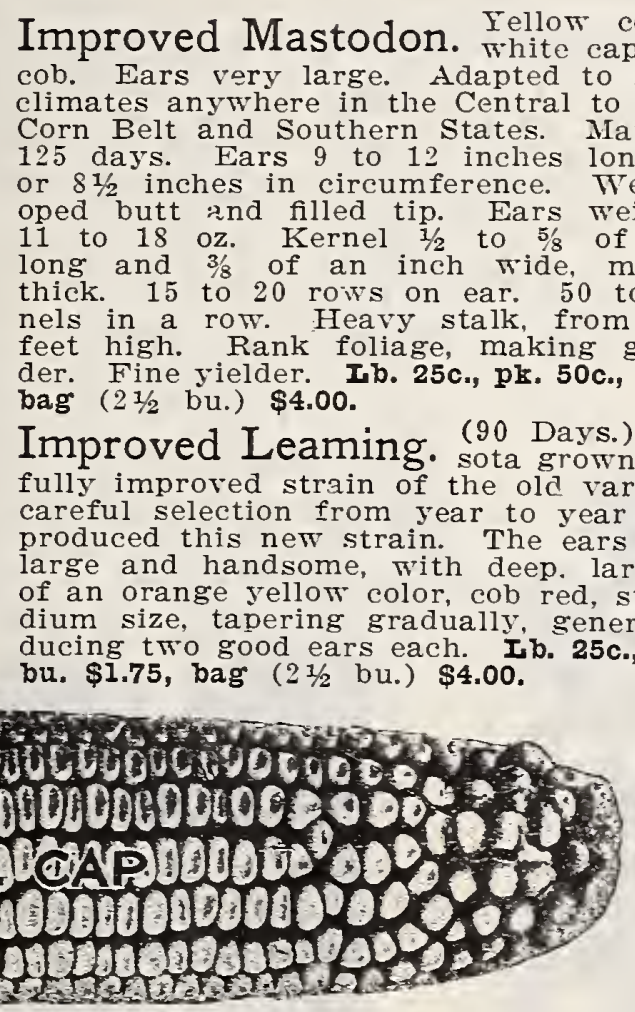

WHITE DENT SORTS.

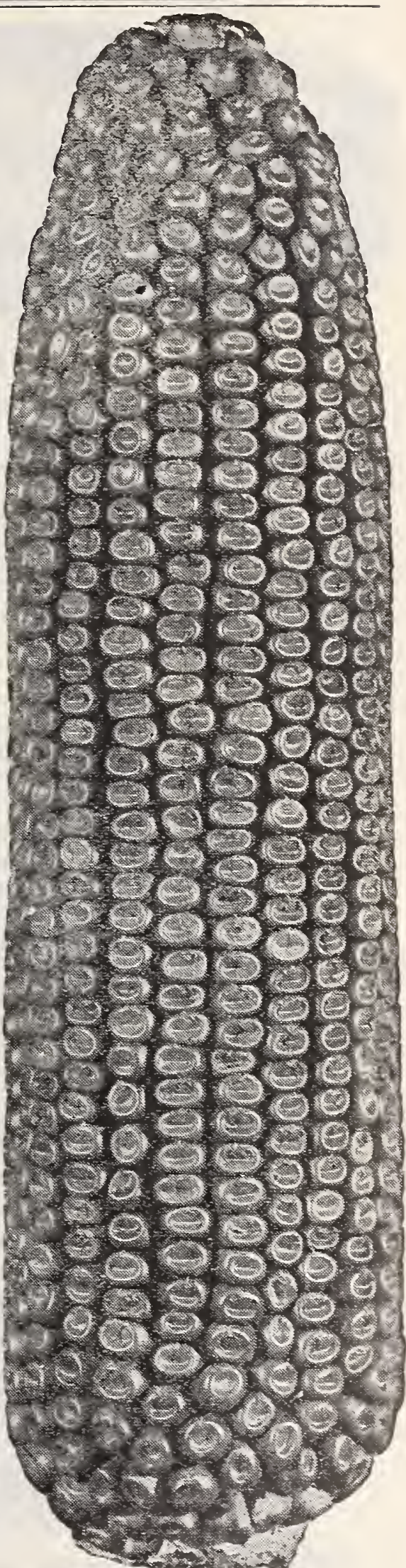

Improved Ieaming.
Mayfield Earliest. Minnesota Grown. A White Dent Corn. The plant is strong deep rooted and stocky, enabling it to withstand drought in a remarkable manner. Matures 80 days from planting. The kernels are very 14 to 16 rows. Ib. 25c., pk. 75c., bu. \$2.50.
Champion White Pearl. (90 Days.) A maturing in 90 to 100 aays. Cobs small, white. The grain is extra long, very heavy and com-
pact. Ib. 25c., pk. 60c., bu. $\$ 2.00$, bag $\left(2 \frac{1 / 2}{2}\right.$ bu.) $\$ 4.75$.

Iowa Silver Mine. A standard variety markable for its large yields. Ib. 25c., pk. 60c.,

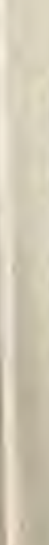

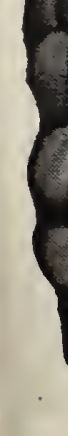

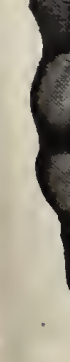

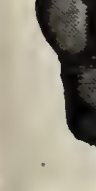

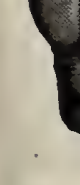

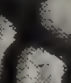

S
$\mathrm{r}$
$\mathrm{a}$
$\mathrm{e}$
$\mathrm{M}$
$\mathrm{e}$
$\mathrm{k}$
$\mathrm{v}$
$\mathrm{v}$
$\mathrm{p}$
$\mathrm{H}$
$\mathrm{H}$
$\mathrm{d}$
$\mathrm{a}$
$\mathrm{1}$




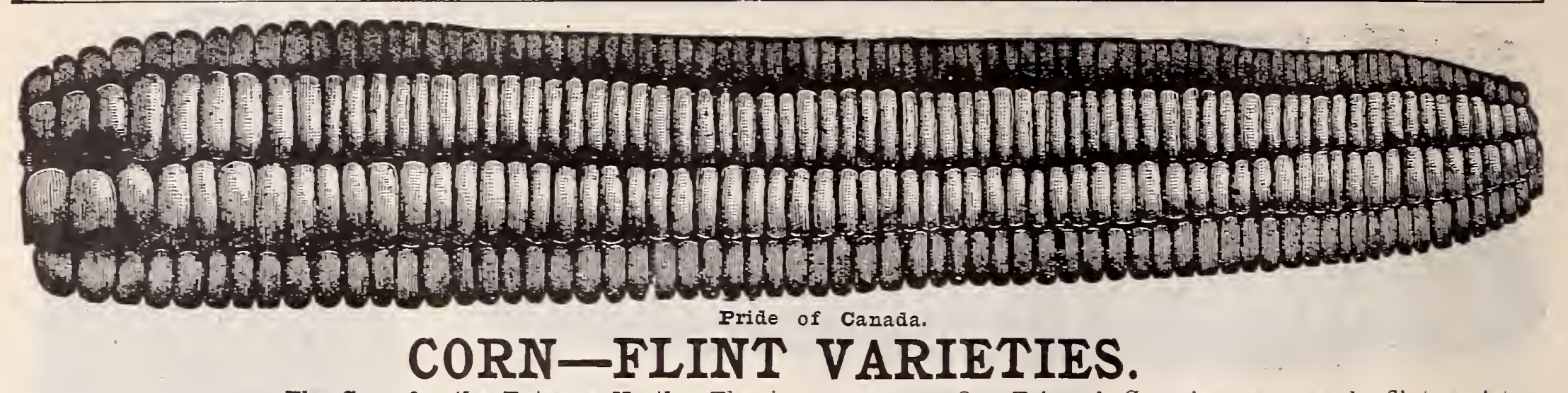

Pride of Canada. The Corn for the Extreme North.

long, of rich yellow color. Enormously productive, outyielding any feld corn we have ever grown. Will prove to be of the

than any of the flints. Don't fail to try it if you want a big
yielding flint corn. Lb. 25 c., pk. 75c., bu. $\$ 2.25$, bag (21/2 bu. $\$ 5.50$. Mercer.

to the

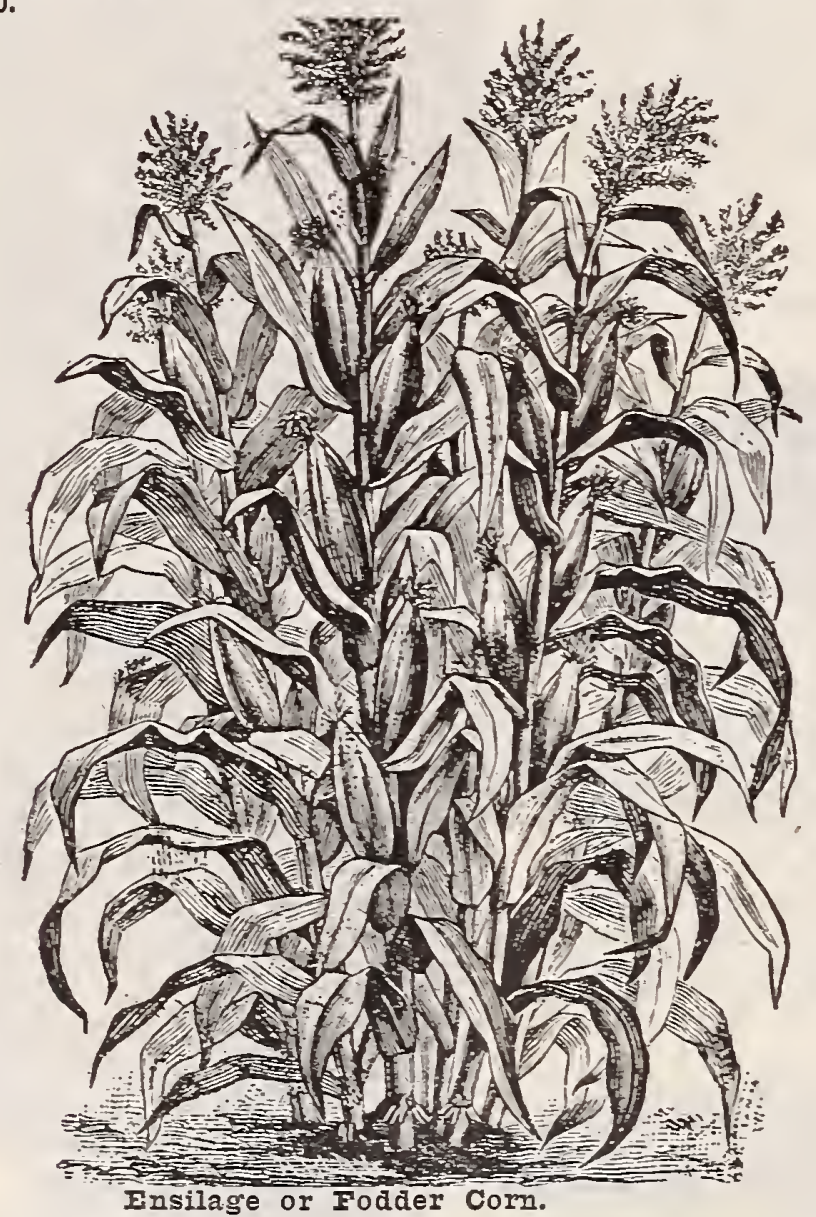

CORN, Ensilage or Fodder Sorts.

Cuban Giant Ensilage. Unequaled in yield and unsursweet and tender as sugar corn. P1. 50c., bu. \$1.50.

Jumbo Ensilage. Large grained, sellow, tall

Red Cob Ensilage. A large, white, heary cropping raWhite Cob Ensilage A pure white fodder corn: ears of White Cob Ensilage. an immense size. PE. 35c., bu. \$1.25: Sweet Fodder Corn.
Triumph.

early flint variety, arerage two to a stalk, growing well up so as to readily admit of being cut Sanford's White. It is quite early, with large sized ears,

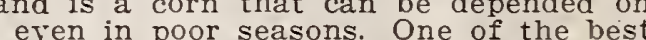
flint varieties for sections where flint corn is grown. Lb. 25c.,

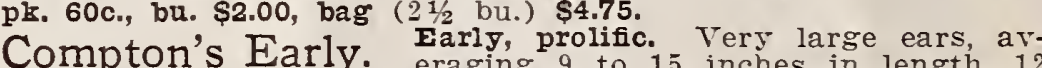
to 14 . eraging 9 to 15 inches in length, 12 King Phili. Lo. $25 \mathrm{cos}$ ps. 60c., bu. $\$ 2.00$, bag Wh. 25 ., pk. 75c., bu. $\$ 2.50$. small cob, large kernel and very broad.

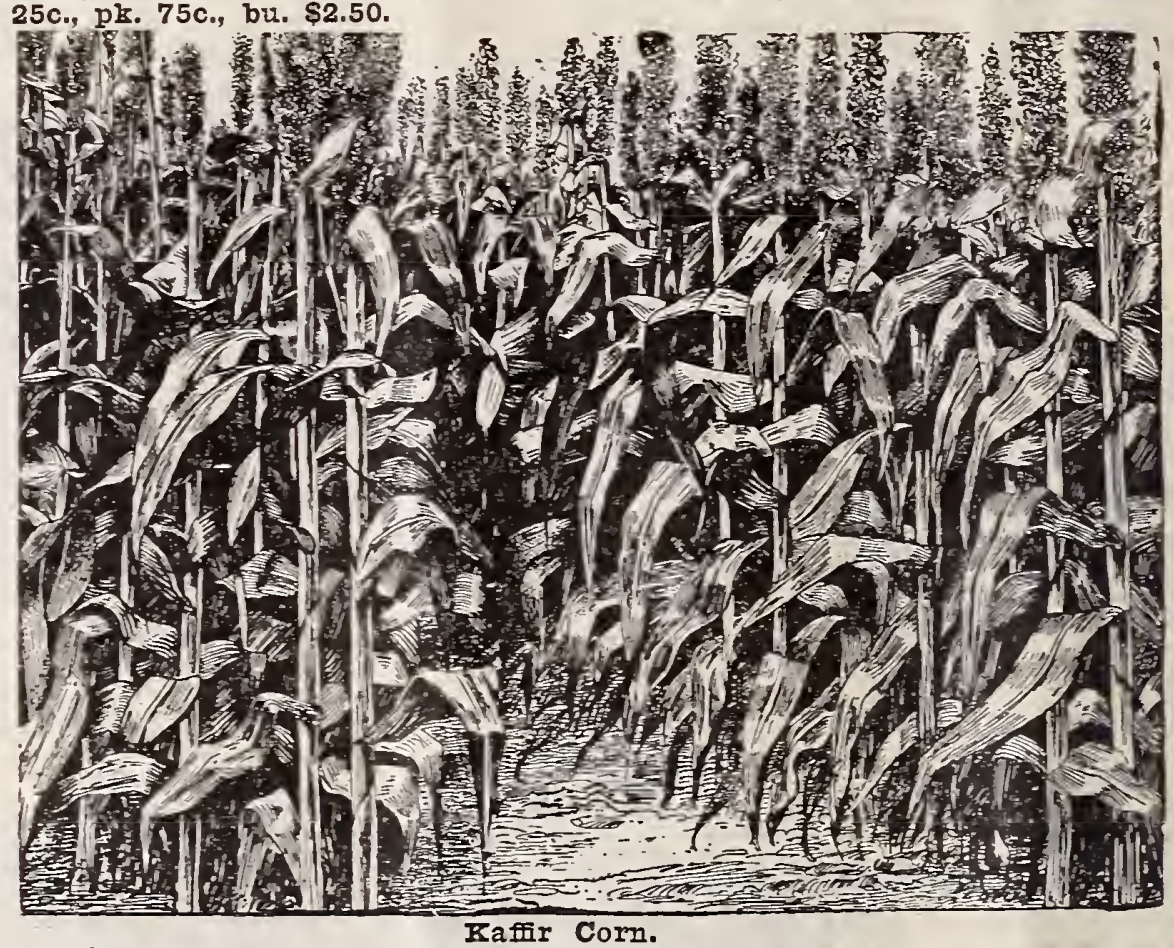

Kaffir Corn. Yields heavily even on the poorest soils. This ular in all sections and is highly recommended $\mathrm{by}$ the leading agricultural writers.- It is a variets of non-saccharine sorstool from the roots, but branches from the top joints, producing two, three and four heads of grain from each stalk. are verr strong and never known to blow down in ordinary wind storms. It has the valuable quality of resisting drought, and if the growth is checked for want of moisture, the plant any app rant detriment to its condition: indeed, reports show that it has never failed to produce a good crop in the most disastrous season. The whole stalk, as well as the biades, cure into excellent fodder; and in all stages of its growth is Kaffir Corn may be planted very early in the spring and should be sown in rows about 3 feet apart, using about three or four pounds to the acre. It can be grown as far north as Minnethis country. Lb. 25c., postpaid; by express, 10 lbs. 50c., 


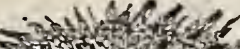

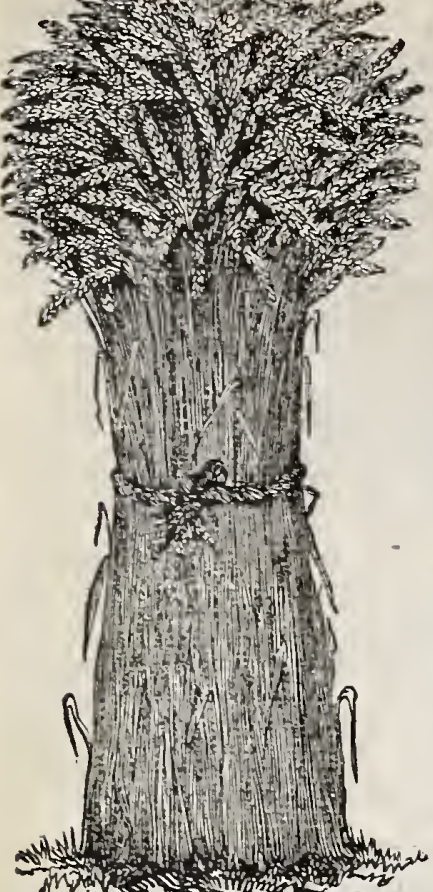

Early wonder Wheat.

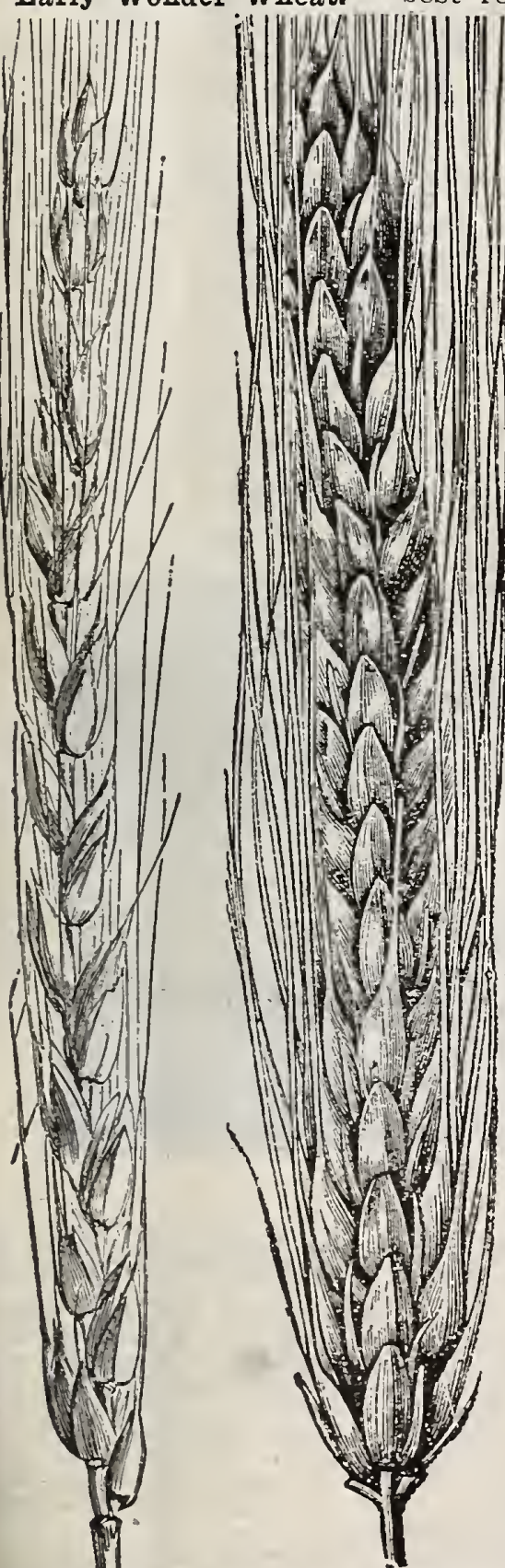

MAY'S EARLY WONDER SPRING WHEAT.

Most Prolific, Heaviest Stooling, and the Best Milling Wheat That Can Be Grown.

Five Good Reasons Why "Early Wonder" Should be Sown by Every Farmer in America. 1. It's the heaviest yielding wneat in the world. 2. It is perfectly hardy. and 4. It makes the choicest flour and is the best milling wheat we know of. 5 . It will in crease your crops and bring you more money per acre than any other wheat, and no bright, intelligent man who wants to make his farm pay looks at a few extra cents that he has to pay 作, with its heavy yields and its earliness, make it the desirable variety for all sections of America. Ib. 25c., postpaid, pk. 50c., bu. \$1.75, 10 bu. \$16.00. Minnesota Spring Wheat No. 163. Originated at State Experimental Farm, and was introfilled with medium sized plump kernels. Flour made from this variety shows a higher gluten

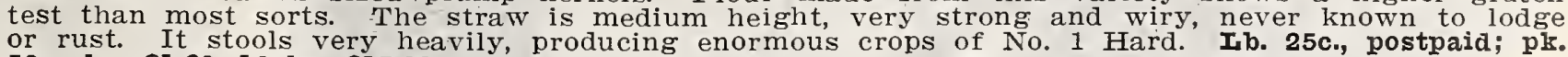
50c., bu. $\$ 1.60,10$ bu. $\$ 15.00$.

Blue Stem Spring Wheat No. 169. Improved. Fields heavily, not only here at home in where and under all conditions. The and the plant stools freely, and under ordinary conditions will yield 40 to 50 bushels per acre. Ib. 25c., postpaid; pk. 50c., bu. $\$ 1.50,10 \mathrm{bu} . \$ 13.50$.

Saskatchewan Fife Spring Wheat. Noted for its earliness, vigor and freedom from smut by it. is recognized as an A No.1 milling wheat, adapted to all states where wheat can be grown. Lb. 25c., postpaid; pk. 50c., bu. $\$ 1.50,10 \mathrm{bu}$. $\$ 13.50$.

Durum or Macaroni Spring Wheat. (Kubauka, the best.) It is not only true that Macaroni grown there in order to produce the best quality of grain. Seeded April 26 , it was ripe cut threshed and in the granary August 6. The shorter the period required for a wheat to grow the more valuable it. Will be to a locality subject to summer droughts and hot winds. Th. The
best results on new land. Ib. 25c., postpaid; pls. 40c., bu. $\$ 1.45$, 10 bu. $\$ 12.50$.

Rye, Spring Dakota Mammoth. Its greatest value lies in the fact that it may grain has been a failure. Sow at the same time you do
$11 / 2$ bushels per acre. Lb. 25c., pastpaid; pk. 50c., bu. $\$ 1.75$.

New Barley, University No. 105. For several years the MinStation has been breeding and testing many varieties of barley with a view to producing an improved sort that would lead all other kinds in the matter of yield. This ambition the Station considers, has been realized in the new six-rowed variety here offered under the name of University No. 105. In comparative tests covering a period of several years and made side by side with the best known and
most popular varieties, it has proven to be the heaviest yielder, and from any standpoint, a most valuable acquisition.
It is early, uniform in maturing and pure. Ib. 20c., postpaid; pr. $50 c$., bu. $\$ 1.75$.

Highland Chief Barley. A new and distinct very robust, vigorous grower. Straw strong, upright; yields from 50 to 60 bushels per acre; usually weighs over 50 lbs. to the measured bushel. Ib. 20c., postpaid; pir. 50c., bu. $\$ 1.75$.

New Beardless Barley. The earliest barley 20 th of March will ripen about the 28th of June: straw same length as common barley; will stand up on any land; has produced 80 bushels per acre. It as early as you can; frost will not hurt it. makes a stronger feed. I Ib. 20c., postpaid; pz. 50c., bu. $\$ 1.75$.

White Hulless. A barley with a grain-like wheat. pecially for hogs. Our seed is Montana grot'n. fine, bright, hulless and beardless. Weighs over 60 pounds
to the measured bushel. It grows very quickly on any kind of soil. It has been sown as late as the $25 c$., postpaid; pl. 50c., bu. \$1.75.

For 10 cents, a sample of this valuable. Barley will be sent to those who wish to inspect it before pur-

Speltz or Emmer. IT MAKES A GOOD CROP DITION OF SOIL AND CIIMATE. It is neither Wheat, rye nor barley, and yet it appears to be a any of the others mentioned. For fattening cattle, poultry, horses, sheep, pigs, etc., it is claimed to be ahead of other grains; in fact, all kinds of animals
seem to thrive on it. Speltz is claimed to be ahead of corn, sunerior to oats and more profitable than wheat. Yields 80 to 100 bushels of richer food than corn, besides giving as much as 4 tons of good hay per acre. Excellent for pasture and can be fed in the green state. As green grass hay food it often gives 100 leafy stalks from one seed, which shows its heavy stooling properties. The heads are someing separated from each other in such a manner that the crop is not easily iniured by the weather. It
is a heavy yielder. Will grow well and produce is a hormous crops on land where wheat will not grow. Sow 75 to 100 lbs. per acre. Lb. 20c., postpaid ; 50
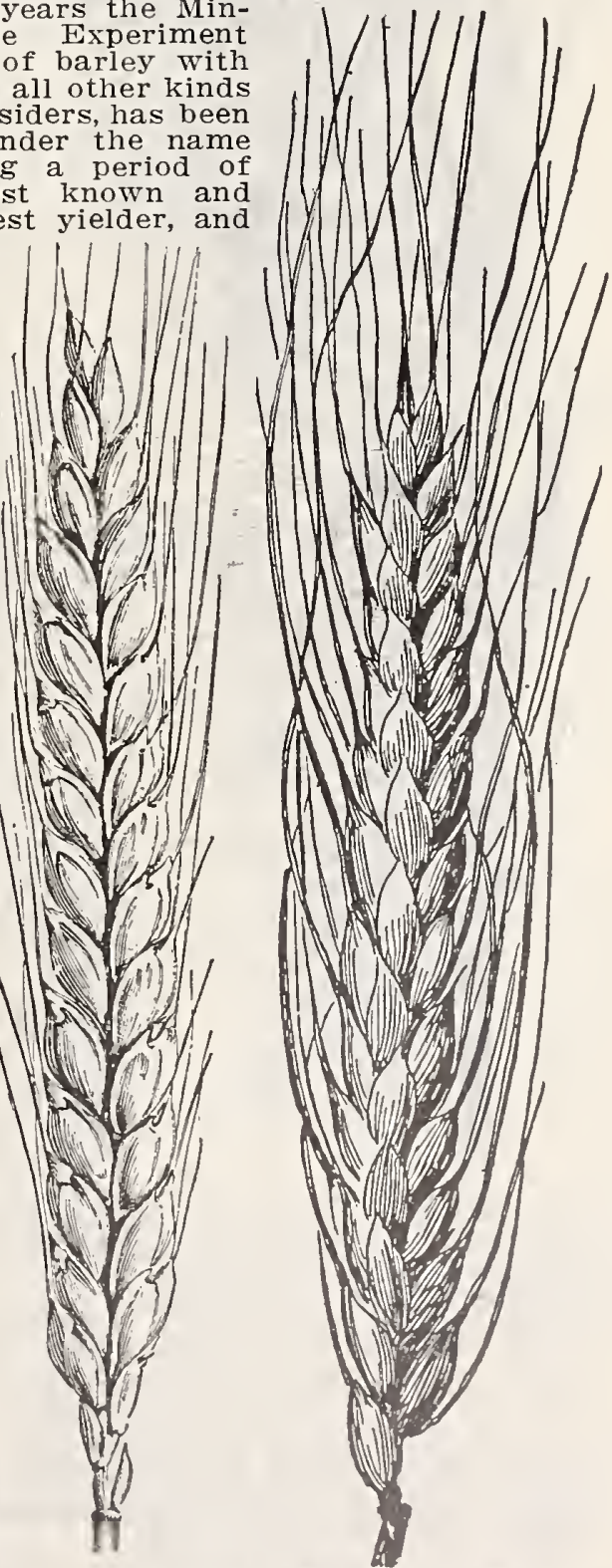

Spring Rye. Mansbury Barley. Ibs. \$1.25, 100 Ibs. \$2.25. 


\section{GF MAY'S NORTHERN GROWN SEEDS BEST FOR ALL CLMES \&}

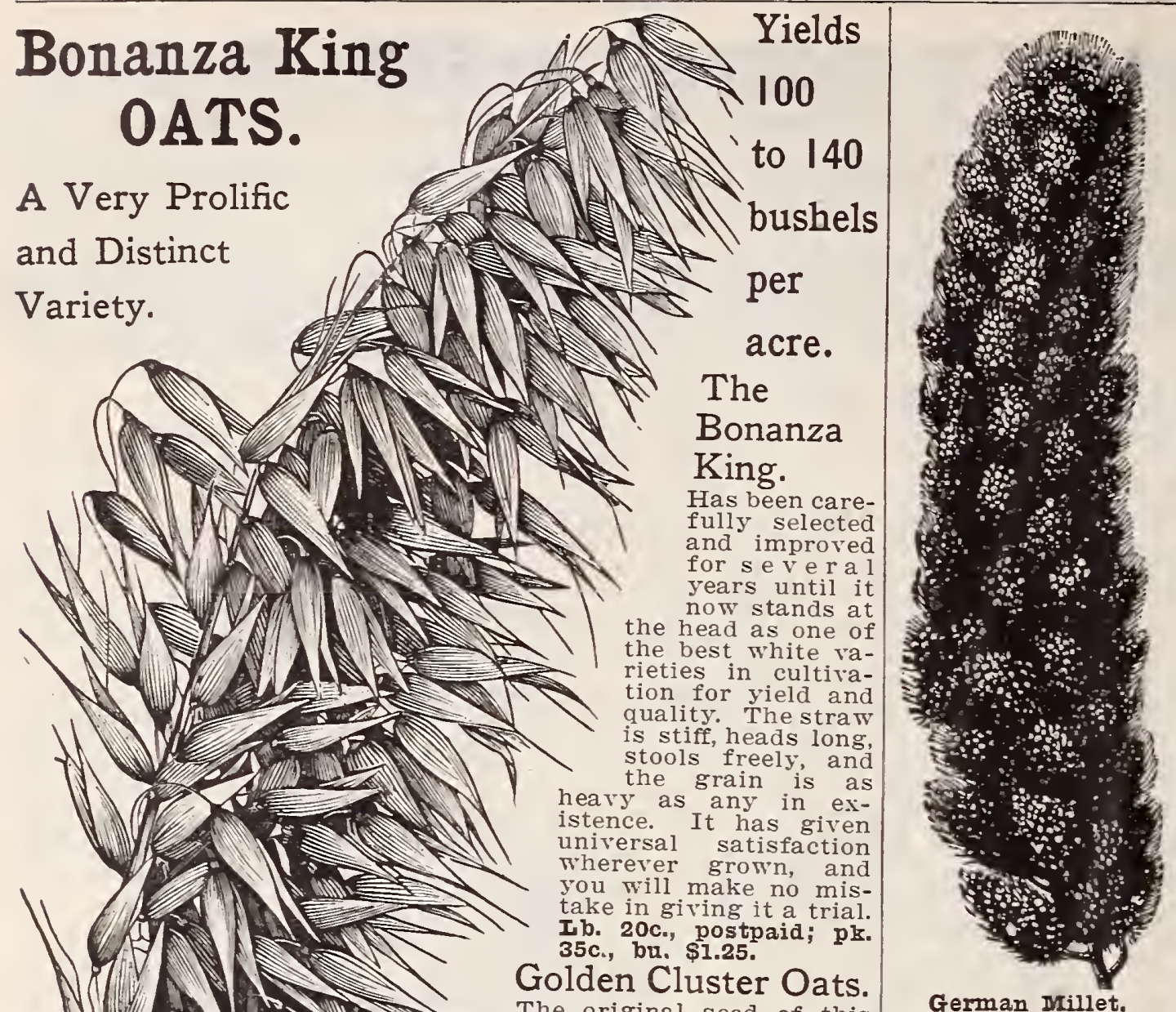

German Irillet.

German or Golden Millet. $\underset{\text { Southern }}{\mathrm{T}} \underset{\mathrm{u}}{\mathrm{u}}$ grown. This is a medium early millet, growing from 3 to 5 feet in height, and in good seasons has been known to produce over 5 tons of hay to the acre, and from 70 to 80 bushels of seed. It will grow in almost any soil or climate. Ib. 20c., postpaid; pk. 50c., bu. $\$ 1.50,10$ bu. $\$ 12.50$

Hungarian Millet. Often called Hungeneral favor for summer forage purposes, as it can be sown in June as a second crop, and will be ready to cut in 60 days. It will yield 2 or 3 tons of hay per acre. $25 \mathrm{c}$., postpaid; pk. 50c., bu. $\$ 1.50$, $10 \mathrm{bu}$. S12.0.

Siberian or Russian Millet. A new wonderfully productive forage plant from Russia, which has given excellent results in the United States. Is earlier than German, extremely hardy and will stand more hot, dry weather than any variety of millet. It makes a very rank growth, with an abundance of leares, which start from the ground. Sow in April, May or June at the rate of $1 / 4$ to $1 / 2$ bushel per acre, according tion to the fact that caur seed is Northern Grown, and consequently hardier and stronger in grownsequenty hardier and lower latitudes. Ib. 25c., postpaid; bu. Early Fortune Millet. A most promof which astonishing yields are reported. proof ery early, and claimed to be rustplant. Ib. 25c., postpaid; pk. 40c., bu. \$1.25. Japanese Barnyard Millet $\mathrm{H}$ a $s$ an enormous yielder in all sections of the U. S., producing hay and fodder of most excellent quality and growing on any soll, 10 In drills 8 1bs. per acre. I Ib. 35c., postpaid; 50 lbs. $\$ 2.75,100 \mathrm{lbs}$. $\$ 5.00$

Hog Millet. Known also as Broom Corn Millet. Quite unlike growth, as well as the appearance of the seed, which is much larger. The name, Hog Milliet, has been applied to emphasize the use to which it is now being put as an economical and valuable food for hogs, while it is also one of the best varieties for use even in the best corn belts, and of much greater value in all is not so important a crop. I 1 . 25c., postpaid; pls. $40 c$. bu. $\$ 1.25$. bushels. Ib. 20c., post-
paid; pk. $35 c .$, bu. $\$ 1.25$.

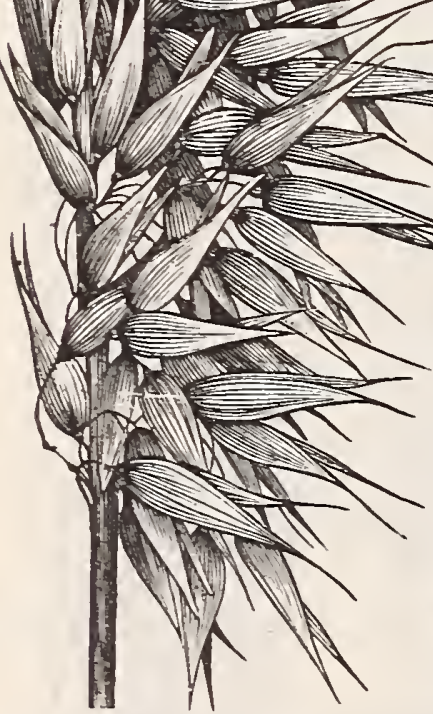
Lincoln Oats.

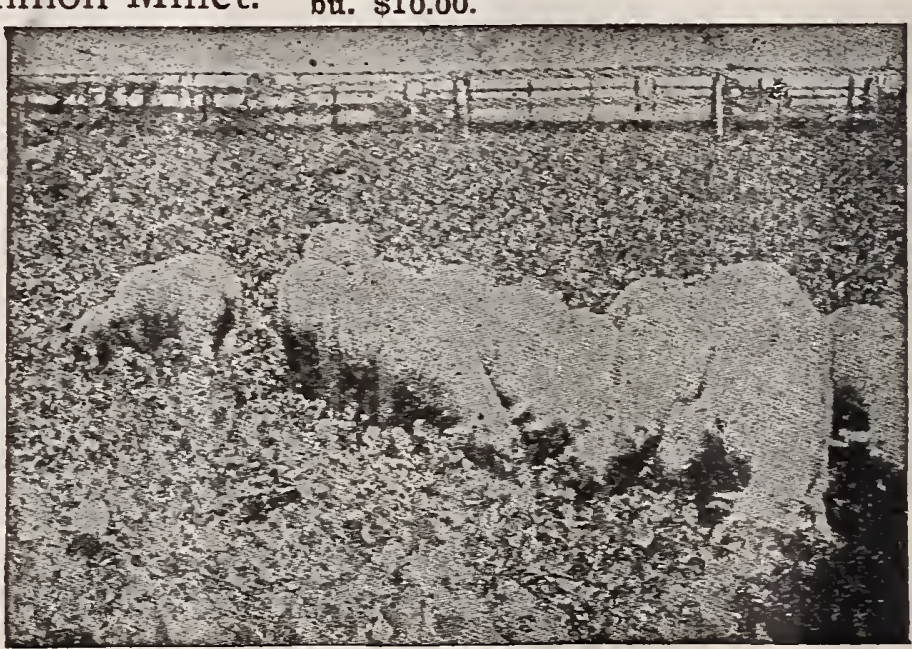

Rape, Dwarf Fssez.

RAPE.

One acre of well grown Rape will furnish pasture for 10 to 20 One acre of well grown Rape will furnish pasture fatten them in good form for the market. The Dwarf Essex. The best forage plant for the sheep ommended by Professor Shaw, of the Minnesota Experimental Station, and many other leading authorities on stock feeding. It of feeding value of green clover. Sheep, swine, cattle and poultry eat it readily, but it is particularly desirable for sheep on account of its fattening qualities. Rape wind $\mathbf{L} b .25$ c, postpaid; 10 ibs. 75 c., 50 lbs. $\$ 3.65,100$ lbs. $\$ 7.00$.

Dwarf Victoria A standard sort of German origin. In our A find that Dwarf Essex will sur10 Ibs. 75 c., 100 lbs. $\$ 6.50$. 


\section{Ge GIOWN IN THE GOLDEN GRAIN BELT OF THE WORLD}

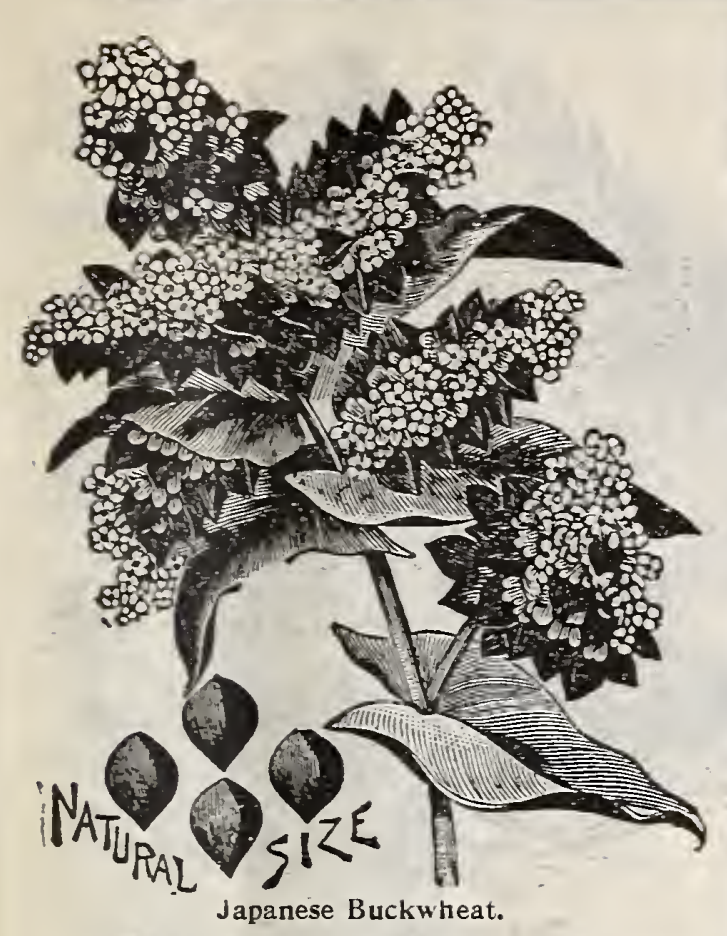

\section{BUCKWHEAT}

Often called "the lazy man's crop," deserves better treatment than it generally gets. It is a "catch crop," easily grown between regular succession than is generally accorded it. Also valuable as a weed exterminator and green manure.

Tapanese. (See Cut.) The best, most variety in cultivation. From $1 / 2$-bushel of seed somn a crop of 40 bushels has been harvesied. In color the grain is a rich dark brown. Flour from Japanese buckwheat is fully equal in quality to that from any other variety. It ripens a week times as much. Excellent for bees. Lb. 25c. postpaid; pk. $40 \mathrm{c}$., bu. $\$ 1.50$.

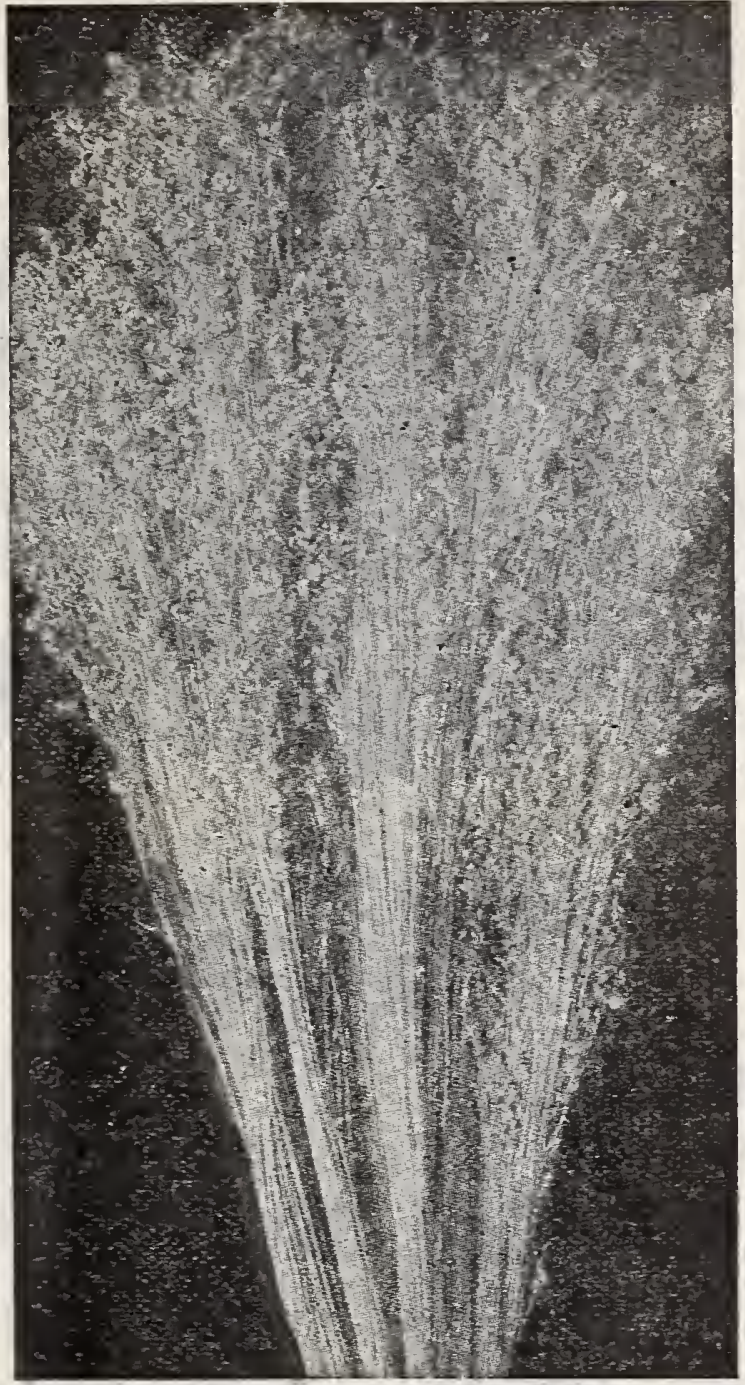

Broom Corn, Evergreen.

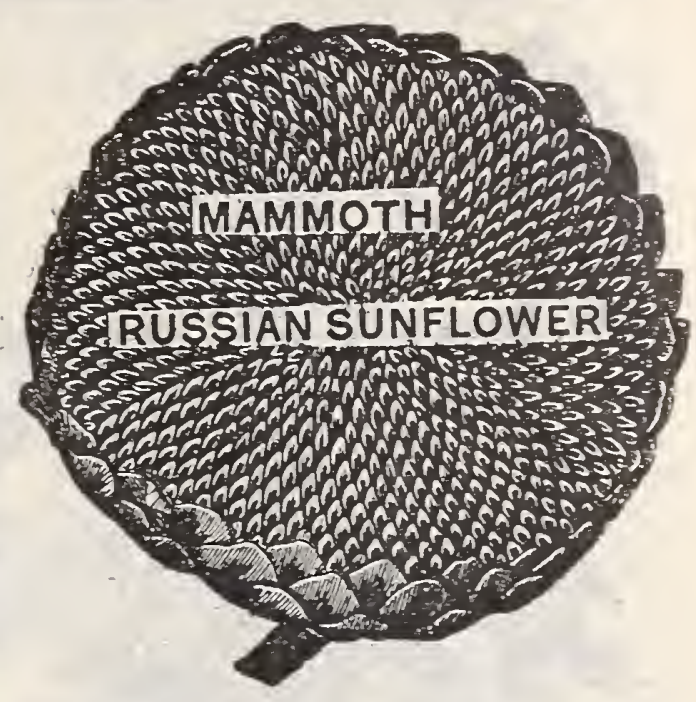

Mammoth Russian. The best egg. food known for poultry. Can be raised cheaper than corn. Single heads measure fifteen to thenty-two inches in diameter, and contain immense amount of seed, which is hrghly valued by all farmers and poultry breeders who have It you keep only a pair of fowls get a pound of this seed just for a trial and be convinced.

It contains the shell to make eggs.

It gives the fowls a bright, lustrous plumage.

fortion.

It makes eggs hatch more vigorous chicks.

It makes them more vigorous than if fed on any other food.

It is a heavy cropper on almost any soil

It can be sown from early spring up to July.

It is also good food for cattle and horses. It

It is fattening to either poultry or cattle.
Its strong, thick stalk can be used as fuel. feather picking.

It is used as a medical her

Silver Hull. An old standard sort that ripens earlier than the comkinds of soils and seldom affected by drought. The berry is of a light silver In fact it is the most wonderful, cheapest and best poultry food known. gray color and the flour is whiter and more nutritious than that made of a common sort. There is a steady demand for this every year and it can be relied upon to produce a good crcp in any
nary season. Lb. 25 c, postpaid; pk. 40 ., bu. $\$ 1.50$.

\section{BROOM CORN.}

Evergreen. (Minnesota Grown.) This variety is more account of the color and grown than any other sort on good length, always green; when ripe it does not get red and has no center stalk, which is most desirable to broom corn grou of this variety, and lnow that it is cartain to faction. Lb. 20 c., postpaid; 10 lbs. 50 c., 50 lbs. $\$ 2.00,100$ lbs. $\$ 3.50$.

Evergreen Tennessee. Of fine quality, good pearance; cut before the seed is ripe it is a beautiful pea green color, ripens early and yields heavy crops. Lb. 25c., post= California Golden. This variety has been carethat the brush is straight and long, a very large proportion of it being suitable for hurl. It is of fine quality, of light green color, turning to light yellow when allowed to become too ripe. Brush straight and long. Lb. 25c., postpaid; 10 Ibs. 50 c., 50 lbs. $\$ 2.00,100$ lbs. $\$ 3.50$.

Dwarf Evergreen. Grows from three to four feet brush; principally used for making whisks and brushes. Lb. 25c., postpaid; 50 lbs. $\$ 2.75,100$ lbs. $\$ 5.00$.

Tapanese. By far the quickest growing variety that will mature in $\mathbf{7 5}$ days when planted late. One grower states that it was planted the middle of July and ready to cut by the first of October. Largely grown in the Southrestern

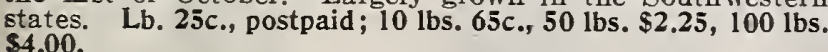

NEST EGGS The BEST AND CHEAPEST. See page 13 for the JAPANESE NEST EGG GOURD.

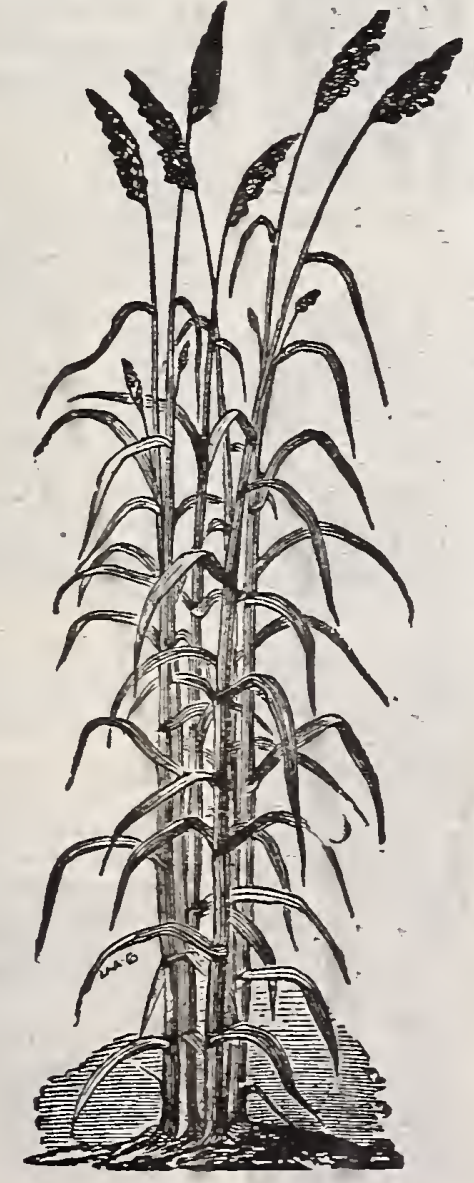

SUGAR CANE or SORGHUM.

As a pasture crop for cattle, sheep and swine it has no superior. When grazed down it will quickly spring up again, hence a large amount of pasture may be obtained from it at sources. As a selling crop it will always prove of great value, since at least two crops can be obtained from one sowing, but its highest value as fThen properly grown it may be fed during more than half the year.

Minnesota Early Amber. Get pure seed of that makes a fine syrup, clear as crystal. When planted beripens, yielding twenty to twenty-five oushels of seed and syrup per a cre. Its earliness adapt it

tion, having been raised with grept itc introduced. For fodder purposes use 50 to $60 \mathrm{lbs}$. per acre suffice. Lb. 20 c., postpaid; by express or freight, 50 lbs. $\$ 2.25$, 100 lbs. $\$ 4.00$.

Southern Cane.

amount of green fodder. Lb. 20 c, postpaid; by
freight, 10 lbs. 35c., 50 lbs. $\$ 1.50$, 100 lbs. $\$ 2.50$.

Edna Crone, Mandaumin, Ont., Canada,

in perfect condition, and are a great bargain. Thanking

for your promptness in filling my order.

\section{BARGAIN DAY.}

Sugar Cane.
Bessie Paul, East Dubuque, Ill., writes:

delighted with them
My plants, ferns and palms arrived in fine condition. Am 


\section{${ }^{32}$ gु MAY'S NORTHERN GROWN SEEDS BEST FOR ALL CLIMES Sf}

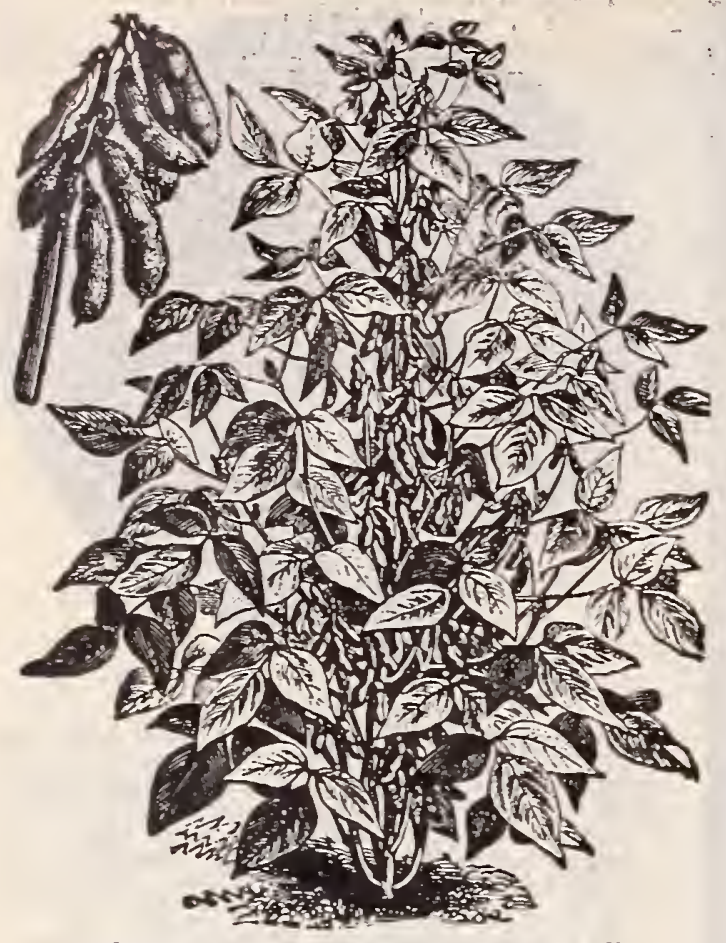

Soja Bean or "German Coffee Berry."

COW PEAS.

THE GREAT SOIL IMPROVER. Makes Poor Land Rich---Makes

Good Land More Productive.

Cow Peas for Hay. If planted early, say the hay the same as clover, then the stubble in a short time now a widespread disposition to plant cow peas farther hort thd their great value for ensilage and soil improve possessing great fertilizing powers. It draws its nourish measure to the soil, thereby enriching it to a degree that food at the e. In the cow pea we have a fertilizer and makes a fine fodder for cattle. The cow pea ranks very nitrogen from the atmosphere. The ripe peas contain no properly cured are a most valuable fodder for cattle and hay. This is not exactly a pea, but belongs more properthe vines plowed under to fertilfed fodd plowing under a crop of cow peas and thus made into a acre.

\section{CANADA FIELD PEAS.}

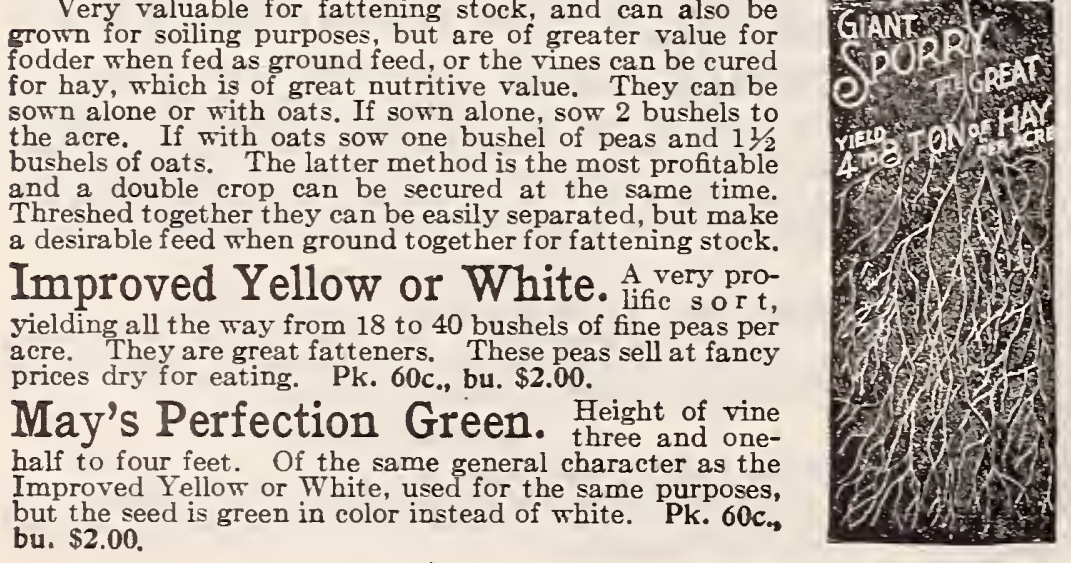

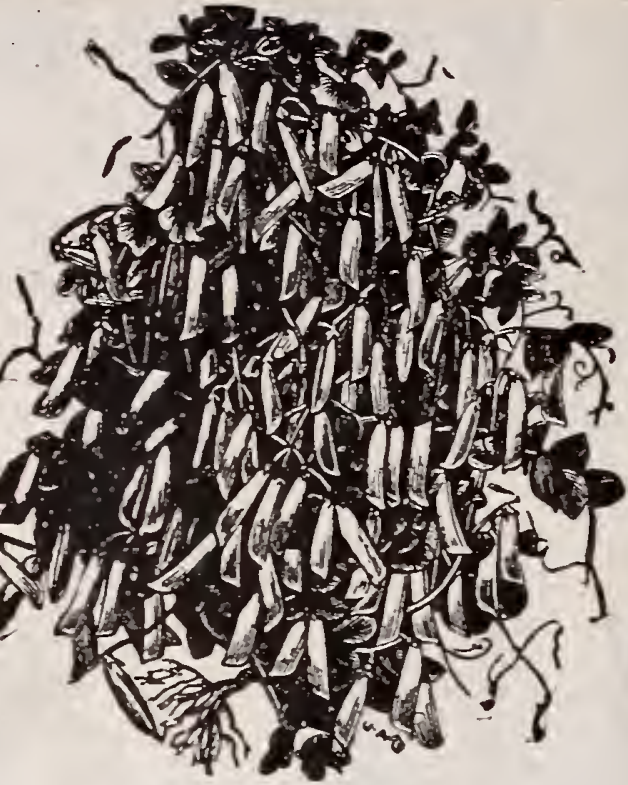
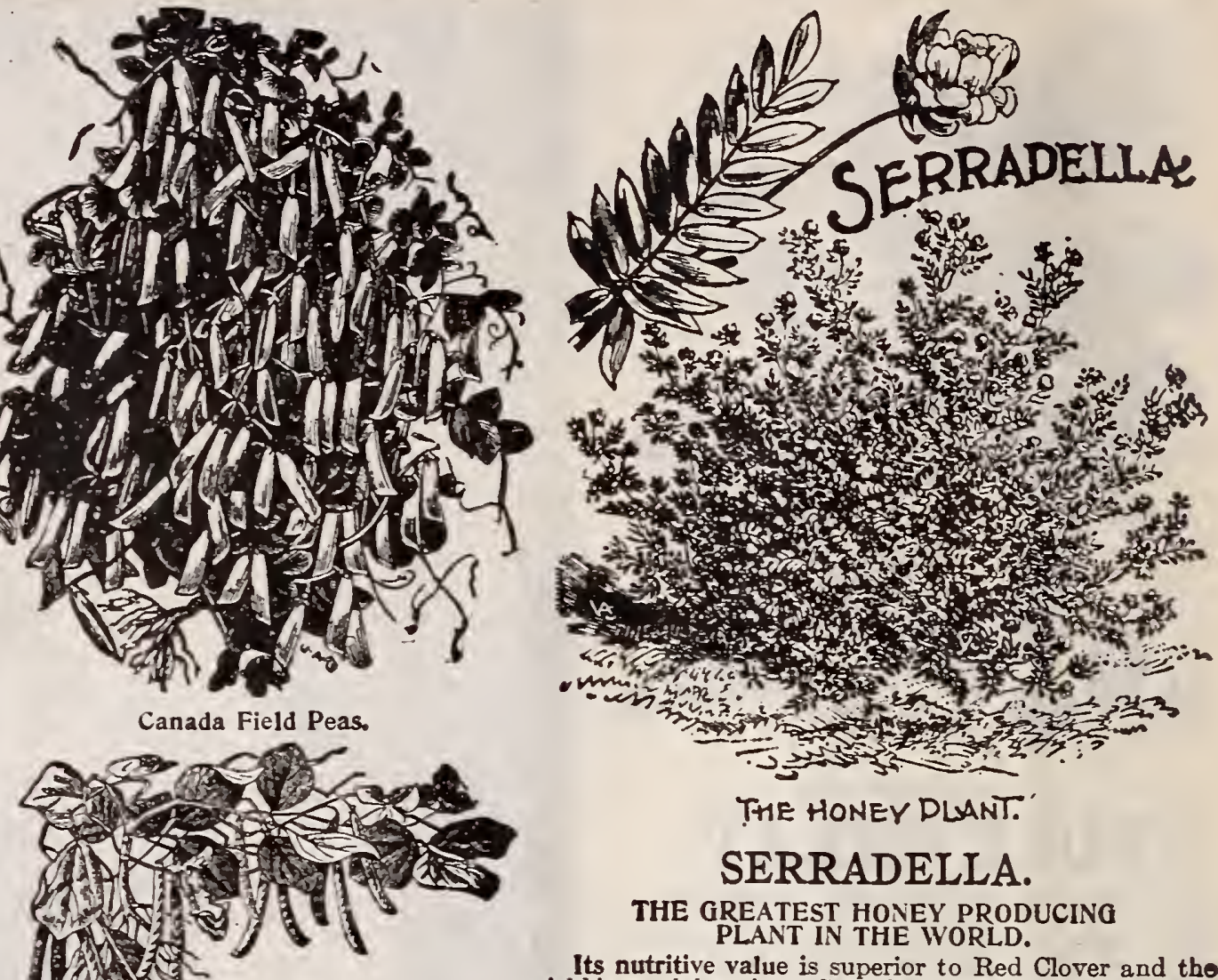

THE HONEY PLANT.

SERRADELLA.

THE GREATEST HONEY PRODUCING

PLANT IN THE WORLD.

Its nutritive value is superior to Red Clover and the yield is much heavier. Serradella also has the peculiarity of thriving on any soil and doing equally well in any local ity. All kinds of cattle been obtained direct and the seed which we this splendid plant. Our supply has been obtained direct and the seed which we offer is of the $\$ 8.50$.

\section{SOJA BEAN, OR COFFEE BERRY.}

MINNESOTA GROWN, EXTRA EARLY.

This variety has been extensively advertised as the "German Coffee Berry," the that when roasted and coarsely ground, it tastes so nearly like Brazilian coffe the difference is scarcely perceptible. It is certainly the best of all substitutes for coffee yet found. This valuable forage plant is one of the most nutritious of all vegetable products. It will produce a crop of 20 to 30 bushels per acre, and it is very valua lb. 30c., postpaid; by express or freight, pk. $\$ 1.25$, bu. $\$ 4.00$.

WHY YOU SHOULD PLANT GIANT SPURRY.

Because it is the most prolific fodder and hay plant for sandy soils, for worn out land, for poor and doubtful soils known. It flourishes on sandy worn soils, where no other plant flourishes, and returns big yields every time. It comes next to clover as a fertilizer. Take the poorest land or the worst land that you can imagine and sow 20 lbs. of Giant Spurry per acre. Do this two years, and you will have a soil for wheat, oats and potatoes. It is of very rapid growth and is sown the latter part of March, April or May, at the rate of $10 \mathrm{lbs}$. per acre if wanted for hay. The seed is sown broadcast on well prepared soil and covered lightly by harrowing. It germinates quickly, and in from 6 to 8 weeks is ready rest of the summer. If wanted as a fertilizer, 20 lbs per acre are sown and when from 15 to 20 inches high, plowed under. Two crops can be plowed under in one year on account of its quick growth. Its value as a manurial plant on light plants. It is readily eaten by cows, sheep and cattle. The reports received rrom parties who have tested Giant Spurry are very gratifying indeed. Everybody pronounces it a tremendous hay producer and the best gred
Lb. $25 \mathrm{c}$. , postnaid; $10 \mathrm{lbs}$. (enough for 1 acre) $95 \mathrm{c} ., 50 \mathrm{lbs}$. $\$ 4.00$.

TOMATOES WEIGHING 22 OUNCES.

Mrs. Henry Geckler, Zoar Station, Ohio, writes: neighbors wonder why I have such a nice garden and I tell them because I plant May's seeds.

Mrs, Ella M. Lester, 3012 Colfax Ave., $S$. Minneapolis, Minn

I have planted your Aster seeds for the past two years and people stand and gaze at the beautiful flowers in my yard. I am well pleased with my seeds from your place.

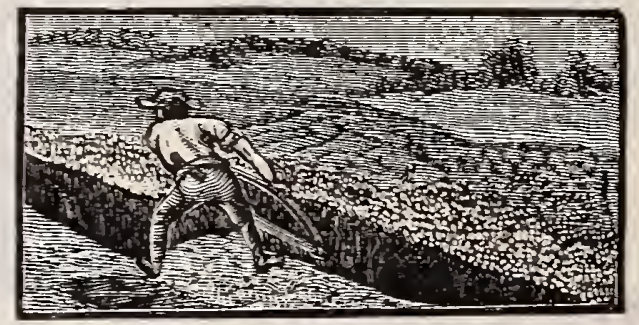

If You Want

a good and cheap chick-

en food, try

KAFFIR CORN 


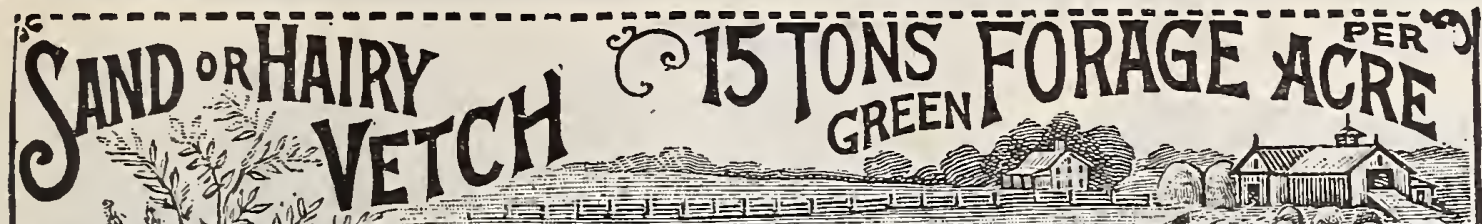
it,
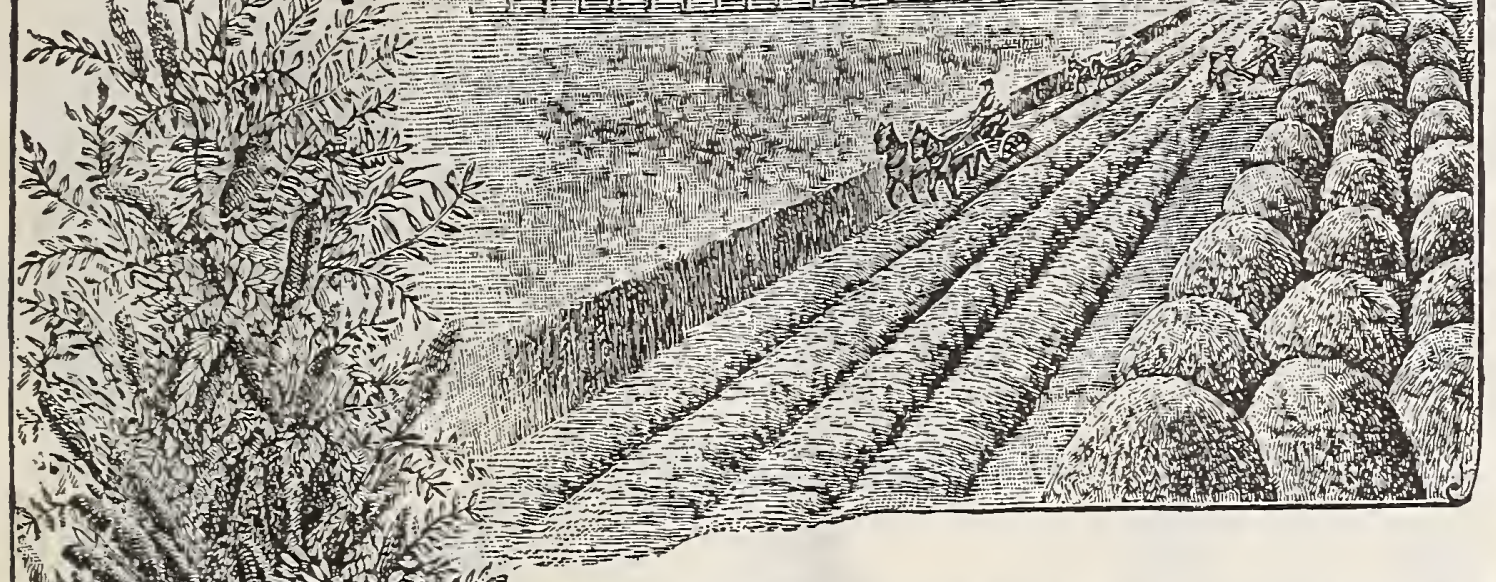

The Wonderful Sand or Hairy Vetch

(Vicia Villosa) Sometimes called the

Winter Vetch,

AS A PASTURE PLANT FOR LATE FALL. AND EARLY SPRING IS WITH. OUT AN EQUAL.

This Vetch is beyond doubt one of the most valuable fodder plants for the West and Northwestern States, owing to its adaptability to withstand severe drought, heat and cold. The vines are very similar to pea vines, but are more slender and much more thickly clad with leaves and side stems, which furnish nice, succulent feed. Individgoing to seed. It is an annual, but drops its seeds freely, and will come up year after year on the same ground. The Washington De partment of Agriculture estimates the value of an acre of this Vetch plowed under equivalent to putting into the ground $\$ 16$ to $\$ 45$ worth of sommercial fertilizer. One important feature is that a sowing made in August or September covers the ground before winter sets in and prevents washing of the soil during the winter and early spring, thus
saving a great portion of soluble mineral fertilizers contained in soil, which otherwise would wash or leech out. It can also be sown in April and will be ready to cut by the middle of July, the second growth affording excellent hog pasture during the summer.

For a Hay Crop. Make sowings in early spring at the rate of 30 lbs. per acre, broadcast, with the admethod will'give the best satisfaction. On good, rich soil it yields enormous crops of green fodder, running from 10 to 15 tons to the acre; equal to 3 to 4 tons when cured as dried hay.
land. Lb. 25 c., postpaid; 10 lbs. $\$ 1.25 ; 25$ lbs. or over, $10 c$. per $1 \mathrm{~b}$.

Spring Vetches or Tares are grown extensively for stock feeding. They are excellent food for hogs acre and cultivated as field peas. Lb. 20 c., postpaid; 10 lbs. 70 c., 50 lbs. $\$ 2.50$,

\section{Hardy, Drouth=Defying, Frost=Proof Grass for the Northwest.} BROMUS INERMUS OR BROME GRASS.

DESCRIPTION. It originated in Russia, and is recommended on account of the manner in which it has stood on the Hungary plains, where the dry, droughts make so many plants succumb. This Bromus, however, stands well, and has been known for thirty years to stand when such robust crops as alfalfa have been destroyed. It gives a luxuriant crop, particularly on fresh sandy loam soil, and There the climate is warm. Animals eat it greedily. in filling up gaps where alfalfa or clover crops have failed. Yields enormous crops of splendid hay and affords early and abundant pasturage. The importance and value of this class to the Northwest is not to proven success, equaling in quality and rivaling in yield almost any other grass. - One sowing will stand for years. Succeeds on poor soils and yields 4 to 5 tons per acre. "THE BEST N O R T HER N Star Brand. GROWN. Lb. 25c., postpaid; by express or freight, 15 lbs., enough for one acre, Bromus, Choice. Lb. 25c., postpaid; by lbs. $\$ 1.75,100$ lbs. $\$ 10.00$.
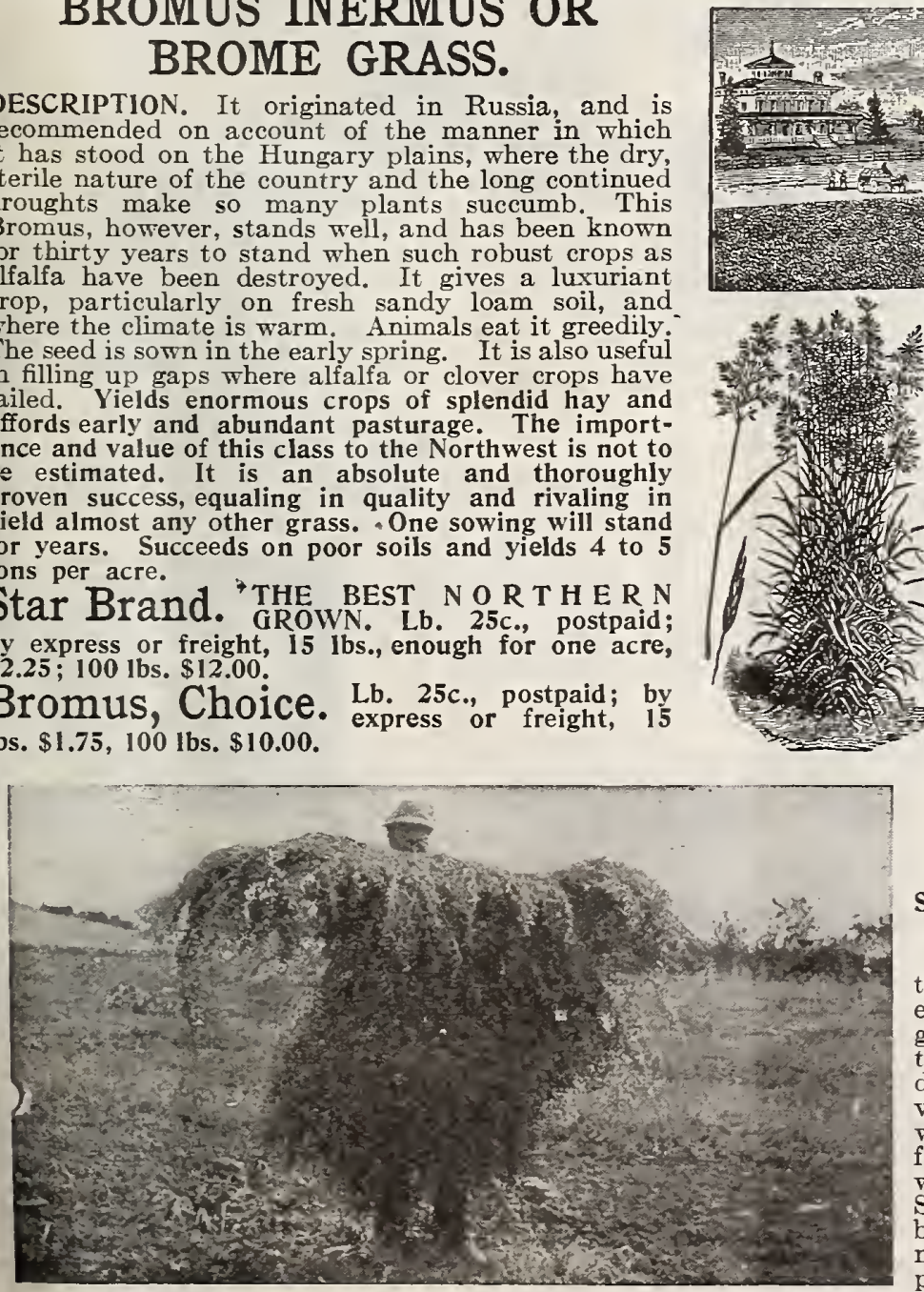

Australian Salt Bush. readily from seed and requires no cultivation. Pkt. 5c., oz. 10c., 1/4 lb. 30c., lb. \$1.00, postpaid.

\section{AUSTRALIAN SALT BUSH.}

A FORAGE PLANT FOR ALKALI SOILS, AND FOR REGIONS SUBJECT TO without irrigation and no rainfall after plants were one inch high.

green fodder have been harvested

ducing any other vegetation. In

where single plants,

when once started will make

Seed should be sown early when the trees are starting out See Photo. Illustration of a single plant, 6 months from planting, grown on dry land

This is a most wonderful forage plant, as it will grow freely
that will produce no other vegetation, yielding a marvelou
eagerly eaten by all kinds of stock. It is of creeping habit.

manner as you would clover, $t$ ty 


\section{कृ MAY'S NORTHERN GROWN SEEDS BEST FOR ALL CLMES \&}

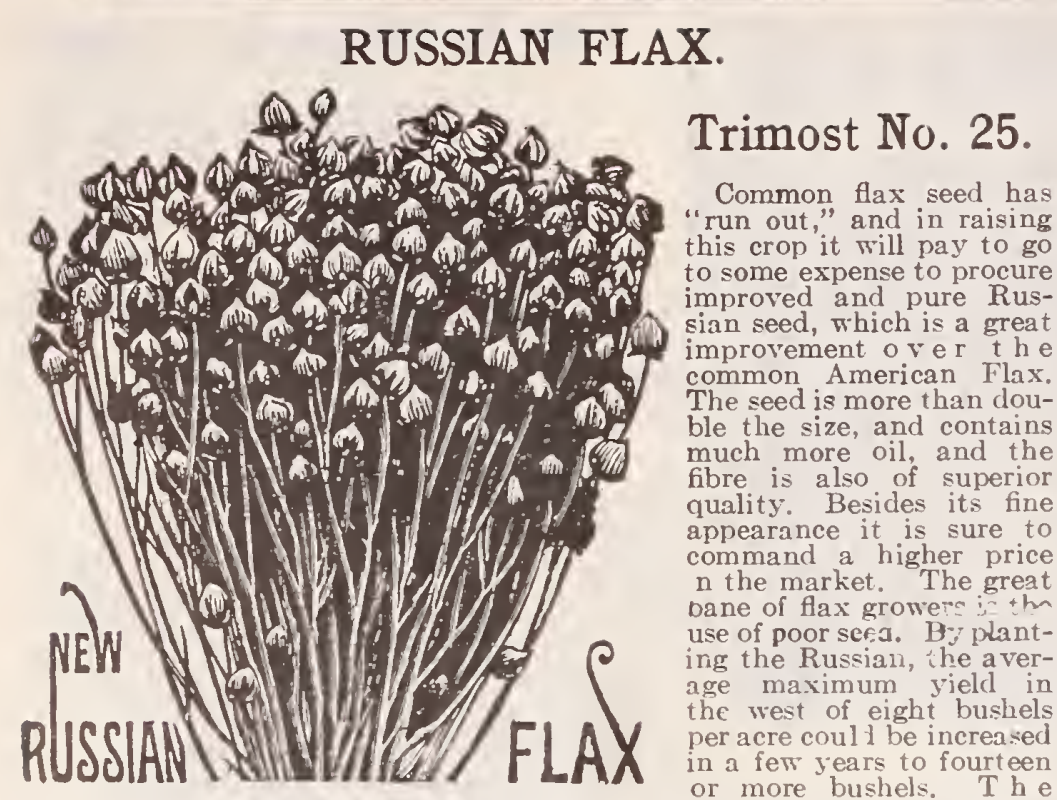

value of common flax seed and in meny sections of the great west flay arefully cleaned from foul seeds. Lb. $25 \mathrm{c}$., postpaid; Dk. 50c., bu. $\$ 1.75$.
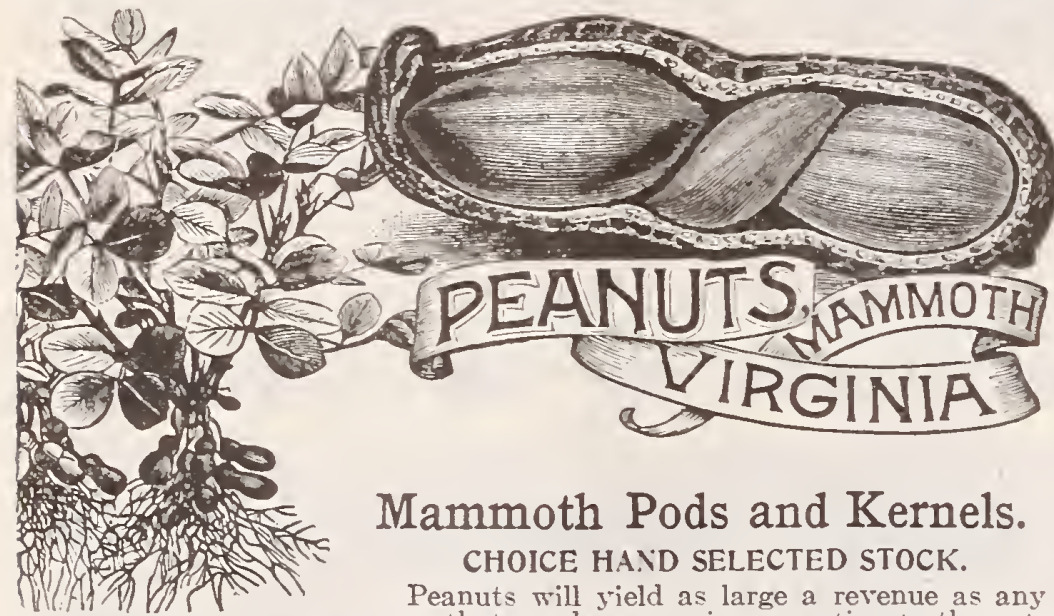

Mammoth Pods and Kernels. CHOICE HAND SELECTED STOCK.

Peanuts will yield as large a revenue as an

and Peanut Butter has come to be regarded as a dainty. The foliage and vines make valuable forage for stock. Large pkt. 10c., pt. $25 \mathrm{c}$., qt. $40 \mathrm{c}$.,

Spanish Peanut. This is an excellent forage plant for light land for hay just before frost. The wlants also set. a large crop of the small nuts which make an excelfent fattening food for hogs, and the hogs may be pasThich make an excele the fat tening food for hogs, and the hogs may be pas-
tured on the land afterr the hay has been gathered. The nuts mature much earlier than the larger southern vareities. For domestic use these can be
grown in garden like bush beans. Large pkt. $10 \mathrm{c}$., pt. $25 \mathrm{c}$. qt. $40 \mathrm{c}$., postpaid. Peanut Culture. Planting should be done as soon as possible feet apart, one kernel being put every 8 to 12 inches in the ridge. The young plant is very weak, hence only fine soil must be used in covering, and the
kernels before planting must be carefully hulled, for if the skin corering them is broken the chances are a cainst their growi-g.

\section{TREE SEEDS.}

Mapy va isties are easily grown. It should also be remembered that While some nds sprout at once, others require several reeks, and a fer lie dormant $\Sigma$ whole season. Evergreen seed should be kept cool in dry
sand. Those vith hard shells should be planted in the autumn. The seeds of other deciduous trees should be planted from April to the middle of Nay in drills about 2 feet apart and oovered about half an inch
eties marked thus $(0)$ will do better if planted in the fall.

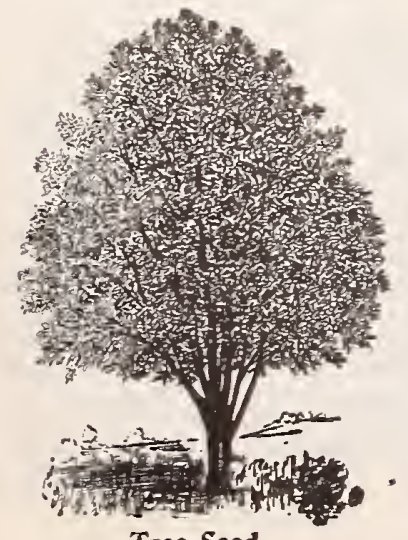

EVERGREEIT TREE SEED.

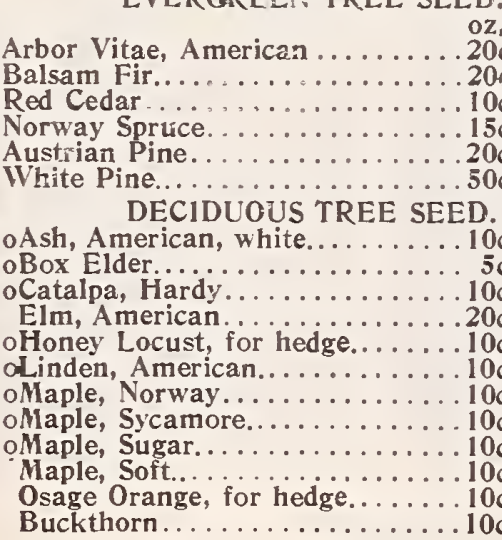

\section{WILD RICE.}
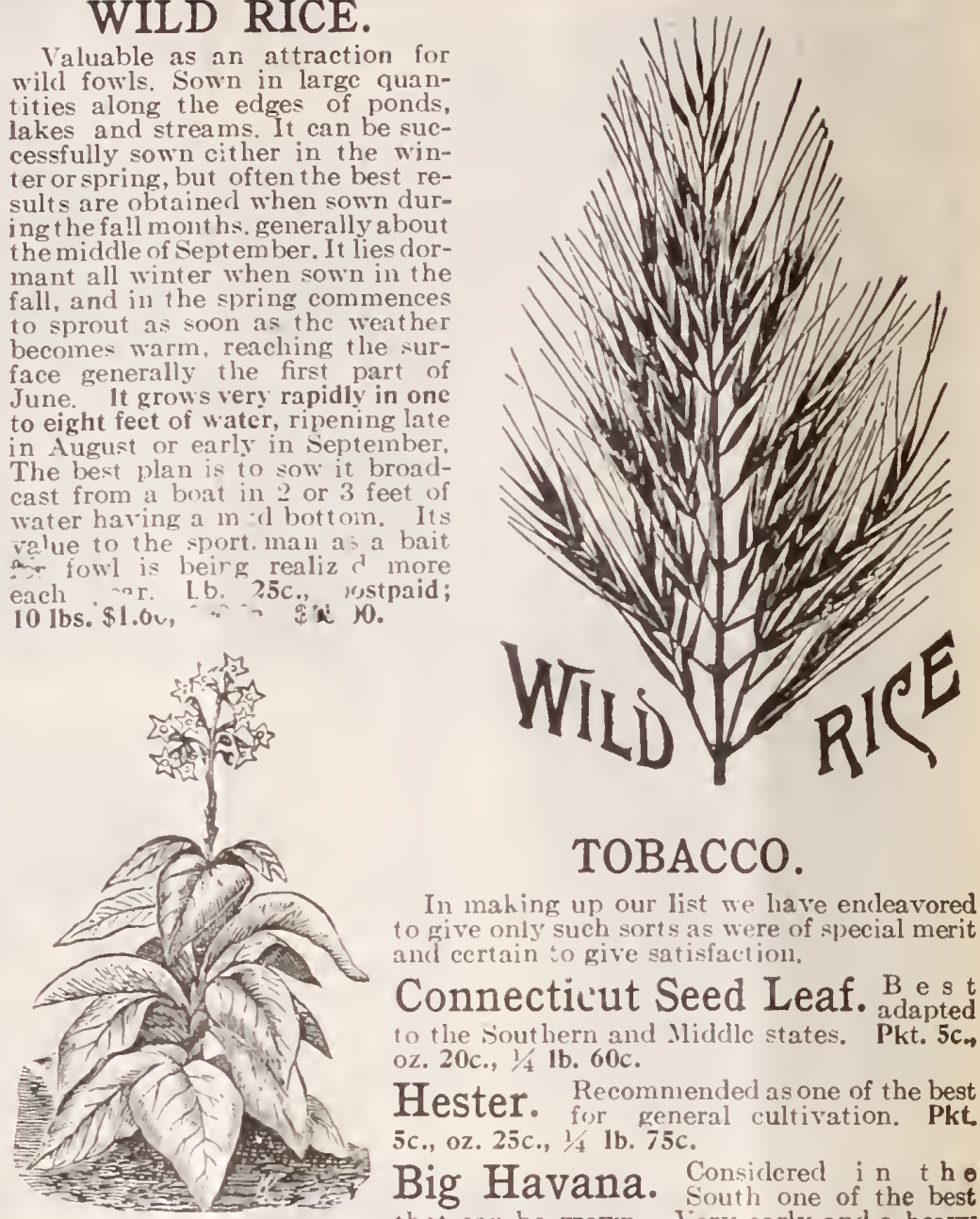

TOBACCO. Connecticut Seed Leaf. B e s Southern and Mliddlc states. Pkt. 5c. Hester Recommiended as one of the best $5 c .07 .25 c, 1 / 1,1 b .75 c$. Big Havana.

red in the ary early and a heavy Bonanza. A white Burley cros on Yellow Oronoko. Mlakes fine BIRD SEED.

FANCY RECLEANED. At prices quoted on Bird Seed we do not deliver MAY'S MIXED BIRD SEED

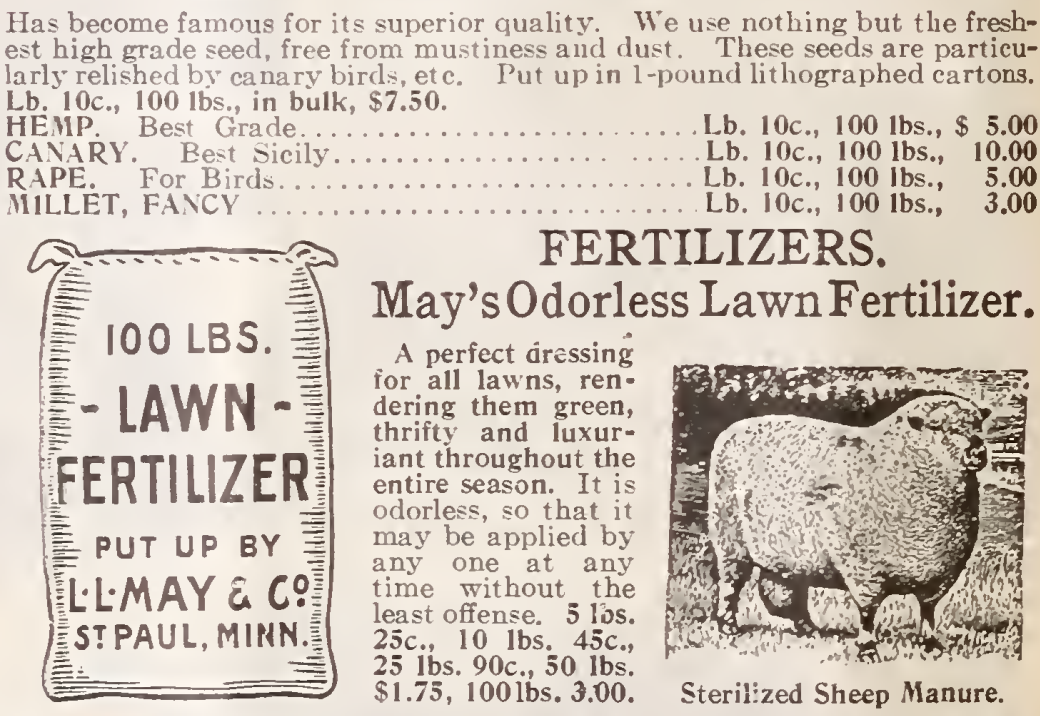

Sterilized Sheep Manure. This is a pure, natural Manure in mediate; it and six part mixing with the soil for greenhouse plants - one part manure For use in liquid form, one pound to five gallons of reter will make a liquid 列 政

Bone- Flour. One of the best fertilizers known. As a lawn dresser it pound to fifty square feet of plants and garder truck. $5 \mathrm{lbs} .25 \mathrm{c}$., $50 \mathrm{ibs}$. $\$ 1.75,100 \mathrm{lbs}, \$ 3.00$.

Guano. A sta.zdard fertilizer. Price, 5 lbs. 40c., 10 lbs. 70 c., 50 lbs. \$2.75, $00 \mathrm{lbs} ; \$ 5.00$. Write for prices on larger lot $\$$-subject At prices quoted on abı ve fertilizers, by express or freight, at purchasers' Bowker's Plant Food. Small size pkg. 15c., by mail, 20c.; 


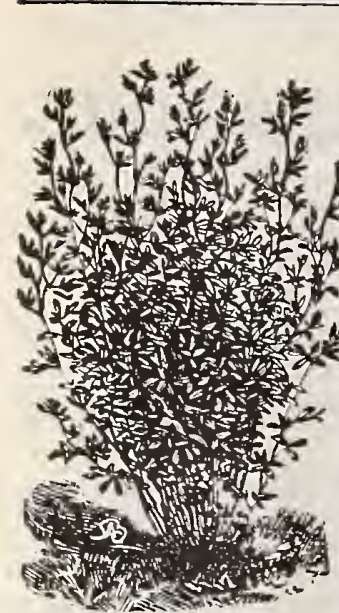

ALFAEFA.

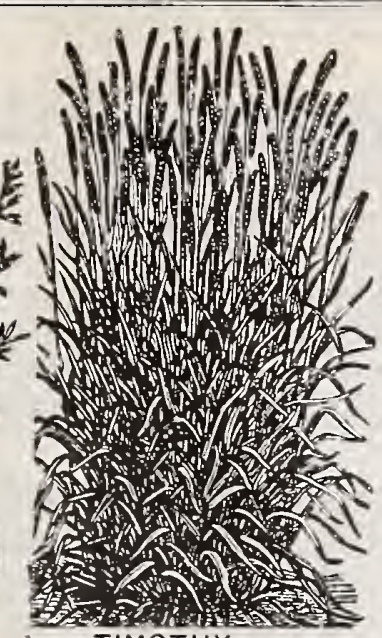

TIMOTHY.

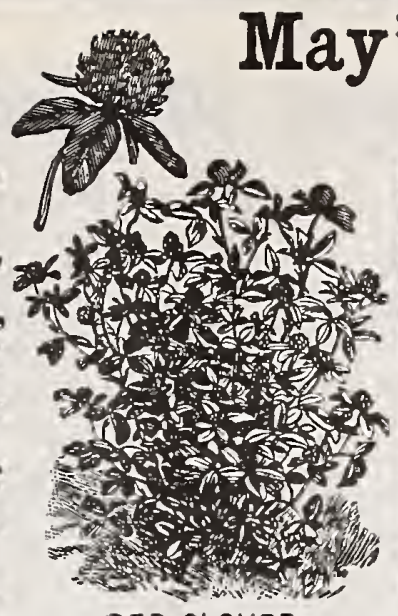

RED CLOVER.

EXTRA CLEANED GRASS

THE FOLLOWING LETTER

Is one selected from many we receive annually asking information about grades of grass and clover seeds:

I. I. May \& Co., St. Paul, Mrinn.:

Gentlemen:-As I wish to sow some grass and clover seed, will write you for prices and some information. Do you consider it necessary or best to purchase best fancy grade grass and clover seed, where grass, adman, R. R. 2, Hurley, S. Dak. The Above Letter from a well known, well informed say to all interested farmers, that we most opportunity to mend the purchase of the very best grade of all grass and clover seed, no matter if wanted for hay, pasture or seed. Nothing is more important to the farmer than that the grass seed he sows should be pure and clean. The seed should also be plump, heavy and well ripened. First-class thoroughly cleaned seed, while a shade higher in price is really much cheaper in the end than the light, chaffy grades so generally sold at much lower prices, even should the latter be free duce a much greater number of strong plants, go farther and give a better stand. While we list two grades of the leadpurchaser, both in a money point of view and a good stand, purchaser, both in a moned obtainable.

Medium Red Clover. (Trifolium Pratense.) This is also Star Grade, 1b. 30c., pk. $\$ 3.00$, bu. (60 lbs.) $\$ 11.00$, 100 lbs. $\$ 18.00$ Choice Grade, 1b. 28c., pk. $\$ 2.75$, bu. (60 lbs.) $\$ 10.50,100$ lbs. $\$ 17.00$. Mammoth Red Clover. (Trifolium Pratense Perenne.) star Grade, 1b. 30c.s pk. $\$ 2.3$; , bu. (60 lbs.) $\$ 11.00,100$ lbs. $\$ 18.00$ Choice Grade, 1b. 28c., pk. $\$ 2.15$, bu. (60 lbs.) $\$ 10.50,100$ lbs. $\$ 17.00$. Giant Crimson Clover. (Trifolium Incarnatum.) Grown and Northern states.

Star Grade, 1b. 25c., pk. \$1.50, bu. (60 lbs.) \$5.75, 100 lbs. $\$ 9.00$ Alfalfa (Medicago Sativa.) Also called Iuceine, Iternal mon clover. for the following reasons: It has a greater root development. It stands drought better. It is less liable to winter kill. It lasts a long term of ye-rs from one seeding. Star Grade, 1b. 30c., pk. \$2.75, bu. (60 lbs.) $\$ 10.75,100$ lbs. $\$ 17.50$. Choice Grade, 1b. 28c., pk. \$2.60, bu. (60 lbs.) \$10.00, 100 lbs. \$16.50. Alfalfa Turkestan. It is more hardy n the Lucerne, havlow zero when the ground was bare. Also stands extreme drought. Choice Grade, 1b. 30c., pk. \$3.00, bu. (60 lbs.) \$11.00, $1001 \mathrm{lbs} . \$ 18.00$. Alsike or Swedish Clover. (Trifolium Fybridum.) On enormous quantity of hay or pasturage, but its greatest value is for sowing with other clovers and grasses.

Star Grade, 1b. 30c., pk. \$2.50, bu. (60 lbs.) \$9.50, 100 lbs. $\$ 15.50$. Choice Grade, 1b. 28c., pk. \$2.30, bu. (60 lbs.) \$8.75, 100 libs. \$14.50. White Clover. (Trifolium Repens.) A small-headed white ingly desirable for mixing with lawn grass seeds.

Star Grade, 1b. 35c. Choice Grade, lb. 30c. Write for special prices on larger lots. Timothy. (Phleum Pratense.) This grass is most commonly ably surpasses all other grasses in cultivation.

Star Grade, 1b. 20c., pk. 70c., bu. (45 lbs.) \$2.60, 100 lbs. $\$ 5.75$. Choice Grade, 1b. 18c., pk 65c, bu (45 lbs.) \$2.40, 100 .1bs. \$5.25. Kentucky Blue Grass (Poa Pratensis.) The great Amerit is superior to all other kinds. Star Grade, solid seed, 1b. 30c., pk. 65c., bu. (14 lbs.) \$2.45,

Choice Grade, recleaned, 1b. 25c., pk. 60c., bu (14 lbs.) \$2.30,
100 lbs. $\$ 16.00$. s High Grade

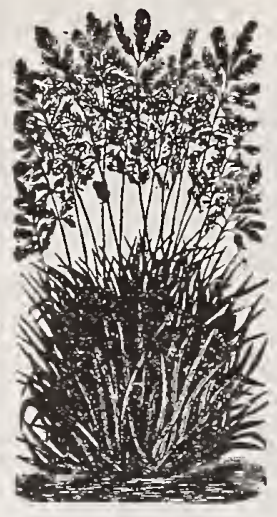

Kentucky Blue.

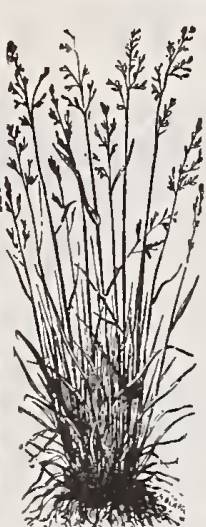

2.
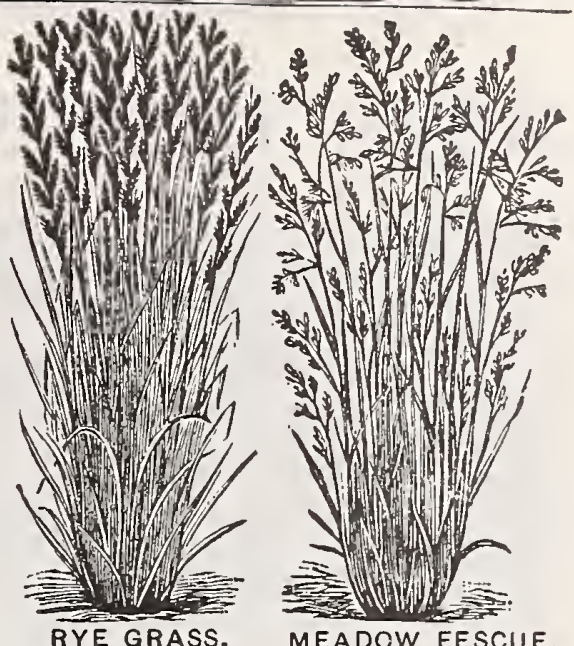

AND CLOVER SEEDS.

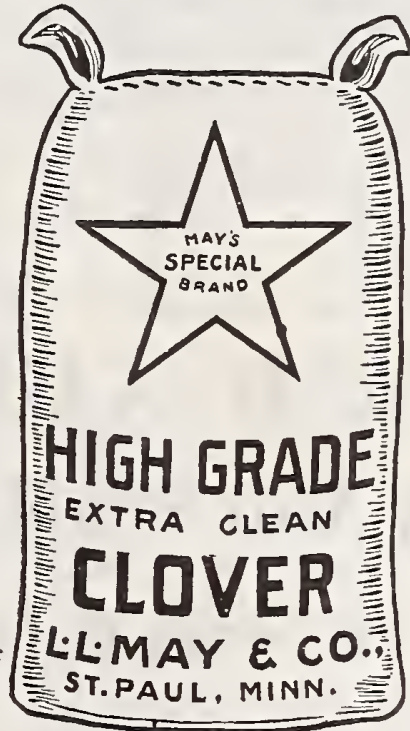

Our Special Star Brand

Means that the seed sold under that

brand is the best obtainable, both as

respects purity and high germination.

ing good seed, but make critical

mination tests before any

exactly as to the vitality

supply, and

plump, heavy and well ripened,

to insure a good stand, and free from

At pound prices, we send by mail
postpaid. In larger quantities or freight (sack included) at pur-

Market Changes. The market Grass and Clover Seeds is constantly

appear high, write for samples and at lowest market price, as it is our intention to meet the competition of all reliable firms.

Canadian Blue Grass. Ib. 25c., bu. \$1.50, 100 lbs. $\$ 10.00$ Red Top. (Agrostis vulgaris.) This is a good, permanent grow with luxuriance on almost any soil, whether wet or dry. $100 \mathrm{lbs}$. $\$ 12.00$.

Choice Grade, solid seed, 1b. 25c., pk. $\$ 1.40$, bu

100 lbs. $\$ 11.00$. $100 \mathrm{lbs}$. $\$ 10.00$.

$\$ 1.50$,

Orchard Grass. (Dactylis Glomerata.)

Star Grade, 1b. 30c., pk. 50c., bu. (14 lbs.) \$1.80, 100 lbs. $\$ 12.50$

Choice Grade, 1b. 25c., pk. 45c., bu. (14 lbs). $\$ 1.65,100$ lbs. $\$ 11.50$.

ENGIISH RYI GRASS. (Iolium Perenne)

lis.) \%0c., 100 lbs. $\$ 4.75$.

ITAIIAN RYE GRASS. (Iolium Italicum.) Ib. 20c., bu. (14

s.) 75c., 100 lbs. $\$ 5.00$.

CRREPING BENT GRASS. (Agrostis stolonifera.) Ib. 30c. bu. (14 lbs.) $\$ 2.25$.

CRESTED DOGTAII GRASS. (Cynosurus Cristatus.) Ib. 5c., bu. (14 lbs.) \$3.50.

FARD FESCUE GRASS. (Festuca Duriuscula.) Ib. 30c., bu. 14 lbs.) $\$ 1.40$.

MEADOW FESCUE GRASS. (Festuca Pratensis.) Ib. 25c., bu. (14 lbs.) $\$ 1.25$.

ROUGH STAIKED MEADOW GRASS. (Poa Trivialis.) Ib.

40c., bu. (14 lbs.) \$3.75.

MIEADOW FOXTAIT GRASS. (Alopecurus Pratensis.) Ib, 30c., bu. (14 lbs.) $\$ 3.75$.

TAII MEADOW OAT GRASS. (AVEna Flatoir.) Ib. 30c:

bu. (14 lbs.) \$2.25.

TAII FISCUE GRASS. (Festuca Flatoir.) Ib. $40 \mathrm{c}$, bu.

$(14$ lbs.) $\$ 3.00$

WATER FESCUE GRASS. (Perennial.) I b. 35c., bu.

lbs.) $\$ 3.50$.

SWIET VERNAI. (Anthozanthum Odoratum.) Ib. 25c., bu.

(14 lbs.) $\$ 2.00$

JOHNSON GRASS. (Sorghum Halapense.) Ib. 25c., bu

bs.) $\$ 2.00$.

BERMUDA GRASS. IT. $80 \mathrm{c}$.

RFODE ISTAND BENT GRASS. I b. 35c., bu. (14 lbs.) \$1.75. 


\section{May's Lawn Grass Mixtures for Special Situations.}

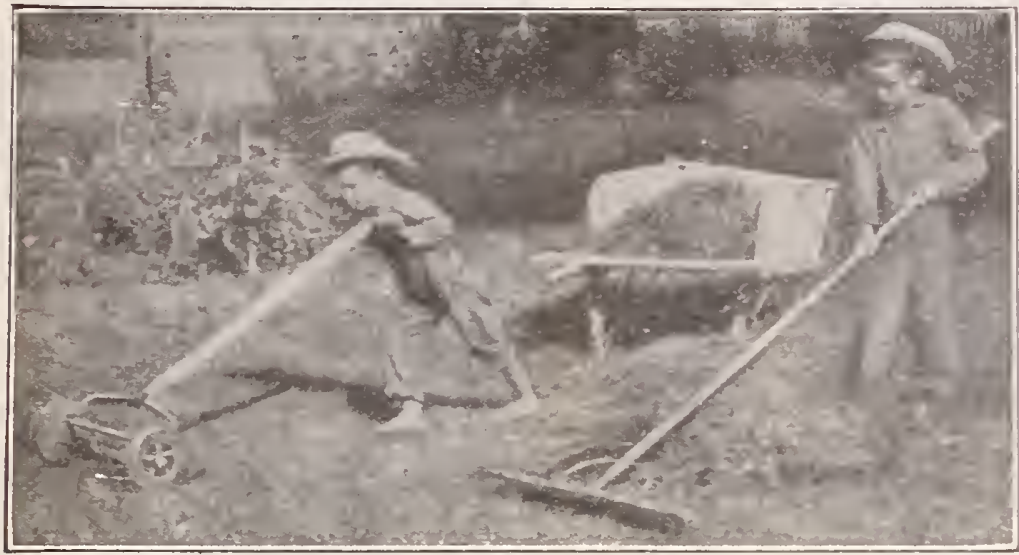

Central Park Mixture. For lawns of any extent we recomquart will sow 300 square feet; four to five bushels will sow one acre. Qt 20 c., pk. $\$ 1.00$, bu. (15 pounds), $\$ 3.00$.

PRICES on grass seed by the quart include prepayment of postage by us. Pecks and bushels are sent by express or freight at purchaser's expense.
HOW TO MAKE AND CARE FOR A LAWN. This useful leaflet will be mailed free to all who ask for it when ordering.
Evergreen Mixed Lawn Grass. This is a good mixture, great a nunber of expensive grases as Central l'ark Mixture, Qt. 20c., pk. 75 c., bu. ( 15 pounds), $\$ 2.50$.

Tennis Court Mixture. Composend of a variety of fine dwarf,

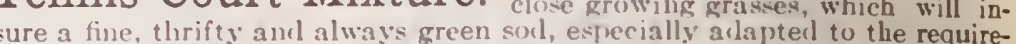
sure a fine, thrifty and always green son, exwecially araptent the requireof the soil should precede sowing of the sced if possible. Qt. 25c., pk. \$1.00, bu. ( 15 pounds), $\$ 3.50$.

Shady Nook Mixture. In many lawns where there are large

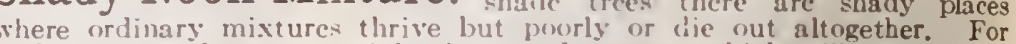
weh spots o have a special nixture of grasses, which will grow in the

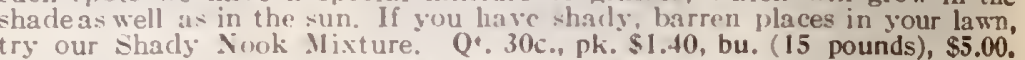
May's Terrace Sod Mixture. Aor special mixture of grasseg hills, producing strong, surcalling ronts, thus preventing heavy raing from rans from , and at the same time produce a rich green lawn throughout the May's Special Golf Link Mixture. This mixture is colf links, and is the result of experiments conducted on ur grounds, as well as careful watching for several years of practical results obtained on golf links sown with our grass seeds. By the use of these world can be successfully rivaled. Qt. 25c, pk. $\$ 1.00$, bu. (15 pounds), $\$ 3.50$.
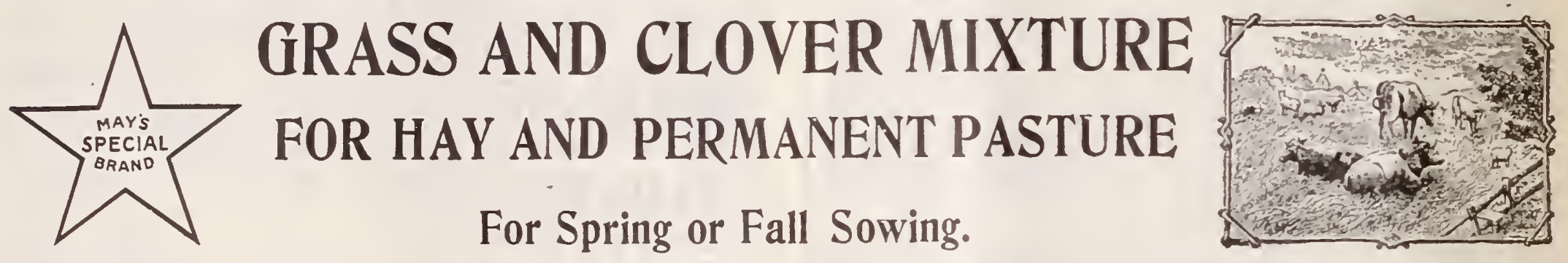

Our Star Brand mixture of grasses and clover yields a very heavy crop of the finest and most succulent hay early in the stason, and after same is cut, continuous and abundant pasturage until winter sets in, It will and pasturage, and will give satisfactory results, both when sown on dry sandy soil, or on moist meadow lands. It is made up of native and foreign grasses and clover combined in proper proportions to insure the best results, from years of practical experience. We recommend using at least $25 \mathrm{lbs}$. of this mixture per acre. Price, $25 \mathrm{lbs}$. $\$ 5.00$, $100 \mathrm{lbs}$
$\$ 15.00$. If you prefer
special prices.
MAY'S FAMOUS HOG PASTURE MIXTURE

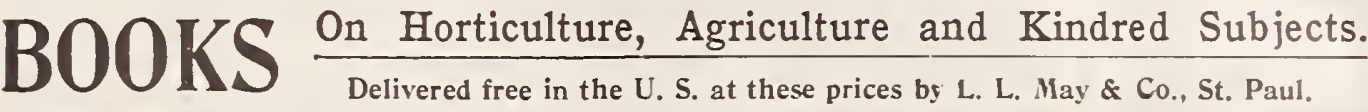

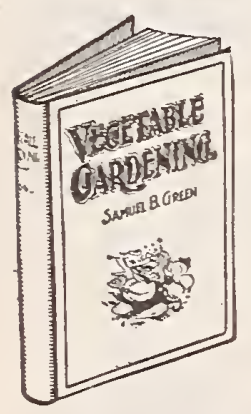

\section{VEGETABLE GARDENING. \\ A Manual on the growing of vetables \\ NEW EDITION JUST OUT. \\ PRICE, PAPER 50c. CLOTH $\$ 1.00$.}

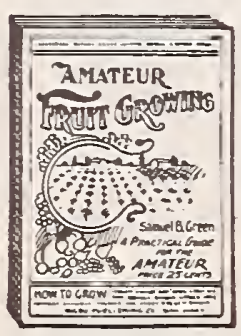

\section{AMATEUR FRUIT GROWING} By SAMUEL B GREEN. A practical guide for the amateur on the cultivatio of all small fruits. Not technical but a book eas-
ily understood by anyone. Just the book for be-
Just ginners. 12 mo., 144 pages, i
50 c., Paper Covers, 25 c.

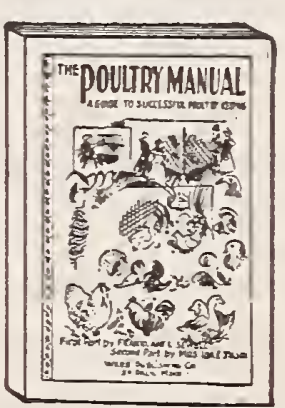

The POULTRY MANUAL.

New Book Written by Up-To-Date Poultry Over 15,000 Copies have been sold.

The first part of the book is devoted to the study of pure bred poultry. The second part is a guide to Profitable and Successful Poultry Raising. tions Taken From Life. Price, Cloth Bound, 50c., Paper Covers, $25 \mathrm{c}$.

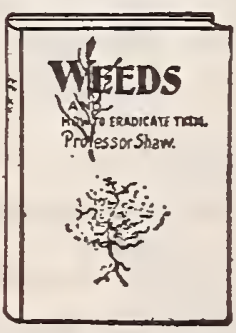

\section{WEEDS And How To}

By THOMAS SHAW.

It describes the evils arising from the presence of weeds; the agencies concerned in their distribution; the possibility of destroying them and the methods and principles applicable towards their destruction and 16 mo., 210 pages, illustrated. Price, Cloth
GRASSES

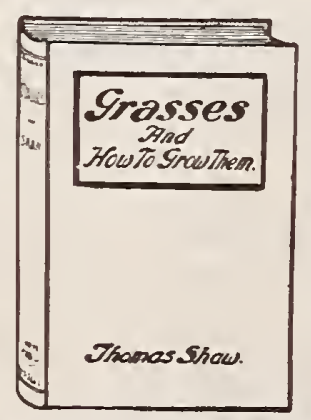

The Most Complete Worl of its Kind Published

BY THOMAS SHAW, Late Professor of Anima Husbandry at the University of Minnesota.

Now used as a text book in many of the leading agricultural colleges of the United States.

Discusses the growing of all the principal grass crops 12 mo., 453 pages, illustrated. Price, Cloth, \$1.50.

Flower Queries.

In this little book is given a selection of 500 questions and answers on practical floriculture, which will be found of assistance to the amateur Hower grower. Price, 25c.

\section{Onions.}

ON10NS, How to Raise Them Profitably. By 17 practical cnion growers. Price, 25c. 


\section{GGOWN IN THE GOLDEN GRAIN BELT OF THE WORLD ${ }^{37}$}

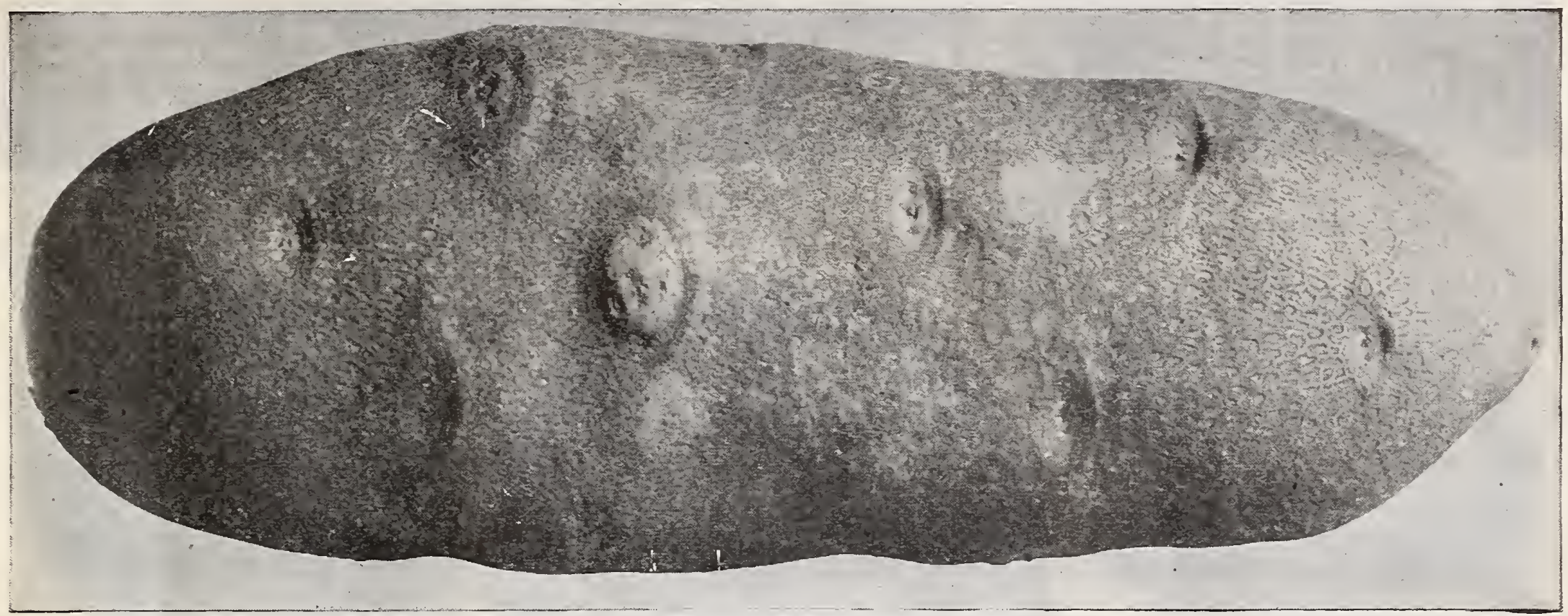

May's Netted Gem, Natin? Size.

\section{NORTHERN GROWN SEED POTATOES.}

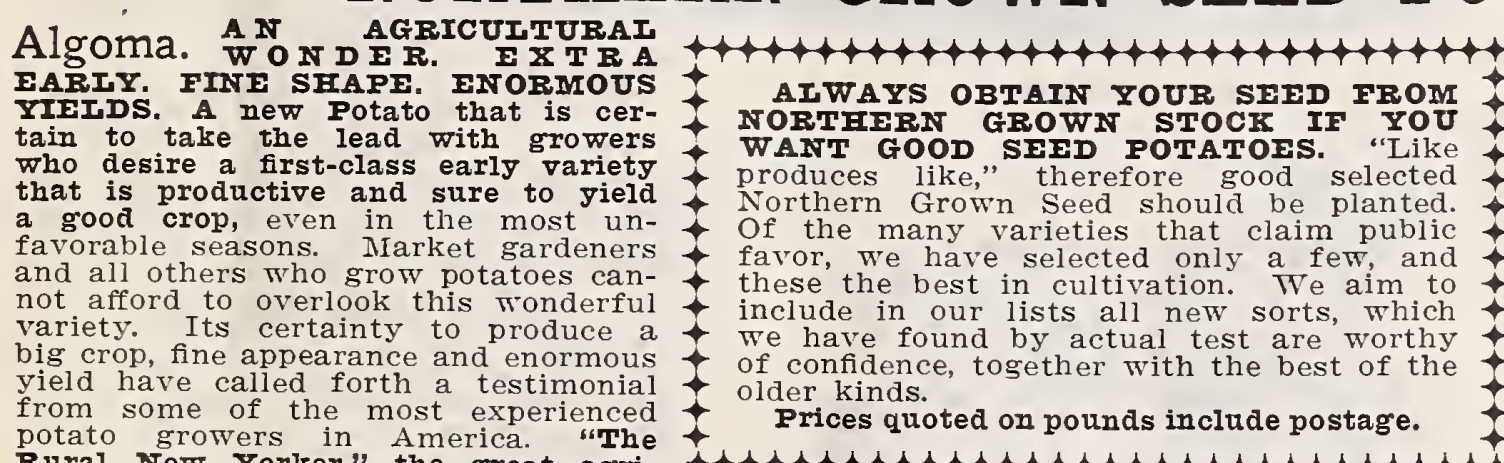

potato growers in America. "The

cultural paper of the Fast, says: "From time to time we have dug a hill of the varieties that claim to be the earliest now on trial on the Rural grounds. Thus far Algoma from I. I. Maj \& Co., of St. Paul, Minn., has given the best yield. It is a most shapely potato, being smooth, oblong and slightly flattened." Ib. 25c., pk. 60c., bu. \$2.00, bbl. (23/4 bu.) $\$ 5.00$.

Early Fortune. A strong grower. In form and color it surpasses it. The quality, shape and color are of the best. We have raised this potato ourselves, on a large scale, and find it to be a very early sort and a sp.endid cropper. Ib. 25c.,

Early Ohio. This well known a short, thick, round-oblong potato. In color it is dull red. It matur week sooner than Early Rose. succeeds best in a rich loamy soil, and is not recommended for light or sandy land. The flesh and mealy quality. Its extreme earliness and the fact that it is mealy when partially grown makes it a great favorite with market gardeners. I $\mathbf{b} .25 \mathrm{c}$. bbi. (23/4 bu.) $\$ 3.75$. Rural New

Yorker No. 2.

The tubers are of large size, with remarkable smoothness of skin; the eyes are few, distinct a $\mathrm{nd}$ treme whiteness, both of skin and flesh, and excellent table qualities. It has great vigor in growth and solidity of $t u b e r$, which enables it to resist disease. $\mathbf{I b}$ 25c., pk. 40c. bu.

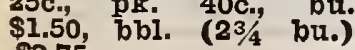

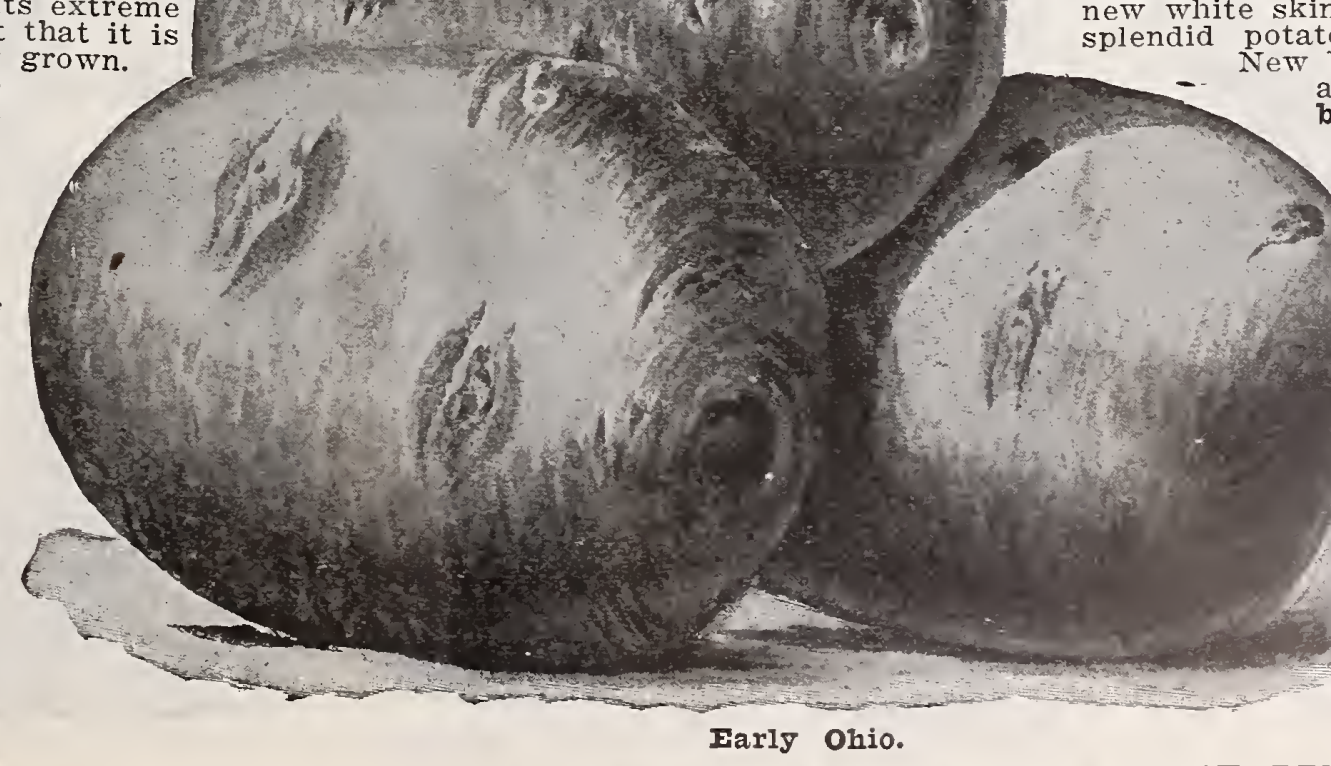
eyes all over. The skin is of most curlous formation for a Ford melon. It is rather thick and does not bruise easily, thu enabling it to withstand shipping exceedingly well, as it will $\mathrm{pk} .75 \mathrm{c} ., \mathrm{bu}$. $\$ 2.00, \mathrm{bbl},\left(2 \frac{3}{4} \mathrm{bu}.\right) \$ 5.00$

May's Late. This is by far the best potato for general late Te know of Flesh white, cooking quali作 uniform. Ib. 25c., pl. 40c., bu. $\$ 1.50$, bbl. (23/4 bu.) $\$ 3.75$.

Bliss Red Triumph Color a beautiful light uniform in growth. Shape nearly round; flesh white, very mealy when cooked. Ib. $25 \mathrm{c}$., pr. $40 \mathrm{c}$.
bu. $\$ 1.50$, bbl. $(23 / 4 \mathrm{bu}) \$ 3.75$. Sir Walter Raleigh. A potato, a quick maturing main crop variety. Of best keeping qualities and rare productiveness. A new white skin main crop potato. It is a splendid potato, much resembling Rural a seedling. I b. $25 \mathrm{c}$., pr. $40 \mathrm{c}$ Carman 3 o $n$ No. 3. best main crop Potatoes of large size and of
the shapeliest form
Eyes are few and
shallow. It is a per-
fect keeper, and is
not surpassed as a
table variety. Skin
and flesh are of ex-
treme whiteness. It
has no hollow hearts
or any dark parts. Ib. $25 \mathrm{c}$, pk. $40 \mathrm{c}$., bu. $\$ 1.50$,

Noroton Beauty. See inside cover page for description and price. 


\section{की MAY'S NORTHERN GROWN SEEDS BEST FOR ALL CLIMES \&}

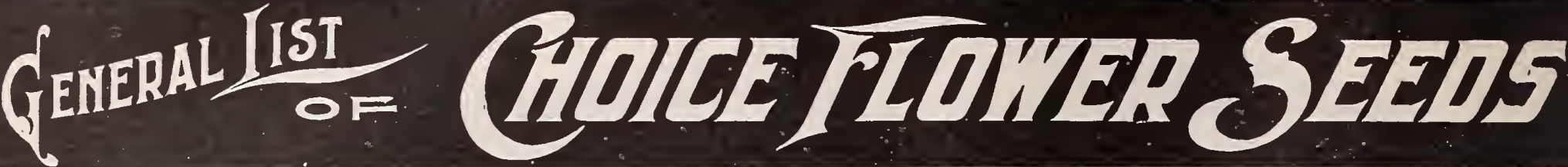

Selected Strains of the very best Quality at Reasonable Prices.

FREE BY MAIL-All Flower Seeds are sent postpaid on receipt of price. Full cultural directions are given on the back of

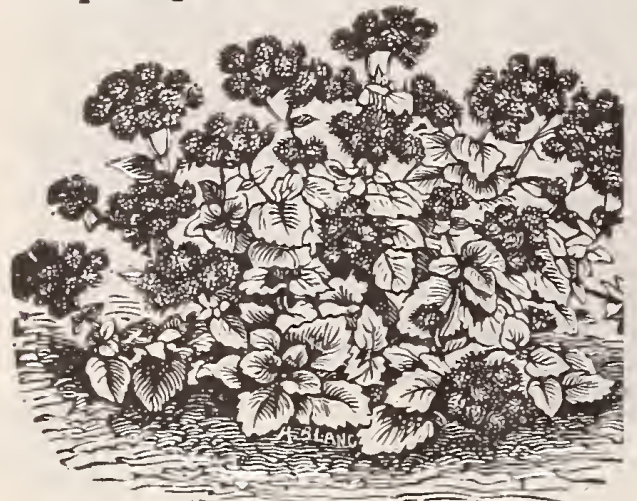

Ageratum

AGERATUM.

summer in the garden, and makes a a

brilliant varieties. Pkt., 5c.

\section{ALYSSUM.}

IITTIF GEM Grow' 6 inches high, immense heads, and when sown early in Pkt., 5c.

SWEFT AIYSSUM. Pure white, free ACROLINIUM (Everlasting.)

A pretty annual "Everlasting" bearing lovely white or rosy-pink flowers, be dried., 5c.

\section{AMARANTHUS.}

Brilliant foliaged annuals, growing from 3 to 5 feet high,some of the varieAll are useful in borders of tall plants 5c.

\section{AMBROSIA.}

A hardy annual, exceedingly fragrant. It is as desirable as the Rose Geranium making up into bouquets and other floral work plat 50

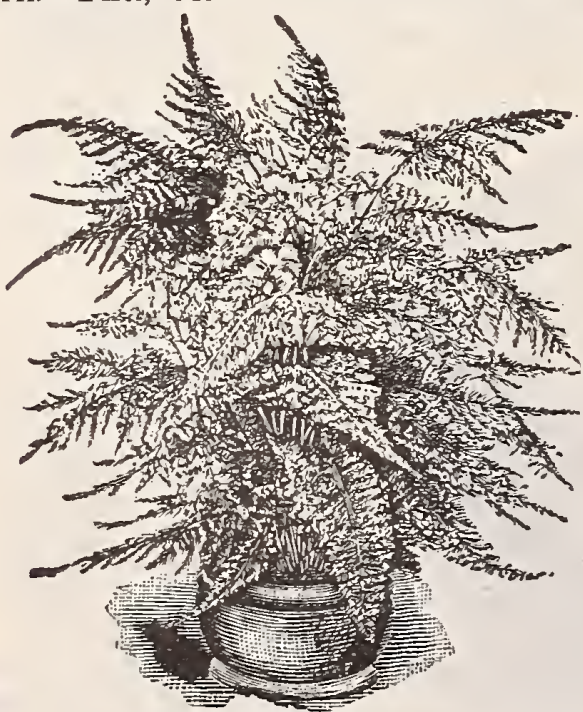

Asparagus Plumosus.

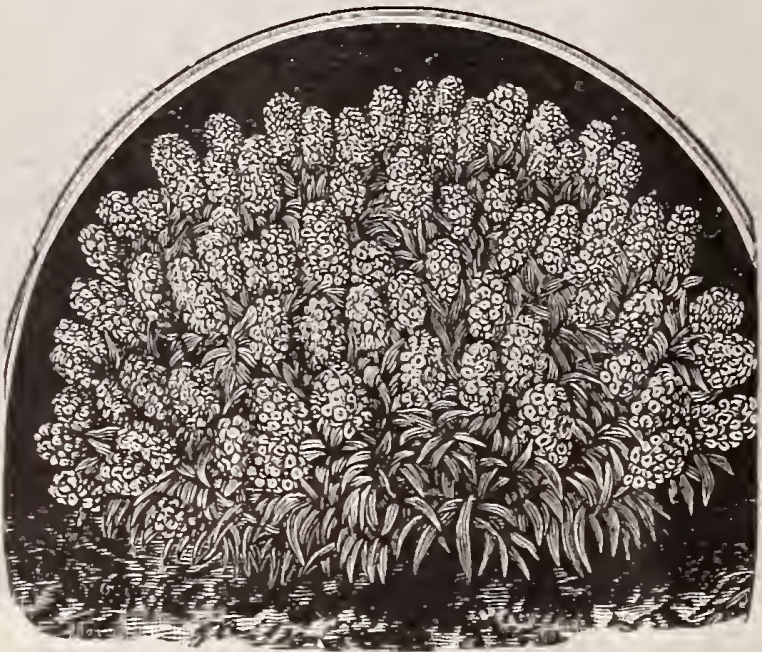

Alyssum, Iittle Gem.

(5) 1260.12

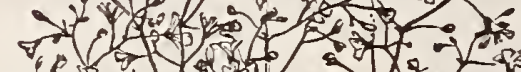
$2=t_{0}^{2}$

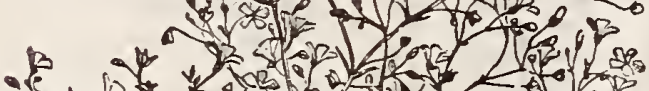

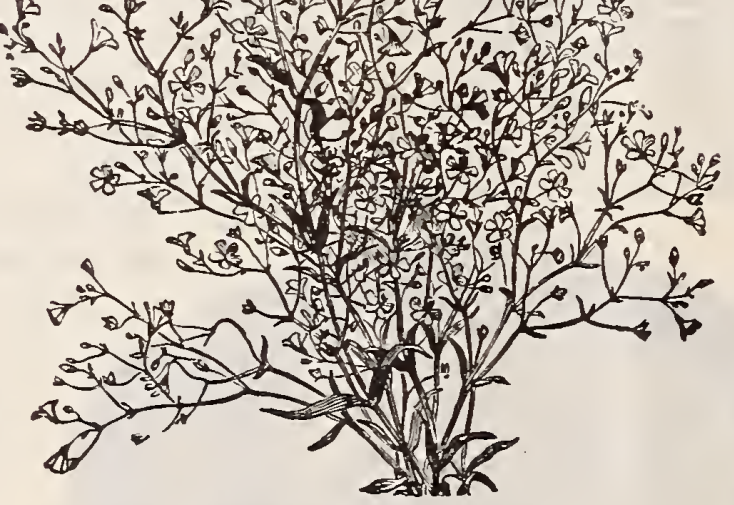

Angel's Breath (Gypsophila.

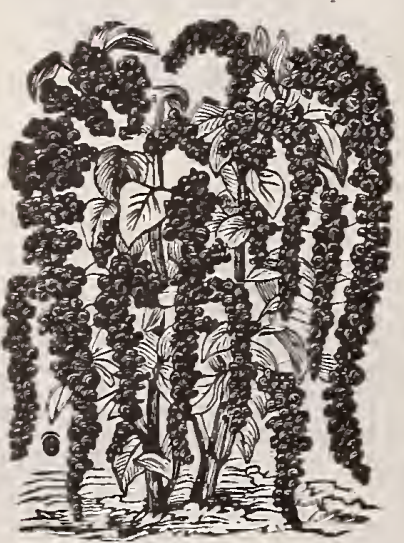

Amaranthus.

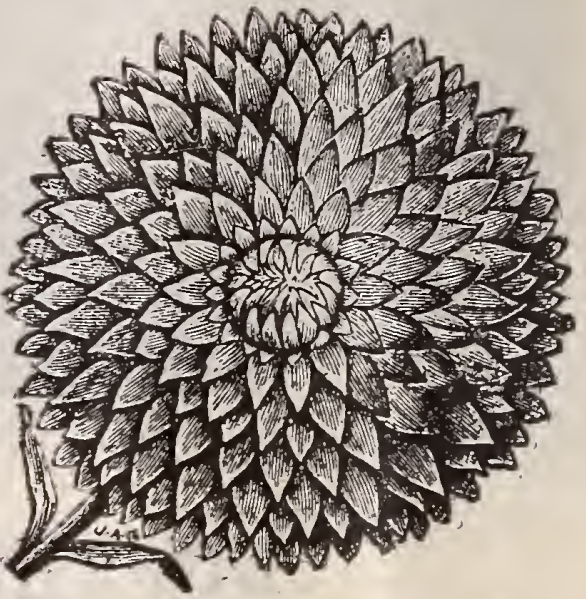

Acroclinium.

ANGEL'S BREATH (Gypsophila.)

An annual that should be in every garden, for it thrives everywhere and furnishes the loveliest material for all

\section{ANTIRRHINUM.}

GIANT. Flowers double the size of older sorts, more closely set on the tems and colors more liant, growing about 12 inches high All colors mixed. Pkt., 5c.

SUNRISE. Beautiful dwarf growing, bushy variety. Flowers are a handsome TOM тHUMB. Finest mixed, all colPkt., 5c.

ASPARAGUS.

PIUMOSUS NANUS. (Iace Fern.) ne of the prettiest house plants. The leaves are bright green, gracefully arched, surpassing Maiden Hair ferns in grace, delicacy of texture and richness house culture. Pkt., 10c.

SPRENGERI. (Emerald Feather.) Of drooping growth, making great, pendulous masses of fine, feathery foliage. Pkt., 10c.

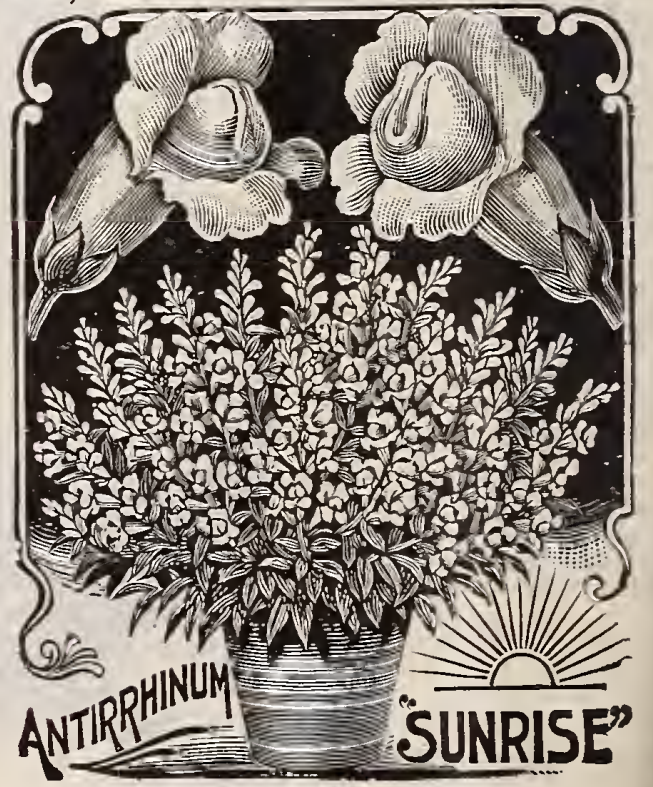


ASTTRS No flower is more popular and few have held so high a place in popular esteem for so many AS LRS years, and is still growing in favor. For an autumn show of flowers we have not its equal.

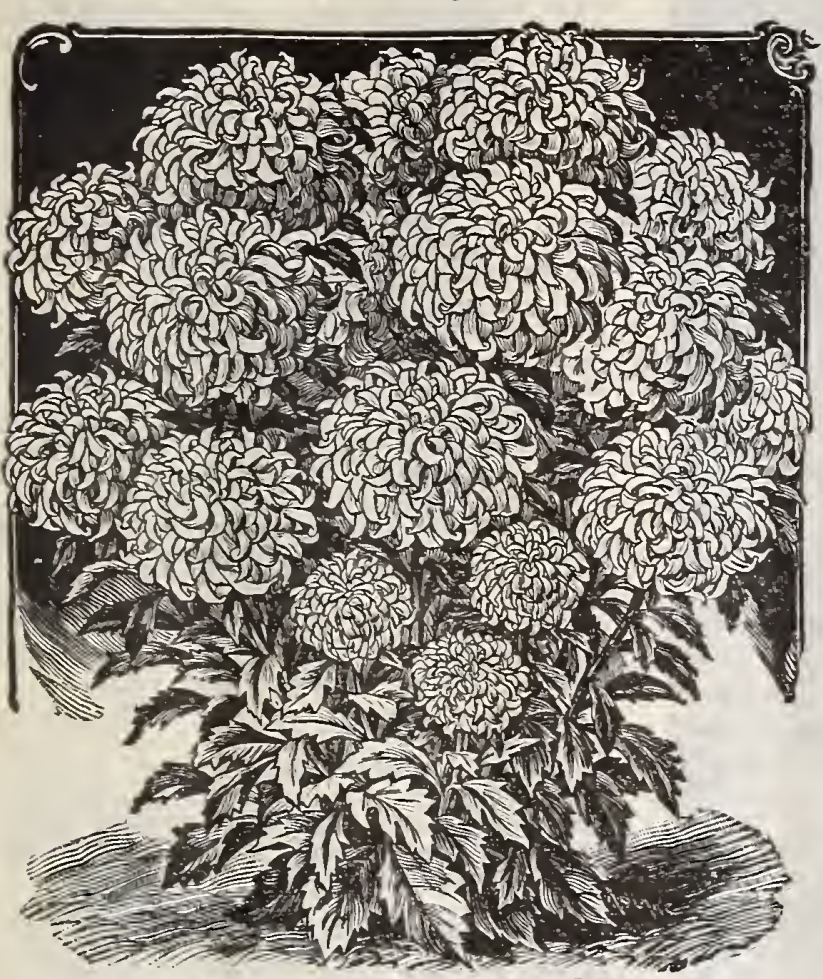

Aster, May's New Branching. May's New Branching. Giants in size. Marplants vels of beauty. The plants are compact and bushy, from 24 to 30 inch20 to 30 blossoms each. In form, shape and color reThey are unapproached by any other Aster. We offer clear pink, lavender blue, purple, pure white and red. Pkt. 10c., 6 plts. 50c. Japanese, or Tassel. Entirely distinct and novel. Plants of pyramidal growth, tbout 18 inches high, bearing on long stems from 40 to 50 flowers, averaging 5 wavy and twisted needleshaped petals, making the appearance. The colors range through all shades of pink, white and pale Christmas Tree. This type has a branching pyramidal form of growth; flowers large and very double
and range through many beautiful colors. Plt. 10c.

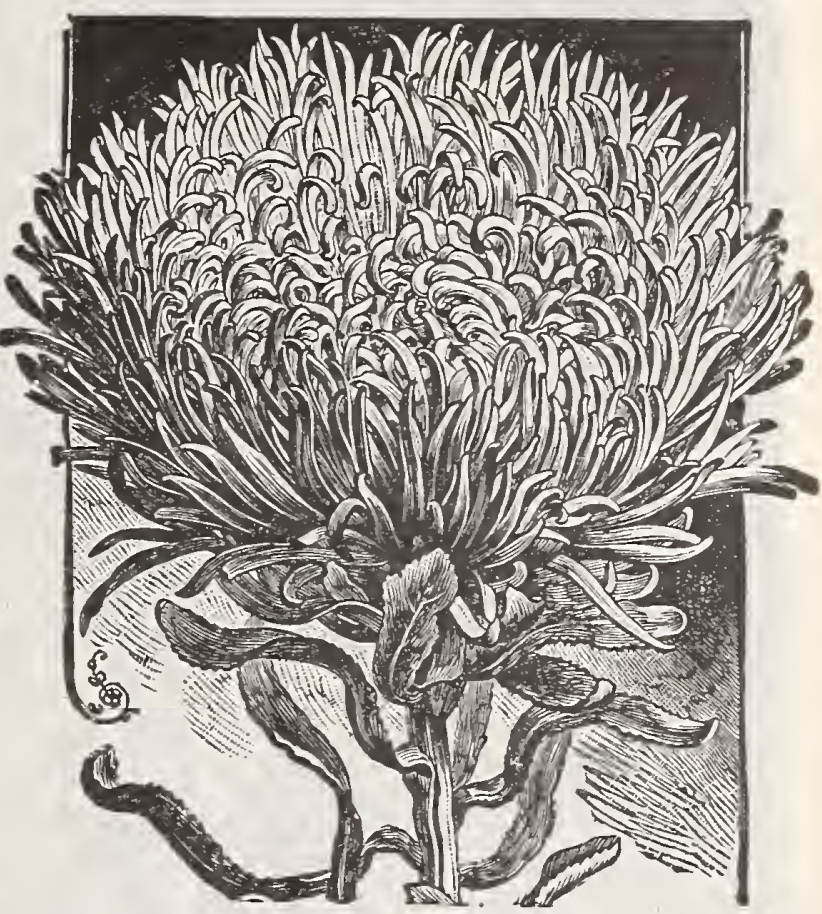

Aster, Japanese or Trassel.
Giant Comet. These desirable large flowered asters attain are early blooming and quite distinct from all others. The double flowers are sometimes four ol five inches across, with long wavy and twisted petals resembling Japanese chysanthemums. Color: Pure white, crimson, rose, dark blue, lavender, Dwarf Comet. mixed. Each 10c. per, and

Dwarf Comet. Mixed colors. Pkt. 5c.

Quilled Comet. A very beautiful Comet aster. growing bloom consists of white quilled florets, artistically arranged and highly effective in appearance, in contrast with the exquisite rose-colored outer petals. This is one of the most charming $10 \mathrm{c}$.

Comet, Crowned. This beautiful aster large 3 to 6 inches across), and of of long graceful petal sembling the most exquisite Japanese chrysanthemums. The cenwhite the flower is pure a charming rosy pink. Pltt. 10c.

Crown or Cocardeau. Very showy, the centers being white and the outside of the blossoms bright colcolors mixed. Plst. 5 c. Chrysanthemum Flowered.

Fine, large double flowers, resembling chrysanthemums, and valuable on account of profuse flowering plants 12 inches high. Ali colors mixed. Plkt. 5c.

Harlequin. One of the ously marked flowers grown. Pure white petals, irregularly interspersed with deep blue or bright red petals, making bright plashes and stripes over the snowy groundwork. Medium height. Odd and beautiful. Pkt. 5c.

Canary Bird. The best yellow variety known; the toria strain of a rich golden color, perfectly double and imbricated. Its greatest value lies in its rich color, colors. Pkt. 10c.
Queen of the Market. Of graceful spreading habit, its Asters begin to

Goliath. Very tall growing, branching freel

Ostrich Plume.

loosely arranged

Truffant's Paeony-Flowered. Free blooming; 2 feet. double, with florets or petals mostly incurved. All colors mixed. Pkt. $5 \mathrm{c}$. New Victoria. Flowers large and 2. an elegant and regular overlapping of the petals. Each plant bears from
10 to 20 fowers, with the ap-
pearance of a pyramid. All col-
ors mixed. Plit. $5 c_{\text {c. }}$ 2.
ors mixed. Plt.5c.
Daybreak. This beautiful

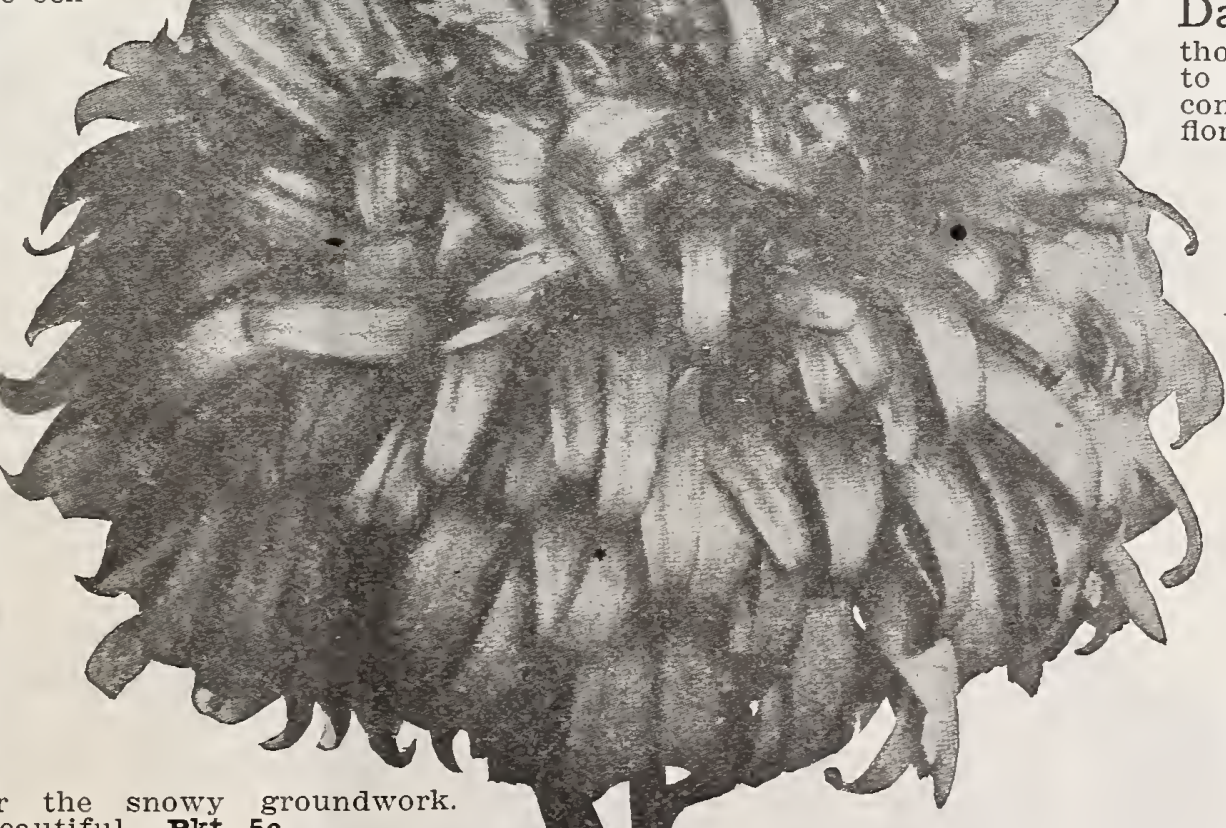
o rare gems that has come without it and for The flowers are round as ovely sea-sh, the color a and is a continuous freea desirable acquisition. Semple's Branching. A fine American strain proolors mixed. Pkt. 10c. Vick's Violet King. A splent full

Lavender Gem. beautiful. Pkt. 15c 


\section{${ }^{40}$ gु MAY'S NORTHERN GROWN SEEDS BEST FOR ALL CLIMES \& o}

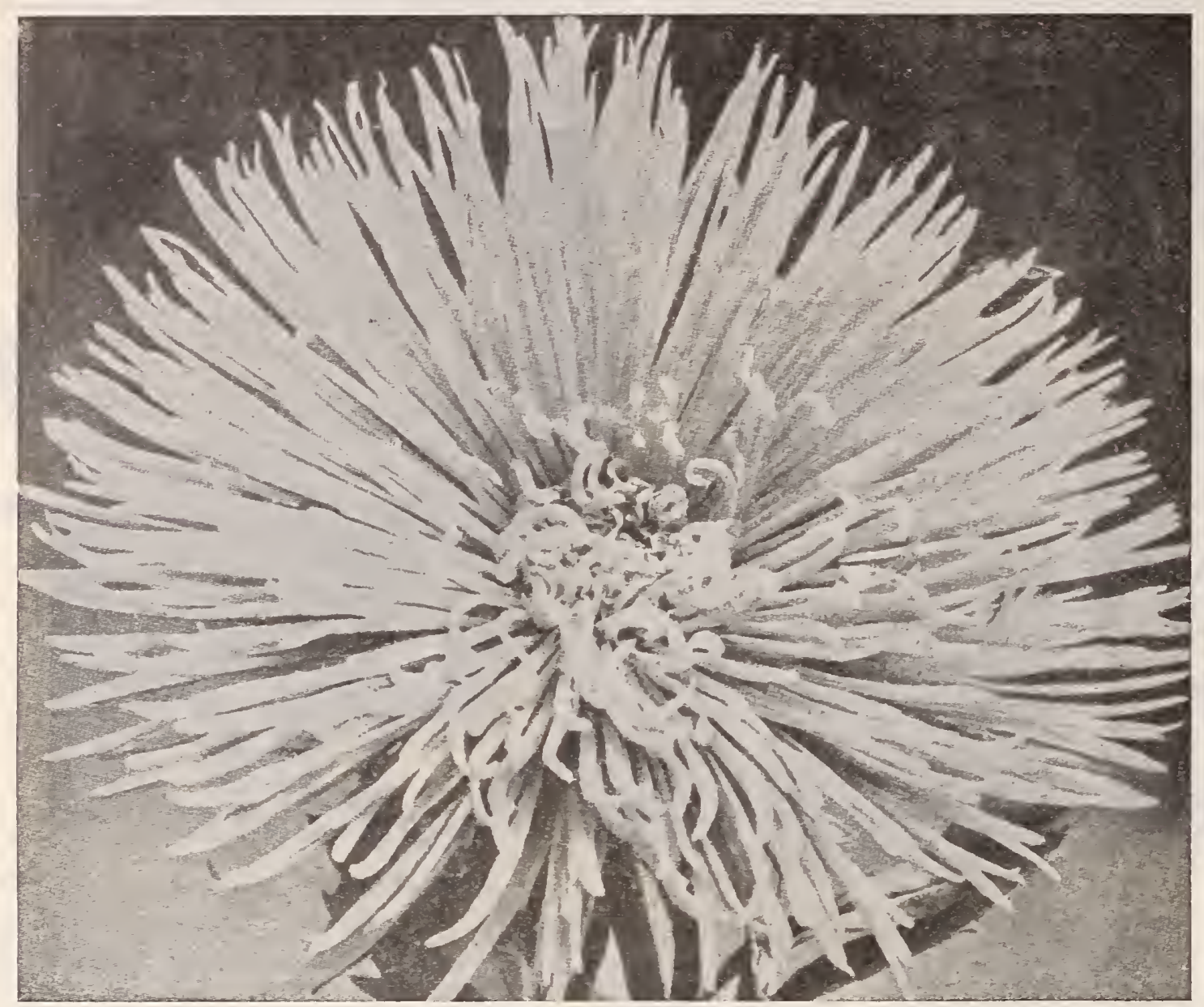

Aster, New Ray. ( $\mathbf{F}_{1}$ a rliest The flowers are very large, often five inches across, are produced on long, thin, wiry stems, perfectly double, with long needle or quilla very distinct appearance The plants are of healthy and vigorous habit, and grow to a height of about 15 inches. We offer this splendid new variety in three separate colors: Carmine rose, pale mauve, and Hercules Aster. This new variCercules Aster. ety - from the German raiser of the Hohenzollern Asters-is reported to be a marvel in size in size, graceful form and doublecentral stem 15 to 20 inches high surmounted by an enormous double flower 6 to 7 inches across, of the finest Comet form, so double that no yellow center shows, while the long encilcling side branches also carry Color, purest white. Pkt. 15c.

Hohenzollern Aster. Comes as provement over the Giant Comet. The blossoms are much larger in this improved sort, the petals being longed. Mixed. Pkt. 10c.

Early Flowering Hohenzollern Aster. Like the above as to flowers, and about twice as large as the Queen of the Market, while just as early as that variety. This is the most perfect of all Early Asters up to date. Pkt. 15c.

New Ray Aster.

To appreciate this unique Aster it must be seen. In form the flower is Entirely Distinct and one of the BEST EVER INTRODUCED.

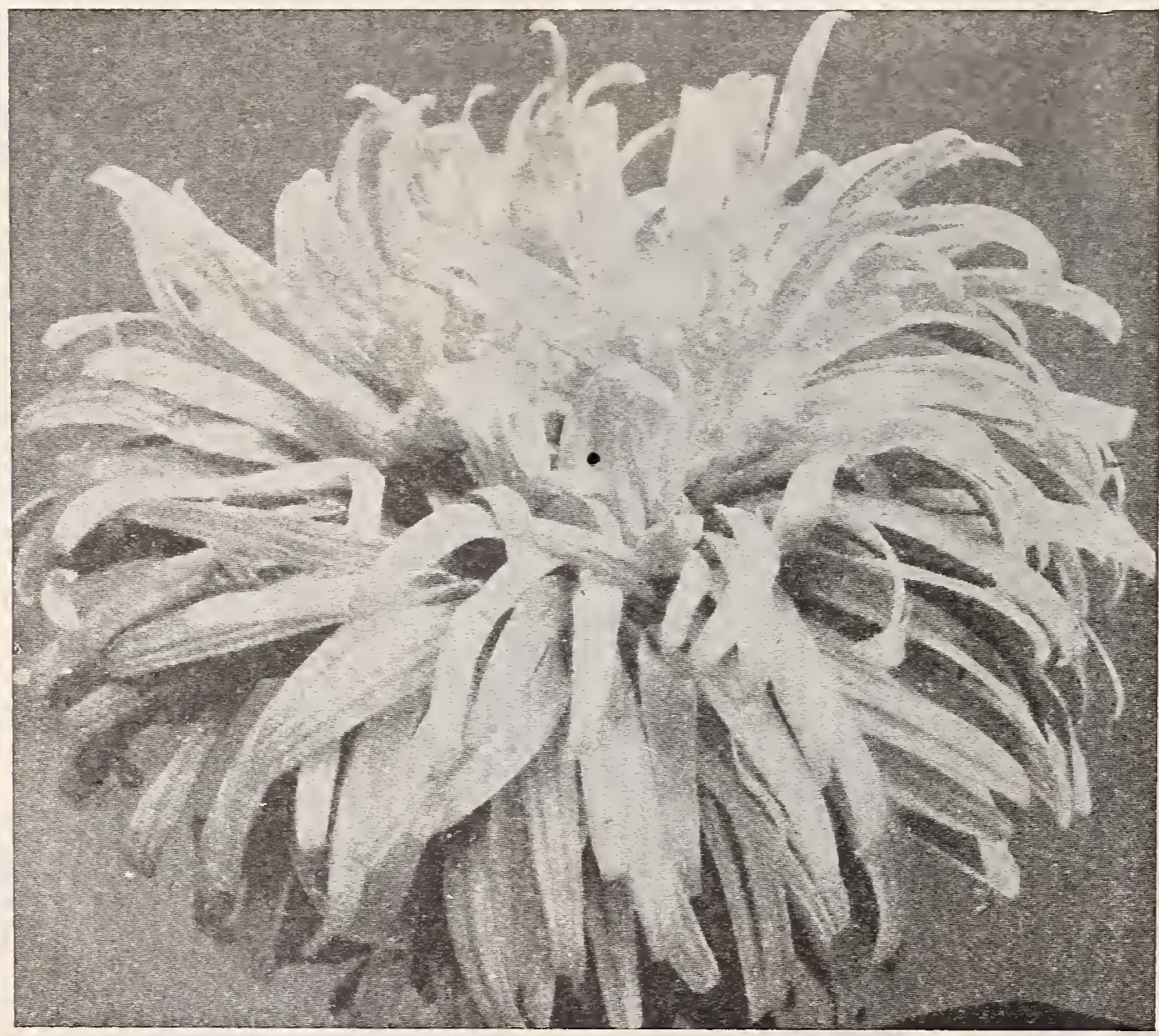

Eercules Aster.
+ THE GREAT CIRIOSITV
+ F L R A L CURIOSII
+ A Bulb that Blooms With
+ out Soil or Water.
+
SEE PAGE 53.

Snowball Aster. Valuable for massing ture. It grows to in beight of about 15 inches, and bears large, rather globeshaped, pure white flowers. Pkt. 10c.

Fire King Aster. One of the most Asters we have ever seen. The flowers crimson, and often measure as much as 5 inches in diameter. The blooms are of perfect form the petals deep, heavy and slightly incurved. Plst. 10c.

Mignon Aster One of the best for enormous quantity of good sized blooms on each plant. Mixed. Pkt. 10c.

Quilled German Aster. Tall and Quilled Germanching. bloomers and very beautiful. Mixed colors. Pkt. 5c.

May's Imperial Aster. Mixed Varievarieties of Asters, including all sorts, sizes, shapes and colors, with many of the fancy and newest shapes. Plt. 10c, 3 pikts. 25 c., $1 / 4$ oz. $40 \mathrm{c}$., oz. $\$ 1.25$.

May's Star Mixture Aster. This is ture of all the best varieties of Asters suitable for cut flowers, consisting principally of white, pink and the brightest of red, with a small proportion of blue and purple and some intermediate shades. This mixture being made by ourselves, we know contains only the most salable colors for cut-flower use, and offer it as a good subors. Iarge pkt. 15c., 0z. \$1.25. 


\section{GGOWN IN THE GOLDEN GRAIN BELT OF THE WORLD 2 :}

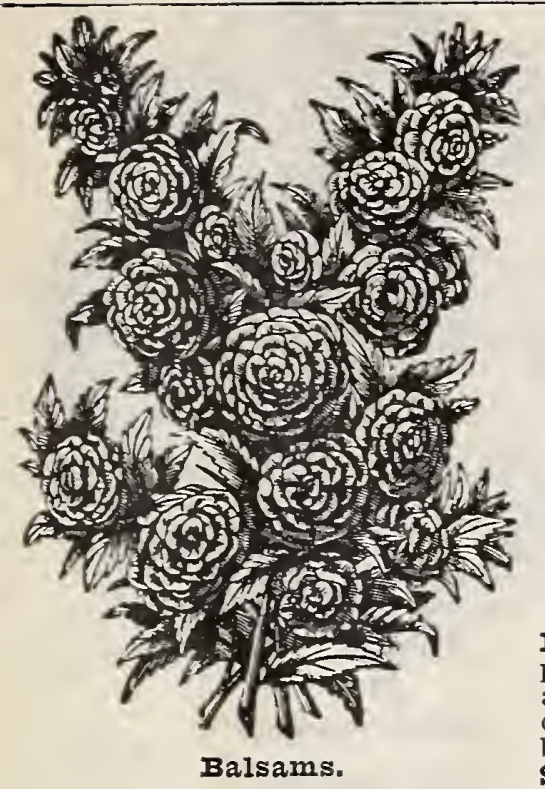

BALSAM ("Lady Slipper").

IMPrgraI MIXrD. The most perfect in form and largest doubleflow The mixture which we offer is composed in nearly equal proportions of eight colors, each having been grown separately. Pkt. 10c.

CAMIIIA FIOWERED. The finest strain of perfectly double Balsams, producing masses of brightest flowers. All colors mixed. Pkt. 10c.

GERMAN DOUBIE MIXED. All colors; very fine mixture of the best types. Pkt. 5c.

\section{BALSAM APPLE.}

A beautiful climbing plant with apple-shaped fruits, which if preserved in alcohol, make a most useful liniment. Plt. 5c. BEAN, Scarlet Runner.

A favorite Old-Fashioned Climber. One of the very few beans that is both ornamental and useful. It grows rapidly to a height of ten or twelve feet, and is covered from July until BEGONIA.

VIRION. Flowers a bright, brilliant orange carmine with bright yellow centers, and the foliage waxy and glossy. Pkt. $10 \mathrm{c}$.

GIAIT FIOWFRING. Pkt. 15c.

REX FY BRIDA. Pkt. 20c.

TUBEROUS ROOTED. Single flowering, mixed. Pkt. 10c. TUBmROU ROOTED. Double flowering, mixed. Pkt. 15c.

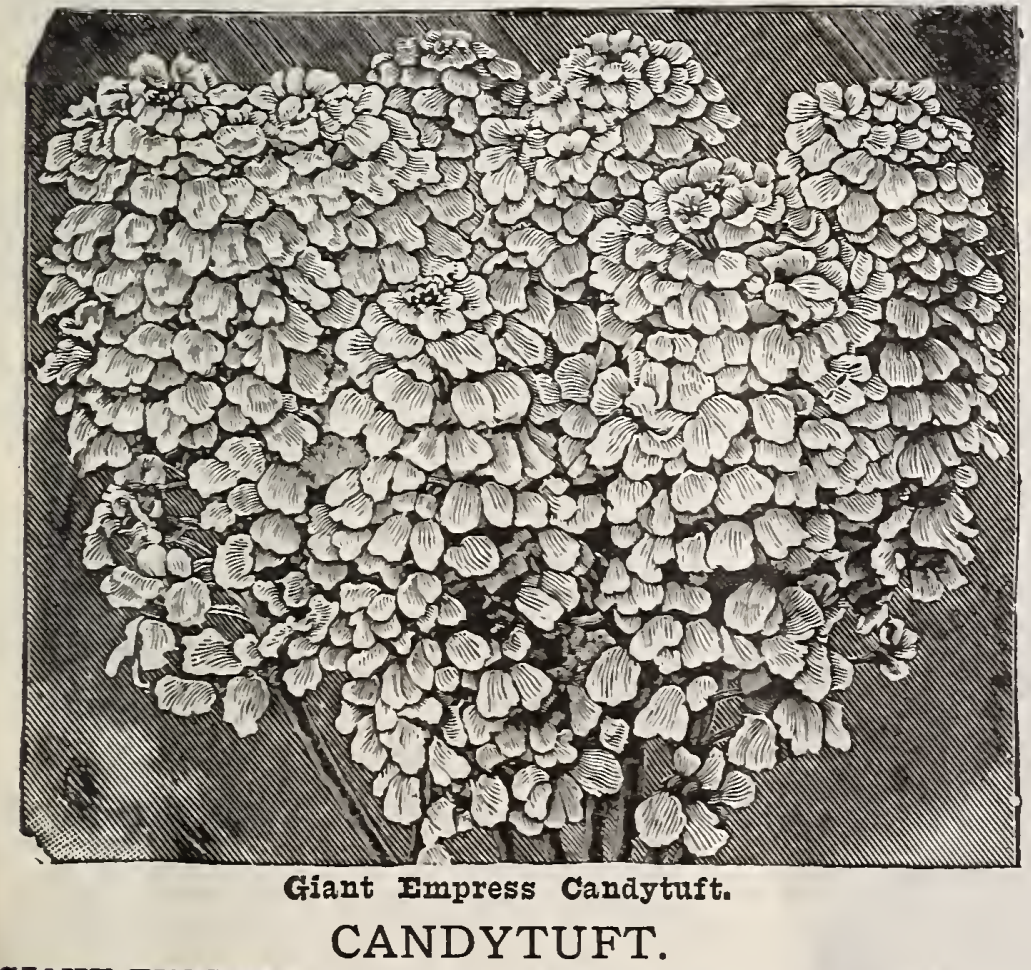

GIATT FMPRESS. One of the finest varieties in cultivation. The plant is of very branching habit, and when fully grown is covered with pure white flowers. Pkt. $5 \mathrm{c} ., 1 / 20 \mathrm{oz} .25 \mathrm{c}$. FINE MIXED. All colors. Pkt. 5c., 0z. 15c.

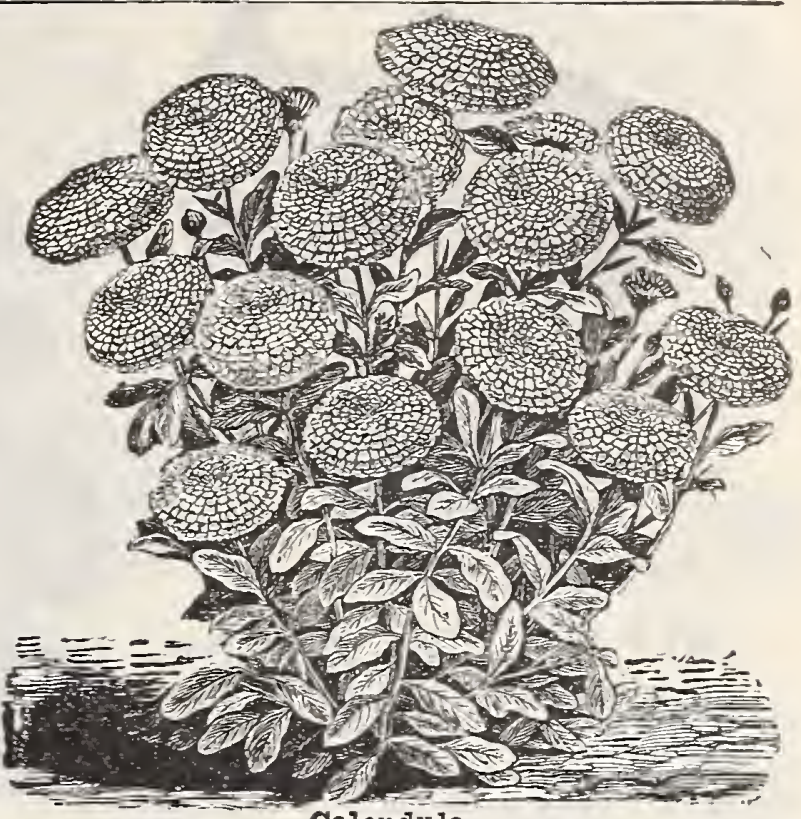

Calendula.
CALLIOPSIS OR COREOPSIS.

quire no care and thrive in any garden. Produce flowers in nearl

CANTERBURY BELLS (Campanula).

Well-known popular

many different colors very freely all summer.
Pkt. 5c. CANARY BIRD FLOWER.

A most desirable cliny BIRD FLOWER.

A most desirable

excellent window

does not get beyond control. Pkt. 5c., oz. $25 \mathrm{c}$.

\section{CALCEOLARIA HYBRIDA.}

of of the most -like flowers of various colors. Splendid Mixed. of showy
Pkt. $20 \mathrm{c}$.

CALEN-

DULA.

Color, bright gold-

en yellow or or-

ange. From see

gorund it comes
into flower early,
and blooms pro
fusely all summer

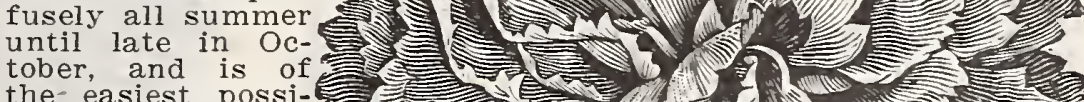

the- easiest possi-

ble mized, pkt. 5c.

CANNA.

CROZY'S NEW

DWARF. One of

the most popular

of bedding plants.

the first year from

seed, if you soak

them in yery hot

water over night;

$\mathrm{y}$ in small pots as soong

convenient, and grow as
rapidly as possible. Plit.

TALI OID TYPE.

ture of all

growing varieties. Plt. $5 \mathrm{c}$

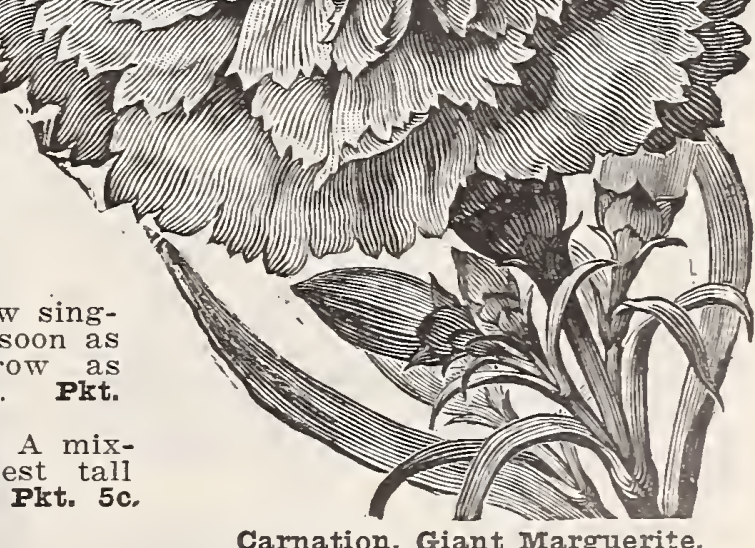

CARNATION.

GIANT MARGUERITE.

the sowing of the seed

include is two inches, or The

CARNATION. Perennial Varieties.

in May or June will flower

FINEDOUBLE MIXED. Fine colors. Pkt. 10c.

WED GRENADIN.

Prt. 10c. $10 \mathrm{c}$

DOUBLE YELIOW. 


\section{Gु'MAY'S NORTHERN GROWN SEEDS BEST FOR ALL CLIMES So}

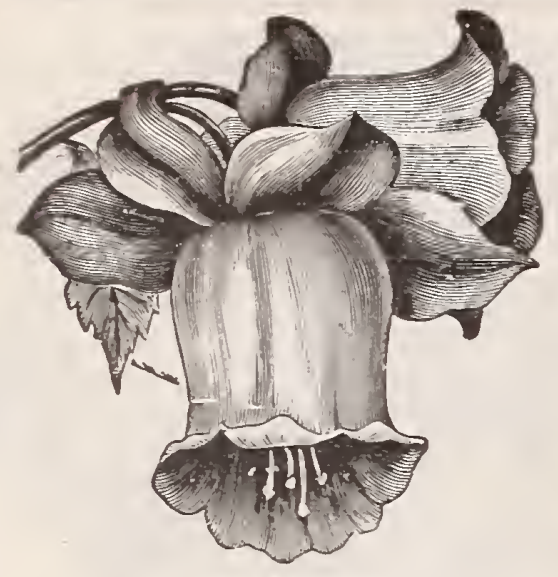

Coboea Scandens.

CALLA LILIES (From Seed) DEVONTENSIS GRANDIFLORA.

beautiful large flowering, new species
producing blooming plants from seed in one year. Old plants often produce six large and borne on stout stalks. Pkt.

\section{CENTAUREA.}

NEW MARGUERITE. The most fragrant and longest keeping cut flower. The

flowers are the size of a medium carnation, freely produced on long stems, which renlasting quality after being cut is remarkmmence to flower in July. Prt. 5c. CENTAUREA IMPERIAIIS.

and improved strain of Marguerite with Pkt. 10c.

CENTAUREA (Dusty Miller).

CANDIDISSIMA.

Pkt. 5c.

GYMNOCARPA: Silver gray foliage. Pkt. 5c.

CENTROSEMA (Butterfly Pea) GRANDIFIORA. A hardy perennial vine f rare beauty, which blooms in July from seed sown in April. Pea-shaped flowers, reddish purple. Plt. 10c.

\section{CHRYSANTHEMUM.}

FANCY PERENNIAI. From the best

\section{Incurved Pompone, Japanese, Chinese an} Anemone-flowered varieties seeds sown in the hotbed in February or March, or even in April, will give plants that will blnom in August or September, and cannot fail, ers proper care, to give magnificent flowforms. Plet. IOc.

FRENCH MARGUERITES.

plants grow 12 to 18 inches high and produce on long stems beautiful large flowparden, and make elePlt. 5c.

CINERARIA, HYBRIDA.

One of the most popular House Plants. The rich and vivid colors range through and crimson to deep maroon. Choice mixPlrt. $10 \mathrm{c}$.

\section{COBAEA SCANDENS.}

Beautiful, large, bell-shaped flowers, green at first, but rapidly changing to a lished plant will run 30 to 40 feet in sea son. Pkt. 10c.
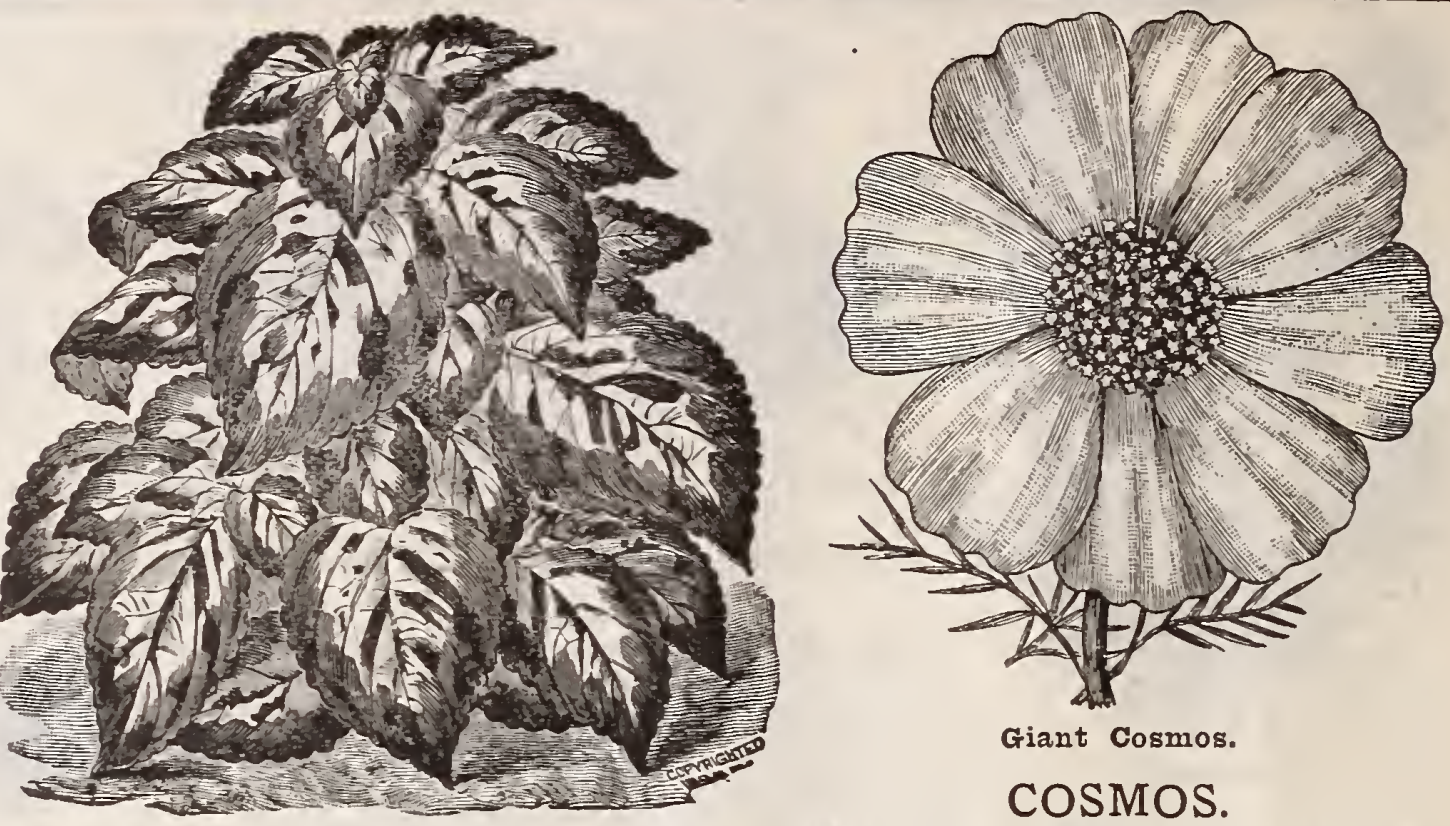

Giant Cosmos.

COSMOS.

Coleus, Rainbow.

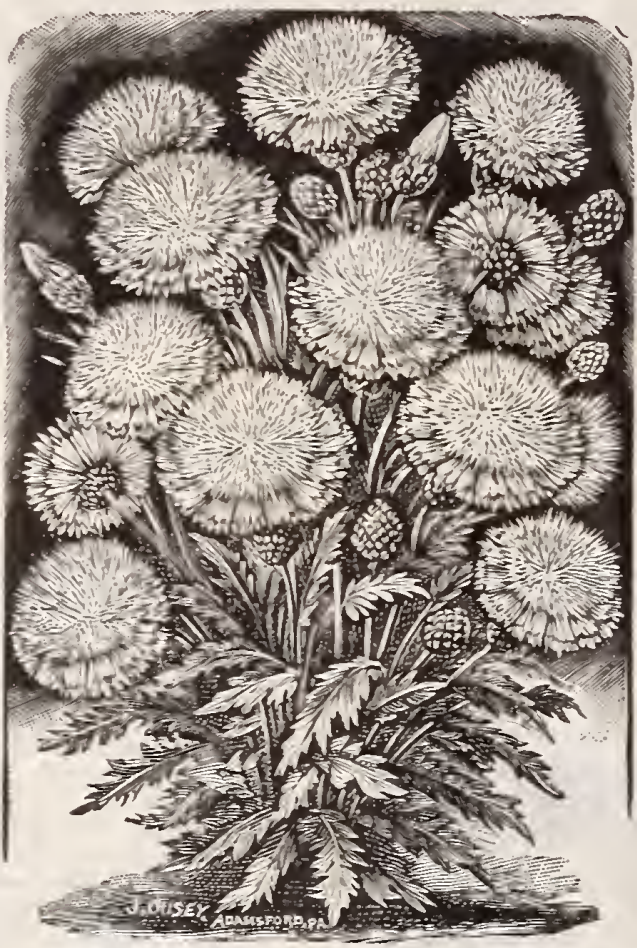

Centaurea Marguerite.

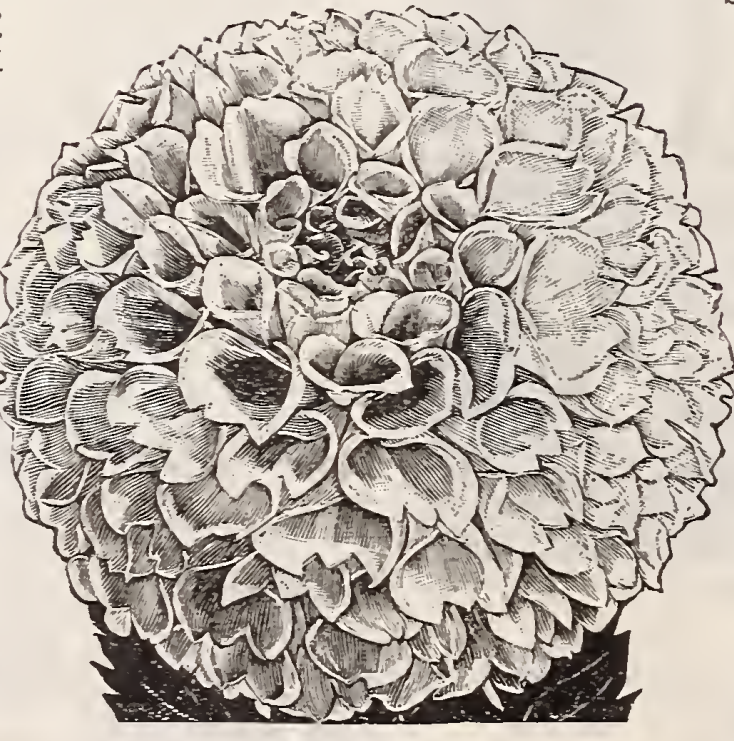

Dahlia, Double.
EARIY FLOWERING. This early flowering strain may now be had in bloom from July to November. It is such a strong rigorous grower, and its fine, fringe-like lovely spreading flowers. Plt. 5c.

GIANT FLOWERING. Mixed. Pkt. 10c.

COCKSCOMB (Celosia.)

DWARF QUEEN. This is the best dwarf growing Cockscomb. Color, a rich ruby red. Pkt. 5c.

OSTRICH FEATHER. Produces very arge plumes, curved and curled in exact resemblance of an ostrich feather. The plant grows about 3 feet high. Most efective ornamental plants for either pot or utdoor planting. Prt. 5c.

DWARF MIXED. All colors and shapes. Prt. 5c.

\section{COLEUS.}

HYBRIDUS. One of the best known and 作 ge plants Easily grown from seed in an endless variety of colors and shadings. Pkt.

RAINBOW. The plants reach a height of from 2 to 3 feet; the leares often measure 10 inches in length and 8 inches in width toothed and frilled. Pirt. 10c.

\section{CRAB'S EYE VINE (Abrus Precatorius.)}

A beautiful climber for pot culture; bears clusters of bright yellow flowers, followed bunches of pods, which, when dry, burst open, disclosing brilliant red seeds with

CYPRESS VINE.

A most beautiful vine with delicate

\section{CYCLAMEN.}

PERSICUM. Well known bulbous-rooted plants, universal favorites as pot plants for winter and spring blooming, producing beautiful variegated foliage, in different

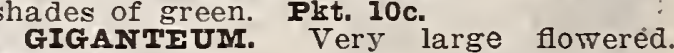
plt. $15 \mathrm{c}$.

DAHLIA.

DOUBIE CACTUS. Mixed. The most beautiful in cultivation. They are unequaled for rich and raried colors and perfection of form. Seed sown in the house in March and April will produce flowering plants as soon as those grown from tubers, so that the purchase DOUBIE FIN MIXED. Pkt. 10c. SINGIE MIXED. Pkt. 5c. 


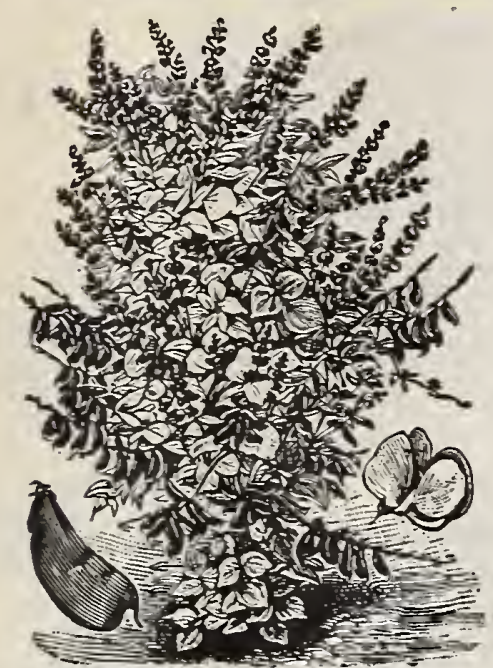

Dolichos, Hyancinth Bean.

DAISY (Bellis Perennis).

GIANT DOUBIE. Daisies are easily grow spring sown seed and come into flower in a very
short time. The flowers are white, pink, red and shariegated. Not all will come double from seed. Finest mixed. Pkt. 10c.

SHASTA. It is a hardy perennial, bearing flowers

averaging 4 inches in diameter, on long, stiff stems.

It blooms freely for several months, and the fiowers

The petals or rays are pure white. Plit. 10c.

BIUE. A fine winter bloomer. Pkt. 5c.

IONGFEIIOW. Rose color. Pkt. 10c.

SNOWBALI. Double white. Pkt. 10c.

DATURA (Trumpet Flower).

CORNUCOPIA. (सlorn of Plenty.) White and

IIIXED. Seed of many varieties. Pkt. 5c.

DIANTHUS · (Pink).

ITTTIE GrM. Wine red suffused and veined with rosy carmine, with white. Pkt. $10 \mathrm{c}$

CHINENSIS. Clusters of small double flowers, fine mixed. Pit. 5c.

HEDDEWIGIr. Double and single mixed. Pkt. 5c. DIADEMUS. Large double flowers. Pkt. 5c. IACINIATUS. Large double fringed. Pkt. 5c. DWARF FIREBAII. Blood red. Pkt. 5c. DWARF SWOWBAIL. Snow white. Pkt. 5c. MMPERIAI MIXED. A choice mixture of all th

GOOD MIXED. Fine colors. Pkt. 5c., oz. 25c. PIUMARIUS. Pheasant eye pink. Prt. 10c.

DIGITALIS (Foxglove).

FINE MIXED. Beautifully spotted flowers. Pkt. 5c.

DOLICHOS (Hyacinth Bean).

MIIx. The old-fashioned variety producing abundant clustered spikes of purple and white flowers. Pkt. 5c.

GIANT CRIMSON. Large spikes of purplish red flowers. Pkt. 5c.

DAYIIGHT. Large spikes, pure white. Pkt. 5c.

ECHEVERIA (Hen=and=Chickens.)

These plants are easily grown from seeds and will furnish a real surprise, for few people have any idea of the great variety, both in shapes and colorings, that ing plants, which are used extensively in our parks for ribbon and carpet bedding. Pkt. 15c.

ESCHSCHOLTZIA (California

$$
\text { Poppy.) }
$$

Rich yellow flowers, fully as valuable a the common poppy for garden ornamentation, and as easily grown. Pkt. 5c.

ESCHSCHOLTZIA, BUSH (Hunnemannia).

This is a most beautiful plant and flow ers freely the first year; brilliant, yellow,
tulip-shaped flowers in abundance. Prt. 5c.

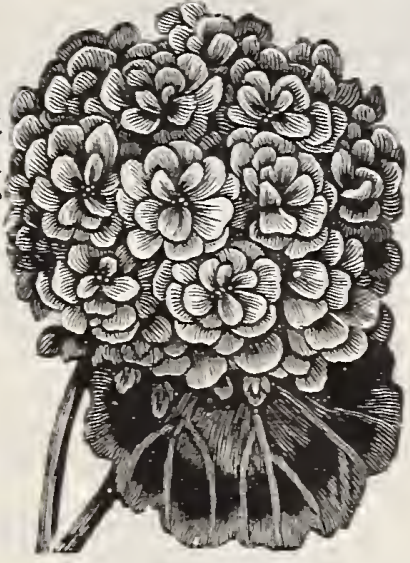

Geranium.

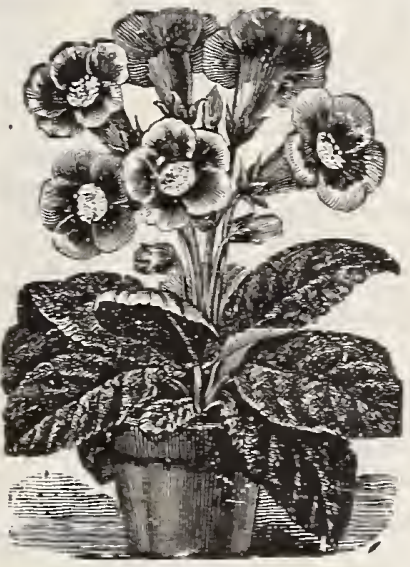

Gloxinia.

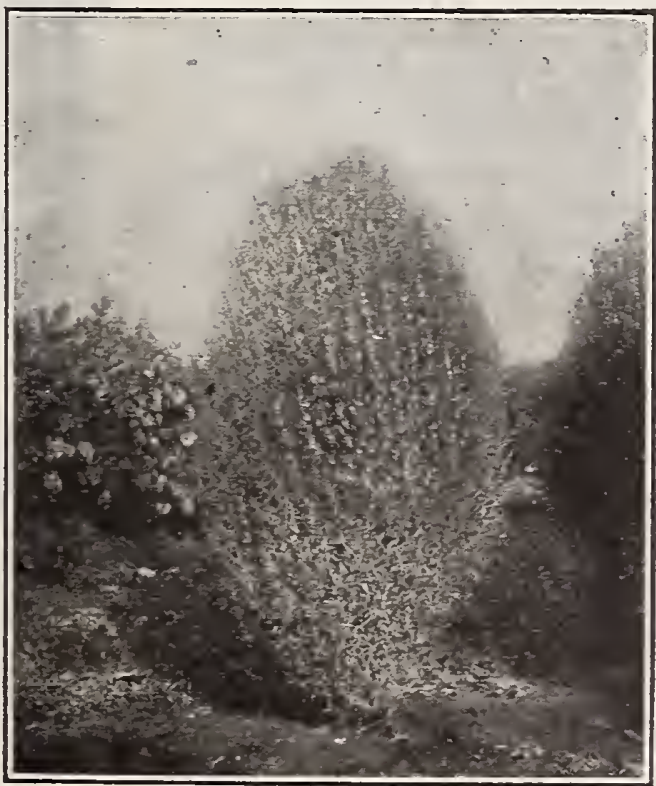

Fawaiian Treasure Plant. (Kochia or Glowing Ball.)

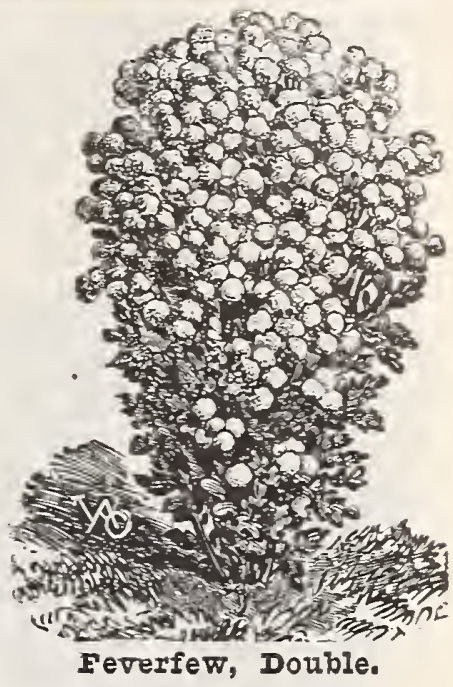

FEVERFEW.

DOUBIE. A fine old-fashioned bedding plant lso suitable for pot culture. It grows about 18 with vis dite

FORGET-ME-NOT (Myosotis).

NEW DWARF BIUE. The true ever-blooming lue. Pkt. 10c.

PAIUSTRIS. Hardy swamp variety. Pxt. $5 \mathrm{c}$

VICTORIA BIUE. Large blossoms. Plt. 5 c.

\section{FUCHSIA.}

Fuchsias are as easily grown from seed as from

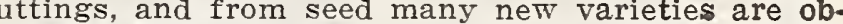
GAILLARDIA.

Large double flowers, valuable for cutting. Tha colors embrace sulphur, golden-yellow, orange, amarGERANIUM.

CAIIFORNIA GIANT. They will bloom from seed 4 to 5 months, trator with charming new rarieties; in fact, propaarieties. Pkt. 10c.

ZONALE. Double fine mixed. Pkt. 5c.

IADY WASHINGTON. Rarest varieties. Plt. 25c. GLOBE AMARANTH.

EVERIASTING. Small globe shaped double flow-

GLOXINIA (Hybrida).

The Gloxinia is a grand flower and makes a lovely pot plant; as easily grown and cared for as many of flowers embrace a great rariety of the richest and most beautiful colors. months from the time the seed is sown. pit. 10c.

\section{GODETIA.}

Beautiful hardy annuals. Flowers deep ose pink, rosy carmine, snow-white with in carmine rose spots, crims

GOURDS (Ornamental).

Tende

which are peculiarly marked. Pkt. 5c.

GREVILLEA ROBUSTA, or SILK OAK.

One of the quickest growin
mental house plants. Pht. 10c.

\section{HAWAIIAN TREASURE}

PLANT (Kochia or Glowing Bush).

A quick growing Annual. 


\section{"G MAY'S NORTHERN GROWN SEEDS BEST FOR ALL CLMES So}

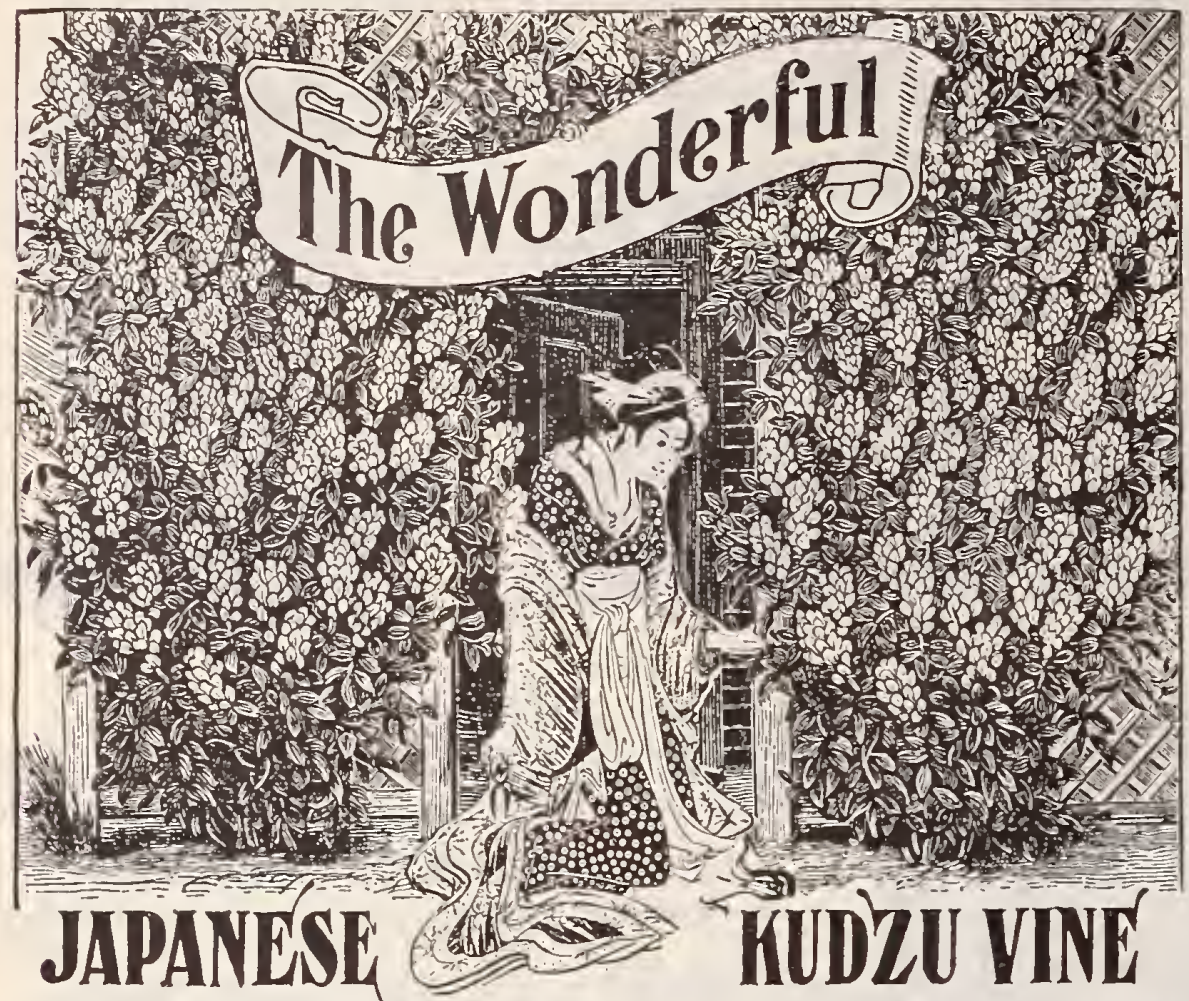

This is the most remarkable climbing vine of the age and one that should be planted by every one desiring a dense shade.

It growth and its handsome flowers. The blossoms are large of a pleasing shade of purple. The

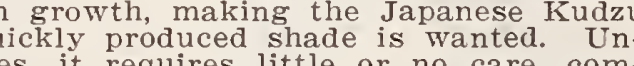
seed pkt. $10 \mathrm{c}$ HELIOTROPE.

the fact that it can be raised trom seed as easily as the verbena.

and blue. Plt. 10c.

HELICHRYSUM (Everlasting).

kt. $10 \mathrm{c}$

HELICHRYSUM (Everlasting).

whaded and tipped. Handsome bouquets

the point of expanding. Prt. 3c. HOLLYHOCK.

MAMIMOTH ALLEGHENY.

the buds develop into flowers in rotation, the largest buds first, then

pink. Pltt. 10c.

ANTUAL EVERBLOOMING.

Plst. 10c.

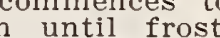

HUMULUS JAPONICUS (Japanese Hop).

One of the most rapid climbers grown. Seed can be sown in the open Plkt. 5c.

ICE PLANT.

A handsome and curious plant for hanging baskets, rock work and vases. LARKSPUR (Delphinium).

Well-known annuals of great beauty and noted for their richness of color DOUBLE DWARF ROCKET. Finest mixed. Pirt. 5c.

PERENMIAL LARISPUR. . Choice mixed. Best varieties. Plt. 5c.

LAVENDER (Old Fashioned Sweet).

, sweet-scented, hardy perennial, bearing long spikes of LANTANA (Hybrida).
LINARIA (Kenilworth Ivy).

A very pretty and well-known hardy perennial trailing plant, for covering rock work, and very useful for hanging baskets. Pkt. 5c.

\section{LOBELIAS.}

Compact or Bedding Sorts.

CRYSTAL PALACE

EMPER OR WILIIAMr. Liglut blue. Pltt. 10c.

GRACILIs. Bright blue with white eyes. Plrt. 5c.

MAURANDIA (Climber).

FINEST MIXED. All colors. Plt. 5c.

MARIGOLD (Indian Rose).

EIDORADO. Large double flowers of all shades of yellow, deeply imbricated. Plt. 5c.

DOUBLE DWARF. Grows 10 or 12 inches colors and produces double flowers of various shades and

MIGNONETTE (Reseda).

A well-known fragrant favorite, which produce a pleasing contrast to the more showy occupants of the

GOLDEN QUEEN. Rich golden. Pkt. 10c., oz. 25c.

MACHET. Deep red blossoms. Pkt. 10c., oz. 25c.

PARSON'S WHITE. Large white. Pkt. 10c., oz. $25 \mathrm{c}$

ODORT RED. Color deep red. Pkt. 10c.

MIMULUS.

MOSCHATUS (Musk Plant). Grown for the musky odor. TIGRINUS (Monkey Flower). Fine Hybrid mixed.

MARVEL OF PERU (Four O'Clock).

It is one of the most brilliant and showy plants that Plt. 5c.

\section{MOON FLOWER.}

GIANT WHITE. Mammoth white blossoms. Plt. 5c. MORNING GLORY.

GIANT JAPANESE. The seed we offer is grown from Japanese stock, and embraces plain singles (which are really the handsomest), semi-doubles, quilled and color, except yellow, and is superior to every hue stock offered, and we guaranteo it will give satisfaction. Pkt. 10c., oz. 25c.

WHITE TASSEL. The flowers are beautifully fringed and never fail to attract attention wherever seen. Easily grown from seed, and will give a good percentage of ROCHESTER. The large, open, trumpet-shaped blossoms are distinctly outlined with a band of silver white. Pkt. $10 \mathrm{c}$

FINE MIXED. A great variety of colors of the popu-

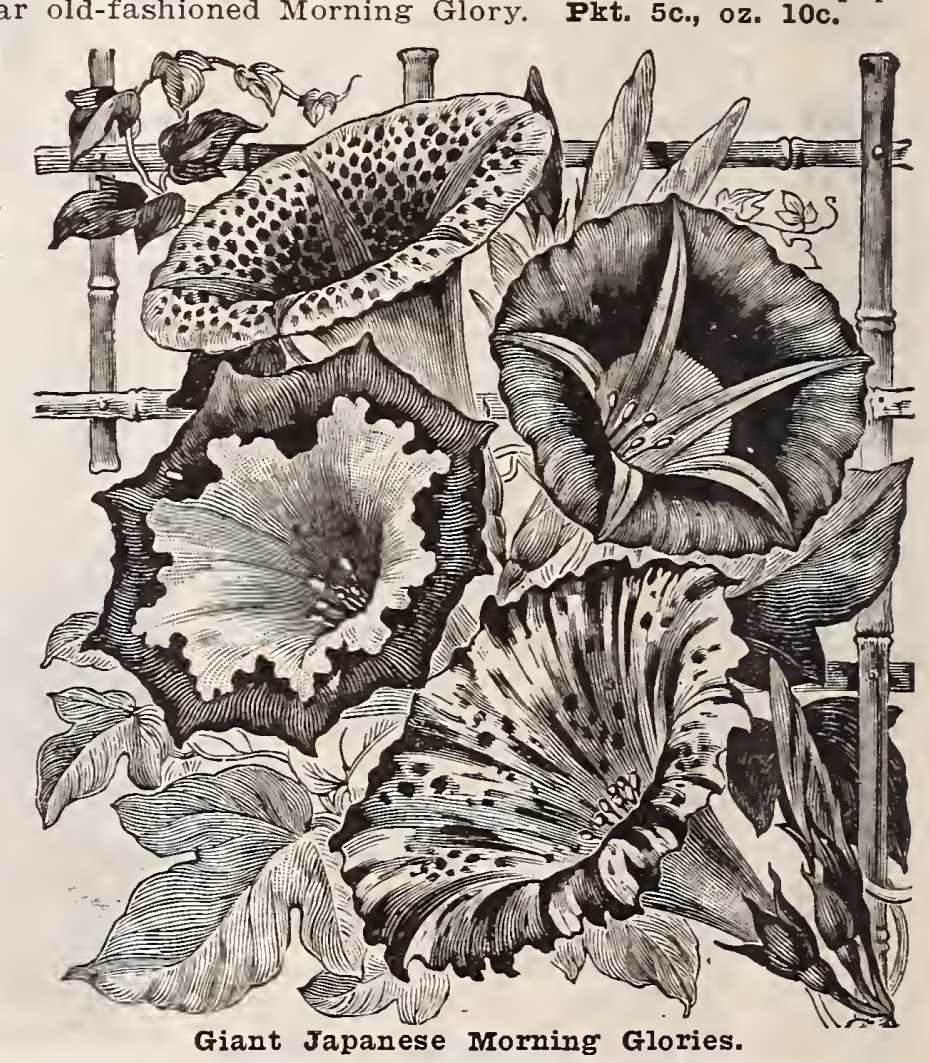




\section{GHOWN IN THE GOLDEN GRAIN BELT OF THE WORLD}

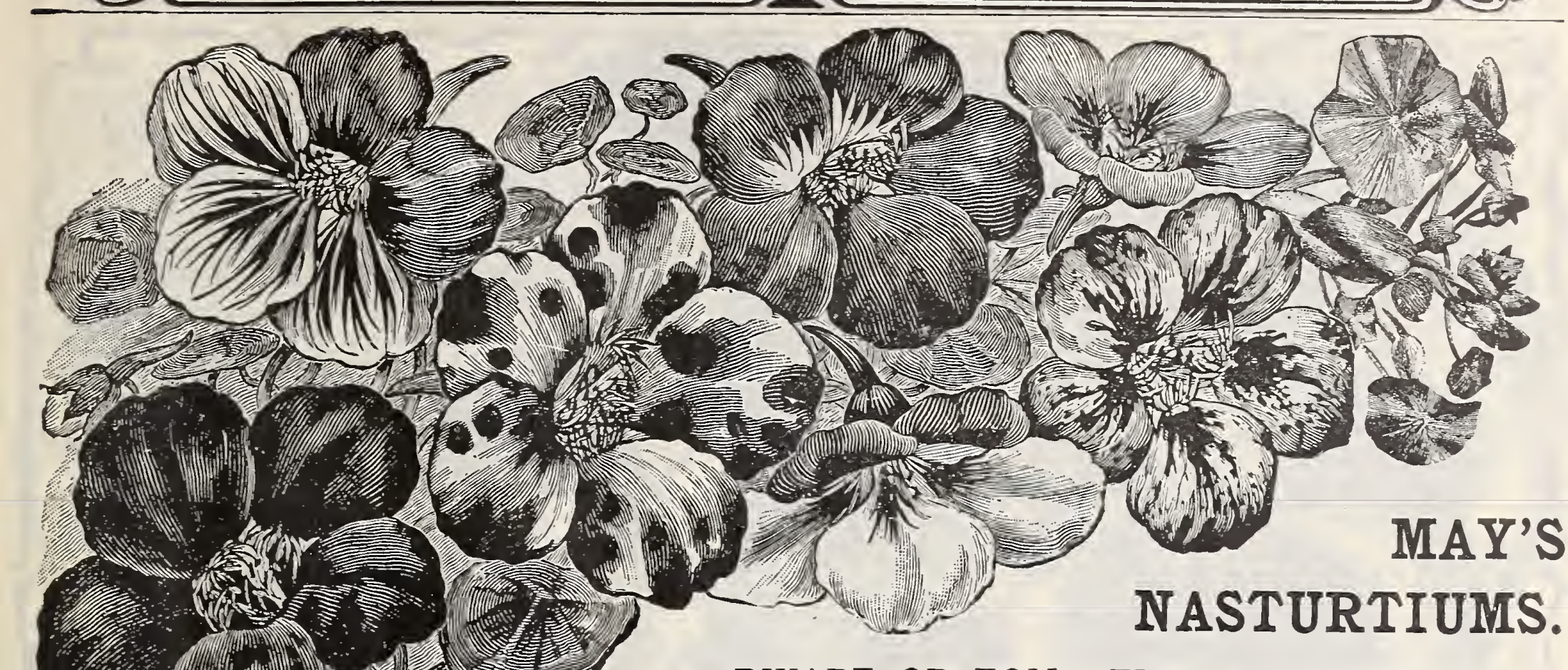

DWARF OR TOM THUMB VARIETIES.

Price: Ang of the following sorts, except where otherwise noted, large pkt. 5c., oz. 10c.

AURORA. Deep chrome yellow,

BEAUTY. Glowing orange, suf- vEsUviUs.

fused scarlet markings.

Jith a cle a

BRONZE COIORED:

CHAMELEON-New French. Flow-

ers of most diversified coloring, and

plant. Plit. 10c., oz. 20c.

CIOTH OF GOID. Compact plants.

with bright golden-yellow
brilliant scarlet flowers.

COFRUIEUM ROSEUM.

CRYSTAI PAIACE GEM.

DEEP SCARIET. A very bright

EMPRESS OF INDIA. Deep pur-

plish-green leaves. Flowers dark

GOIDEN KING. Rich glowing KING OF TOM THUMBS. Glow-

SPOTTED KING. Rich orange,

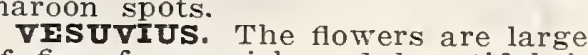
olor. The broad petals are heavily KING THEODORE. Dark foliage PEARI. Light lemon-yellow, fadPRINCE HENRY.

the most distinct and charming.

With a salmon tint. Variegated Foliage. This charning novelty produces flowers of a rich
bright crimson "which forms a very pretty contrast to the silver variehandsome and useful bedding

Pkt. 10c. DWARF IMPERIAI GFRIMAN KING OE IOM THUin

H. M. STANLFY. A beautiful purplish mauve. petal is barred with a broad vein DWARF GOOD MIXED. TALL OR CLIMBING VARIETIES.

Price, each variety, except where noted, Prt. 5c., oz. 10c. CARDINAI. Brightest scarlet. EDWARD OTTO. Brownish lilac
FIRE FLY. ROSy salmon and car FIRE FIX. Rosy salmon and car-
GIANT OF BATTLES. Sulphur

changing until it fades. Plit. 10c. Oz. ISC. HEMISPHERICUM.

JUPITrR. Rich golden yellow. JUPITER. Rich golden yellow. KING THEODORE.

PEARI. Pale lemon-yellow
PRINCE HENRY. Light

REGEIANUM. Rich crimson. ROSEQUEEN SUNIIGET. VESUVIUS.

TALI CHAMEIEON.

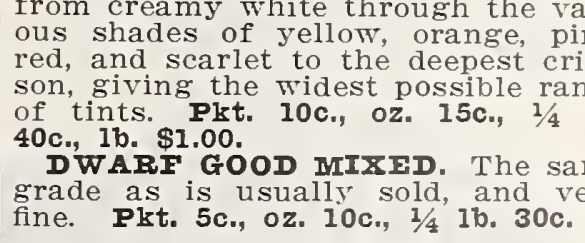
ground. Pkt. 5c., oz. 10c., $1 / 4$ 1b. $30 \mathrm{c}$ 1b. \$1.00. Climbing Pkt. 10c., oz. 15c. TALI GOOD MIXED.

oz. $10 \mathrm{c}$., $1 / 4 \mathrm{ib}$. $20 \mathrm{c}$.

NICOTIANA.

BE SURE and have a bed of Nasturtiums this display of sweet-scented flowers for three months than almost any other plant. On
plant a bed ten feet in diameter.

of this novel sort is in full bloom. CoIOsses.

every shade of color and form of or SANDERAE.
marking known to nasturtiums. No Prt. 10c. 


\section{${ }_{40}^{6}$ ? MAY'S NORTHERN GROWN SEEDS BEST FOR ALL CLIMES \&o}

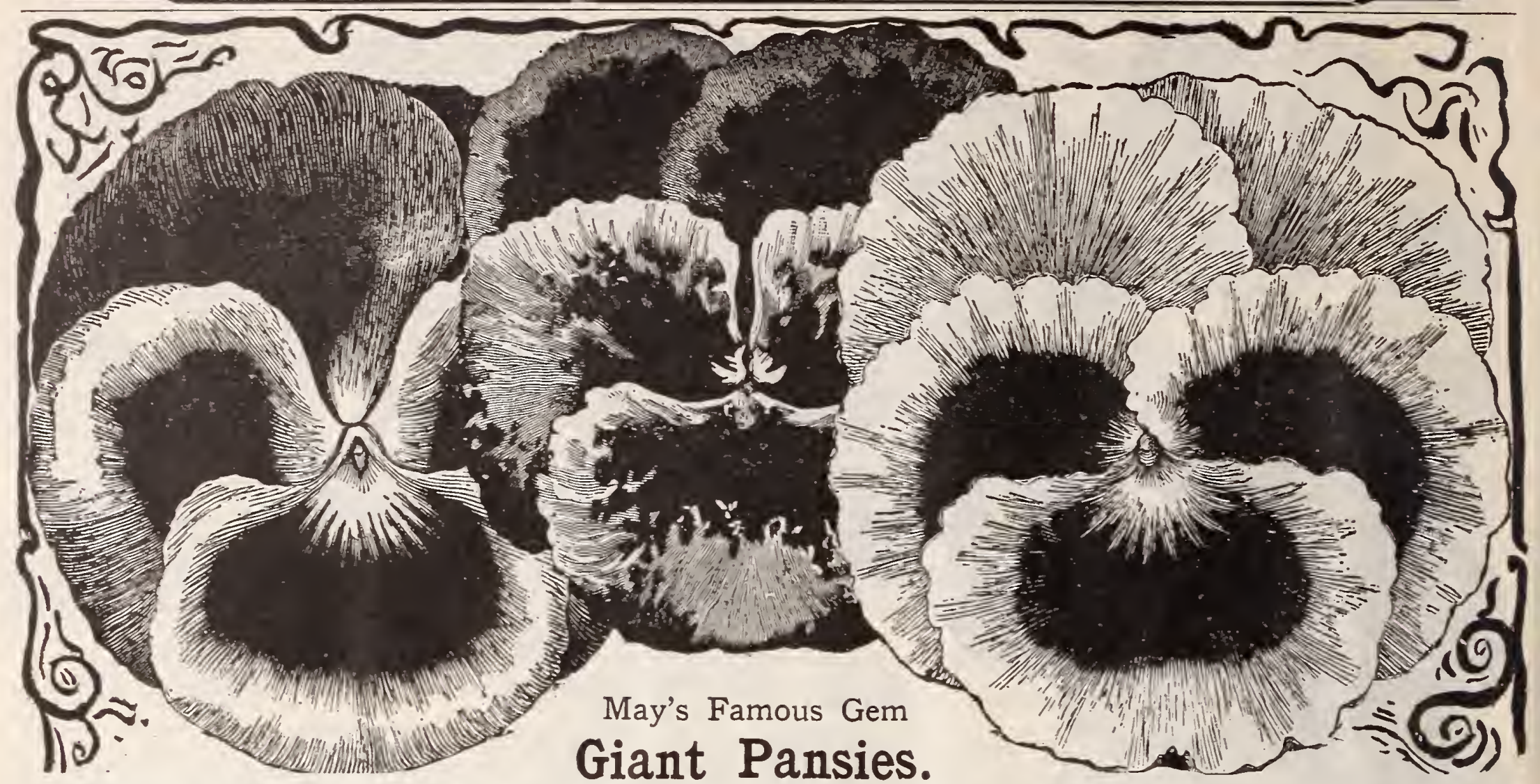

THE MOST BEAUTIFUI KNOWN AND BEST “TRUIY GIANT FIOWERED" VARIETIES.-For extraordinary size of the 作 growers of pansies, mixed and blended by ourselves. We offer this special blend to pansy lovers with the full assurance that

GIANT AURORA. The largest pure white

GIANT ADONIS. Color a magnificent light blue with a

most striking manner. Pkt., 10c.

GIANT BUGNOT.

appearance, shadings comprise tints of red,

GIANT STRIPED. The flowers are striped and mottled in

GIANT CASSIER. This is a very fine mixture of Pansies

marked with three or five blotches on rich blackgrounds.
Pkt., 15c.
GIANT YELLOW PRINCE. The color is pure golden yellow, shaded

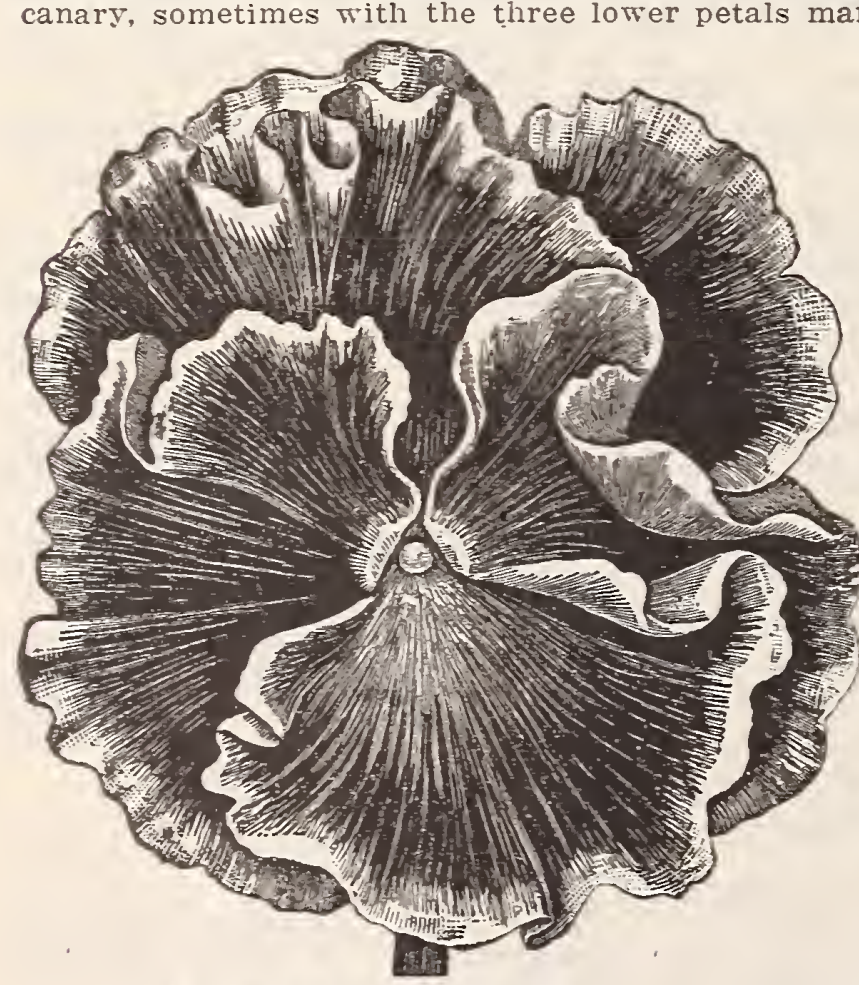

Pansy, Giant "Masterpiece.
GIANT "MASTERPIECE." This magnificent new Pansy comes nearer to double pansies than anything ever introduced under that name, the border of every petal being conspicuously crimped and curled in such a fashion that the flowers very odd and striking. Pkt., 10c.

GIANT RUBY. This new variety embraces the richest shades of red colors, from scarlet, scarlet-orange, wine-red to MAMMOTH BUTTERTI. The flowers are very large, of good form and substance and produced freely. They are mot-

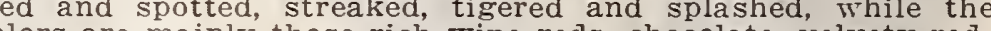
rown, lavender, violet and purple shades which are only found in a Pansy blossom. Pkt., 10c.

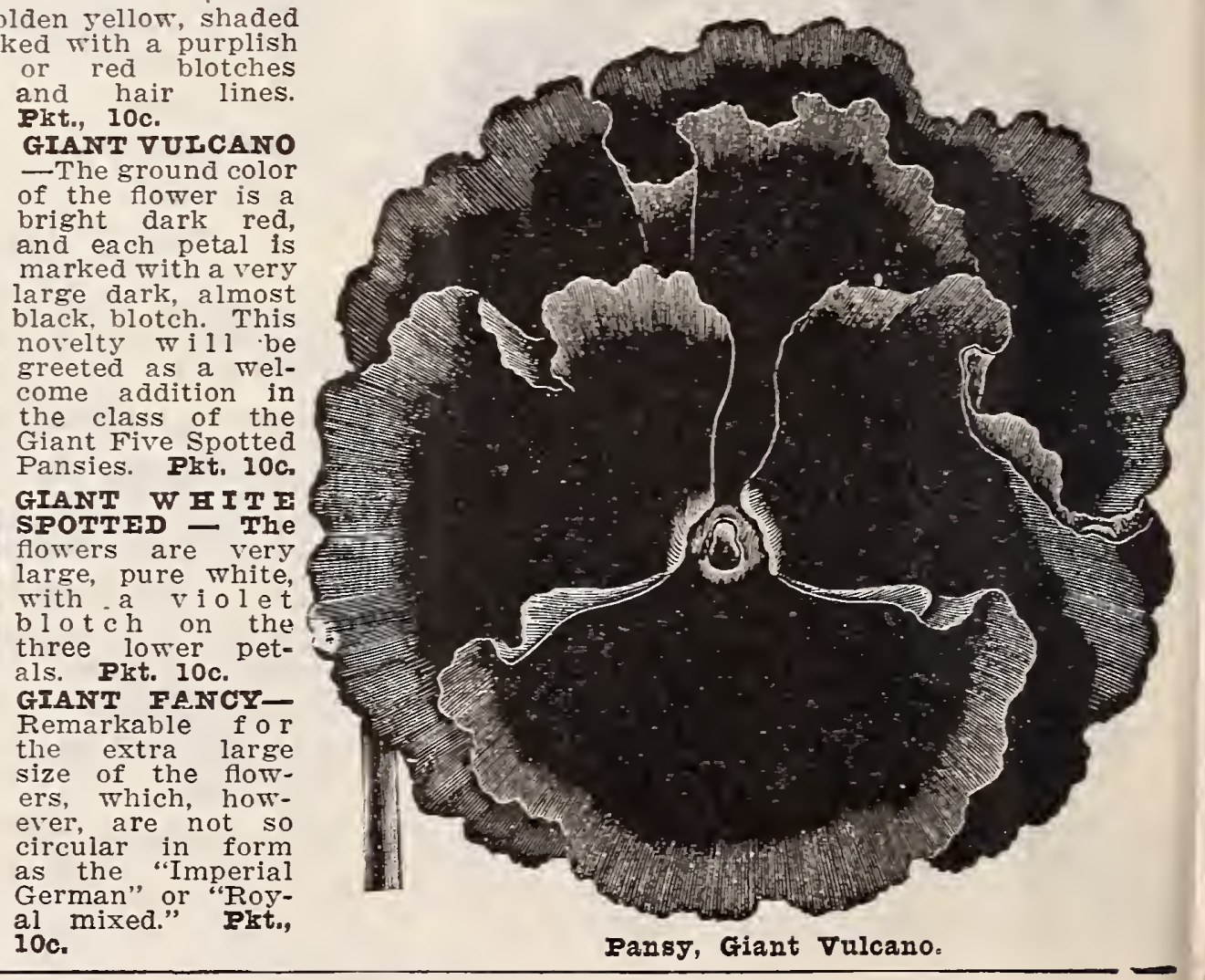

L. L. MAY \& CO., ST, PAUL, MINN. 


\section{GGROWN.IN THE GOLDEN GRAIN BELT OF THE WORLD}

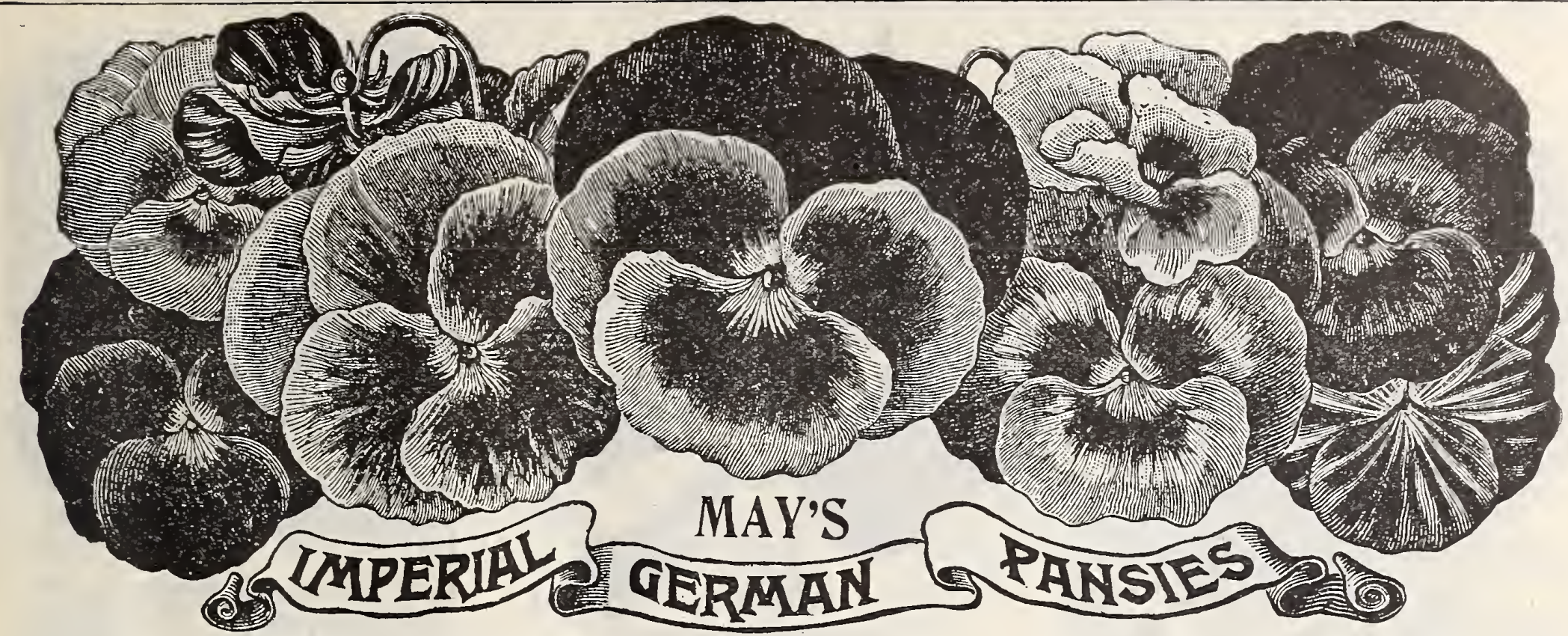

Unrivaled for diversity of coloring and markings, beauty of form, large size, satiny texture and compact growth.

They embrace all tha soin or self-colors, and contain those with ground color, light yellow; the lower petals blotched violet, the upper petals carmine edged with white; others with clear, distinct eyes, dark and light marbled $\nabla a r i e t i e s$, large spotted, blotched, mottlea, striped, eilocolate, lilac, white borders, and an almost endless $\nabla$ ariety of charming shades of color that cannot be procured in any other mixed strain of pansies (over 50 colors and markings), including a fair proportion of several new and grand sorts secured this season.

Imperial Mixed. Packet containing 100 seeds, 10c; 1/4 oz., 75c; oz., \$2.75.

Imperial German Pansies. In named varieties.

Auricula Colors. Of exquisite shadings. Fire King, magenta, margined with yelBromze Colored, shades of brown.
Cardinal, scarlet, with a dark brown Gowd Margined, very handsome.

Cardinal, scarlet, with a dark brown Gold Margined, very handsome
blotch.

Dark Purple, new and distinct shades.

Dark Mahogany, with white margin.

Dark Mahogany, with yellow margin.

Deep Yellow, or "Golden Queen."

Emperor william, blue, purple edge.

Victoria Red, nearly blood-red color.

Emperor Frederick, velvety brown.

King of the Blacks, almost coal black.

Meteor, bright canary-yellow; spotted

Iright Biue, a clear light blue color.

Iright Biue, a clear light blue color.

Odier or Blotched, large eyed flowers.

Fairy Queen, azure-blue, margined white.

Pelargonifiora, resembles geraniums.

Prince Bismarck, brown and gold.

Peacock, the lovely ultramarine-bl

Quadricolor, marbled and spotted.

Black Prince, rich glossy black.

Striped and Mottied, very fine.

violet, margined with white.

Snow Queen, the ever popular spotless

Rosy Iilac, soft rosy-lilac shade.
Royal Pr.ple, deep rich purple.

We wish to encourage more extensive culture of Pansies in named varieties, and offer purchasers choice from this list

only-any single pkt. 5c. or 6 pkts. for 25c.; 12 pkts. for $45 \mathrm{c}$; or one pkt. each of the above list (30 pkts. in all) for $\$ 1.00$.

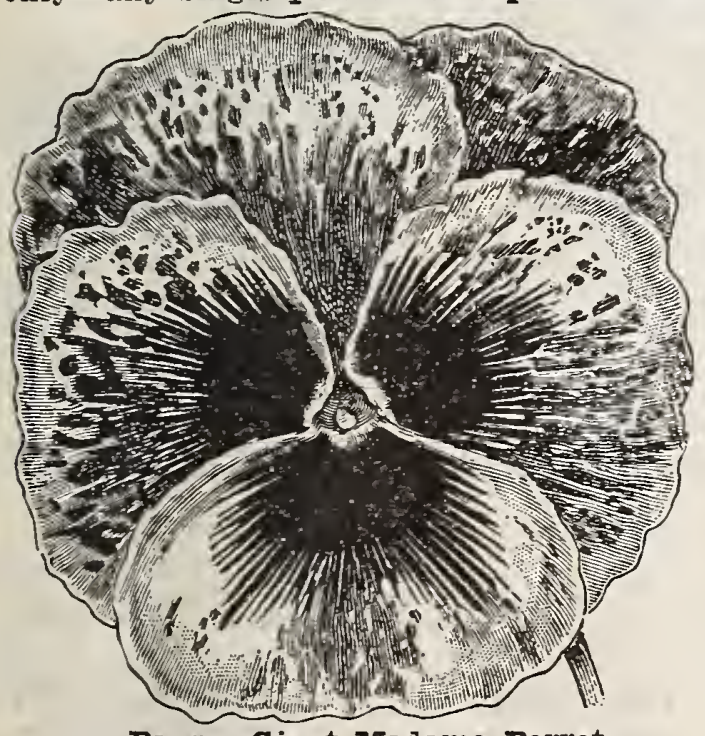

Pansy, Giant Madame Perret.

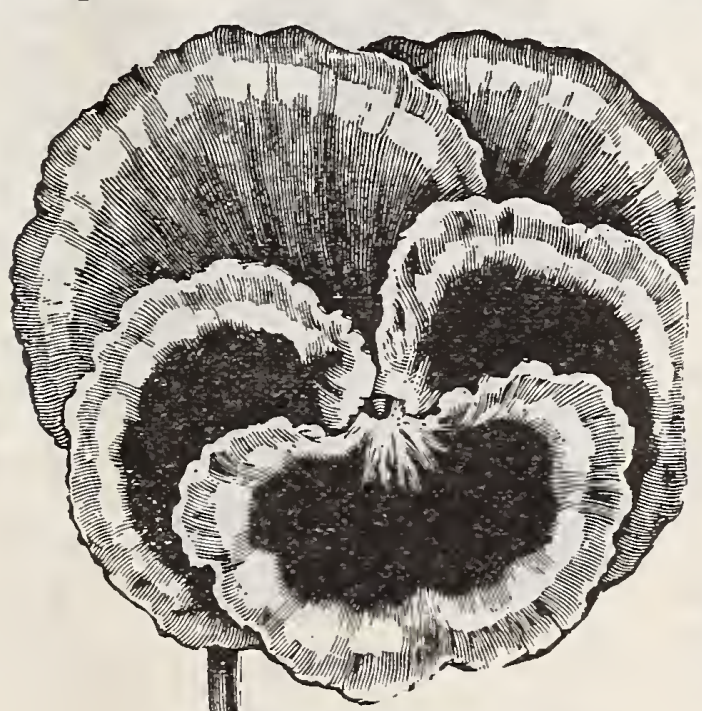

Pansy, English Show.

English Show. This is made up of the ties introduced a few years since by the royal gardener to Her Majesty,. Queen Victoria. They are remarkable for their larg
size, varied colors, and the thick, tough nature of their petals, which enables them to damage. Plit. 10c.

May's Royal Mixed. Selected separbest German, French, English and American growers, mixed and blended by ourselves. Pkt. 10c.

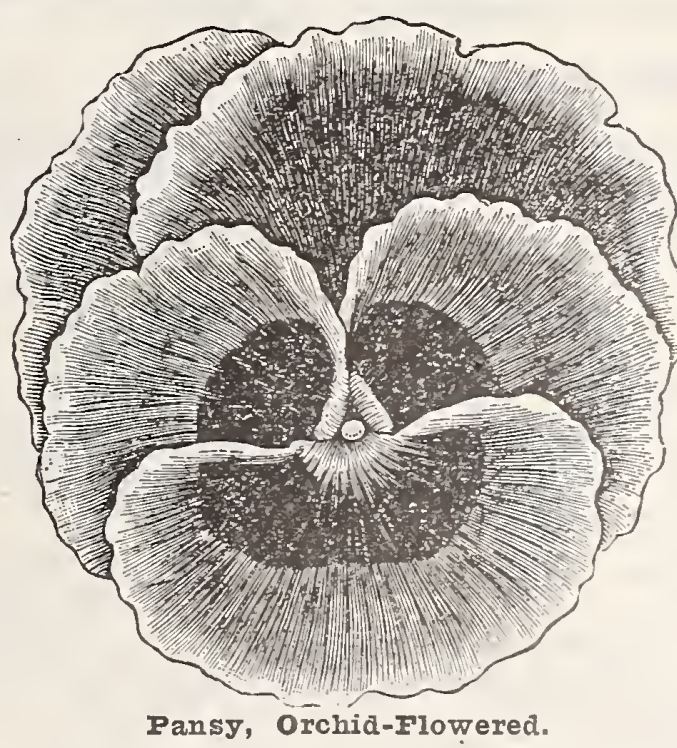

Orchid-Flowered.

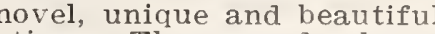
fowers is in light shades, th
marked with large brown or
blotches, which gives the flo
semblance to orchids. The
in the terra cotta shadings a
the flesh, orange, rose pin
Pkt. 10c.
Good Mixed. Fine for bed rich colors.
oz. 25c., oz. 75 c. 


\section{${ }_{48}$ Gु MAY'S NORTHERN GROWN SEEDS BEST FOR ALL CLIMES \& 8 ?}

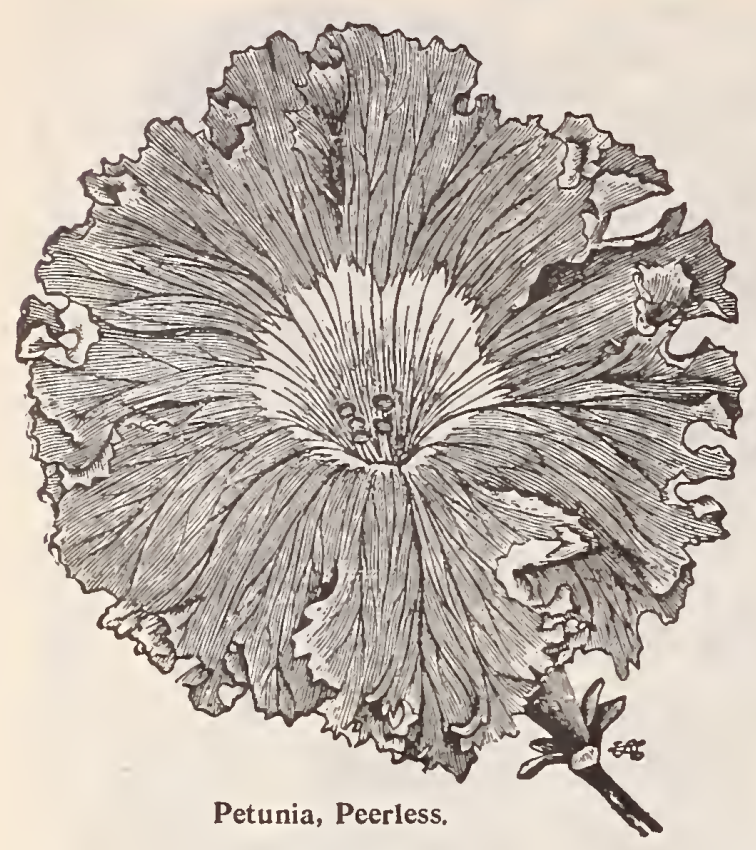

PETUNIA.

California Giant. The largest flowering and

cultivation. Single flowers frequently measure over five inches in diameter, ruffed or fringed on the edges and of the chief points of excellence is the deep throat and the

Peerless. and marked it beautifully fringed and delicately streak forming a most glorious combination, never before found
in a petunia. Pkt. $10 \mathrm{c}$. Howard's Star-Shaped. Entirely distinct. of violet. The five-petaled blooms have star-shaped ground. Very lovely. Pkt., 10c.

Single Fringed. The colorings are markings Large Flowering. A fine asso

Fine Mixed. A good strain. Pkt. 5c.

Double Fringed.

and our customers would be well repaid for sowing the

\section{PHLOX DRUMMONDII.}

\section{Large Flowering Mixed.}

ness of color, renders them of invaluable service in the
flower garden. The color ranges in every conceivable shade; prod

Fine Mixed. Invaluable for bedding and cut "Starred and Fringed." In the Fringed als are distinctly bordered with white, which, together with the bright eye of the center, con-
trasts with the magnificent velvety colors, in more than twenty shades. In the Starred Phloxes the central teeth are five to six times as long
the lateral ones. Finest mixed. Pkt. 10c.

Phlox, Double. Double Phlox is one of nuals for cut flowers; they last much longer than larly fine strain of the double from France which and perfectly double and semi-double. Pkt. 10c. Phlox, Perennial. The varieties of the among the choicest of our flowers for bedding and tection Pkt. 10c.

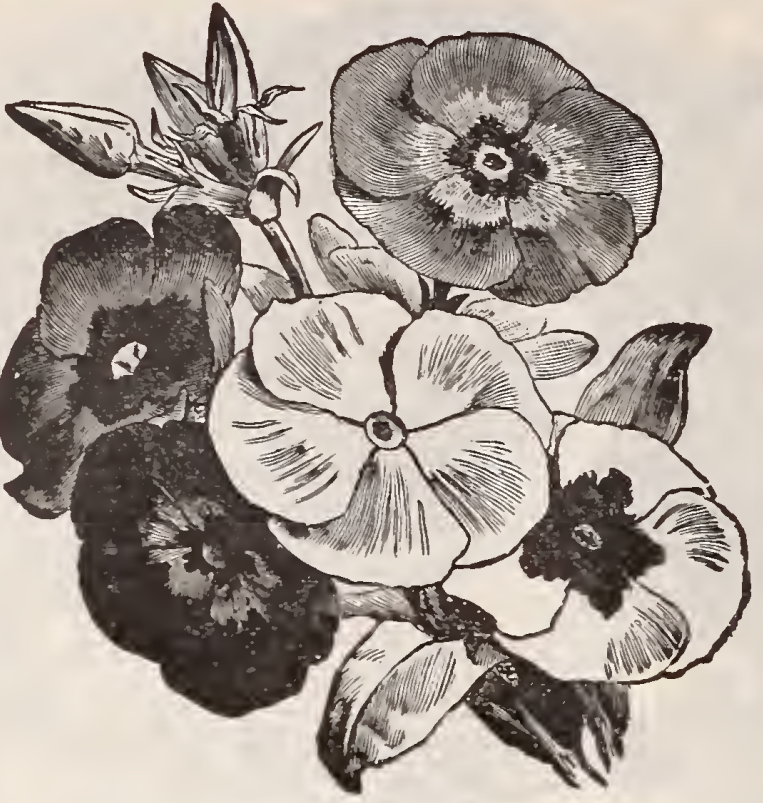

Phlox, Large Flowering.
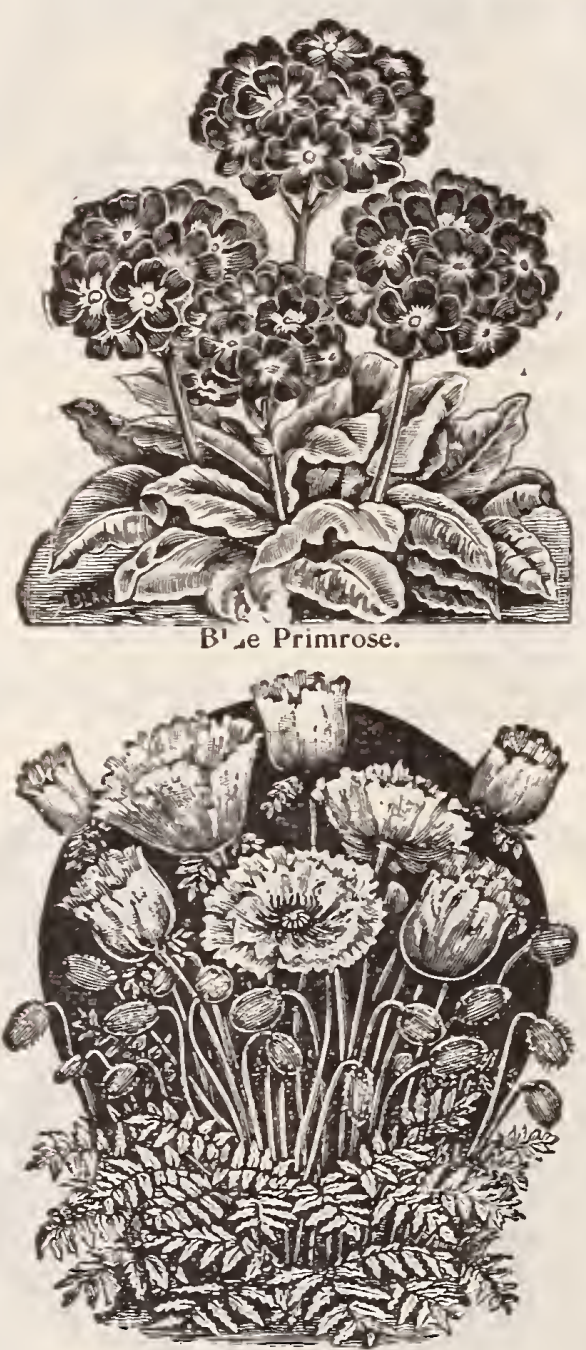

Poppy, Orientai

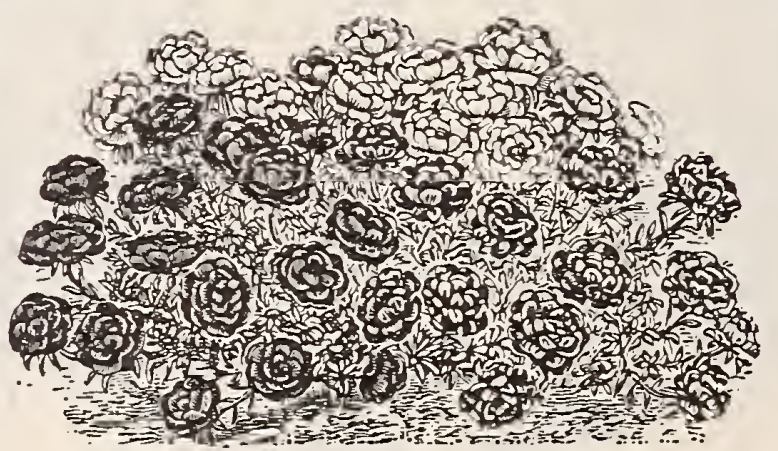

Double Rose Flowered Portulaca.

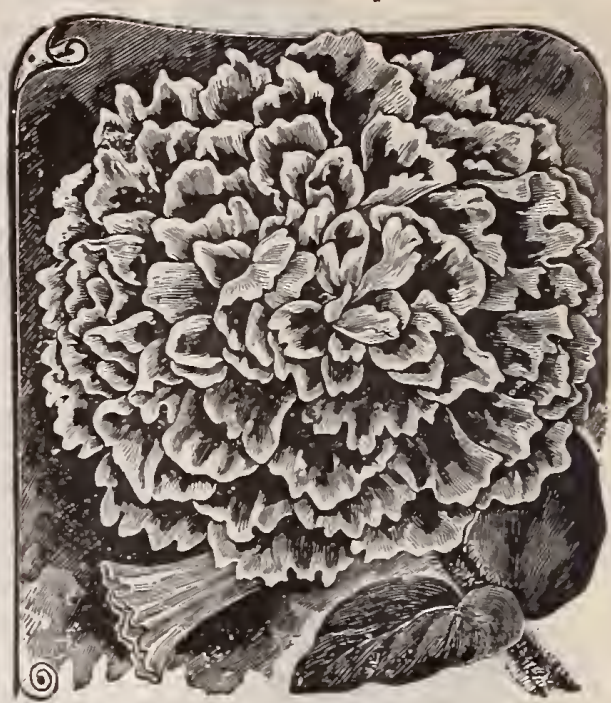

Double Fringed Large Flowering Petunia.

POPPY.

Mayfield Giant Mixed. Specianty prepared from all the double giant varieties, including some entirey new ones. For dazzling richness and variety of colors The Shirley. The colors range through all shades brilliant crimson. Ilany of the large single flowers are edged with white. Pkt. $5 c$. Iceland. These are perfectly hardy, grow about 12 orange colored blossoms. Single mixed. Pkt. 5c.

Fairy Blush. A distinct variety with very large, ringed with white except the tips, which are distinctly Burbank's Silver Lining. C u p-shaped rich scarlet, spotted with black, but each spot appears to be covered with a shield of white tissue paper; altogether unique. Pkt. 10c.

Snowdrift. A grand variety. The large pure Paeony Flowered. Splendid large double flow20c. pht. 5 . New Oriental. The flowers are of enormous

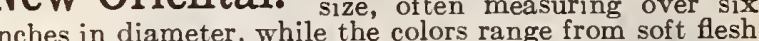
and rose to the most brilliant dazzling scarlet and richest PRIMULA Sinensis (CHINESE

Irany persons seem to think primulas are sucMany persons seem to think primulas are successfully propagated only in a greenhouse, hence we. They a mateurs often reluctant to atcempt easily grown, if the are unequaled as winter beded, and give a succession of Howers throughout the season, and are prized for both beauty and their delicate fragrance. Single, finest mixed. Pkt. 10c.

Large Flowering, Fringed, Mixed. Prt.

Double. Best mixed, all colors. Pkt. 20c.

Obconica. Primula Obconica is as near an evertain. It has been known to flower for over twelve months without a break. Pkt. 10c.

Japonica. One of the most beautiful. shades of crimson, maroon, lilac, pink, white, shades of crimson, maroon, high. Nixed colors. Pkt. 15c.

Forbesi. (Baby Primrose.) Blooms when continuously throughout the year. Pkt. 10c.

Primrose, Blue Garden. A beautiflowering variety of a rich blue color, flowers of good size and perfect form. Pkt. 10c.

\section{PORTULACA.}

DOUBLE FLOWERED. One of the most howy and beautiful annuals with abundant highly-colored flowers. Pkt. 10c. SINGLE. A great variety of colors mixed.
Pkt. 5c. 


\section{SWEET PEAS.}

May's Giant Flowered. Best mixed. Absomatchless combination of colors and giant sweet matcented flowers. This mixture is carefully blended by ourselves from all the finest selected colors in the right proportion for the most beautiful show, Iade up especially for critical buyers that have the money to spend for the best only: Iarge pkt. 10c., 0z. 15c., 1/4 1b. 30c., 1b. \$1.00, postpaid.

Imperial Mixed. This blend or mixture emthe Eckford varieties of improved type, with a fair proportion of the new shades and colorings up to proportion of the new shades and colorings up to at this price. Plkt. 5c., oz. 10c., 1/4 1b. 25c., 1b. 75 c., postpaid.

Good Mixed. A cheap mixture, but a real good do not care for the fancy new varieties of late introduction. Plt. 5 c., oz. 10c., 1/4 1b. 15c., 1b. 50c., postpaid.

New Double Sweet Peas. The flowers are extremely inches across. They will not all come double but if the plants are grown strong and luxuriant they usually produce from 20 to 40 per

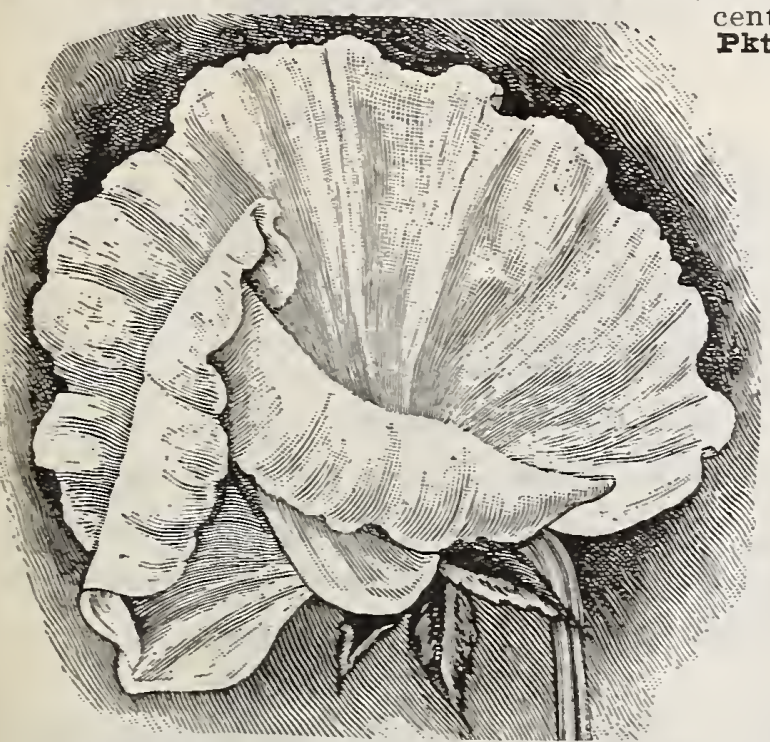

The New Orchid-Flowering Sweet Pea.

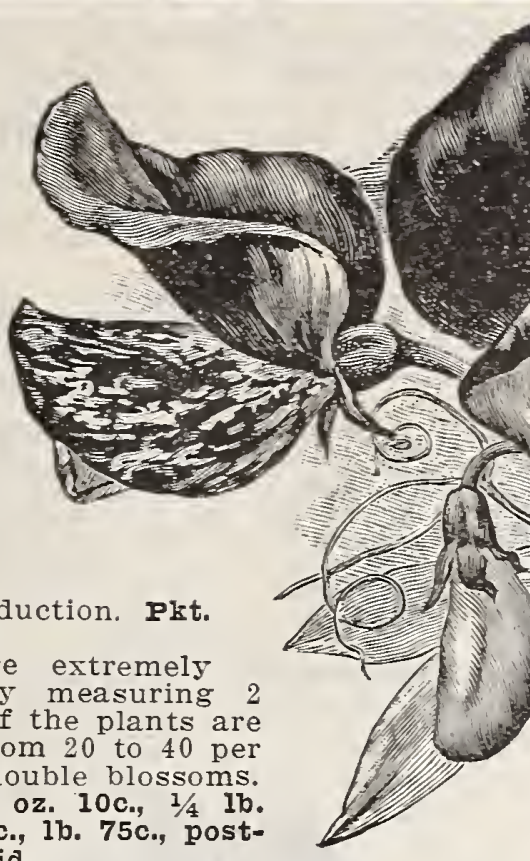
25c., 1b. 75 c, postpaid.

Dwarf Cupid Sweet Peas.

The Cupid Sweet Peas should become popular for bedding and borders. They are of true dwarf habit and literaly oz. 10c., 1/4 1b. 20c., 1b. 60c., postpaid.

N e w "Orchid Flowered" Sweet Peas. A new and distinct Sweet Peas. The flower stems are

unusually long and the flowers are so

set on the stenl that there is a graceful fuffiness to a bunch of them in distinct contrast to the ordinary kinds of Sweet Peas. So far but a few colors have been dereloped in this trpe, and some of these sport or change more

ing. The wings and standards of the flowers are very large, and its graceful Sweet Peas, as fast as standard colors appear and become fixed. of this new class will be found deep pink, light pink, orange pink, white with pink edging. Plt. 10c., oz. 15c., 2 oz. $25 \mathrm{c}$., $1 / 4 \mathrm{lb}$. 40 c., 1b. $\$ 1.00$, postpaid.

Peas, Perennial. (Lathyrus.) Mixed, perfectly hardy.

WRITE.

Dorothy Eckford. Fine pure white. Emily Fenderson. Large, pure white. Mont Blanc. The earliest-flowering whit Sadie Burpee. (Black seeded), white and

White wonder. Pure white, very large. CREAM OR IIGHT YEILOW.

Coquette. Primose shaded lavender.

Hon. Mrs. E. Kenyon. Beautiful primrose Queen Victoria. Primrose yellow.

Sue Earl. Primrose, maure edges.

Sunbeams. Richest primrose. CREAM OR PIN $K$

Marchioness of Cholmondeley.

Cream and

Stella Morse. Cream, pink and apricot. IIGHT BIUSH.

Dainty. White with pink edge. IIGHT PINK.

Iovely. Soft shell pink.

Lovely. Soft shell pink.

Venus. Rosy buff pink.

Price, any of the above named sort

\section{A Select List of Best New Varieties}

Arranged According to Color.

DERP PINK SEADES.

Janet Scott. Very best deep pink. Prima Donna. Exquisite rose pink. Apple Blossom. Deep rose pink. Royal Rose. Crimson pink.

$$
\text { ROSE. }
$$

Iord Roseberry. Rose carmine. Mrs. Dugdale. Rose and primrose Prince of $\mathrm{W}$ ales. Deep rose tint. RED AND SCARIET.

Coccinea. Bright cherry red. King Edward VII. The finest red. Salopian. The finest scarlet. scarlet Gem. Dazzling scarlet. Iady Mary Currie. Salmon pink. Miss Milmott. Orange pink an

Blanch Ferry. Rosy pink and white. Earliest of All. Pink and white Extra Early Blanch Ferry.

IAVENDER AND IIGHT BLUE. Adora Norton. Beautiful rich lavender.
Helen Pierce. Light

Iady Grisel Hamilto

Iady Nina Balfou

Mrs. Walter wright.

BIUE AND PURPLE.

Capt. of the Blues.

Countess of Cadogan

David R. Williamson

Navy Blue.

MAROON SHADES.

Black Michael.

Othello.

STRIPED AND VARIEGATED.

America.

Aurora.

Mrs. Jos. Chamberlain.

Princess of Wales:

Ramona.

Senator.

\section{GRAND NEW SWEET PEAS.}

Gladys Unwin. Of the new orchidto Countess Spencer, but several shades lighter in its lovely pink color. Pkt. 10c., oz. $20 \mathrm{c}$.

Henry Eckford. An intense bright color, quite unique and absolutely distinct. Pkt. 15c., oz. 30c.

Florence Spencer. Giant orchidcolor of both standard and wings a most delicate pink, deepening to a richer pink

Helen Lewis. A grand orchid-fio

wings and the standard intense rich erim-

wings and the standard intense

John Ingman. Deep carmine rose in

Tings of a deep rosy pink. Plit. $10 \mathrm{c}$. , oz. $15 \mathrm{c}$.

Phyllis Unwin. A beautiful
Sybil Eckford.

Pit. 10c., oz. $25 \mathrm{c}$

Queen Alexandra

$15 \mathrm{c}$., oz. $30 \mathrm{c}$.

True Countess Spencer

10c., oz. $15 \mathrm{c}$ 


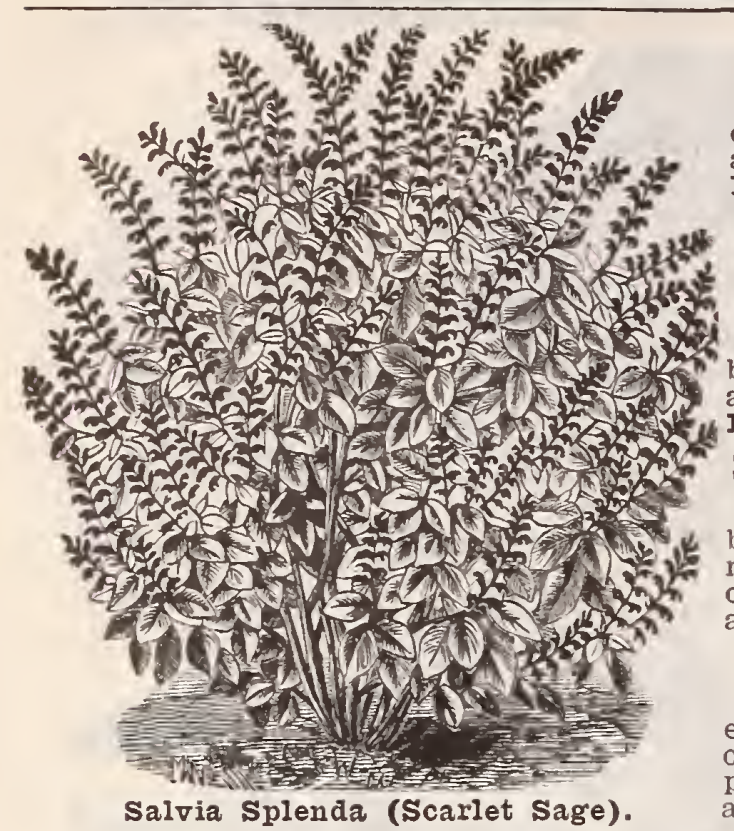

ROSES (From Seed the First Year).

NEW FAIRY ROSE. The only genuine dwarf variety, blooming in 4 to 5 months after tions of single, semi-double and double flo colors of cultivated roses. Plt. 5c. SMILAX.

account of its charming, glossy green, ele
and graceful foliage, and will grow sev
feet high the first season. Also fine for h
ing baskets. Plt. 5c., oz. 30c.
SCHIZANTHUS (Butterfly
Flower). much interest and beauty; flowers spotted with crimson, lilac, purple and yellow, and the pet-

STOCKS (Ten Weeks). WHITE VIETINA.

very early and is of most compact IARGE FIOWERING PYRAMID
AI. Immense spikes of perfectly dou ing in colors from crimson, rose, white, DWARF GERMAN. Fine mixed PVENING SCENTED PERFUM equals this in delc

SUNFLOWER (Helianthus). NEW DOUBIE. Perfectly double yellow. Plt. 5 C.
GIAIT RT mous size. Prt. 5 c.

GLOBOSUS. A rich saffron shade. Plt. Sc. SIUVRR IEAF. Silvery foliage; blooms STELIA. Rlack. Plit. 5c. golden yellow with

SWEET WILLIAM (Dianthus Barbatus).

SINGLE, MIXED. A spiendid strain flowers of many bright colors, large size
and varied markings, including auriculaeyed varieties. Plt. 5

beautiful as the single. Plst. 5c.

The Great Floral Curiosity
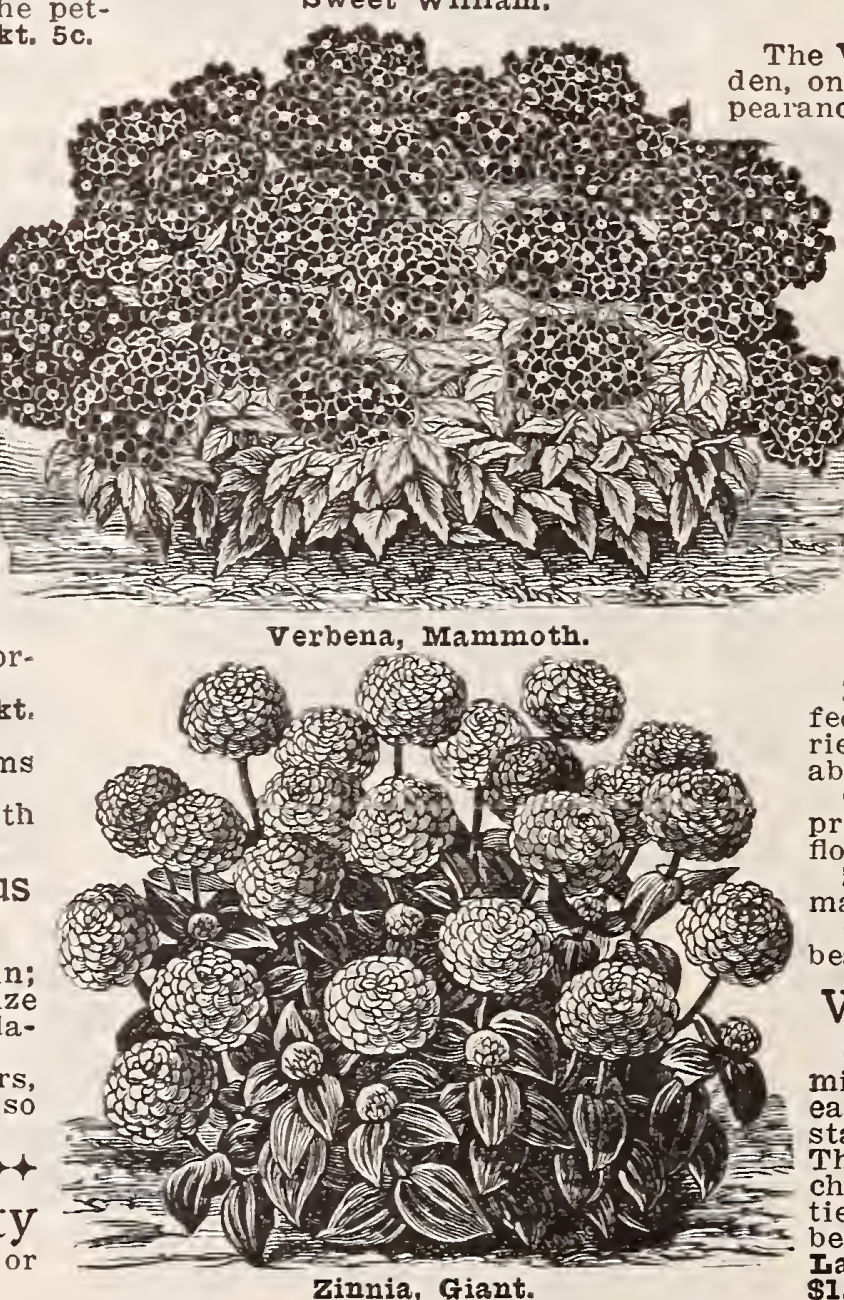

RICINUS (Castor Oil Bean). ZANZIBARENSIS. From seeds sown in the pen ground in May the plants are in full foli14 feet. Pkt. $5 \mathrm{c}$.

MIXED. Many choice rarieties. Plt. 5 c. SALVIA SPLENDENS (Scarlet Sage).

One of the grandest plants in cultivation,
anium in brilliancy and the contint scarlet ger
Plt. 10c.
SALPIGLOS bloom
GRANDIFLORA. The graceful flowers, most delicate shades of light blue and straw and maroon. Mixed. Prt. 5c.

SCABIOSA.

IARGE-FLOWERED DOUBLE. of colorings is most remarkable, shading from pure white to rich pink, crimson to deep red,
and from lilac to almost black. Plrt. 5c.
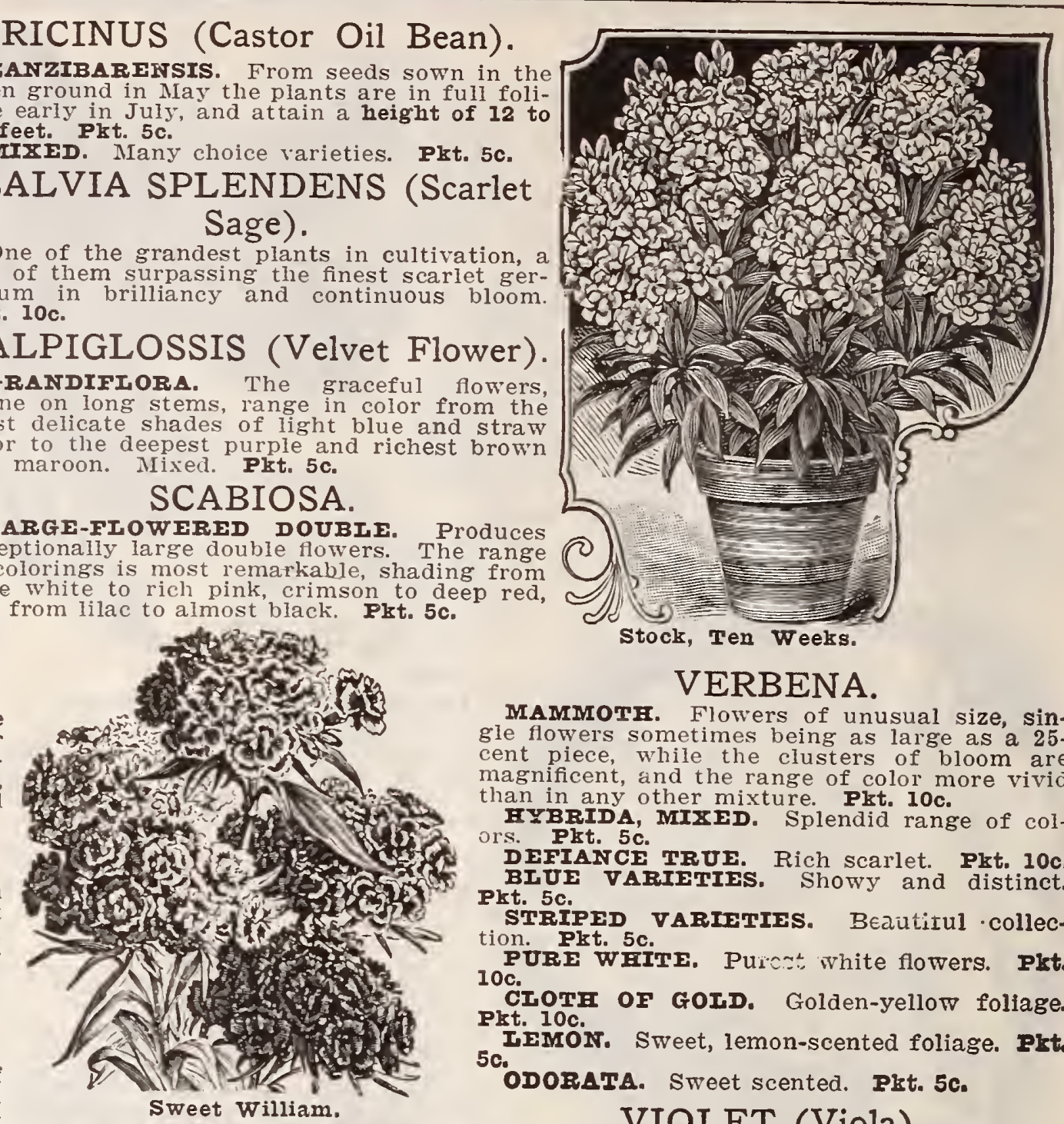

Stock, Ten Weeks.

VERBENA.

MAMMOTH. Flowers of unusual size, sinhowers sometimes being as large as a 25magnificent, and the range of color more vivid an in any other mixture Pkt. 10c.

HYBRIDA, MIXED. Splendid range of colDEFIANCE TRUE. Rich scarlet. Pkt. 10c. BIUE VARIETIES. Showy and distinct. STRIPED VARIFTIES. Beautitul collecPURE wHITE. Purc: white flowers. Plat. CIOTH OF GOID. Golden-yellow foliage. Pkt. 10c.

IEMON. Sweet, lemon-scented foliage. Pkt. ODorata. Sweet scented. Pkt. 5c.

VIOLET (Viola).

The Violet should not be wanting in any garaccount of its fragrance and early applace, and can be easily increased by dividing the roots. Finest mixed.

WALL FLOWER.

SINGIE PARISIAN. This new annual variety will flower throughout the summer and fall, from seed sown the Same spring. Pkt. 10c. ciously fragrant flowers, combining orange-purple predominating. Pkt. 10c. WILD CUCUMBER VINE A quick climber, for covering porch-
es, arbors, trellises, etc. Pkt. 5c., oz. 25c. 2 INNIAS.

NWW GIANT. Giant in size, and perWost vaied colors and shades; particularly valule for groups. Choice mixed. Pkt. 10c. CURIED AND CRESTED. Each plant produces from 100 to 200 large double ZEBRA. Handsomely striped and CHorce Mr. 10c. Many choice and eautiful colors. Pixt. 5c. WILD FLOWER GARDEN.

CHOICE MIXED FIOWER SEEDS. A mixture of many varieties of beautiful, easy-growing fowers, producing a conThis mixture is especially prepared from This mixture is especially prepared from ties being carefully proportioned and will be found superior to any mixture offered. $\$ 1.75$. 


\section{GROWN IN THE GOLDEN GRA BN BELT OF THE WORLD}

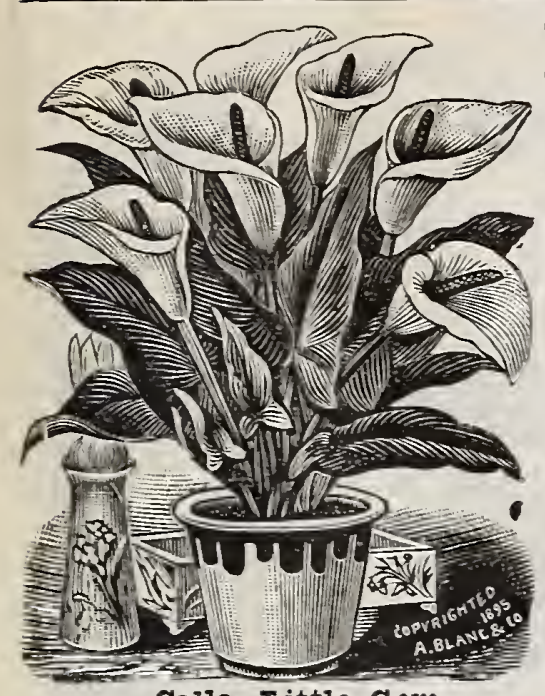

Calla, Iittle Gem.

\section{May's Summer Flowering Bulbs.}

We grow and offer only the most popular sorts that are inexpensive, easily grown, require scarcely any care, and make a showy and gorgeous display, none of which can fail to give satisfaction.

Remember, the bulbs offered are large, sound and solid, and are far superior to the small bulbs frequently offered. All our bulbs are sure to grow and bloom.

\section{CALLAS (Strong Bulbs).}

WHITE CAIIA. (Ethiopica, Iily of the Nile). The White Calla is a well-known plant of easy culture, and

NEW YELLOW. Flowers light clear

hite. Each 20c., postpaid. SPOTTED IEAT. Dark green leaves, beautifully spotted with hite. Flowers white with purple throat. Each 15c., postpaid.

RED. (Arum Cornutum) Flowers red, spotted black; stems mot-

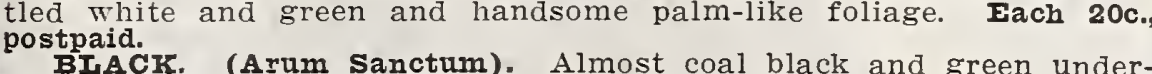
BIACK. (Arum Sanctum)

IITTIL GEM. It is of dwarf habit and does not grow scraggly ike the taller varieties. Snowy white in color. Each 20c., postpaid.

CALADIUM (Elephant's Ears).

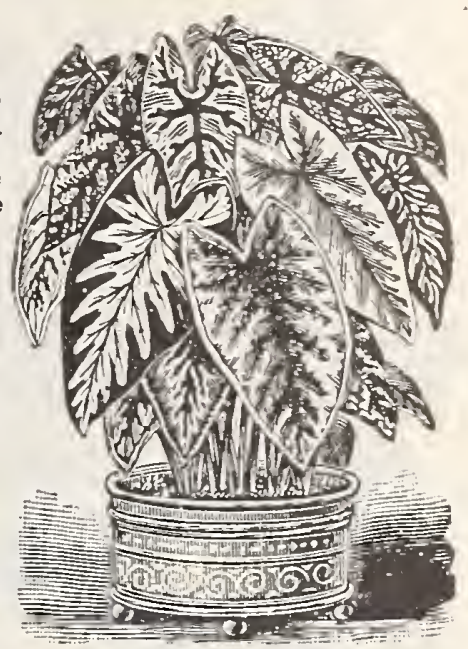

Fancy Ieared Caladium. Good sized bulbs

ESCUIFNTUM. A handsome plant of tropi
c., large bulbs 25 c., mammoth 35c., postpaid.

CALADIUM (Fancy Leaved).

\section{For window boxes, house or greenhouse growing this is one of the}

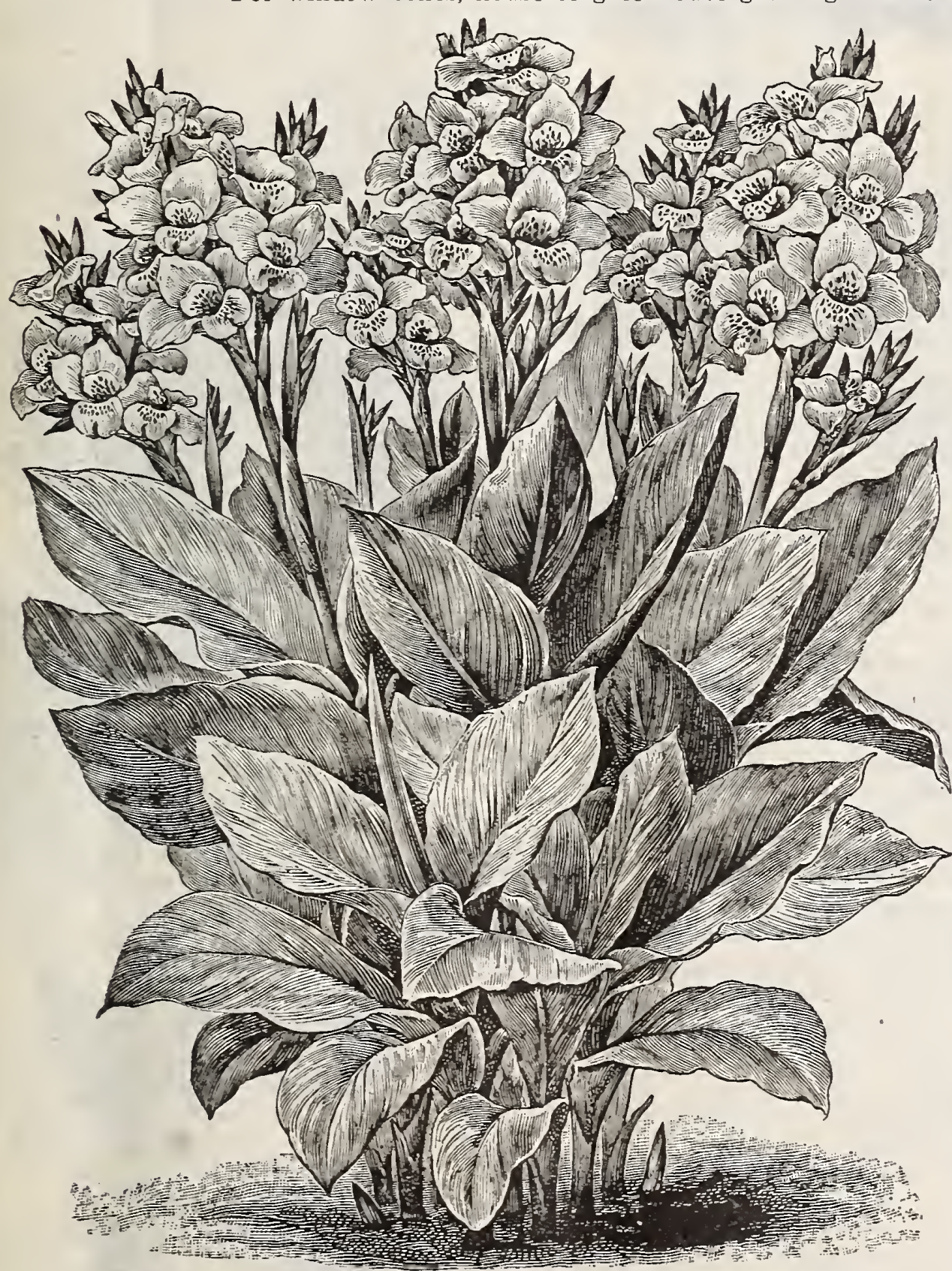

The Canna is one of the Most Beautiful of Bedding Plants. MIXED IARGE FIOWERING CANNAS.

ARASSUAHY.

BARAO DE MAMORE. White ground, dark red

CANDIDUM. White ground with green ribs.

CHANTINI. Red ground, white spots, green margin. CORCOVADA. White markings on green ground, EDMOND IMOREAU.

red center. ROSSINI.

TRAFIRAS. White ground with

with green

Price, any Fancy I eaved Caladiums, 20c. each. CRINUMS.

Large, lily-lik

beauty and

KIR KII. Magnificent, fragrant flowers. The petals the center of each. Iarge bulbs $25 \mathrm{c}$. each, postpaid. FIMBRIATUIUM. Also called Milk and Wine Lily.

Very fragrant. .20c. each, postpaid.

FRENCH CANNAS. TWEIVI BEST VARIETIES.

From

best in their respective colors.

the standard varieties.

AISACE. Pale sulphur.

BEA UTE POITEY

COMTE DE BOUCHA

EASTERN BEAUTY.

EVOIUTION.

FIORENCE VAUGHAI

GOVERNOR ROOSEVEIT.

MARTHA WASHINGTON.

PARTFENOPE. Da

PIIIAR OF FIR.

Any of above, each 15c., doz. $\$ 1.50$, postpaid.

SIX ORCHID-FLOWERED CANNAS

Of the

AMIRICA.

AUSTRIA.

BURBAN I

ITAIIA. Bright

MRS. KATE GRAY.

Any of the above, 15c. each or $\$ 1.50$ doz., postpaid. EXTRA STRONG PIANTS.

pot-grown plants 15 th, custome

From all varieties grown at our nurseries, including som liay 15th, customes.

effect on the lawn, as many of them woz. $\$ 2.00$ or 100 for $\$ 15.00$, by express at purchaser's expense. 


\section{"20 MAY'S NORTHERN GROWN SEEDS BEST FOR ALL CLIMES So}

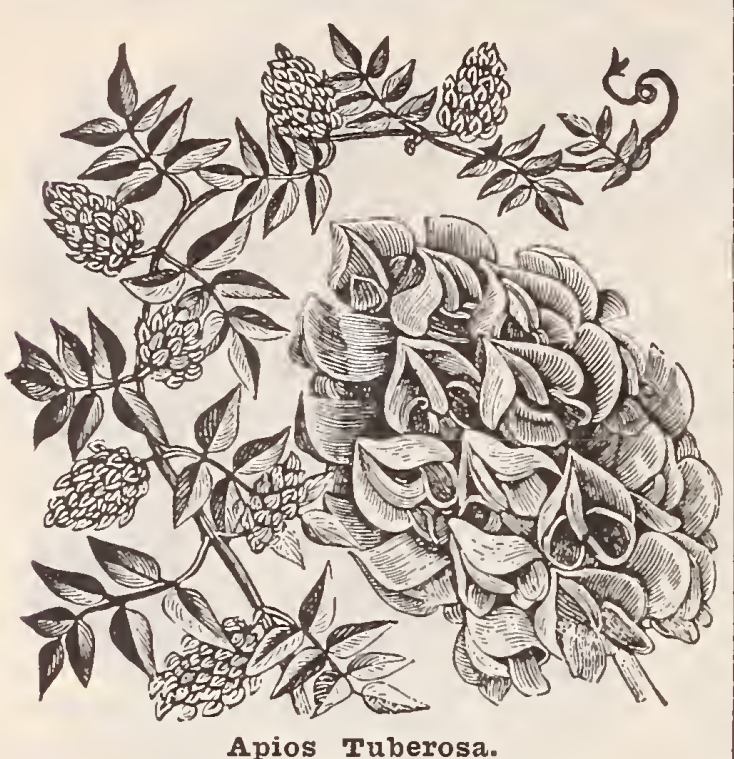

Apios Tuberosa.

APIOS TUBEROSA.

Tuberous-rooted wistaria

flowers of violet fragrance. Small racemes
resemble wistaria in shape. It is widely
popular and should be in every home where
flowers are grown. 5c. each, 6 for $\mathbf{2 5 c}$

doz. 45c., postpaid.

CINNAMON VINE.

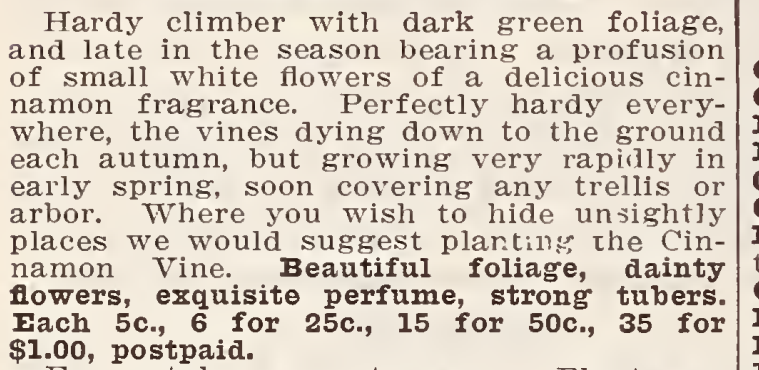

$\$ 1.00$, postpaid.

\section{MADEIRA VINE.}

flowers: very pretty and useful Each 5c.

doz. 40c., postpaid.

See Inside Cover Page for BEGONIAS and GIOXINIAS.

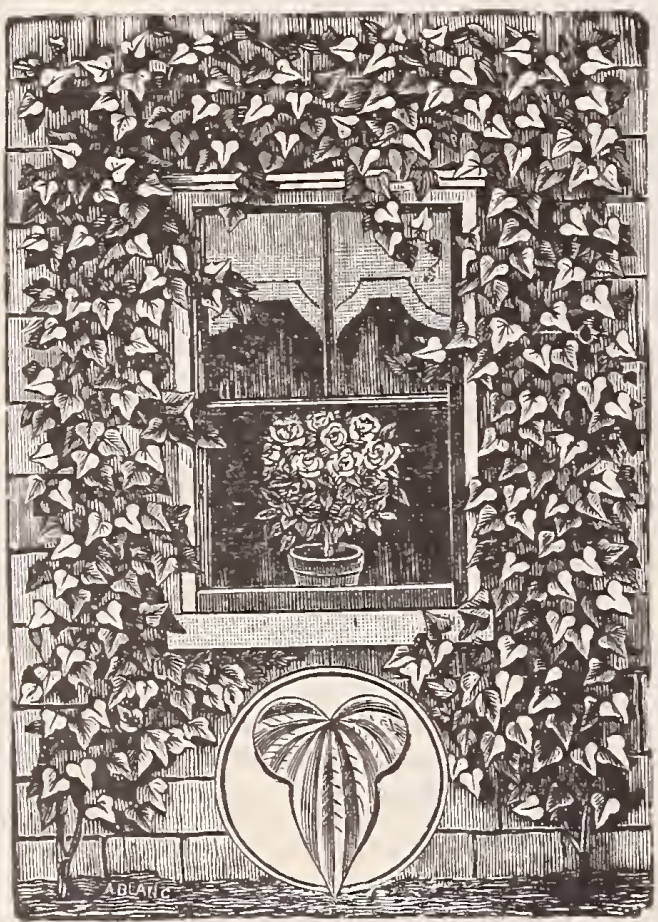

Cinnamon Vine.

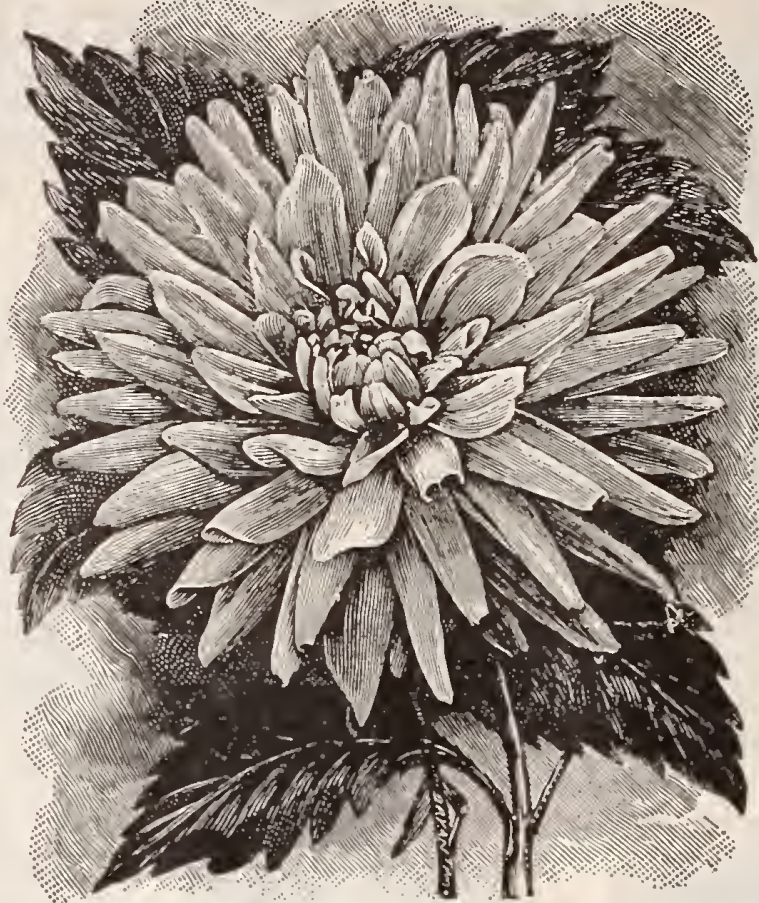

Cactus Dahlia.

DAHLIAS

(Double Show or Decorative). CATHARINE DUER. Geranium red. C. W. BRUTTON. A fine bright yellow. FRANK SMITH. Maroon, tipped white. FIRE RAIN. Brilliant cardinal red. GEM. Deep velvety crimson. PEOF. MANSFIEID. Yellow, white and rose QUEEN OF YELLOWS. Best clear yellow. RED HUSSAR. Pure cardinal red. RUBY QUEEN. Brilliant deep purple. WM. AGNEW. Rich dazzling carmine.

MLS. DEXTER. Rich deep salmon.

postpaid, at 20c. each, any 3 for $50 \mathrm{c}$., or any 7 for $\$ 1.00$. The complete set of 12 varieties by mail for $\$ 1.50$; by express, at purchaser's

NEW CACTUS DAHLIAS.

CAPSTAN. Brick red, shaded apricot. EARI OF PEMBROKE. Bright plum color. KRIEMHILDE. Delicate shell pink and white. CORONATION. Rich glowing red.

GAIIIARD. Deep red or crimson.

GOTEIINDE. Primrose yellow.

J. H. JACKSON. Crimson maroon.

slack

VOLKER. Free flowering, pure yellow.

WINSOME. Fine creamy white.

GFO. MARLOW. Primrose yellow, shaded red.

JOHN ROACH. Clear pure yellow, fine form. MRS. BENNETT. Soft crimson. A rich color.

Fine roots of the above cactus dahlias, 20c. chaser's expense, $15 \mathrm{c}$. each, $\$ 1.25$ per doz. POMPON DAHLIAS.

SUNSHINE. Vivid scarlet. The richest. SNOWCLAD. The finest white. Very desira
EIEGANTE. Soft pink, tipped deep pink.

PHIIIP FREND. Rich orange salmon.

Fine roots $20 \mathrm{c}$. each or the set of 4 for $70 \mathrm{c}$. postpaid; by express at purchaser's expense, 15c. each.

Mixed Double Dahlia Roots.

Over 100 choice and valuable sorts, including many of last year's novelties, in mixture unnamed. Each 10c., 6 for 50c. doz. $\$ 1.00$, postpaid. By express at purchaser's expense, $\$ 6.00$ per 100 .

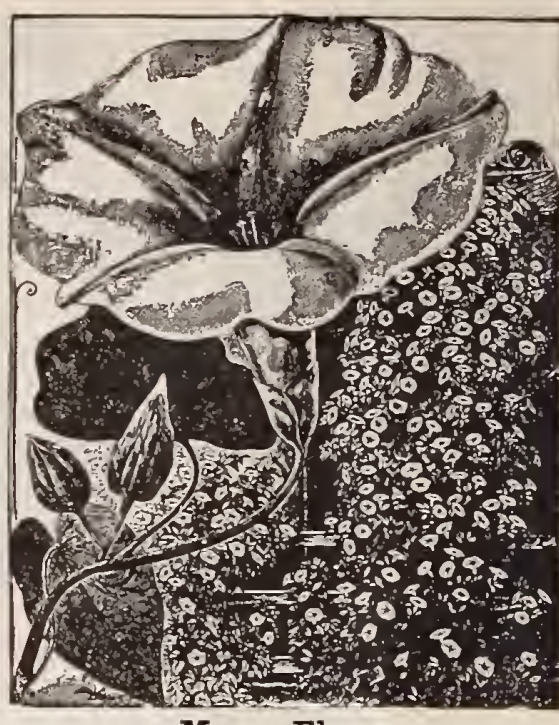

Moon Flower.

IPOMOEA.

PANDURATA (Day-Blooming Moon Flower) will grow and thrive in any soil, producing luxuriant, compact with a purple throat. It is perfectly hardy. Each 15c., postpaid. NOCTIFIORA. The well-known popular white, fragrant Moon Flower. Fach 10c., postpaid.

IFARII (Blue Dawn Flower). Indiameter Each 10c., postpaid.

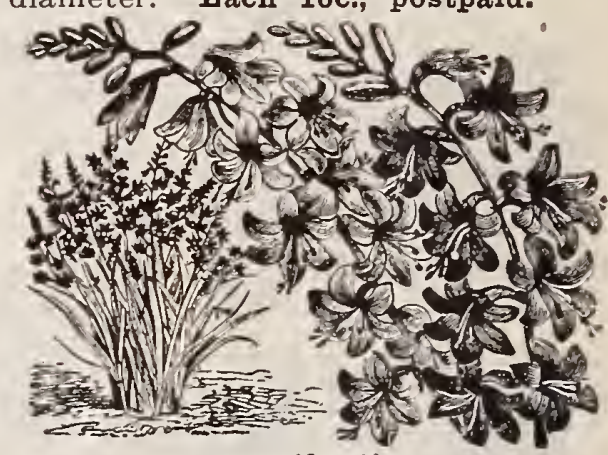

Montbretia.

MONTBRETIAS.

One of the brightest and best of summer flowering bulbs. They greatly resemble the Gulbsolin growth shaped flowers in various shades of orand rieties, 3 for $10 \mathrm{c}$, doz. $30 \mathrm{c}$., postpaid. HYACINTH CANDICANS A stately bulbous plant, with large yucca-like leaves, growing as high as Each $5 \mathrm{c}$. 6 for $25 \mathrm{c}$., 12 for $50 \mathrm{c}$., or 30 for $\$ 1.00$, by mail, postpaid.

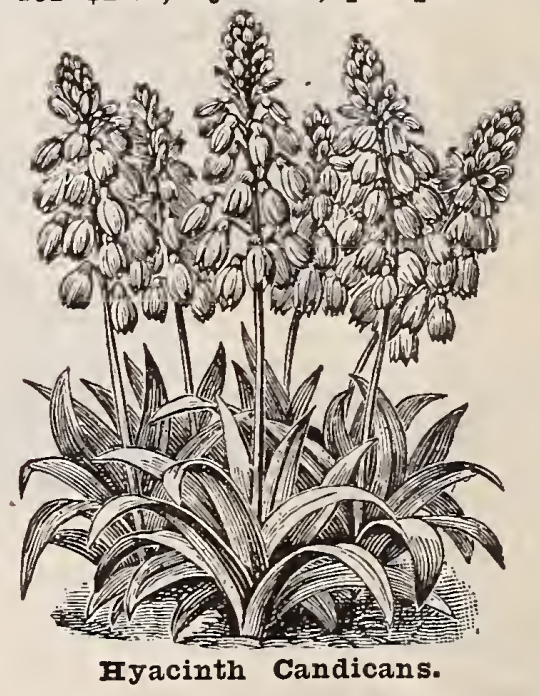




\section{GROWN IN THE GOLDEN GRAIN BELT OF THE WORLD}

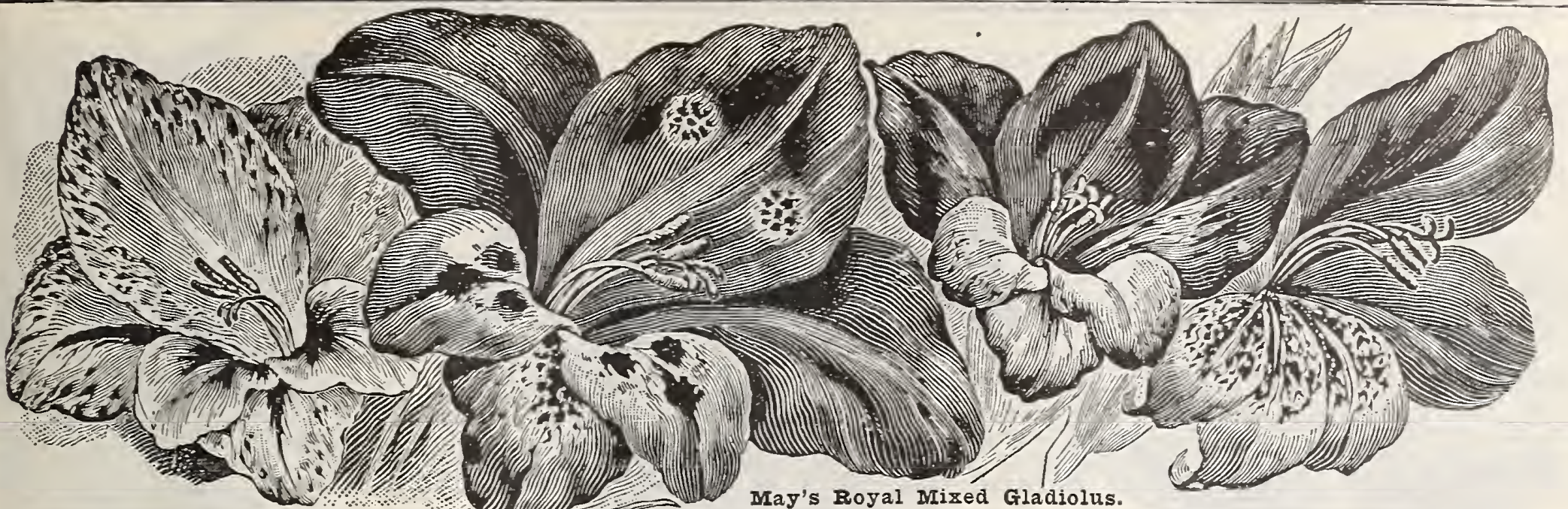

GLADIOLUS.

They d

Maj's Royal Irized Gladiolus.

buson, and by successive plantings ever

\section{SELECT NAMED VARIETIES.}

The following varieties are selected from a long list of named Gladiolus as being the finest large flowering sorts, all worthless kinds being discarded.

AUGUSTA. Lovely pure white, with blue anthers... Each. Doz. BRENCEIEYENSIS. Vermillion-scarlet ..............04 CFRES. Pure white, spotted with purplish-rose..........04

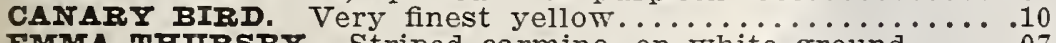
FMMA THURSBY. Striped carmine, on white ground.... 07 FUGFNE SCRIBE. Tender rose, blazed carmine-red........08 GEN. PHII. SHRRIDAN. Fiery red with white lines....... .07 GIORY OF BRIGITWOOD. Scarlet with lemon throat... .08 ISAAC BUCRANAN, Very fine yellow. . . . . . . . . . . 08 JOEN BUII. White, slightly tinted sulphur............ 05

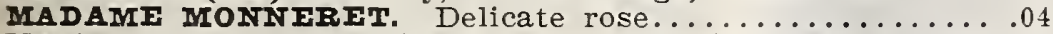
MAY. A lovely pure white flower, finely flaked rosy-carmine .04 MRS. KRIIAGE. Fiery red, white blotch with carnine... 07 TAPOIFON III. Bright scarlet, white line on each petai...04 OCTOROON. A beautiful salmon-pink; very distinct..... .07 PROIIFIC PINK. A fairly good pink variety............. . 4 REINT BIANCER. Pure white, dark carmine blotch..... 05 SHAKFSPFARE. White, suffused with crimson-rose..... 08 THAIIA. White, fTI FIOWTER GIADTOLTS

This giant race of Gladiolus produces large flower spikes of great variety and beauty, much stronger and more vigorous growers than the older sorts. They are tall and erect, often standing 4 feet high with spikes of bloom 20 inches long.

AMFRICA. Large flower, flesh pink, beautiful. .......... 15 BRIIIIANT. Orange-red, with carmine and white throat. . .10 BIANCFr. Pure snow-white, with faint marks of soft rose .15
COIUMBA. Light orange-scarlet, blotched and penciled. .06 DEBORAF. Dark red, tinged with amaranth............08 BIUE JAY. A rich deep indigo shade................. FIORIDA. Dark crimson, very early ..................05

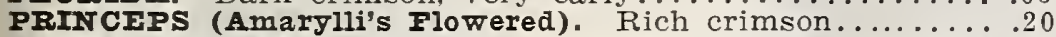
HFRY GIIIMAN. Salmon-scarlet, with pure white bands .05 IITTI BIUSE. Dwarf habit, spike of blush-white......07

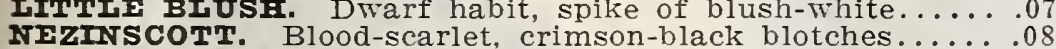
ODDITY. Amaranth-red, suffused with purple-blue....... .07 SAIEM, Fine salmon-pink, maroon blotches...........07

WI. FAICONFR. Beautiful clear light pink.............08

\section{GLADIOLUS IN COLORS.}

Red and scarlet shades................ $\$ 0.04$

Pink shades

Yellow shades

White and light shades.

Each and dozen prices by mail, postpaid

Price per 100 by express, at buyer's expense.

\section{MAY'S ROYAL MIXED GLADIOLUS.}

In this mixture we have placed many of the best named rarieties. By carefully growing for a series of years, and rejecting the poorer kinds each season, We have produced a strain which, for size of bloom and brilliancy of coloring, is unsurpassed

Large bulbs, guaranteed to bloom, 3 for $10 c ., d o z .30 c ., 50$ for $\$ 1.00$ or 100 for $\$ 2.00$, postpaid; by express, at purchaser's expense, 100 for $\$ 1.50$, 1,000 for $\$ 14.00$.

Second size bulb which will flower the first summer if planted early, 5 for 10c., doz. 15c., 100 for \$1.00, postpaid; by express, 100 for
MONARCH of the EAST.

The Great Floral Curiosity.

The magnificent flower .85 of this remarkable plant, 85 as shown in the illustra85 tion, actually come out of 50 the dry bulb, without its 40 being placed in soil or 40 water. The only treat-

75 ment it requires is to sim-

ply place the large, flat,

.30 round bulb on a table or shelf

50 in a warm room, and very head, and within two or three weeks a most CURIOUSIY FORMED FLOWIR 16 to 20 inches long, derelops, of a red brown color, tipped with red and yellow, while the inner 1.00 part of the flower is equally as .6 brilliant, entirely different from 85 any other flower known, thriving - entirely upon the nourishment 50 contained within the bulb. After flowering, the bulb should be 50 planted in the open ground, where .75 it throws up elegant dark green 75 umbrella-shaped foliage on a ite-like color, and sometimes

rar
which itself forms a fine or-
namental subject in the garden, partcularly when planted in May or June in a moist and tumn the leaf fades, when water should be lessened, and
as soon as it has died off, the bulb should be lifted out of the soil, cleaned up, and a warm room, when the previous year's display may be
repeated. Price, extra large, strong bulbs, 25c. each, postpaid.
From Central ASIA

Produces a Beautiful Flower

out of the dry bulb without being placed in soil or water, as shown in the illustration.

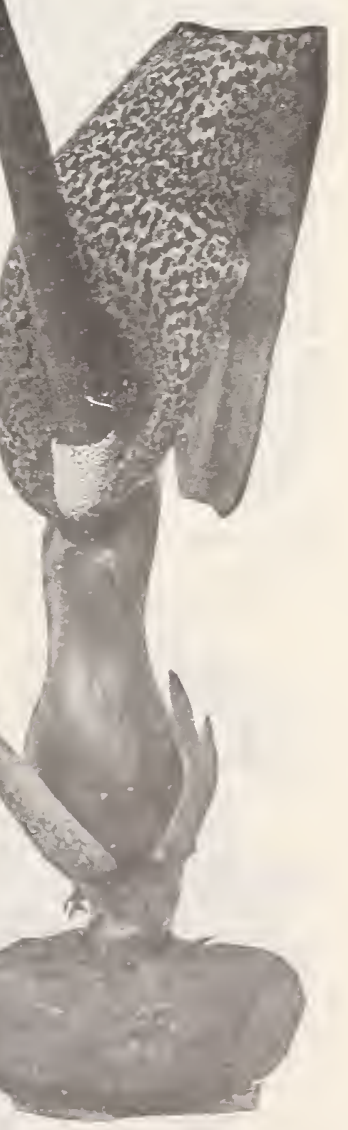

Monarch of the Fast. 


\section{${ }^{54}$ gु MAY'S NORTHERN GROWN SEEDS BEST FOR ALL CLMES \&o}
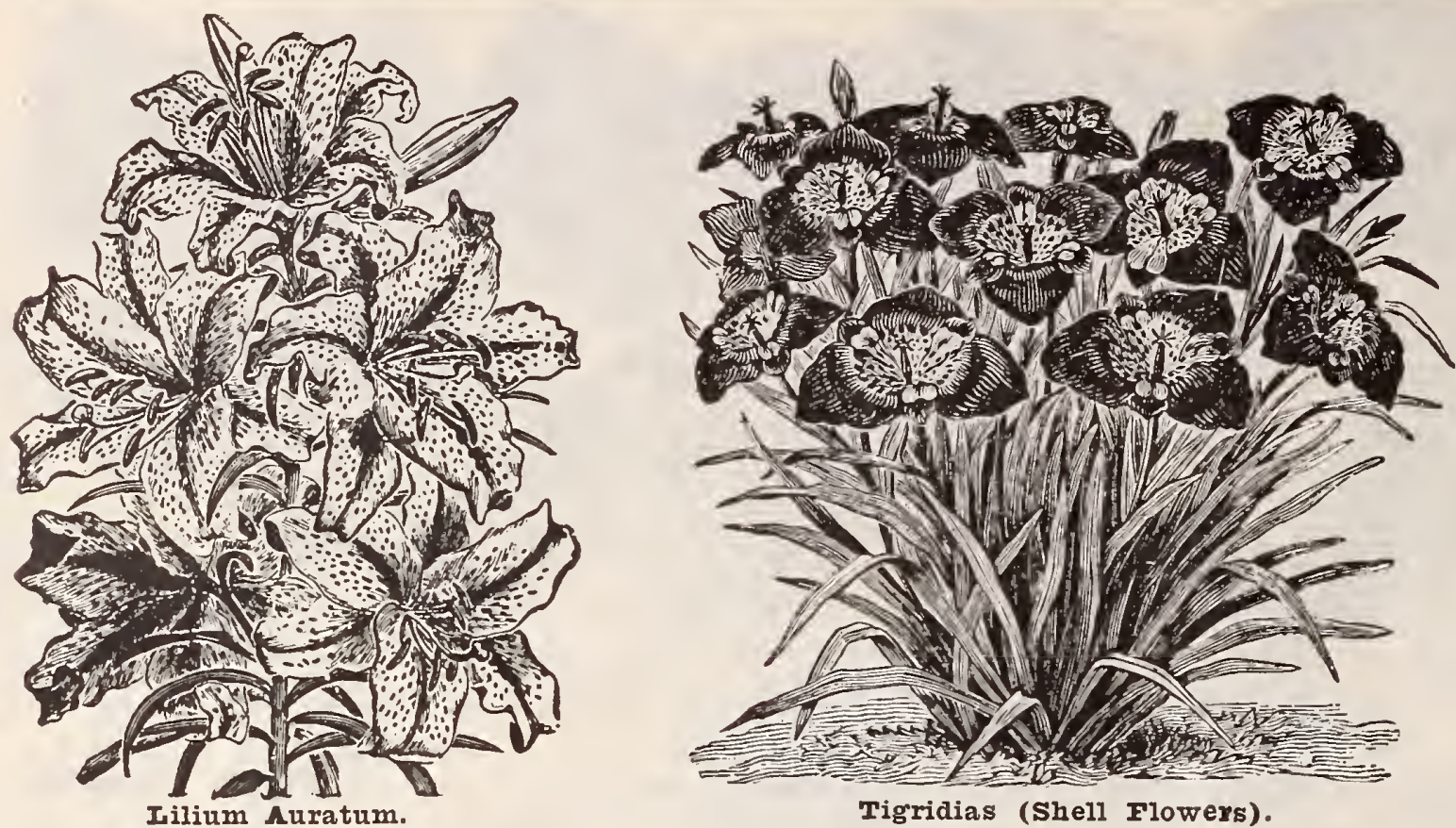

Tigridias (Shell Flowers).

HARDY LILIES.

As a whole, the most desirable section of

Auratum. (The Golden-Banded Iily of tled to the Japan.) Tiven it -The oueen of Lilies. The large white petals are thickhave ted with rich chocolate-crimson, and

Album Very fragrant large flowers, Each 20c., doz. $\$ 2.00$, postpaid.

Rubrum. White ground, with band and each petal. Each 20c., doz. \$2.00, postpaid. Melpomene. white, heavily spotted rich blood crimson. Each 25c., postpaid. Philippensis. This is a charming new from the Philippine Islands Beautiful, rant and exceedingly handsome. Perfectly 35c. each, 3 for $\$ 1.00$, postpaid.

Butterfly Lily. A popular variety and scented white flowers in existence. Each 15c., postpaid.

Hardy Spider Lily. This grand new the advantage of being perfectly hardy, and large, imposing clumps that are a mass of clustered heads of pure white, fragrant
flowers. Fine flowering bulbs, 20c. each, 3 for 50c., postpaid.

Queen Lily.

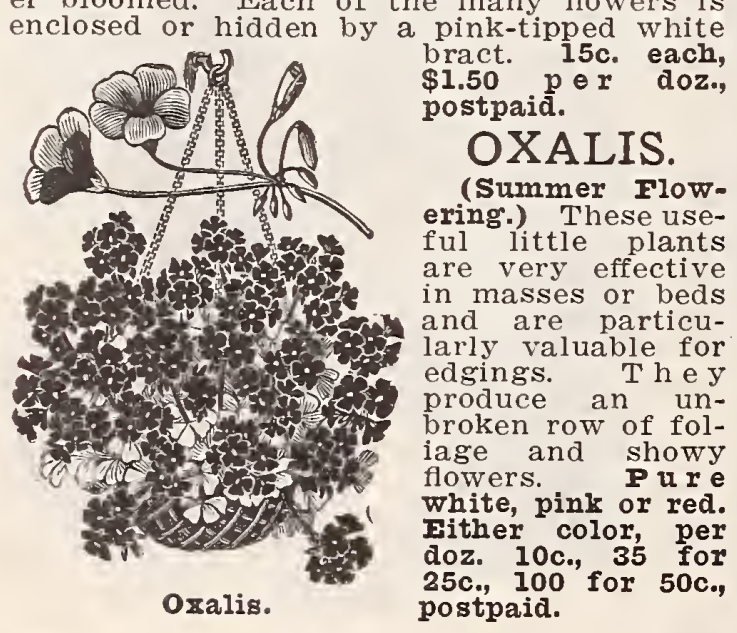

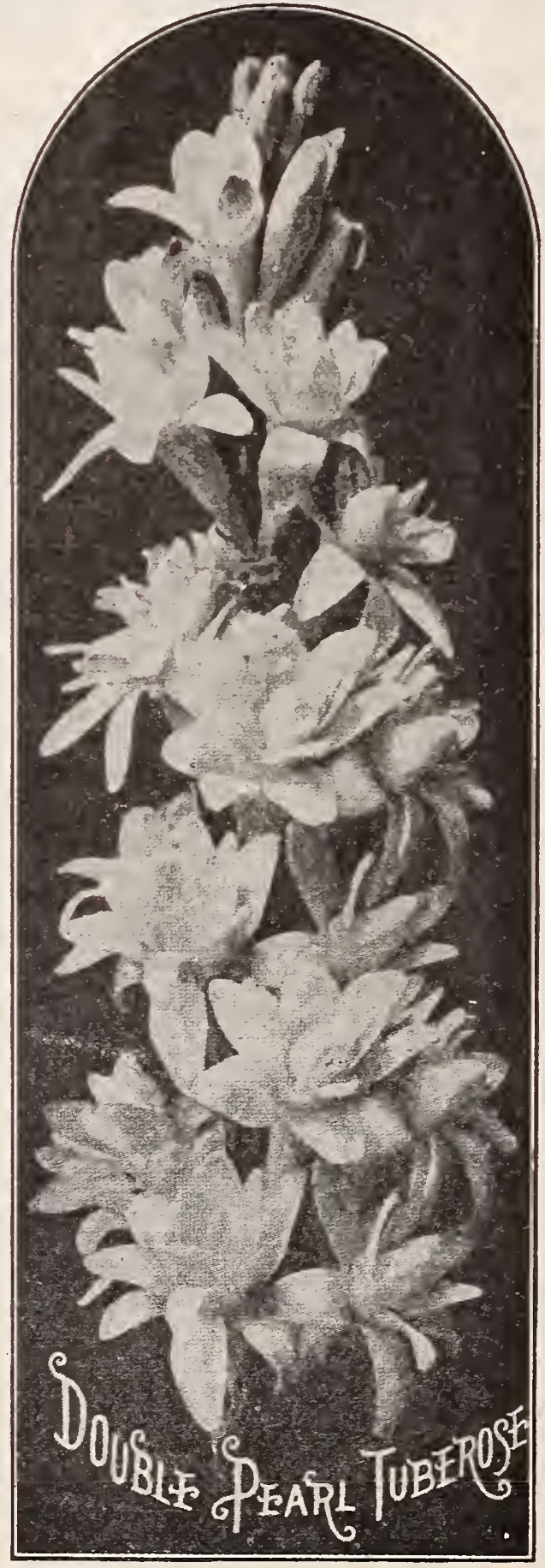

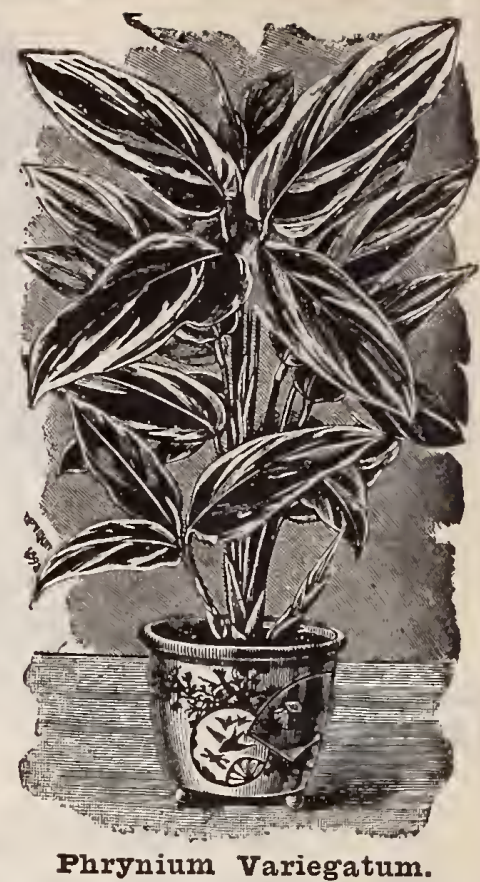

PHRYNIUM VARIEGATUM.

A beautiful variegated foliage plant; does equally as well when grown as a pot the decoration of the house or The leaves are bright pale green, beautifully variegated with white and gold. Dry ISMENE CALATHINA.

Throws up flower stalks 10 or 12 inches high, and bears beautiful clusters of large. curiously shaped lily-like flowers, pure blooming size bulbs, 20c each, postpaid.

TUBEROSES.

Double Dwarf Pearl. An improved Dwarf Pearl bearing very heavy spikes of largest double flowers. Price 5c. each, 6 for 25c., postpaid.

TIGRIDIAS (Shell Flowers).

CANARIENSIS. Bright yellow.

CONCHIFIORA. Yellow spotted.

SPECIOSA. Deep red, spotted purple.

GIIANDIFIORA ALBA. White, crimson Price, any of the above varieties, $5 \mathrm{c}$. each, 50c. per doz., postpaid.

ZEPHYRANTHES ( $\left.\begin{array}{c}\text { Fairy } \\ \text { ilies. }\end{array}\right)$

Pretty flowers, similar to the Amaryllis, but of miniature growth. All colors mixed. Each 5c., doz. 50c., postpaid.

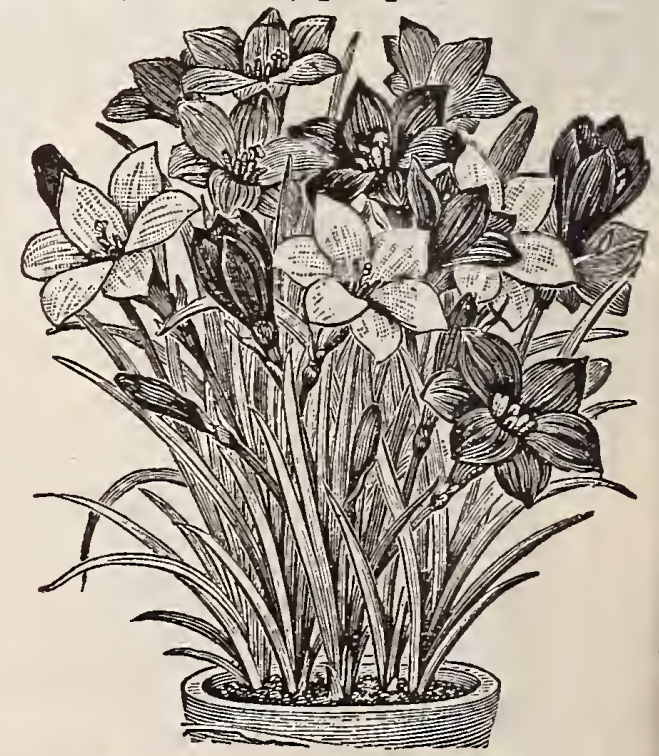

Zephyranthes (Fairy Irilies). 


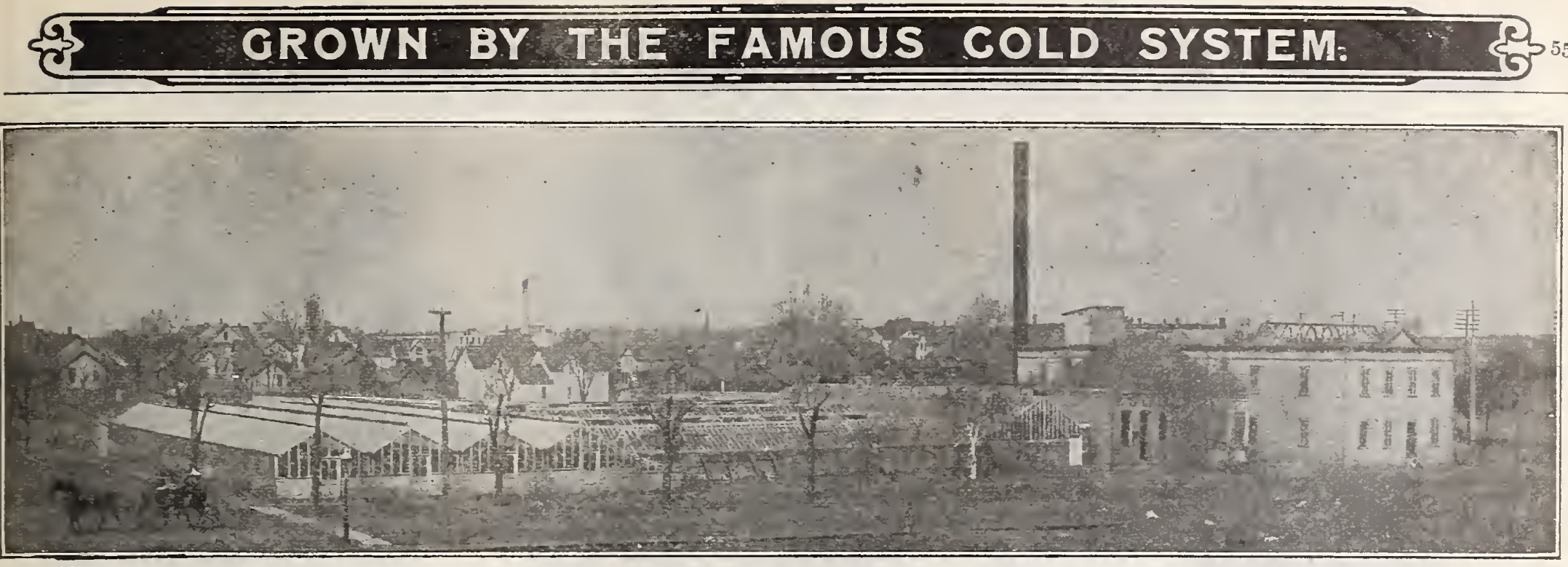

May's Greenhouses, Como Are., St. Paul, 75,000 square feet of glass.

\section{PLANT DEPARTMENT.}

All Plant Orders Will be mailed as soon as possible after All Plant Orders receiving them, weather permitting. any plants before March 1. Not only will the unsafe to ship better condition if shipped at that time, but they will be much larger and stronger than if shipped earlier, so that customers will lose nothing by waiting. If, however, our customers desire their plants immediately we will comply with their wishes in the matter as soon as we think it safe after receiving their orders. All plant and bulb orders are filled from our greenhouses and will be mailed in separate packages from there and not with the seeds.

Plants by Express. While plants can be safely sent by all such shipments, we would advise all customers ordering plants to have them sent by express. The cost is a trifle more, but our patrons are repaid by receiving larger and stronger plants, and we always include extras more than sufficient to
cover express charges.

Free. with all orders for plants we send our booklet-The valuab A B C's of Successful rloriculture, containing many valuable hints on the care and culture of house plants.

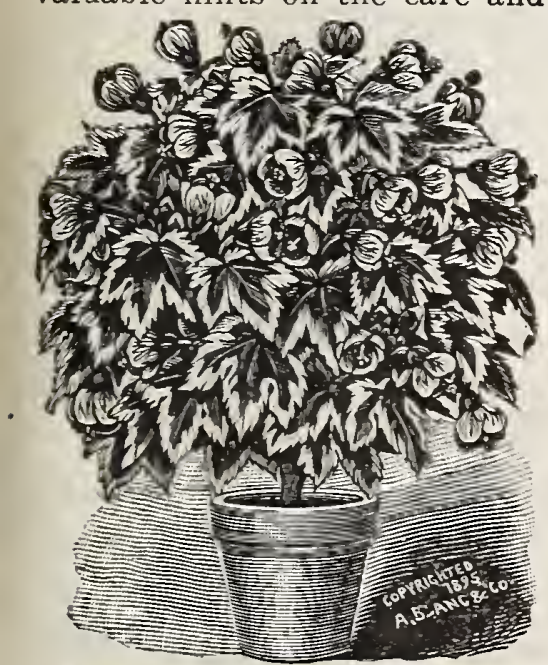

Abutilon Souvenir de Bonn.

$$
\text { ABUTILON. ( Flowering } \text { Maple. }
$$

Each 15c.,postpaid, unless otherwise noted.

INFANT EUIAIIE. Clear satiny pink.

GOIDEN BEIIS. Golden yellow.

SAVITZII. A striking variety.

SPIENDENS. A beautiful deep red variety. SOUVINIR DE BONN. A distinct variety. NEW DOUBIE, THOMPSONI PIENA. Rich orange, shaded with crimson.

ECIIPSE. A pretty trailing variety.

\section{ASPARAGUS.}

Sprengeri. One of the most rapid growing masses of fine feathery foliage, exceedingly grace ful and beautiful. Each 25c., postpaid ; large plants 50c. to $\$ 1.00$ by express.

Plumosus Nanus, or Lace Fern. ${ }^{\text {T }} \mathrm{h}$ e ful dark green foliage surpasses the Maiden Hair Fern in delicacy of texture. Each 25 c., nostpaid; large plants by express 50c. and $\$ 1.00$ each.
Extra Plants. While we do not offer discounts on plant charge on all orders whether will give extra plants free of prices named by us are as low as good plants can be sold at. Our stock is well-grown, carefully facked, and guaranteed to reach destination in good condition. We prefer to send out stock that will give satisfaction rather than offer big discounts and send out puny plants that will never be thrifty.

Important Plants sent by mail inave but little soil left on the root, and should receive careful attention on their arrival. If they appear wilted, place them in luke warm
water for 15 or 20 minutes. This will revive them. They are guaranteed to reach our customers in the United States in a perfectly healthy, living condition. If they do not, and we are notified immediately on their arrival, we will replace free of charge any that do not show signs of life. After arrival at destination in good condition our responsibility ceases. All plants will be sent by mail, postpaid, unless otherwise noted in plants will be sent by mail, postpaid, unless otherwise noted in our catalogue or customer instructs otherwise. If sent by exwe guarantee the safe arrival of vil plants sent by mail to any point in the United States, provided the above conditions are complied with by the customer.

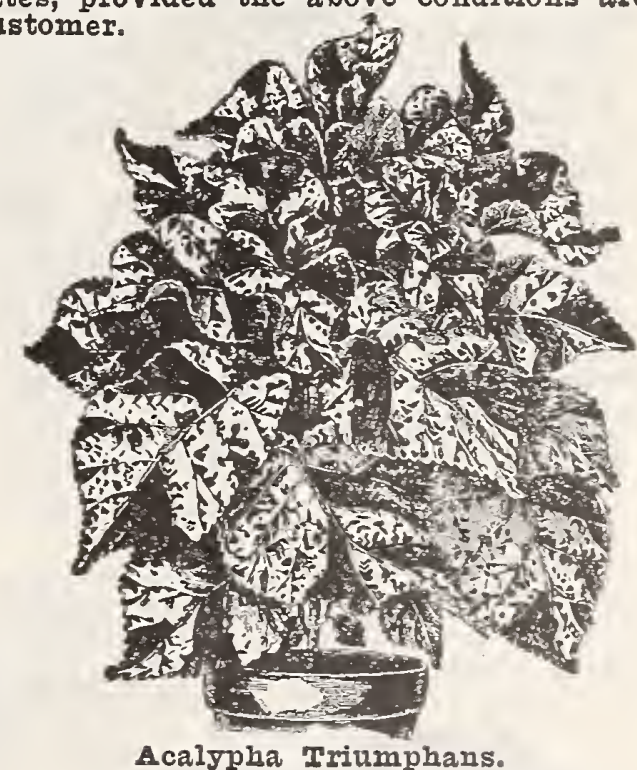

Asparagus Plumosus.

Acalypha Triumphans.

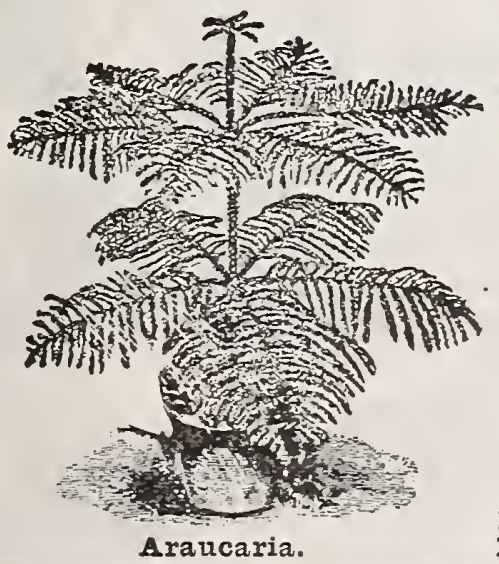

ACALYPHA TRIUMPHANS.

Beautiful foliage plant with large, showy foli age. Color, red, streaked and dashed green, yel-

\section{ARAUCARIA EXCELSA.}

(Norfolk Island Pine.) Sometimes called the "Christmas Tree Palm" and "Star Palm."

As a decorative plant for the halm.

one of the handsomest and most serviceable It

has deep green, feathery foliage, arranged in whorls, risin distances; its symmetry of form, grace and foliage are unequaled. It is so hardy that the ture, have apparentiy no deleterious effect upon it. plants, each 75c., extra fine, $\$ 1.00$ to $\$ 1.50$ By express only. 


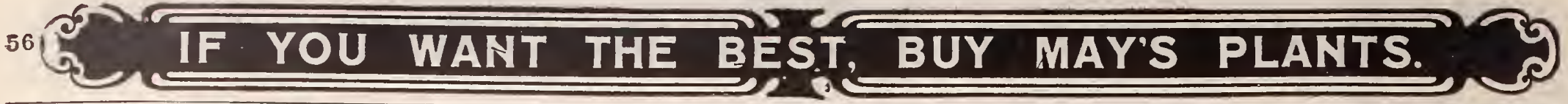

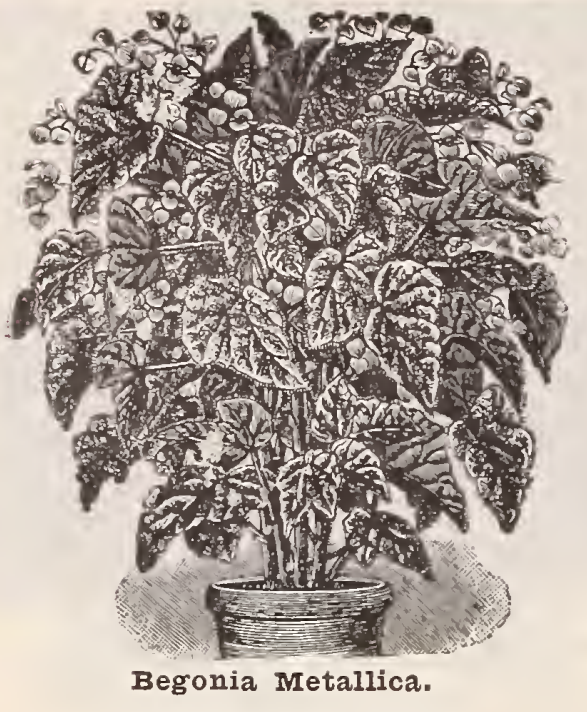

ANTHERICUM.

VITTATUM VARIEGATUM.

Each 20c., postpaid.
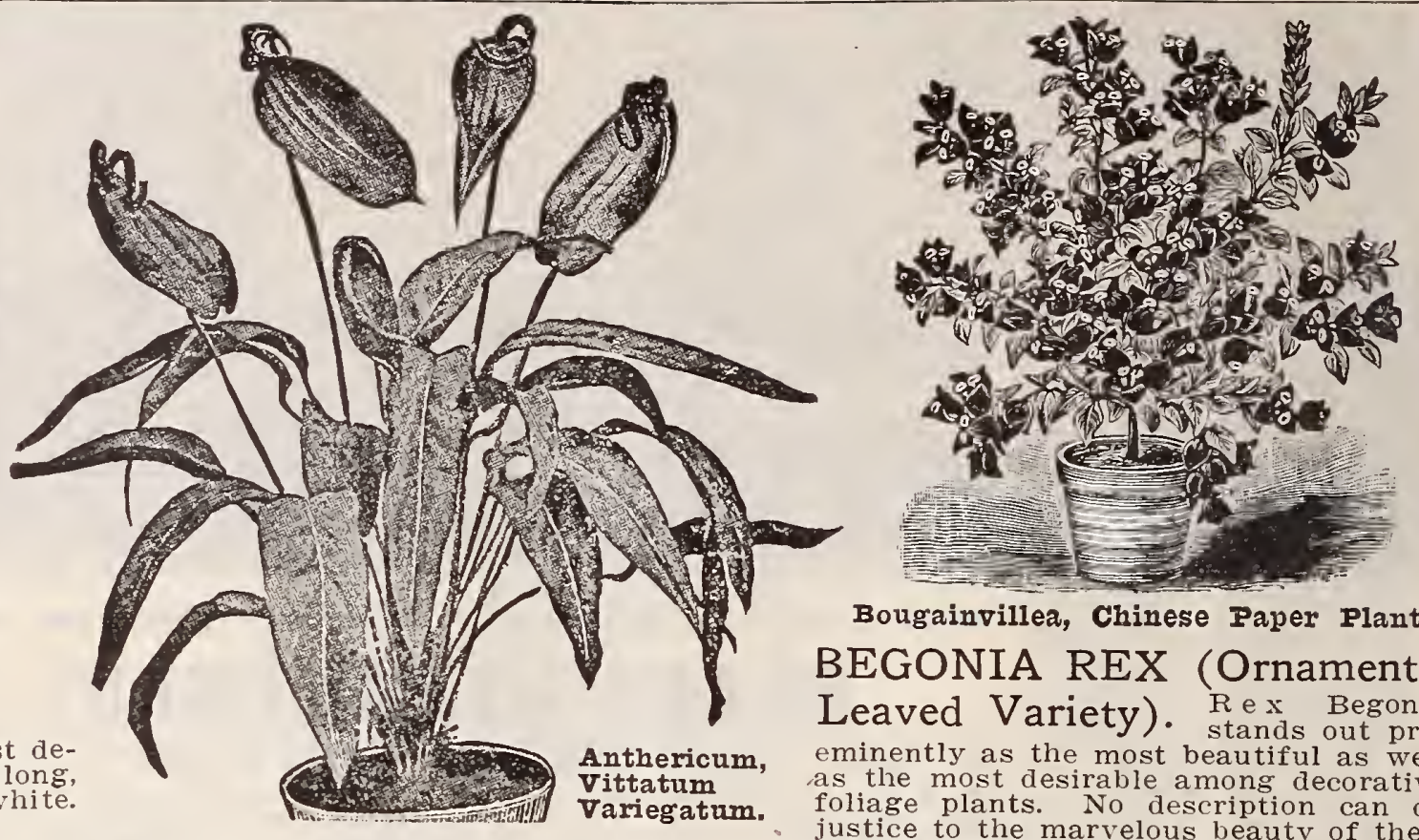

Bougainvillea, Chinese Paper Plant.

BEGONIA REX (Ornamental Leaved Variety). $\begin{aligned} & \mathrm{R} \text { ex } \\ & \text { stands out pre- }\end{aligned}$ minently as the most beautiful as well foliage plants. No description can do ustice to the marvelous beauty of their BOUGAINVILLEA (Chinese Paper Plant).

GLABRA SANDERIANA. As a pot plant it is magnificent,

Each 10.., postpaid, except where noted.
AIBA PICTA. Leaves narrow, green, and

AGATHA.

DIADEMA. Each 15c.

GIOIRE DE LORRAINE.

all Begonias. Grows from 10 to 12 inches high
Throughout the entire winter completely hi

W with soft, rosy-pink flowers. Each 15c.
"TRIUMPHE DE I'EST.; Bright rosy-red

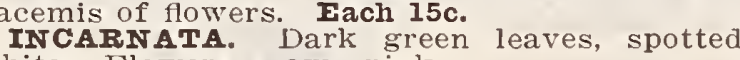

MARGUERITE. Blossoms rose colored.

MI. DE LESSEPS. Leaves green, richly spotted

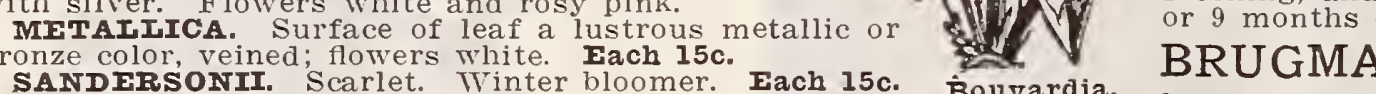

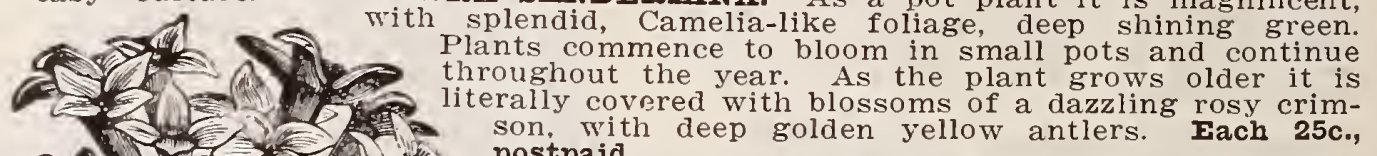
convin

GIABRA, W. K. HARRIS. In this new variety,

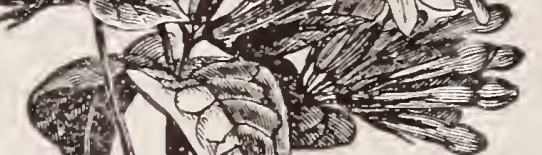

beautifully variegated or marbled, with creamy

white or a dark green ground, the two color

about equally divided. Each 30c., postpaid.

BOUVARDIA.

AIBA. A beautiful single, free flowering, pure white variety; excellent for cut flowers

OTTO HACKER. Flowers bright coral red.

ANSIA. of recent introduction. The flowers are drooping, bell shaped, of immense size, many of them WEITONIENSIS ALBA.
ROSEA MUITIFIORA.

SUBPEIIATUM NIGRICAN S. Darkest foliage.
PRES. CARNOT. Flowers coral red.
RUBRA. Deep green leaves, coral

THURSTONI. Pink flowers and

VERNON.

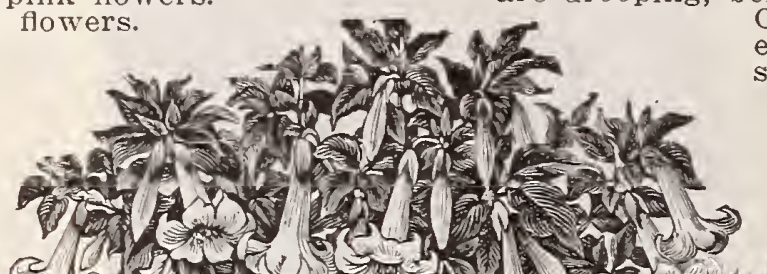

1.5.
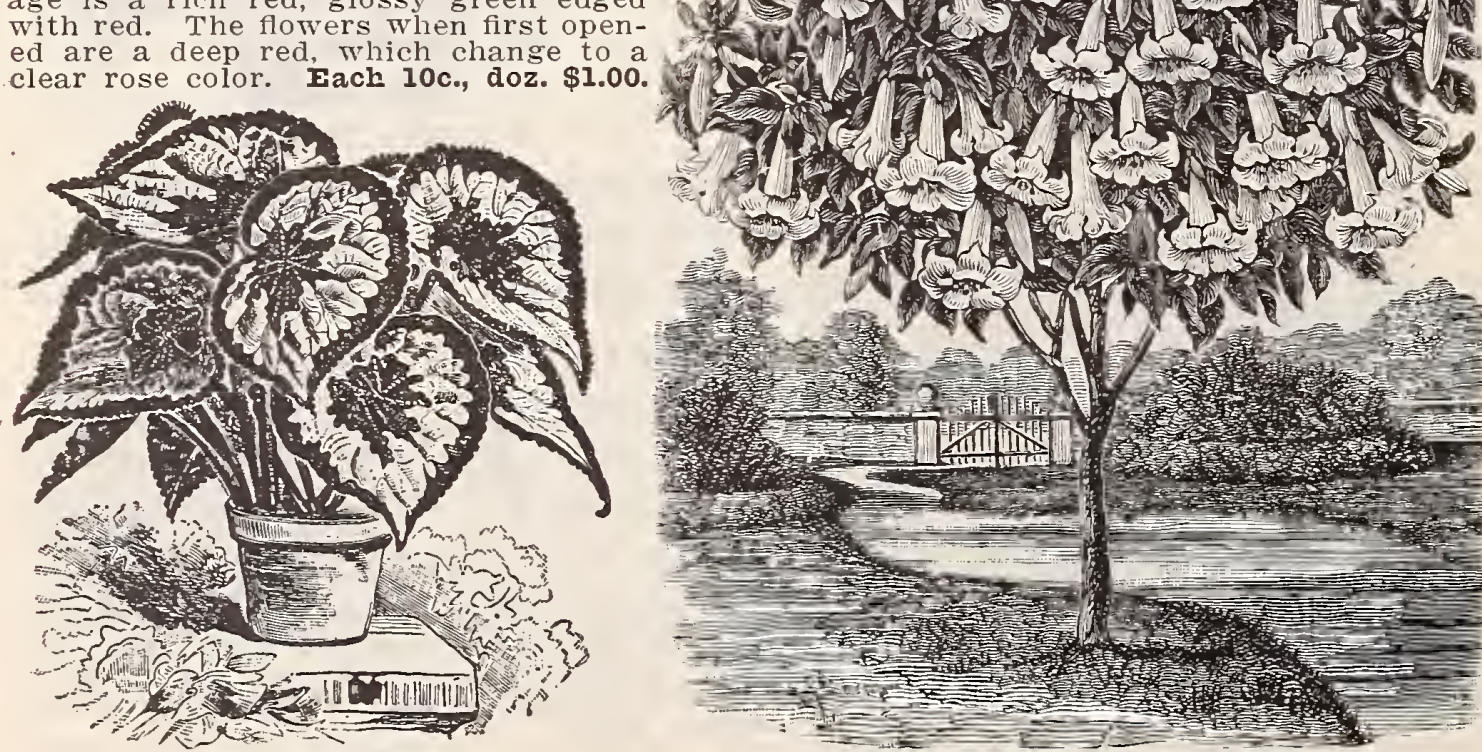

Begonia, Rex.

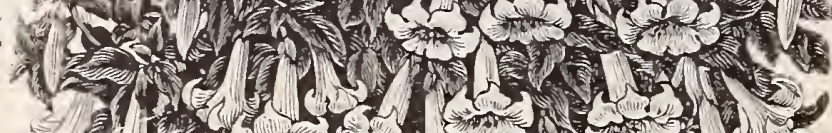

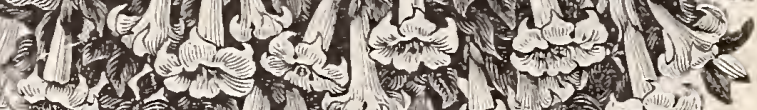

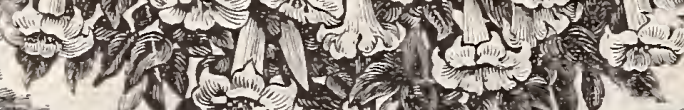

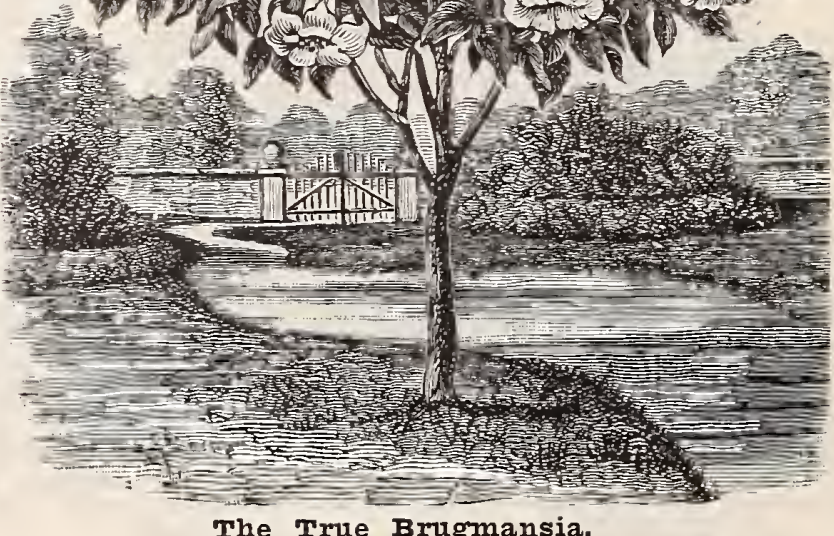

The True Brugmansia.

reamy white, very fragrant, robust growight to see 20 to 30 blooms open at the same time. Can be grown outside in 20c., postpaid.

\section{BROWALLIA.}

JAMESONIA. An old but neglected plant, forming compact, bushy heads, which, when plants are in bloom, are $f$ a bright orange color, giving it a rich Gach 15c., postpaid.

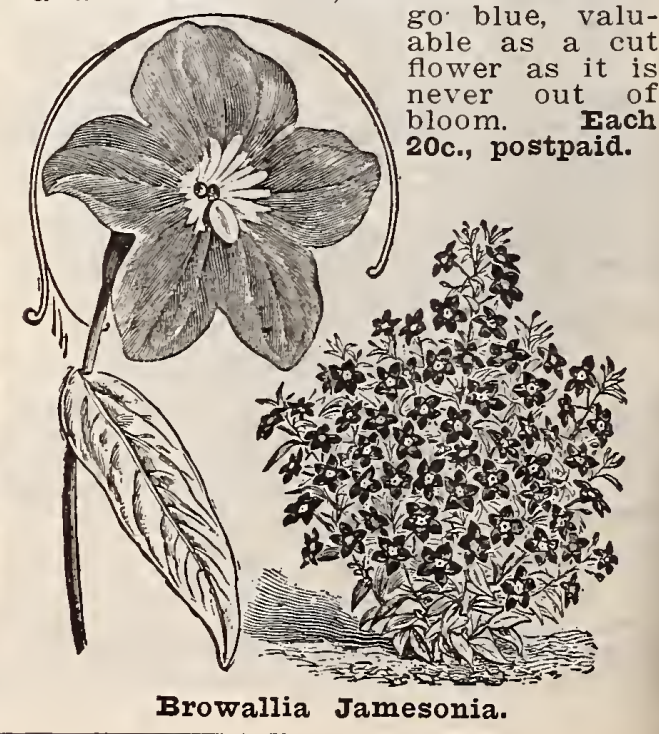


की GROWN BY THE FAMOUS COLD SYSTEM. ही ?

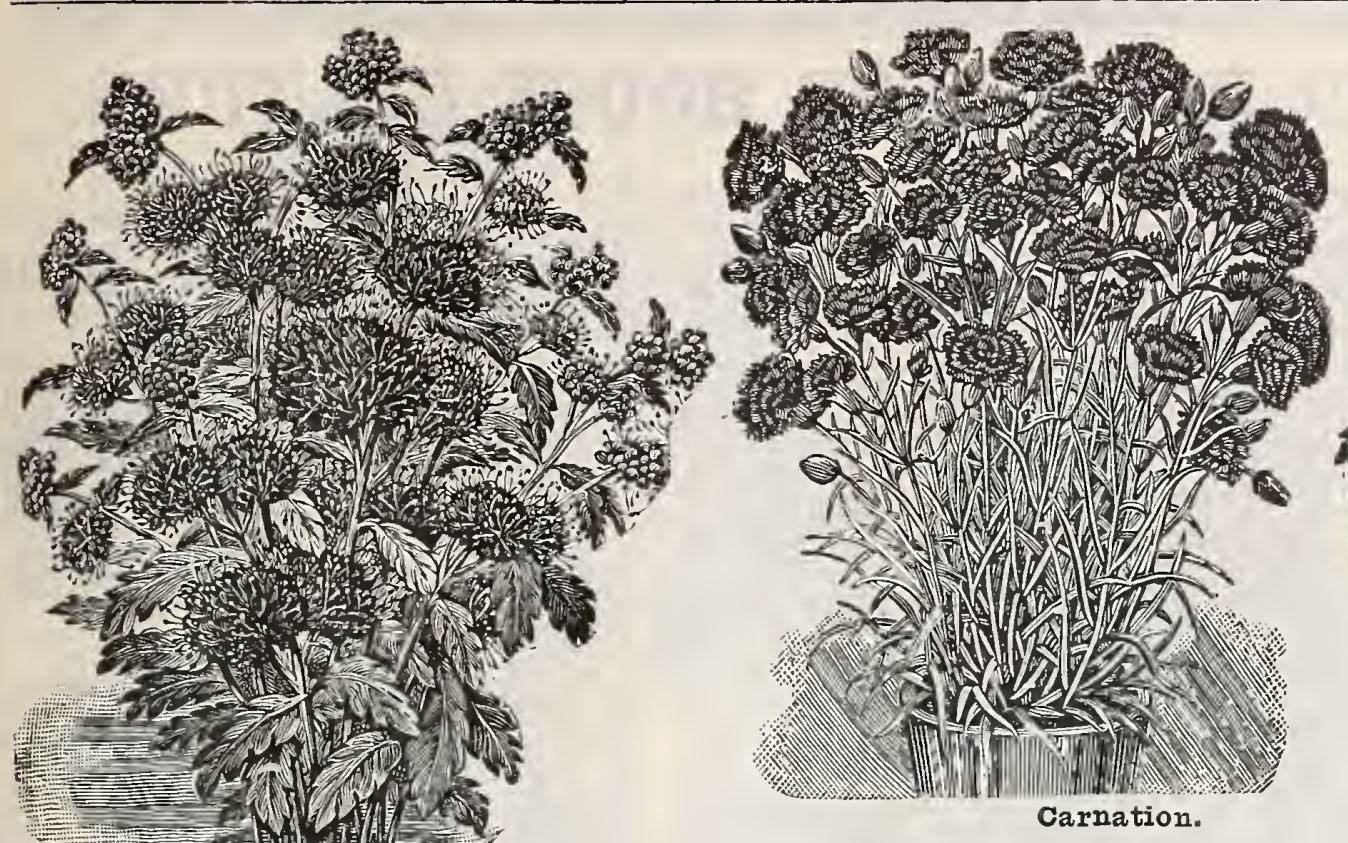

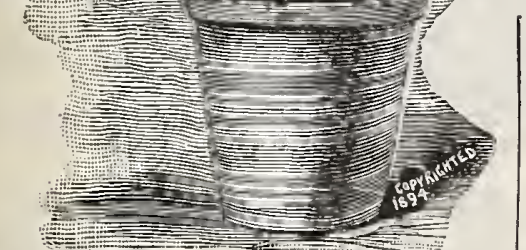

Caryopteris (Mastacanthus).

\section{CARYOPTERIS.}

(Mastacanthus.)

A beautiful hardy perennial which is equally well adapted to growing in the open ground Each 15c., postpaid.

CHENILLE PLANT.

The flower spikes, which appear in pairs from the axils to three feet in length. They are of bright crimson color. Each 25c., postpaid.

\section{NEW DWARF}

CORAL PLANT.

\section{(Erythrina Christa-Galli} Compacta.)

This new variety is not only dwarf-never exceeding thirty inches in height-but each branch terminating with a spike of flowers. These are of a brilliant crimson-scarlet, produced from early July unti plant. Each 30c., postpaid.

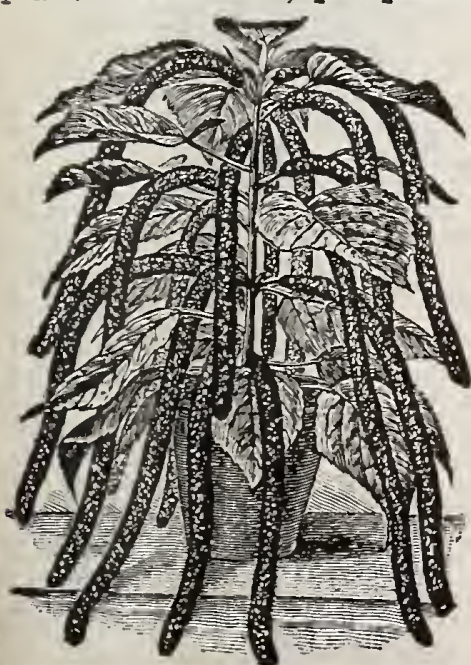

Chenille Plant.
SELECT CARNATIONS.

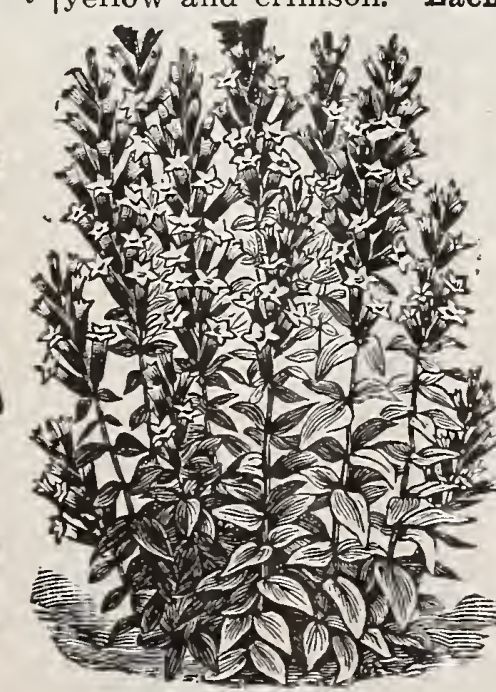

Cuphea Eminens.

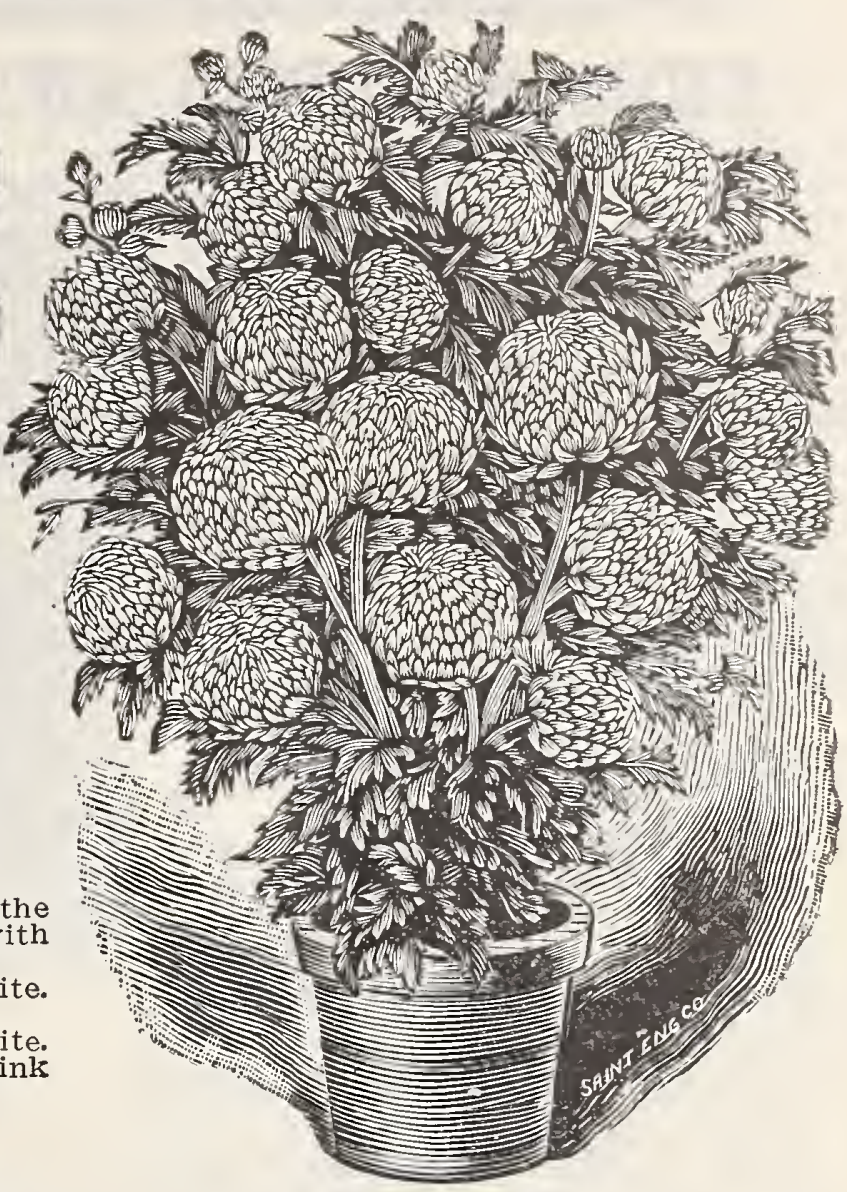

Chrysanthemum.

CHRYSANTHEMUMS (Best Varieties.)

postpaid. We can supply strong, field-grown plants in doz. by express.

\section{CUPHEA.}

PLATYCENTRA (Cigar Plant). An old and favorite plant for the summer flower garden; u

EMINENS (Giant Cigar Plant). A charming plan which grows rapidly to a height of 15 or 18 inches, beargreen. Each 15c., postpaid.

\section{CROTONS.}

The Crotons are among the finest decorative foliage plants known. As easy to grow as Coleus, and much

BARONESS ROTHSCHIID. Broad leaves of bright (anson, yellow and green markings. Each 25c., postpaid. DAYSPRIYG. Orange-yellow, edged

GOIDIANA. Brightest green, large center of bright llow. Each 20c., postpaid.

NESTOR. Olive ground. Pink mid-rib and green ots. Finest of all Crotons. Each 25c., postpaid. VETTCHII. Bright green, marked an yellow and crimson. Each 20c., postpaid.

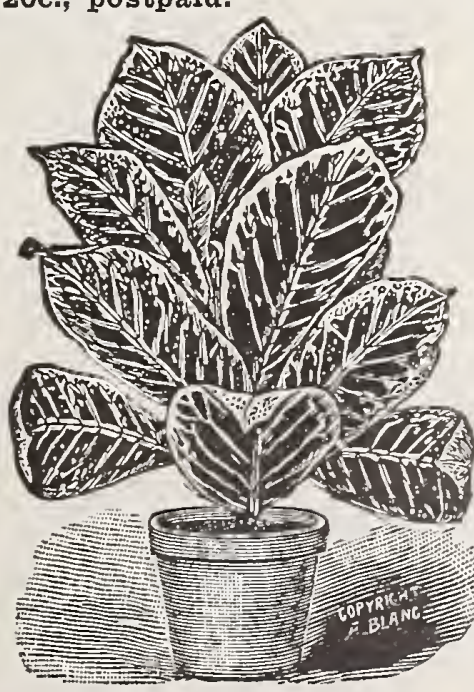

Croton IARIY FIOWERING.

ADELE. Delicate pink. Early white MIIE. F. BERGMAN.

MONROVIA.

OCTOBER FROST.

\section{MID-SUMMER.}

COI. D. APPIETON Bright yellow.

DR. ENGUEHART. Bright pink,

IVORY

MARY FOSTER.

PHILADELPHIA

PINK IVORY. B

PENNSYIVANTA. Rich bright yellow

WM. H. CHADWICK. Waxy white.

MRS. W. B. CHAMBERIAIT

W. DUCKHAM. A

YEIIOW EATON.

\section{IATE FIOWERING.}

GEO. W. CHILDS.

WHITE BONNAFON.

MAJOR BONNAFON.

IMRS. JEROME JONES.

GOIDEN AGE.

INTENSITY.

MURDAF.

Price 10c. each, $\$ 1.00$ doz., postpaid.

Special quotations made on large lots to parties desirous of orowing them for flower shows.

ply large plants of the leading sorts 10 to $\$ 1.00$ each by express.

\section{DRACENA INDIVISA}

(The Fountain Plant.)

decorative plant. Small plants $25 \mathrm{c}_{\text {e each, }}$
postpaid. Strong plants, 15 to 18 inches tall, \$1.00 each by express.

\section{FABRIANA IMBRICATA.}

charming, pure whit 
20 IF YOU WANT THE BEST, BUY MAY'S PLANTS. ?ै?

\section{CHOICE FERNS AND PALMS FOR HOUSE CULTURE.}

FERNS AND PAIMS have oecome an almost indispensable feature in all decorations, whether for apartments, in summer. The following varieties are of easy culture in the parlor or consmall plants by mail, postpaid; the large plants must be sent by express at purchaser's expense.

\section{FERNS.}

THE BOSTON. It is of such easy culture and rapid growth, and is so graceing nearly all other varieties, both with ful drist and amateur. Its long, gracehealthr, not subject to the attacks of 1st size, $25 \mathrm{c}$. each by mail; $2 d$ size, $75 \mathrm{c}$. each by ezpress; large size, $\$ 1.50$ each by express.

NEW, ELEGANT, FIUMED EERN. (Nephrolepis Piersoni Elegantissima; This is a sport from the Pierson of the original form is even more disthe side pinnae being again subdivi
and standing at right angles to the
rection of the midrib, makes both si the same time, the plant is of much mor

plant for all purposes, and one of the
handsomest decorative varieties ever in-
troduced, attains a large size in a short
time, and at all stages of its growth and development is most handsome. Strong plants 50c to $\$ 1.50$ each, by express. NEPHROLEPIS BARROWSI (Improved Pierson Fern.)

igorous growth which is characteristic ture front. The fronds grow broad and least 6 inches across. Strong yonng plants press, $50 \mathrm{c}$ to $\$ 1.50$ each.

ASSORTED VARIETIES for jardinieres and ferneries. Strong thrifty plants $20 \mathrm{c}$.

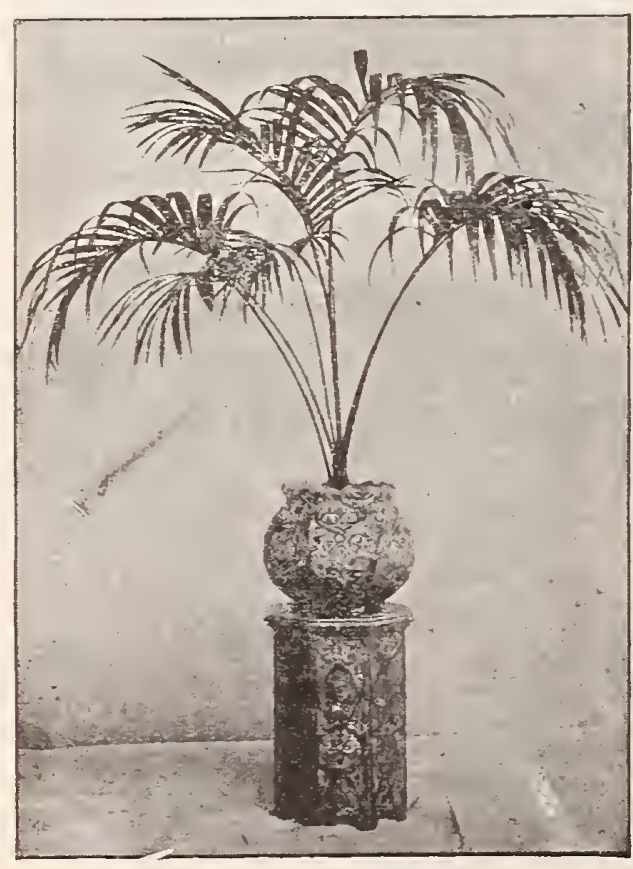

Kentia (Palm) Belmoreana.

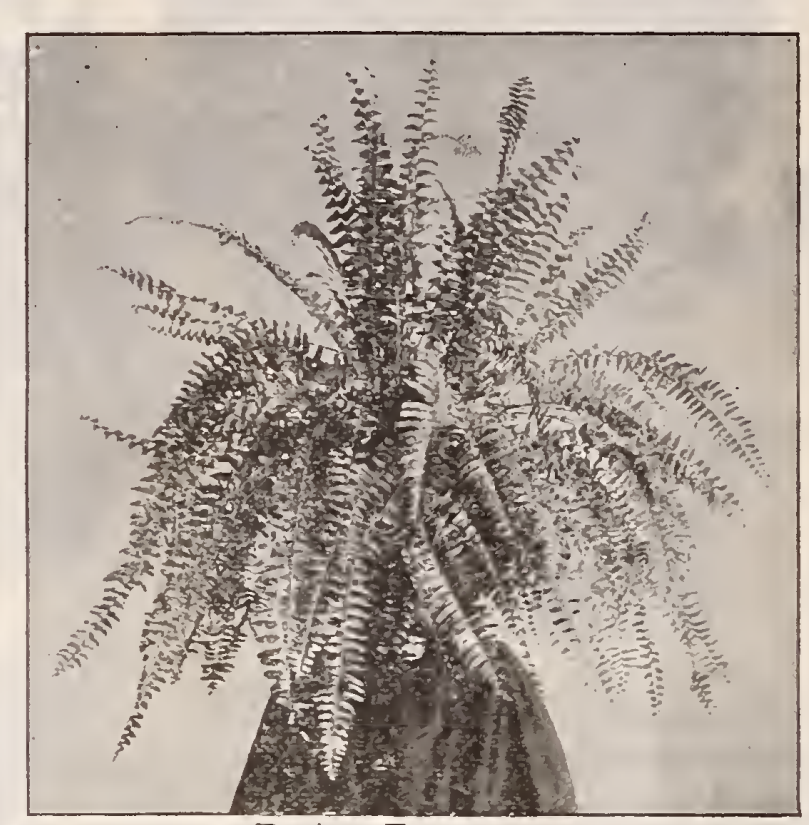

Boston Fern.
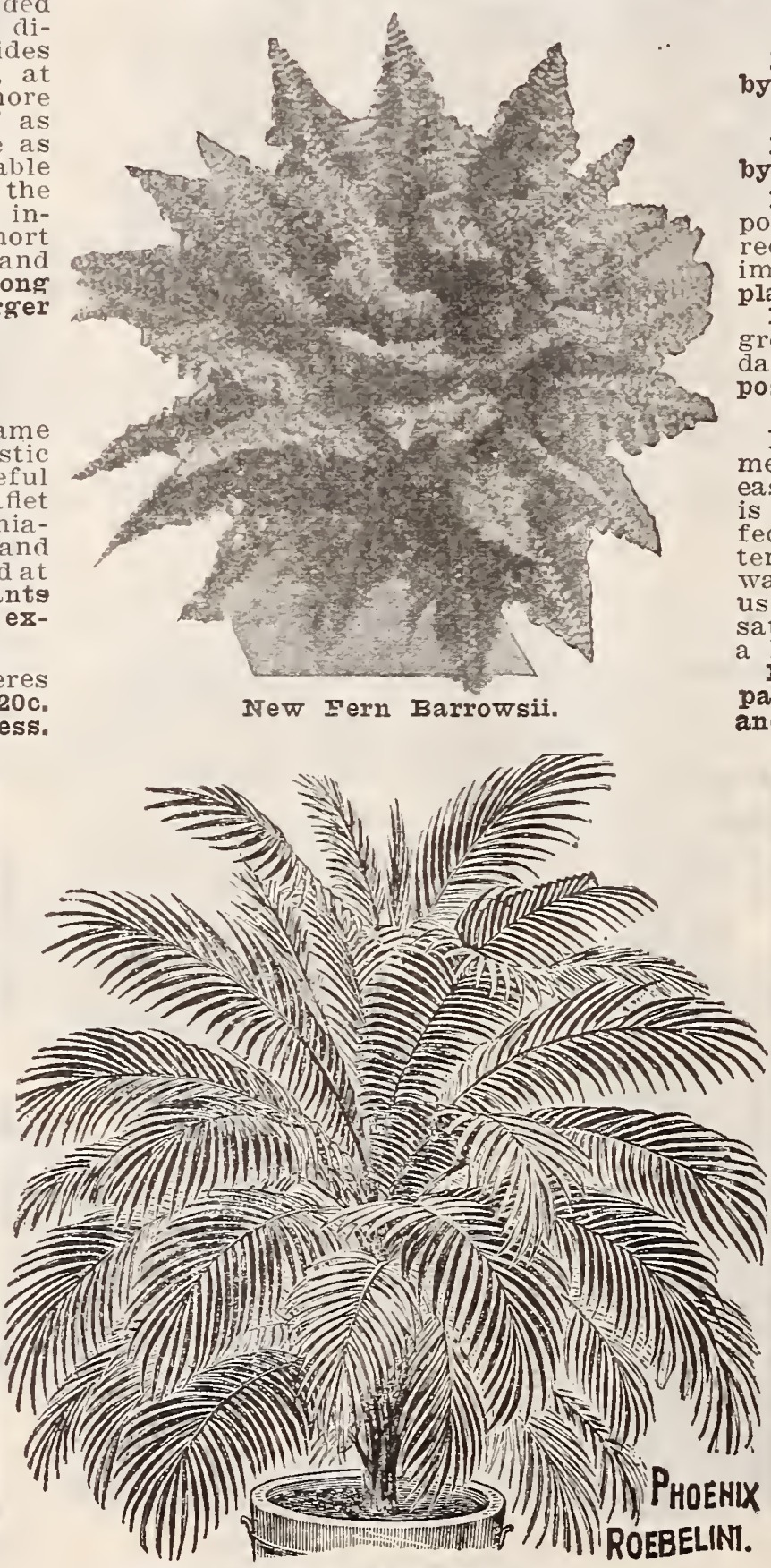

The Magnificent New Palm.

\section{PALMS.}

PHOENIX ROEBELENII.

Our illustration conveys but a faint dea of the delicate beauty of this the most graceful of all the Phoenix. and a Palm which we feel safe in popular varieties for room decoration. The plant is of for rous aecoration. its prant is of vigorous growth, and very narrow dark green pinnae, give the plant $a$ lightness and airiness not surpassed, if equalled, by the popular Cocos Weddeliana; at the same time ing adinirably as a house plant. 30c. each, postpaid.

\section{IRENTIAS.}

The Kentias, both Belmoreana and Forsteriana, are the hardiest in cultivation, and give better satisfaction rieties They than any other vaThey are or slow growth are not affected by the dust and atmosphere of the house, and were we to select one Palm only, it cerar be a Kentia. The two the former being awarfer and more er eading, and the latter is of strong age. TENTIA BEIMOREANA.

Price, 30c. each, postpaid; large plants by express $\$ 1.00$ to $\$ 10.00$ each.

TENTIA FORSTERIANA

Price, 30c. each, postpaid; large plants oy express $\$ 1.00$ to $\$ 10.00$ each.

IATANIA. (Chinese Fan Palm.) This popular variety is too well known to require description. We grow them in plants $\$ 1.50$ to $\$ 10.00$ each, by express PHOENTX - RECIINATA. A strongrowing form of the Date Palm, with postpaid. glossy foliage. 30c. each, UMBREIIA PAIM.

For house culture we cannot recommend this plant too highly. It is so easily managed; all it is particular about is plenty of water. To have it in per作 er. use in aquaria, where it gives entire atisfaction. Any temperature usual in Nice growing plants $15 \mathrm{c}$. each, postpaid; large plants, by express, 25c., $50 \mathrm{c}$ and $75 \mathrm{c}$. each.

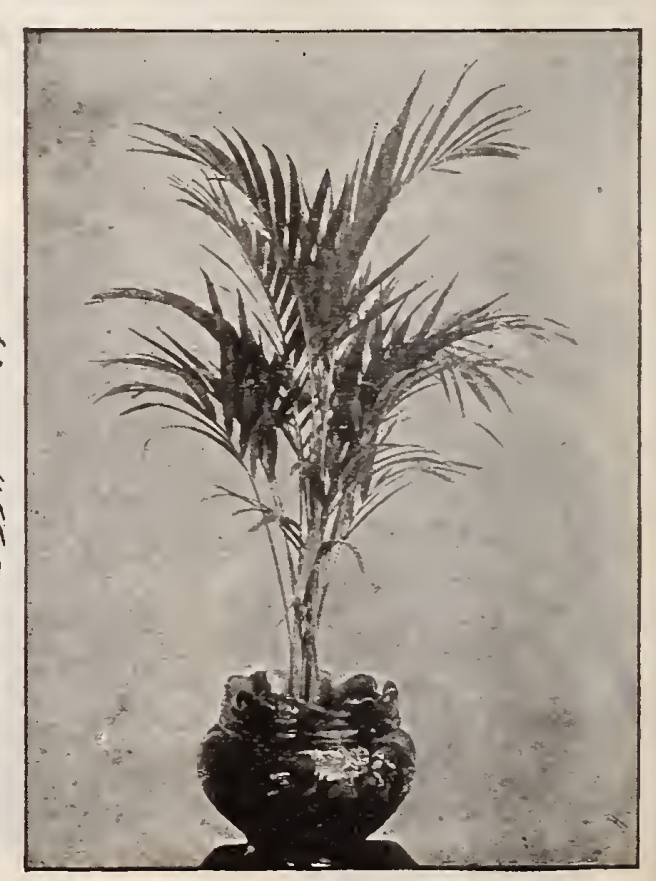

Kentia (Palm) Forsteriana. 


\section{कु GROWN BY THE FAMOUS COLD SYSTEM. हु}

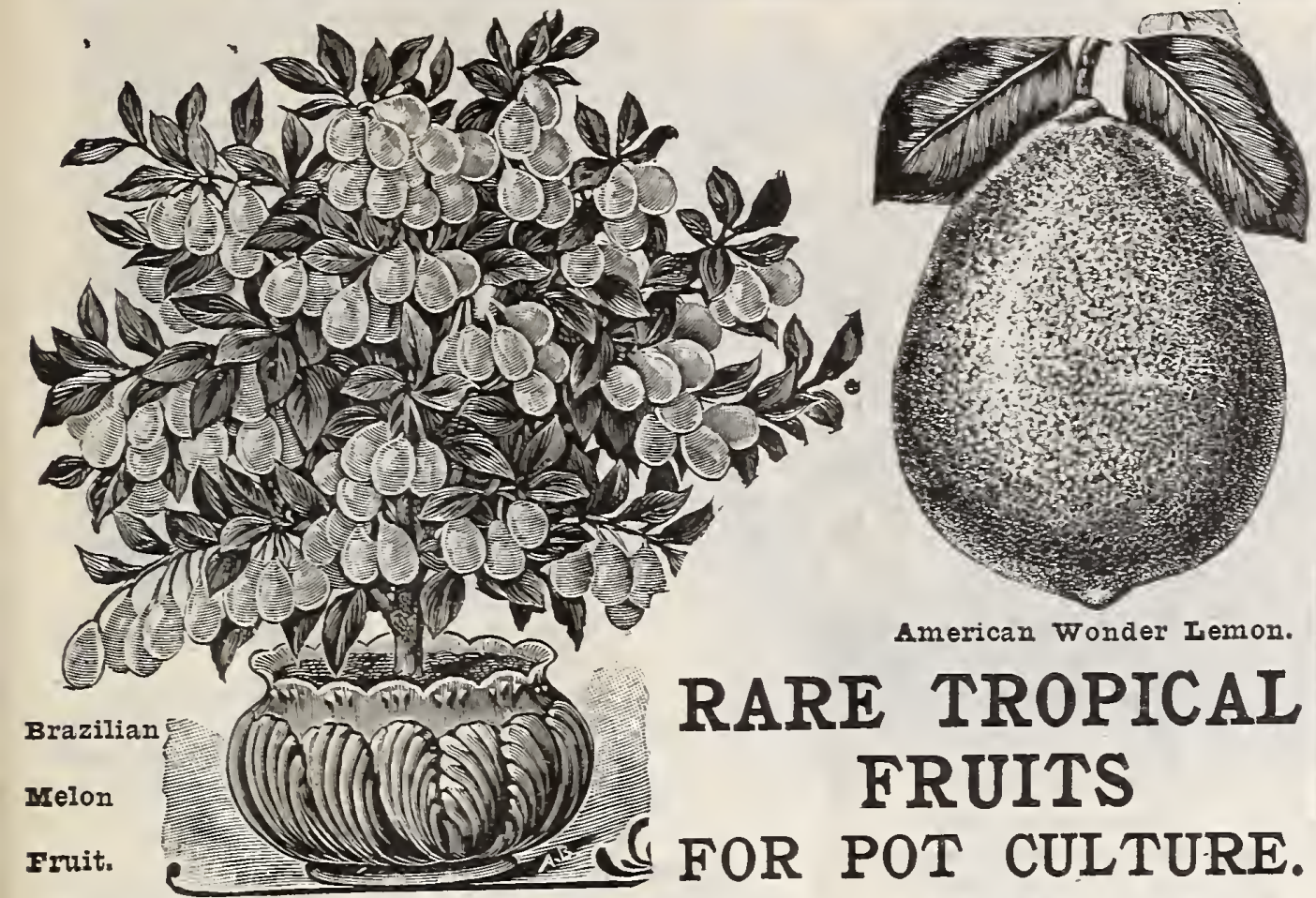

The easiest of all pot plants to grow, handsome, showy foliage and blossoms and lus. cious fruit.

Brazilian Melon Fruit. As an ornahas few equals, its splendid bushy habit, healthy growth and charming foliage giving it the preference orer many of the It also furnishes a colored fruit. Which hangs pendant in clusfruit is of the most delightful flavor, having a slightly sub-acid taste, entirely different For eating out of the hand, slicing or making into preserres, it is simply delicious. Strong plants, 25c. each, postpaid.

American Wonder Lemon. and

able fruit for house culture. ange, are easily kept clean and bright, times. In addition to this. its waxy white, fragrant blossoms, produced in clusters, fol

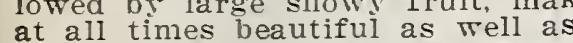

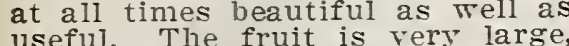

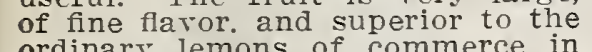

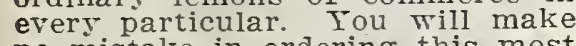
beautiful plant. as it is raluable alike as an ornamental plant or

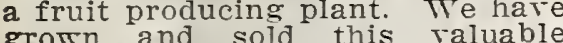
never received a single complaint
from a customer who purchased it. It is beyond doubt one of the
very finest plants for house culture ever introduced. 25c. each, postpaid.

Strawberry Guava. Another tropical fruit and charming house plant, rivaling the famous Otanice, clean grower, with thick, glossy green leates, and like the
orange, it bears both flowers and

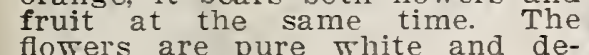

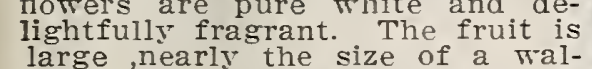

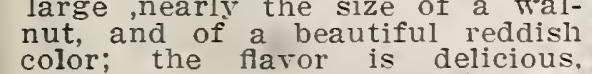
sweet and spicy, and ret rich and teresting. The plant begins to small. 25c. each, postpaid.

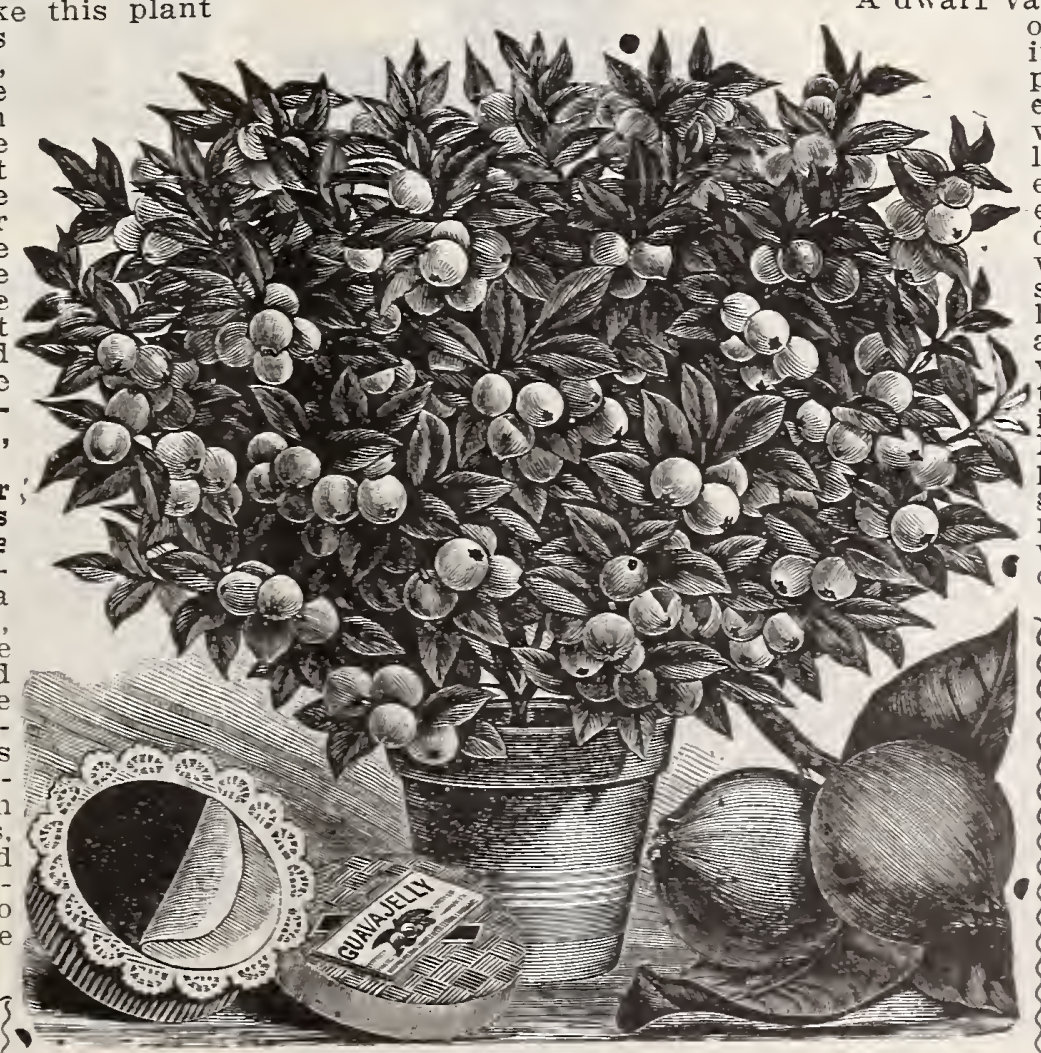

Strawberry Guava.

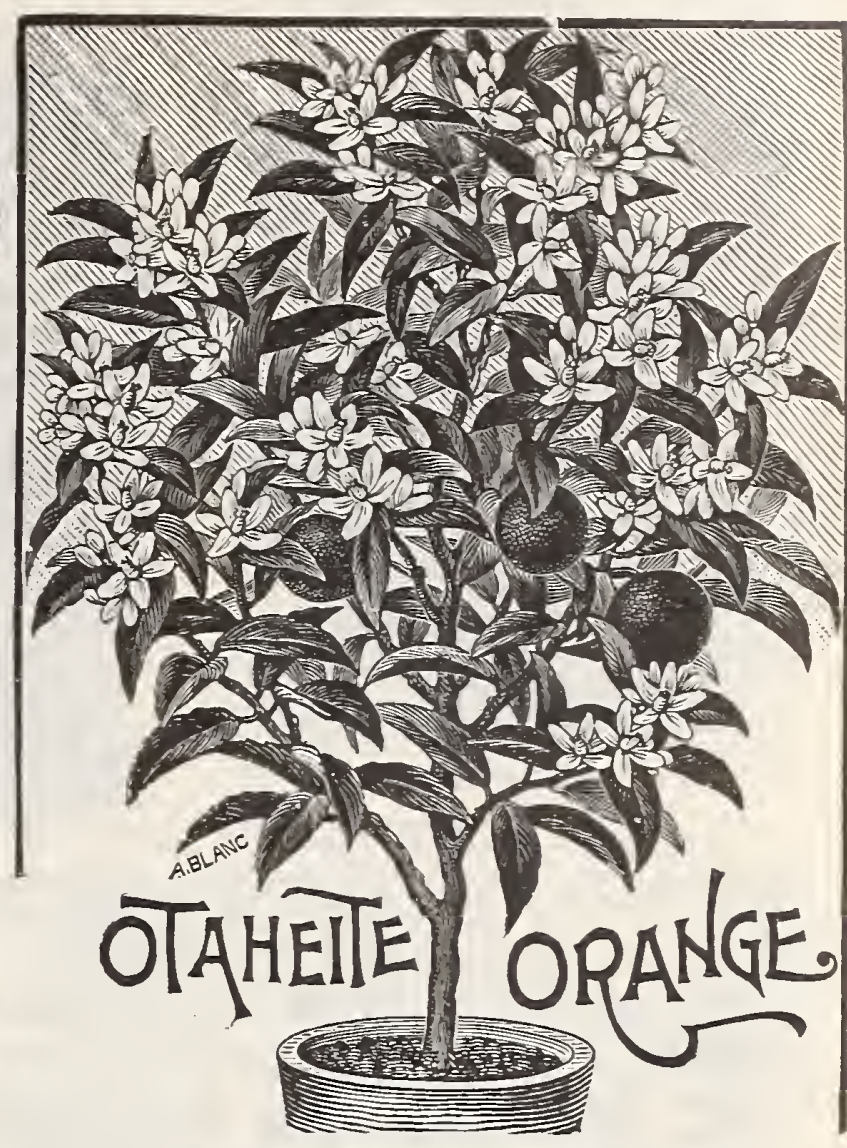

FOR HOUSF CUITURE.

One of the grandest pot plants for flowering we have ever seen, and being useful as well as ornamental, should be grown by every one.

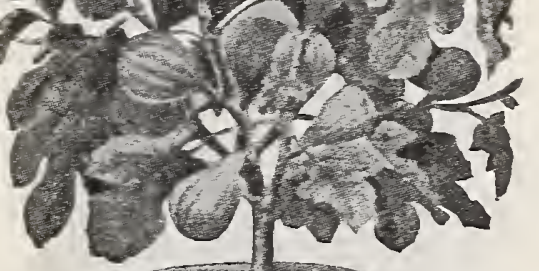

room. The stock we offer is strong and thrifty. 25c. each, postpaid.

THE GENUINE SMYRNA FIG.
SPECIAL OFFER

For $\$ 1.00$ 


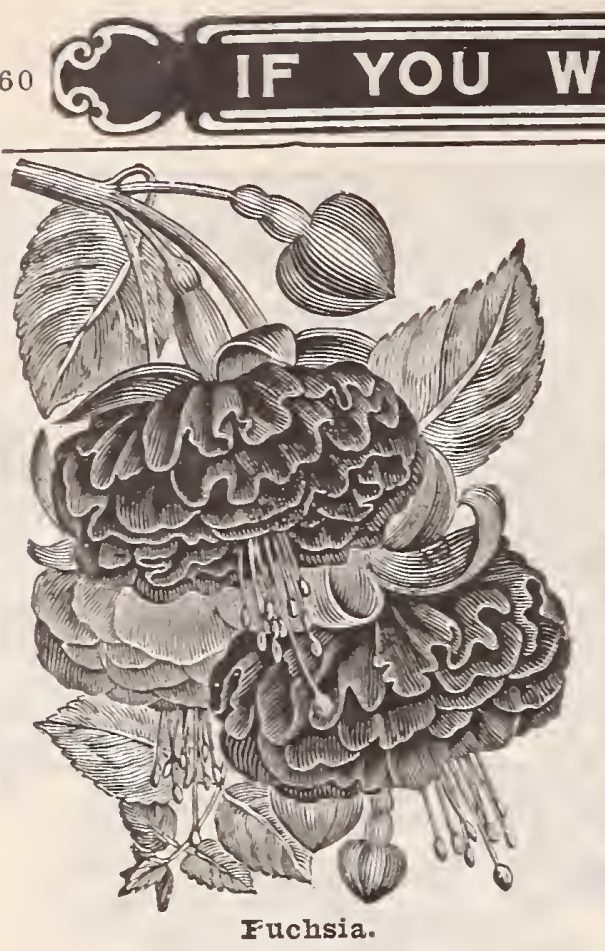

FUCHSIAS.

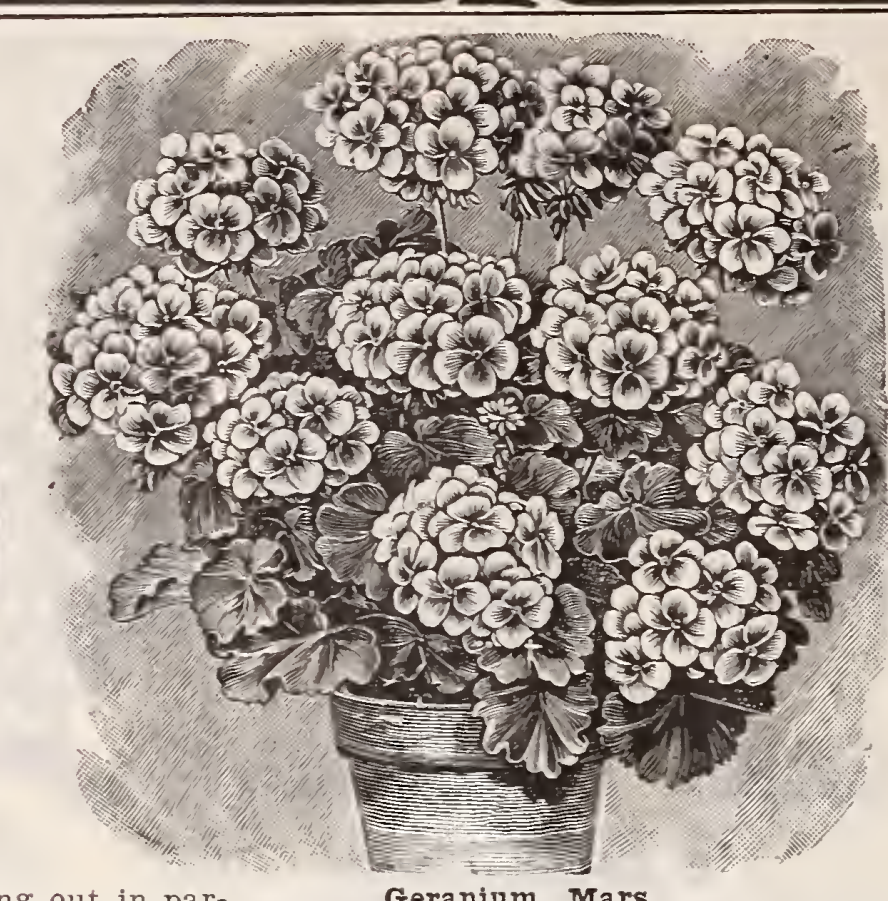

Geranium, Mars.

THE WONDERFUL

BABY RAMBLER ROSE
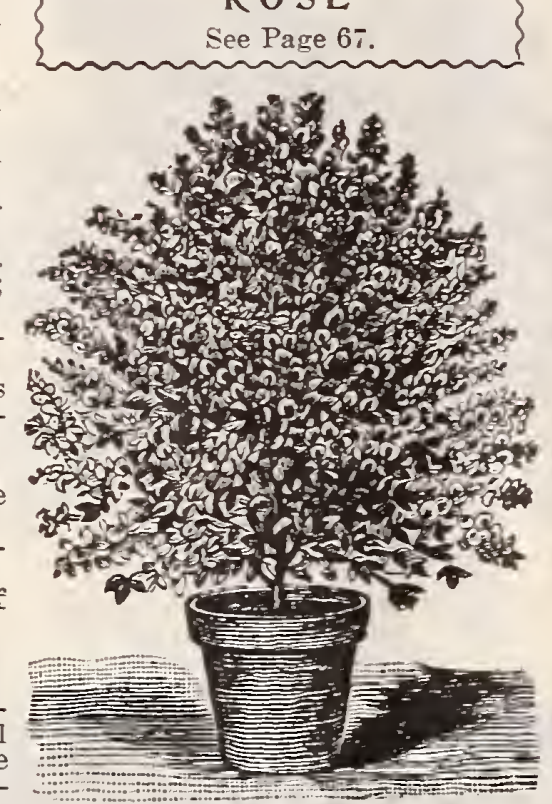

20c.
Genista (Shower of Gold).
GENISTA CANARIENSI. (Shower of Gold.) A beautiful yellow flower
plant that grows and fow
freely with ordinary care, fl
ering so freely as to litera
corer the plant with its
golden yellow blooms when
grown. A very popular pha
for Easter decorations, at Wh
torme it is usually a mass
bloom. 15. each, postpaid.
blom. HELIOTROPE. The Heliotrope is prized more for its fragrance than for the
beauty of its flowers, though as
grown to-day ther are very handculture, a single plant filling a $10 c_{\text {. }} 3$ for $25 \mathrm{c}$, doz. $\$ 1.00$, postPaid. BERT DELEAUX.

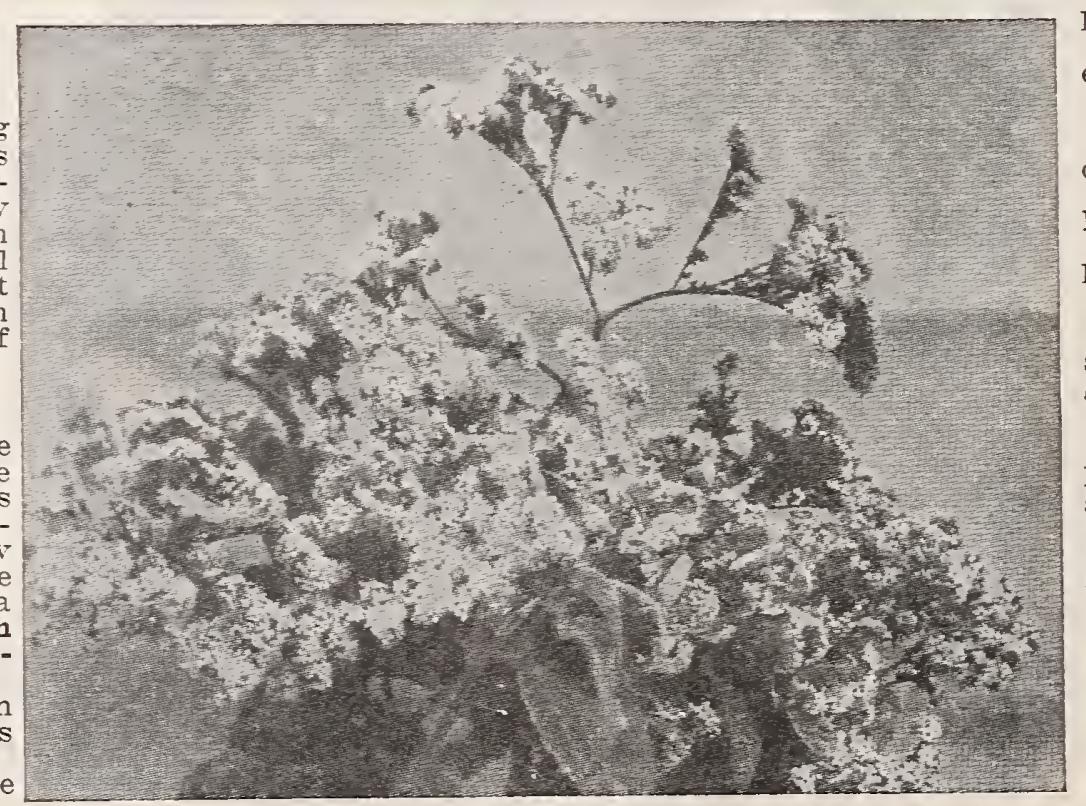

Heliotrope, a favorite with everyone.
AIPHONSO RICCARD. Bright vermilion

A. H. TREGO. Dazzling crimson scarlet, AIIrANCE. Iilac white, blotched crimson BEAUTY POITEvINE. Rosy salmon, semiFIEUR BIANC. Beautiful pure white. JEAN VIAUD. Semi-double, pure pink. IA INCONTABIE. Rose color. MAD. ROZAIN. White. 15c. each. PRIDICTION Cerise pink. S. A. NUTT. Dark crimson. 15c. each. IA FAVORITE. Snowy white. Each 15c. IA FAVORITE. Snowy white. Each 15c. VIIIE DE POITIERS. Intense pure scarlet. MISS FRANCES PERIiNs. Beautiful pink.

BEST SINGIE VARIETIES.

AIICEOF VINCENNES. White veined scarlet. GRANVIIIE. Soft, clear pink.

JACQUPRIE. Dark crimson scarlet. MRS. E. RAWSON. Salmon-sliaded crimson MARs. Single. rose shading to white.

MRS. E. G. RIyI. Single salmon.

MRS. J. M. GARR. Single white. MAS. POIRIER. Violet carmine, single flower. QUEEN OF THE WEST. Single scarlet. (I $\nabla$ Ieaf.)

BEAUTY OF CASTIE HIII. Soft rose color JEANNE DE ARC. Very SOUV. CHAS. TURNBE. Flowers bright pink.

(Variegated Ieaved.)

MRS. POIIOCK. Golden triMOUNTAIN OF Sirow. Large IMAD. SAIIIROI. S ma 11 aves, tinted white.

(Sweet Scented.)

ROSE. This is the most desirable of the scented and fragrant varieties.

\section{(Iady Washington.)}

SANTFORD'S SURPRISE. Big black blotches in upper petals, edged fiery red, surrounded with bright red er petals wher each. 30c. each. MRS. SANDIFORD. A splenMRS. SANDiforD. A fower, some flowers showing a small rich maroon spot in upper petSANDIForD's BEST. A beauiful shade of pink, surrounded with a deep band of the purest $30 \mathrm{c}$. each; the set of 3 for $75 \mathrm{c}$. 


है GROWN BY THE FAMOUS COLD SYSTEM. हु?

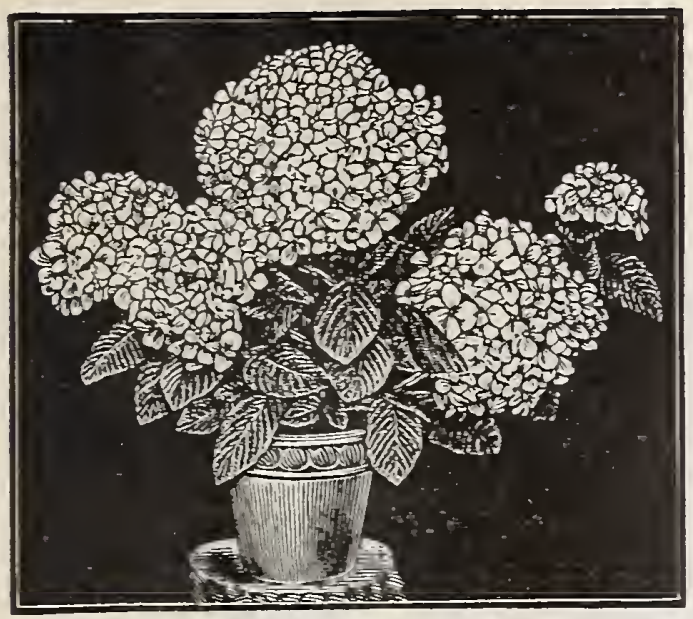

Ejarangea.

HYDRANGEA.

HORTENSIA. The well-known and favorite old variety, producing immense clusters of pink blooms. Each $25 \mathrm{c}$., postpaid.

THOS. HOGG. Large. pure white flowers, produced very freely. Each 25 c., postpaid.

\section{HIBISCUS.}

COIIERI. Lemon yellow, base of petals cimson scarlet. Each 15c., postpaid.

COOPERI. Foliage rariegated. Flowers single, imson. Each $15 \mathrm{c}$., postpaid.

d. Each 25 c., postpaid.

d. Each 25c., postpaid. Each 25 c., postpaid.

All summer and fall handsome and very striking covers itself with son, shading darker in the throat. Each $25 \mathrm{c}$. postpaid.

\section{HONEYSUCKLE.}

FUCHSIA FIOWERT.

with long trailing branches with beautiful trumpet-shaped blossoms. Each 15c., postpaid. GOIDEN IEAVED. A most beautiful little house plant with golden vellow leaves, mottled and veined green. . Each I0c., postpaid.

HOYA CARNOSA (Wax Plant).

The flowers are blush-white, resembling wax, and are borne profusely in large umbels. The foliage is thick and fleshy, and extremely handsome in appearance. It is a quick grower and time. Fach 25c., postpaid.

\section{IVY.}

GERMAN OR PARIOR.

G kets and vases. Tender. Each 10c., pos's paid.

FNGIISH. The old popular variety Hardy. Each 10c., three for 25 c., postpaid IMPATIENS.

SUITANI. A perpetual bloomer, bright rosy-red flowers. Each $15 \mathrm{c}$., postpaid. HoISTII (New). One of the finest shade. Each 15c., postpaid.

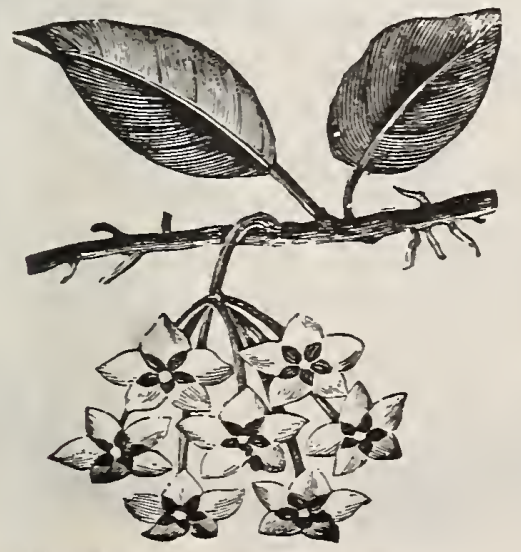

Foya Carnosa (Waz Plant).

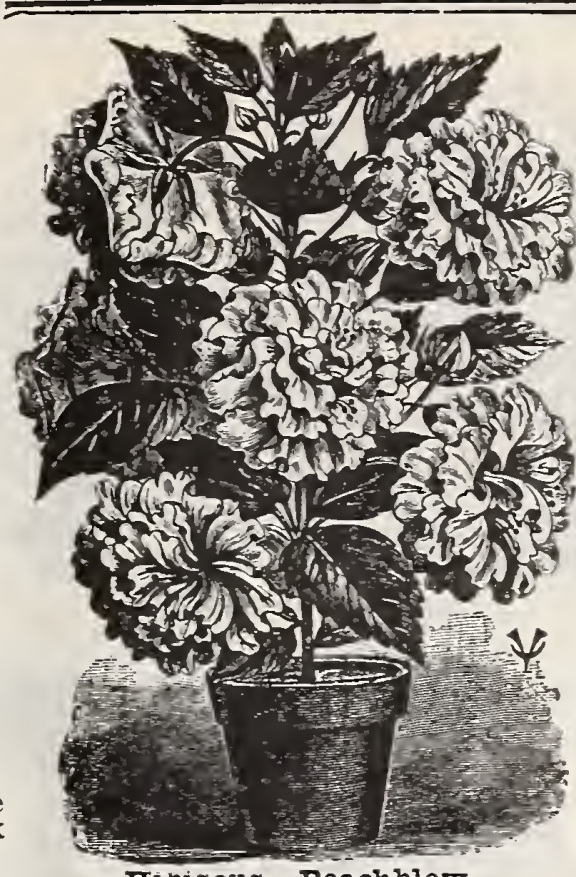

Bibiscus, Peachblow.

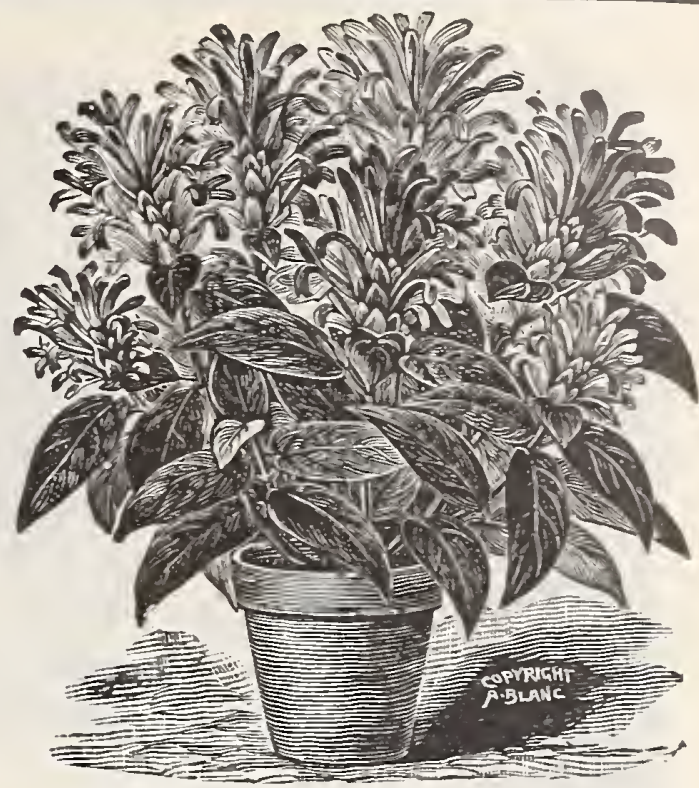

New Justicia Velutina.

JUSTICIAS (Plume Plants).

These flowers, when quite young, throw up large, pl

FIAVA. Wellow. New and desirable. Each 2c., postpaid.

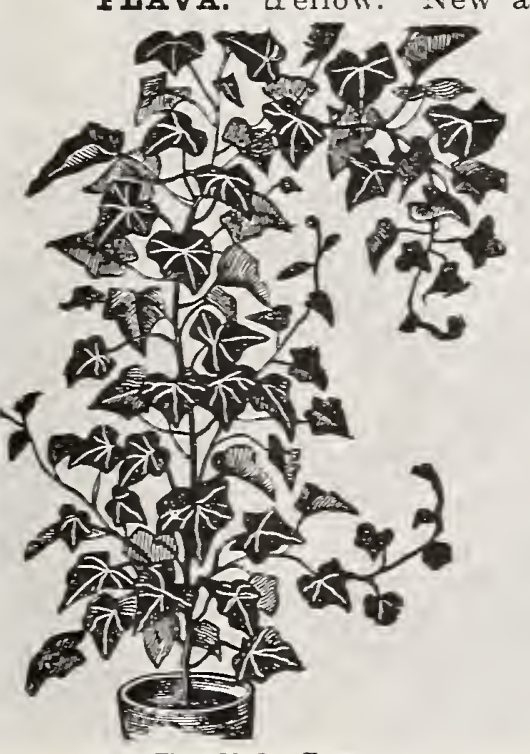

English Ivy.

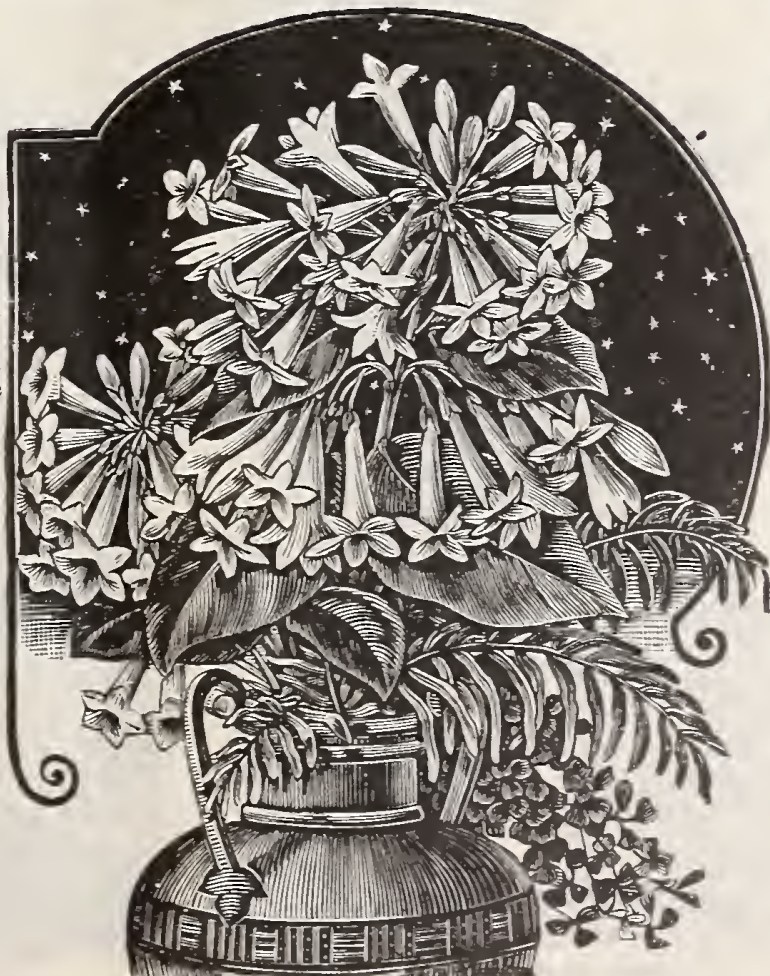

Night Blooming Jessamine.

\section{VEIUTINA. Grown exten} ters of large, pink, feather-like for a long time, and is never thereafter out of asy growth. Each 20c., postpaid.

JESSAMINE (Night Blooming).

fully fragrant at night. It commen aloom through summer's heat and winter's cold Fach 25c., postpaid. dense cluster of pure white fragrant flowers, postpaid.

MAID OF ORIFANS. Elegant fragrance, and pearance. Each 15c., postpaid.

LANTANA.

The Lantana produces a compact head of flowcrimson, scarlet and yellow-sometimes HENDERSON. Beautiful orange, changgach 10 c., postpaid. IA NEIGE. Pure white with faint NEW wErPING. This Lantana is ne plant, of graceful, drooping habit,

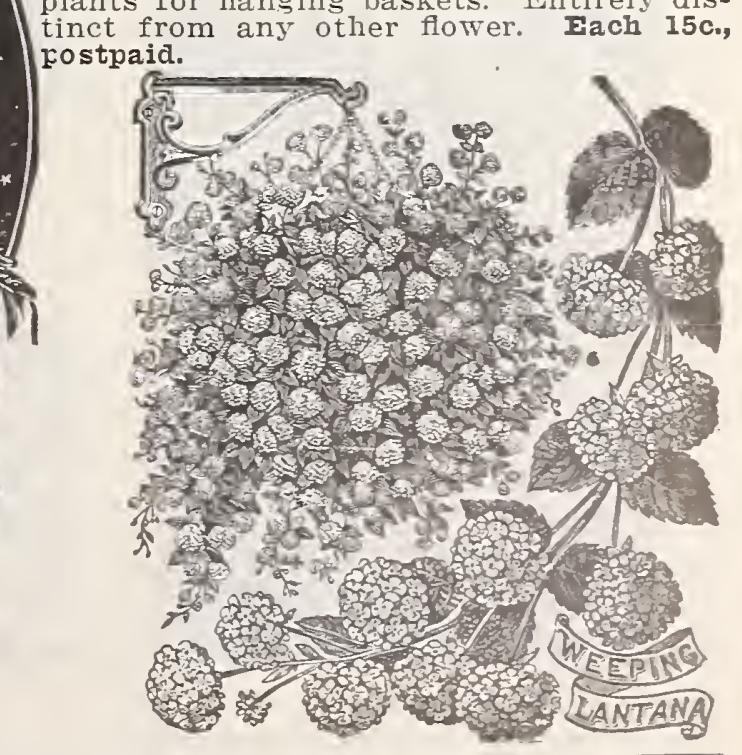




\section{IF YOU WANT THE BSST, BUY MAY'S PLANTS, 2}
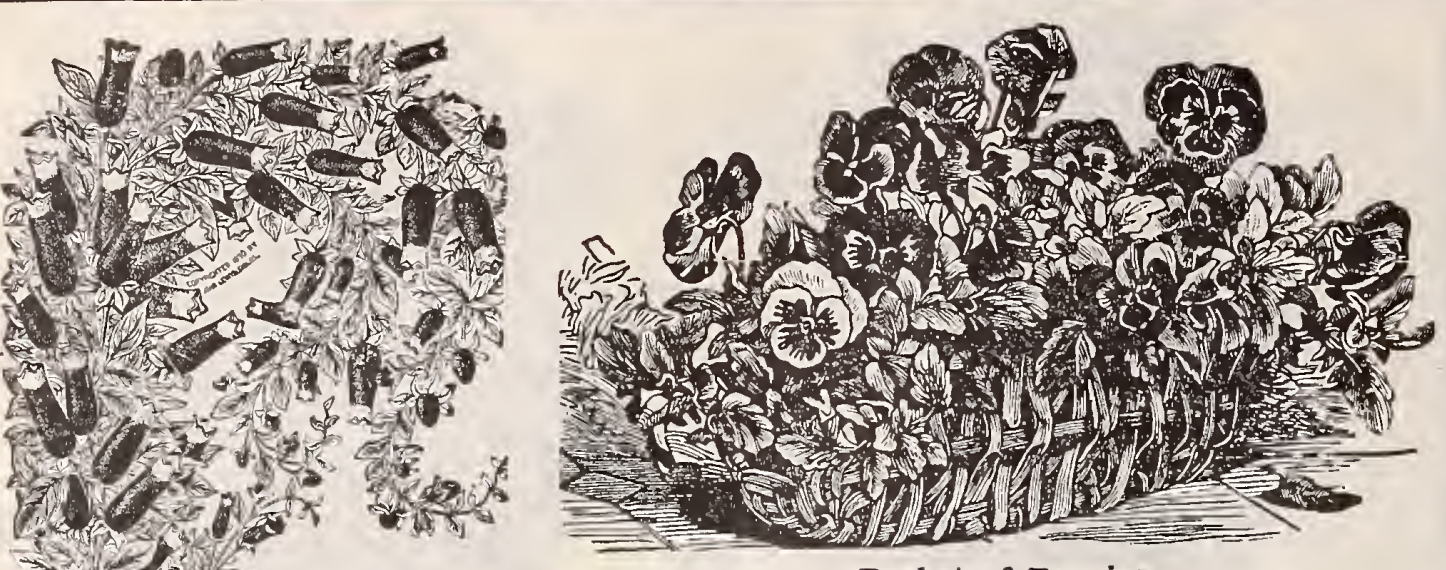

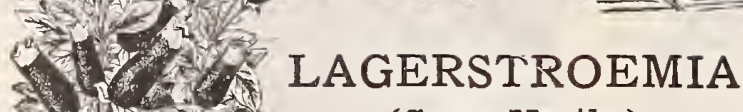

\section{(Crape Myrtle.)

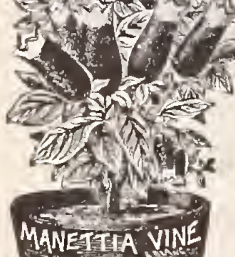 \\ MANETTIA VINE.}

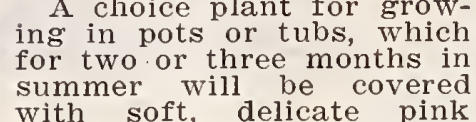

Basket of Pansies.

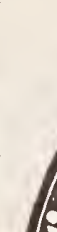

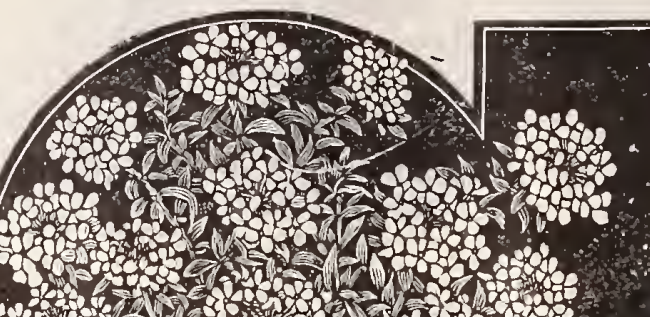

IMANETTIA BICOIOR.

twinin

are intense fiery scarlet, with
yellow tip. Each 15c., postpaid. MALABAR VINE.

ing plant. The leaves are light creamy and green. Flowe.

MINNEAPOLIS VINE.

ring porches, trellises, screens, etc.

Each 10c., postpaid.

OLEANDERS.

Each 30c., set of 3 for $75 \mathrm{c}$., postpaid. PRINCE AIBERT.

IA ROSFRIE.

GOIDEN WEST.

PANSIES.

and bloom at any time. Each 10c., $40 \mathrm{c}$., 100 for $\$ 3.00$.

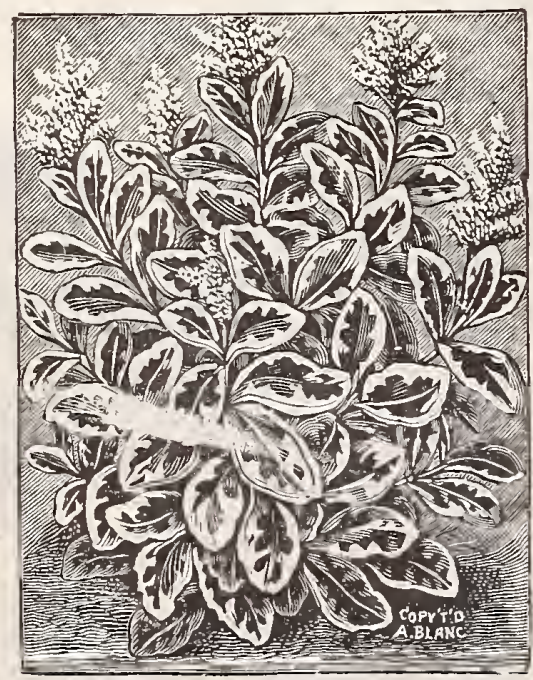

Malabar Vine.

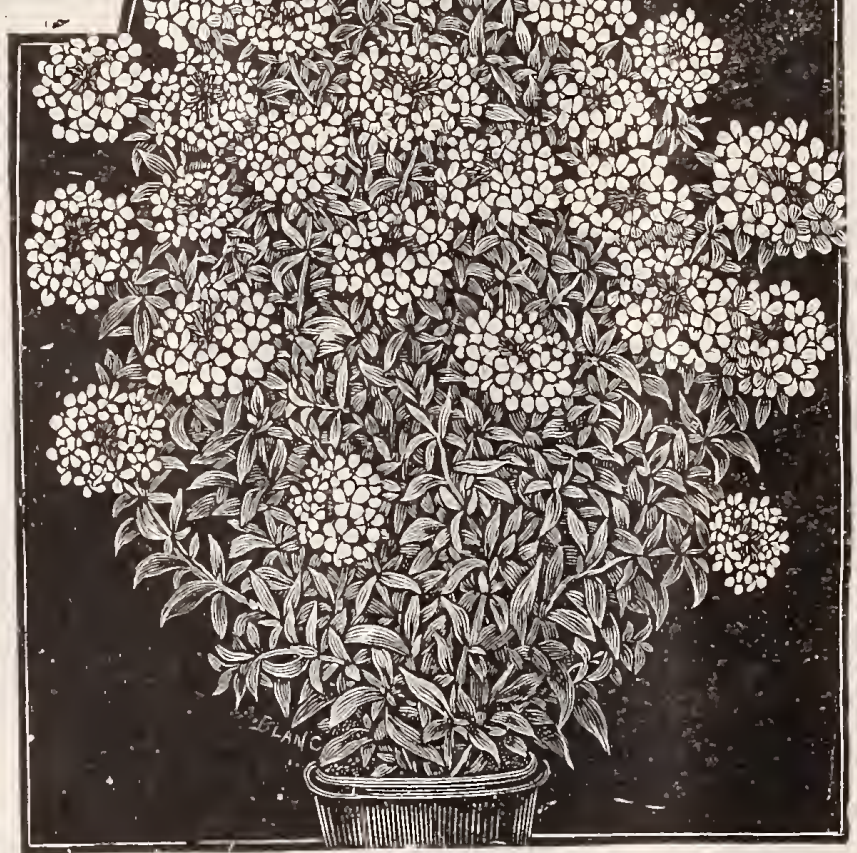

Plumbago Capensis.

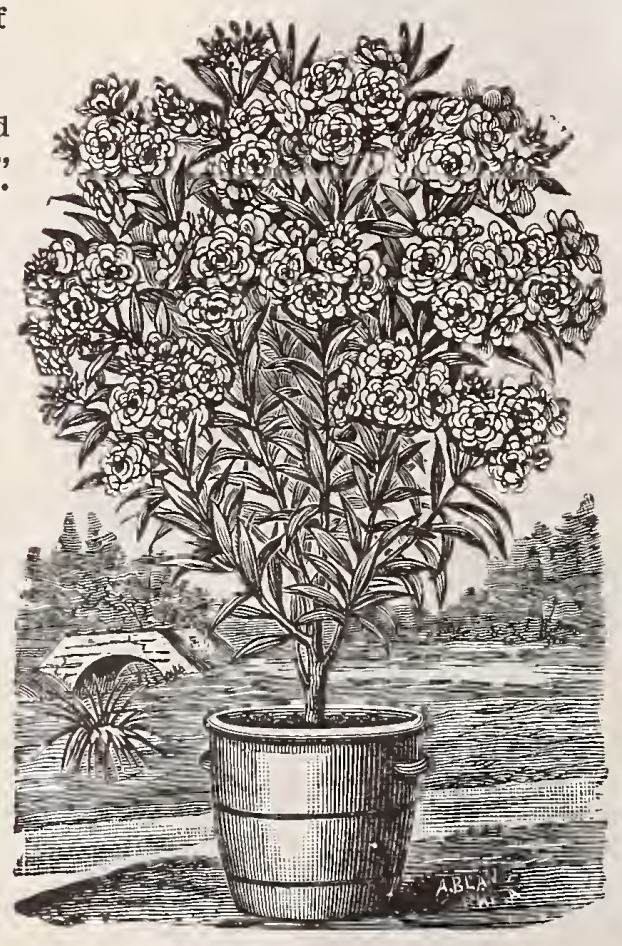

oleander.

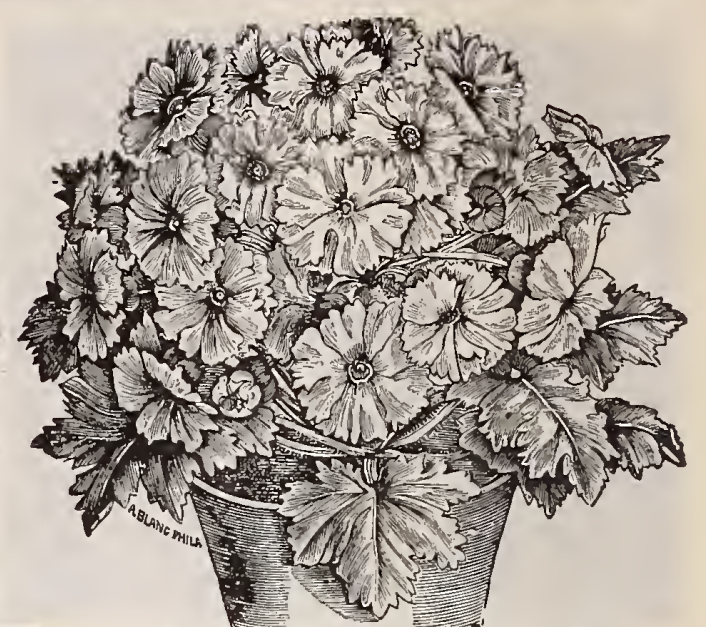

Primula (Chinese Primrose). PASSIFLORA (Passion CONSTANCE EIIIOTT. BloSSOMS pure white except a slight coloring at PFORDI. This is the best variety very freely, even on small plants. Rich shade of blue, suffused with rose.

\section{PRIMULA Primrose.)}

Our stock has been grown from the hoicest strain of seed to be obtained. strong plants, each $15 \mathrm{c}$., postpaid. FORBESI (Baby Primrose). A new most prolific bloomers we have ever pinkish white, borne on long stems. Each 20c., postpaid. trong, compact grower, with beautiful green leaves and tall, graceful stems, bearing large fringed flowers of a deli
cate pink tinge. Each 25 c., postpaid.

\section{PETUNIAS.}

15c. each or set of 4 for 50c., postpaid. SNOWBAIL. Double white, imADONIS. Double. A delicate shade of pink. Da . Double. An elegant red varimz. Double. Deep purple,
marked and penciled with cre $m$ and

\section{PLUMBAGO.}

Plumbagoes are always satisfactory plants, ers and their delicate and graceful CAPENSIS. A well-known favorite. Beautiful CAPENSIS ALBA. Flowers creamy white. Each 15c., postpaid.

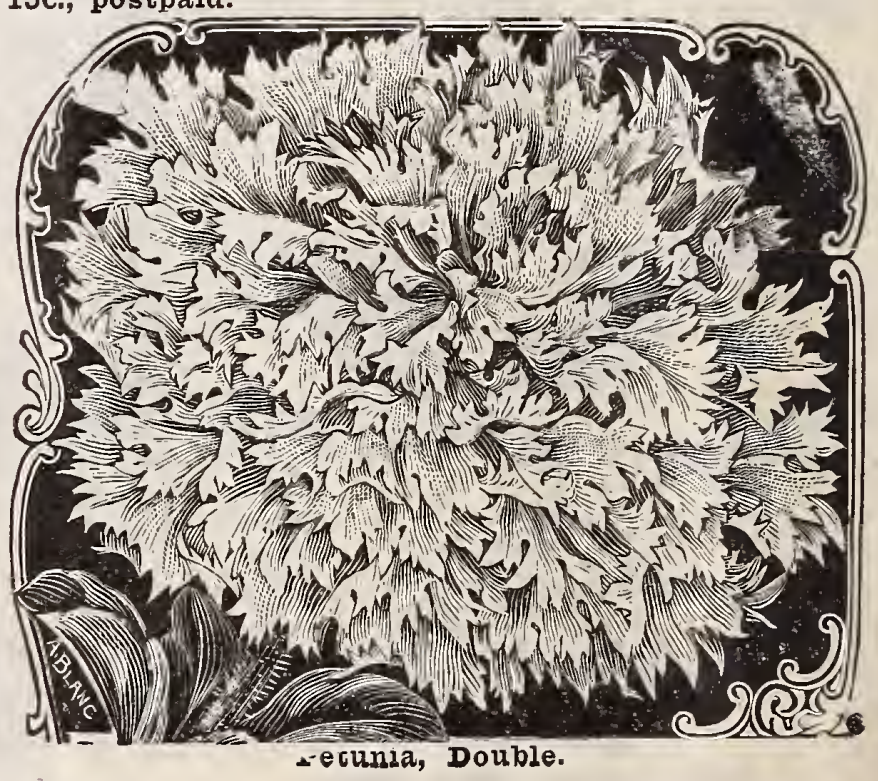

L. L. MAY \& CO., ST. PAUL, MINN. 


\section{G. GROWN BY THE FAMOUS COLD SYSTEM. हु?}

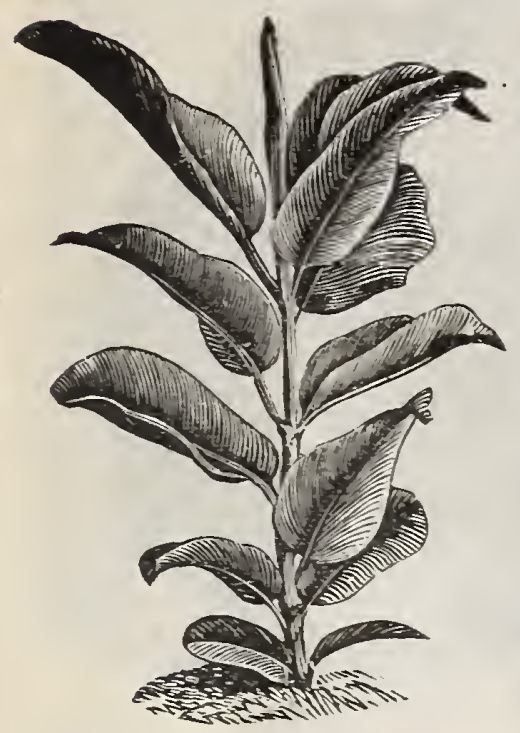

Rubber Plant.

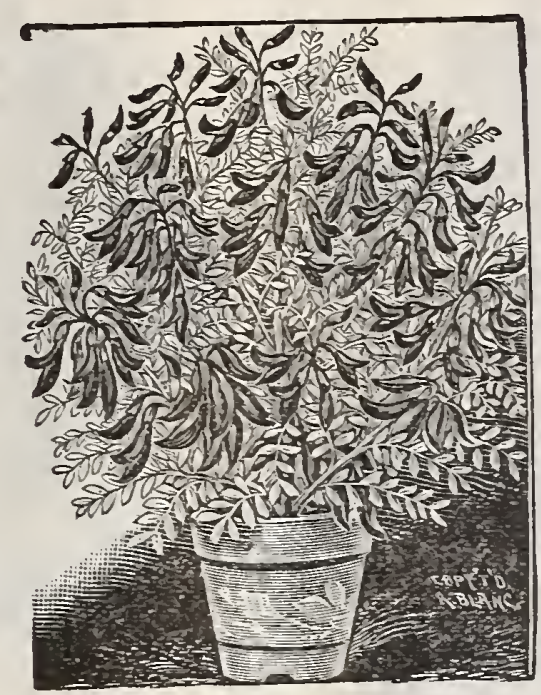

Sutherlandi.

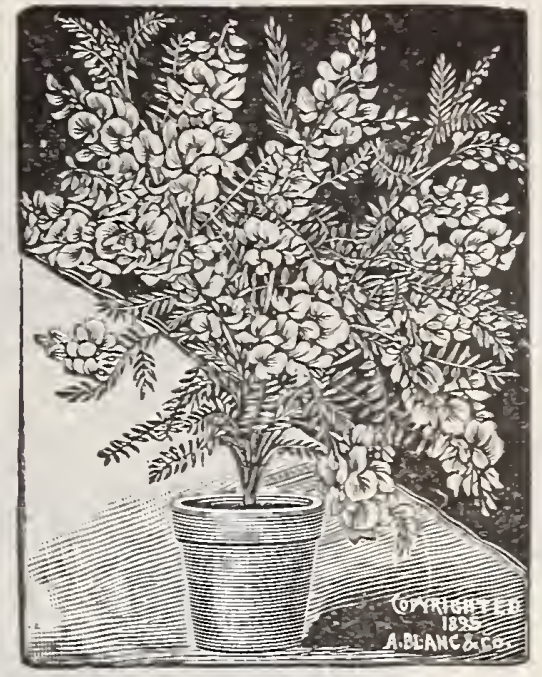

Swainsonia.

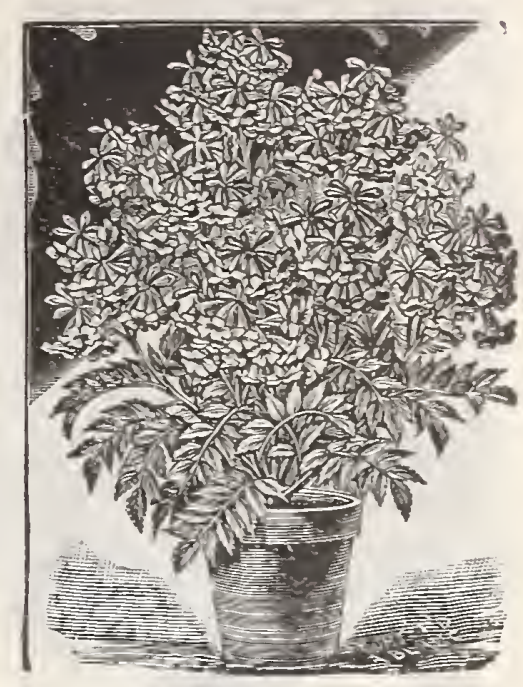

Tecoma Smithii (Australian Beauty).
RUBBER PLANT. (Fiscus Elastica.)

A very graceful, ornamental plant with broad, glossy leaves of deep
$\$ 2.00$ each.

\section{RUSSELIA JUNCEA.}

It produces numerous long, wiry stems, which are leaf¿se ana shape ot IIanettia blossoms. 15c. each.

\section{SERISSA.}

It has bright, glossy green foliage, and produces

\section{SOLANUMS.}

Capsicastrum. (Jerusalem Cherry.) A dwarf branchance of small scarlet verries during the fall and winter. Very handsome and decorative. $15 \mathrm{c}$. each.

Jasminoides Grandiflorum. A be autiful shaped lowers borne in clusters of purest white, with a violet tinge on back of petals. $15 \mathrm{c}$. each.

\section{SMILAX.}

$A$ beautiful climber of rapid growth and easy culture. 15 c. each.

\section{STROBILANTHES, (Porto Rico Coleus.)}

The leaves are beautifully variegated with a deep metallic purple shaded with bright rose and margined light green. It is particularly fine for beds and border and is entirely distinct from any other bedding plant. It produces small spikes of bloom, but its chief value lies in its. decorative bright and effective and at all times presents a very pleasing appearance. 10c. each, $\$ 1.00$ per doz.

SUTHERLANDI. (Scarlet Bush.)

It is of dwarf, compact habit, with bright green foliage delicately cut. The flowers, which are borne in great procolor brilliant scarlet. $15 \mathrm{c}$.

SWAINSONIA ELEGANS.

The flowers are of the most beautiful shade of rose, freely produced. Fine for cutting. $15 \mathrm{c}$. each.

\section{THUNBERGIA FRAGRANS.}

A magnificent variety of climbing habit, deep green waxy leaves, and flowers as large as silver dollars, of pure waxy or throat. 20c. each.

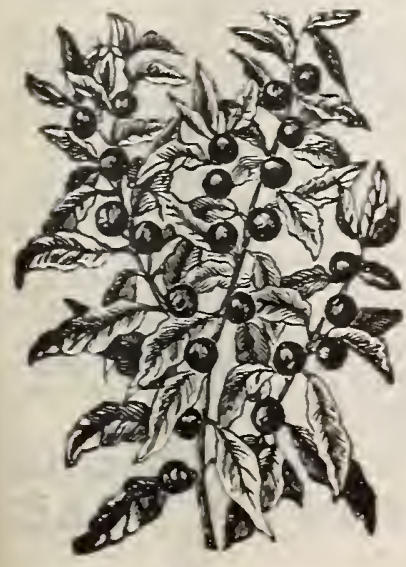

Solanum.

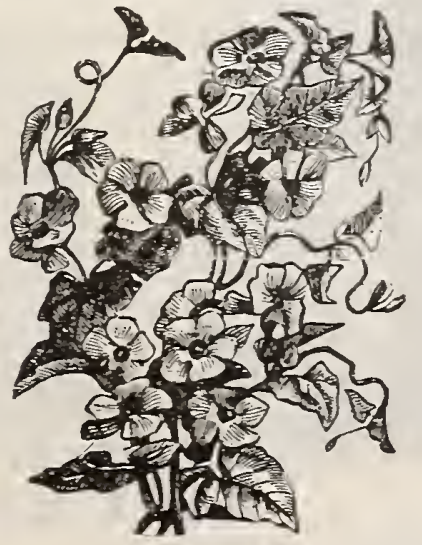

Thunbergia.

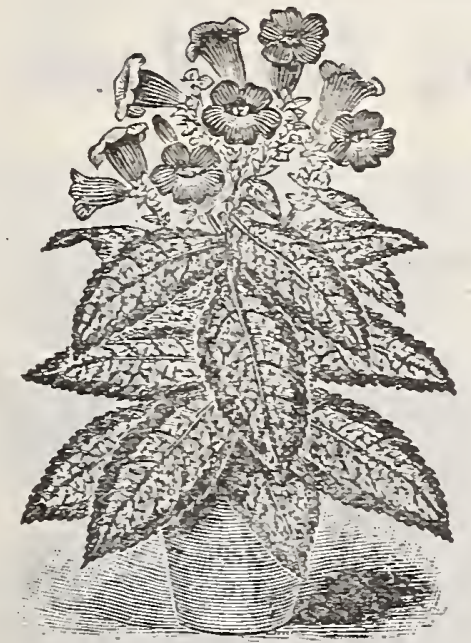

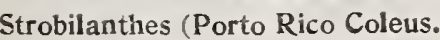

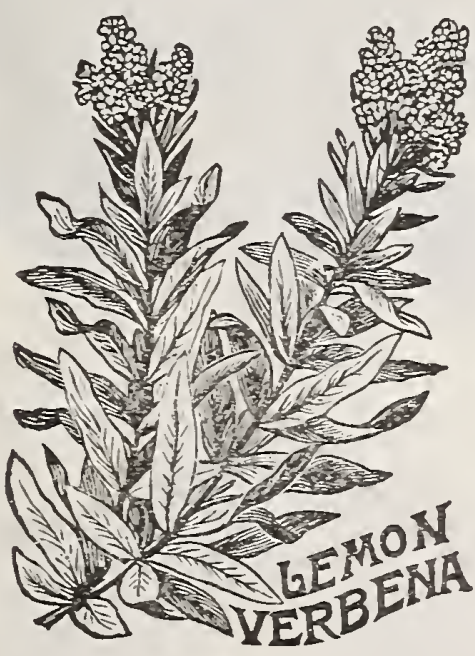

TECOMA SMITHII.

warf, bushy trumpet creeper, with flowers over in length, of a rich lemon color shading to dark each

\section{VERBENAS.}

the giant flowering varieties.

\section{LEMON VERBENA.}

A beautiful plant with rerbena-like foliage which is doVINCAS.

Major Variegata. Trailing vines for windor boxes, variegated leared, 20c, each.

\section{VIOLET.}

Princess of Wales. The flowers are single and cover a silver dollar; they are borne in great profusion on stems 10 to 12 inches high all through the season. The color is true violet blue and the fragrance rich and delicious. The plant is a hardy and vigorous grotrer and most abundCalifornia.

ciously fagrant and borne on long, stout stems. 10c. each. Double Russian.

hardy. requires no protection; immense bloomer; extra
large, perfectly double flowers borne well up on long, stout
stems, lovely deep blue and exceedingly sweet; extra value
every way. 15c. each BEDDING PLANTS.

bloom, for immediate effect in May or June.

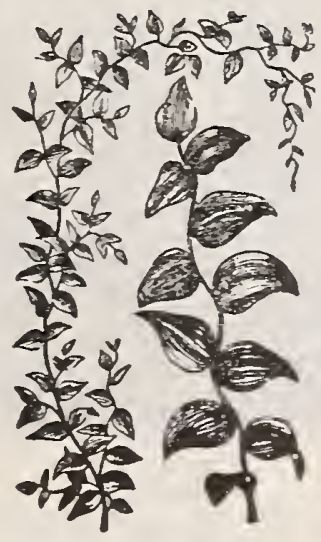

Per Doz. Per 100

AGERATUM, Blue................. \$1.00 \$ 6.00

ALTER NANTHE $\quad 75 \quad 4.00$

ASTERS.

ASTERS.

CANAS.

COLEL

DUSTY MHLLER

GERANIUM

LOBELIA

PANSIES.

PETUNIAS. Single

ROSES. From 2 -in.

VERBENAS. 

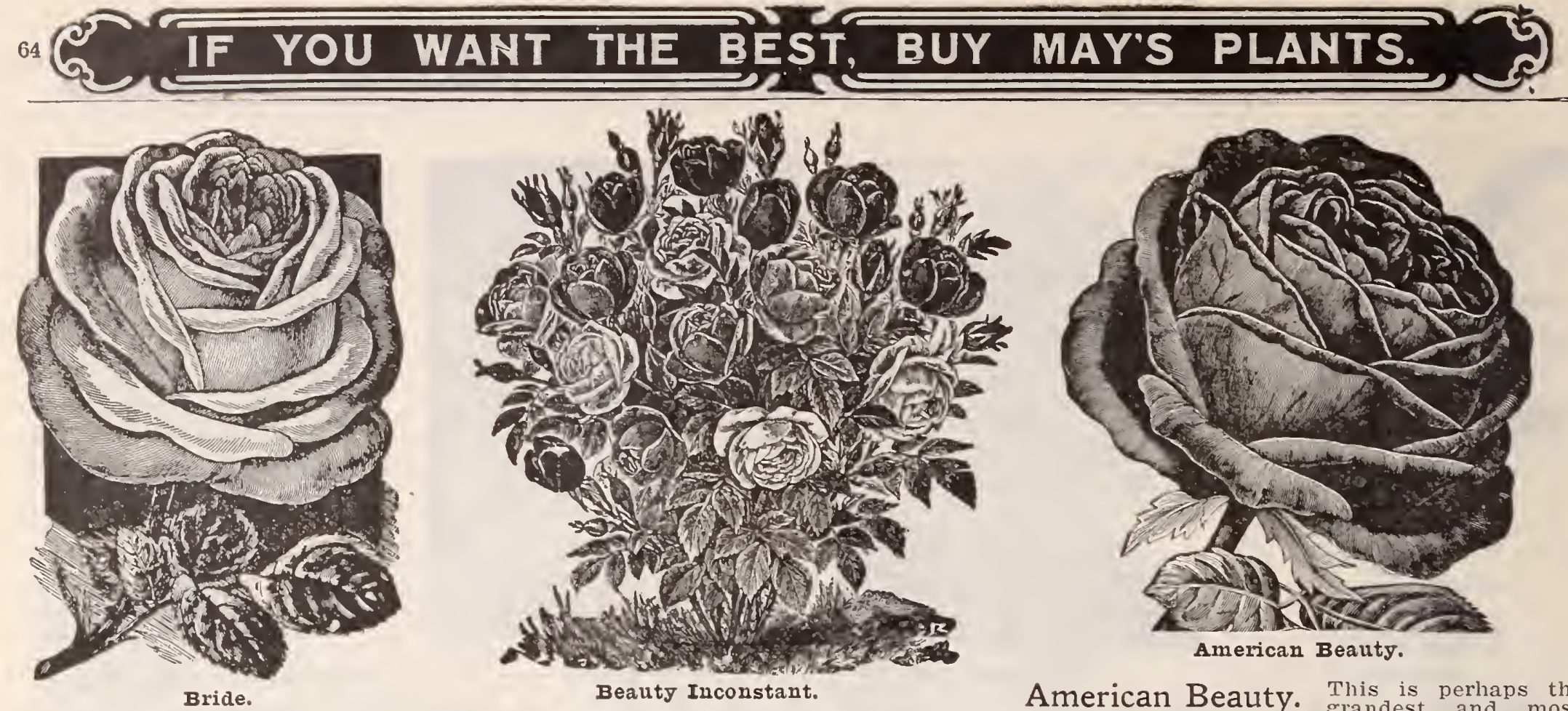

\section{Monthly Ever-Blooming Tea Roses.}

Our Growing Methods Differ radicalnever force our young plants. The
grown in a cool situation, thoroughly
rooted in sand, then potted up and kept
ing slowly. This gives them an abun
of fibrous roots and a strong, healthy
stitution. Plants grown in this manne
ship a long distance in perfect conditio
commence growing vigorously the m
they are transplanted.
Everblooming Tender Roses.

beds, producing an abundance of bloom the
entire season. They are also well adapted
for pot tains the best roses grown, and will afford Unless otherwise noted, $10 \mathrm{c}$. each, $\$ 1.00$ per doz., postpaid. By express, $\$ 5.00$ per 100 , for Betty.

with golden yellow). It's deliciously per-
fumed blooms are extremely large, full and long, and it is never out of bloom from early
June until cut off by frost. It is a Rose that postpaid.

Bridesmaid.

Each 25c.,

scented; color, clear rose-pink. A free
and constant bloomer; makes elegant

Bride.

ers, pure creany
ed blush; ear
Richmond.

a real red rose as flowers mature Flowers full an nomenass of color produced being pheSucceeds under the most ordinary conOur Bargain Collection of $6 \underset{\text { everblooming }}{\text { choice }}$ Tea Roses for 50c. See page 68 .

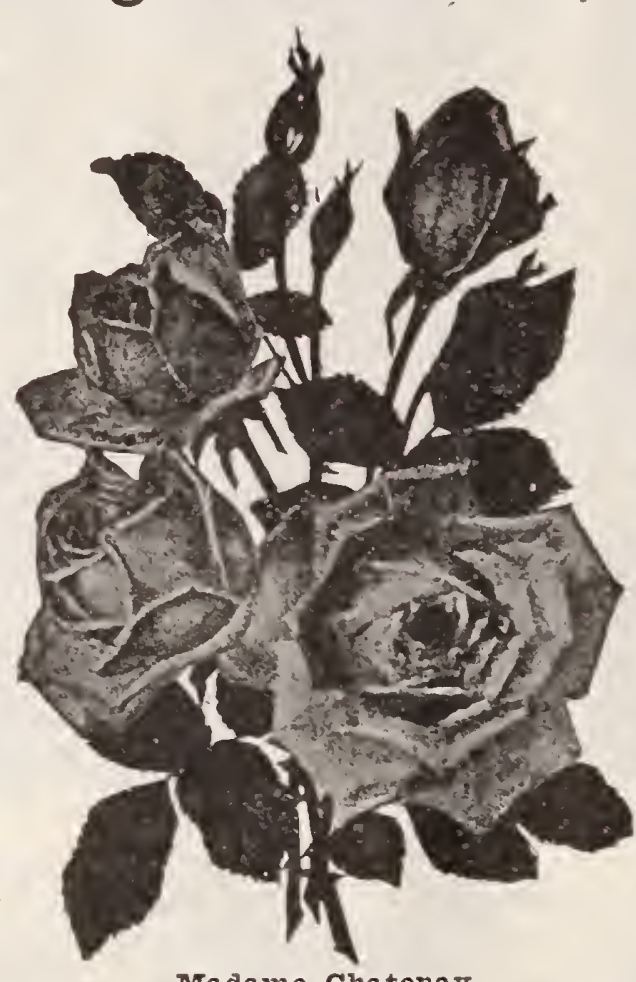

Madame Chatenay.

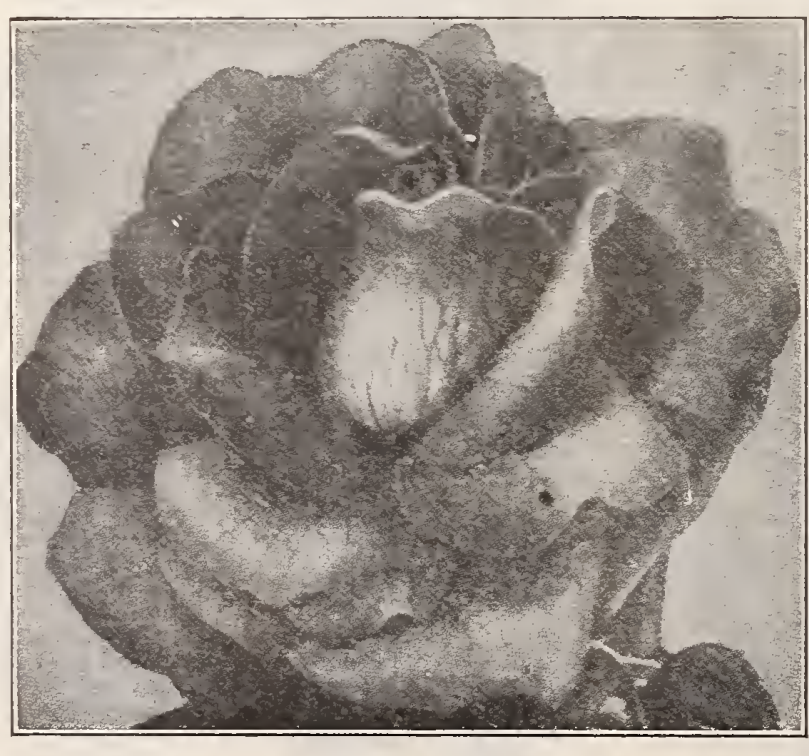

Richmona. paia.
American Beauty. This is perhaps the beautiful rose now linown It is a genuine Hardy Ever-Blooming Rose For immensity in size, rich color, exquisite form and delicious fragrance it stands without an equal. It is a quick and bushy grower and a continuous
bloomer, makes magnificent buds and large, deep, double flowers, and is valuable both for house and garden culture. Color is a rich, rosy crimson, shaded and reined in the most

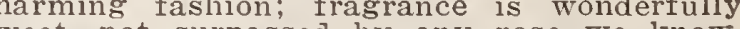
15c. each, postraid. Strong 2-year-old dormant plants 40c. each, postpaid, or $\$ 4.00$ per doz., by express or freight. Madame Chatenay. A rare and verytiful rose of novel distinct color, rich golden pink or rose flushed with orange and fawn. Flowers large, well filled and very fragrant. A strong, healthy fine for the yard or garden. Each 15c., postpaid. Ivory. This exquisite new rose resembles the Golden Gate, in form and exeliness, but is pure ivory white. It is an with lovely buds and flowers the whole growing season; the buds are wonderfully beautiful are large, full and sroeet Beauty Inconstant. This is the most reintroduced. A single bush will at the same time bear flowers of various colors, ranging from crimson to light pink, through the varisalmon. The buds are particularly basutiful, large, pointed and N'ell made. 20c. each, post-

Perle Des Jardens. Clear golden yellow. and beautiful shade, entirely distinct Clothilde Soupert. For pot culture is a strong, dwarf grower, and most is a strons, dwarr grower, and most Wonderful bloomer, being continuously
in flower the entire year. The blossoms are large, round, flat, perfectly full and double, and deliciously fragrant. The color is pure white, shading Pink Soupert. A worthy companion to the White and the White Soupert, but of a deep, rich pink color. Yellow Soupert. bines the form and size of the Tea Roses with the free flowering, branching habit of the Polyanthias; may be left in open ground ter. Color, light yellow, shading to white at edge of petals. Price of Souperts, 10c. each, $\$ 1.00$ per doz., one of each fo: 25 c., postpaid.

See page 67 for the Wonderful BABY RAMBLER ROSE 


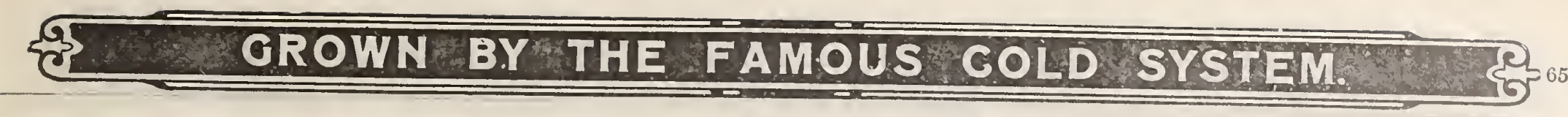

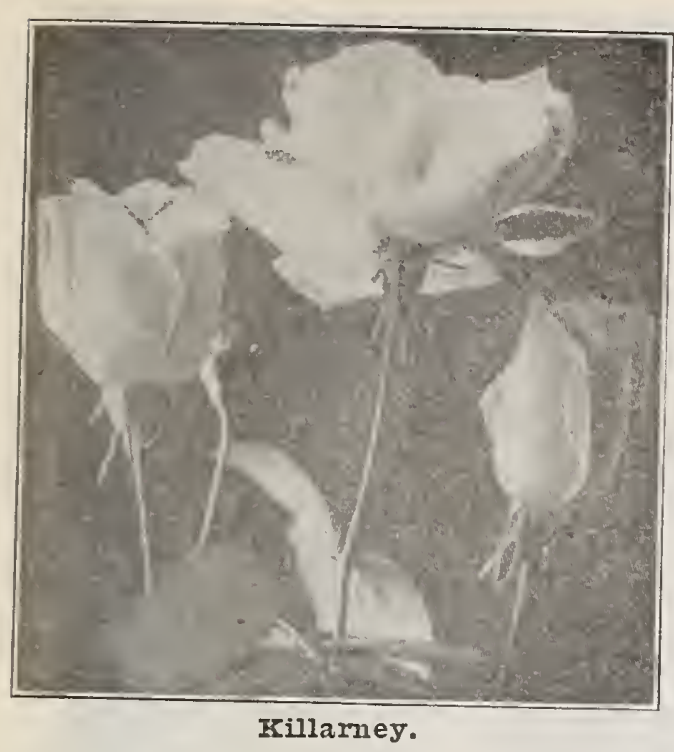

Killarney. No other rose has attracted so much Tea Killarner. Coming as it does from the north of Ireland, it seems to revel in our more genial wherever tried. It is a strong, robust grower and free and continuous bloomer. The color is brilliant sparkling pink: the flowers

are extra large and full, with broad, thick petals and delightful tea tection it is quite hardy, and altogether a rose of great beauty and excellence. Each 15c.

President Carnot. The flowlarge, full and double, exquisitely shaped, with heary, thick, shelllike petals. The buds are wonderfully beautiful-long and pointedperfection in every line. The color triffe deeper at center of flower. Fragrance delicious, strong grower and free bloomer, has no weak Etoile de France. The gold of France, and claimed by the raiser, J. Pernet Ducher, to be the finest rose he has ever sent out. A very strong, vigorous grower, with handsome green-bronzy foliage, and exceedingly free flowering. The flowers are very large and borne on good, long, stiff clear, red-crimson velvet: very fragrant and keeps well. Each 15c. Moulton. An ideal rose in color, shape and size; outer petals delicate light pink opens up perfectly, keeps its color well and petals do not drop off like other roses of this class: lons, stiff stems. Each 15c.

Golden Gate. A variety of growth, clean, healthy habit of foliage and handsome bloom, The blossoms are of largest size and Each 10c.

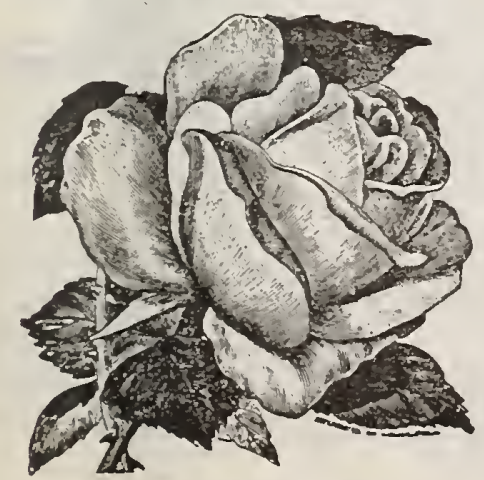

Golden Gate.

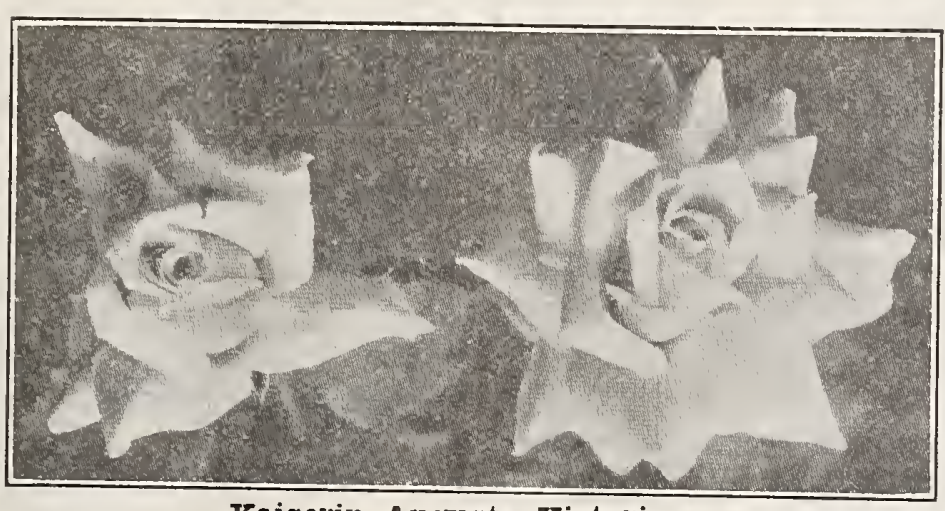

Iraiserin Augusta Victoria.

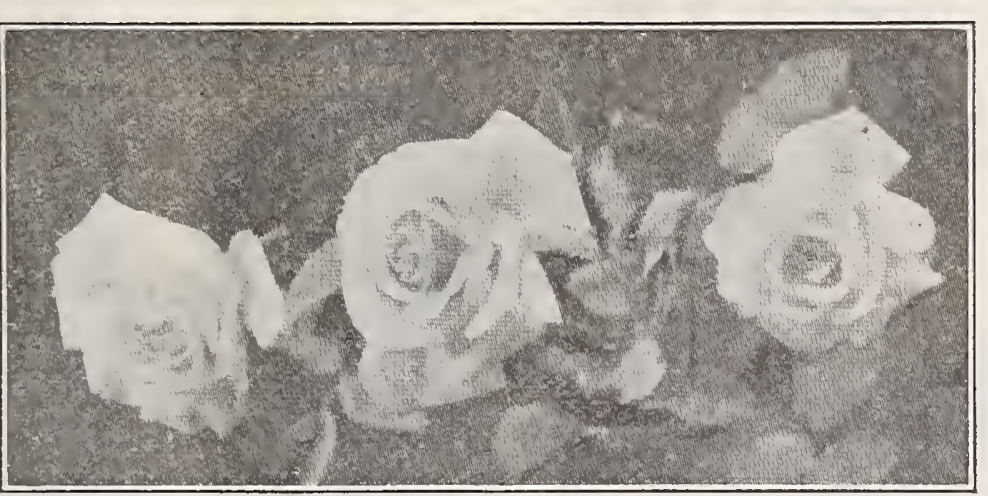

President Carnot.

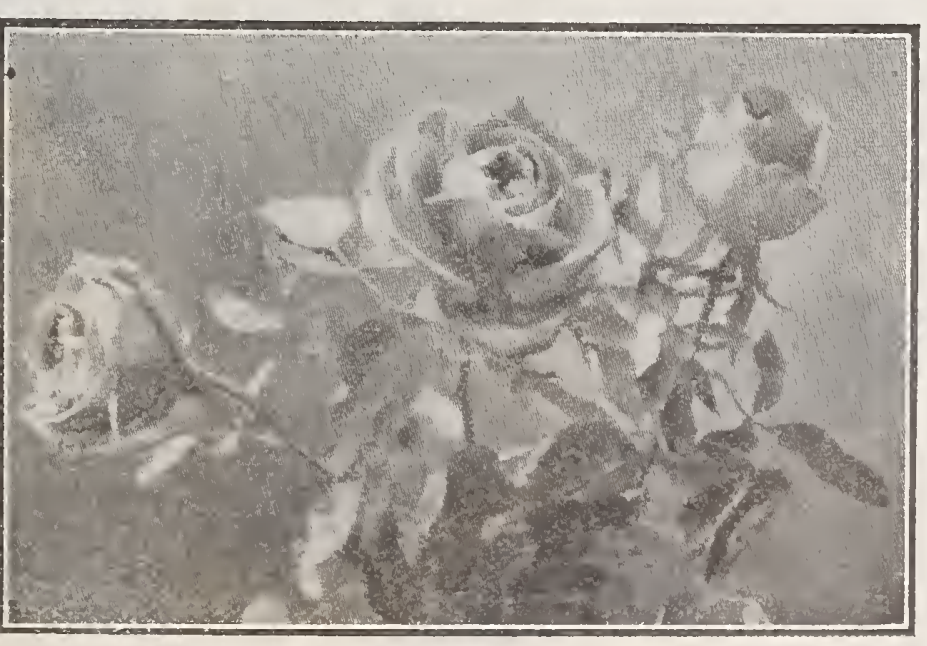

IMoulton.

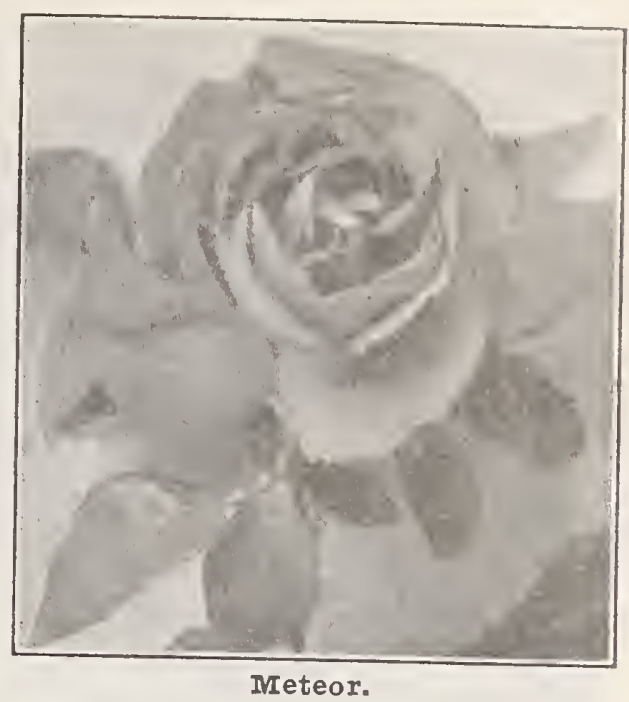

Kaiserin Aug̊usta Victoria.

most beautiful of all Roses for open of the buds and large full double flowers, which are delightfully fragrant. Color is a delicate creamy white. Each loc. Meteor No red rose is better for general purposes any perfect shaped flowers on or long stems. The color is rich velvety crimson; plant is of vigorous growth and very free-flowering; a
constant bloomer. Fine for bedding or pot culture. Each 10c.

Liberty. This variety, the acme rose growers domain, will fill the long felt want, not only with the ers for profit, but who wants flowamateur, who grows them for the ure and the grows them for pleasIt is an ever-blooming hybrid tea, said to be hardy in many localities ous grower. It is a rapid, vigorwith a beautiful, clean, healthy foliage at all times. The color is a deep, glowing crimson the petals being covered crimson, the petals bloom. It is very rich, velvety sembling the Hybrid Perpetuals in this respect. The buds are of gradually expanding appearance, soms of the largest size, which last a long time. Planted in the open ground it makes a wonderful growth, and is covered profusely large, fragrant blossoms. As a pot plant it is without a peer, as it forms a compact, bushy plant, bud and bloom. Each 15c.

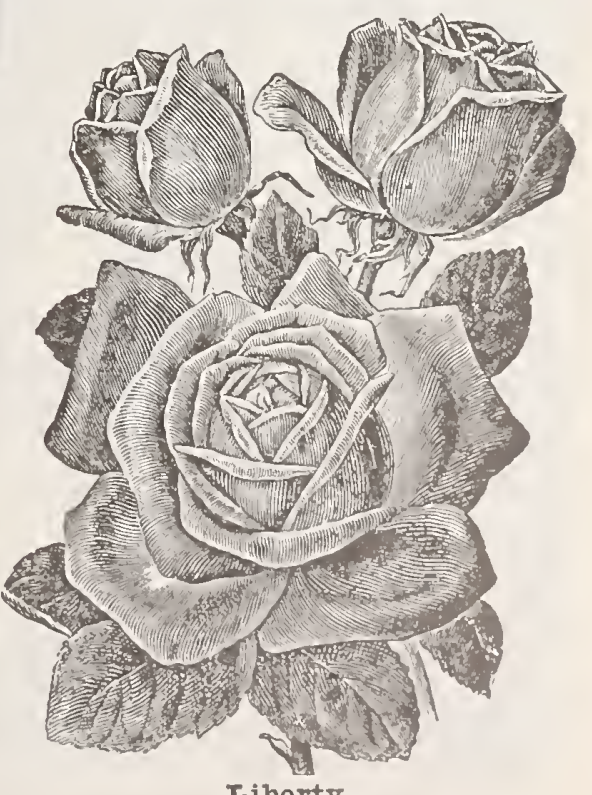




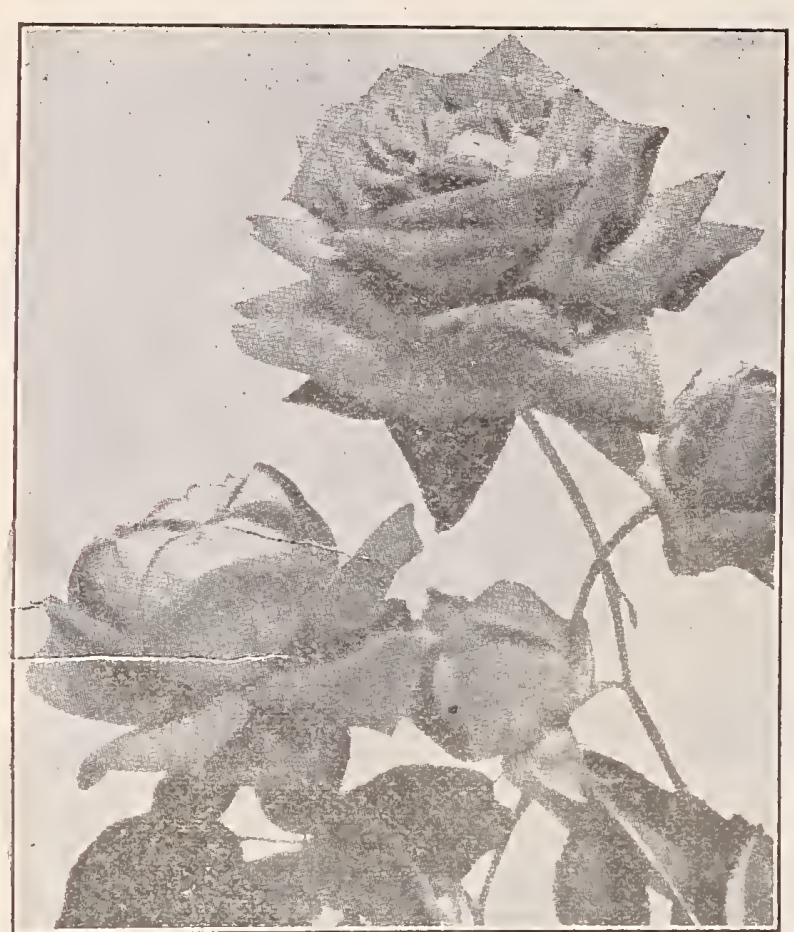

Princess Camille De Rohan Rose.

MARGARET DICKSON.

Distinctively a garden Rose, and 作 MARSHAII F. WIIDER. crimson, richly

generally, as its ease of grow th, freedom of blom and fine

MRS. JOHN IAING. Rich satiny-pink, large and full, deprious fragrance. This fine rariety cannot be too highly praised. For freedom of bloom it is unsurpassed in its class, For 50 cents we will send, by mail, postpaid, the above
dormant plants for $\$ 1.50$ by express, at purchaser's expense.

\section{GENERAL LIST OF HARDY HYBRID PERPETUAL ROSES.}

ALFRED COIOMB. Brilliant carmine imson, very large, full and of fine form.

ANNA DE DEISBACF. Briliant rose colBARON DE BONSTETTIN. BARONESS ROTHSCHID. Bright rosy pink, of immense size and globular form, someCIIo. Delicate satin blush, COQUETTE DES AIPS. Large, full flowers of pure DUKE OF EDINBURG. A sturdy, compact grower. Blossom large and full, bright scarEARI OF DUFFERIN. Rich Fith dark maroon.
FRANCOIS IEVET. Soft china Fink, shaded carmine and bl ideal hardy whice Rose, pure in color, perfect in form; strong GEN. JACQUEMINOT. A rich elvety crimson, changing to scaret crimson. HARRISON'S YEIIOW. SemiJOFN HOPPER. Bright rose with carmine enter, large and full. MAGNA CFARTA. Rosy red, flushed violet crimson. Very large and fragrant.

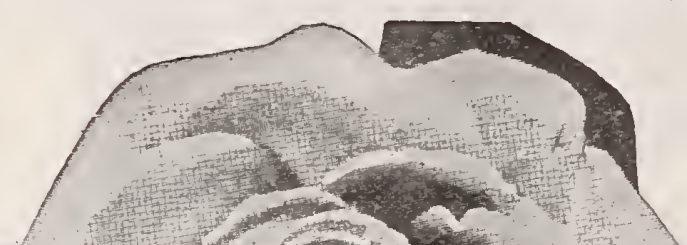

MAD. GABRIFI IUIZET. Flowers extra large; color, clear coral rose suffused MAD. CHAS. WOOD. Bright, fiery scarlet, passing to fine rosy crimson shaded

MAD. PIANTIFR. Very large, double,

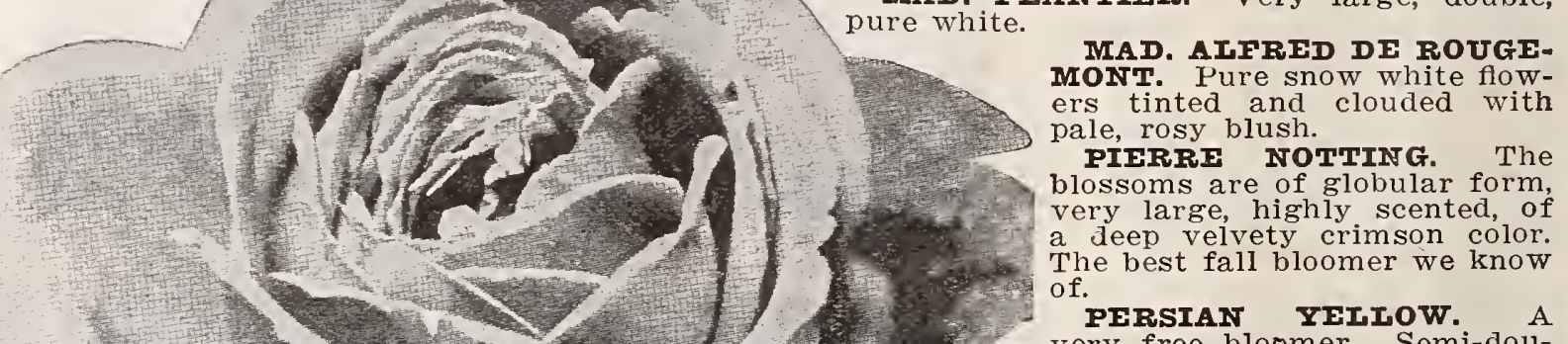
PERSIAN YEIIOW. A
ery free bloomer. Semi-douvery free bloomer.
ble.
Strong, young, growing plants from our greenhouses plants from our greenhouses paid.

Strong, 2-year-old, dormant plants 35c. each, postpaid; by express, per dozen $\$ 3.00$, per $100 \$ 20.00$.

U. S. GRANT. The hardiest Rose. Almost as hardy as an oak. Will thrive Blossoms freely the entire summer. The flowers are of enormous size, cup-shaped, full and deep, the petals thick, heavy and of a peculiarly rich velvety red color. It is a magnificent rose, either in bud or as an open flower, and its deep color makes it especially desirable for cutting. Strong, well-rooted, young, growing plants 25c each, postpaid; 2-year-old dormant plants, by express, 50c each, $\$ 5.00$ per doz. 


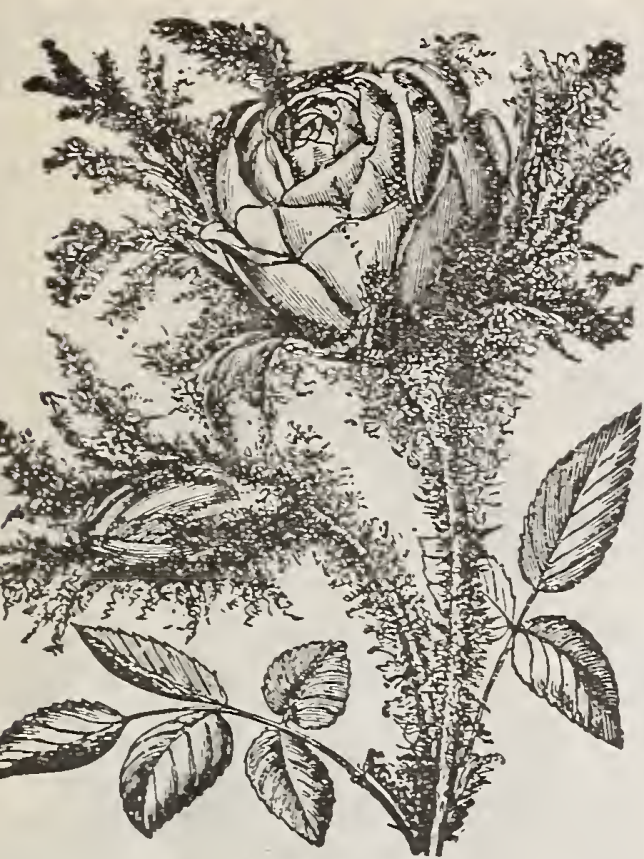

Moss Rose.

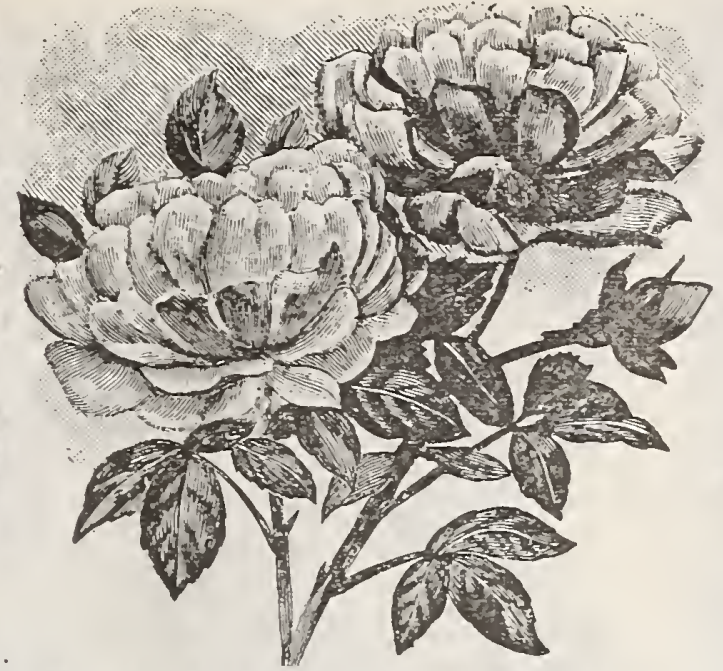

Memorial Rose (South Orange Perfection.)

\section{Choice Miscellaneous HARDY ROSES.}
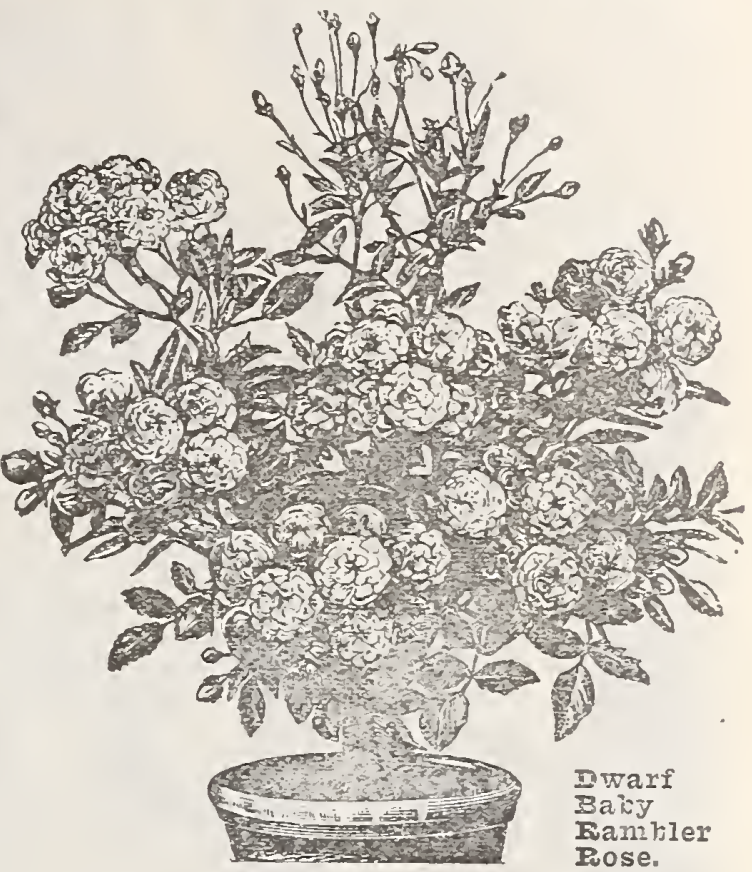

warf

Eamiler

Eose.
MOSS ROSES. A class of roses much admired. The covering which surrounds the bud, and gives to the opening lower a unique appearance.

ASHBOURNE PRIZE. The flowers are a rich, deep velvety red, extra large and highly perfumed.

BIANCFE MOREAU. Creamy white, tinged rose.

PRINCESS ADEIAIDE. Bright silvery rose.
PRINCESS MAY. The most free-flowering white.

PRINCISS MAY. The most free-flow
WIIIIAM IOBB. Deep bright pink.

Two-year-old plants, 40c. each, postpaid; by express, 30c. each, $\$ 3.00$ doz.

RUGOSA ROSES (Japanese Roses). The Japanes feet high, covered with terminal clusters of 10 to 20 fiowers,
each 3 inches in diameter. Perfectly hardy. A valuable plant for the hardy border or shrubberies.

AGNES FMIIY CARMAN. Semi-double, crimson

MAD. GEORGR BRUANT. Semi-double, whit

SIR THOMAS IIPTON. Double, pure white.

CONRAD F. MIFYRR. Double, silvery rose. Two-year-old plants, each 50

ALBA. Single, pure white.

Two-year-old plants, 40c. each, postpaid; by express, 30c. each.

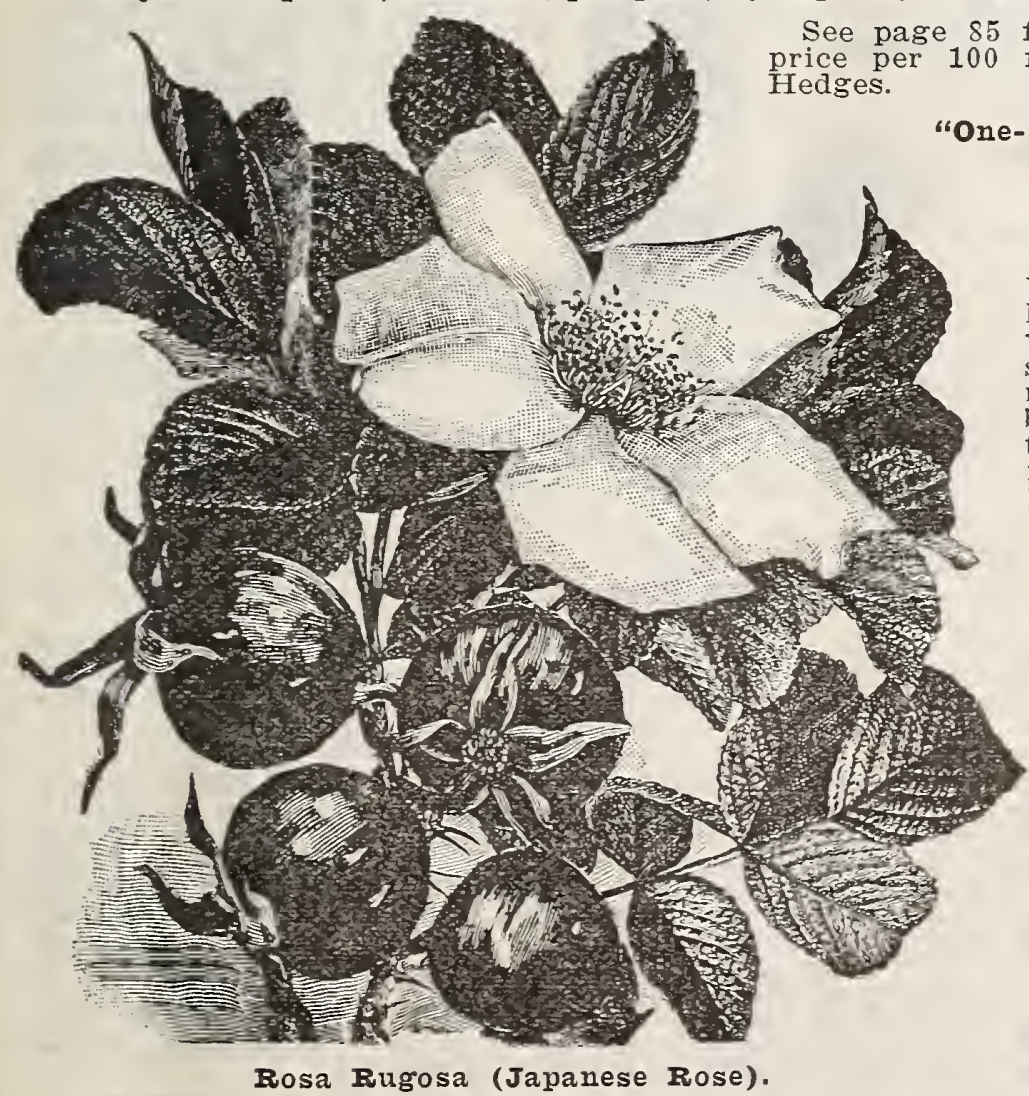

MEMORIAL or Evergreen Roses (Rosa Wichuriana.)

IUCIDA.

MANDA'S TRIUMPH.

SOUTH ORANGE PERT',

UNIVERSAI FAVORITE.

2-year-old plants, 40c. ea., postpaid ; by express, 30c, ea., $\$ 3$ āoz

BABY RAMBTER ROSE A t dwarf (Bush not Climb-

Rambler, and, furthermore, ever-bloomin

Rambler, and, furthermore, ever-blooming. Blooms continuously

Soupert for bedding. Grown in pots just as easily as Clothild treatment from one year's end to another. Strong young pot HYBRRID SWEET BRIAR ROSES.

\section{tween the common $S$ weet Briar and various garden}

ANMIE OF GEIERSTEIN. Dark rich crimson.

AMY ROBSART. LOVely deep ros

BRENDA. Delicate peach, dainty and charming.

IADY PENZANCE. Beautiful copper tint.

IARD PENZANCE. Soft fawn shade.

ROSE BRADWARDINE. Beautiful clear rose.
2-year-old plants, 35c. ea., postpaid; by express, 30c. ea., $\$ 3$ doz.
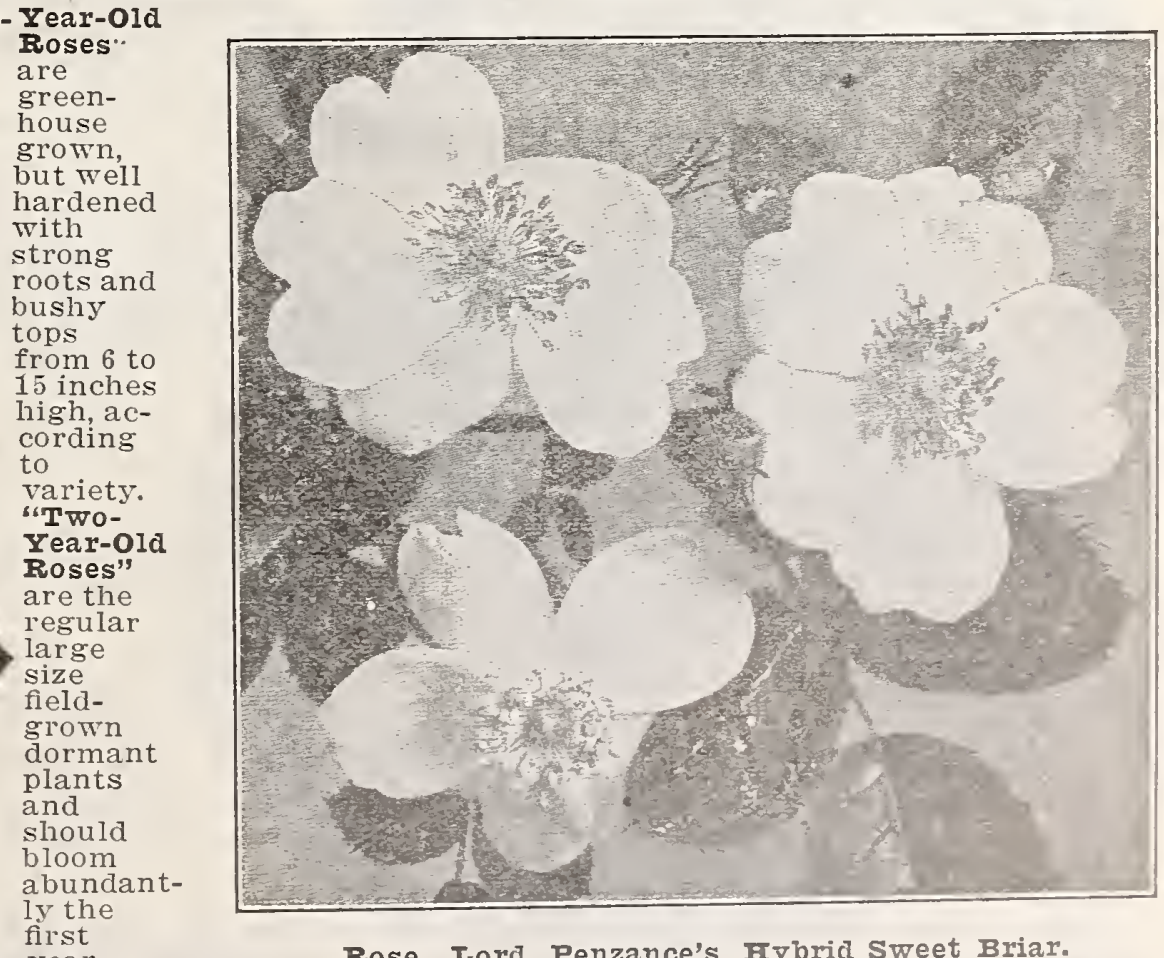

Rose, Iord Penzance's Hybrid Sweet Briar. 


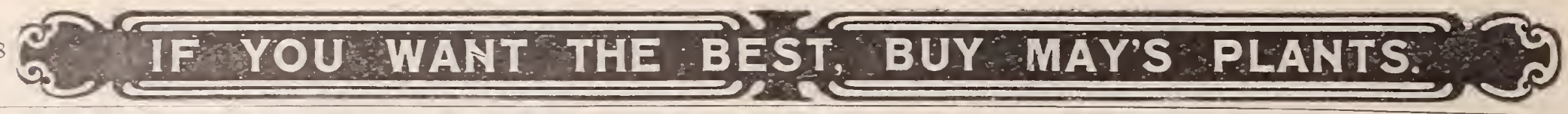

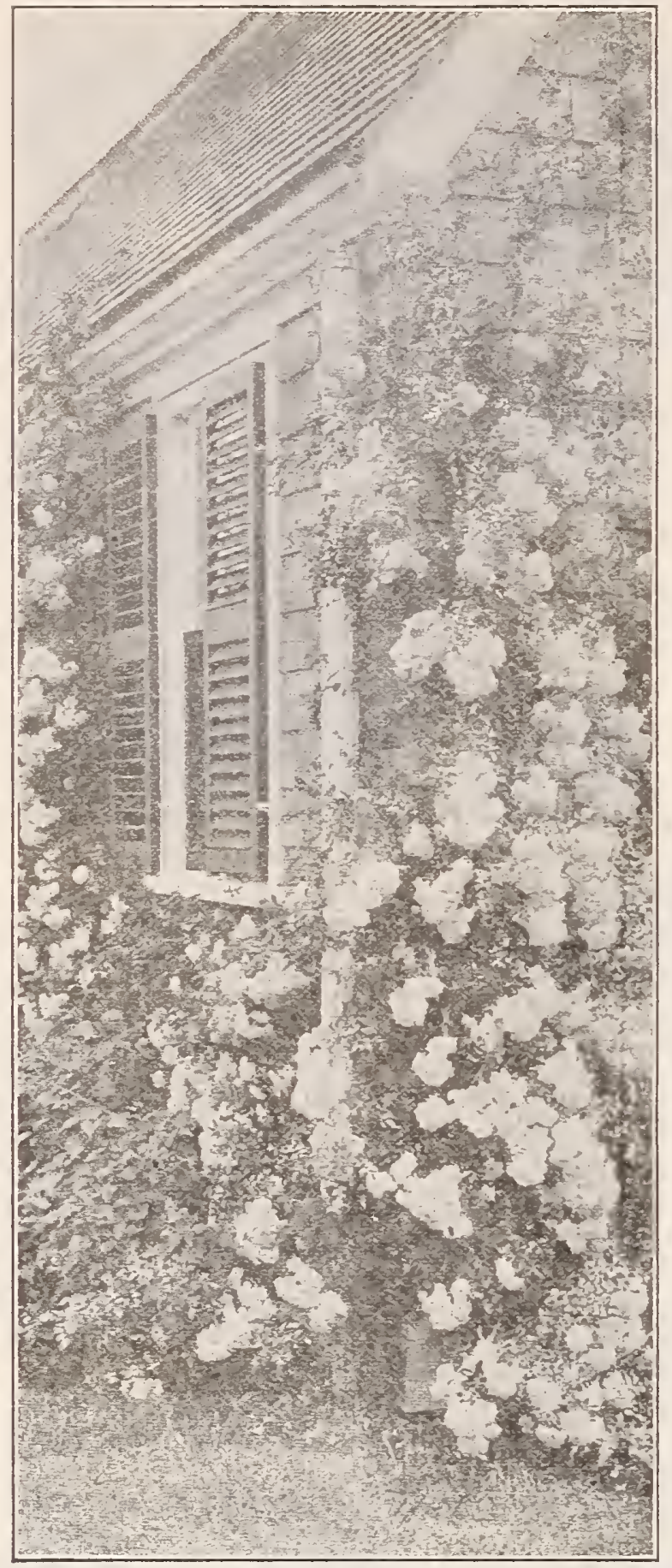

Dorothy Perkins.

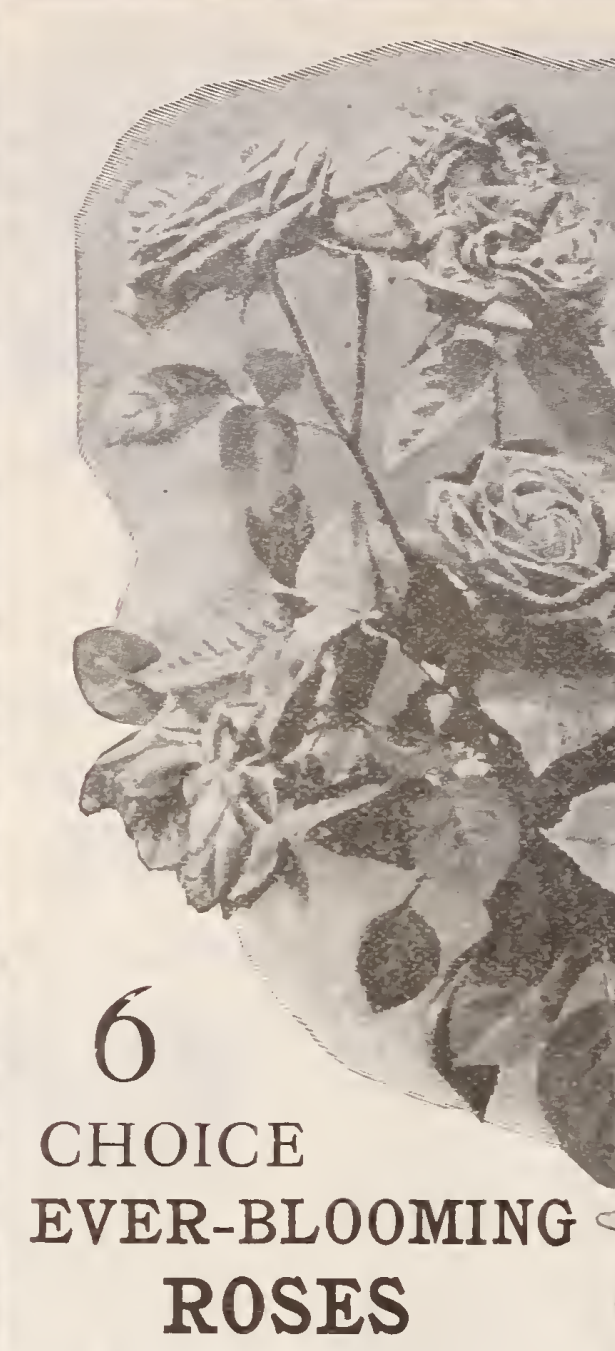

For 50c., Postpaid.

METEOR. Rich crimson. GOIDEN GATE.

MAD. CHANTENAY.

BABY RAMBIER.

YEILOW SOUPERT.

CLOTHILDE

so

One strong plant of each of the 6 sorts, prepaid, for 50c.

THE RAMBLER ROSES.

CRIMSON RAMBLER.

strengthens our confidence in it. It is absolutely hardy in all localities, a most vigorous grower, a most prolific bloomer, fine for growing on trellises, unezcelled for covering porches, walls, etc.; admirable for pot cultire for Easter forcing, at all times when in bloom, producing a gorgeous mass of crimson blossoms which remain on the plant a long time.

DOROTFY PERKINS (New Pink Rambler Rose).

$1 \frac{1}{2}$ inches across, borne in clusters of 10 to 30 , and rery double: petals PHIIADEIPHIA CRINSON RAMBIIR.

This variety is a cross

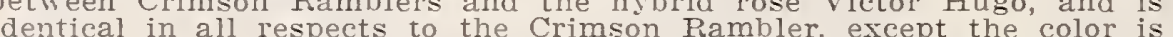
to the cher last longer in

YILIOW RAMBIIR. The flowers are borne in clusters, after the WHITE RAMBIFR. Almost ier. The color is a decided yellow. at the flowers are pure white and sweetly scented. Price of Rambler Roses: Mail size $15 \mathrm{c}$. each or 4 for $50 \mathrm{c}$, postpaid;
2-year field-grown, 35c. each, $\$ 3.00$ doz. by express, purchaser's expense. 
Our nurseries, located fifteen miles east of this city, consisting of growing of all classes of nurser stock that is hardr and adapted to the mest and northmest. Years a go we conceived the idea that nursery stock could be grown in this section, and that the people wanted just such enough in unhardy stock, but were willing to invest their money n stock that wo suited and acclimated to the Northwest, hence our trade has been built on this basis. "Northern Grown Nursery liable for planters in all parts of the United States.

Prices by Mail Postpaid. Means we deliver all trees, address by mail, and it will be thrifty stock, well rooted and established and sure to grow under ordinary care and conditions.

Prices by Freight or Express. Means that purchaser charges upon receipt of stock. We make no charge for boxing, packing and delivering to express or freight office. All Stock Will Be Packed ner, so as to reach our customers in the best possible condition. All heavy packages In Fillino Orders the right to substitute vaIn Filling Orders rieties considered by us of equal merit, provided we are sold out of the variety ordered. In such cases we label the variety substitute with its true name. But if der, we will fill order as far as possible and return money for the unfilled portion.

Our Guarantee. Tre guarantee all our stock to be up to in a healthy living condition when it leaves our hands. This guarantee holds good only when we are notified promptly on arrival of goods, stating any errors or cause for complaint. We that in case it does not prove so, we will replace such stock free of charge.

Our Packing Sheds and Cellars are the most comenabling us to pack and ship in all kinds of weather, in the winter as well as spring.

Note All trees, plants and vines that comprise Nursery Stock and must be sent in a dormant condition will be formarded to purchaser as soon as the weather conditions will permit them to be planted
separate from seed orders.

\section{PLANTING AND CULTURE.}

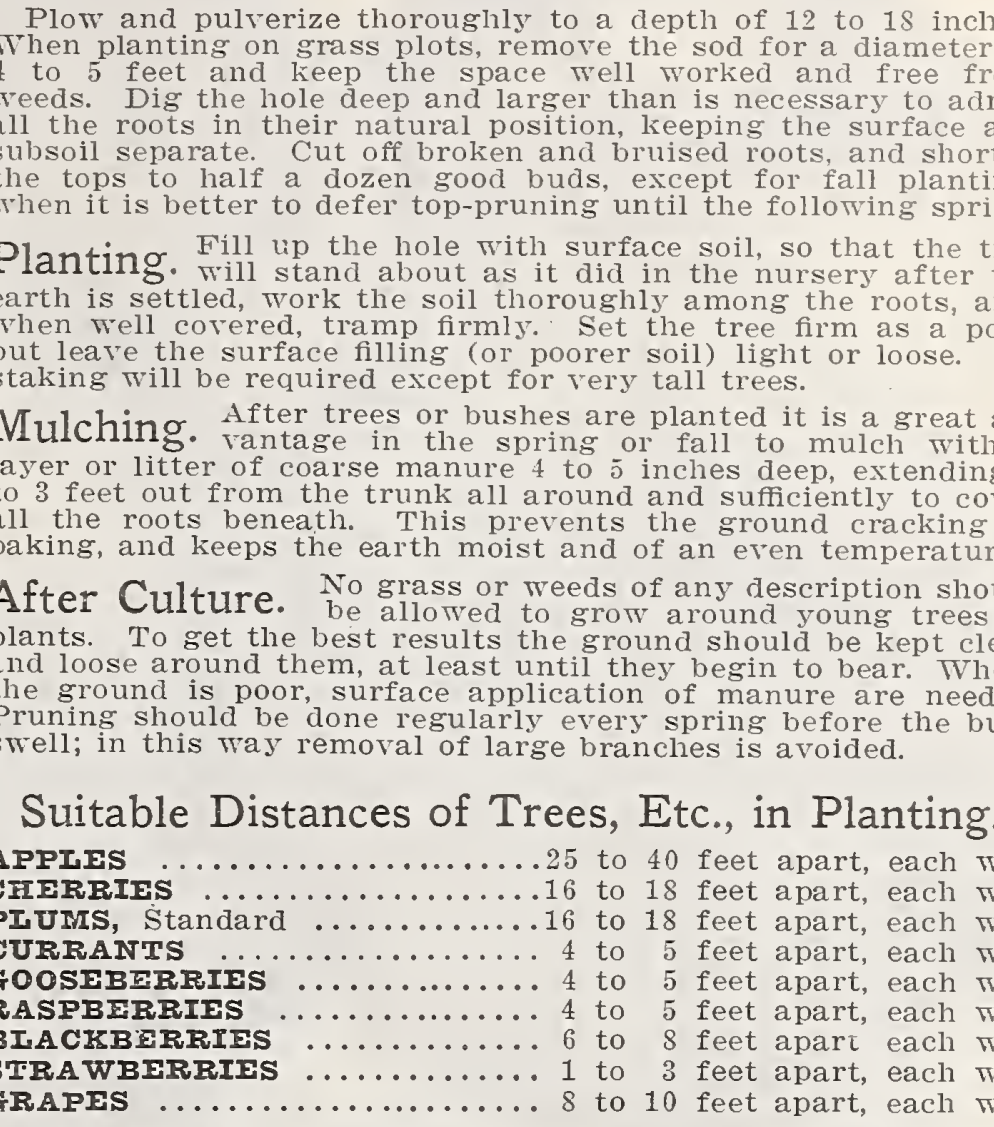

A certificate of inspection from the State Inspector of Nurseries, showing our stock to be free from San Jose Scale and all other injurious insects and diseases, will accompany eacb shipment.

\section{THE "MINNETONKA" APPLE.THE GUARANTEED APPLE.}

\section{A MINNESOTA SEEDLING AND MINNESOTA GROWN}

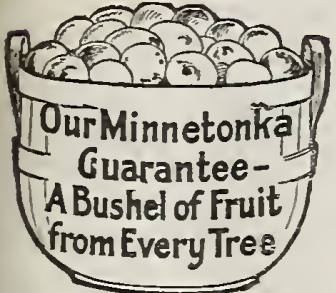

AS HARDY AS AN OAK. IT THRIVES AND YIFIDS WHERE AII OTHER VARIFTIES FAIT. FRUIT VERY IARGF, COIOR RED, FIFSF TENDER, CRISP, SUB ACID. THF IDEAT COOFING AND CHOICE DESSERT APPIE. SEASON IATE, KEEPING TWO IMONTHS IONGER TEAN THE WEII KNOWN WEAITHY.

concern.

concer fore found to be the

west.

\section{Grown in the "IMOST NORTFERN NURSERIFS IN AMERICA."}

\section{Originated near Lake Minnetonka, Minn., and original tree purchased by us some}

selves and the fruit-growing public of the Northwest, that it

ness to thoroughly test this new Seedling before pushing its

ing it for commercial

than any other apple

duced in the West or Nortl.

to the tree until late in the

pick for market almost the entire crop.
VERY SMAII CORE-GOOD IEEPR-BIIGET PROOF.

have in the "Minnetonka," the apple which we have been seeking to place in the hands of farmers of the Northwest for twenty jears.

have worked hard for it, testing everything which promised to be of value, until we can now, and without hesitation, cry "Eureka-found at last." TVe were not satisfied with one or two season's testing, bu followed it up until we are now sure that we hare a most valuable shall accomplish a benevolent work by propagating and placing this variety in the hands of the farmers of the West and North.
TWO TREES OF THE MINMETONIA ARE WORTH A WEOLE ORCEARD OF COMMON APPIES.

WE GUARANTEE

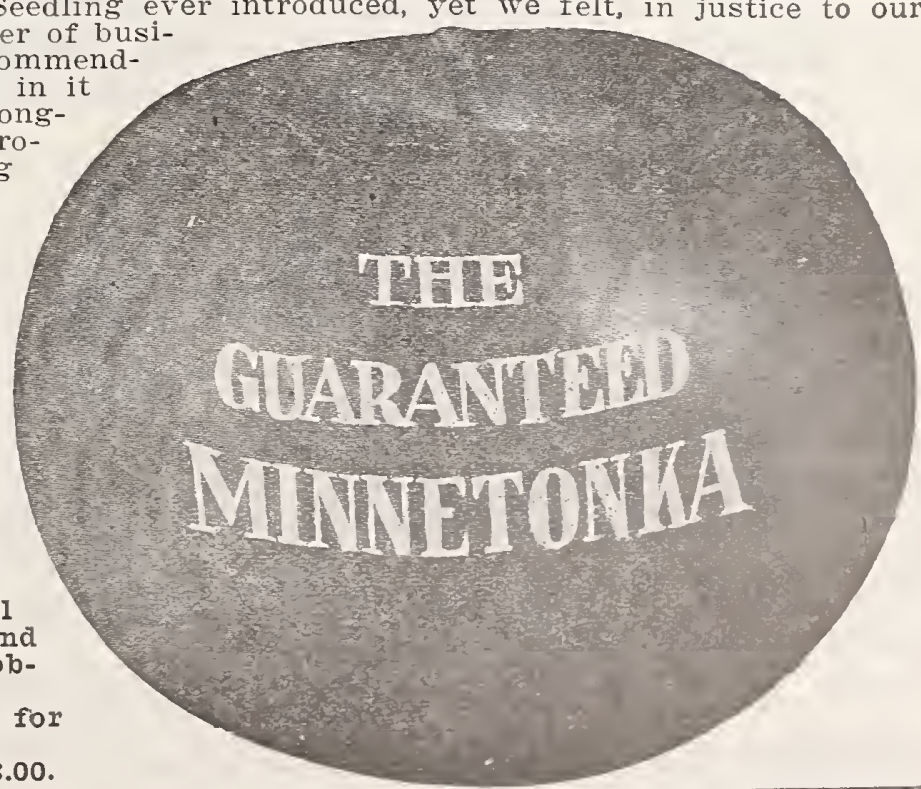
will replace free of charge any tree that may die before this result is obtained. What stronger recommendation can we give?

$\$ 6.00$.

Mail size, one year old, $40 \mathrm{c}$. each, 3 for $\$ 1.00,6$ for $\$ 1.75,12$ for $\$ 3.00$. 


\section{MOST NORTHERN NURSERIES IN AMERIGA.}

Michahon White.

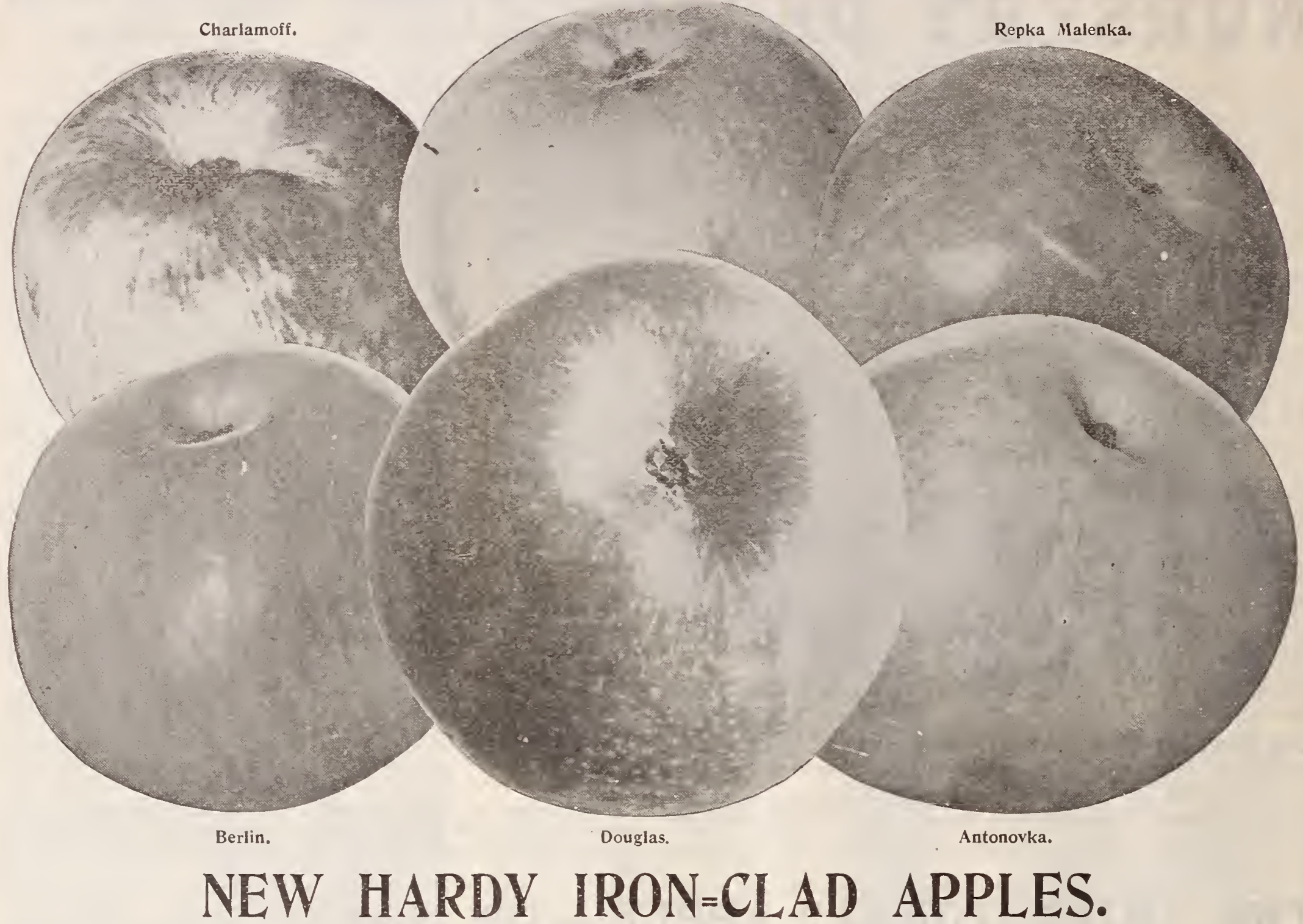

Prices. Mail size postpaid, $15 \mathrm{c}$. each, 4 for $50 c$.

Express or 3 to $4 \mathrm{ftc}, 2$ y ear, 30c, each, doz. $\$ 3,100 \$ 18$.

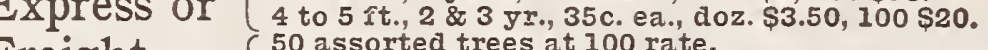

Freight. $\quad \int \begin{aligned} & 50 \text { assorted trees at } 100 \text { rate. } \\ & \text { Prices for larger sizes on application. }\end{aligned}$

The following varieties have been selected as the best suited for the Northwest. They are all new and have been tested so that we can heartily recWest. They are all new and have been tested so that we can heartily recommend them, as they comprise the cream of the list, and should be planted mended by the experimental station of the Northwest and indorsed by the fruit growers. Anisin. This is a most valuable sort from Russia. The tree is a strong, most excellent flavor, and keeps a long time in good condition.

Ántonovka. A true iron-clad tree of Russian origin, perfectly hardy, Fruit times lightly splashed with crimson. Quality best. Arabskoe. One of the new Russian varieties. Medium size, roundish; Arabskoe. skin dark red, with purple bloom; flesh white and juicy; August, A Minnesota variety, originating with Peter Gideon, the pioheavily streaked and splashed with bright red. It ripens a little later than Duchess, and is of unsurpassed quality for either cooking or eating from the Berlin. This kind originated from a seed of the Duchess planted in Berlarge as the Duchess, splashed more hea vily with red, somewhat longer and of much finer appearance. Tree as hardy as the hardiest.

Borovinka. Resembles the Duchess in form, size and color, but and a much better eating varity. An early and full bearer and a true ironCharlamoff Of Russian origin. One of the hardiest and best Charlamoff. we have ever grown. Fruit of medium size, slightly oblong, heavily splashed with red and of the finest flavor,

Cross. A Russian iron-clad sort. Fruit medium to large, yellowish green Douglass Nininesota seedling of unusual merit Fruit medium to Douglass. large of delicate flavor and good keeping qualities. Tree
Gilbert. A choice rariety resembling the Duchess in color but ripening but not quite so acid.

Greater Duchess. Wonderfully hardy. A vigorous, symmetrica! ly ever year Fruit about the same size, color and shape as the Duchess, except that it is a little flatter.

Harry Kaump. Originated in Wisconsin and is one of the best and with a show of color on sunny side; mildly acid and unsurpassed for dessert

Jenny. Originated in Canada. Tree very healthy and vigorous; fruit . about the size and color of the Northern Spy. A very handLindfield. Of Wisconsin origin. Tree rugged, thrifty, smooth and color as the Longfield, but more than three times as large. Malinda. This is an exceedingly hardy variety, one of the very best in tions of the country. The tree is a strong, symmetrical grower, one of the McMahon's White. Fruit very large, nearly white and most Oree a good grower and very Oelfka. A Wisconsin seedling. One of the best growers we have ever Repka Malenka. A true Russian iron-clad. As hardy as the in flavor. Fruit medium to large, yellow and finest quality. This is one of the best keepers of the Russian varieties and while not large in size is very thaluable in the Northwest for its keeping qualities. It is regarded as the best apple for planting in Northwest Canada; in fact it has not shown any sign of tenderness wherever planted.

Recumbent: Of Russian origin. A fine hardy tree and early bearer. Recumbent: Fruit resembles the Duchess.

Rose. A seedling of the Duchess, which originated in Wisconsin. Tree The fruit is dark rose mottled red; tart fine flavor and an elegant cooking sort.

Sheatteal. A chance seedling of the Duchess. As hardy as an oak tened some at ends, greenish red-striped and splashed like the Duchess, but fully one-half larger than that variety.

Snyder. Fruit of medium size, pleasant acid, and a good bearer. Octo 
Perfectly

Hardy. Acclimated

to the

Northwest.
Patten's Greening.

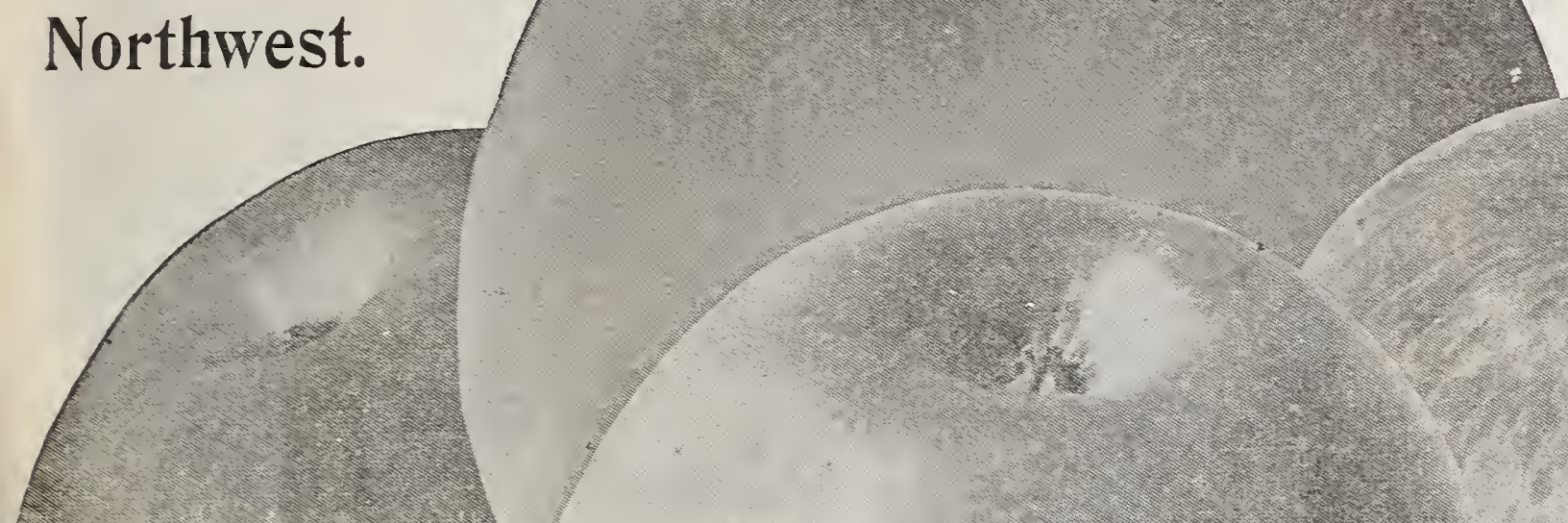

Four Varieties of

Commercial

Value and

Special Merit。 


\section{MOST NORTHERN NUUS ERIES IN AMERICA}

CRAB APPLES.

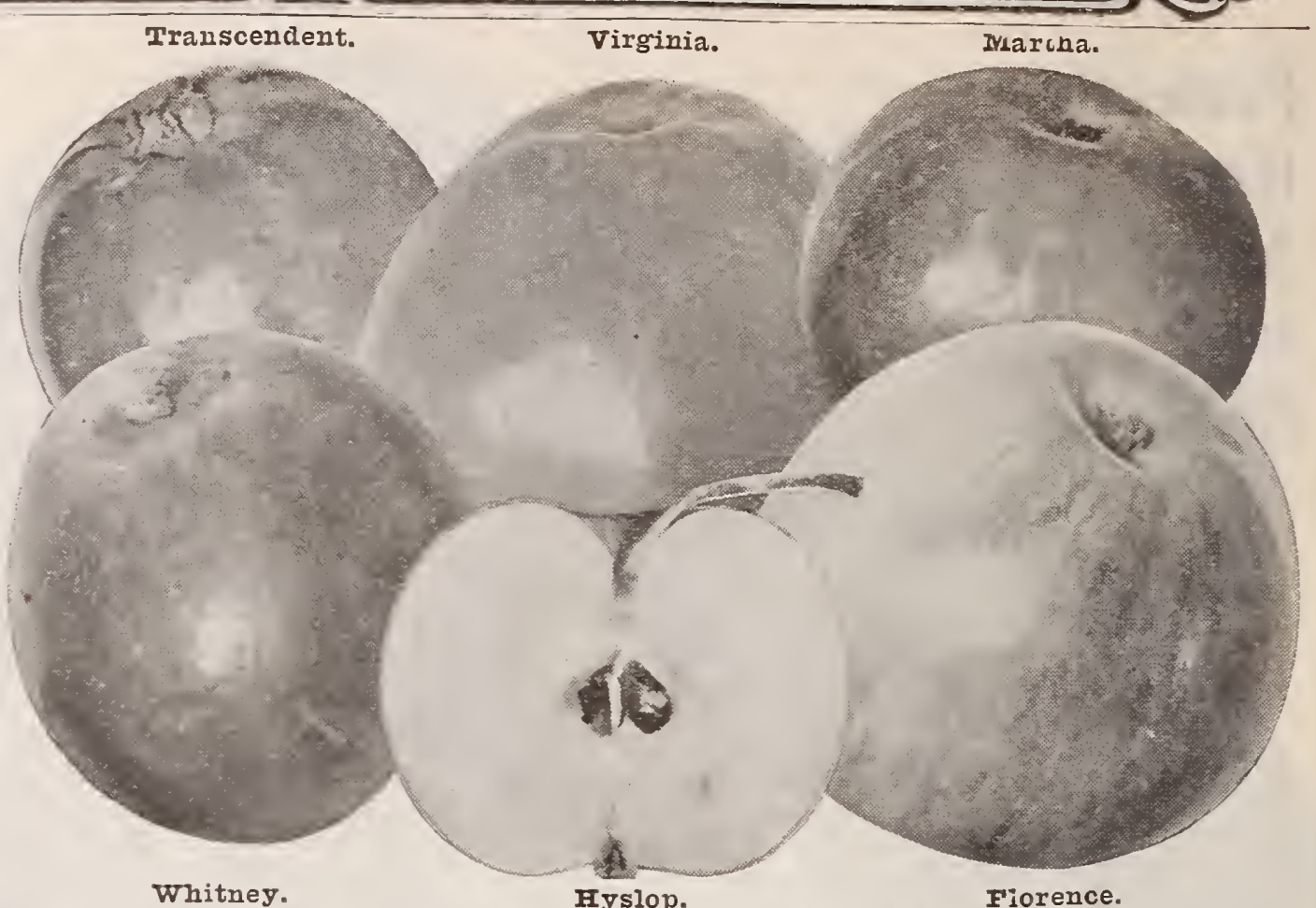

These trees are perfectly hardy, and succeed anywhere. They are ornamental and shade trees as well as splendid fruit producers. They commence to bear when quite fine fruit, especially prized for serves, cider, etc. Mail size, each 15c., postft. each $25 \mathrm{c}$., doz. $\$ 2.50,100 \$ 15.00 ; 4$ to 5 ft. each $30 \mathrm{c}$., doz. $\$ 3.00,100 \$ 18.00$. Price of 5 to 7 ft., 3 years, on a pplication.

Arctic A new rariety of great merit; fruit Dartt. A handsome fruit about same size

Early Strawberry. The tree is vigorous, carly Strawight, symmetrica and very hardy. The fruit is somemhat larger juicy. Fine for eating and for jelly. Florence. This is a splendid Minnesota valarge, light yellow, heavily streaked with light red. For jelly, as a dessert fruit, marmalade and jams, it is especially good, while ts large size and splendid appearance

Gen. Grant. Fruit of largest size, bright The finest Ripens in October. We cannot too highly recommend this splendid variety for general planting. It is one of the largest grown, and on this account is preferred by many growers. Hyslop. is yellowish; excellent for cider and fine for market. Lyman's Prolific. Iarge red striped; splendid for cookMartha. This variety is a seedling from the Duchess of Gideon of Excelsior, this state. The tree is a firm, stiff, upright grower, pyramidal in form and very handsome. It bears well, the fruit being a glossy vellow, shaded with bright red.

Minnesota. Mottled yellow with blush; fine flaror for cookRed Siberian. Fruit, about 1 inch in diameter, grows in cheek, crisp and acid. The tree bears when very young and abundantly afterwards.

Sweet Russet.

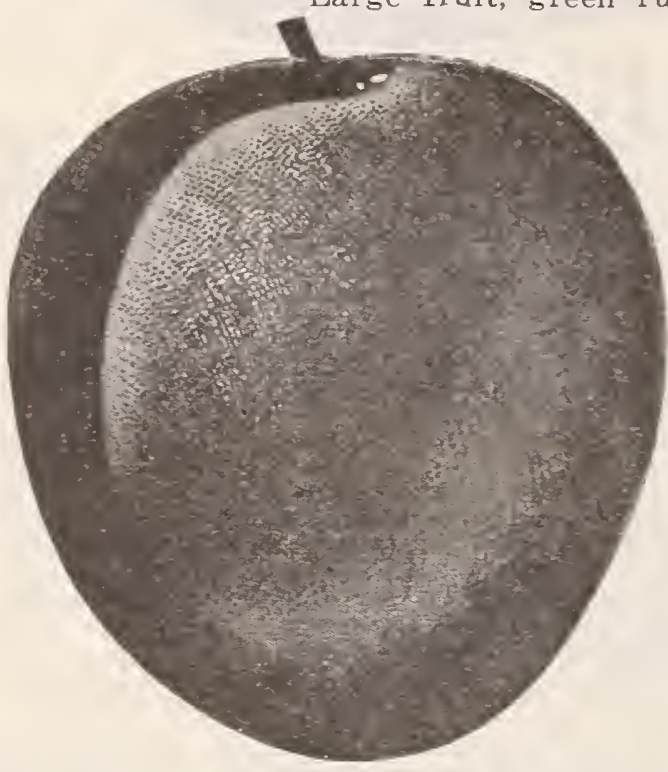

Quaker Beauty. A hardy, strong growing sort, which bears large growers one of the best. Sylvan Sweet. Fruit large, pale yellow, with rich blush; Transcendent. This tree is very productive, bearing after the fourth year. The second year and producing good crops by large enough to quarter and core for preserving and drying. It is excellent for sauce and pies and the best of its class for cider. The skin is yellow, striped with red.

Virginia. The fruit is small, round, dull red, dotted with Whitney. Fruit extra large, skin smooth, glossy green, striped Whitney. Fruit extra large, skin smooth, glossy

Yellow Siberian. Fruit small, bright orange yellow.

\section{PLUMS.}

New and Standard Hardy Varieties.

No class of fruit is more universally popular. They fruit at an early age, are profitable to grow the market or in small lots for home use, and none yields more readily to care most luscious fruit. All our plums are budded on hardy native plum stocks, thus insuring their hardiness and their adaptability to all sections. each 35 c., doz. $\$ 3.50,100 \$ 25.00 ; 5$ to $7 \mathrm{ft.}$, 2 year, each 45c., doz. \$4.50, $100 \$ 30.00$. Express or freight only.

50 assorted trees at 100 rates.

Cheney. An unusually good native variety. tree is of good form and as hardy as the oak. The fruit arerages large and is of finest quality. The flesh is very firm, Cottrell. Medium size, red. Vigorous grower De Soto. The fruit is of medium size, dappled ber, and is firm, sweet and juicy. The tree is hardy and productive. Good for general plant-

Etta. Large, round, red on yellow ground. Tree of fine form

Forest Garden. The fruit is very large and round, purplish the red, mottled with yellow, juicy, sweet and Hammer. Of large size, firm, juicy and delicious. Tree a Hawkeye. The tree is hardy, thrifty and an annual bearer. Hawkeye. The fruit is large, light in color, mottled with red, of superior qualit

Milton. Another native variety of great merit. The fruit skin is thin, the flesh firm and of excellent quality. It is the earliest variety in cultivation. Ocheeda. Medium size, round, red. The flesh is firm, sweet Prairie Flower. Similar to the Miner in size, form and

Rockford. The fruit is reddish purple and of medium size. Rollingstone. Fruit of medium size, round, firm flesh. ous bearer when the tree attains some size. Stoddard. One of the largest native plums. It is a light tough, sweet skin.

Surprise. The tree is a strong, upright grower, withstandfruit is large, deep red in color, and has good keeping. Thalities. The flesh is very firm and of an excellent flavor. Price, 4 to $5 \mathrm{ft}$., each $50 \mathrm{c}$., doz. $\$ 5.00 ; 5$ to $7 \mathrm{ft}$., each $60 \mathrm{c}$., doz. $\$ 6.00$. Weaver. Originated in Iowa. The fruit, ripening in August, a constant bearer.

Wyant. A very popular sort. The fruit is large, oblong, sometimes slightly flattened; a deep, purplish red Wolf Fruit round, oval, color crimson orer orange dotted, Wolf. Fruit round, oval, color crimson ore 


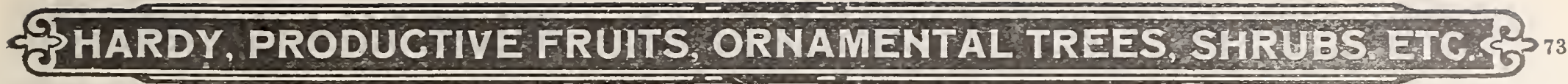

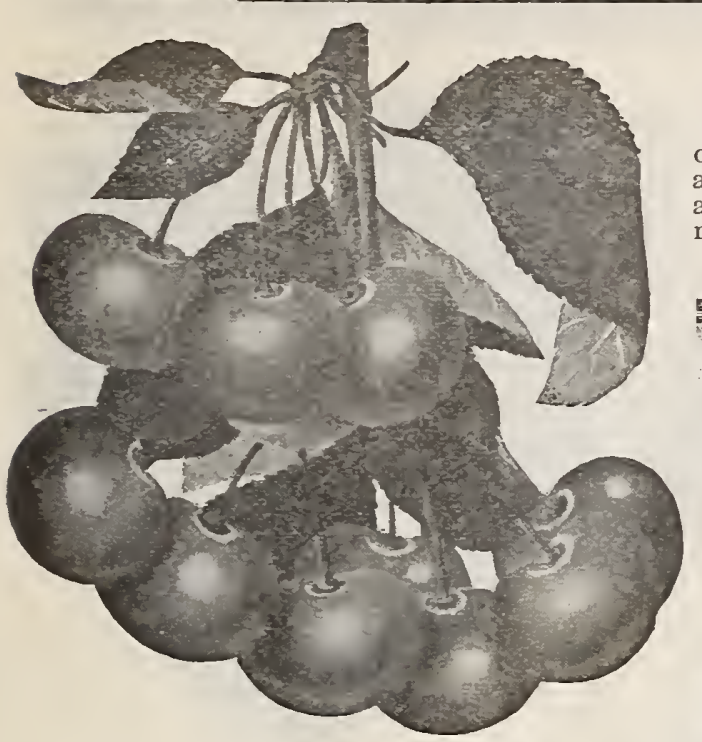

Lutovka, 1/2 Natural Size.

STANDARD SORTS.

Early Richmond. The tree is an exwith spreading head, and is very productive. The frvit is dark red, melting and juicy, with a sprightly acid flavor. It ripens early and is considered very good.

English Morello. One of the best of The fruit is very dark red, large, rich and acid.

Late Richmond. A fine old variety reRichmond in shape and color, but ripening three weeks later. Lutovka. Mhis is a Russian variety of the vigorous grower and very productire. The fruit in color and size resembles August; is firm, of mellow quality, with a sprightly acid flavor. Montmorency. The tree is very hardy and bears profusely. It nually. The fruit is very large and bright shining red. It ripens about the

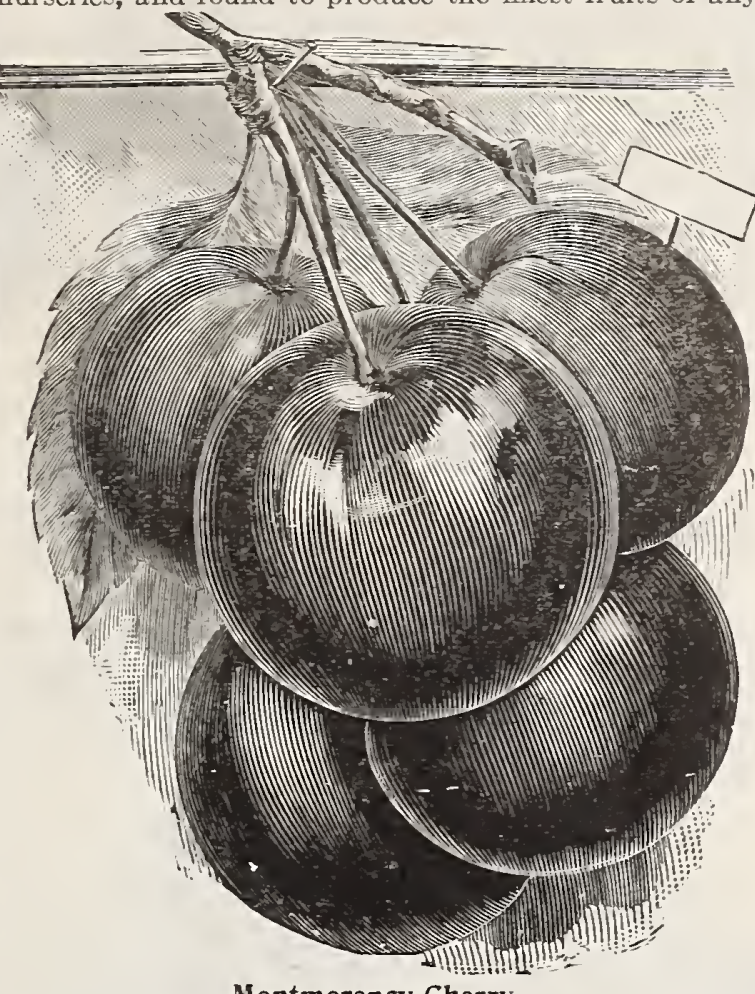

Montmorency Cherry.

Woese A new variety brought from Siberia, exceedingly hardy Vhomir fruit of good size and high quality, dark color and ripens with 5 Prices, 3 to $4 \mathrm{ft}$., ea. $30 \mathrm{c}$., doz. $\$ 3 ; 4$ to 5 ft., ea. $40 \mathrm{c}$., doz. $\$ 4$; 5 to $6 \mathrm{ft}$, ea. 50c., doz. $\$ 5.00$. By express or freight only.

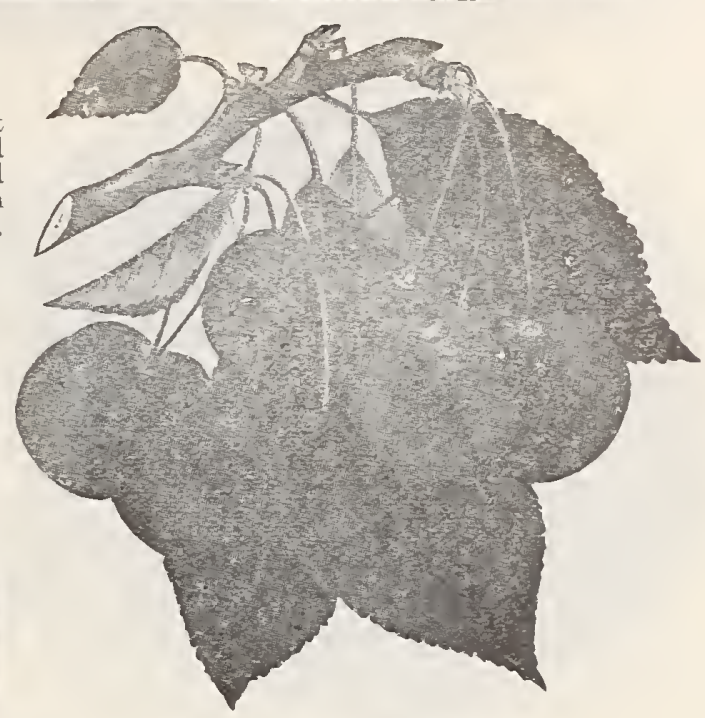

Ostheim. This variety is very hardy and Vladimir. A very hardy Russian sort, comof Moscow, where, from large tracts of land planted with it, train loads of fruit are sent annually Early Richmond, black, with highly colored Wragg.

Wragg. Very hardy, vigorous and productmedium size, and of most excellent quality. are large, very dark red, tender and juicy, with a last of June, a week later than Early

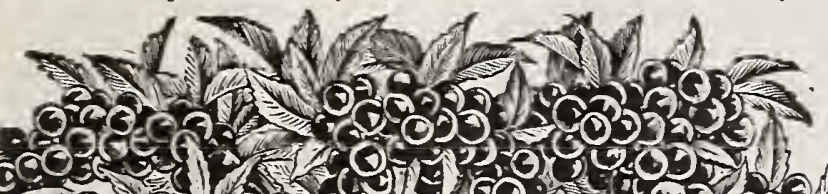

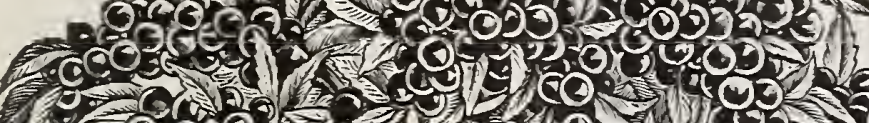

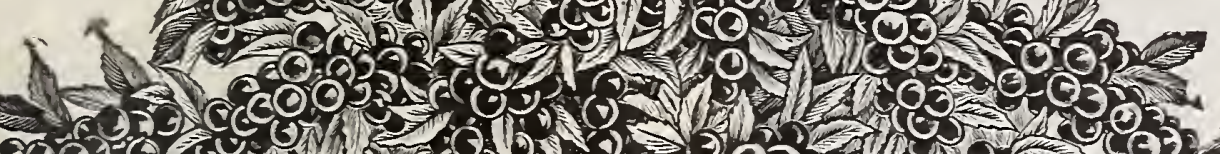

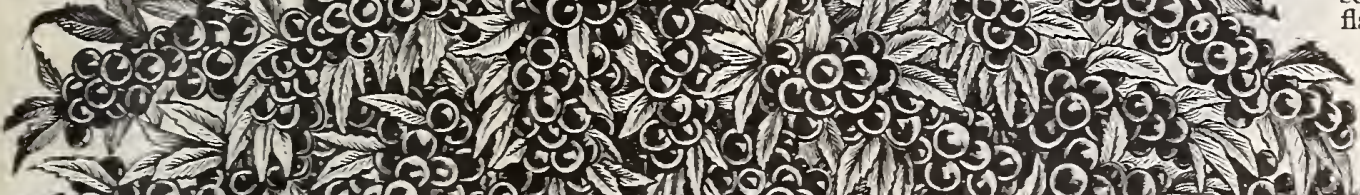

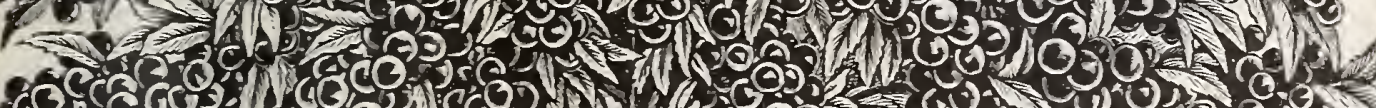

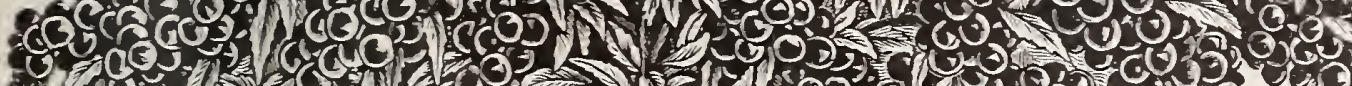

F

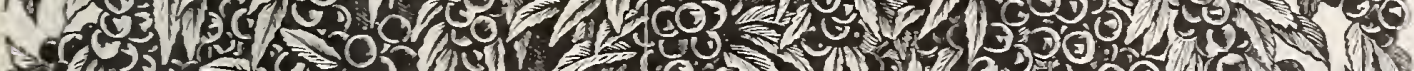
alf

Ro

$$
\text { }
$$$$
\text { (o) }
$$

(1) 30.03

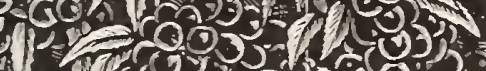

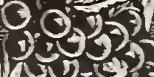

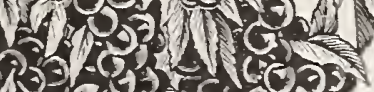

Rocky Mountain Cherry. A fruit for all peo-

One of the greatest novelties in the fruit line ever ir troduced. It bears every year and is as prolific as a currant bush, 16 quarts having been picked from a three year old tree. Grows to a height of four feet and has never been affected by insects,
black knot or other disease. The fruit is a rich red and changes to almost black when ripe, of good size, fine flavo eason of ripening being after all others are gone. In any fruit grown in this section. Mail size, postpaid, each $15 c_{0}, 4$ for $50 \mathrm{c}$. Express or freight, 18 to 24 in. each 25c., 3 for 60c., $\$ 2.00$ per doz.

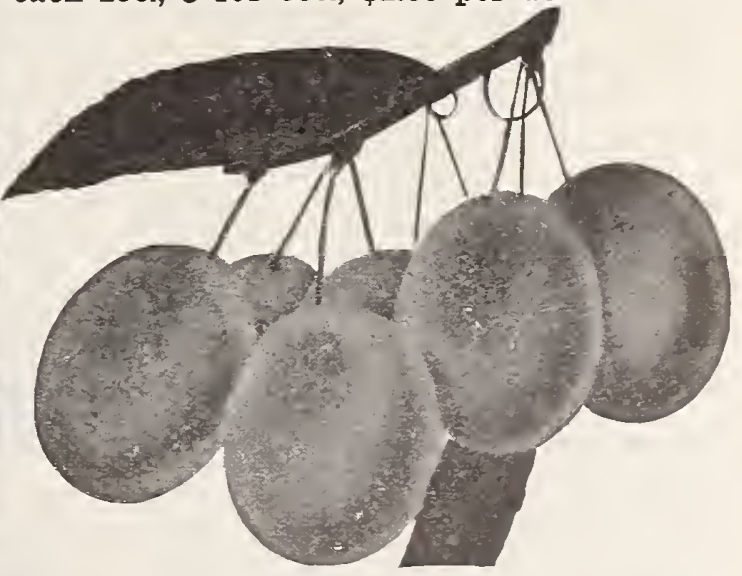

Compass Cherry. A b s o 1 u t el y hardy

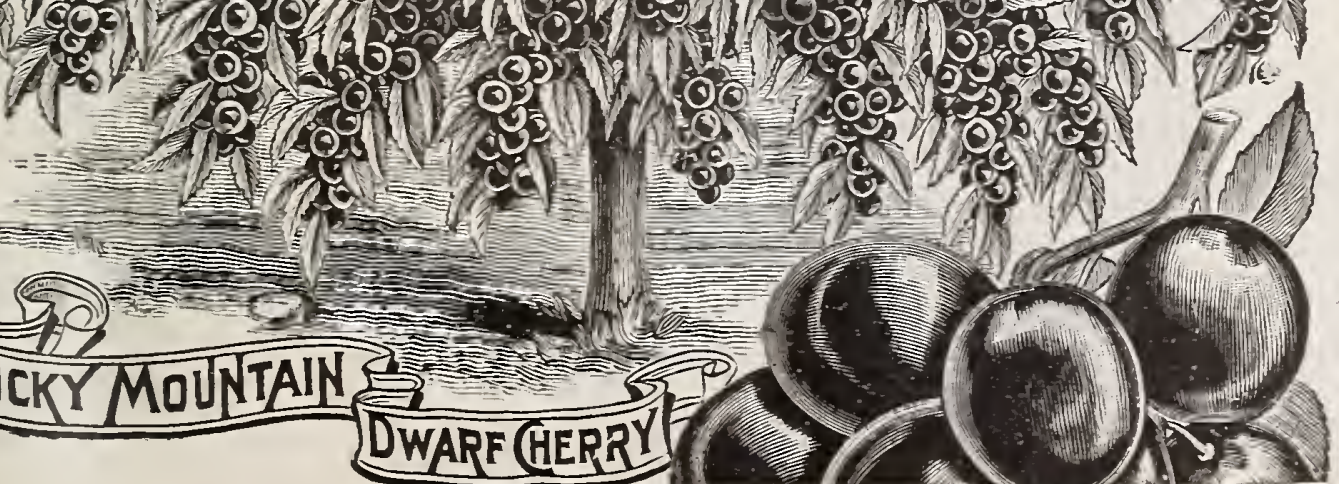




\section{MOST NORTHERN NURSERIES IN AMERICA.}

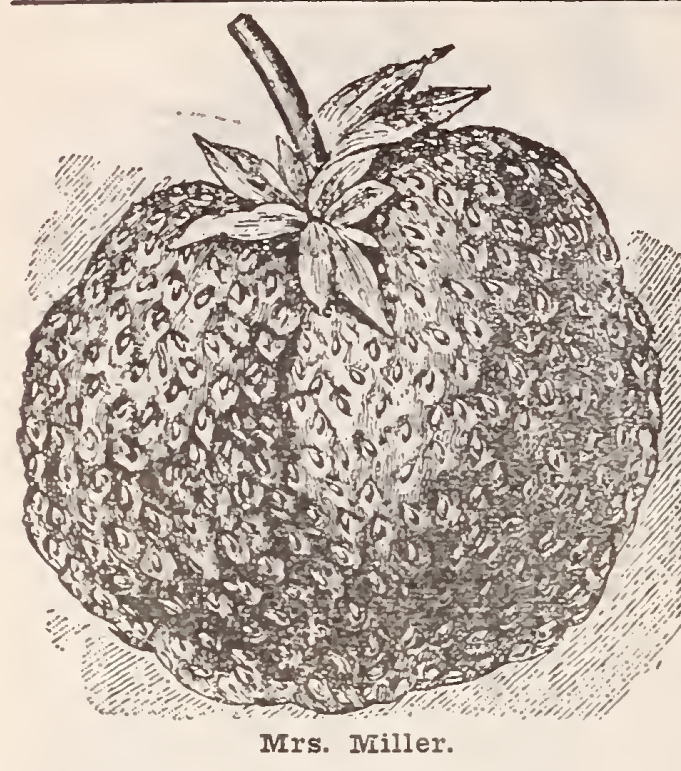

NEW VARIETIES.

Mrs. Miller. X.

\section{STRA WBERRIES.}

\section{light in good rich soil, but will grow}

By planting early, medium and late rarieties, fruit is supplied the entire season. As a fertilizer we For fie For feld culture plant in rows $3 \frac{1}{2}$ leet apart, 18 nches apart each way, leaving a pathway every After ground is frozen in the fall give a light covering of leaves or straw, enough to shade the plants, to keep soil from thawing and freezing spring when plants begin to corering in early mulch and lelp truit clean.

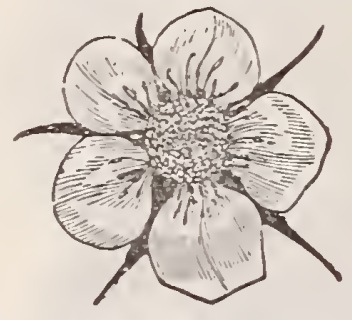

Perfect Blossom. PERFECT AND IMPERFECT BIOSSOMS: Vaeties marked " $\mathrm{P}$ " have perfect blossoms and will ther rarieties. Varieties marked " $\mathrm{X}$ " have imperfect flowers and should be mixed or planted ill be they

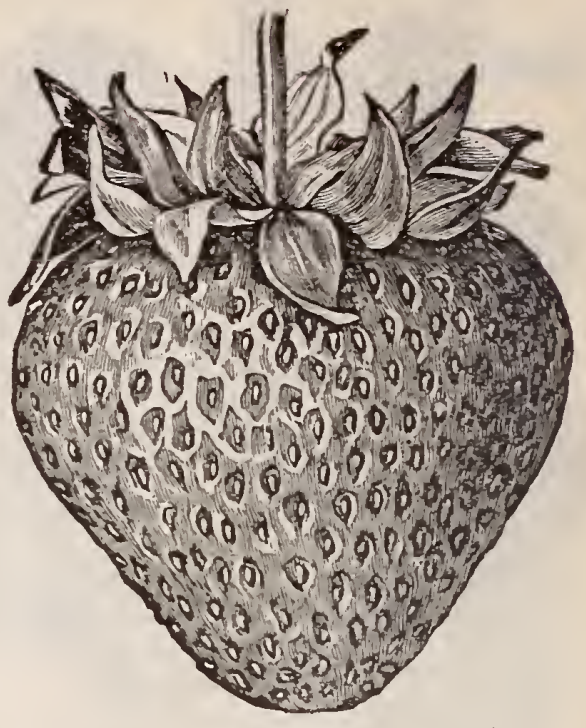

Nimrod.

Clyde. P. Fruit is large, firm orular conical shape and holds Crescent Seedling. $\mathbf{x}$. Medibright scarlet, vigorous and hardy Gandy. Pright crimson, uniform in size and shape, large and firm; Glen Mary. P. Berries large to

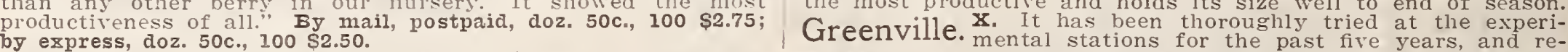

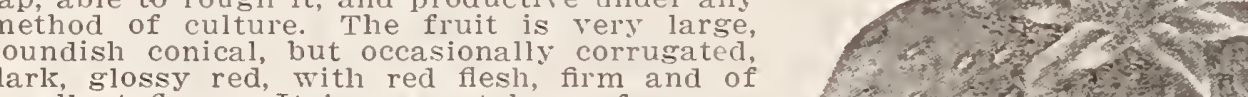

mediu mail, postpaid, doz. $40 \mathrm{c}$ 100 \$2.25; bJ express, doz. 40c., $100 \$ 2.00$. Nimrod.

Dakota.

Price same as victor.

(1) Alaska and per. Destined to become the leading berry in winters without any injury whatever. Price by mail, postpaid, $\$ 1.00$ per doz, $\$ 5.00$ per 100 . STANDARD VARIETIES.

By mail, postpaid, doz. 25c., 100 S1.00; by ezpress, doz. 25c., $10075 \mathrm{c} ., 1,000 \$ 4.00$

Please Note Not less than six of a vari50 at 100 rates, 500 at 1,000 rates. Iarger quantities priced on application.

Bederwood.

Brandywine. so

glossy red, extending to the center.

fine form and color, unsurpassed productive-

Challenge. P. Essentially a market berry.

perance and a

splendid shipper. For resisting drouth it has ports are unanimous in its favor.

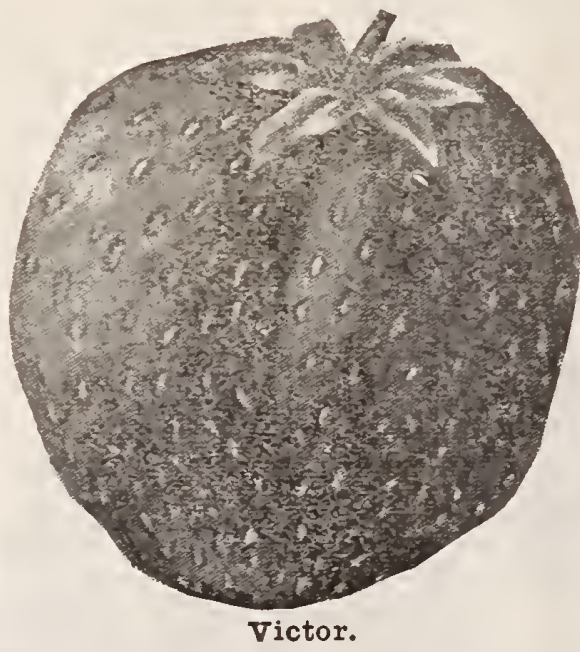

wize, good quality, yery eren and fine color fro ron rust, and attains its greatest productiveHaverland. $\mathbf{x}$. A fine grower, very pro(n) leadin Toe P. Strong, beautiful plant. Nultiplies Joe. rapidly. Berries large, brilliant, glossy red, conical in form, borne well up off the ground on strong stems; of good quality; medium to late. One of the very finest we have Lovett $\mathbf{x}$. The berries are produced in clusters of 8 to 10 ; are globular, tightly conical, brilliant red; ripen uniformly general market purposes it has no superior. Michel's Early. P. First and earliest of Michel's Early. its kind. It is strong. hardy and productive. The berries are bright most delicious size, full and round and

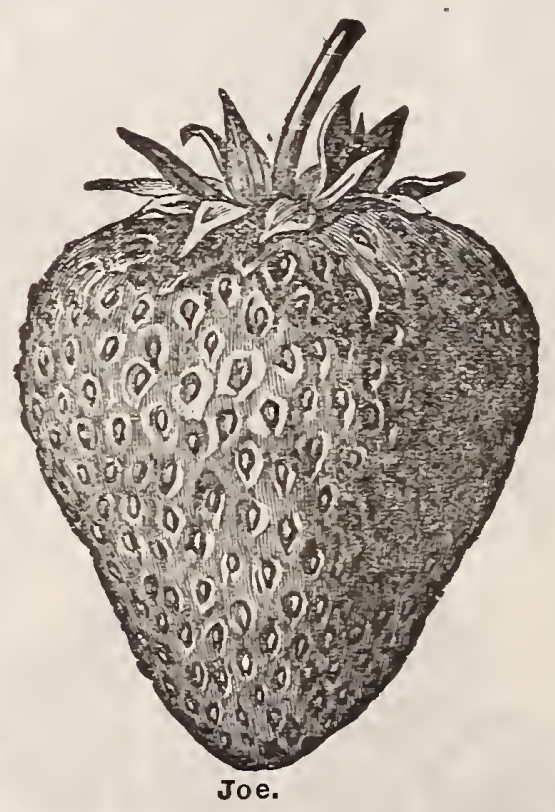

Parker Earle. P. Uniformly large, regu( ver; flesh moderately firm. no hollow core, quality good; flowers perfect. Plant very vigorous, healthy and remarkably productive. Rough Rider. P. Enormously productive large, round, somewhat flattened and pointed, dark and red in color Stock from our own srowing. One of the best late strawberries. Te highly recommend this as the best sort for late ripening.

Senator Dunlap. P. Exceedingly vigorous. Senait large, regular and attractive in form, deep red without and within, firm, excellent quality. Begins to ripen wh

Wm Belt P. Vigorous, heavy plant, very Beles large, conical, uniform in shape, glossy crimson. All ripen without green tips, of good qualing. Warfield $\mathbf{x}$. Far the best and most profitfor shipping on account of its firmness and great beauty. Very productive and vigorous, 


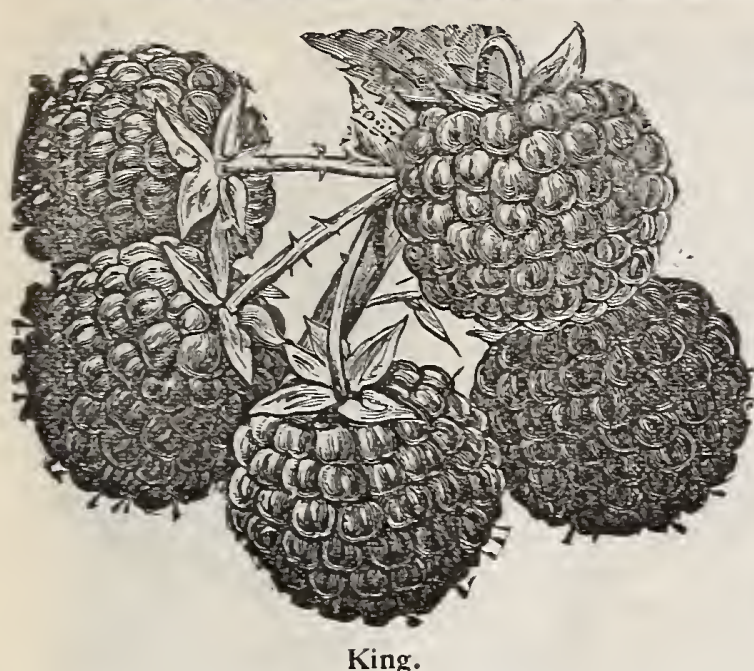

King.
RASPBERRIES.

Of all the fruits grown by the amateu or professional, none will give greater returns for the time and money expended than They thrive well ways sells at good prices. We believe there is no surer road to fortune for any young farmer residing near any of the large cities of the fruits for market purposes. The earliest and latest ripening varieties are the most profitable, though mid-season sorts should also be
planted to give a succession throughout the fruiting season. We send out only extra strong, healthy plants, which will give good results and satisfaction to our customers under ordinary good care and condition.

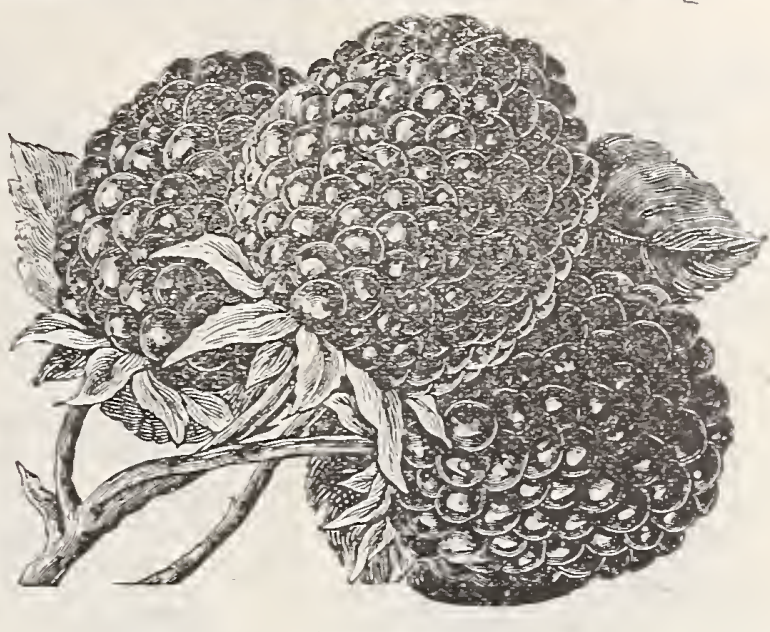

Cumberland.
CHOICE RED VARIETIES.

Cardits fullness of its meritsCardinal. its oreat growth, extreme hardiness, and the exceeding productiveness of its choice red, rich, pure flavored berries. It will pay. It is not a novelty, but a variety of great merit. The new Cardinal is claimed to grow ten feet high, and bears in proportion. Leading horticulturists who have seen this berry say that it is one of the wonders of the century, so doz. $\$ 1.00$, postpaid. By express, $\$ 2.50$ per 100 .

Kingston Beauty. Th is most raspberry is another product of Minnesota. Its growth is of the strongest, making from 10 to 15 canes from one hill or plant, thus needs more room than ordinary varieties. Very few thorns, practically thornless, and after the first year makes strong upright growth wood ripens well, leaves staying on late, and very hardy, bearing after the severest winters an immense crop of fine, rich, plump berries. Prices same as Cardinal.

King. Several of our best fruit growers red raspberries. It has large and attractive bright red fruits of good flavor, ripening, with the earliest and firm enough to ship nicely. In hardiness, growth and productiveness all postpaid. By express, $\$ 2.00$ per $100, \$ 15.00$ per 1,000 .

Black Hills. A very hardy variety, vere test of a Northern winter at our nurseries without any protection and surpasses nearly

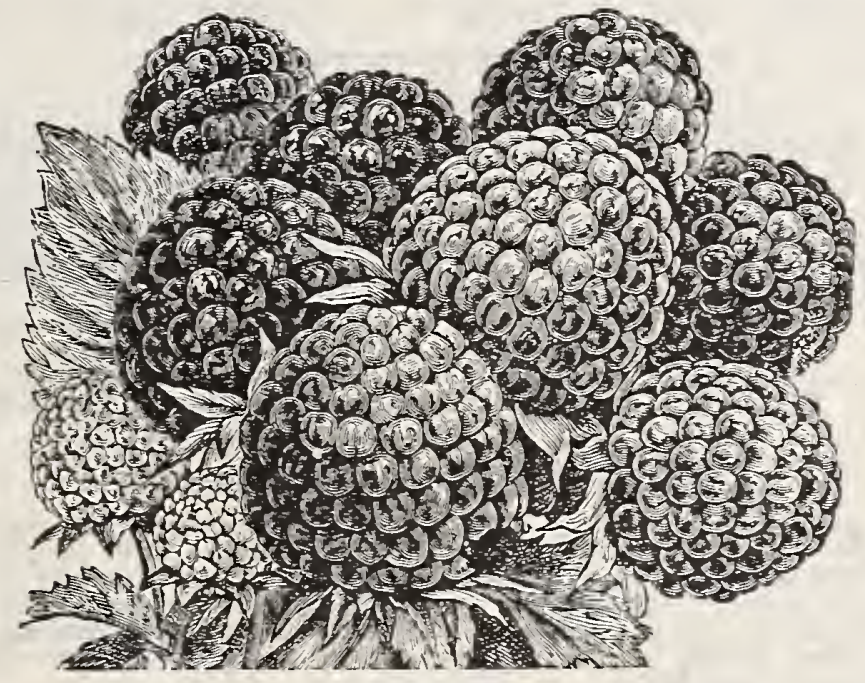

Cardinal.
CHOICE BLACK VARIETIES.

Cumberland. A valuable acquisition among black raspberries, able characteristics of great firmness, splendid quality and ductiveness. The plants are entirely hardy, very vigorous and healthful, and seem entirely unaffected by either anthracnose or yellow blight. In making a mid-season variety. Each $10 \mathrm{c}$. , doz. $\$ 1.00$, postpaid. By express, all other varieties in yield, length of season and flavor. The fruit is rich red in color, very large and of most delicious quality. It originated in Dakota, and experiments at our nurseries have convinced u
highly recommended to large planters. Prices same as King.

\section{STANDARD RED VARIETIES.}

Cuthbert. A standard hardy variety, enduring northern winters and postpaid. By express, $\$ 1.25$ per 100 , $\$ 8.00$ per 1,000 . Columbian. This berry is widely known as a very hardy variety, the Canes growing from 12 to 15 feet in length, many being Each $15 \mathrm{c}$., doz. $\$ 1.00$, postpaid. By express, $\$ 2.50$ per $100, \$ 15.00$ per 1,000 .

Golden Queen. A beautiful, large, golden seedling of the Cuthbert, surpassing it in size, beauty, seeding of the Cuthbert, surpassing it in size, beauty, Prices same as Cuthbert.

Loudon. We particularly wish to recfinest on the market. It is a northern grown variety originated by $\mathrm{L}$. W. Loudon, of Wisconsin. Each 10c., doz. $75 \mathrm{c}$., postpaid. B Marlboro Vigorous and productive. light A good, well-tested, early berry for the north. Prices same as Cuthbert.

Miller's Red. A thoroughly reliable growth. The canes reach a height of 6 feet and do not winter kill in the least. Prices same as Cuthbert.

Shaffer's Colossal. On e of the in both fruit and plant on the market. in both fruit and plant
Munger. The fruit is black, and resembles Gregg very much. It ture, and therefore a better shipper. In size it excels Gregg by almost 25 per cent, being

STANDARD BLACK VARIETIES. Price, each 10c., doz. 50c., postpaid. By express, $\$ 1.50$ per $100, \$ 10.00$

Gregg.

under good cy

Kansas.

Mammoth Cluster.

yet retain

Nemaha.

Ohio.

Palmers.
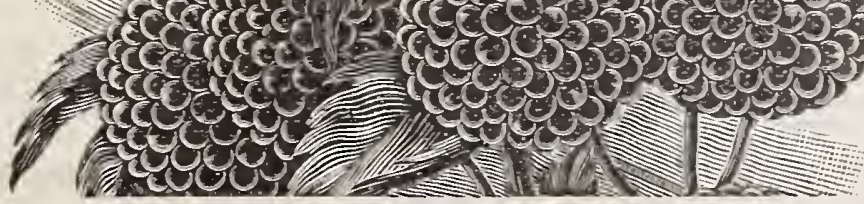

Mayfield Prize.
Our Berry Plants are Unequaled. 


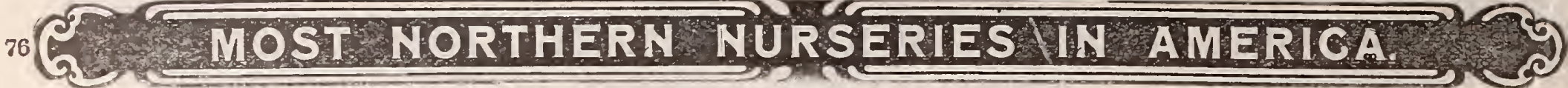

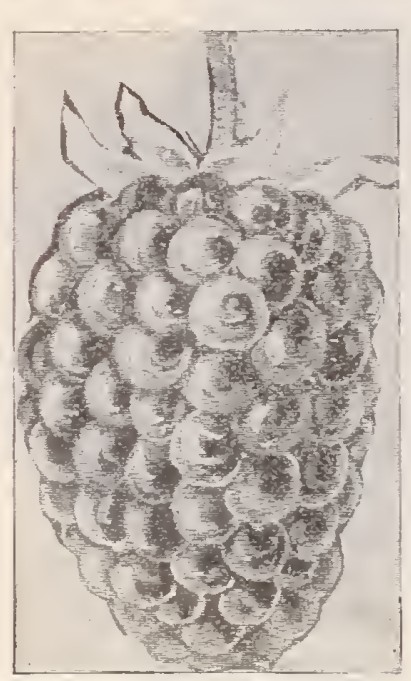

IMay's Surprise Blackberry.

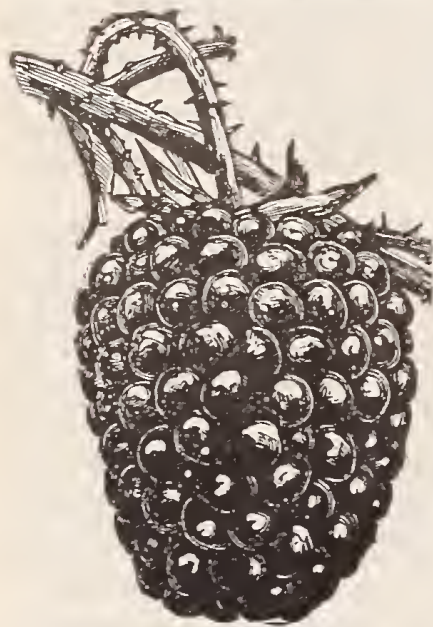

Ward Blackberry.

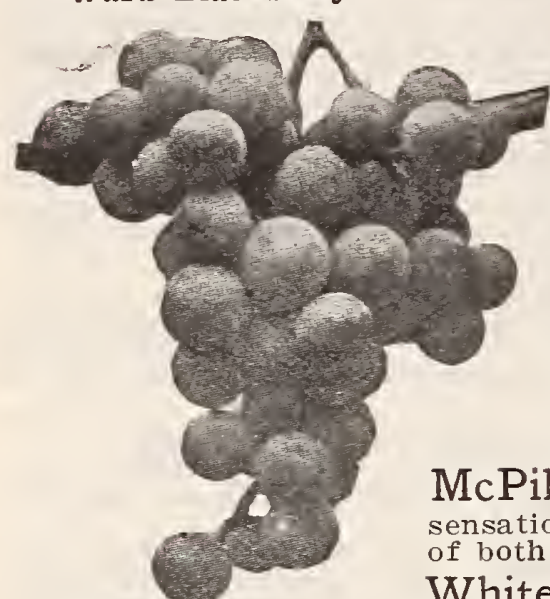

Eldorado.

\section{BLACIRERRIES $\underset{\text { VARIETIES. }}{\text { cBOICES }}$}

our serere winters without injury. Fruit very large, borne in clusters which ripen very evenly, quality unsurpassed and an excellent shipper. Each 15c., doz. 75c., postpaid; by express, per 100, $\$ 2.50$.

May's Surprise. This is one of the hardiest, earliest and most problack, and of fine substance and flavor. An ideal shipping variety. Desirable for canning and preserving on account of its rich flavor, good form and coleless nature. Each 15c., doz. $\$ 1.50$, postpaid; by express, per 100, $\$ 4.00$ Rathbun. Fruit is of largest size, sweet and delicious, without the har seed, and firm enough to handle and ship well Each 15c., doz. \$1.00, postpaid;by express, per $100, \$ 3.00$.

Ward Is a good shipper; perfectly hardy, no superfluous sprouts, a great all on per $100, \$ 4.00$.

\section{BLACKBERRIES, STANDARD VARIETIES.}

Each 10c., doz. 60c., postpaid; by express, per 100, $\$ 2.00$, per 1,000, $\$ 15.00$. Ancient Briton. A perfectly hardy variety, very vigorous and healthy. luscious flavor, that bear shipping well and bring the highest market price Snyder. Extremely hardy, enormously productive, finest flavor, ripening Stone's Hardy. Originated in Wisconsin, and is very hardy, sweet immense crops of delicious fruit. Taylor. Berries large, of fine flavor; canes of strong growth and hardy.

\section{DEWBERRIES.}

Austin's Improved The following extract from American Gardening - variety better than we possibly can: "The berries are much larger than those blackberry. It requires no trellises or stakes and it outrivals all fruit is jet black and of superior flavor. For productiveness by express, per $100, \$ 3.00$.

Lucretia. As hardy as snyder; as productive as any. The berries are far Lucretia. larger and incomparably better than any blackberry, and of unequalled excellence; soft, sweet and luscious throughout; of brightest, glossy black color. Each 10c., doz. 50c., postpaid; by express, per 100, $\$ 2.00$.

\section{GRAPES ${ }_{\text {HARDY VARIETIES. }}^{\text {CHOICEST }}$}

Beta. A hardy variety originating in this state. A cross beBeta. tween a cultivated sont and the native wild grape. The vine withstands our severest Northern winters without protection or injury. The fruit is jet black, of medium size. It $25 \mathrm{c}$, doz. $\$ 2.50$, postpaid; express or freight, 2 year strong, each 50c., doz. $\$ 5.00$.

Campbell's Early. The berries are large, often an inch with a purple bloom, sweet and juicy, with few seeds. They ripen from the 15 th to the last of August. As a keeper and shipper this variety is unequaled by any other American grape, doz. $\$ 2.00$, postpaid ; express or freight, per $100, \$ 10.00 ; 2$ year strong, each $30 \mathrm{c}$., doz. $\$ 3.00$, per $100 \$ 15.00$, express or freight. McPike This mammoth black grape has been exhibited in all parts of the sensation. It is a seedling of Worden and has many of the good qualities . White Diamond. Valuable for all sections of the United States, as it is $\$ 2.00$, postpaid; express or freight, 2 year strong, each 30c., doz. $\$ 3.00$.

GRAPES, STANDARD HARDY VARIETIES.

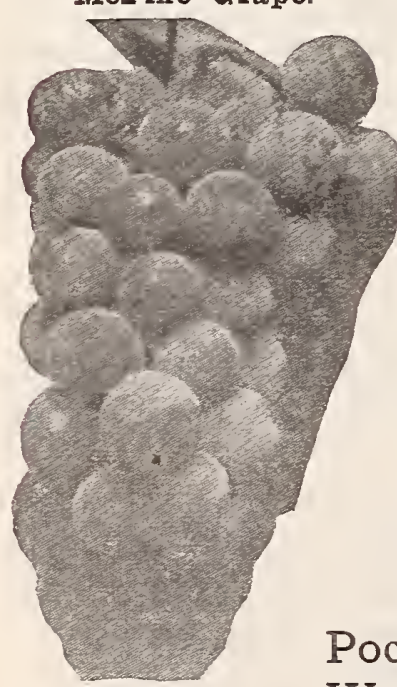

Agawam. A vigorous grower, producing large, red, thick-skinned grapes, which or freight, 2 year strong, each $20 \mathrm{c}$., doz $\$ 2.00$.

Concord. The well-known standard variety. It succeeds wherever grapes are freight, per 100 , $\$ 3.00 ; 2$ year strong, each $15 \mathrm{c}$, doz. $\$ 1.50$, per $100 \$ 5.00$, express or freight.

press or freight. Delaware. The bunches are all compact, shoulder

Eaton A seedling of the Concord, which it $r \in$ sembles in generai appearance, Eaton. but the berry is much larger. Prices same as Agawan.

Empire State A fine large white grape, very highly regarded in Eastern Empire State. sections. Price same as Niagara.

Moore's Early. One of the best early ripening varieties. The bunch is passing the Concord. Price same as Agawan.

Niagara. A most desirable white variety and one that is hardy, vigorous and . productive in all sections. 1 year strong, each 15c., doz. \$1.50, per 100 \$7.00, express or freight.

Pocklington. A very beautiful white variety. Frice same as the Niagara.

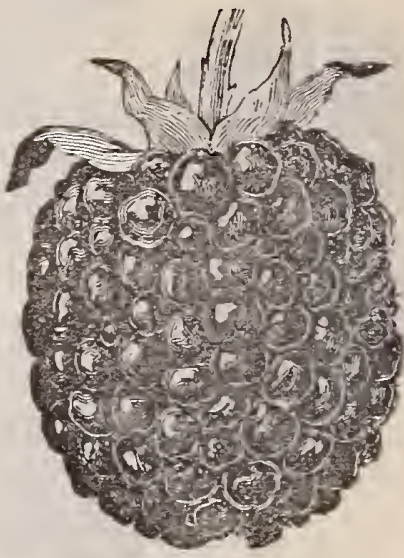

Eldorado Blackberry.

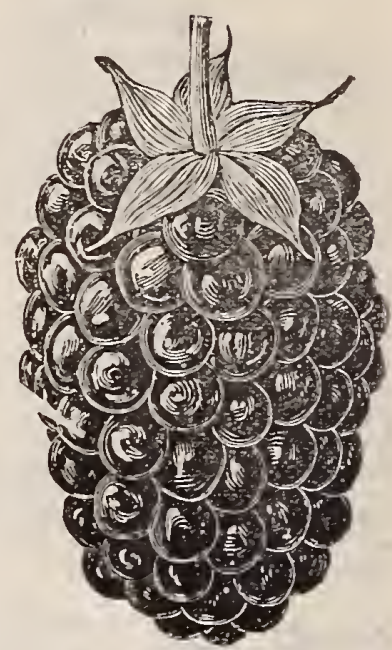

Austin Dewberry.

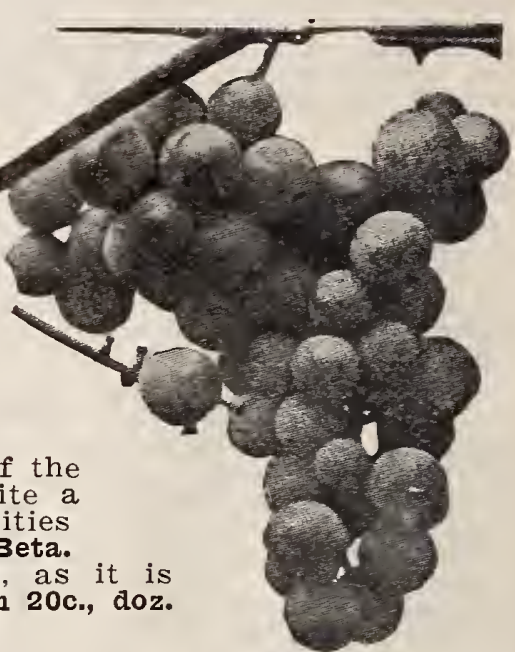

Campbell Grape.

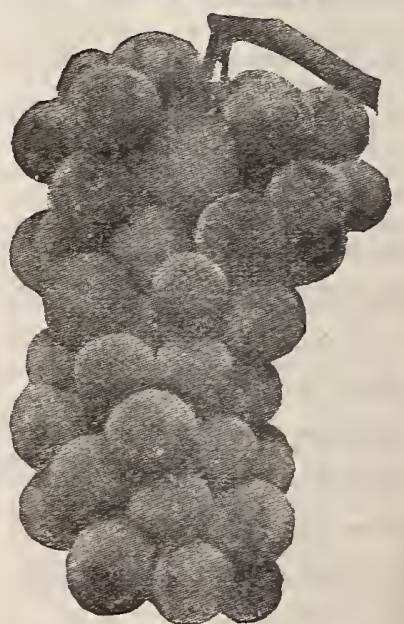

White Diamond Grape 


\section{C2. MOST MORIHERN NUR SRIES IN AMERIGA 39}

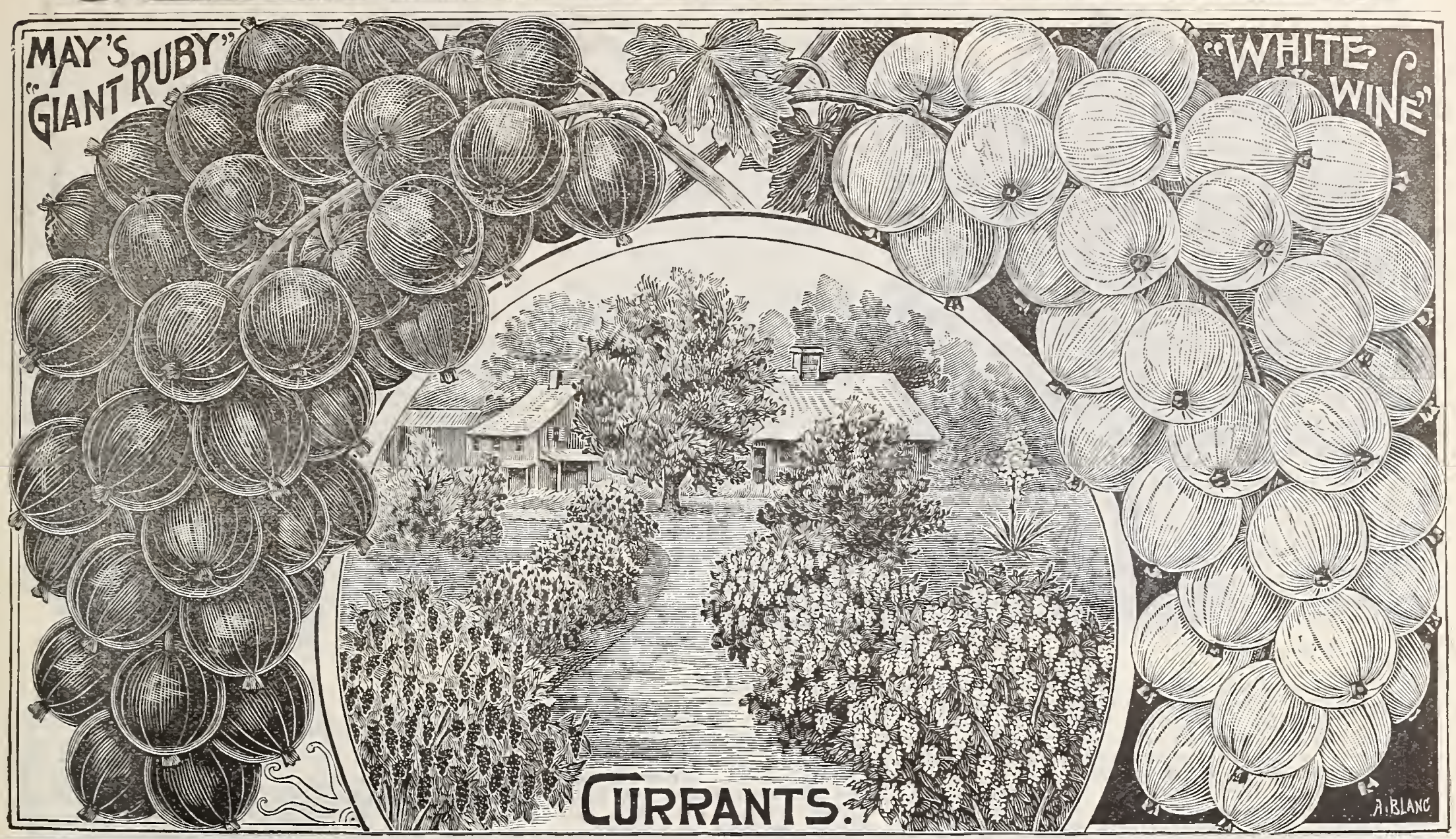

Hardy, easily cultivated, responding liberally to cultivation, GENERAL LIST OF STANDARD VARIETIES and standing neglect well, no class of plants grown will afford better returns for the investment, either for home use or the will pay handsomely for the market. Plant four feet apart in rich ground, cultivate well and mulch heavily.

mbracing the hardiest, most prolific and best quality grown.

\section{FOUR DELIGHTFUL CURRANTS.}

May's Giant Ruby. The largest red currant in existence habit of growth and bear profusely. The berries are beautiful light red and grow in immense clusters, more resembling bunches of red grapes than bunches of currants. Many
fruit growers are now planting largely of this variety in frut growers are now planting largely of this variety in place of the older sorts on account of its enormous yield. 1 year, each $15 \mathrm{c} .$, doz. $\$ 1.50$, postpaid; $100 \$ 5.00$, by express. 2 year, each 20c., doz. \$2.00, postpaid; 100 $\$ 8.00$, by express.

Perfection Currant. The latest introduction, Prolific with White Grape and combinss the best qualities of both parents. In color it is a beautiful bright red and of size larger than the Fay; the clusters average longer and the size of the berries is maintained to the end of the bunch. It is one of the most productive currants we have ever known, and in quality it is superior to anything in the market to-day, being of a rich, mild, sub-acid flavor each 20c., doz. \$2.00, postpaid; $100 \$ 8.00$, by express. 2 year, each 25c., doz. \$2.50, postpaid; 100 \$10.00, by express.

Red Cross. Jacob Moore, the originator, savs: Cross clusters are long and have well-neched berries, double the size of Victoria, and far superior in quality to Cherry or Victoria Nothing will compare in quality with Red Cross but White Dutch which is so small Red Cross was first fruited in 1889 . I have seen the fruit growing in such masses as to hide the upper branches from the growth later than Cherry. much fruit I recommend it with confidence. I con sider Red Cross one of the best of the new currants. Price same as May's Giant Ruby.

White Wine. This is the hardiest white sort ever cially desirable for the middle and northern states. It bears great bunches of pearly white currants of tne the best of all currants in both quality and yield, surpassing even the well-known valuable Fay's Prolific, Price same as May's Giant Ruby.

Black Champion.

cellent quality.

Black Naples.

Cherry.

Fay's Prolific. Until the introduction of Giant Ruby this

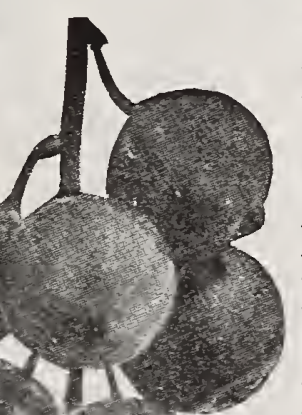

easily picked of excellent quality. The plant is easily picked, of excellent quality.

London Market. A new currant of meritcropper Read description from its her and sure money making market currant, we believe this vatry by Henry Bowles, of Michigan."

Lee's Prolific. of excellent quality.

Long Bunch Holland. The best of late vaproductive; fruit clusters long and of large size.

North Star.

Pomona.

older sorts and fre quat

to supersede all

clear,

Victoria.

clusters of large, bright

White Grape.

Wilder.

tive. Berr

PRICE STANDARD VARIETIES

1 year, express or freight 2 year, each 15c. doz. \$1.50; 100 $\$ 5.00$, express or freight. 1,000 rates on application. 


\section{C2 MOST NORTHERN NUR SERIES IN AMERICA 32}

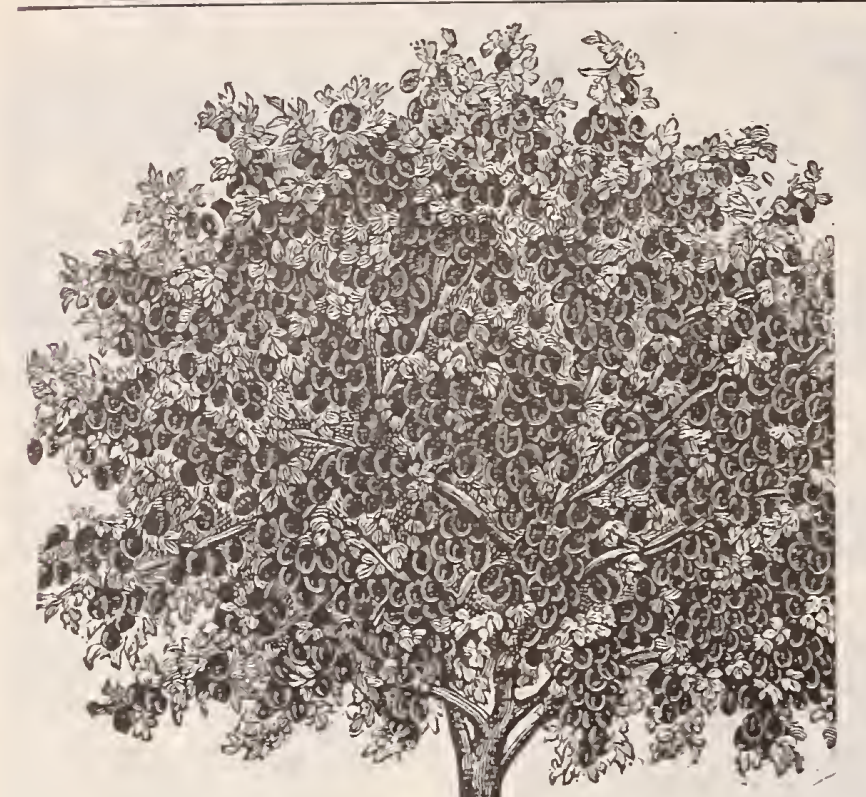

\section{GOOSEBERRIES.}

Whinham's Tree. This grows in tree form, throwing its branches straight The fruit is very large, often measuring $11 /$ to 2 inches in length of a rich deep red color and in quality and flavor unequaled. It has been proven perwinters of the Torth without protection. 1 year strong, 20c. each, doz. $\$ 2.00$ postpaid; 2 year strong, each 25c., doz. $\$ 2.50$ i $100 \$ 15.00$, express or freight. Keepsake. At new English variety, possessing unusual merit. Plants grow dew and very hardy. The fruit is very large, straw colored, of excellent flavor The blossom is well protected by

Pearl. A very prolific variety, healthful, vigorous of growth, free from and handsome. 1 year strong, each $15 \mathrm{c}$., doz. $\$ 1.50$, postpaid; 100 \$8.00, express or freight. 2 year strong, each $20 \mathrm{c}$., doz. $\$ 2.00,100 \$ 10.00$, express or freight. Red Jacket. Fruit as large as the Windham, a bright shiny red, a most ( Plant and foliage are at all times and mas been tested in many sections under most trying circumstances and has proven at all time and in all places Columbus. A new American seedling of English type. Of large size, oval Plant a strong, robust grower, with large spines or thorns. Has never shown

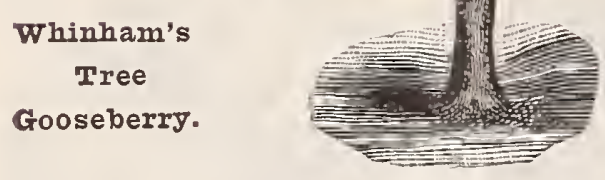

Chautauqua.

trace of mildew on either fruit or foliage. Price same as Chautauqua.

\section{STANDARD VARIETIES.}

Smith's. Large, pale yellow, thin-skinned. of quality. A favorite for home and market. The bush is a vigorous grower and

Houghton. cooking. Moderately vigorous and exceedingly fruitful. Where conditions are favorable, a valuable sort. Price, 1 year strong, each 15c., 2 year strong, each 20 c., doz. $\$ 2.00$, $\$ 100$ \$10.00, $\$ 10.00$, express or freight.

shoots slender and

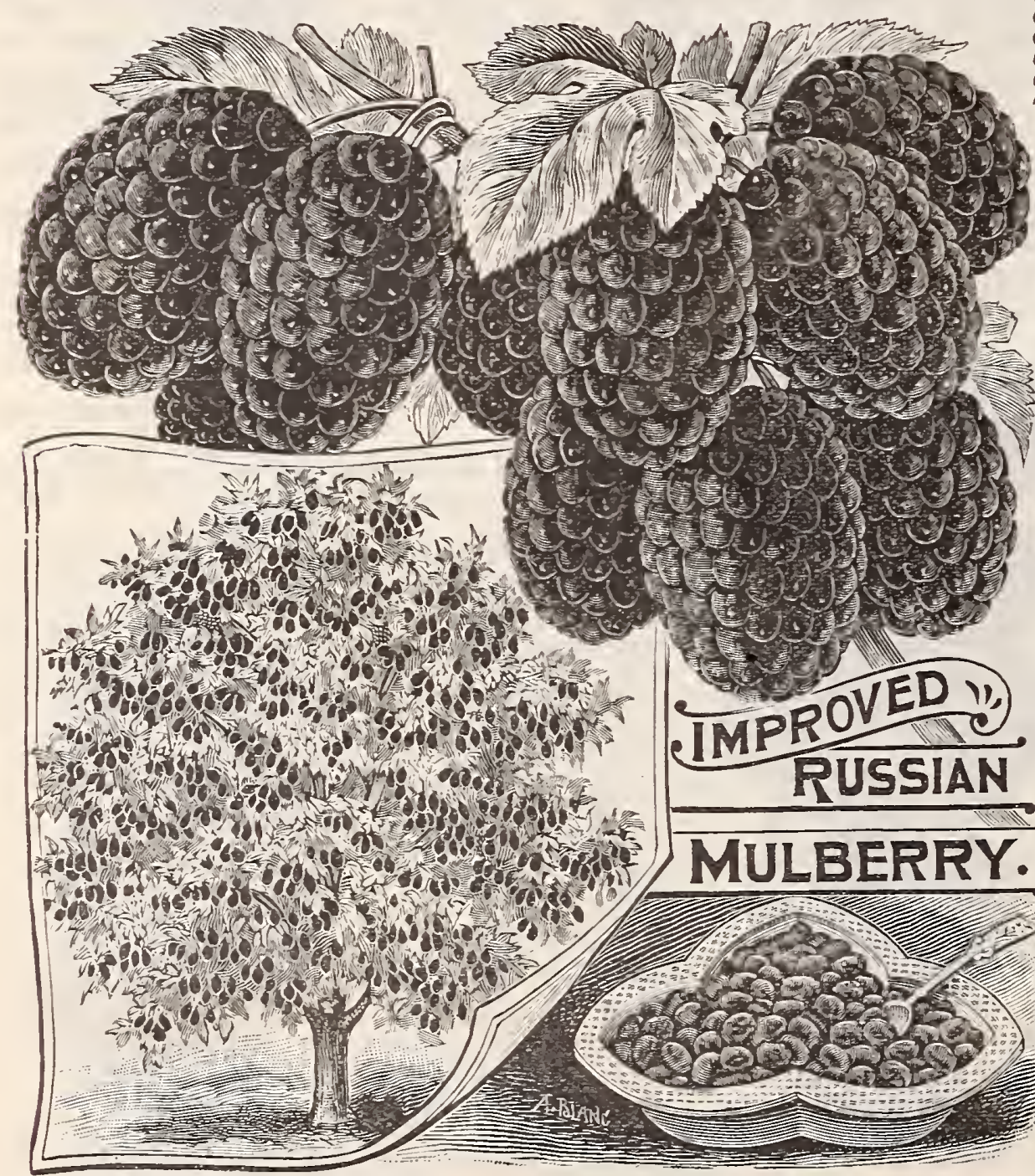

THE MINNETONKA\} Guaranteed Apple IMPROVED RUSSIAN MULBERRY.

An ornamental, hardy fruit bearing tree for America. Suitable for all sections of this country. Fruit larger than blackberries and of delicious flavor. This valuable from Western Russia by the Mennonites. The tree is a very rapid grower. Grows very large, often reaching the height of 50 feet and from 3 to 5 feet in diameter, the fruit being larger than the average blackberry. Fruit has a fine, aromatic s we use blackberries or raspberries. A beautiful, raluable for table use. In all our experience we have found no fruit so admirably adapted to all parts of the 6 for 50c., postpaid. By express or freight, 3 fo $40 \mathrm{c}$. each 25c., doz. $\$ 2.50$; 4 to 5 ft., each $35 \mathrm{c}$., doz. $\$ 3.50$.

Japan Orange. 1 at this

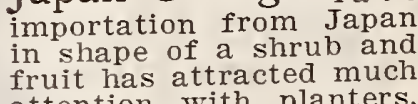

fruit has attracted much ear

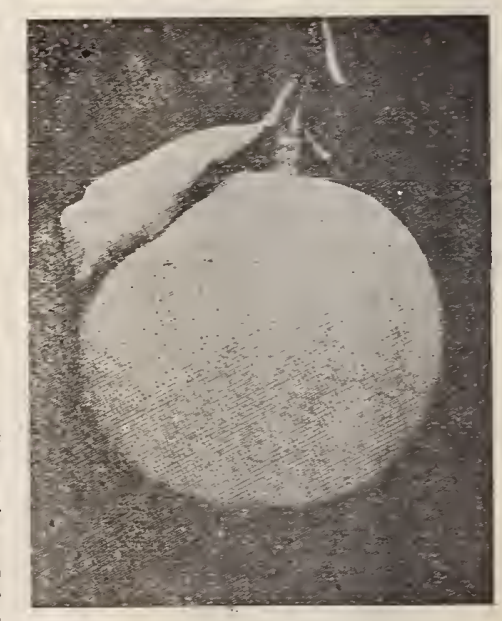
each 20 c., doz. $\$ 2.00$, postpaid. By express, 18 to 24 inch, each 30 c., doz. 24.10
$\$ 3.00$. 


\section{HARDY, PRODUGTIVE FRUITS, ORNAMENTAL TREES, SHRUBS. ETC. Sf}

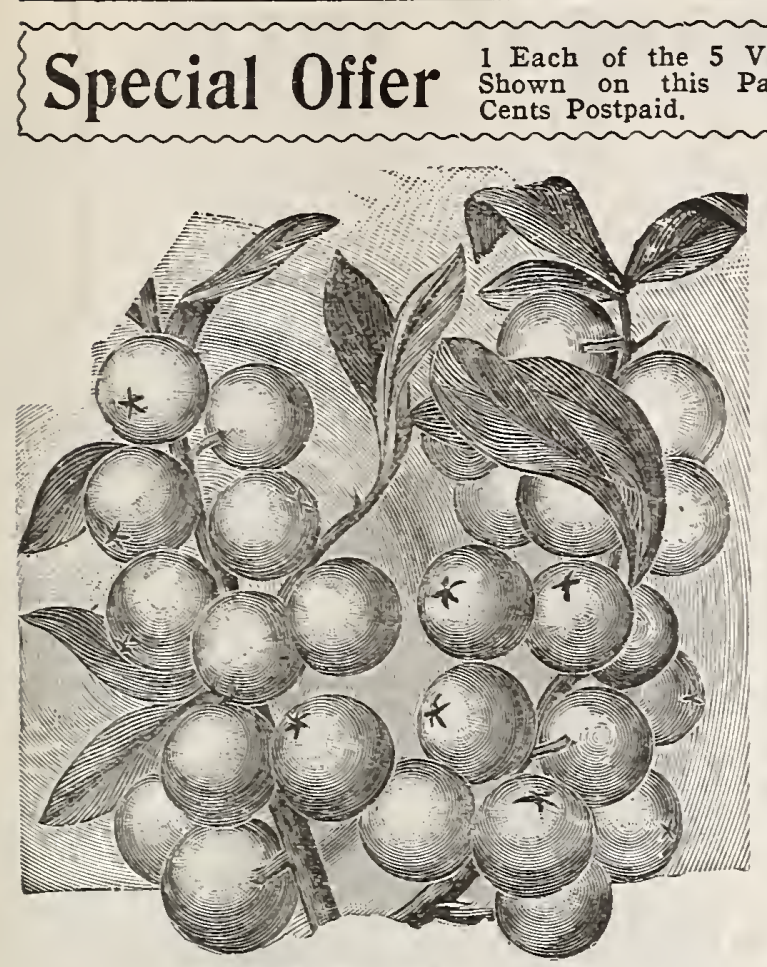

Buffalo Berry.

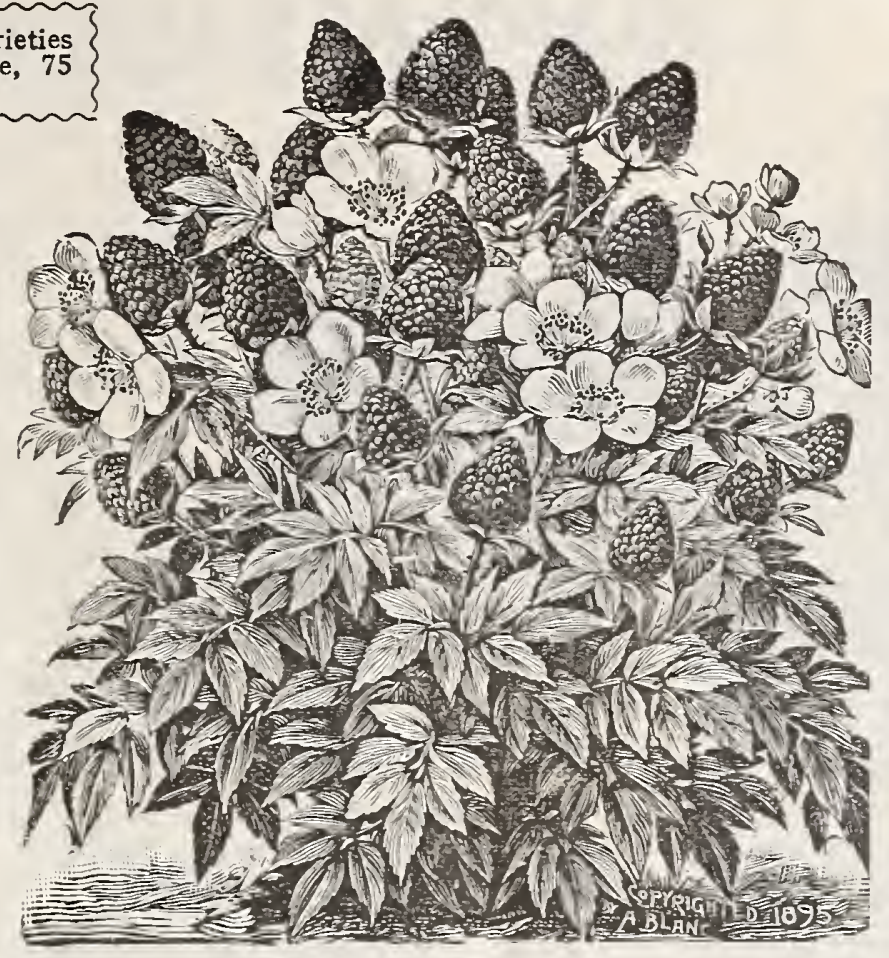

Strawberry Raspberry.

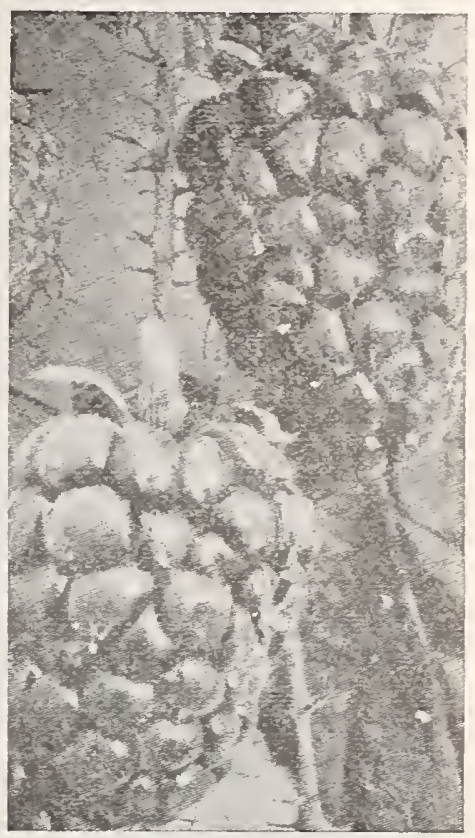

Jogan Berry.
Buffalo Berry. This is a hardy fruit discovered on the tas. It is a handsome shrub, as mell as a splendid fruit, growclusters resembling great clusters of currants and cannot be ing all summer. Mail size, postpaid, 15c. each, 3 for $35 \mathrm{c} . ;$ by express, large size, 25c. each, $\$ 2.50$ doz.

High Bush Cranberry. the foliage being dense and dark green. The flowers, which are pure white, hang in large showy clusters in early summer, which are followed by scarlet berries that remain on the plant all winter. The fruit is acid in
flaror like the Common Cranberry and is highly esteemed for jellies, pies, etc., being fully equal in quality to the low bush or swamp variety. It is extremely hardy, thrives well everyno training; has handsome, clean, attractive foliage at all times. Mail size, 15c. each, 3 for 35 c., postpaid; large size, express or freight, 30c. each, doz. $\$ 3.00$.

Improved Dwarf Juneberry. This fruit is a native of the most ironclad hardiness. It is a quick grower, forming 1 or 2 feet in height. The berries are the size of ordinary cherries, being green in an unripe state, changing to a bright scarcolors hang in clusters upon a bush they present a most charmkeep on the bush in perfect condition for two or three weeks without decaying or dropping. It is exceedingly sweet and has

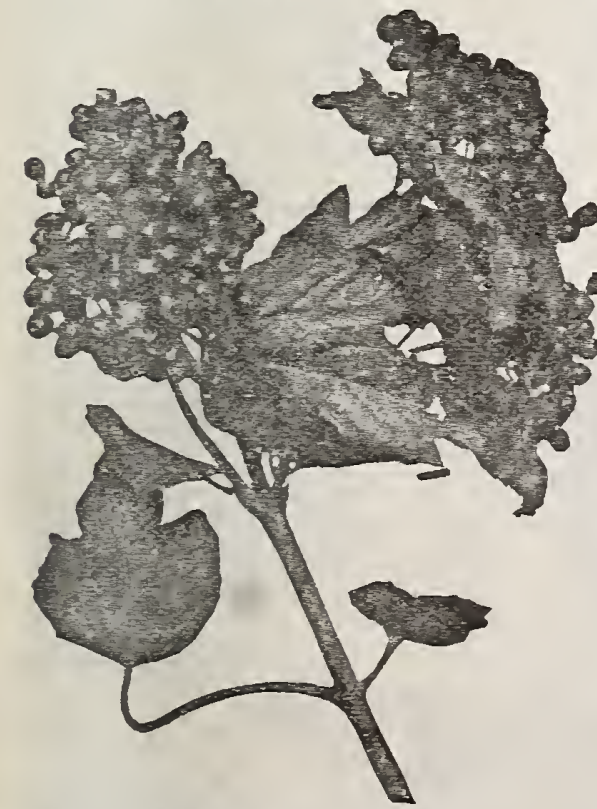

scious flavor. Mail size, 15c. each, 4 for $50 \mathrm{c}$., postpress, 25 c. ea., doz. $\$ 2.50$. BOWKER'S PLANT FOOD. A dressing made expressly for plants grown conservatory; clean, odorless and producing early healthy, luxuriant plants. One small package is enough for 30 plants for 3 months. Small packages, 25c., large packages, 45c. postpaid.

RUBBER PLANT SPRINKLER.

For sprinkling cut flow ers, seedlings, plants, clothes, etc. They are mabber and are very desirable. Straioht neck, 90c. crook neck, $\$ 1.00$, postpaid.
The New Logan Berry. (Blackberry Raspberry.)

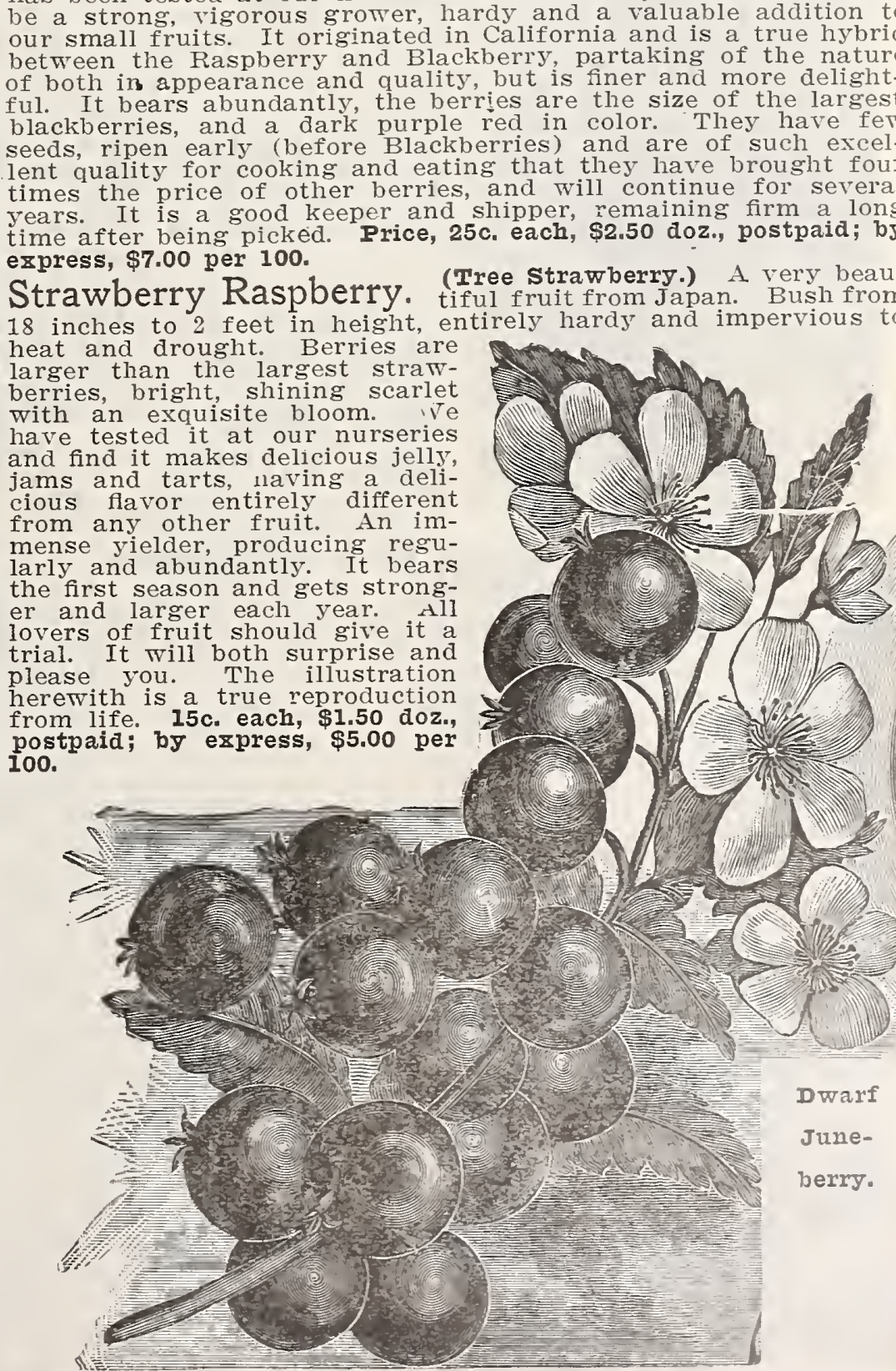




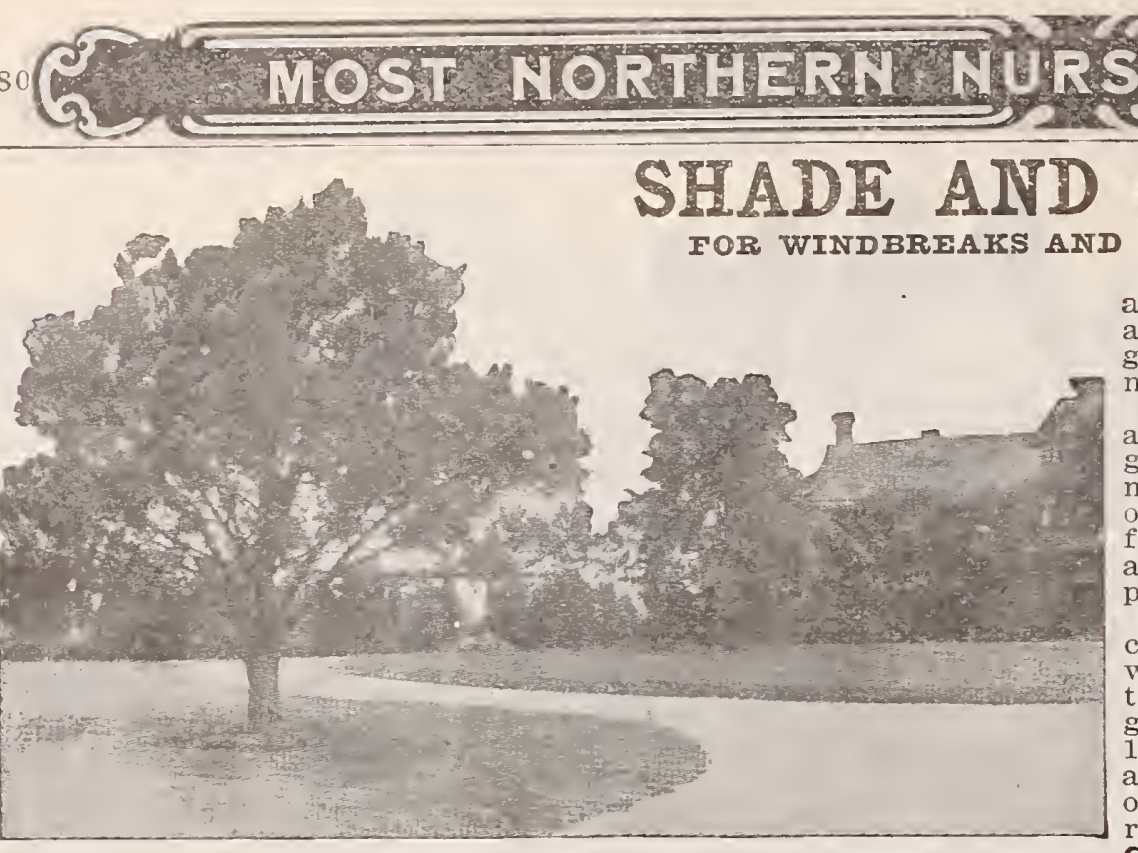

This department of our business is very extensive, where avenue and park trees are cultivated in large blocks; many acres are assigned to the field culture of shrubs and small
crowing trees; thousands of rows, in the borders, contain the more delicate shrubs and herbaceous plants.

Many of the most active business men are also men of taste, and would be glad to beautify and improve their home grounds, but they are so occupied with business that they or to lay out their grounds. Where such is the case, we cheerand willingly furnish plans and estimates for large or smali All our trees are grown under a thorough, clean system of cultivation, frequently transplanted, and are well supplied with an abundance of fibrous roots which enable them to bear rown trees, for disapoint be deceived into planting forest 00 . In many varieties we have large specimen trees, which re not quoted herein. Prices on these will be cheerfully given n application. For hardiness and quick growth, we especially Carolina, Iombardy and Silver Poplars.

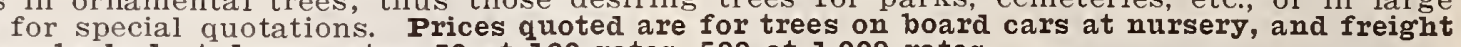
or express to be paid by purchaser. Six can be had at dozen rates, 50 at 100 rates, 500 at 1,000 rates.

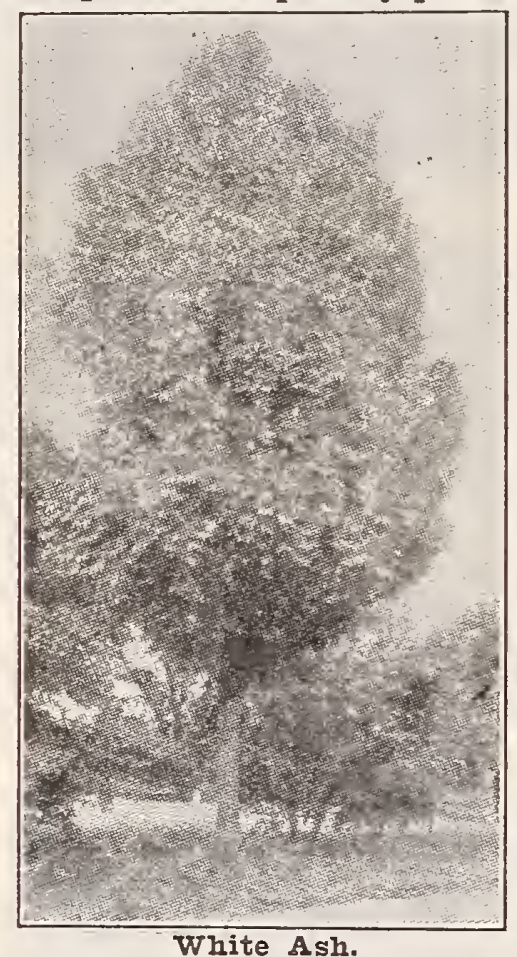
Ash, American White. Arowth, forming straight, clean trunks and broad, oval shaped heads. Desirable for parks, public grounds and street planting, also for timber and forestry purposes. $\$ 5.00$, 100 \$25.00; 8 to $10 \mathrm{ft}$., each $60 \mathrm{c}$., doz. $\$ 6.00$, 10 n $\$ 30.00$.

European Alder. A remarkably rapid growing tree, attaining roundish, wedge-shaped and wavy, 4 to $6 \mathrm{ft}$., each $40 \mathrm{c}$., doz. $\$ 4.00$; 6 to $8 \mathrm{ft}$., each $50 \mathrm{c}$., doz. $\$ 5.00 ; 8$ to $10 \mathrm{ft}$., each $75 \mathrm{c}$., doz. $\$ 7.50$.

Box Elder. See Maple, Ash Leaved, on opposite page.

Birch, European White A distinct, native species of vigorleaves triangupe grow in sandy makes a beautiful shade and ornamental tree. Price, 4 to 5 ft., $75 \mathrm{c}$., doz. $\$ 7.50$; 8 to $10 \mathrm{ft}$., each $\$ 1.00$, doz. $\$ 10.00$; 10 to $12 \mathrm{ft}$., each $\$ 1.50$, doz. $\$ 15.00$.

Birch, Paper or Canoe. One of the handsomest trees in grows older, to a shining, silky white, rendering it clean looking each $\$ 1.00$, doz. $\$ 10.00 ; 10$ to $12 \mathrm{ft}$., each $\$ 1.50$, doz. $\$ 15.00$.

Birch, Purple. A most handsome variety, of vigorous growth,

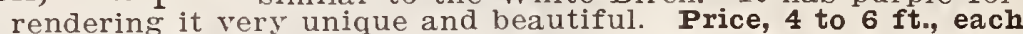
$75 \mathrm{c}$, doz. $\$ 7.50 ; 6$ to $8 \mathrm{ft}$., each $\$ 1.00, \mathrm{doz} . \$ 10.00 ; 8$ to $10 \mathrm{ft}$, each $\$ 1.50$, doz. $\$ 15.00$.

Birch, Pyramidal. Of elegant pyramidal habit like the Lom-

distinct and ornamental. Price, 3 to 4 ft., each 40c., doz. \$4.00; 4

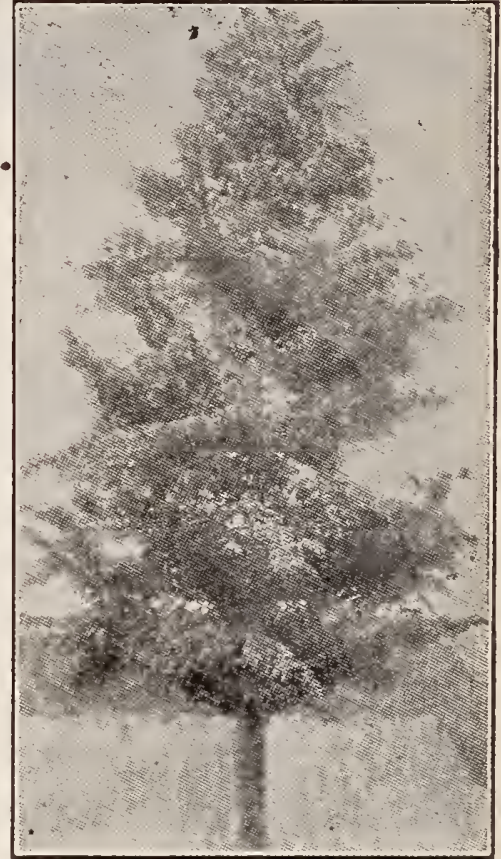

Hackberry.

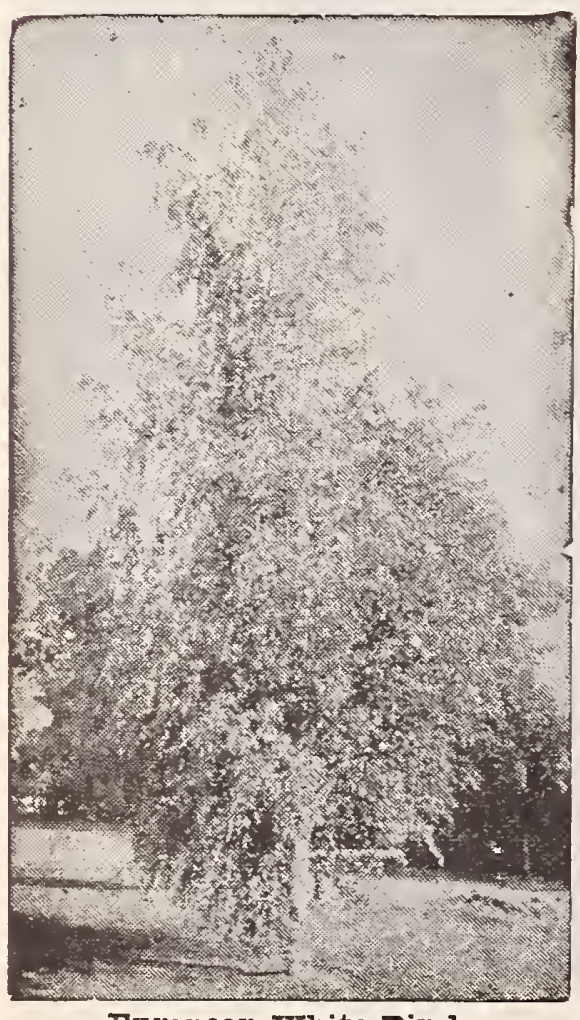

$5 \mathrm{ft}$., each $50 \mathrm{c}$., doz. $\$ 5.00$

Catalpa, Speciosa. This hardy native rariety is one of the finest for shade and ornament-

ribbed, never subject to the attacks of insect.s, and $8 \mathrm{ft}$., each $40 \mathrm{c}$., doz. $\$ 4.00,100 \$ 25.00 ; 8$ to $10 \mathrm{ft}$., each $60 \mathrm{c}$., doz. $\$ 6.00,100 \$ 30.00$; 10 to $12 \mathrm{ft}$., each $75 \mathrm{c}$., doz. $\$ 7.50$. Specimen Trees from $\$ 3.00$ to $\$ 5.00$.

Catalpa, Bignonoides. A rapid growing tree, ed leaves and pyramidal clusters, a foot long, of purciosa. We have stock of Catalpa of extra sizes, 3 to 5 inches in calibre. Special prices given on application. Cottonwood. Canadian Poplar. A tall, native rowing 80 to 100 feet high. 4 to $6 \mathrm{ft}$., each $25 \mathrm{c}$. doz. $\$ 2.50 ; 6$ to $8 \mathrm{ft}$, each $35 \mathrm{c}$., doz. $\$ 3.50,100 \$ 15.00$ 8 to $10 \mathrm{ft}$. each $50 \mathrm{c}$. doz. $\$ 5.00,100 \$ 25.00 ; 10$ to 12 ft., each 60c., doz. $\$ 6.00,100 \$ 35.00$.

$\mathrm{Elm}$, American. This is well known and thrives doz. $\$ 3.50,100 \$ 20.00 ; 6$ to $8 \mathrm{ft}$., each $50 \mathrm{c}$., doz. $\$ 5.00$, $100 \$ 30.00 ; 8$ to $10 \mathrm{ft}$., each $60 \mathrm{c}$., doz. $\$ 6.00,100 \$ 35.00$ Elm, Scotch. Fine spreading tree, rapid grow.

Hackberry. A very handsome native tree, of easy as American Ilm.

Horse Chestnut. Ohio Buckeye. A native of to $3 \mathrm{ft}$., each $25 \mathrm{c}$, doz. $\$ 2.50$.

Kentucky Coffee Tree. Native tree of mediea. $25 \mathrm{c}$., doz. $\$ 2.50 ; 4$ to $6 \mathrm{ft}$, ea. $35 \mathrm{c}$. , doz. $\$ 3.50,6$ to 8

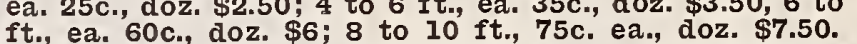
Linden European Similar to the American doz. $\$ 2.50 ; 5$ to $6 \mathrm{ft}$., ea. $40 \mathrm{c}$., doz. $\$ 4 ; 6$ to 8 ft., ea.

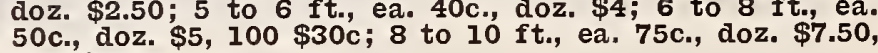
$100 \$ 35.00$.

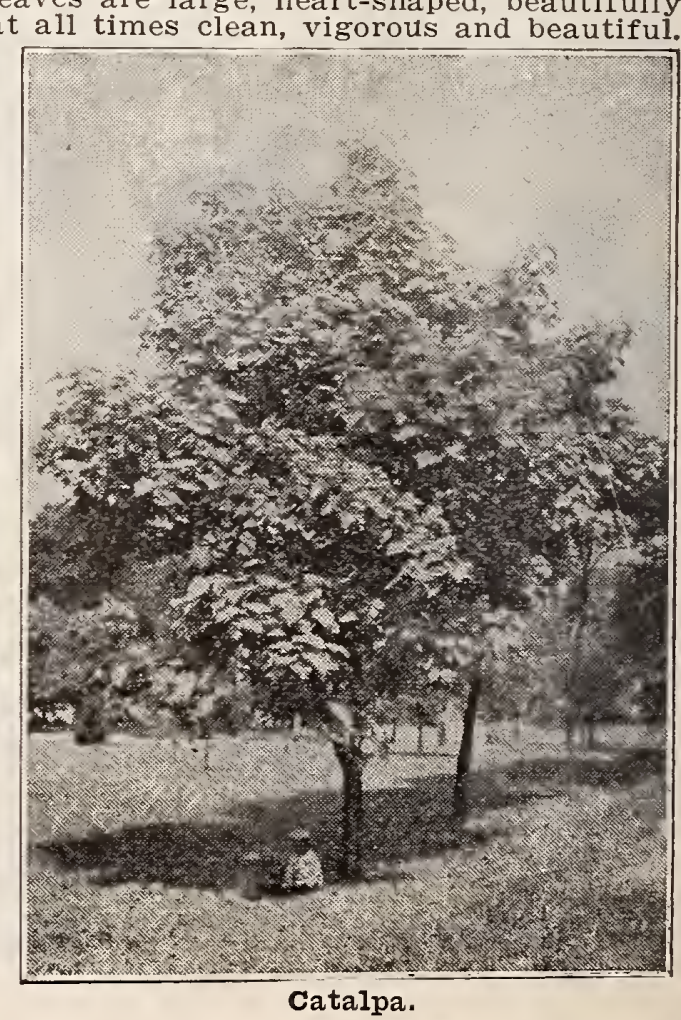




\section{ORNAMENTAL TREES--Cont.}

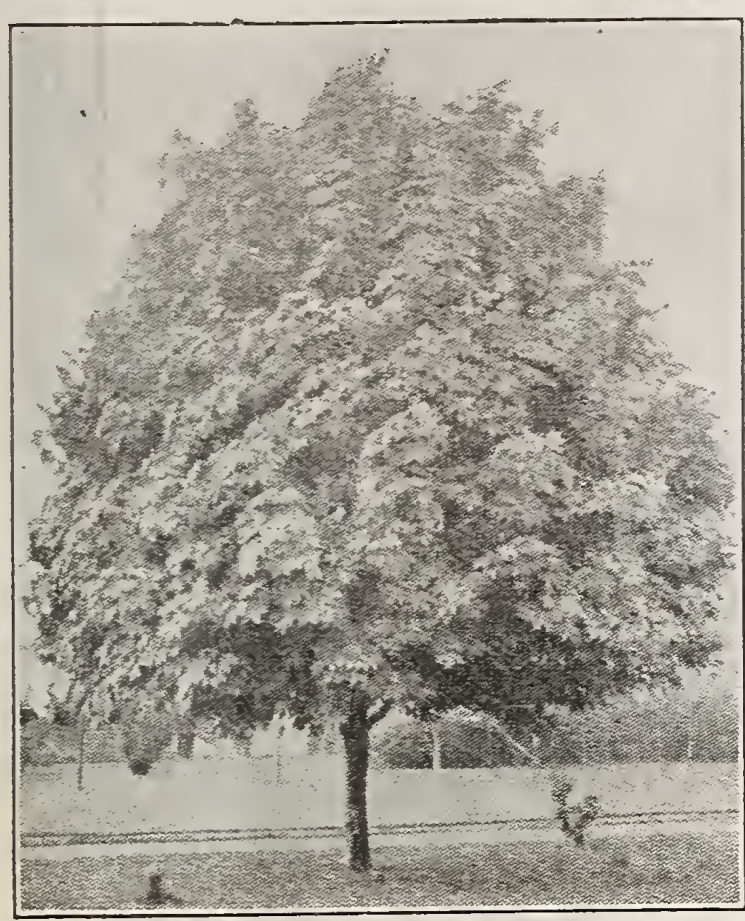

Silver or Soft Maple.

Linden, American. $\mathrm{B}$ a $\mathbf{s} \mathbf{s}$ wood. dy everywhere, vigorous in growt handsome foliage, and formPrice same as European Iinden. Linden, Silver.

of its silvel-lined leares.
great brilliancy when ruffled by the wind.
Handsome vigorous prramidal. Price, same as European Iinden.

Larch, European.

branches and light green, needle shaped 12 to 18 in., 20c. ea., $\$ 2.00 \mathrm{doz}$; 18 to 24 in., 25c. ea., $\$ 2.50$ doz.; 2 to $3 \mathrm{ft.,} 40 \mathrm{c}$. ea., 4.00 doz.; 3 to 4 ft., $50 c_{\text {a }}$ ea., $\$ 5.00$ doz.

Locust, Black or Yellow.

arge size, rapid growth; flowers are disposed in pendulous racemes, white 4 to $6 \mathrm{ft}$., $25 \mathrm{c}$. ea., $\$ 2.50 \mathrm{doz}$. 6 to $8 \mathrm{ft}$. $40 \mathrm{c}$. ea., $\$ 4.00 \mathrm{doz}$; 8 to $10 \mathrm{ft}$., 50c. ea.,
$\$ 5.00$ doz.

Maple, Schwedleri. The most ormaples; extremely hardy; of German origin. In the spring the leaves and young sprouts are purplish red, changing to copa pure golden tint. 2 to 3 ft., ea. $40 \mathrm{c}$., doz. $\$ 4.00 ; 3$ to $4 \mathrm{ft}, 50 \mathrm{c}$. ea., $\$ 5.00$ doz.; 4 to 6
ft., $60 \mathrm{c}$. ea., $\$ 6.00$ doz.; 6 to $8 \mathrm{ft}$., ea. $\$ 1.00$ ft.y $60 \mathrm{c}$. ea.,
doz. $\$ 10.00$.

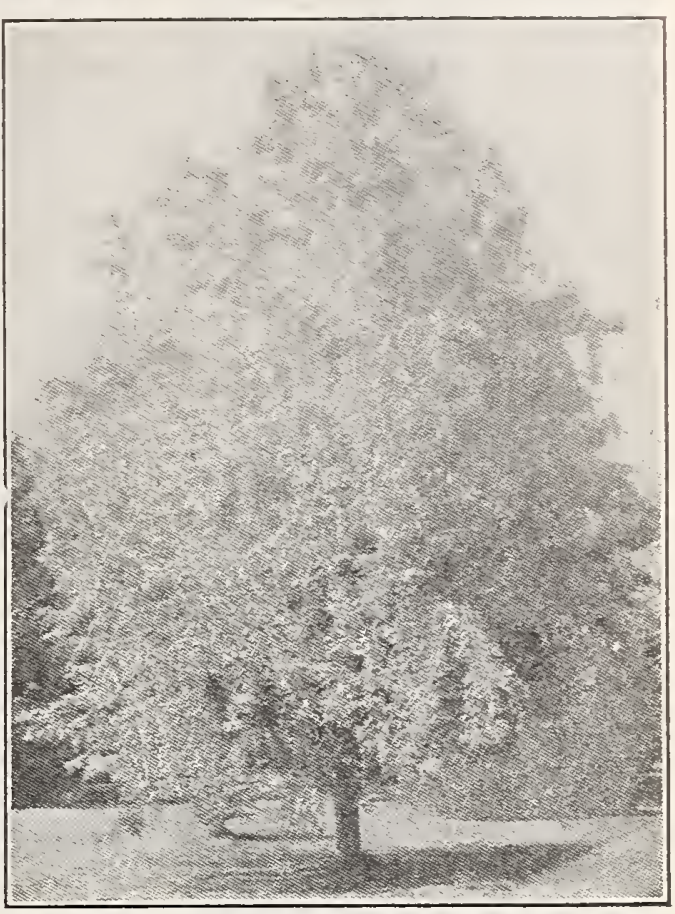

Weirs' Cut Ieaf Maple.
Maple, Ash Leaf. (Manitoba) Bor Elder. A durable tree planting mell and grows rapidly, producing considerable shade in a very short time; most used in the West and Northwest, as attains a height of 70 feet. Succeeds in a variety of soils. 4 to $6 \mathrm{ft.}$., ea. $25 \mathrm{c}$., doz. $\$ 2.50$, $100 \$ 15.00$; 6 to $8 \mathrm{ft}$., $40 \mathrm{c}$., doz. $\$ 4.00$, $100 \$ 20.00$; 8 to $10 \mathrm{ft}$., ea. 50c., doz. $\$ 5.00,100 \$ 25.00$; 10 to $12 \mathrm{ft}$., ea. 75c., doz. \$7.50, 10 \$35.00. We have extra sizes 2 to $3 \frac{1 / 2-i n c h}{2}$ calibre. Special price given on application.

Maple, Silver or Soft. A magnificent shade and ornais perfectly hardy and will thrive in any soil and any locality. The leaves are beautifully shaped and have a silver gleam Prices same as Ash Ieaf.

Maple, Norway. A tree of foreign origin, a sturdy symspreading, rounded head. 3 to $4 \mathrm{ft}$., ea. $25 \mathrm{c}$., doz. $\$ 2.50 ; 4$ to 6 ft., ea. 50c., doz. $\$ 5.00$; 6 to $8 \mathrm{ft}$., ea. $75 \mathrm{c}$., doz. $\$ 7.50 ; 8$ to $10 \mathrm{ft}$., ea. $\$ 1.00$, doz. $\$ 10.00$.

Maple, Sugar or Rock. A valuable tree for sugar as well It is adaptable to all locations, roots deeply and grows symmetrical into a tree of large proportions. 4 to 6 ft., ea. 40c., doz. $\$ 4.00$;
doz. $\$ 10.00$.

Maple, Weirs' Cut Leaf. A very beautiful silver leaf sort, with delicately cut leaves and dis tinct. half drooping habit. 4 to 6 ft., ea. $40 \mathrm{c}$., doz. $\$ 4.00 ; 6$ to 8 ft., $75 \mathrm{c}$. , doz. $\$ 7.50$; 10 to $12 \mathrm{ft}$., ea. $\$ 1.00$, doz. $\$ 10.00$.

Maple, Globe. (Acer Globoshardy Maple from Europe, and after a thorough test find it a valuable acquisition to the North2 to 3 ft., ea. $50 \mathrm{c.s}$ doz. $\$ 5.00 ; 3$ to $4 \mathrm{ft}$., ea. 60c., doz. $\$ 6.00 ; 4$ to $5 \mathrm{ft}$., ea. S1.00, doz. $\$ 10.00 ; 6$ to 8 ft., ea. ea. $\$ 1.00$, doz. $\$ 10.00$
$\$ 1.50$, doz. $\$ 15.00$.

Oak, American White. One of the finest American trees, of large size and spreading branches; leaves lobed, pale green above and glaucous beneat
to $4 \mathrm{ft}$., ea. $30 \mathrm{c}$., doz. $\$ 3.00$.

Oak, Scarlet. A native tree growth. pyramidal outline, and especially remarkable in autumn, when the foliage changes to a bright scarlet. Prices same as American White.

Oak Pin. Foliage deep green, sumes a drooping form with age. 3 to $4 \mathrm{ft}$., ea. $35 \mathrm{c}$., doz. $\$ 3.50$.
Maple, Siberian. (Acer Ginnala.) This tree is of miniature tensively used in eastern and southern states, where they are hardy, but these do not compare with Siberian, for it has more vitality and is more robust in its habit. Its beautiful dark green, glossy foliage, with leaf gracefully cut, makes it a tree to be marked or colored foliage in the autumn. It begins taking on its marked or colored foliage in the autumn. It begins taking on its its beauties are much admired. One of its most valuable qualities is its extreme hardiness and clean habit, never dropping any
leaves until late in fall. The flowers appear in June and are leaves until late in fall. The flowers appear in June and are duces. This tree can be termed a shrub, and by pruning can be $3 \mathrm{ft}$., ea. $20 \mathrm{c}$., doz. $\$ 2.00 ; 3$ to 4 ft., ea. $30 \mathrm{c}$., doz. $\$ 3.00 ; 4$ to $5 \mathrm{ft}$., ea. 50c., doz. $\$ 5.00 ; 6$ to $8 \mathrm{ft}$., ea., $75 \mathrm{c}$., doz. $\$ 7.50$.

Maple, Tartarian.

ish grinct and attractive tree of dwarf-

appearance at all times. Leaves small and finely cut, turning to

May Day Tree This tree is one of the finest we ever sent

May Day Tree. This tree is which till in a we ere supering

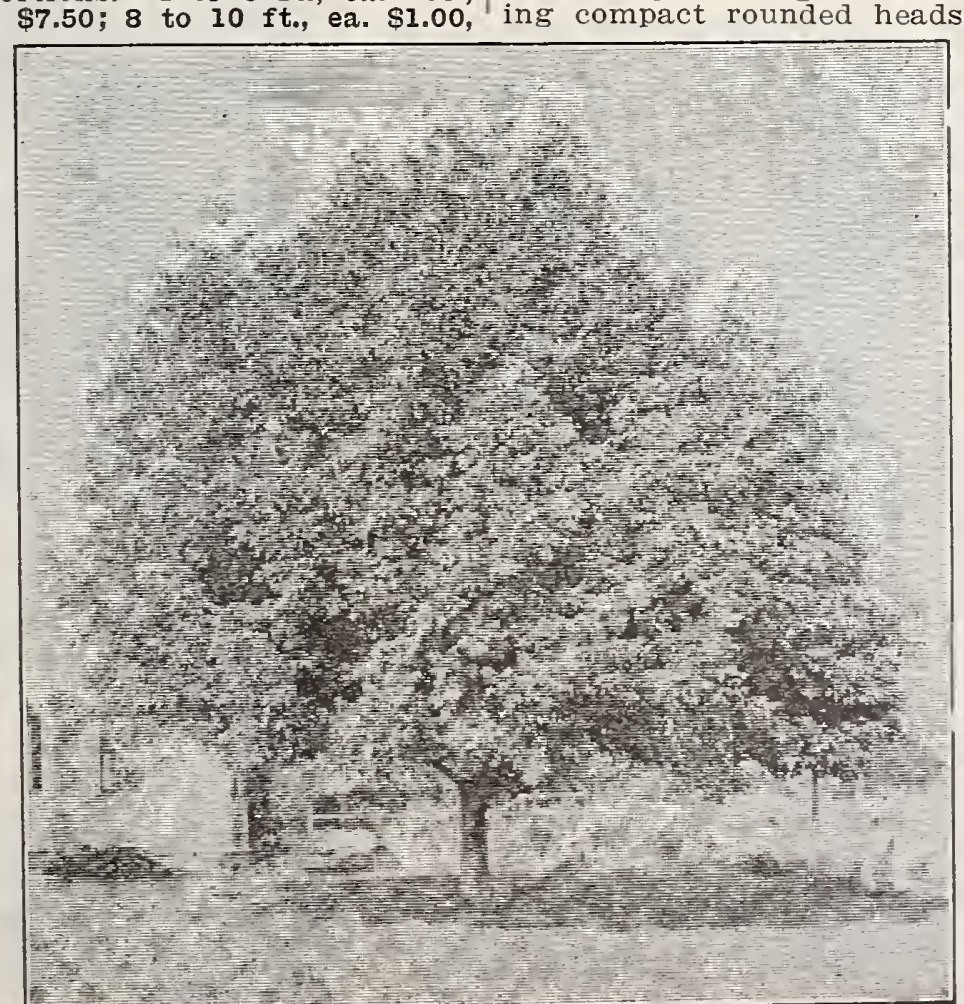

Box Elder or Ash Ieaf Maple. form, handsome trees at all stages usually by May tree its name. These hanging amid the dense green folily hardy and for lawn and park We offer it as one of the prettie troduced. 3 to 4 ft., $50 \mathrm{c}$. ea., $\$ 5.00$
doz.; 4 to $6 \mathrm{ft.} 75 \mathrm{c}$. ea., $\$ 7.50 \mathrm{doz}$. Mountain Ash, European. compact berries. 4 to $5 \mathrm{ft}$., ea. $30 \mathrm{cos}$ doz. S3.00; 6 to $8 \mathrm{ft}$., ea. $50 \mathrm{c}$., doz, $\$ 5.00$; $12 \mathrm{ft}$. ea." $\$ 1.00$, doz. $\$ 10.00$.

Mountain Ash, American.

perfect hardiness and great b

Mountain Ash, Oak Leaf. growth, forming

lobed, resembling the oak. 3 to 4 ft., ea. $35 \mathrm{c}$., doz. $\$ 5.00$; 6 to $8 \mathrm{ft.}$, ea. $75 \mathrm{c}$., doz. $\$ 7.50$. 


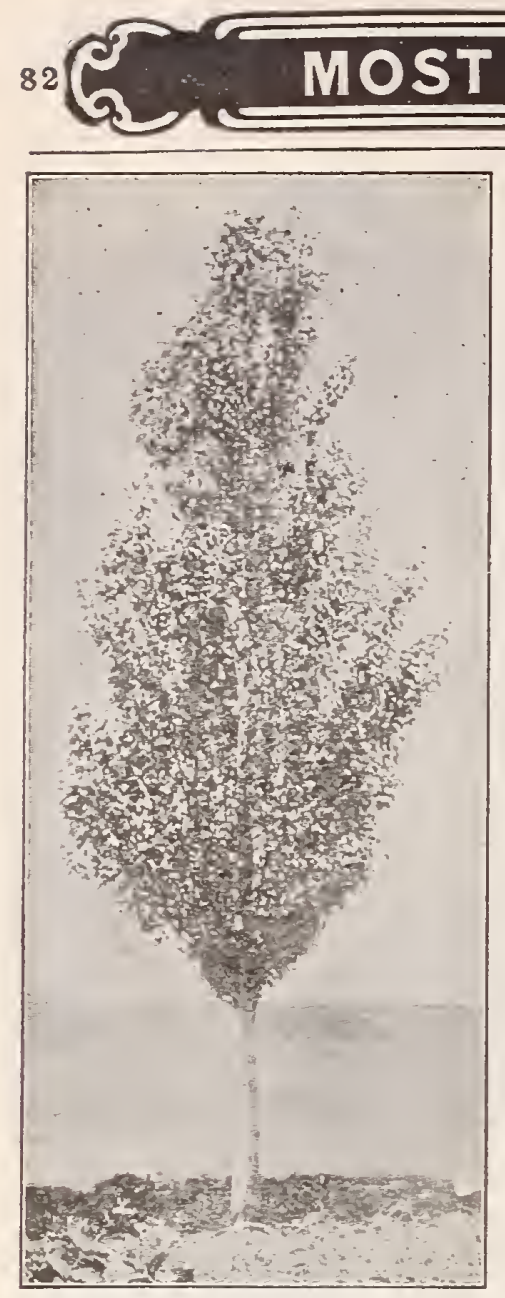

Iombardy Poplar.

\section{Ornamental Trees. Continued.}

Poplar, Carolina. The largest, most est and best Poplar for general planting. al in form, with large glossy leares. It trees. If properly cut back and trimmed everywhere, is not affected by sewrer gas, mend it rery strongly for park and street planting. Planted alternately with Elms, abundance of shade. 4 to 6 ft., ea. 255 ., doz. $\$ 2.50,100 \$ 15.00$; 6 to $8 \mathrm{ft}$., ea. $35 \mathrm{c}$., doz. \$3.50, $100 \$ 20.00 ; 8$ to $10 \mathrm{ft}$., ea. $50 \mathrm{c}$., doz. $\$ 5.00,100 \$ 25.00$; 10 to 12 ft., ea. $60 \mathrm{C}$. doz. $\$ 6.00,100 \$ 30.00$. F'or specimen Trees write for prices.

Poplar, Golden.

Price same as Carolina.

Poplar, Lombardy.

grows rapidly. It is planted largely in

of any landscape. It is perfectly har
everywhere. Prices same as carolina.

Poplar, Norway.

the cottonwood that comes to us from Es.00; 4 to 6 ft., ea. $30 \mathrm{cos}$, doz. $\$ 3.00,100$ $\$ 15.00 ; 6$ to 8 ft., ea. $40 c$., doz. $\$ 4.00 ; 8$ to $10 \mathrm{ft}$, ea. $50 \mathrm{c}$., doz. $\$ 5.00$; 10 to $12 \mathrm{ft}$., e2. $75 \mathrm{c} .$, doz. $\$ 7.50$.

Poplar, Balsam. (Balm of Gilead.) A handsome native, with thick, of the buds is used medicinally. 4 to $6 \mathrm{ft}$., ea. $30 \mathrm{c}$., doz. $\$ 3.00 ; 6$ to $8 \mathrm{ft}$., ea. 50c., doz. $\$ 5.00 ; 8$ to $10 \mathrm{ft}$., ea. $60 \mathrm{c}$., doz. $\$ 6.00$

Poplar, Bolleana. Similar to the well-known Lombardy Poplar in tony of lower, round-topped trees. Its leaves are glossy green above, Balsam Poplar.

Poplar, Silver. One of the most beautiful and ornamental trees ever of shade. This rariety is of more spreading growth than the others, arice same as Balsam Poplar.

Poplar, Trichocarpa. A fine new Poplar with long oval leaves, vigorous growth. Price same as Balsam Poplar.

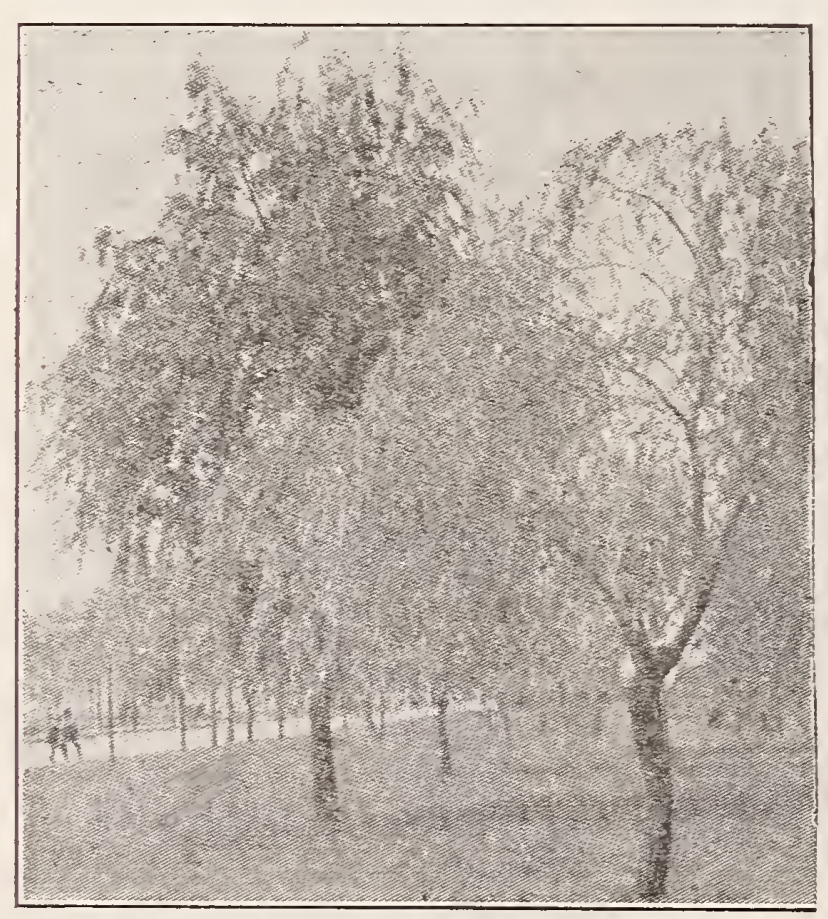

$\mathrm{Sum}$ a c, CutLeaved. A beautiful of the preceding, with leaves of very large size, deeply cut, and drooping gracefully Autumnal color a rich red. Price, 18 to 24 inch, each $35 \mathrm{c}$., doz. \$3.50; 2 to 3 feet, each 50c., doz. $\$ 5.00$ 3 to 4 feet, each $60 \mathrm{c}$. doz. $\$ 6.00$.

Sumac, Staghorn A densely hairy species, with oblong fiowers in dense, terminal panicles and ruit in red clusters most briliant. A good grower in light, dry planting on ste e p banks. 3 to $4 \mathrm{ft}$. ea. $25 \mathrm{c}$., doz. $\$ 2.50$; 6 to 8 ft. ea. 40 c., doz. $\$ 4.00$; 8 to $10 \mathrm{ft}$. ea. $\$ 40 \mathrm{c}$., doz. $\$ 6.00 ; 10$ to $12 \mathrm{ft}$. ea. $\$ 1.00$, doz. $\$ 10.00$.

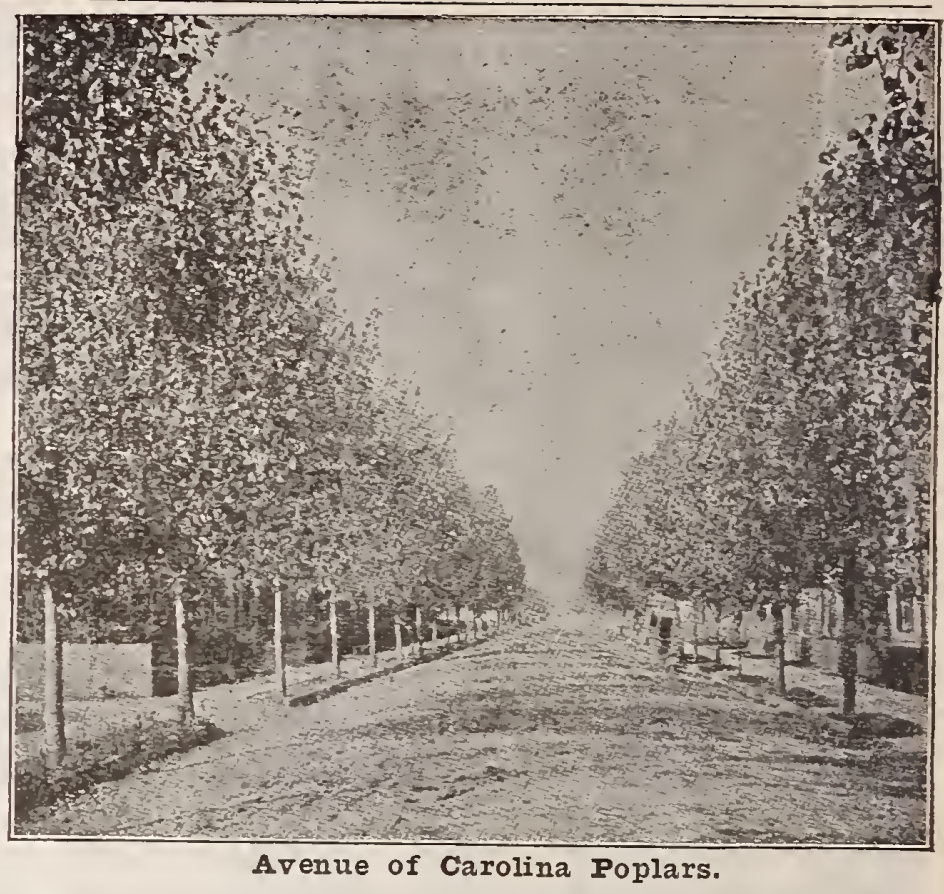

Willow, Laurel Leaf. One of the finest in the broad dark green, very entire list. The leaves are ders it the most conspicuous of green trees. The bark siped form like th inter. It can be clipped to any deis not inferior to that high priced plant For trarrow 4 to 6 ft for hedges and ornamental screens. Price, each 40c., doz. $\$ 4.00,100 \$ 20.00 ; 8$ to 10 ; 6 to 8 ft. doz. $\$ 5.00,100 \$ 25.00$; 10 to $12 \mathrm{ft}$. each $75 \mathrm{c}$., doz. $\$ 7.50$. Willow, Petzoldi. Another charming variety of Price same as Laurel Ireaf.

Willow, Golden. Handsome. A valuable variety red golden bark contrasting harmoniously with other Price same as Iaurel Ieaf.

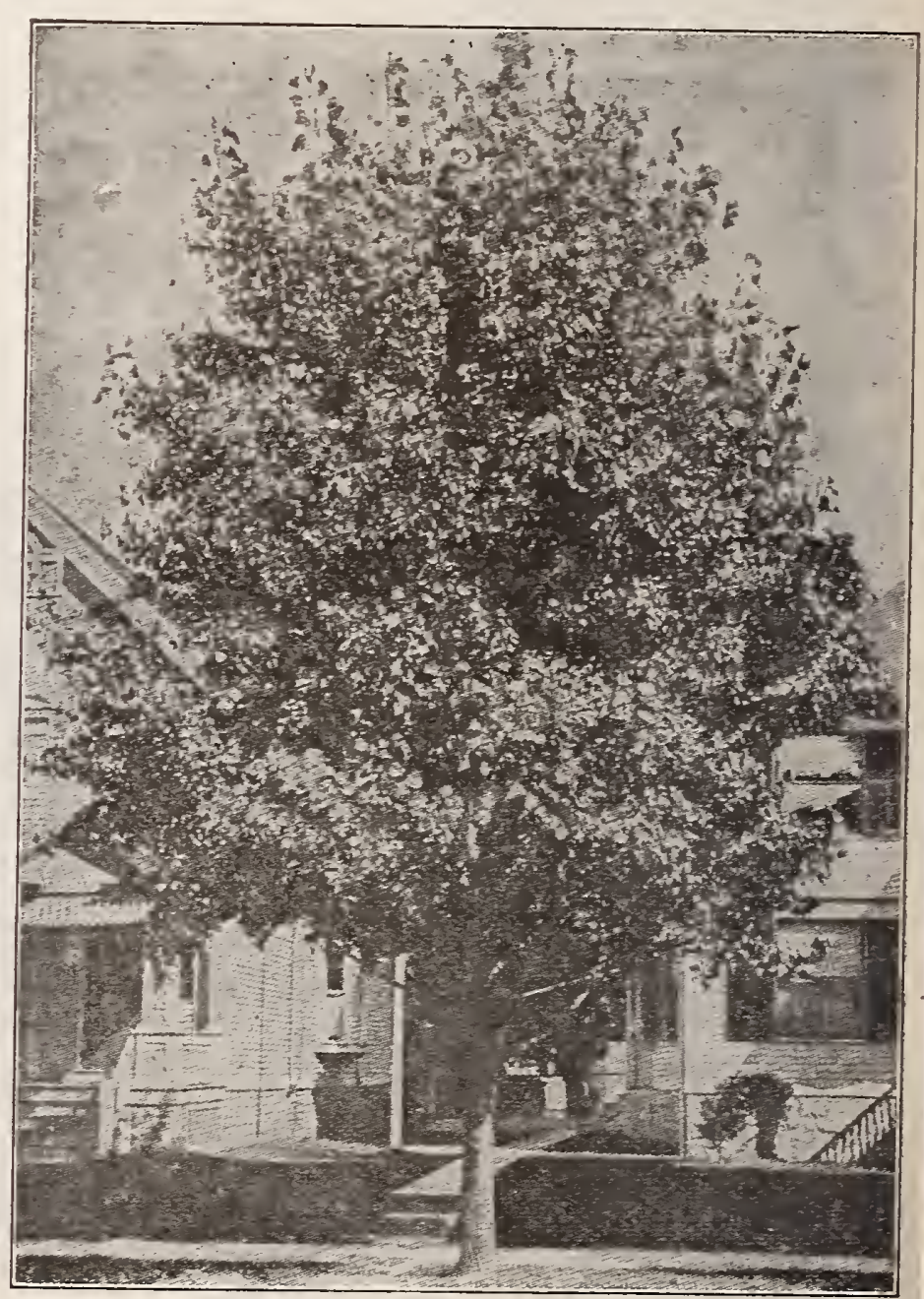

Carolina Poplar. 


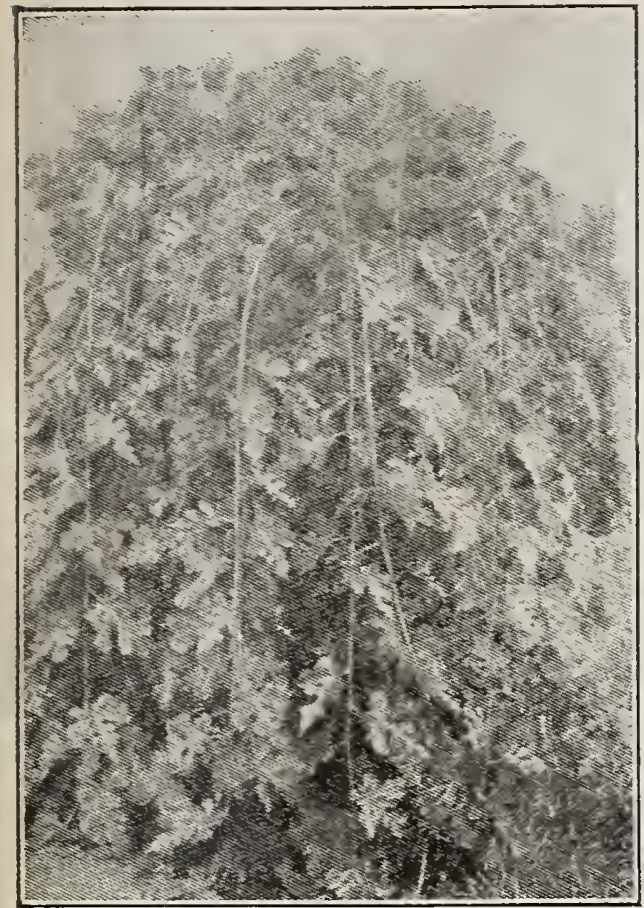

Tea's Weeping Mulberry.

\section{WEEPING TREES.}

Birch, Cut Leaf.

trees for the lawn es are of graceful, drooping habit, with foliage delicately cut and very fine. The bark is sitthe white, forming a beautiful contrast with perfectly hardy in all sections of the country. Mr. Scott, in his "Suburban Home Grounds" says of it: "No engraring can do it justice; seen in motion, swaying in the lightest breeze, its leaves trembling in the heated summer air, its white bark glistening through the bright foliage and sparkling in the sun, to enable $u$ 4 to $5 \mathrm{ft}$., $60 \mathrm{c}$. each, doz. $\$ 6.00 ; 5$ to $6 \mathrm{ft}, 75 \mathrm{c}$. each, doz. $\$ 7.50 ; 6$ to $7 \mathrm{ft}$., $\$ 1.00$ each, doz. $\$ 10.00 ; 7$ to $8 \mathrm{ft}$., $\$ 1.25$ each, doz. $\$ 12.50$.

$\mathrm{Elm}$, Camperdown. A very graceful tree covering arbors. The foliage is large luxuriant, dark green and the tree has the umbrella form so desirable. $6 \mathrm{ft}$. 1-yr. head, 75c. ea., doz. $\$ 7.50$; 6 ft. 2-yr. head, $\$ 1.25$ each, doz. $\$ 12.00$. Mountain Ash, Weeping. A beautiful vigorous growth, with straggling, pendant branches, turning and twisting in all direcwith branches years forming an immense head clusters of fragrant, feathery blossoms. Price, 6 to $7 \mathrm{ft}$., $1-\mathrm{year}$ head, $75 \mathrm{c}$. each, doz. $\$ 7.50$.

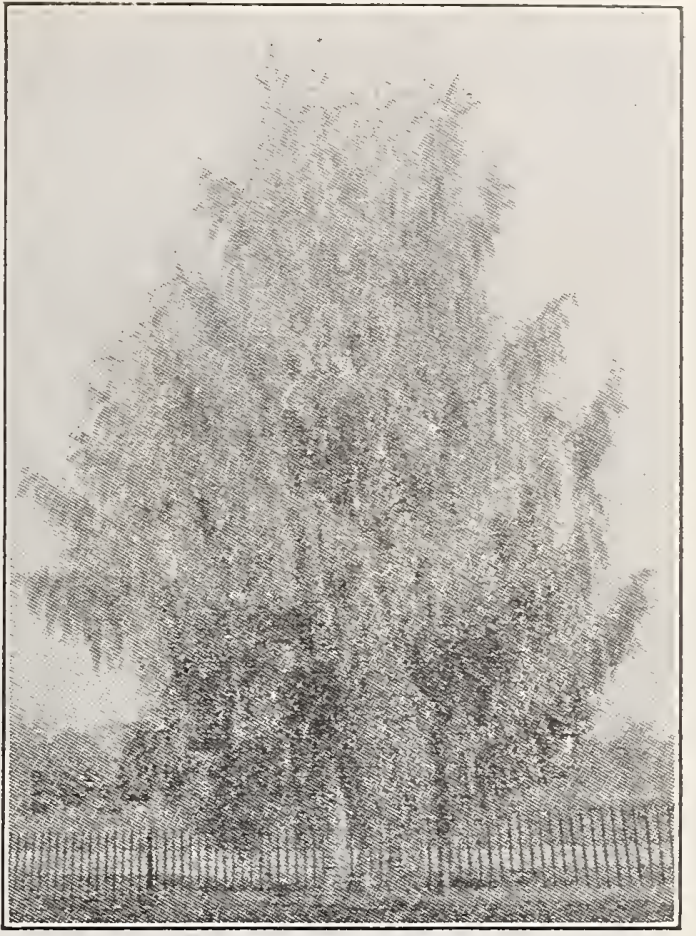

Cut Ieaf Birch.
Mulberry. (Tea's Weeping Russian.) One of the most gracewholly unique, having a perfect umbrella shaped head and slender willow branches. The foliage is glossy green and with delicacy of form and motion it combines Russian health and vigor. Admirably adapted to cemetery planting. Price, 5 to 6 ft. 1 year head, $\$ 1.00$ each, doz. $\$ 10.00 ; 5$ to $6 \mathrm{ft}$., 2-year head, $\$ 1.25$ each, doz. $\$ 12.00$.

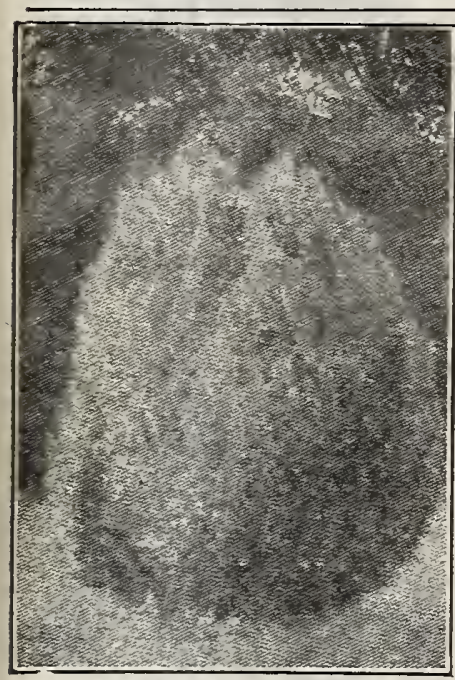

American Arbor Vitae.

The Trees which offer here are all nursery grown, transplanted stock. In transplanting nerer alsun for a single moment. A mulching of straw or leaves will be found seasons. Allow them to branch Arbor Vitae, American. One the most popular evergreens in cultivation, either for single specimens on the lawn, planted in clumps, or for ornamental hedging. It readily adapts itself to all situations, is perfectly hardy. 12 to 18 -inch, $20 \mathrm{c}$. each, doz. $\$ 2.00$; 18 to 24 inch, $30 \mathrm{c}$. each, doz. $\$ 3.00 ; 2$ to 3 ft., $40 \mathrm{c}$. each, doz. $\$ 4.00$.

Arbor Vitae, Pyramidalis.

\section{EVERGREENS.} very 'beneficial, especially in dry The most beautiful of all the Arder, pyramidal shaped heads of dark green, at all times conspicuous and very ornamental. 18 to 24 -inch 50c. each, doz. $\$ 5.00 ; 2$ to $3 \mathrm{ft}$. $75 \mathrm{c}$. each, doz. $\$ 7.50 ; 3$ to $4 \mathrm{ft}$. $\$ 1.00$ each, doz. $\$ 10.00$

Arbor Vitae, Chinese. A dense growing globular form, to 18-inch, 50c. each, $\$ 5.00$ doz.; 18 to 24 -inch, 60c. each, $\$ 6.00$ doz

Fir Balsam. A well known and popular tree, assuming the above, silvery beneath; retains its color throughout the severest winters. 18 to $24-i n c h, 40 c$. each, doz. $\$ 4.00$

Fir Silver. (Colorado.) Very hardy and a rapid grower. and have the typical fir odor. 12 to $18-i n c h, 35 c$. each, $\$ 3.50$ aoz. Juniper Savin. (Sabina.) A low, spreading tree with and suitable for lawns and cemeteries. 15 to 18-inch, 40c. each, doz. $\$ 4.00 ; 18$ to $24-$ inch, $50 \mathrm{c}$. each, doz. $\$ 5.00 ; 2$ to $3 \mathrm{ft} .75 \mathrm{c}$. each, $\$ 7.50 \mathrm{doz}$

Pine, Austrian. Remarkably robust, with long, stiff spikes and raluable for planting as wind-breaks, screens, etc. 18 to 24-inch, 40c. each, doz. $\$ 4.00 ; 2$ to $3 \mathrm{ft}$. 50c. each, doz. $\$ 5.00 ; 3$ to $4 \mathrm{ft}$. $60 \mathrm{c}$. eacly, doz. $\$ 6.00$.

Pine Scotch. A most beautiful rariety, similar to the Aus\$4.00; 2 to $3 \mathrm{ft}$. 50c. each, doz. $\$ 5.00$; 3 to $4 \mathrm{ft}$. 60c. each, doz. $\$ 4.00 ; 2$ to $3 \mathrm{ft} .50 \mathrm{c}$. each, doz. $\$ 5.00$.
$\$ 6.00 ; 4$ to $5 \mathrm{ft}$. $75 \mathrm{c}$. each, doz. $\$ 7.50$.

\section{Willow, Golden Weeping. One of the sho} disappear and remainin, secthrou more of are of graceful drooping habit, forming a large rounded head each, doz. $\$ 3.50$; 6 to $8 \mathrm{ft}$., 50c. each, doz. $\$ 5.00$; 8 to $10 \mathrm{ft.}$, $60 \mathrm{c}$. each, doz. $\$ 6.00$.

Pine, White. ft. $50 \mathrm{c}$. each, doz. $\$ 5.00 ; 3$ to 4 ft. $60 \mathrm{c}$. each, doz. $\$ 6.00 ; 5$ to $6 \mathrm{ft}$. $75 \mathrm{c}$. each, doz. $\$ 7.50$.

Pine, Dwarf Mountain. A dwarf bushy species, foliage dark 12 to 18 -inch, 60c. each, $\$ 6.00 \mathrm{doz}$.

Red Cedar.

作 18 to 24 -inch $40 \mathrm{c}$. each, doz. $\$ 4.00 ; 2$ to $3 \mathrm{ft}$. $50 \mathrm{c}$ each, doz. \$5.00.

Spruce, Black Hills.

tree, of compact growth, with

leaves; rery hardy. 12 to 18-inch

$50 \mathrm{c}$. each, doz. $5.00 ; 18$ to $24-$ inch, $\$ 1.00$ each, doz. $\$ 10.00$.

Spruce, Colorado Blue.

Our stock is the best selected colors. Price, 18 to 24-inch \$1.00 each, doz. $\$ 10.00 ; 2$ to $3 \mathrm{ft}$. $\$ 2.00$ each, doz. $\$ 20.00 ; 3$ to $4 \mathrm{ft}$. $\$ 3.00$ each, \$30.00 doz.

Spruce, Colorado Blue. (Koster's Grafted.) Extra col$\$ 10.00$ doz.; 18 to 24 -inch $\$ 2.00$ eacl, $\$ 20.00$ doz. Special Trees up to 5 feet, from $\$ 5.00$ to $\$ 25.00$ each.

Spruce, Douglassi.

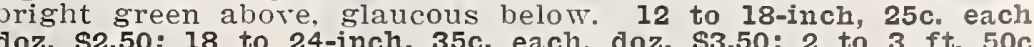
each, doz. $\$ 5.00 ; 3$ to $4 \mathrm{ft}$. $60 \mathrm{c}$. each, doz. $\$ 6.00 ; 4$ to $5 \mathrm{ft}$. $75 \mathrm{c}$. each, doz. $\$ 7.50$.

Spruce, Hemlock.

makes a highly ornamental hedge. 12 to 18 -inch $30 \mathrm{c}$. eacli, $\$ 3.00$ doz.; 18 to $24-i n c h 50 c$. each, doz. $\$ 5.00 ; 2$ to $3 \mathrm{ft}$. $60 \mathrm{c}$. each, doz $\$ 6.00$. Special Trees from $\$ 3.00$ to $\$ 4.00$ each.

Spruce, Norway.

ich and luxuriant. 12 to 18-inch, 20c. each, doz. $\$ 2.00$; nch, 35c. each, doz. $\$ 3.50$

Spruce, White.

ing its branches to th

ries in color from light green to glaucous blue. A grod

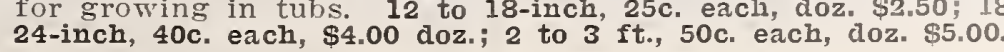




\section{(2) MOST NORTHERN WUR ERIES IN AMERICA:}

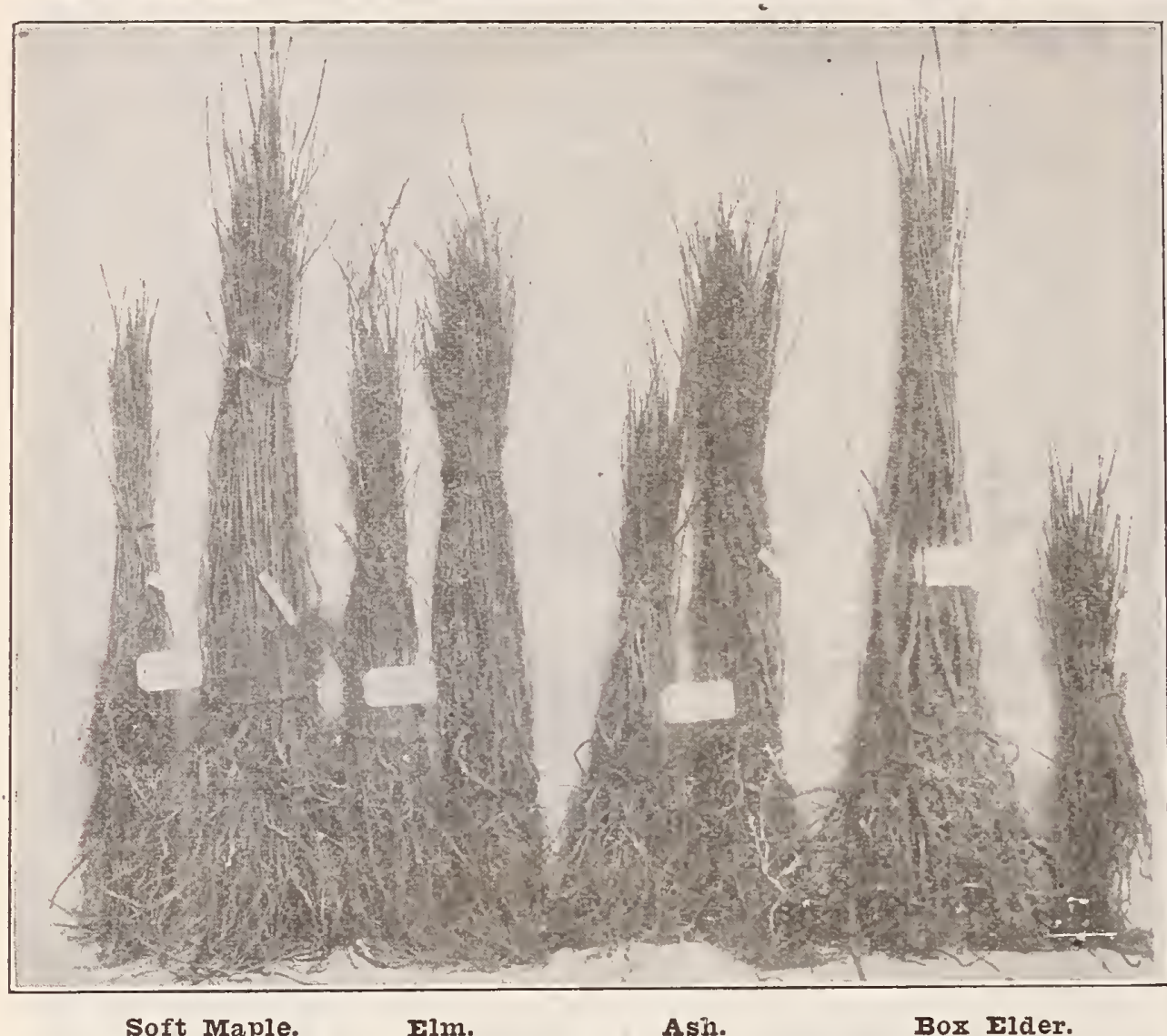

FOREST AND ORNAMENTAL TREE SEEDLINGS.

well Rooted, Nursery Grown and Iowest Prices.

These are all cultivated nursery stock with good roots and are far superior to many of the seedlings pulled from forests and river bottoms, with few, if any, roots, such as are offered by many nurserymen, and sold through agents. They are intended for planting groves, tree claims, wind bre

\begin{tabular}{|c|c|c|}
\hline 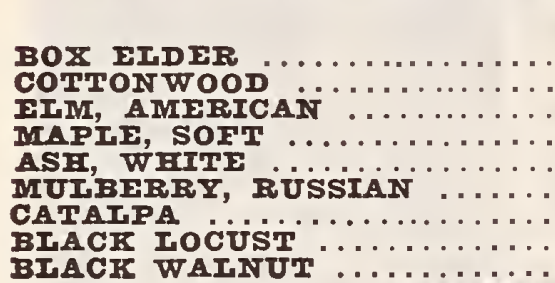 & $\begin{array}{c}\text { Per } 100 . \\
\$ 1.25 \\
.75 \\
1.00 \\
1.00 \\
1.00 \\
1.00 \\
1.00 \\
1.00 \\
2.00\end{array}$ & $\begin{array}{c}\text { Per } 1,000 \\
\$ 5.00 \\
4.00 \\
5.00 \\
5.00 \\
5.00 \\
5.00 \\
5.00 \\
5.00 \\
15.00\end{array}$ \\
\hline
\end{tabular}

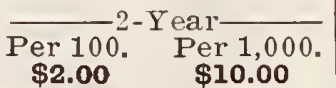

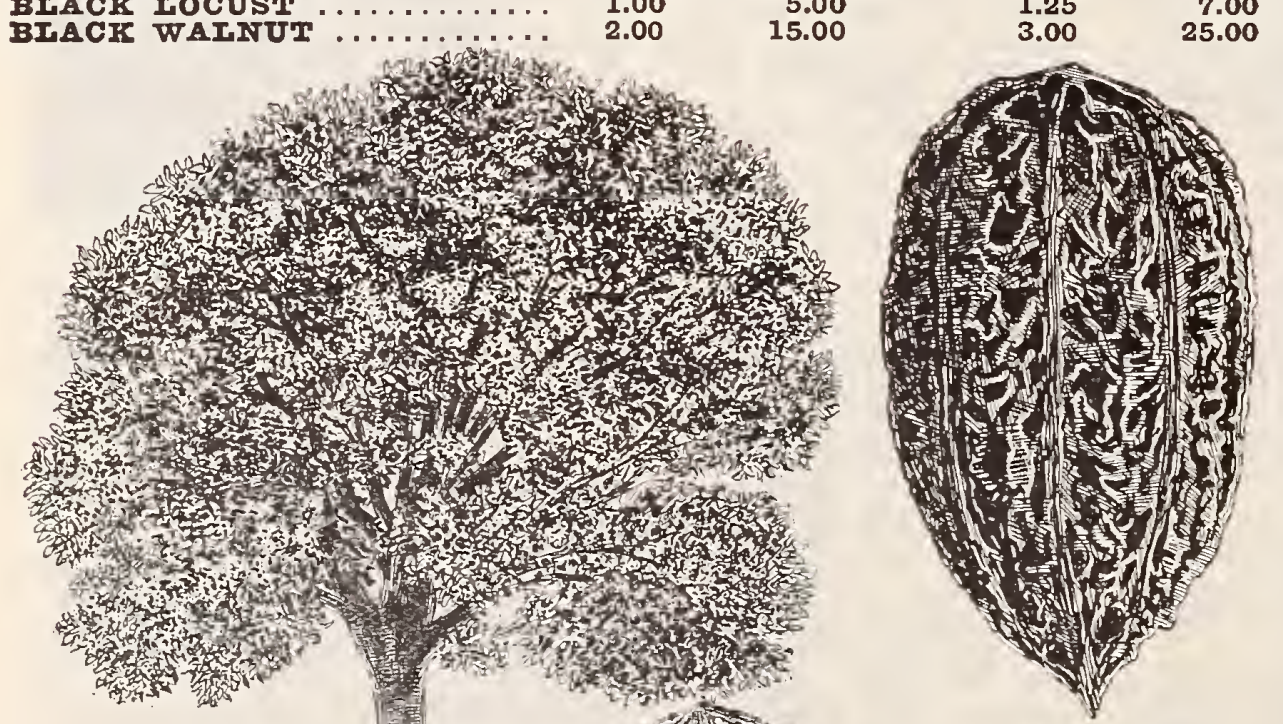

Butternut.

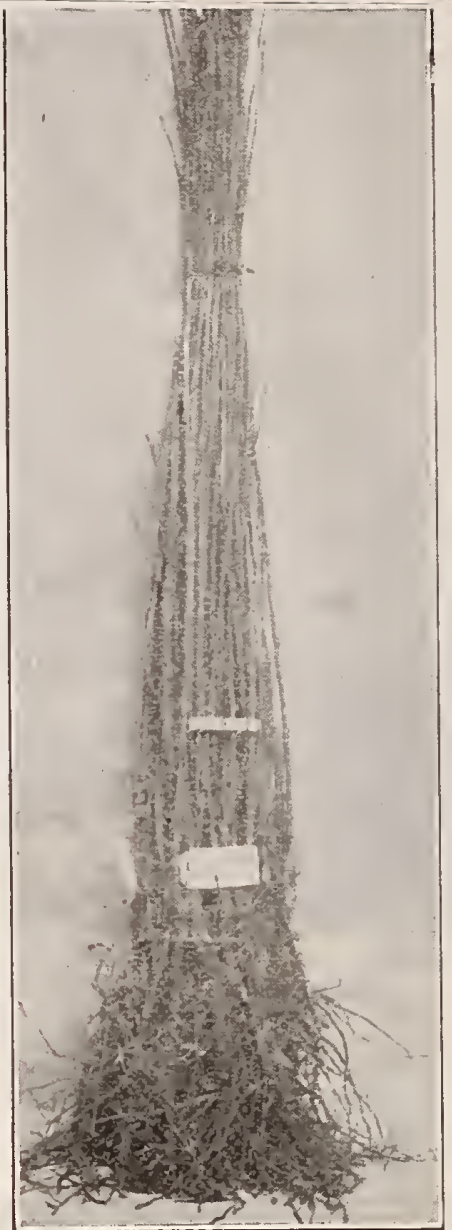

Carolina Poplar.

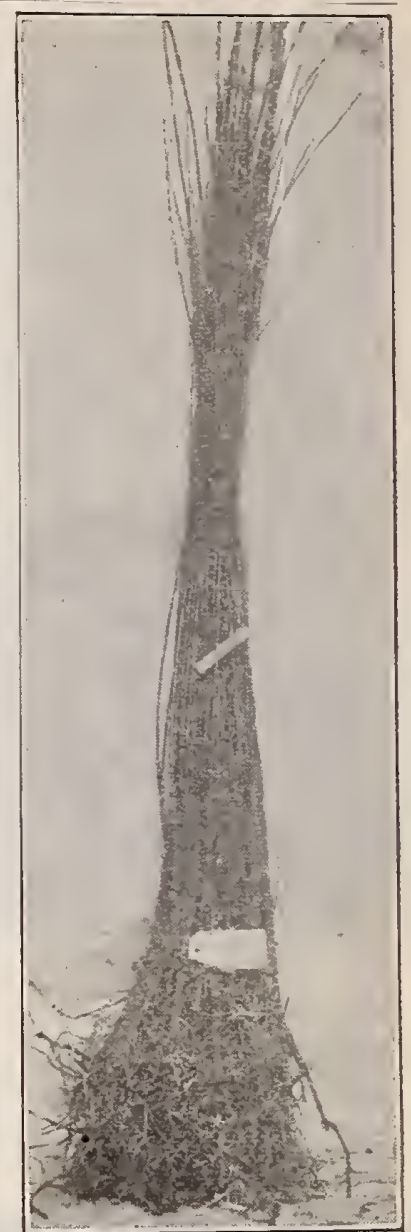

Golden Willow.
ROOTED CUTTINGS.

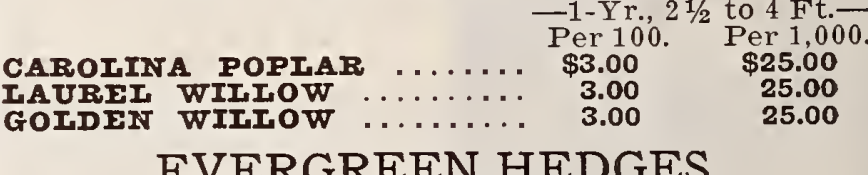

EVERGREEN HEDGES.

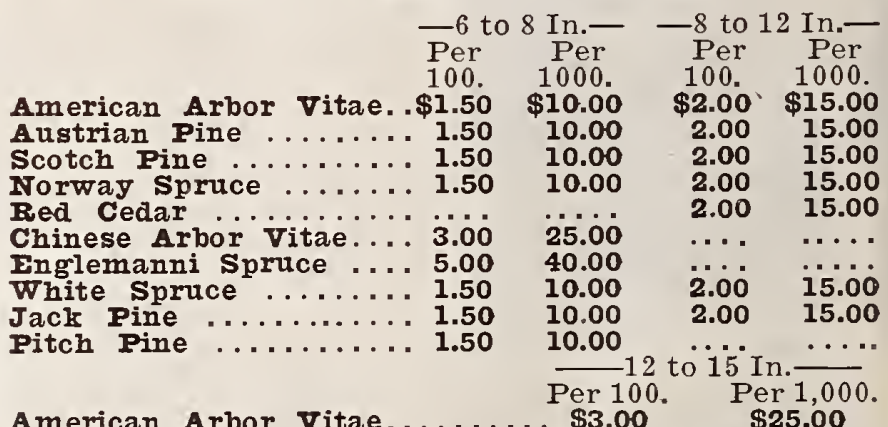

American Arbor Vitae......... \$3.00 $\$ \mathbf{\$ 2 5 . 0 0}$ All Evergreen should be planted in the spring.

\section{NUT BEARING TREES.}

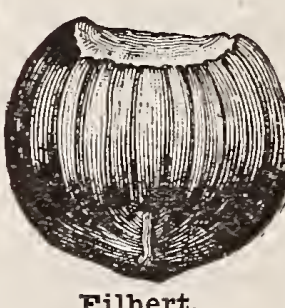

Filbert.
Nut culture is an indistry that, Nutil recently is an industry that, little attention by American planters Probably no branch of tree culture pays larger profits or offers better inducements to planters than this, while most kinds are growing into valuable timber trees that will of themselves pay large dividends on the investment.

Filberts or Hazelnuts. These are easy of culture, of dwarf habit, Ches., pach 35c., 3 for 90c., by express. Chestnut, American Sweet. ornamental; timber is very durable, and possesses a fine grain for oil finish. Price, 5 to $6 \mathrm{ft}$., each 50c., doz. \$5.00.

Walnut, Black. A well known winter variety, being valuable for its timber, commanding a very high price on the market. The tree is large and majestic, rich in foliage, making a most beautiful shade tree. It bears profusely, the nuts being large and round, ery sweet and doz; 5 to $6 \mathrm{ft}$., each $50 \mathrm{c}$., $\$ 5.00 \mathrm{doz}$; 6 to 8 feet., each $60 \mathrm{c}$., $\$ 6.00 \mathrm{doz}$. (See Tree Seedlings above for smaller sizes.)
Butternut, or White Walnut. Hards where well-binown and popular The nuts are rars the black; oily and nutritious, with very delicate flauable for timber. Prices same as Walnut. 


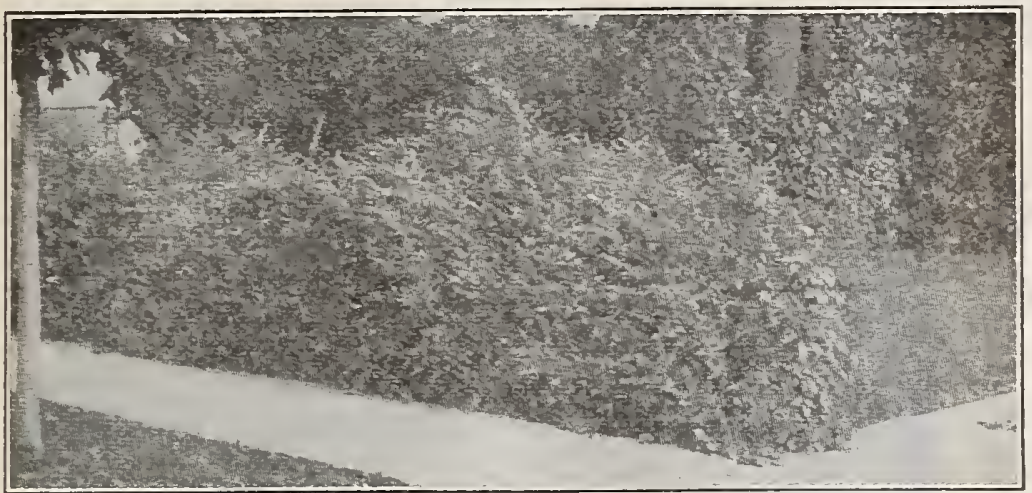

A Hedge of Barberry Thunbergii.

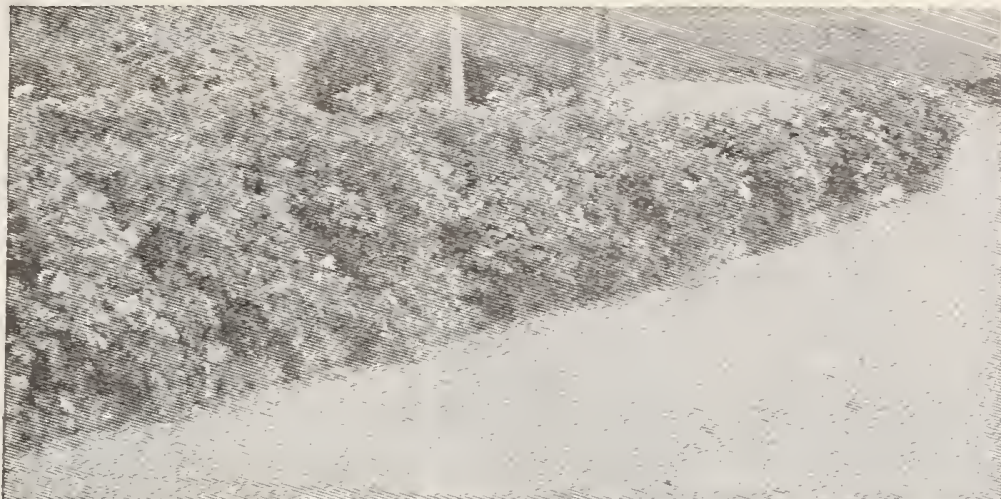

A Hedge of Rosa Rugosa.

A Hedge is more Appropriate than a Fence and more Attractive for a Border.

The idea of planting hedges for use and ornament, and screens
for the protection of orchards, farms and gardens, is a pracfor the protection of orchards, farms and gardens, is a pracmore beautiful than ornamental hedges, well kept and pruned, more beautiful than orname between neighbors, or as a division to serve as a boundary line between the lawn and garden, or to hide unsightly places. By using medium sized plants a hedge can be made as cheaply as a good board fence can be built. "Tith a little care, it behedges constitute a principal attraction in our best lept places. Barberry Thunbergii. Well adapted for ornamental dia slowy, hardy hedge is desired; dwarf and stocky; foliage and fruit both being violet color, form a striking combination. Price, $\$ 10.00 ; 18$ to 24 in, doz. $\$ 2.50,100 \$ 12.00 ; 2$ to 3 ft., doz. $\$ 3.00$, $100 \$ 15.00$. For other varieties see page 86 .

Bulcer a thorough test of all varieties listed here, as well as many others, we consider this the of the country. It stands our cold winters without a particle of injury commences growtl very early in spring, retains its foliage late in autumn. Price, 12 to 15 in., 100 \$5.00; 18 to 24 in., $100 \$ 7.50 ; 2$ to $3 \mathrm{ft} ., 100 \$ 10.00 ; 3$ to $4 \mathrm{ft}$., $100 \$ 15.00$.

Carragana Arborescens. (Siberian Pea Tree.) A hardy Russia, now being extensively planted in Manitoba and Dakota. Foliage resembles the Locust. Price, 1 yr. strong, doz. \$1.50, $100 \$ 5.00 ; 2$ Jr. strong, doz. $\$ 2.50,100 \$ 10.00$.

Cormus Siberica. (Bed Branched Dogwood.) This is the either most beautiful shrub for winter effects, red in winter, turning in early fall and remaining all winter. This is used extensively in the Northwest, owing to its extreme hardiness, for hedges and its attractive winter effect. Price, 12 to 18 in., 100 \$10.00; 18 to 24 in., $100 \$ 15.00$; 2 to $3 \mathrm{ft}$., $100 \$ 25.00$; 3 to 4 ft., $100 \$ 30.00$. Also Cornus Stolonifera and Sanguinea, see page 86 .

English Hawthorne. A celebrated English hedge, which equally as hardy as Buckthorn. Flowers single, white. Price, 12 to 18 in., 100 \$5; 18 to 24 in., $100 \$ 7 ; 2$ to 3 ft., 100 \$12.

Honeysuckle Tartarian. The popular old-time variety, in three colors of fragrant flowers, white, pink and red. This is the tallest sort and is called the upright variety. Price, 18 to 24 in., $100 \$ 15 ; 2$ to 3 ft., $100 \$ 20 ; 3$ to 4 ft., $100 \$ 25$.

\section{Honey Locust. in many sections of the North this is still} perfectly hardy, thrives with ordinary care and on account of its strong, $100 \$ 3.00 ; 2$ year strong, $100 \$ 5.00$.

Japan Quince. The foliage is bright glossy green, retaining fowers, which are borne in the greatest profusion, are brilliant crimson, rery showy and attractive, and are produced before 18 to 24 -inch, $100 \$ 10.00 ; 2$ to 3 feet, $100 \$ 15.00$.

Privet, California. A recent introduction that has met makes a very rapid growth, has shining, dark green leaves, which it retains until late in
$\$ 4.00 ; 2$ to 3 feet, $100 \$ 5.00$.

Rosa Rugosa. This Japanese Rose forms a sturdy bush, 4 glossy foliage, crowned with terminal clusters of 10 to 20 flowglossy foliage, crowned With terminal clusters of 10 to 20 fiowplant for the hardy border or shrubberies, its large, handsome, scarlet fruits being very ornamental all through the autumn and early winter months. It also makes a splendid hedge, its Price, 2 Jr. strong, 100 \$20.00. See page 67 for named varieties. Russian Olive. A native of the Northwestern plains. The yellowish, produced very abundantly. Perfectly hardy, and resists drought and heat in a remarkable degree. By cutting back each season, it forms a very compact, dense hedge of most beautiful appearance. Price, 1 Jr. strong, $100 \$ 3.00 ; 2$ Jr. strong, $100 \$ 5.00 ; 2$ to $3 \mathrm{ft}$., $100 \$ 10.00$.

Siberian Sandthorn. This hardy shrub or hedge plant was S. D. Experimental Station, and number of years and has proven entirely hardy. It resembles the Russian Olive somewhat in appearance; the foliage being of a silvery coloring, growing dense and compact, making it one of the best plants for a hedge in the Nort
inch, $100 \$ 7.50 ; 18$ to 24 inch, 100 \$10.00.

Willow, Vitellina. From Russia, very conspicuous in winto 24 inches, $100 \$ 7.50 ; 2$ to 3 feet, $100 \$ 10.00$.

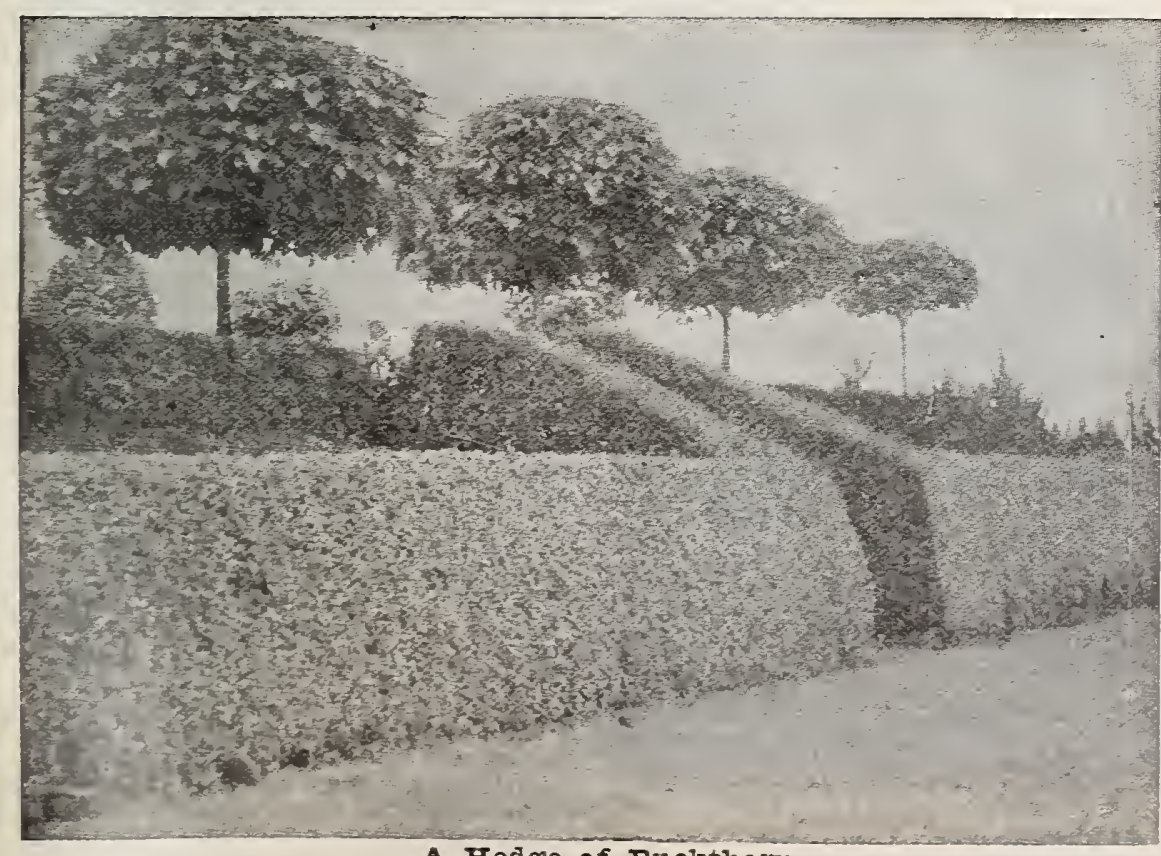

A Hedge of Buckthorn.

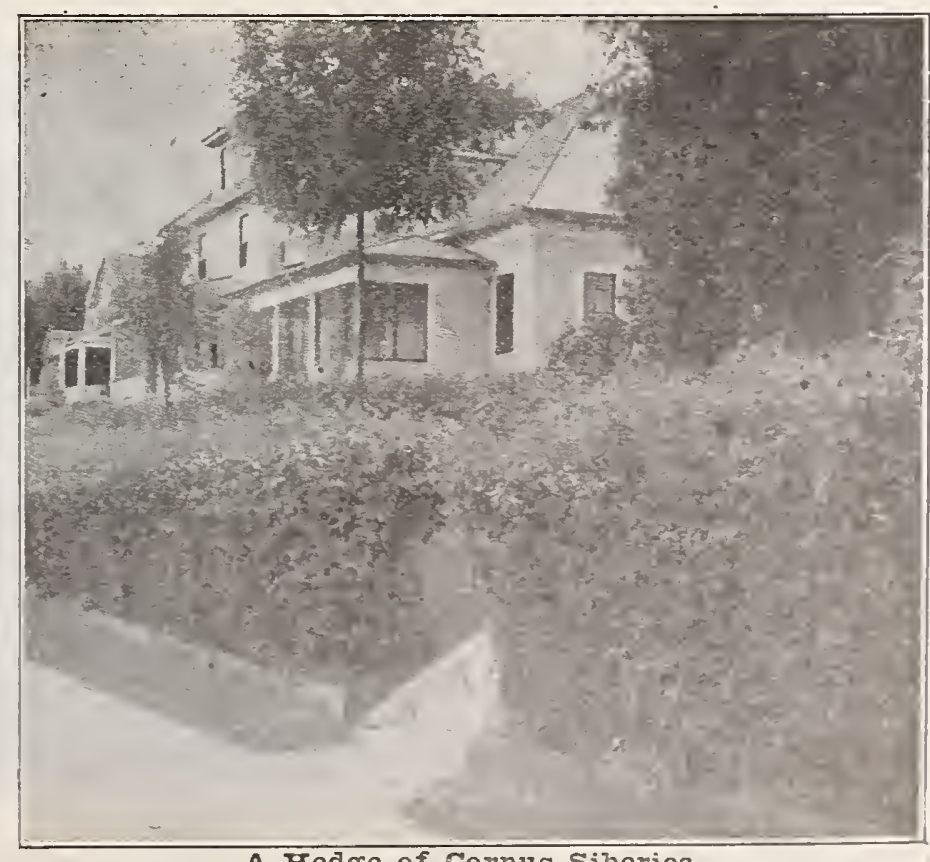




\section{MOST NORIHERW VUU SERIES IV AMERICA.}

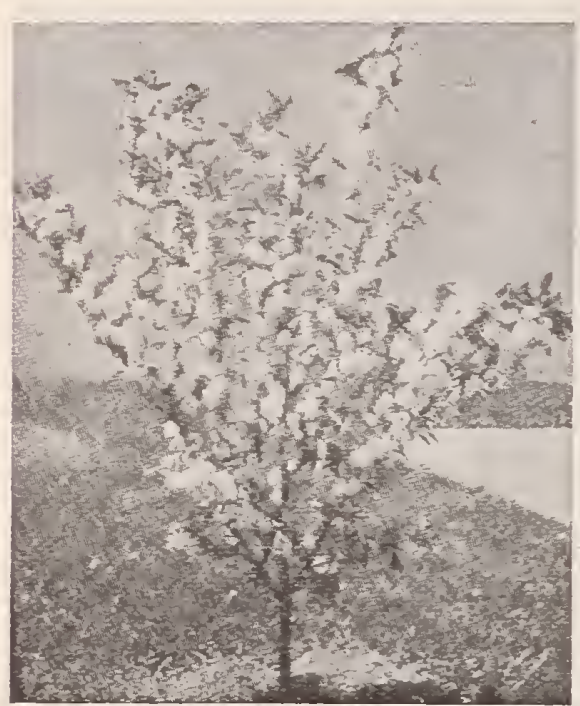

Almonds.

\section{FLOWERING AND \\ O R N A M E N T A L \\ S H R U B S}

Special Notice P R I c $\mathbf{s}$

\section{ALMONDS.}

Double Pink. under the heading of shrubs, as

in the early spring. The shrub
pink. 2 to 3 ft.s strong, ea., 40 c.

Double White.

2 to $3 \mathrm{ft}$., strong, ea., $40 \mathrm{c}$.

ARALIA MANDSHURICUS. A rery ornamental shrub, with long sub-tropical aspect to a group. 2 to 3 $50 \mathrm{c}$., doz. $\$ 5.00$.

\section{BARBERRY.}

Purple.

singly plants. The leaves are deep violet or
purple, and in June it produces yellow-
ish-white flowers, which turn to purple
berries as the season advances 10c. ea.,
3 for $25 \mathrm{c}$., postpaid; 18 to 24 -inch, $25 \mathrm{c}$. ea.; 2 to 3 ft., strong, 30c. ea.

Green.

followed 3 for 25 c., postpaid; 18 to 24 -inch, 20 c. Thunbergii. (See page 85 for defor $25 \mathrm{c}$., postpaid; 18 to 24 -inch, $30 \mathrm{ce}$ e. ea. 2 to $3 \mathrm{ft}$., $35 \mathrm{c}$ each.

\section{CALYCANTHUS.}

(Sweet Scented Shrub.) The peculiarity and pleasing fragrance of this, together with its rich makes it rers interesting. It blossoms in June and at inter2 for 25 c., postpaid; 18 to 24 -inch, ea. $25 \mathrm{c}$; 2 to $3 \mathrm{ft}$., $35 \mathrm{c}$. each.

CLETHRA ALNI. FOLIA.

(Sweet-Pepper Bush.) A very hrdy, neat. upright groming demand for the honey bee to feed uncing pure white fragrant flow-
ers in spikes 3 to 6 inches long. 10c. ea., 3 for $25 \mathrm{c}$., postpaid; 18 CURRANT, YELLOW FLOWERING.

The beautiful gold and crimson in pendant clusters in NIay. 2 to
3 ft., ea. 30 c.

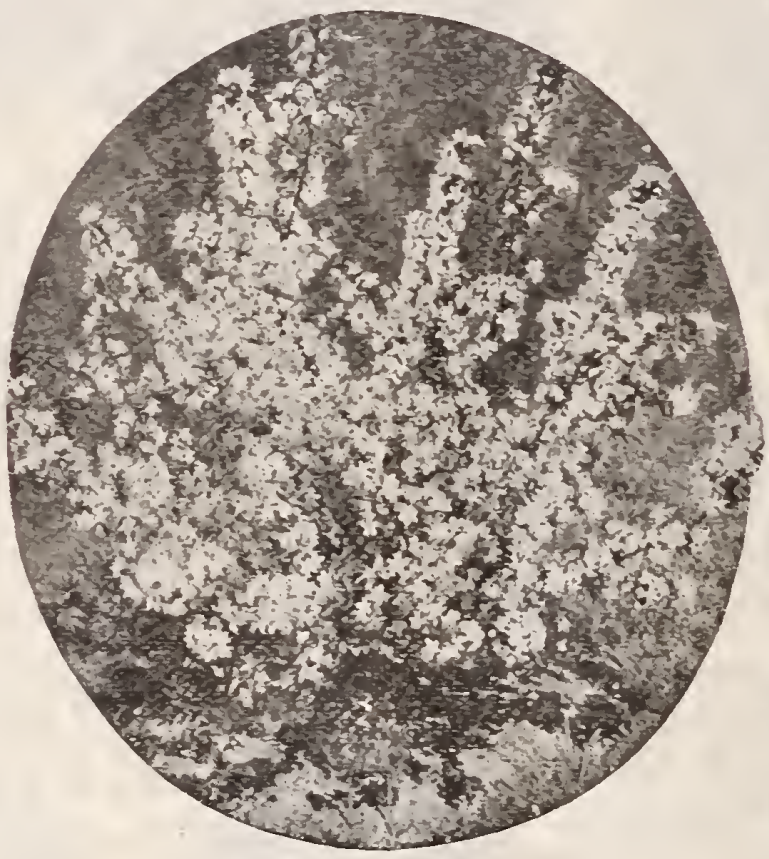

Currant, Yellow.

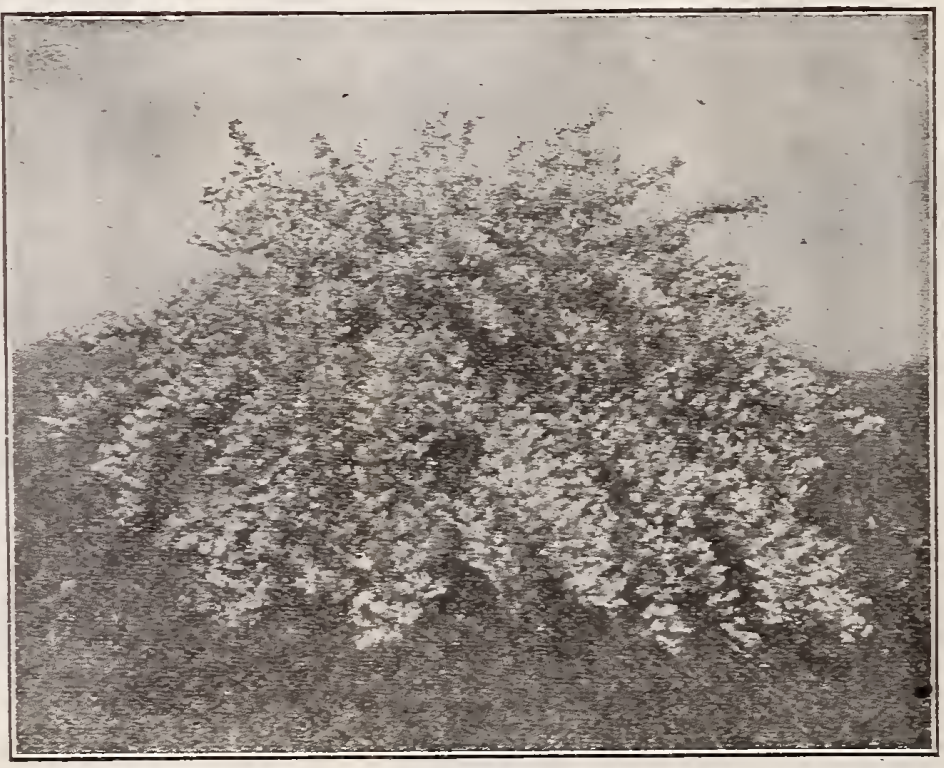

Deutzia $40 \mathrm{c}$.

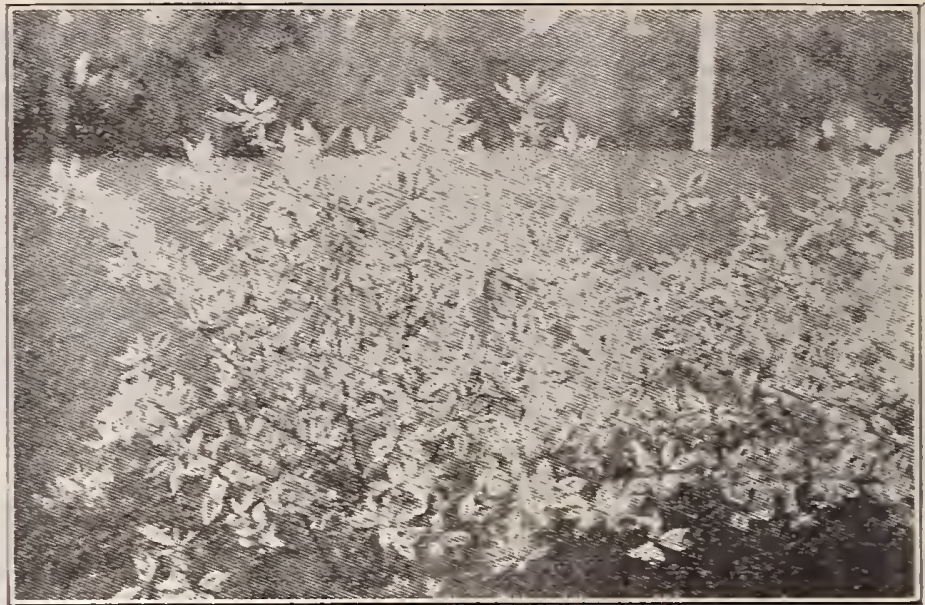

Cornus, Variegated.

CORNUS.

Sanguinea. (Red-branched Dogwood.) A perfectly mes more brilliant wh the with a showy red bark, which early spring it is corered with yellow flowers. It is a good sized, handsome shrub and serves as an ornament the year
round. $10 \mathrm{c}$. ea., 3 for 25 c., postpaid; 18 to 24 -in., ea. 25 .; 2 to Cornus Siberica, (See page $\delta 5$ for 24 -in., 25c. ea.; 2 to $3 \mathrm{ft}$., $35 \mathrm{c}$. ea.; 3 to 4 ft., 50c. ea.

Siberica, Variegata. A large, spreadwhite flowers in June variegated foliage and coral red bark. $15 \mathrm{c}$. ea. 2 for $25 \mathrm{c}$. postpaid; 15 to 18 -in., ea. $25 \mathrm{c}$; ; 18 to 24 in., 30c. ea.; 2 to $3 \mathrm{ft}$., $40 \mathrm{c}$. each.

Paniculata. Ter $y$ handsome $\pi \mathrm{h} \in \mathrm{n}$ clusters, and again in autumn when laden With red-stemmed white fruits. 15c. ea. Stolonifera. A medium sized spreadbark and white flowers, followed by white berries. 10c. ea., 3 for 25 c., postpaid; 15 to 18 -in., ea. 20 c; 18 to 24-in., ea. 25 c.; 2 to $3 \mathrm{ft}$., 30c. ea.; 3 to $4 \mathrm{ft}$, $40 \mathrm{c}$. ea.

Gouchalt. A beautiful golden variered bark. 15c. ea., 2 for 25 c., postpaid; 15 to 18 -in., 25 c.; 18 to 24 -in., 30 c.; 2 to 3 ft.

\section{DEUTZIAS.}

Crenata. The flowers are tery large, is very hardy and pure thite. The shrub est Deutzias. 10c. ea., 3 for 25 c., postpaid; 18 to 24 -in., ea. $25 \mathrm{c}$; 2 to 3 ft., ea. $30 \mathrm{c}$. Double Rose. Exquisite blosa rosette, tinged with delicate pink, rert large. 10c. ea., 3 for $25 \mathrm{c}$. postpaid; is to 24-in, ea. 25c.; 2 to $3 \mathrm{ft}$., ea. $30 \mathrm{c}$.

Pride of Rochester. On e of varieties, producing large double White flowers; the back of the petals slightly tinted with rose. ea., $25 \mathrm{c}$; 2 to $3 \mathrm{ft}$., ea. $30 \mathrm{c}$. EUONYMUS.

American (Burning Bush.) AtAmerican tractive deep purple scarlet fruit. 18 to 24 -in., $25 \mathrm{c}$. ea. Euonymus (Europaeus.) A very in the autumn and winter, when loaded with scarlet seed-pods, from Which the orange-colored berries in., $25 \mathrm{c}$. ea.

Tne advise the extensive use of advise the extensive use of
shrubs, as they malie a beartiful showing the first season. 


\section{S3HARDY PRODUGTIVE FRUITS, ORNAMENTAL TREES: SHRUBS, EIC. ${ }^{2}$}

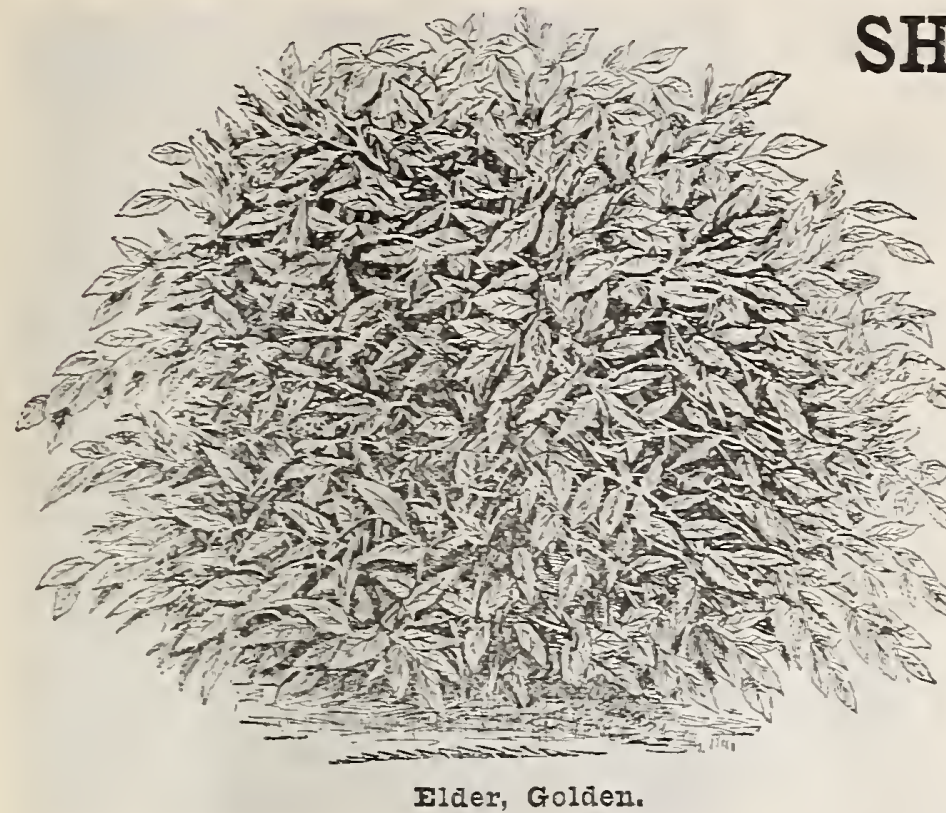

ELDER.

Golden. (Sambucus Aurea.)

when planted in contrast to other shrubs The blossoest effect resente those of the common elder, appear in July. It is a parts of the country and rers hardy. Each $10 \mathrm{c} ., 3$ for $25 \mathrm{c} .$, postpaid; 18 to 24 -in., ea. 25 c.; 2 to 3 ft., ea. 30 c.; 3 to 4 ft., ea. $35 \mathrm{c}$. Cut Leaved. Thermation, and the shrub is of half-drooping

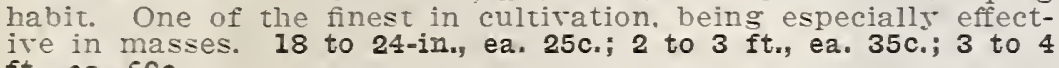
ft., ea. $50 c_{\text {. }}$

Red Fruited. Of somewhat stockier growth than the comred fruits. 15 to 18 -in., $25 \mathrm{c}$. ea.; 2 to $3 \mathrm{ft}$, ea. $35 \mathrm{c}$.

FILBERT. (Hazelnut.)

See page $\delta 4$ for prices and description.

Suspensa. One of the best early flowering shrubs, producany other tree or shrub shows a leaf. Ea. 10 c., 3 for 25 c., postpaic; 18 to $24-i n .$, ea. $25 \mathrm{c}$.; 2 to $3 \mathrm{ft}$, ea. $35 \mathrm{c}$.; 3 to $4 \mathrm{ft}$, ea. $50 \mathrm{c}$. Viridissima. A fine shrub, with bright Yellow flowers with 24-in., ea. $2^{5}$ c.: 2 to 3 ft., ea. 35 c.

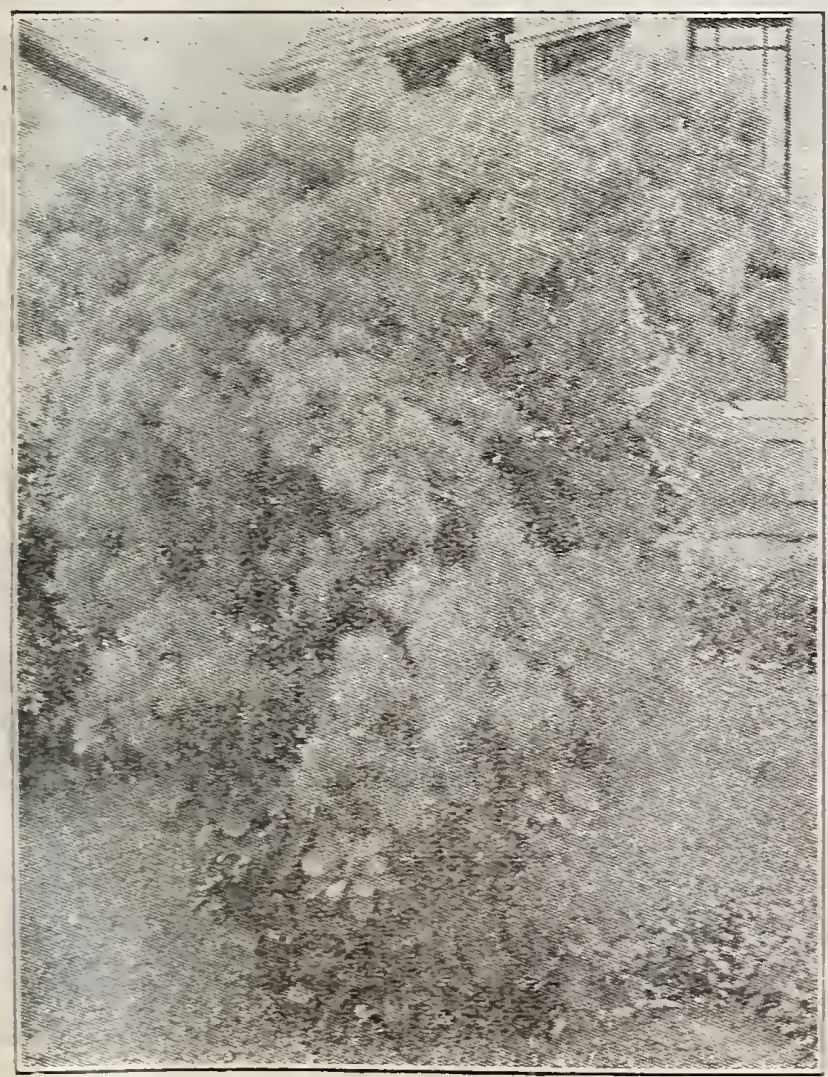

Fringe, Purple.

graduall ft., each $75 \mathrm{c}$. (Globe each $30 \mathrm{c}$.

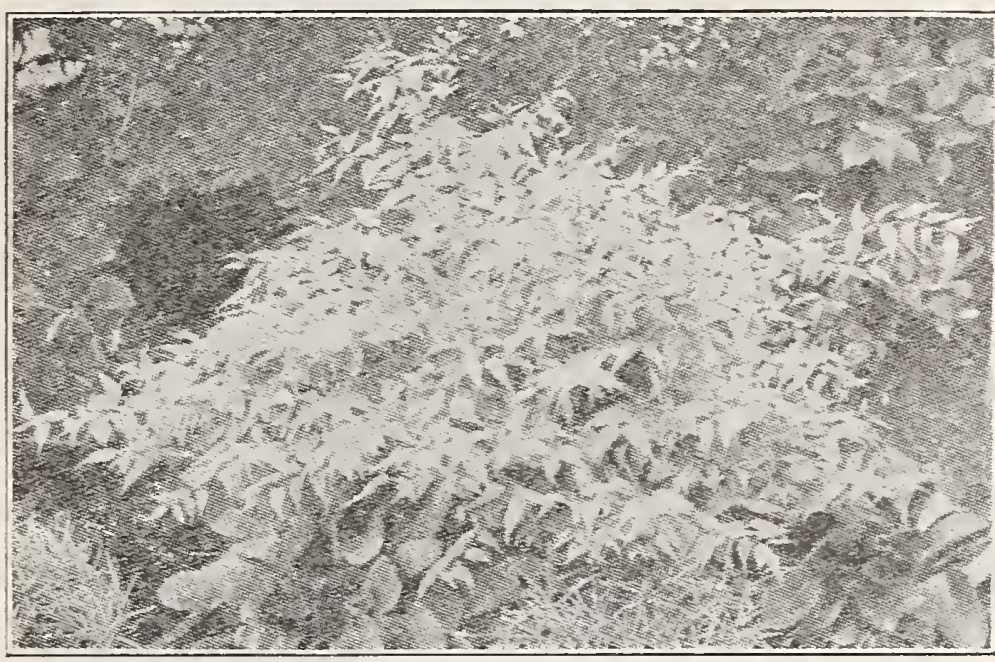

Kerria, Japonica.

FRINGE. (Smoke Tree.)

Purple. A

18 to 24 -in., ea. $25 \mathrm{c}$; 2 to $3 \mathrm{ft}$, ea. $35 \mathrm{c}$; 3 to $4 \mathrm{ft}$.,ea. $50 \mathrm{c}$

White. Fringed thite flomers, very fragrant, Which appear in., ea. $25 \mathrm{c}$. 2 to 3 ft., ea. $50 \mathrm{c}$.

HONEYSUCKLE.

Red Tartarian (See page 55 for description.) Fa. 10c., White Tartarian.

Ea. $10 c_{\text {., }} 3$ for $25 \mathrm{c}$, postpaid; 18 to 24 -in., ea. $25 \mathrm{c}$.; 2 to $3 \mathrm{ft}$, ea $35 \mathrm{c}$.; 3 to $4 \mathrm{ft}$., ea. $50 \mathrm{c}$

Pink Tartarian. Same as Red, except color HYDRANGEA.

Paniculata Grandiflora.

through the sunset shades

Flowers, and can be kept indoors all winter.

it is back, and for specimen plants, groups, borders or ornamental dirision 2 to $3 \mathrm{ft}$., each $35 \mathrm{c}$. Extra selected, $50 \mathrm{c}$. each.

Tree Hydrangea. Same as Hydrangea Paniculata Grandiflora, except lamn decoration. With a broad surface, should be planted in groups of 6 to 10 plants and make each 50c.; 4 to 5

KERRIA, JAPONICA. Flower.)

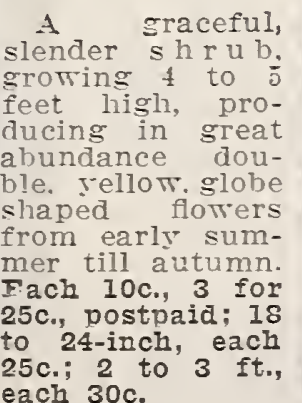

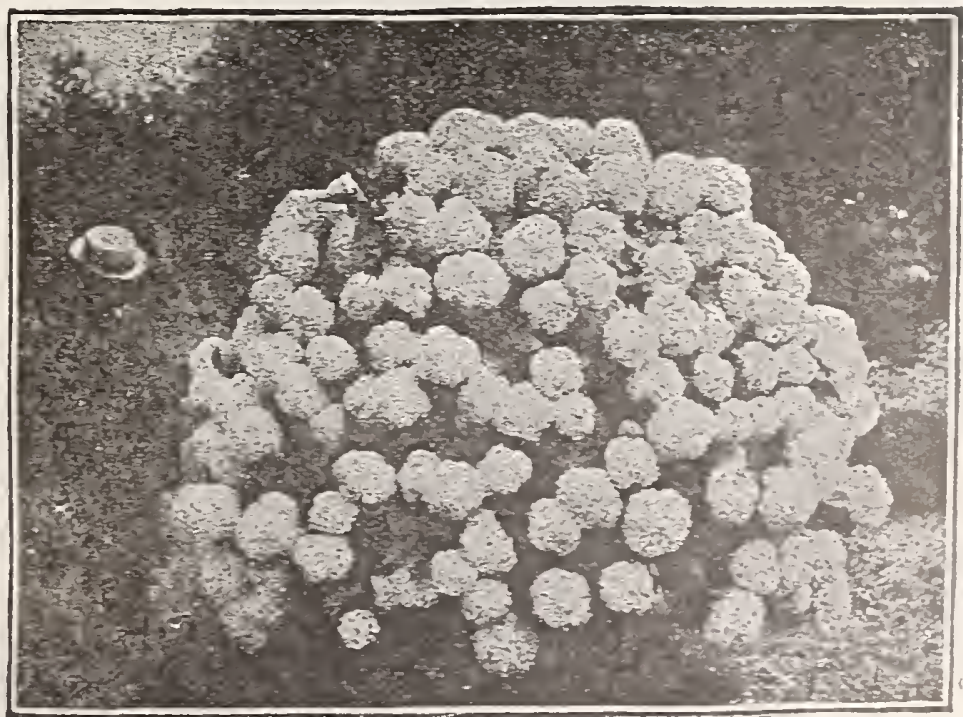

Hyarangea, Faniculata Grandiflora. 


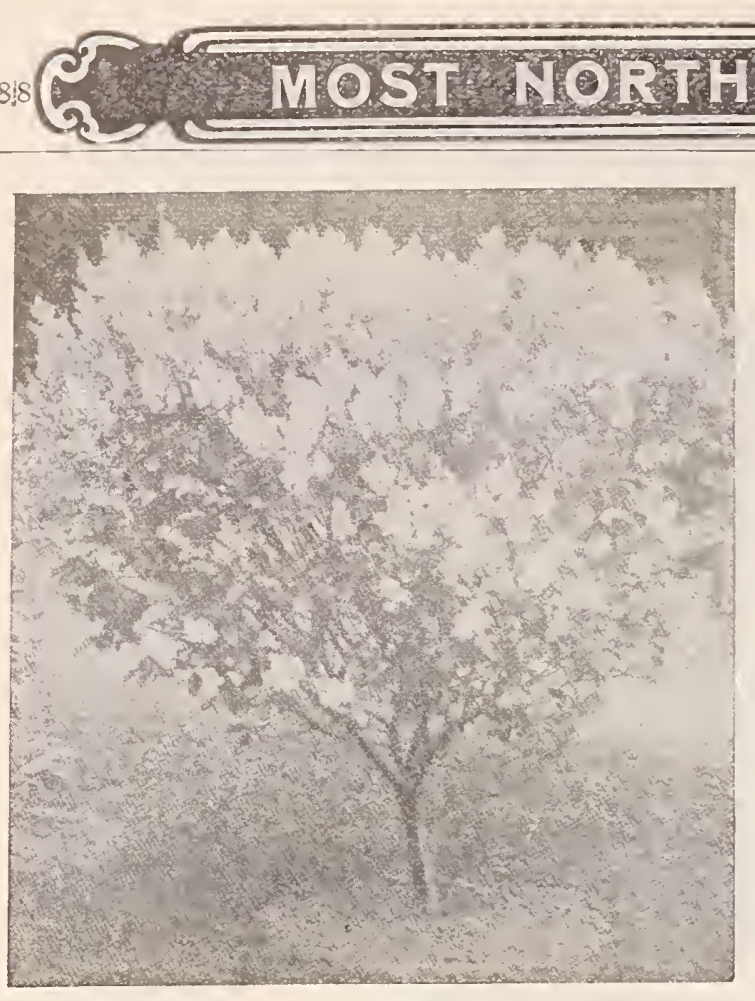

Iilac, Josikea.

\section{SHRUBS. - Cont.}

LILAC.

Large Flowering Purple.

A well-known, popular shrub. Flow ers deep purple; their familiar fravery easy of culture, grows in any 18 to 24 inch, each $25 \mathrm{c}$; 2 to 3 feet., each 30c.; 3 to 4 feet, each $40 \mathrm{c}$.

Large Flowering White.

Identical with the above, except in Each 10c., 3 for 25c., postpaid. 18 to 24 in., each $25 \mathrm{c}$; 2 to 3 ft., each $30 \mathrm{c}$; 3 to $4 \mathrm{ft}$., each $40 \mathrm{c}$.

Belle de Nancy. very late; large, double, light purtowards the center. Strong budded, 18 to 24 in., each $35 \mathrm{c}$; 2 to 3 ft., each 50c.

Charles X. Of exceptionally

rather loose trusses of reddish purple flowers. Strong budaed, 18 to 24 3 in., each $35 \mathrm{c}$.; 2 to $3 \mathrm{ft}$., each 50c.; Josikea. Hungarian. A fine, distinct species, of tree-like in June after other sorts are through blooming. 18 to 24 in., Madame Abel Chatenay.

very large panicles. One of the best budded varieties, the flower stem being long and bloom
very full and compact. 18 to 24 in., each $35 \mathrm{c}$.; 2 to 3 ft., each 50c.; 3 to 4 ft., each $60 \mathrm{c}$. Marie Le Gray.

Bush of dwarf compact growth, and attractive Strong budded, 18 to 24 inch, each 30 .; 2 to 3 fto, each $40 \mathrm{c}$.; 3 to $4 \mathrm{ft}$., each $50 \mathrm{c}$.

Giant Tree A magnificent variety from finest. The blossoms are borne in panicles 18 to 20 inches long, are pure white, very frarieties. It forms a tree 20 to 30 feet ligh, the
foliage being large, dark green. 18 to 24 inch, each 30 c.; 2 to 3 fto, strong, each $40 \mathrm{c}$.; 3 to 4 $\mathrm{ft}$., each $50 \mathrm{c}$.; 4 to $5 \mathrm{ft}$., each $60 \mathrm{c}$.
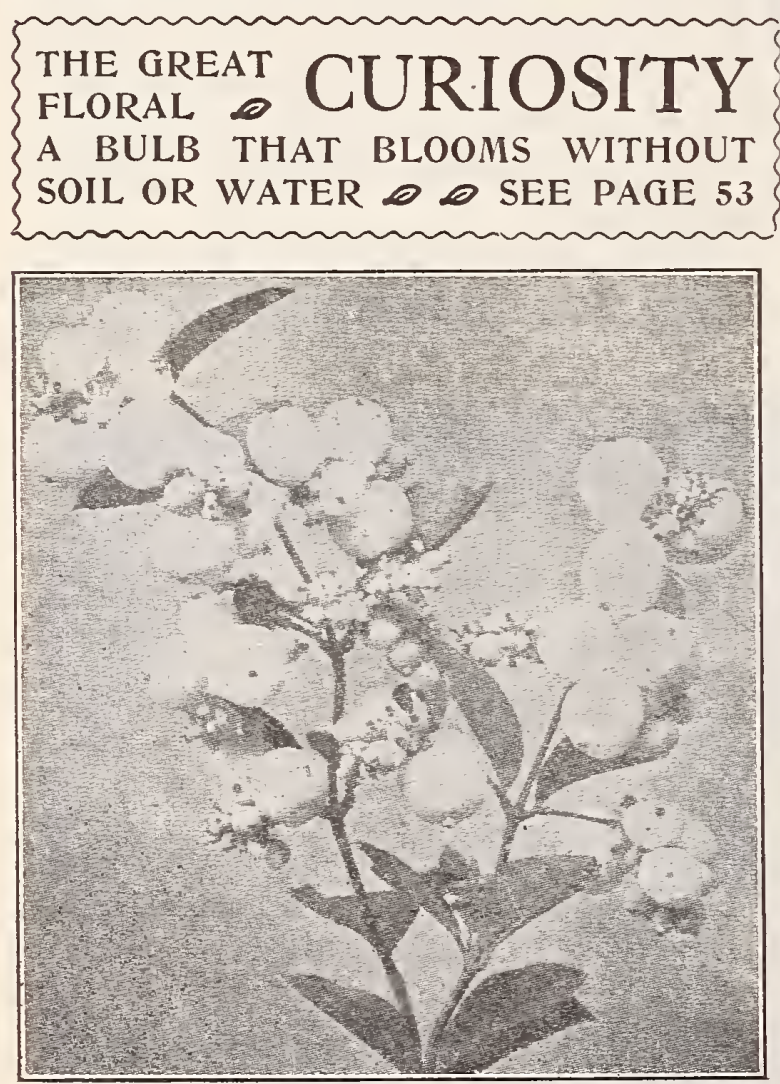

Snowberry.

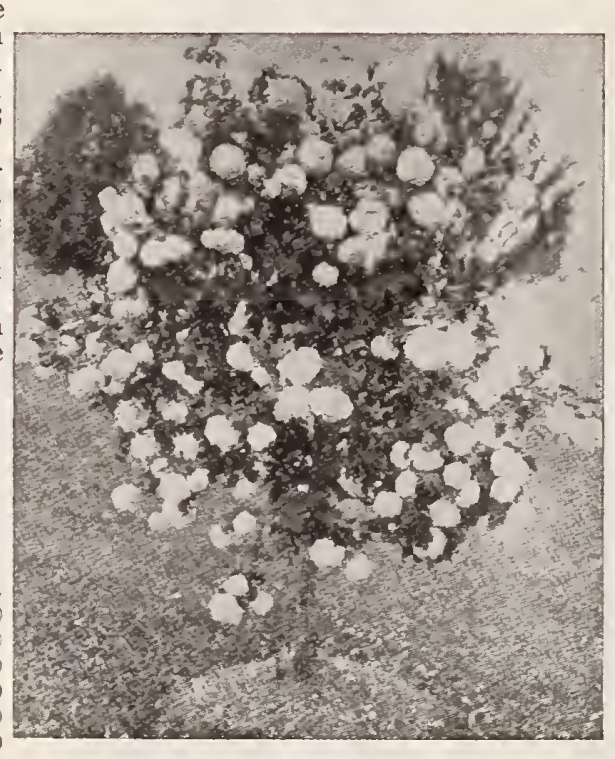

Snowball.

SNOW-BERRY.

White. A most beautiproducing a little shrub, flowers in early summer. and large white, waxen $10 c ., 3$ for 25c., postpaid; 18 to 24 inch, each 25c.; 2 to 3 ft., each $30 \mathrm{c}$.

Red. Similar to the cept that its fruits are red, and that the smaller red berries cluster in stems, which droop beneath their weight. Fach 18 to 24 inch, each $25 \mathrm{c}$. 2 to $3 \mathrm{ft}$., each $30 \mathrm{c}$.

Japan Quince.

See page 85 for defor $25 \mathrm{c}$., postpaid; 18 to 24 inch, each 25 c.; 2 to 3 ft., $40 \mathrm{c}$.
, forming nice

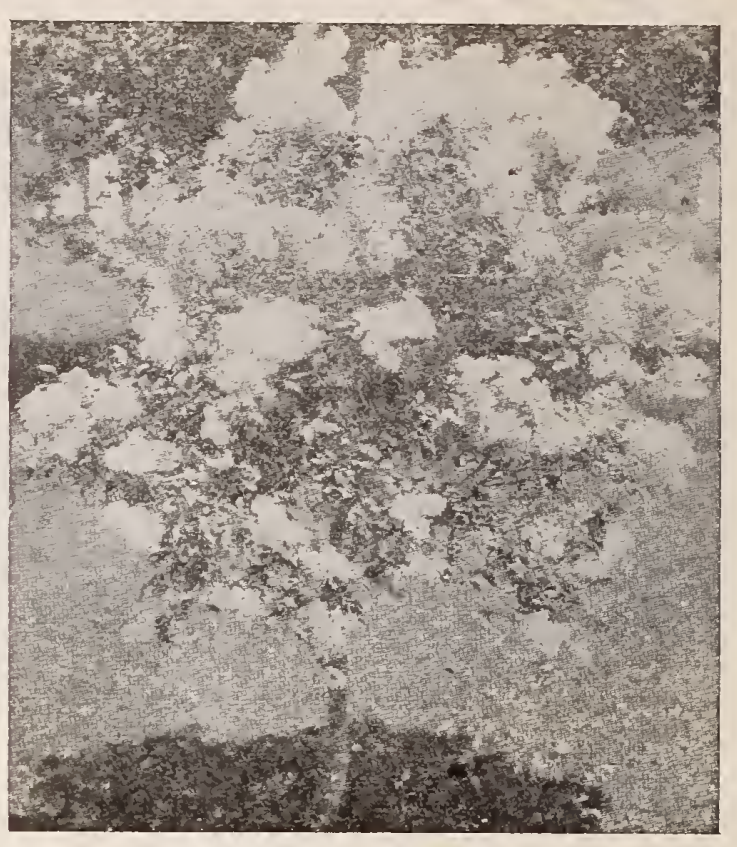

Iilac, Giant Tree.

SNOWBALL.

(Viburnum Sterilis.) Attains a height of 10 to 12 feet. Blooms in the latter orial Day decorations. Flowers are large balls, 10c., 3 for $25 \mathrm{c}$., postpaid; 18 to 24 inch, each $25 \mathrm{c}$.; 2 to $3 \mathrm{ft}$., each $30 \mathrm{c}$.; 3 to $4 \mathrm{ft}$., each $40 \mathrm{c}$. Japan. (Plicatum.) Handsome p l i c a t ed neutral flowers, early in June. It surpasses the common variety in several respects. Its habit is better, foliage much handsomer flowers whit er and more delicate. 18 to 24 inch., each $40 \mathrm{c}$. 2 to $3 \mathrm{ft}$., each 50c. Lentago. (Sheep-berry.) Flowers creamy glossy green. 18 to 24 inch, $25 \mathrm{c}$.; 2 to 3 ft., $35 \mathrm{c}$.

SYRINGA OR MOCK-ORANGE.

Coronarius. A medium sized shrub, bearing scented flowers the last of May. Fach 10c. postpaid; 18 to 24 inch., 25c.; 2 to $3 \mathrm{ft}$., 30c. 3 to $4 \mathrm{ft}$., $40 \mathrm{c}$.

Golden. A brilliant little shrub, with bright, throughout the entire season. Each 10c., 3 for $25 \mathrm{c}$., postpaid; 18 to 24 inch, each 25c.; 2 to 3 Lemoinei. Of dwarf, sturdy, erect growth; Each 10c., 3 for $25 \mathrm{c}$., postpaid ; 18 to 24 inch, each $25 \mathrm{c}$.; 2 to $3 \mathrm{ft}$., each $35 \mathrm{c}$.; 3 to $4 \mathrm{ft}$, each $40 \mathrm{c}$.

Zeyheri. Of medium growth and graceful habit; iest shrub of its group. Each 10c., 3 for $25 \mathrm{c}$., postpaid; 18 to 24 inch, each $25 \mathrm{c}$.; 2 to 3 ft., each $35 \mathrm{c}$.

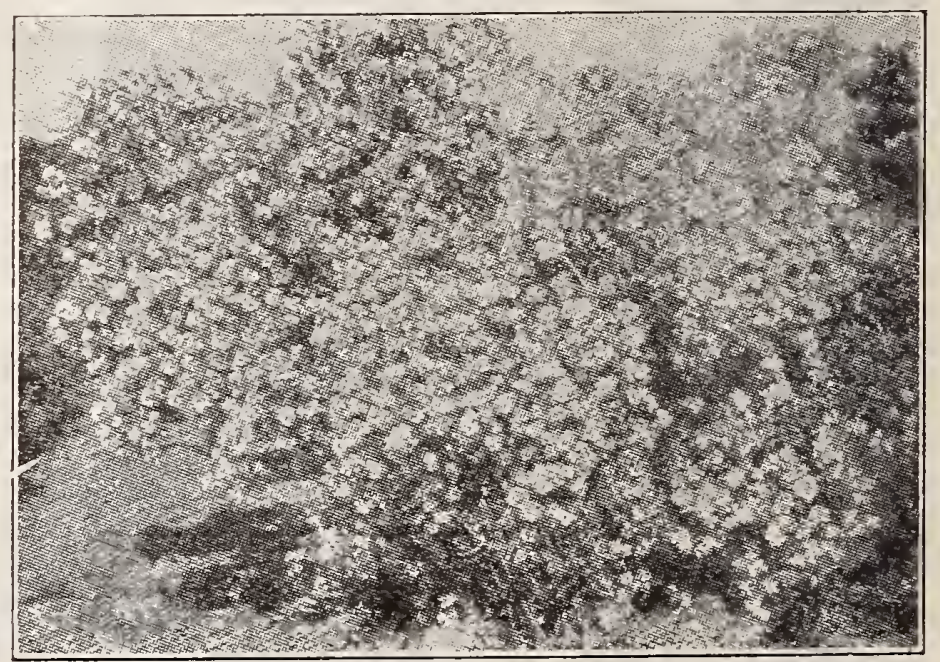

Syringa. 


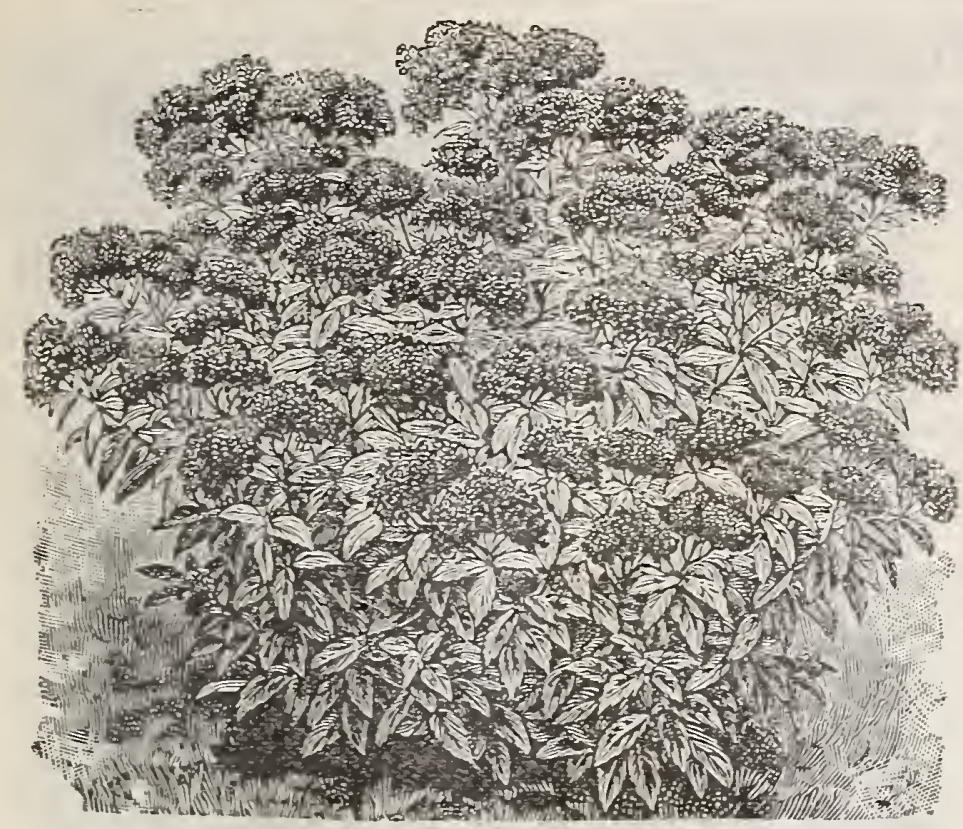

Spirea Anthong waterer.

SHRUBS-Continued.

\section{SPIREAS.}

Some varieties of this class of shrubs are in bloom nearly all the season. All kinds have a riotous extravagance of blocm that and growth that monotony from planting too many kinds is impossible. They are hardy and easily grown in all situations. A
collection of all the different varieties which we offer will give much pleasure. Iakes a dwarf bush 18 to 24 inches Anthony Waterer. high, covered from spring till late in Grand for border to taller growing shrubs, single specimen plants for the lawn or for winter and spring blooming in pots. Ea. $10 \mathrm{c}$. 3 for 25c., postpaid; 12 to 18 -in., ea. $25 \mathrm{c}$; 18 to 24 -in., ea. $30 \mathrm{c}$.

Aurea. Of similar habit. The leaves are bright yellow in Ia. 10c., 3 for 25 c., postpaid; 2 to $3 \mathrm{ft}$., ea. $30 \mathrm{c}$.

Callosa Alba. A dwarf variety bearing pure white flowers good companion to Anthony Waterer. Ea. 10c., 3 for 25 c., postpaid; 15 to 18-in., ea. $25 \mathrm{c}$.

Sorbifolia. A vigorous species, with leaves like those of the flowers in July. 12 to 18-inch, 20c.; 18 to 24-inch, $25 \mathrm{c}$

Billardii. One of the prettiest on the list. Bears handsome Billardil. spikes of pink blossoms from June until killed by the frost in late autumn. It forms beautiful hedges for lawns and along sidewalks. It may be kept low by pruning it in the back yard, but in this case should not be pruned rery much. For groups, in beds, on the lawn, it is always attractive and desirable. Reevesi. Last of May. Attractire foliage and beautiful cluspostpaid; 18 to $24-i n .$, ea.
$25 \mathrm{cos} 2$ to $3 \mathrm{ft.}$ ea. $30 \mathrm{c}$.

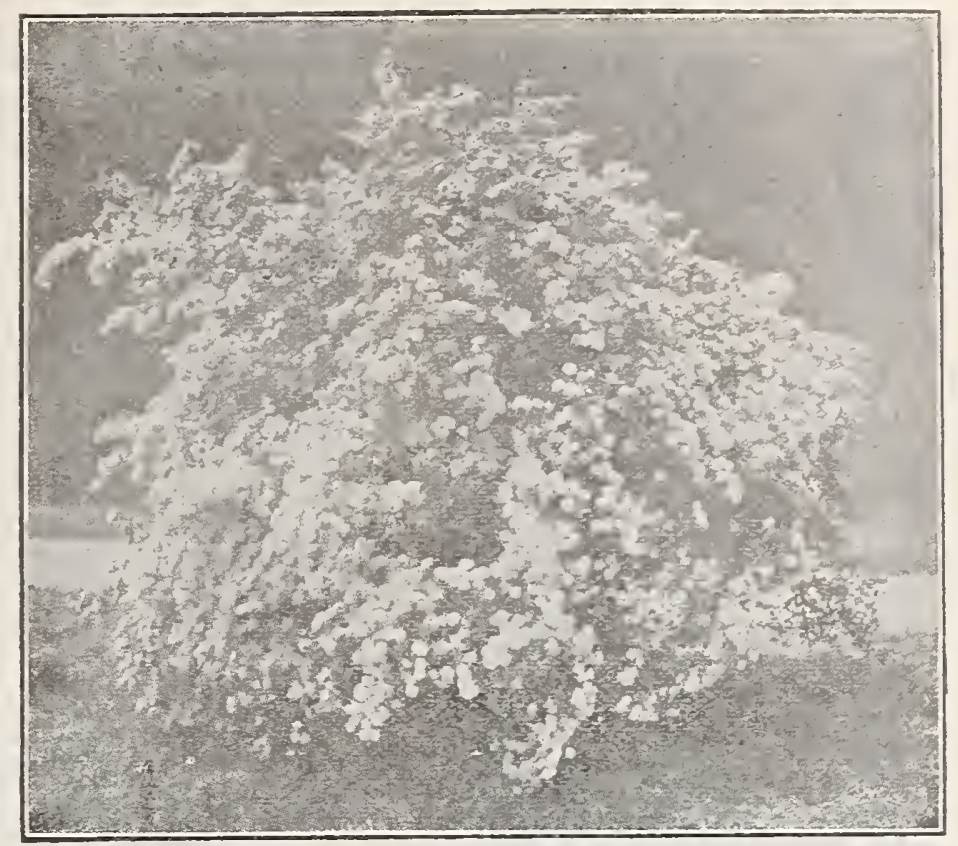

Spirea Van Houtti.

Opulifolia.

branches upright, though drooping wh loaded with umbels lent sort for backing shrubberies or mass-planting. 12 to 18 inch, each 25c.

Van Houtti. One of the most charming and beautiful of clusters or panicles an inch in diameter. Astonishingly profuse cently introduced from France, and considered by many the paid; 18 to 24 -inch, each $25 \mathrm{c}$; 2 to $3 \mathrm{ft}$, each $30 \mathrm{c}$; 3 to $4 \mathrm{ft}$, each $40 \mathrm{c}$; 4 to $5 \mathrm{ft}$., each $50 \mathrm{c}$

\section{TAMARIX AFRICANA.}

Bright pink flowers in slender racemes on shoots of the pre24-inch, each $25 \mathrm{c}$.; 2 to 3 ft., each $30 \mathrm{c}$.; 3 to $4 \mathrm{ft}$., each $40 \mathrm{c}$.

\section{WEIGELIAS.}

These shrubs bloom after the lilacs, in June and July. They make a strong growth, erect when young, gradually spreading and drooping into most graceful shape with age. Their large flowers are of wide trumpet shape, of all colors from white to Used for borders, groups, immediate effects and low screen

Abel Carriere. best. 2 to 3 ft., ea. $35 \mathrm{c}$; 3 to 4 ft., ea. $50 \mathrm{c}_{\text {. }}$ Ambalis. A pink-flowered variety and one of the best. 18 to Eva Rathke. see back cover page for illustration. The 2 for $25 \mathrm{c}$., postpaid; 15 to 18 -inch, each $25 \mathrm{c}$; 18 to 24 -inch, each $30 \mathrm{c.}$; 2 to 3 ft., each $35 \mathrm{c}$.

Kost Variegata Of dwarf, compact growth leaves borfine. 2 to $3 \mathrm{ftos}$ each $30 \mathrm{c}$.

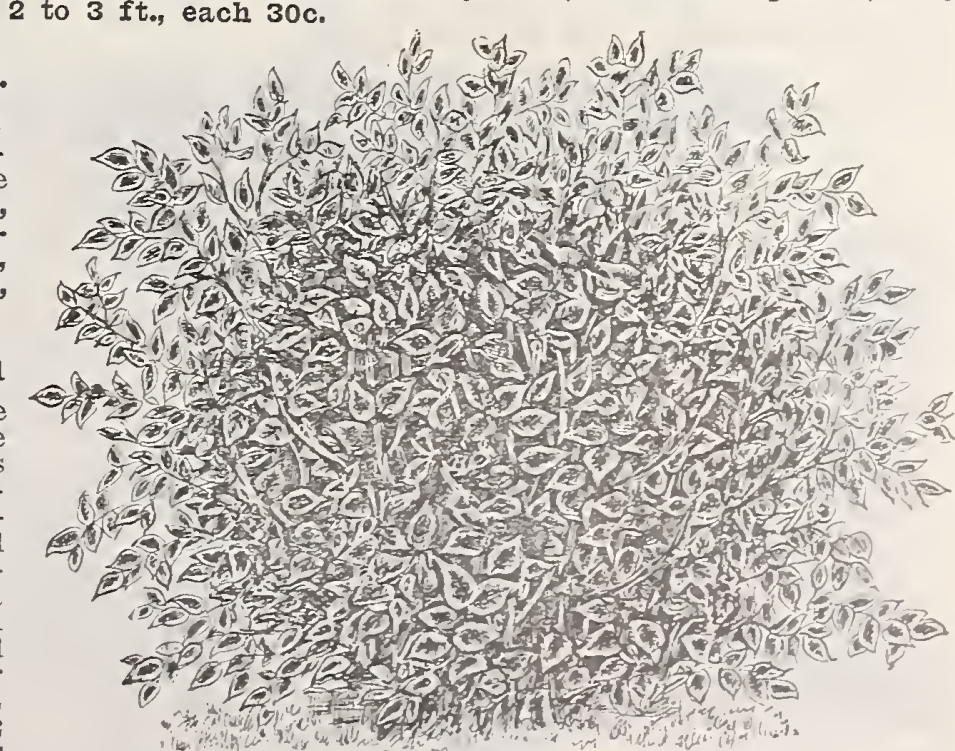

Weigelia Nana Variegata.
Weigelia Rosea. Bears an abundance ers in May and June Ea. $15 \mathrm{c} ., 2$ for $25 \mathrm{c}$. postpaid; 18 to 24 in., $25 \mathrm{c}$.; 2 to $3 \mathrm{ft}$. ea. $35 \mathrm{c} . ; 3$ to $4 \mathrm{ft}$. ea. 50c.

Ros e a Nana Variegata. Of $\mathrm{n}$ e most conspicuous shrubs that we cultivate; leares beaucreamy white; flow ers pink. It is a admirably adapted to small lawns or gardens. Fa. 15c., 2 for 25 c., postpaid; 2 to 3 ft., ea. $35 \mathrm{c}$. 


\section{MOST NORTHERN NURSERIES IN AMERICA.}

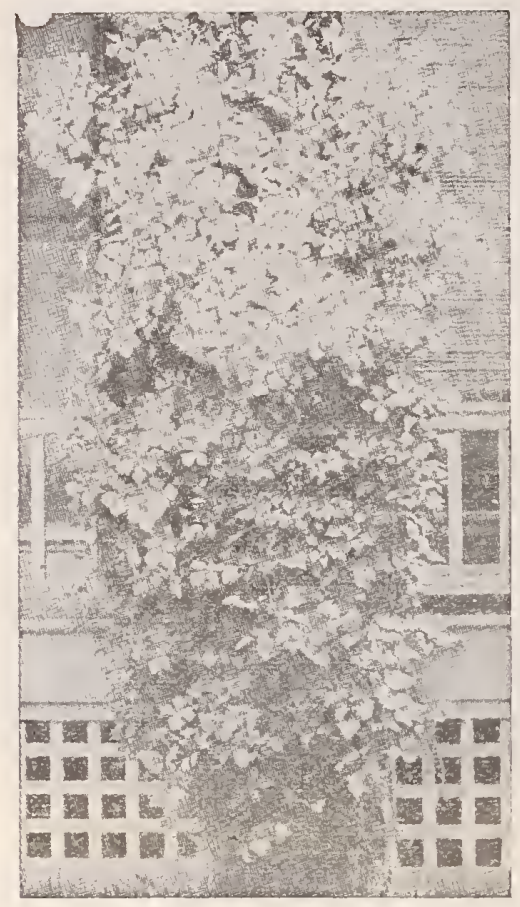

Clematis, Jackmanni.

\section{HARDY CLIMBING VINES.}

SPECIAI NOTE.-Single plants each, 1 jear, postpaid. Doz., \& and 3 year, express or freight at purchaser's expense. Single price at 10c. are $\$ 1.00$ per doz., 15c. $\$ 1.50$ per doz., 20c. $\$ 2.00$ per doz., 25c. $\$ 2.50$ per doz., 30c. $\$ 3.00$ per doz., 35c. $\$ 3.50$ per doz., 40c. $\$ 4.00$ per doz., 50c. $\$ 5.00$ per doz.

ACTINIDIA POLYGAMA. (Silver Sweet.)

Foliage resembles the lilac On ends of flowering shoots the third season it changes to a silvery white color, giving the effect of large white lowers among the green leaves. yellow anthers; fragrance resembles the Lily of the Valley. Each 10c., 3 for 25c., postpaid. 3 year strong, 30c.

\section{AMPELOPSIS.}

Quinquefolia. (Virginia Creeper.) A well-known, hardy, postpaid. 2 year strong, each 25c., 3 year strong, each $30 \mathrm{c}$. Englemanni. (Engleman's Ivy.) One of the hardiest and Foliage resembles the Virginia Creeper. Fach 15c., 2 for $25 \mathrm{c}$. postpaid. $2 \mathrm{yr}$. strong, each 30c., 3 yr. strong, each 35c Veitchi. (Japan or Boston Ivy.) autumn to tints of crimson and orange. Each $15 \mathrm{c}$., 2 for $25 \mathrm{c}$. postpaid. $2 \mathrm{yr}$. strong, each 25c., $3 \mathrm{gr}$. strong, each $35 \mathrm{c}$. BIGNONIA RADICANS (Trumpet Flower.)

The flowers are orange and scarlet. Each $15 \mathrm{c} ., 2$ for $25 \mathrm{c}$. 2 year strong, each 30c., 3 year 40c. CELASTRUS SCANDENS (Bitter Sweet.) followed by clusters of orange-scarlet

\section{CLEMATIS.}

Paniculata. Fardy in all parts of the U. S. Blossoms pure the foliage. Price, 1 year, each $15 \mathrm{c}$., 3 for $40 \mathrm{c}$., postpaid. 2 year strong, each $25 \mathrm{c}$., 3 year strong, $35 \mathrm{c}$.

Jackmanni. The best of all the large flowering varieties. $30 c ., 2$ for $50 c .$, postraid. 2 year strong, each 50c., 3 year strong,

Henryi. Creamy white; large and of fine shape; a free growpostpaid. 2 year strong, each $50 c ., 3$ year strong, each $75 \mathrm{c}$.

Ramona.

attractive. 1 year strong, each $30 c ., 2$ for 50 c., postpaid. 2 year strong, each 50c., 3 year strong, each 75c.

Madame Edouard Andre. Has been called the Crimson strong, vigorous grower, and verimson-red. 1 year strong, each $30 \mathrm{c}$., 2 for 50c., postpaid. 2 year strong, each 50 ., 3 year strong, $75 \mathrm{c}$.

Virginiana. American White Clematis. A remarkably rapid feet. Each 15c., 2 for 25 c, postpaid. 2 year strong, each 30 ., 3 year $50 \mathrm{c}$.

Davidiana. Flowers bell-shaped in clusters, color deep lavDuchess of Edinburgh. Large flowering double pure postpaid, 2 year strong 50c.

Viticella. Purplish red flowers and pretty foliage. 1 year
Each 10c., paid. 2 year strong, each $35 \mathrm{c}$.

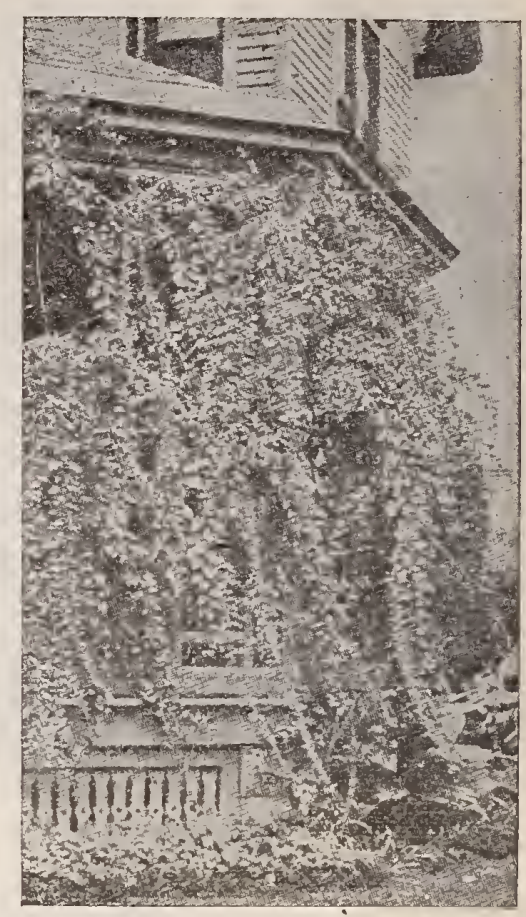

IMatrimony Vine.

\section{DUTCHMAN'S PIPE.}

magnificently hardy vine of rapid growth, with very large heart-shaped leaves and brownish flowers, resembling in shape HONEYSUCKLE.

Japan Golden-Leaved. Of vigorous growth, forming radclear golden leaves; flowers creamy white. Each $15 c ., 2$ for $25 c$.,
postpaid. 2 year strong, each 35 .

Hall's Japan. Pure white and creamy yellow; fragrant flow$25 \mathrm{c}$, postpaid. 2 year strong, each $35 \mathrm{c}$. Scarlet Trumpet. Must brilliant of all honeysuckles, problossoms. Each 15c., 2 for 25 c., postpaid; 2 yr. strong, 35c. each.

\section{MATRIMONY VINE. (Lycium Chinensis.)}

A most vigorous, hardy, climbing plant, with purple flowers, long. Each 15c., 2 for 25 c, postpaid. 3 year strong, each 25 c.

\section{SILK VINE. (Periploca.)}

A rapid-growing, beautiful climber. Foliage glossy and purple-brown clusters of flowers 2 year strong, each 30c.

\section{WISTARIA.}

Purple. A perfectly hardy and popular vine with large clus-

White. Pendulous clusters of pure white flowers. 1 year

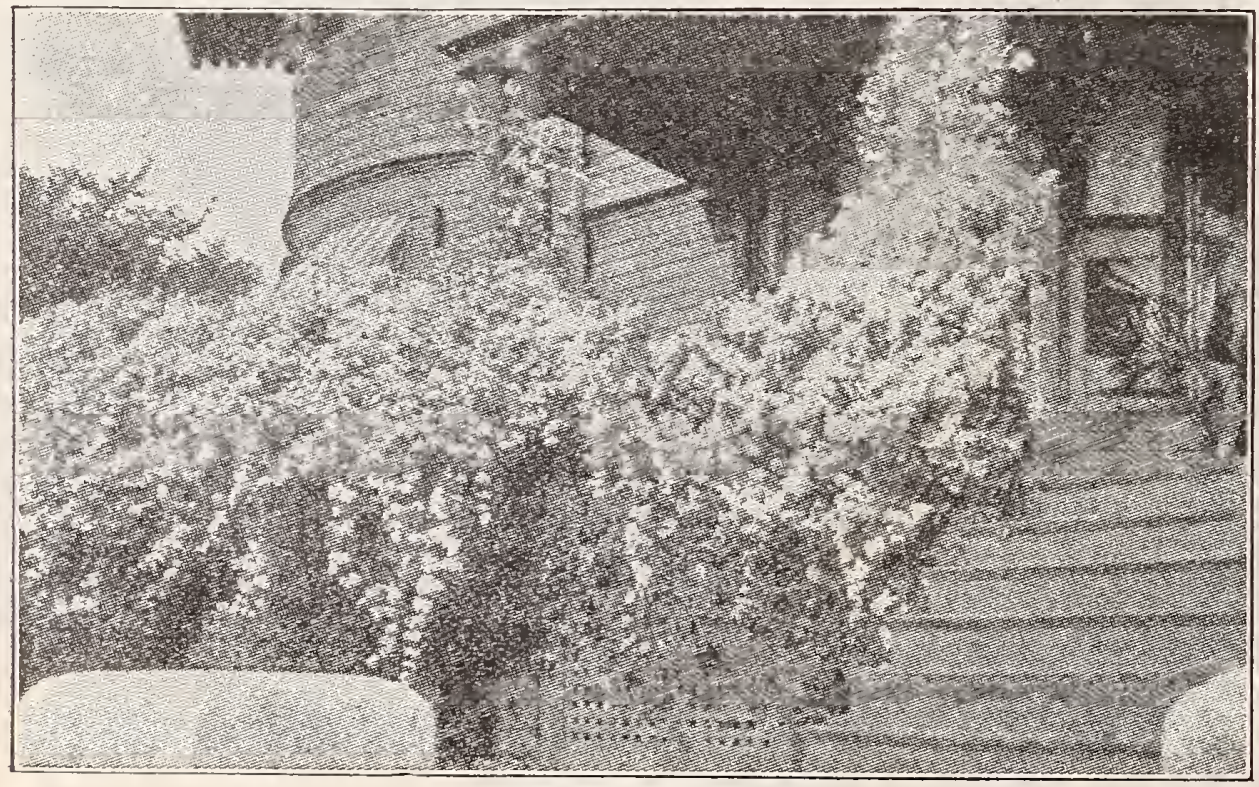

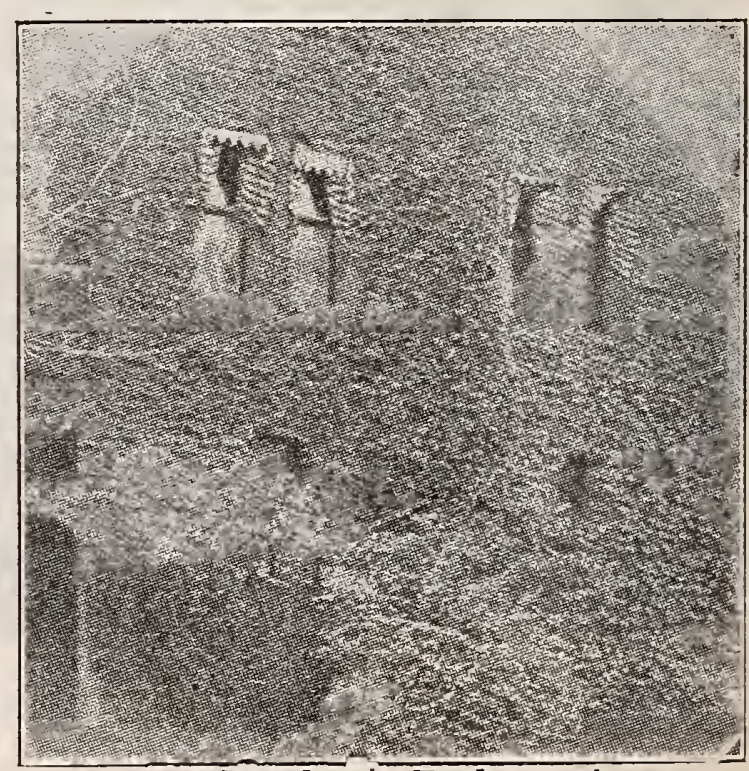

Ampelopsis Englemanni. 


\section{OPHARDY, RRODUCTIVE FRUITS; ORNAMENTAL TREES, SHRUBS. ETC. E⿱}

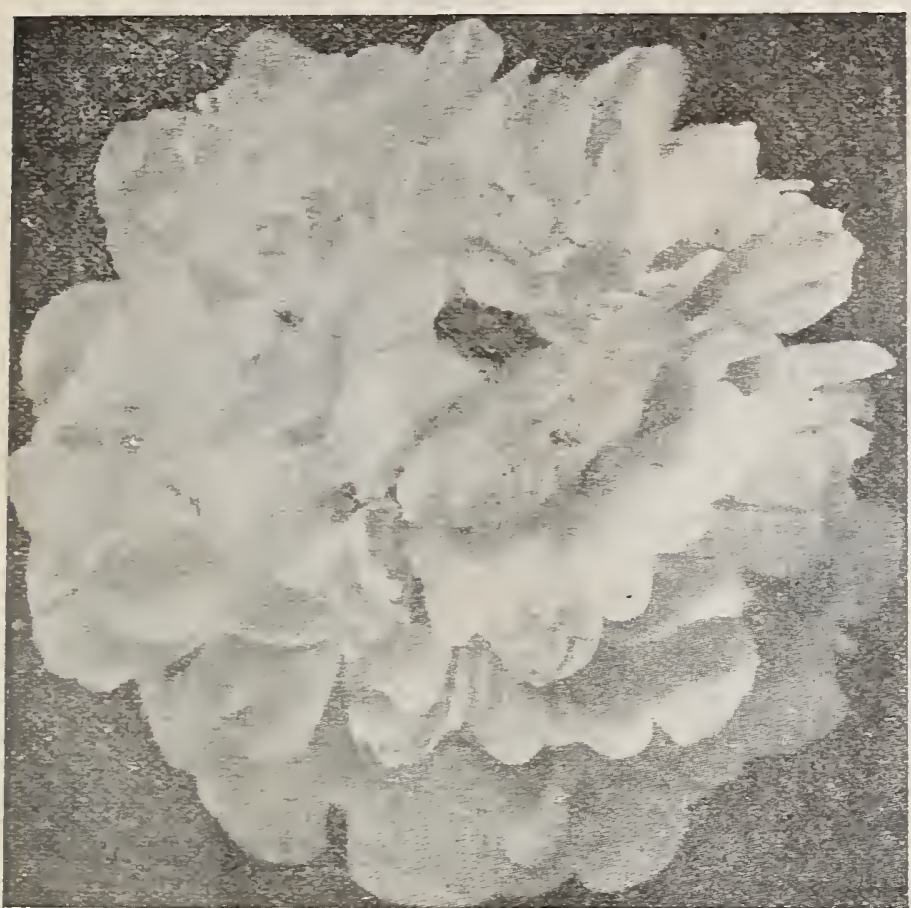

I'estiva Maxima.

PAEONIES, Herbaceous.

SPECIAI NOTI.-Single plants mailed free, dozen by ex-

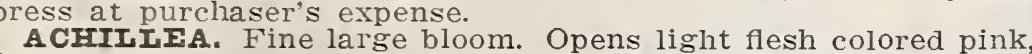
nishing blush white, with an occasional creamy spot. Each $40 \mathrm{c}$ AGIDA. Rich glowing dark red. Each 50c.

AGNES MARY KELWAY. Guard petals of light rose, yellow petaloids. with rose tuft. Each $75 \mathrm{c}$.

AIBERT CROUSSE. Fine flesh pink, fragrant. Each \$1.25. ANDRE IAWRIES. A fine late flowering deep red. Iach $30 \mathrm{c}$ BARON ROTHSCHILD. Outside rose, center salmon. Fach 30c. BERLICZ. Currant red, dwarf and compact. Each 50c. CANARY. Large cream, yellow. Each 30c.

CARNIIE CALOT. Pinkish white. Each 30c.

CYNTHEA. Large flowering white. Each 50c.

DEIICATISSMA. Fine large, very full convex bloom of very

lear delicate pink, shading light at center. Each 50c.

DORCEISTIR. Salmon flesh color, free bloomer. Each $\$ 1.00$. DUCFES de NIMOURS. Very fine cup-shaped bloom, sulphurwhite with greenish reflex, fading to pure white. Late. Each $\$ 1.50$ DUKE OF WEIIINGTON. Very large, well-formed sulphur-

white bloom; very fragrant. Each $\mathbf{7 5 c}$.

EDOURD ANDRE. Deep crimson red, shaded black, with metalic lustre. Each 75c.

EDUIIS SUPERBA. Tinted riolet, whitish ligules; silver re-

lex. Each 50c.

EI I GA I S SUPERBISSIMA.

Dark pink with salmon center. Each 50c.

FMILY IEMOINE. Very rich red. Each $40 \mathrm{c}$.

ITHEFI BROWNELI. Pure white one of the largest. Fach 50c.

FEIIX CROUSSE. Brilliant red

with ruby flamed center. Each $\$ 1.00$ IESTIVA. A good white, much Each $50 \mathrm{c}$.

FESTIVA MLAXIMA. Early, enor-

mous, very full, shell formed bloom,

often 7 to 8 inches in diameter, color snowr white, shaded to

FRAGRANS. Ver'y late, dark red. Each $25 \mathrm{c}$.

GOIDEN FARVEST. Very striking variety, large tri-colored blooms, guard petals blush pink with a disnct blush white color. Each 50c.

GRANDIFLORA AIRA. Resem GRANDIFIORA ROSEA. $40 \mathrm{c}$. size. clear even pink. Each $50 \mathrm{c}$ FUMEA. The guare petals ire light pink. The center has a thread-like color of light flesh petals. Each 50c.

JEANNE 'ं'ARC. Large flowers of soft rose, sulphur-white and lively rose, center stained carmine, lovely flesh coloring. Each 75c. IADY BERESFORD. The petals are tipped with carmine. A soft
blush-pink shade. Each $\$ 1.50$.

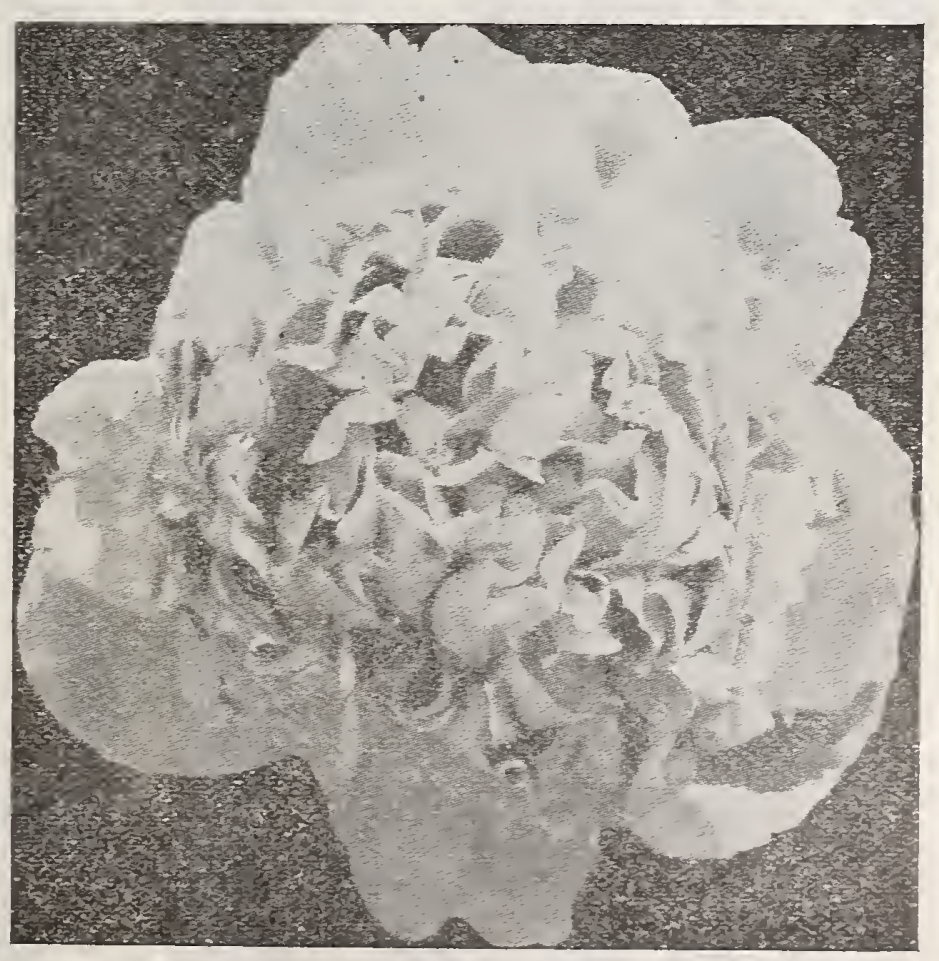

Irodele de Perfection.

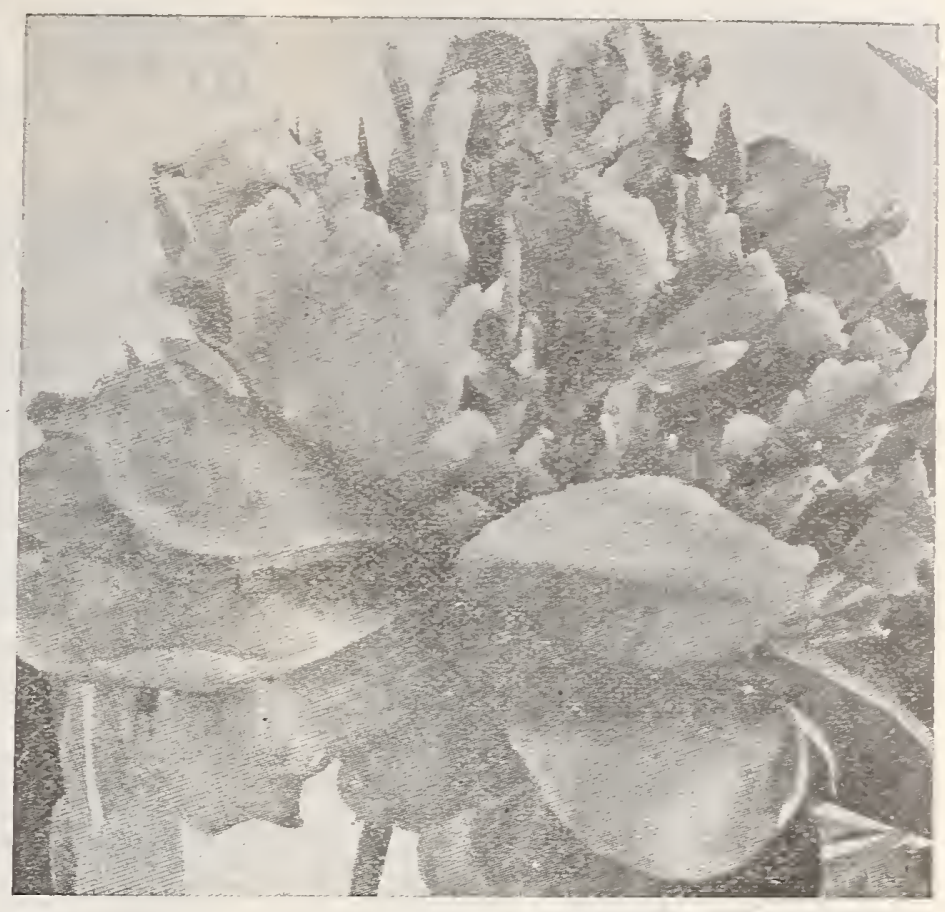

Rubra Superba.

IADY BRAMWEII. Late mid-season bloom; color delicate petals tipped with crimson at the center. Each 50c. IA TUIIPE. Flesh pink, changing to white. Each $\$ 1.00$ IOFENGRIN. Pink and cream, very double. Fach 50c. IOUIS VAN HOUTTI. Bright red; late. Each 50c. MAGNIFICA. Soft rose, sulphur edged carmine, Each 50c. MAD. BUCQUET. Black velvety a maranth. Each 40c. IMADAME DE VERNEVIIIE. Pure white with red flakes in enter, fragrant. Fach $\$ 1.00$

AEMOINI. Sulphur-white

II. IIREIAGE. Deep rose red, very fine shade. Each $\$ 1.00$. MODIII de PrRFECTION. Flesh pink, marked with bright rose and bordered with silvery rose, some salmon-shaded petals ntermixed with the central petalage. Each $75 \mathrm{c}$.

MODESTE GUERIN. Bright rosy purple; solid color. Fach $\$ 1.00$ MONT BLANC. Sulphur white, extra fine. Each 75c. MRS. LOWE. Blush, center cream yellow. Each 50c. OFFICINAIIS ROSEA. Beautiful clear pink, double. Each 30c. OFFICINAIIS RUBRA. The old-fashioned paeony; very ear-

, deep crimson. $\mathbf{E a c h} 40 \mathrm{c}$.

POTTSII. Brilliant crimson. One of the best. Each 35c. PRINCESS MATHILDE. Rose tinted violet. Each $35 \mathrm{c}$. PURPUREA SUPERBA. ark red. Each 50c. OUIEN VICTORIA.

white center petals tipped with red blotches. Each $75 \mathrm{c}$.

REINE VICTORIA. Guard flesh, center penciled with cle cleat carmine. Each 50c

ROSEA SUPERBA.

Each 50c.

RUBRA SUPERBA (Richardson.) Brilliant deep crimson. Each 75c. RUBRA TRIUIMPHANTS. Inte

lowing, rich crimson. Each 50c.

TAGIIONI.

THE BRIDE.

tinged with flesh

VICTORIA TRICOLOR.

ish. Each 60c.

JAPANESE TREE PAEONY.

Tre

dinner plates. Each $75 \mathrm{c}$

NОTЕ.-

$100 \$ 15.00$.

will sell at each $25 \mathrm{c}$., doz. $\$ 2.50$ 


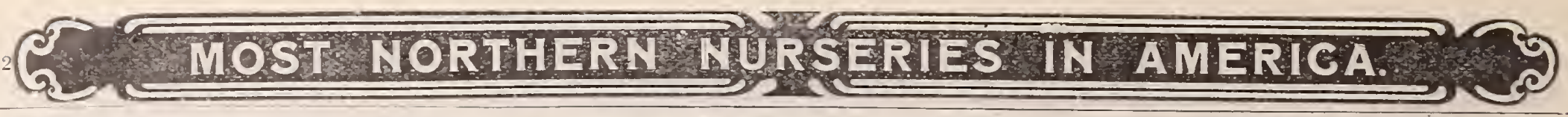

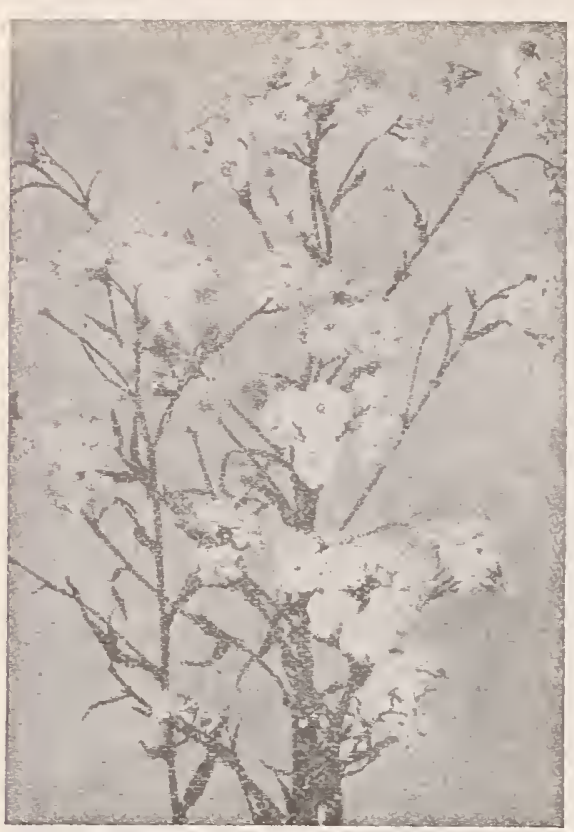

Achillea, The Peari.

ACHIIIEA, "The Pearl."

ANEMONE, Pulsatilla.

AQUILEGIA (Columbine) Candidissima,
A

pure white; Coerulea, the true blue; Giant of Battles, rimson; Hybrida Grandiflora,

Price of above Aquilegias, 10c., each, $\$ 1$ per doz. ANTHEMIS TINCTORIA.

mmer. 15c. each, $\$ 1.50$ doz.

ARMERIA, Formosa. Deep

ARUNCUS, Astilboides.

rly summer. 15c. ea., $\$ 1.25$ doz.

ASPERUIA, Galiodes. For bouquets. 15c. each,

ASTERS, HARDY, Novae Angliac. Purple, yellow BAPTISIA, Austrailis. Blue pea like

rk green foliage, 2 ft. high. 15c. ea., $\$ 1.50 \mathrm{doz}$.

BLEEDING HEART, Dielytra Spectabilis.

June. - 15c. ea., \$1.50 doz.
BLEDING" HEART, Dielytra

Formosa. Dwarf shom? pink for

CAMPAN UIA, Carpatica Alba.

CAMPANUIA, Glomerata. Blush

Price of a bove campanulas, $15 \mathrm{c}$. CEPHAIARIA.

$\$ 1.50$ doz. CHRYSANTHEMUM, MaXimum.

flaisy, but twice as large. 15c. each, $\$ 1.50$ doz.

COREOPSIS, Giant Golden.

bloom in June and continuing a
mass of golden loreliness until

each, \$1-25 doz.

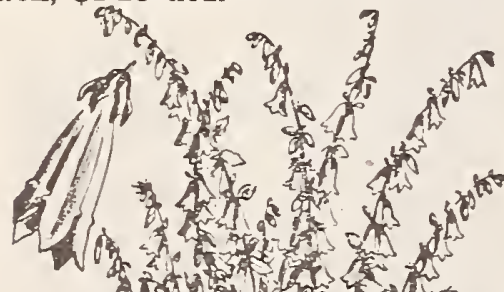
anth

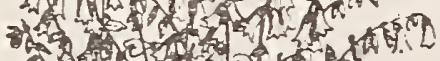
,

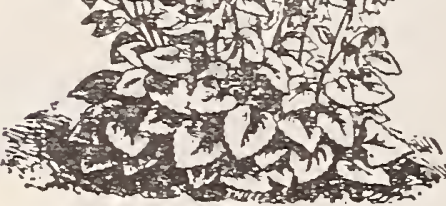

Campanula Glomerata.

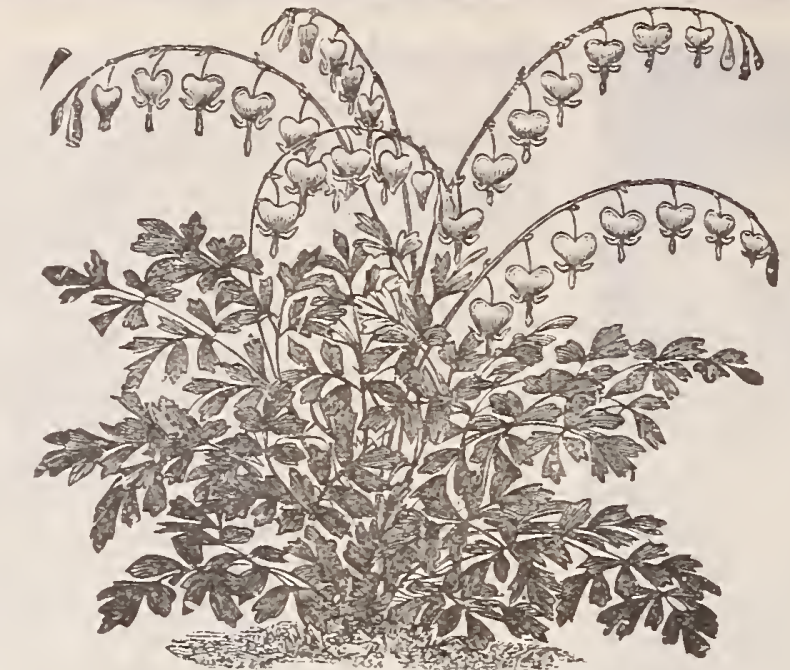

Bleeding Heart, Dielytra.

HARDY PERENNIAL PLANTS.

SPECIAI NOTE.-P

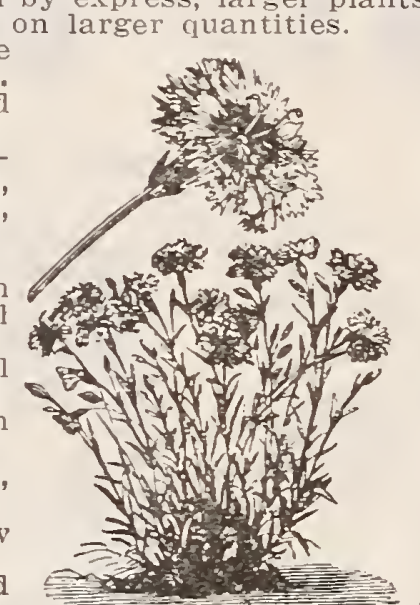

Dianthus Plumarius.

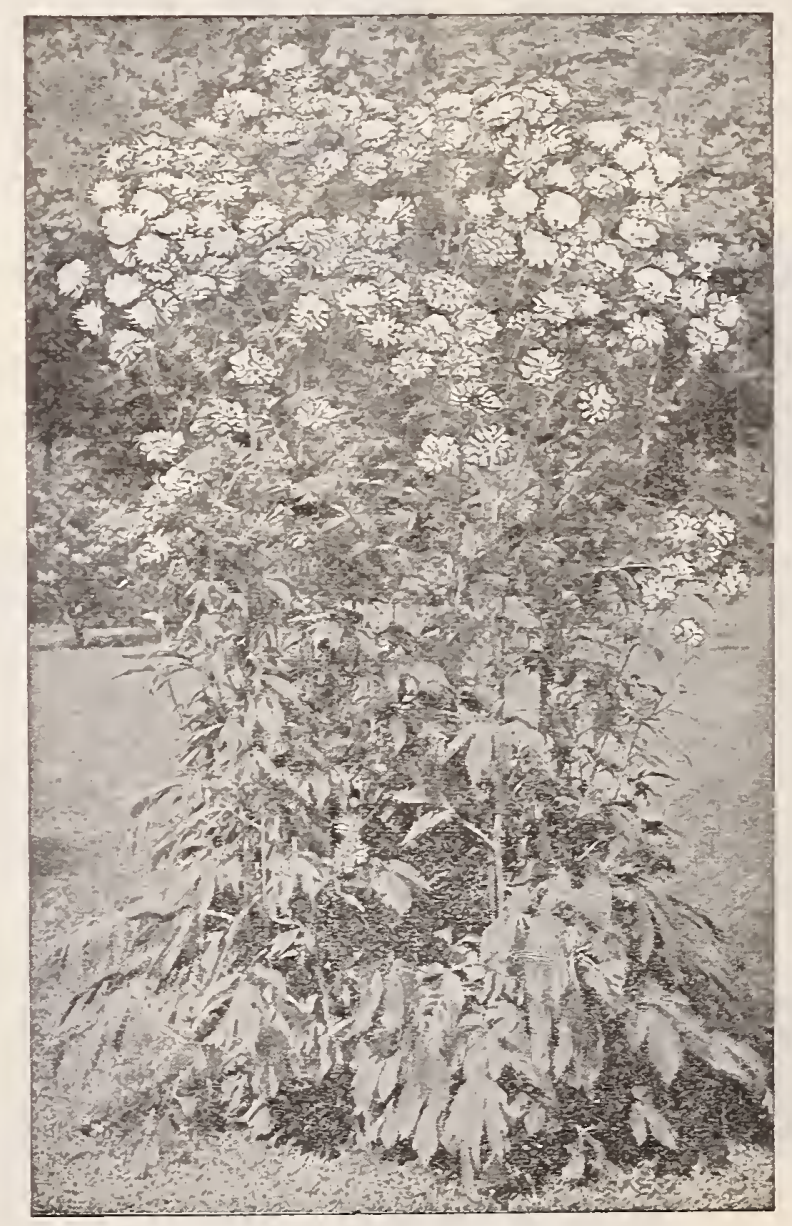

Golden Glow (Rudbeckia).

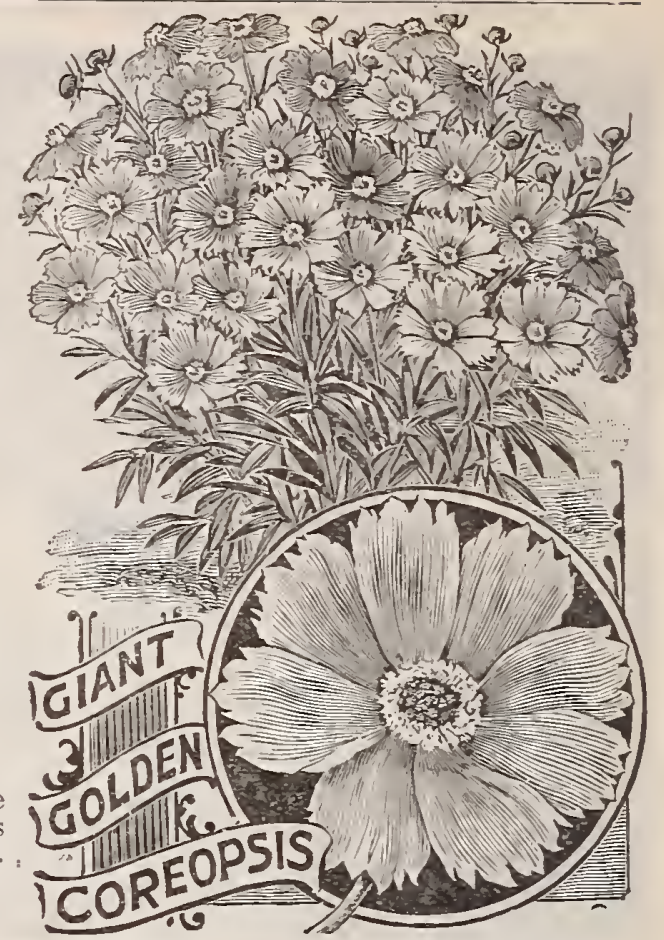

CAIAMINTFA, Alpina. A pretty branched tufted ant; flowers purple. $15 \mathrm{c}$. ea., $\$ 1.50 \mathrm{doz}$. DICTAIINUS, Fraxinella. Showy rosy-pink flowD. $15 \mathrm{c}$. ea., $\$ 1.50$ doz.

DAISY, Shasta. Petals pure white. 15c. ea., $\$ 1.50$ doz. DRACOCEPHAIUM, Grandiflora. Dainty blue DRACOCEPHAIUM, Ruyschiantum. Purplish flowS. July. 15c. ea., $\$ 1.50$ doz.

DELPHINIUIM, Formosum (Iarkspur). Flowers ummer; 18 to 20 inches. 15c. ea., $\$ 1.50 \mathrm{doz}$.
. DEIPHINIUIM, Grandiflorium (Siberian Iarkspur). tinted flowers, from deep blue to white. One of the July and August. 15c. each, $\$ 1.50$ doz.

DIANTHUS, Deltoides Alba (Hardy Pink). A low-growing or creeping variety, with me-
dium-size white flowers, especially suited or the rock garden. $15 \mathrm{c}$. each, $\$ 1.50 \mathrm{doz}$. (tink). hardy. Its use either as a cemetery or garden fower is always satisfactory. 15c. ea., DIANTHUS, Semper Florens. Dark pink, fragrant flowers; May and June. 15c. ea., \$1.50 doz. FRIGERON, Glauous, Large purple flowERIGERON, specious. Light blue flowGellow center. 15c. ea., \$1.25 doz. GAILIARDIA GRANDIFIORA (Blanket Thile the petals are rariously marked with rings of brilliant scarlet, crimson, orange nd vermilion. 15c. ea., $\$ 1.50$ doz.

GOIDEN GIOW (Rudbeckia). The flowers are produced in enormous quantities on long stems and resemble a fine double in late summer when most shrubs and plants are through blooming; September and October. 15c. ea., $\$ 1.50 \mathrm{doz}$.

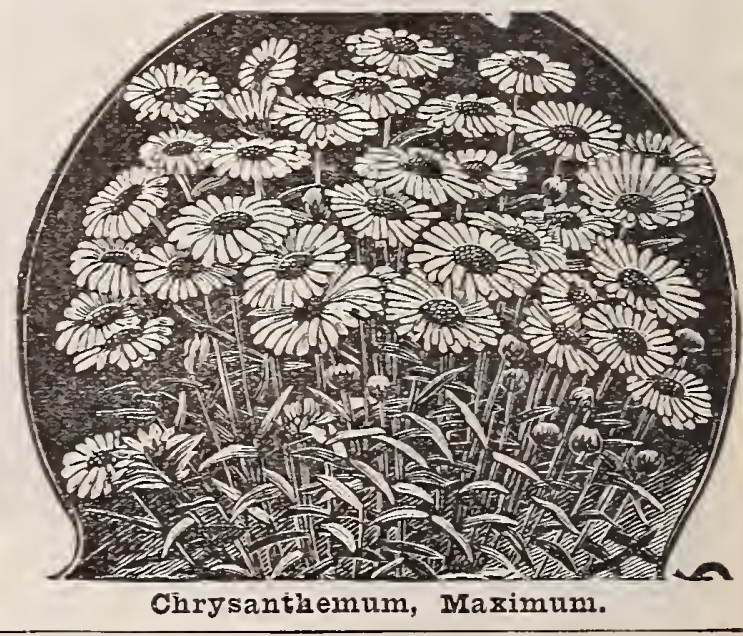




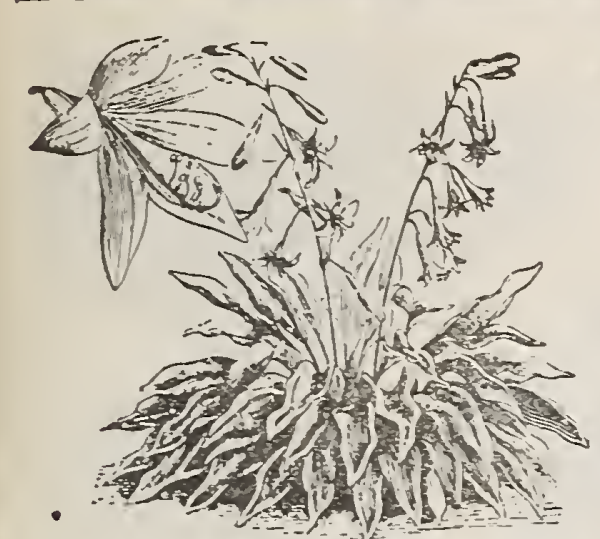

पemerocallis, Day Iily.

HTIOPSIS, Pitcheriana. ea., $\$ 1.50 \mathrm{doz}$

HEMEROCAIIIS, Flava (Lemon Day Lily). Clear jellow flowers; fragrant; $1.50 \mathrm{doz}$

HEMEROCALIIS, Dumortieri. ange sellow, tinged brom

HIBISCUS, Crimson Eye. uring 20 inches in circumference. son HoJ' 15c. ea., \$1.50 doz. them in all shades of color, all double blossoms. Pink, red, white, yellow, fiesh, purple, crimson and rose. 15c. ea., $\$ 1.50$ doz.
HYPIRICUM MOSERIANUM.

flowers are 2 to $1 / 2$ inches eter, of rich golden vellom rendered effective by numerous yellom sta$\$ 1.50$ doz.

IINARIA, Alpina. Dwarf blue floters. $15 \mathrm{c}$. ea., $\$ 1.25$ doz.

IIT OF THE VAIIEY. The stock we offer is strong imported clumps, especially suited for outdoor plantmiddle of April. 15c. ea., $\$ 1.50$ doz. IINUM PERENNE. A Tery desirable plant either for border or rockerJ, with light, graceful foliage ana September. 15c. ea., $\$ 1.50 \mathrm{doz}$.

IYCHNIS (Haageana HJbrida). Brilliant orange-scarlet flowers in May and June; grows 12 to

IYCHNIS, Chalcedonica. Brilliant orano-scarlet. blooms all summer. 15c. ea., $\$ 1.50 \mathrm{doz}$.

IYCHYIS, Alvina. Pink flowers; May. $15 \mathrm{c}$. ea., $\$ 1.50$ doz.

IUPINUS, Perennis. Blue and white flomers in June. 15c. ea., $\$ 1.50$ doz.

MERTENSIA, Siberica. Purplish blue flomers; May and June. 15c. ea. $\$ 1.50 \mathrm{doz}$

TICODON (Japanese Bell Flower) Album. White. 15c. ea., $\$ 1.25$ doz.

PIATICODON (Japanese Bell lower) Grandiflorum. Blue. 15c. ea. $\$ 1.25$ doz.

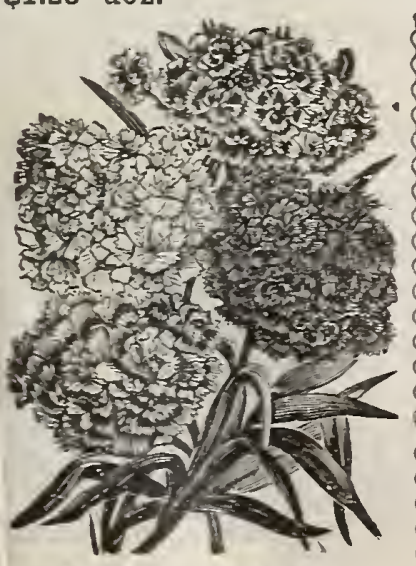

Hardy

Perennials

last for

years,

and are

specially

useful

as cut

Sweet William.

flowers.
Hardy Perennial Plants

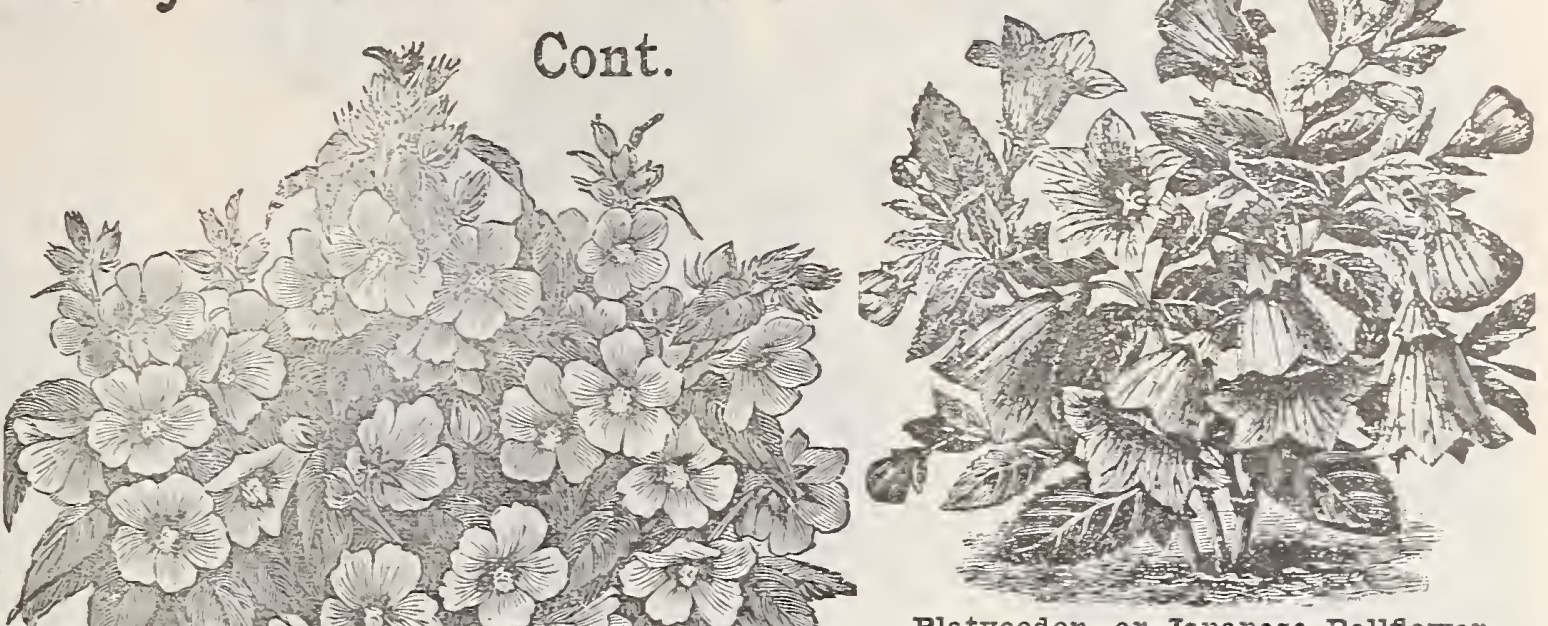

Platycodon, or Japanese Bellflower.

PIATICODON (Japanese Bell Flower) Marissi. Large blue flow

PEYSOSTEGIA, AIba

isummer. $15 \mathrm{c}$. ea., $\$ 1.50 \mathrm{doz}$

PHYSOSTEGIA, Speciosa.

. $15 \mathrm{c}$ ea., $\$ 1.50 \mathrm{doz}$

POPPY, Iceland.

scarlet. $15 \mathrm{c}$. ea, $\$ 1.50 \mathrm{doz}$

POPPY, Oriental.

Hibiscus, Crimson Eye.

POTENTILIA, Formosa.

POTENTIIIA, Pyrenaica.

SIDUM, Acre. Yellom floters. 10c. ea., $\$ 1.00$ doz.

SEDUM, stoloniferum. Pink. 10c. ea. $1.00 \mathrm{doz}$.

SEDUM, Maximowiczi. Striking heads

f yellow flowers. 10c. ea., $\$ 1.00 \mathrm{doz}$

SEDUM, Telephium. "The Common

$\$ 1.00$ doz.

SMIIACINA, Racemosa. White flo

s, early spring. 15c. ea., $\$ 1.50$ doz.

SMIIACINA, stellata. The star-flowdoz.

TRIFOIIUM, Rubens, Tivid carmine fomers. $15 \mathrm{c}$. ea., $\$ 1.50 \mathrm{doz}$.

SWEFT WIIIIAII (Dianthus Barbatus). Double crimson, double White, doz.

VERONICA, Candida.

$15 \mathrm{c}$. ea., $\$ 1.50 \mathrm{doz}$.

VERONICA, Iongifolia: Blue flowers, $15 \mathrm{c}$. ea., $\$ 1.50$ doz.

YUCCA (Adams Needle). Broad

like foliage and tall bran

a very effective plan

Hardy Ornamental Grasses.

FULAIIA GRACILIIMA UNIVITTATA

JAPOIICA VARIEGATA.

M I I CA ALTISSIMA (Japanese Plume).

PHAIARIS ARUNDINACEA (Variegated Ribbon Grass)

\section{ZEBRINA.}

Hollyhock.
Price ornamental Grasses, 25 c. ea., $\$ 2.50$ doz. 

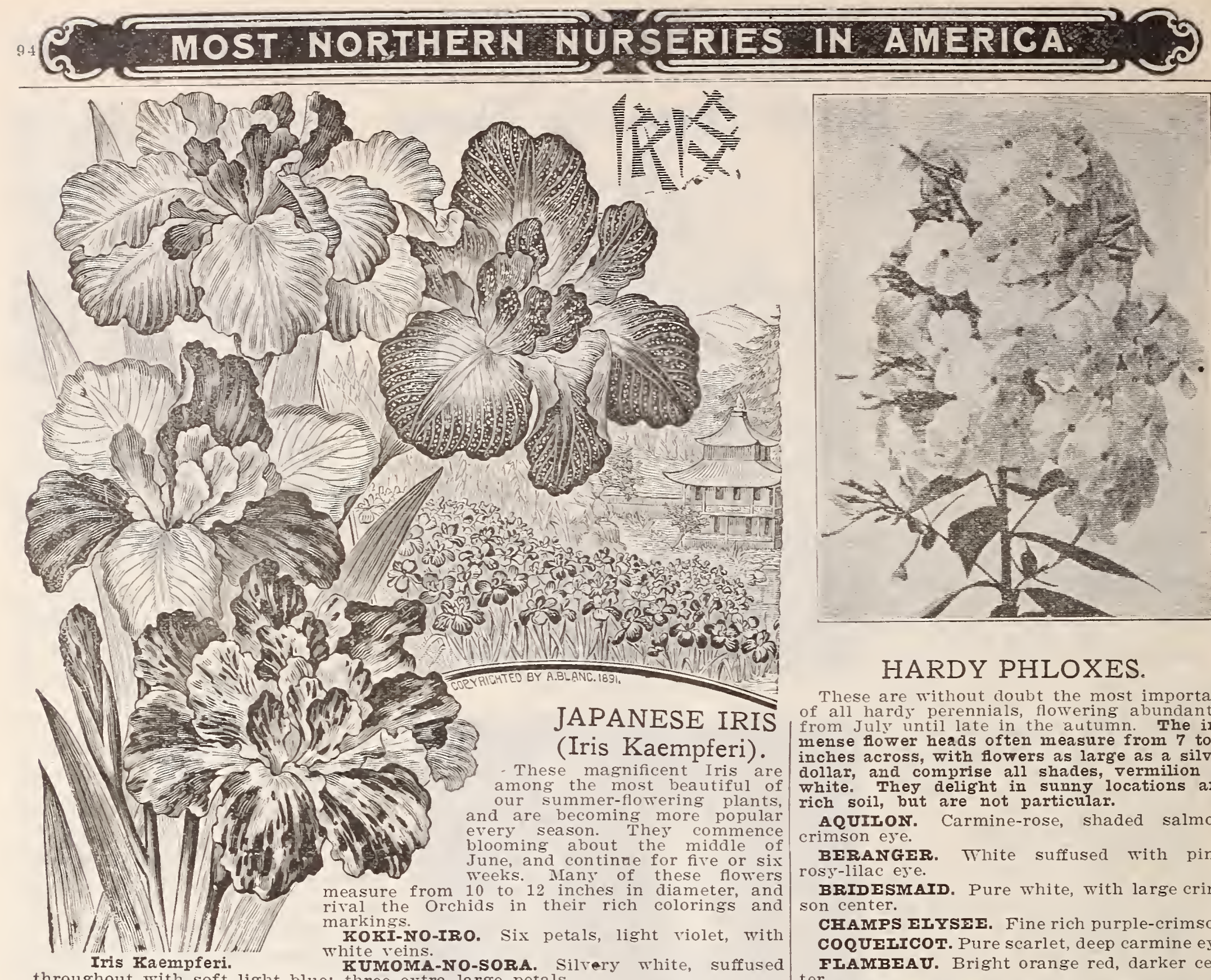

throughout with soft
SHISHI-IKARI.

KUMOMA-NO-SORA.

JAPANESE IRIS (Iris Kaempferi).

SHISHI-ODORI. Rich deep purple, with golden center; six petals.

SHI-UN-RYO. Th

Price of abore named Iris, each 25c., postpaid; by express, per doz. \$2.50 EXTRA CHOICE MIXED VARIETIES, 20c. each, postpaid; by express, $\$ 2.00$ per Doz.

\section{GERMAN IRIS. (Germanica.)}

We especially wish to call attention to the ralue of this Iris for groups for planting in masses on the la $\pi$ n or among shrubbery, or for naturalizing in

ASIATIC.

ASIATIC. Purplish blue and lilac.

DARIUS. Lemon

DONNA MARIE.

FAIRY.

FIORENTINA.

GIADSTONE. Pure White, stweet scented.

GLADSTON. Thite reticulated deep purple. Fach $25 \mathrm{c}$. , doz. $\$ 2.50$.

IORD SAUISBURY, Purple and bronze.

MADAME CHEREAU.

ORTHELO.

PENEIOPE.

PIUMERI. Deep coppery bronze; early and free.

TINEAE. Large, deep blue.
SANS SOUCT. Crimson brown. Each 20c., doz. \$2.00.

QUEEN OF MAY. Standards bright violet, falls heliotrope. Each 25c., doz. \$2.50. SIR WAITER SCOTT. Bronzy yellow and deep carmine. Each 25c., doz. \$2.50.

doz. \$1.50.

Each 10c., postpaid; by express, doz. \$1.00.

IRIS, SIBIBIRICA.

Intense violet-purple, prettily marked with white veinings at base of petal.

AIBA. White. Each 15c,, postpaid; by express, doz. $\$ 1.50$.

ATROSANGUINEA. Blue. Bach 15c., postpaid; by express, doz. \$1.50.

IRIS ORIENTAL.

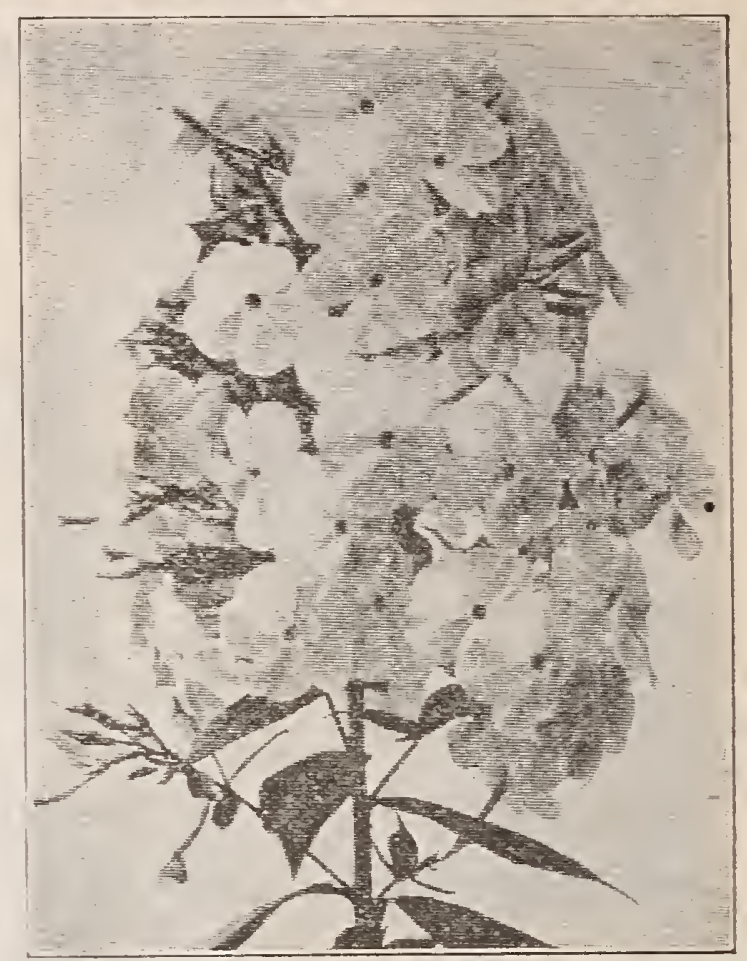

\section{HARDY PHLOXES.}

These are without doubt the most important of all hardy perennials, flowering abundantly mense flower heads often measure from 7 to : inches across, with flowers as large as a silver dollar, and comprise all shades, vermilion to white. They delight in sunny locations and rich soil, but are not particular.

AQUIrow. Carmine-rose, shaded salmon, BERANGER. White suffused with pink, BRIDESMAID. Pure white, with large crimon center.

CHAMPS EIYSEE. Fine rich purple-crimson. COQUELICOT. Pure scarlet, deep carmine eye. FIAMBEAU. Bright orange red, darker cen-

HENRI MURGER. Purest white, rose center. JEANNE D'ARC. Pure white; a late flow-

J. H. SIOCUM. Salmon pink, maroon eye. IA VOGUE. Rosy pink with red eye.

IOTHAIR. Richest crimson.

MINNESOTA BEAUTY. Lilac shade.

ECIAIREUR. Purplish crimson with white alo.

M. P. IANGIER. Vivid red color.

MISS IINGARD. A grand free-flowering,

ORNAMENT. ROSy magenta with crimson PANTHEON. Salmon rose.
PANTER

P. BONNETAIN. Salmon rose.

PROF. SCHIIEMAN. Salmon rose with car-

RICHARD WAILACr. Violet, edged white. RINGIEADER. Light magenta with crim-

R. P. STRUTHERS. Rosy-red with crimson ye. Dwarf.

THE OUEEN. A standard. Pure snow white. PRICES: Named varieties, each 20c., doz. $\$ 2.00$. Mixed, each 15c., doz. $\$ 1.50$, postpaid.

\section{PHLOX SUBULATA.}

(IMoss, or Mrountain Pink.)

An early spring-flowering type, with pretty moss-like evergreen foliage, which, during the flowering season, is hidden under the masses the border, and invaluable for carpeting the ground or covering graves.

AIBA. Pure white. Each 15c., doz. \$1.50, postpaid.

ROSEA. Bright rose. Each 15c., doz. $\$ 1.50$, postpaid. 


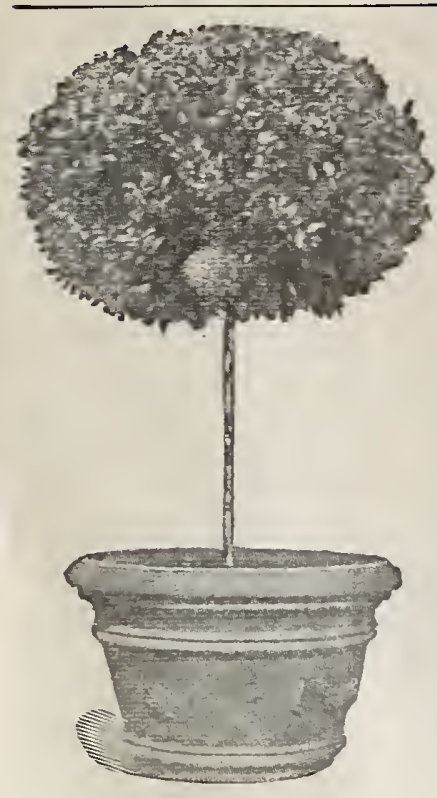

Bay Tree.

For decorat BAY TREES. (Laurus Nobilis.) standard and pyramidal form.

\section{STANDARD, or TREE-SFAPED.}

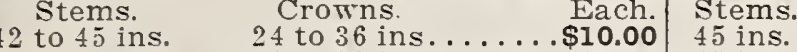

45 ins. $\quad 30$ to 32 ins........ 15.00 45 ins.

BAY TREIS, PYRAIIIDAI SEAPED.

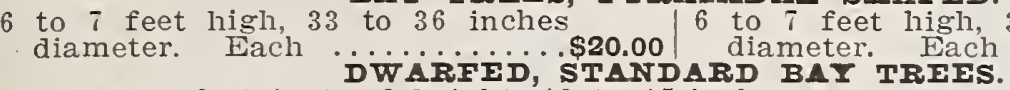

Not over 4 feet in total height, 12 to 15 -inch crowns, each $\$ 5$

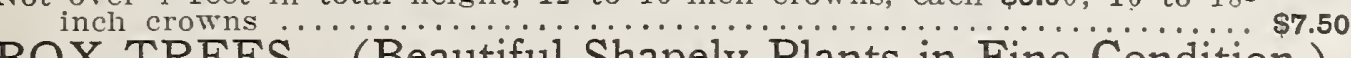

BOX TREES. (Beautiful Shapely Plants in Fine Condition.)

The plants are sheared in compact, pyramidal form, and make very beautiful bay trees. Prices do not include fancy tubs.

\section{STANDARD OR TREE SHAPED BOX TREES.}

Stems 3 feet, crowns 30 inches in diameter. Each 3 BAI

16 inches in diameter. Each.

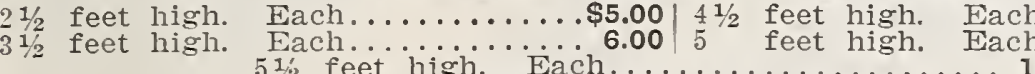

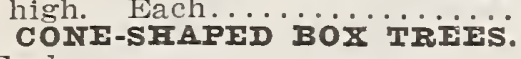

12.00

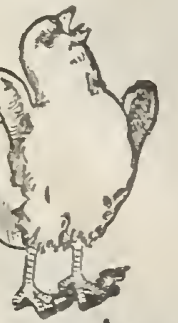

\section{POULTRY SUPPLIES.}

We carry a full and complete line of poultry supplies of every description. Our foods are put up with the tions, and sold as cheap as reliable goods can be.

A perfect food for 100 Ibs. \$2.50.

BEFF SCRAPS. Nakes chicks strong and healthy. 50 Ibs.

2.00, 100 lbs. $\$ 3.00$
GROUND BONF.

0 lbs. $\$ 1.25,100$ Ibs. $\$ 2.25$

lbs. $\$ 1.25,100$ Ibs. \$2.25. 1bs. $\$ 2.50$.

IAYING FOOD. A balanced ration for the daily mash. 50 1bs. $\$ 1.15,100$ lbs. $\$ 2.00$.

CUT CIOVझR. Among green foods the clovers stand at the top. Can be fed with mash or dry.
each bas. 50 lbs. $\$ 1.00,100$ 1bs. $\$ 1.75$.

CRUSHED SHELIS. Put up in right size for hens. 25 lbs. 35c., 50 lbs. $50 \mathrm{c} ., 100$ Ibs. $75 \mathrm{c}$.

Comper the business pay, a first the essentials for a perfect grit: No. 3, for brooder chicks; No. 1, for hens; No. 2. for half gromn chicks,
etc. 25 1bs. $35 \mathrm{c}, 50$ lbs. $50 \mathrm{c}$., $100 \mathrm{lbs}$. $75 \mathrm{c}$.

THE STANDARD CORNELL INCUBATOR. PFEP-O'-DAY BROODERS.

We are state agents for the manufacturers and are now in a position to sell Cornell Incubators and Brooders f. o. b. cars, st.

Paul, Minn., at exactly factory prices, under guarantee. copy of mammoth Incubator and Brooder catalogue.

\section{PLANET, JR., GARDEN TOOLS.}

Fo. 1. Combined Drill, Cultivator, Rake and Plow......\$9.00

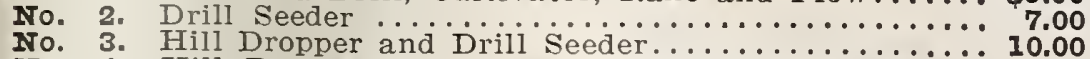
No. 4. Hill Dropper, Drill Seeder, Cultivator, Rake and

No. 12. Double wheel Hoe, Cultivator and Plow ........ 6.00 No. 17. Single Theel Hoe, PIow and Cultivator.......... 4.50 Jr. Tools, but we will send a fully illustrated catalogue free to all who desire it and will ask for it, and we can supply promptiy anything ordered.

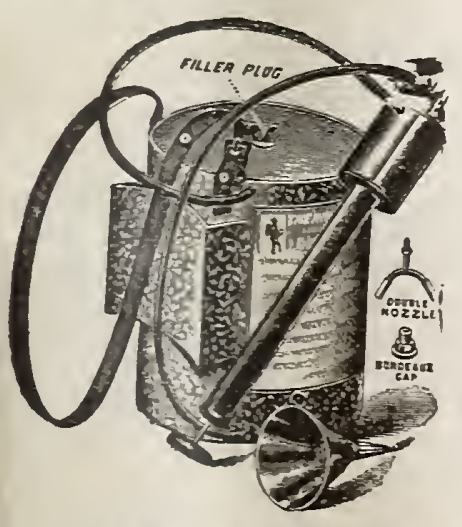

Brandt Sprayer.
THE BRANDT SPRATER. A the many objections to the commarket. Instead of pumping the air into the reservoir before starting to spray this sprayer is fitted with a pump which can

the pressure at will. Can be used for one or two rows, and will spray from 15 to 25 hills of potaReservoir holds 3 gallons of liquid, enough to spray a row a mile long, vanized steel tank, single nozzle and funnel, 35.00 ; double nozzles, \$1.35; No. 2 caps, 30c. eztra.
ASPARAGUS KNIFE. Made of solid steel........ GARDEN TROWEIS.

English forged steel.....50 c American forged steel......40c If by mail, add 10c. extra. GRASS OR SEEEP SEFARS. For trimming grass.......5 FEDGE SHEARS.

Best steel, 8 -inch.....\$1.50 By express only.

PRUNING SHEARS.

German, $41 / 2$-inch $\ldots . .775 c$ If by mail, add ioc. extra. PRUNING SCISSORS.

Nickel plated, postpaid...75c HAZITTINE'S IA IND WEEDER.

steel, oil tempered, $7 / 8$ inch on all its edges. Price, postpaid, 30c

IANG'S IAND WEIDER. It is neatly and strongly made Price, postpaid, 30c.

OUT OF SIGET MOIE RA. Considered to be Traps on the market. If set correctly it is absolutely sure io express.

RUBBER PIANT SPRINKIER.

Straight neck, postpaid...990c TRIUMPI CORN PIANT. ER. A well known and well made planter. Simple, durable kin seed attachment the pumpcan be planted at the same time as the corn. Price, plain, tachment, $\$ 1,00$, by express. EURERA SFEDER. Ther

a demand for a low priced seeder, and the Eureka is designed to fill that want. rately. Price, $\$ 1.25$, by express. CYCIONE SEEDER

lass perfect seed sower. Sows all kinds of grain. Price, \$1.75, by express.

ACME POTATO PLANTER. this is undoubtedly the most mproved, strongest, and ret market at the present time. I of soil. Price, $\$ 1.00$, by express.

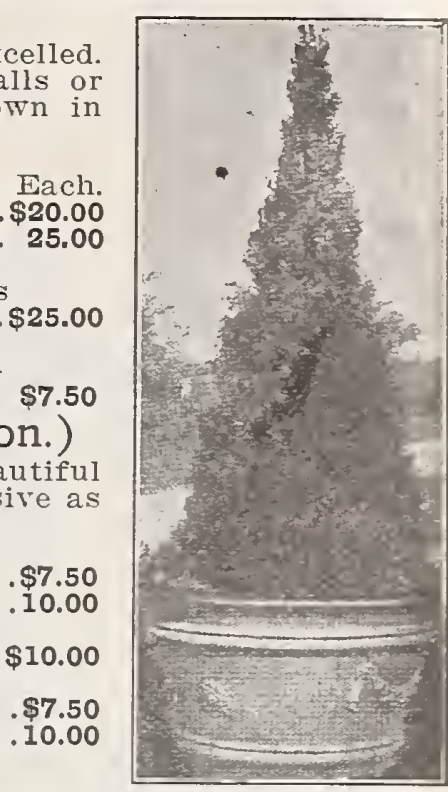

$\$ 12.00$

Box Tree. OR. For " WEED EXTRACT-

le. 60c. each, by express.

WATER'S TREE PRUNIR. imbs up to $3 / 4$ inch in diam With 8-foot handle, $90 \mathrm{c}$;
with 10-foot handle, \$1.00, by

IITTIE GIANT DUSTER. di $\$ 5.00$, bJ express.

CFAMPION DRY POWDER GUN. This useful machine applies the pure Paris Green in vines, killing the bugs quicker an be powdered at a time. It

hen boxed). Four styles of

FAWREYI TREE PROTFCTUR. A sure protection mice and other vermin. Made inches wide. Per 100, $\$ 1.00$;
50 at 100 rates, by express. SIUG SHOT, HAMMOND'S. bugranteed to destroy potato gg plants

melons, turnips, beets, onions, BORDEAUX IMITTURE. In y form. Ib. $25 \mathrm{c}$., by express. TOBACCO DUST.

\section{c. 5 lbs. $25 \mathrm{c.}$, bJ express.}

box 30c., by mail, postpaid.

WHAIE OII SOAP.

eggs affect th
$30 c$. postpaid.

BOWKER'S PUANT FOOD. 


\begin{tabular}{|c|c|c|c|c|c|}
\hline 1 & Cont. & $\begin{array}{l}\text { ER SE } \\
\text { Cont. }\end{array}$ & Page & $\begin{array}{c}\text { NURSERY DE } \\
\text { Cont. }\end{array}$ & $\begin{array}{c}\text { NURSERY DI } \\
\text { Cont. }\end{array}$ \\
\hline $\mathbf{B I E}$ & $\ldots \ldots 33$ & Marvel of Peru.. 44 & Chinese & Carragana & Ornamental \\
\hline EDS & $\ldots \ldots .33$ & Naurandia ..... & Plant & Catalpa... & Trees....80, 81,82 \\
\hline Page & $\begin{array}{l}\text { peltz } \ldots \ldots \\
\text { purry } \ldots \ldots\end{array}$ & $\begin{array}{l}\text { Mignonette } \ldots . .4 \\
\text { Mimulus } \ldots . . . \\
44\end{array}$ & $\begin{array}{l}\text { Chrysanthemuins } 5 i \\
\text { Coleus ........ } 63\end{array}$ & $\begin{array}{l}\text { Cedar ...... } \\
\text { Celastrus } \\
\text {..... }\end{array}$ & $\begin{array}{l}\text { Paeony ..... } \\
\text { Plialaris } \ldots\end{array}$ \\
\hline rtichoke.... & ugar Cane. & Morning Glory . . 44 & Coral Plant .... 57 & Cephalaria $\ldots . . .992$ & $\begin{array}{l}\text { Phalaris } . . . . \\
\text { Phlox } . . .\end{array}$ \\
\hline rtichoke Roots. & flower ... & & Crotons $\ldots .$. & Cherries ..... & Pine ........... \\
\hline $\begin{array}{l}\text { sparagus ..... } \\
\text { eans.......2, } 2 \\
\end{array}$ & $\begin{array}{l}\text { Timothy } \\
\text { Tobacco } . .\end{array}$ & $\begin{array}{l}\text { Nasturtium .... } \\
\text { Nicotiana ...... }\end{array}$ & $\begin{array}{l}\text { Crape My } \\
\text { Cupliea }\end{array}$ & estnut & Platicodon .. \\
\hline$\ldots \ldots,{ }^{7}$ & $\begin{array}{l}\text { Tobacco .... } \\
\text { Tree Seed ... }\end{array}$ & $\begin{array}{l}\text { Nicotiana ..... } \\
\text { Pansies ... } 45 \\
\end{array}$ & Duplea ......... & $\begin{array}{l}\text { Chrysanthem } \\
\text { Clematis ... }\end{array}$ & $\begin{array}{l}\text { Plums } \ldots . . . \\
\text { Poplars ....... }\end{array}$ \\
\hline$\cdots$ & vetches . & Petunia ........ & Dusty Miller ... & Clethra... & Poppy $\ldots . . . \cdots$ \\
\hline $\begin{array}{l}\text { russels spre } \\
\text { abbage..... }\end{array}$ & $\begin{array}{l}\text { Wheat } \ldots . . . . \\
\text { WVild Rice ... }\end{array}$ & $\begin{array}{l}\text { Plilox } \ldots \\
\text { Pinks }\end{array}$ & iana $\ldots . .$. & opsis. & entilla \\
\hline abbage...... & & $\begin{array}{l}\text { Plnks } \ldots \ldots \ldots \ldots \\
\text { Poppy } \ldots \ldots \ldots \\
\end{array}$ & 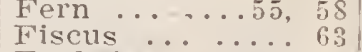 & $\begin{array}{l}\text { Cottonwood ..80, } \\
\text { Cornus ......855, }\end{array}$ & $\begin{array}{l}\text { Privet } \\
\text { Purple Fri }\end{array}$ \\
\hline auliflower $\ldots \ldots$. 9 & FIOWEI SEEDS & Portulaca ...... 48 & Fuchsias .....6 60 & Crab Apples .... & Quince ......s \\
\hline $\begin{array}{l}\text { ery } \ldots \ldots \ldots \\
\text { eriac } \ldots \ldots\end{array}$ & Ageratum. & rose $\ldots \ldots$ & Genista $\ldots$. & Currants .... & berries .... \\
\hline cory $\ldots \ldots \ldots$ & $\cdots \cdots$ & , Fairy ..... & $\begin{array}{l}\text { Geraniums } \\
\text { Heliotrope }\end{array}$ & & Cedar....83, \\
\hline es $\ldots \ldots \ldots 10$ & $\begin{array}{l}\text { osia ..... } 38 \\
\text { l's Breatin.. } 38\end{array}$ & Salpiglossis .... & $\begin{array}{l}\text { Hellotrope } \\
\text { Hibiscus } . . .\end{array}$ & berry. & $\begin{array}{l}\text { a Rugos } \\
\text { ted Cutt }\end{array}$ \\
\hline ards $\cdots . .$. & Antirrhinum $\ldots$. is & Salria .......... & Honeysuckle. & Diantlius. & sian Olire.. \\
\hline Corn, Salad $. \ddot{10}, 11$ & ragus $\ldots . .$. & Diosa ....... 50 & Hoya Carnosa .. & Dictamnus & d Thorn .. \\
\hline Cress $\ldots \ldots \ldots 10$ & $\cdots \ldots \ldots 39$ & Smilax ....... & $\begin{array}{l}\text { Hydrangea } \cdots \text {... } \\
\text { Impatiens }\end{array}$ & $\mathrm{ra}$. & $\operatorname{dum} \ldots . . .$. \\
\hline umber $\ldots \ldots$ & $\begin{array}{l}\text { Bachelor Button. } 41 \\
\text { Balsam ....... } 41\end{array}$ & Stocks ........ & Iry ................. & $\begin{array}{l}\text { olialum.. } 92 \\
\text { nn's Pipe. } 90\end{array}$ & $\begin{array}{l}\text { Seedlings ...... } \\
\text { Shade Trees, }\end{array}$ \\
\hline $\begin{array}{l}\text { gg Plant } \ldots . . . \\
\text { ndive } . . . . . .\end{array}$ & Bean .......... 41 & $\ldots 31,50$ & Jessamine $\ldots .$. & geron. & so, 81 , \\
\hline arden Huckle- & Beg & et Pras .... $4^{4}$ & $\begin{array}{l}\text { Tusticias ....... } \\
\text { Iagerstroemia .. }\end{array}$ & & $\begin{array}{l}\text { Sheep } \\
\text { Shrub }\end{array}$ \\
\hline $\begin{array}{l}\text { berry } \ldots \\
\text { rarlic } \ldots\end{array}$ & $\begin{array}{l}\text { olaria } \\
\text { dula. }\end{array}$ & sure Plant.. 43 & Lantana ......... & Eulalia ........... & $S \pi, S S$, \\
\hline$\cdots \cdots \cdots 13$ & Ponny & et $\ldots . . . \cdots \cdots$ & Terb & onymus & Vine ...... \\
\hline $\begin{array}{l}\text { erbs } \\
\text { lorse Radish ... } 13 \\
13\end{array}$ & $\begin{array}{l}\text { rnia Poppy } \\
\text { psis } \ldots . . .\end{array}$ & lfower ..... & Malabar $¥$ ine.... & Ei & weet $\cdots$ \\
\hline $\begin{array}{l}\text { Torse Radish .. } \\
\text { Cale .......... } 13 \\
\end{array}$ & psis $\ldots \ldots$ & Cucumber.. & Manettia Tine.. & $\begin{array}{l}\mathbf{F} i \\
\mathrm{Fi}\end{array}$ & oalls .... \\
\hline olnl Rabi ..... 13 & Canary & $\begin{array}{l}\text { Wild Flower Gar- } \\
\text { den }\end{array}$ & Yinneapolis Tine & thia. & berry .. \\
\hline tuce $\ldots \ldots 1_{13}$ & 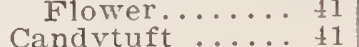 & Zinnia $\ldots \ldots \ldots \ldots 50$ & $\begin{array}{l}\text { Oleanders ...... } \\
\text { Palms ........ }\end{array}$ & nge ... & Sp \\
\hline $\begin{array}{r}13 \\
6\end{array}$ & $s \ldots \ldots \ldots+1$ & 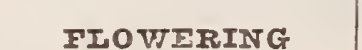 & Pansies ........ & $\begin{array}{l}\text { Gaillardia } \\
\text { Golden El }\end{array}$ & berries .... \\
\hline lon, Misk … 15 & tions ..... 41 & BUIBS & 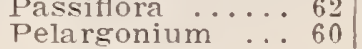 & Golden Glow & berry \\
\hline on, Water... & $\begin{array}{l}\text { Castor Oil Bean. } \\
\text { Celosia (Cocks- }\end{array}$ & BULBS & Petunia .....62, & $\begin{array}{l}\text { berries } \\
\text { s } \ldots . . .\end{array}$ & Sum \\
\hline $\begin{array}{l}\text { shroom spawn } \\
\text { stard ....... }\end{array}$ & comb) .......... & nia ...2d cover & bago ..... & berry & William. \\
\hline a ......... & Cent & ium ...... 51 & $\begin{array}{l}\text { Primrose } \quad \ldots \ldots \ldots \\
\text { Primula } \quad \ldots \ldots \ldots\end{array}$ & Hardy Per & 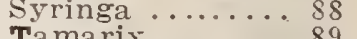 \\
\hline on $\dot{\text { on }} \ldots \ldots 1 \mathrm{k}$ & osema & ... 51 & Roses, & $s \ldots \ldots$ & Seedling \\
\hline $\begin{array}{l}\text { on Sets } \ldots \ldots \\
\text { sley } \ldots . . .\end{array}$ & aria $\ldots . . .42$ & non $\ddot{v i n}$ & $65,66,67$ & $\begin{array}{l}81 \\
90\end{array}$ & $u m \ldots$. \\
\hline nip $\ldots \ldots \ldots .21$ & $\ldots \cdots \cdots+2$ & $\mathrm{~ms} \ldots . . .51$ & elia $\ldots . . \cdots$ & horn & ca $\ldots \ldots \ldots$ \\
\hline 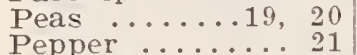 & comb ( $\mathrm{Ce}-$ & ias ....... 52 & 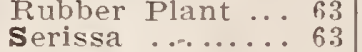 & .84 & uts ing Trees \\
\hline orn $\ldots \ldots \ldots$ & Coleus $\ldots \ldots \ldots \ldots+42$ & lioli ...... 53 & lax .......6. 63 & $\begin{array}{r}93 \\
93\end{array}$ & gelia, \\
\hline phin $\ldots \ldots \ldots \ldots 21$ & Cosmos $\ldots \ldots \ldots+2$ & 2 il cove & $\mathrm{ms} \ldots \ldots$. & $\begin{array}{l}93 \\
93\end{array}$ & 89 and \\
\hline $\operatorname{sh} \ldots \ldots \ldots \ldots .22$ & Eye Vine. $4 ?$ & nth $\ldots$ & $\begin{array}{l}\text { ithes. } \\
\text { ndi... }\end{array}$ & bush & $\begin{aligned} & 83, 87 \\
& 84\end{aligned}$ \\
\hline $\mathrm{rb}$ Roots... & $\begin{array}{l}\text { Cyclamen } \\
\text { Cypress Tine .... } 42\end{array}$ & ea & nsonia & & ria....... 90 \\
\hline $\begin{array}{c}\text { arb Roots.. } \\
\text { Baga .... } 2 \frac{22}{2}\end{array}$ & Dahlia ...... t? & 52 & & suckle & a...... 93 \\
\hline $\mathrm{fy} \ldots \ldots \ldots 223$ & & a Tine... 52 & $\begin{array}{l}\text { ergia } \\
\text { na } . .\end{array}$ & suckle, & Zebrina ........ \\
\hline $\begin{array}{l}\operatorname{ach} \ldots \ldots \ldots \\
\text { ish } \ldots \ldots \ldots\end{array}$ & $101 \mathrm{~s}$ & reh of East 53 & Vincas ..... & $\mathrm{H}$ & SUN \\
\hline ato $\ldots \ldots \ldots$ & $\cdots \cdots$ & bretias $\ldots . .55$ & Violet ..... & rangea & Bo \\
\hline & chos & Phrynium $\ldots \ldots 54$ & NURSERY & pericum .... 93 & $\mathrm{i} x-$ \\
\hline able Plants 23 & erea...... 43 & 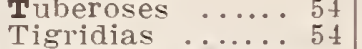 & & 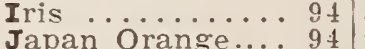 & $\mathrm{Br}$ \\
\hline & 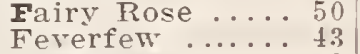 & & $\begin{array}{l}\text { Achillea } \ldots \ldots \ldots \text {. } 92 \\
\text { Alder } \ldots \ldots \text {. . }\end{array}$ & in Orange.... & $\begin{array}{l}\text { ken Food } \\
\text { Planter }\end{array}$ \\
\hline$\ldots \ldots$ & & Greenhous & sis & $\begin{array}{l}\text { Juneberry . } \\
\text { Juniper .... }\end{array}$ & Tre e \\
\hline seed Inermis. 33 & $n \ldots .$. & butilon & $69, \ddot{i} 0,71$ & tucky C & Trowe \\
\hline n Corn $\ldots$. & Amaranth. & ha & egia $\ldots . .$. & ee. & Dust. \\
\hline wheat .... 3 & ia $\ldots . .$. . & & A & rria & \\
\hline & & thera .. & - Vitae...83, & $\mathbf{I}$ & \\
\hline $\begin{array}{l}\text { ren, Field.26, } 27 \text {, } \\
28 \text { and...3d cover }\end{array}$ & ea ${ }^{\cdots}$ is ilk & $\mathrm{n} \ldots \ldots \ldots$ & runcas...... & $\begin{array}{l}\text { Lilacs } \text { Lily of the Tal- } \\
\text { Lily }\end{array}$ & $\begin{array}{l}\text { Mole } \mathrm{Tr} \\
\text { Oyster }\end{array}$ \\
\hline w Peas ..... 32 & $\ldots \ldots \ldots$ & gus .... & la. & & t, Shells \\
\hline er Corn .... & as- & & & ia & Food ..... \\
\hline $\begin{array}{l}\text { der Corn ...3. } \\
\text { ss Seed....35, }\end{array}$ & Plant & & & & $\mathrm{P} 1$ \\
\hline $\begin{array}{l}\text { ss Seed....35, } \\
\text { ss Mixtures. }\end{array}$ & irysum & Primrose... & $y \quad \ldots$ & $\mathrm{m}$ & o Plan \\
\hline $\begin{array}{l}\text { s Mixtures . } \\
\text { Pasture ... }\end{array}$ & pe.. & ian Melon & ees & $\mathrm{L}$ & es. \\
\hline Pasture ... & & & nia. & t. & $\mathrm{r} \mathrm{D}$ \\
\hline ir Corn ..... & us $\ldots . .$. & Plants... & 0 , & us & ng Scis \\
\hline 11 Grass .... & int $\ldots \ldots$. & & & nis & \\
\hline & & & er... & les ... & \\
\hline $\begin{array}{l}30 \& \\
\text { its } \ldots\end{array}$ & e. & illea & & mony & lot \\
\hline its & & ansia & & rtensi & \\
\hline 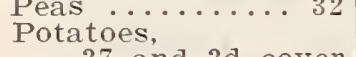 & & $\ldots \ddot{51}$ & ffalo Berry & intain & $\begin{array}{l}\text { co Dust } \\
\text { co Soap }\end{array}$ \\
\hline & & on. & la .. & lberry..78, 83, & Protector \\
\hline$e \ldots \ldots \ldots \ldots$ & & eris & ius & Trees ...... & \\
\hline & & & & 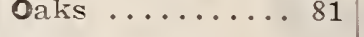 & \\
\hline
\end{tabular}

STERIINGWORTF PLANT FOOD TARIETS contain nitrogen, ammonia, phosphoric acid and potash. A new scientific, odor-
less, concentrated fertilizer for potted plants and veretables. Takes the place of liquid manure. Used by dissolving in water. They start the plants at once into healthy and vigorous growth and some insects and worms from the soil.

They are odorless, non-poisonous, uninjurious and are clean and easy to handle, and owing to their concentrated form are far superior to to handle, and owing to their concentrated form are far superior to useless filler. If your plants are not doing well, try Sterlingworth Plant Food Tablets, and see how quickly
they are benefitted. Trial size boz, sufficient for 10 house plants for 3 months, 10c. postpaid. Regular they are benefitted. Trial size box, sufficient for 10 house plant
size box, sufficient for 35 plants for 3 months, 25 c, postpaid.
OUR AUTUMN CATAIOGUE of Bulbs, Plants, Trees and Fruits for FAII PI.ANTING will be ready September 15th, and sent without request to regular customers, and FREE to any address on application. Be sure and ask for a copy. It will contain all the novelties of late introduction. 


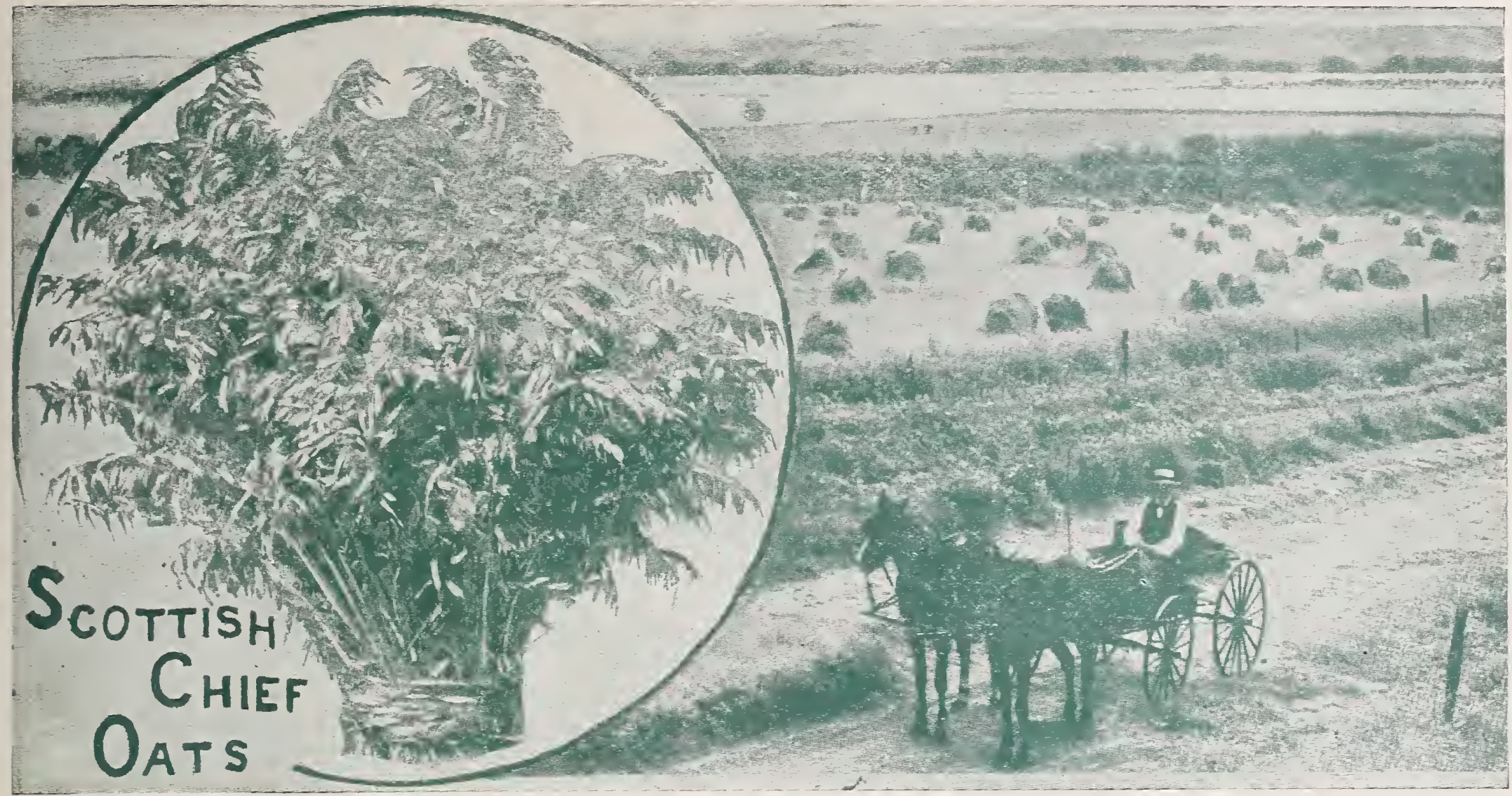

BEYOND DOUBT THE BEST VARIETY KNOWN

No other oat can approach it for yield, weight, size of grain, fine appearance, earliness, freedom from rust and smut, and adaptability to all soils and climates.

In all our tests of many varieties (over 50), this sort has proven superior to others in both quality and yield. The straw is exceedingly strong and wiry, enabling it to hold up its enormous heads of grain without breaking or lodging in the least, and is rust proof. The grain is of the largest size, full and plump, pure white and very heavy. It withstands drought remarkably well, and is well fitted for all soils, seasons and conditions. Here is an opportunity to obtain the heaviest vielding, hardiest, best oat ever offered. Average yields of 100 bushels per acre under ordinary circumstances are common. Measured bushels of these oats in. variably weigh 40 to $42 \mathrm{lbs}$.

We bank our reputation on this variety and want every pro= gressive farmer in the Iand to plant them. They have given Satisfacton Everywhere and Thousands of Farmers Throughout the Country Having Raised Them say that They Stand at the Head.

Don't delay until late in the season when you are ready to plant, order to-day.

SURE

\section{CROP CORN}

The best early yellow Dent variety. (Minnesota Grown)

It matures its crop in 80 days, which is of special interest to the farmers of the north west. The ears (borne two to a stalk) are large, long, 12 to 16 romed. The kernels are extra long and the cob small. We recommend itfor general planting. as its earliness, productireness (150 bushels to the acre) and quality are the great essentials to all growers. It will make a first-class crop of corn farther north than any other dent rariety and can be used in the middle sectinns successfully for late crop.

Price, shelled, peck 75 c; bushel $\$ 2.50$ by freight at pur. chaser's expense.

Price per Ih. 25c postpaid.

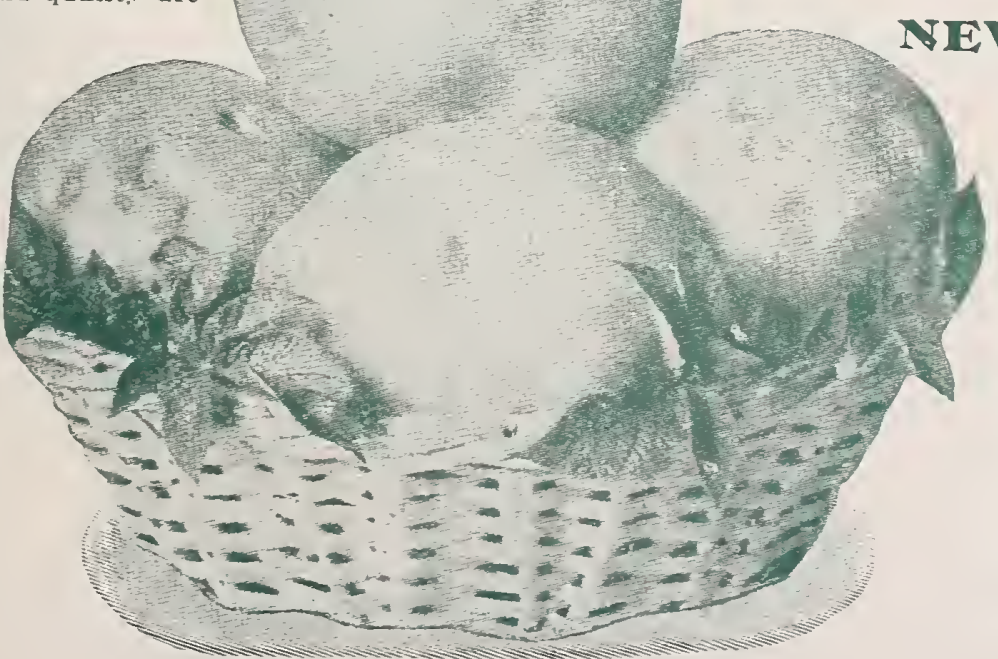

Price. Peck, 50c; bushel, $\$ 1.25 ;$ bag $21 / 2$ bu., $\$ 3.00$; 10 bu., for $\$ 11.00$.

\section{POTATO}

Norotan Beauty.

The Earliest Potato ever grown and fully as productive as any main crop or late sort. This ness, also good keeping qualities, has never before been attained. It is handsomer it appearance and more uniform in size and shape than any other variety. Its table quality is superb, and keeps longer in good condition than any other sort, early or late and is one of the best all-around poPrice, lb., 25c postpaid. By express or freight, peck $75 \mathrm{C}$, bushel $\$ 2.00$, barrel $\$ 5.00$. 


$$
\begin{aligned}
& \text { Most Northern Nurseries } \\
& \text {. (a) G in Almerica. } \\
& \text { THE MOST BEAUTIFUL } \\
& \text { HARDY ORNAMENTAL SHRJUB } \\
& \sigma^{2}
\end{aligned}
$$

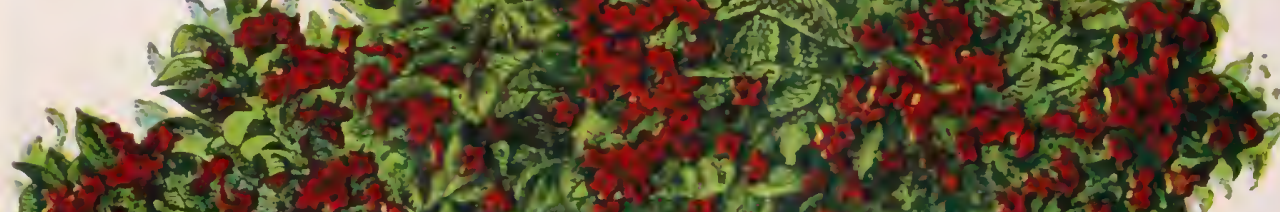

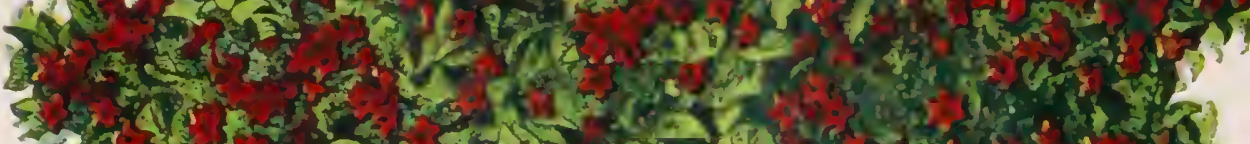

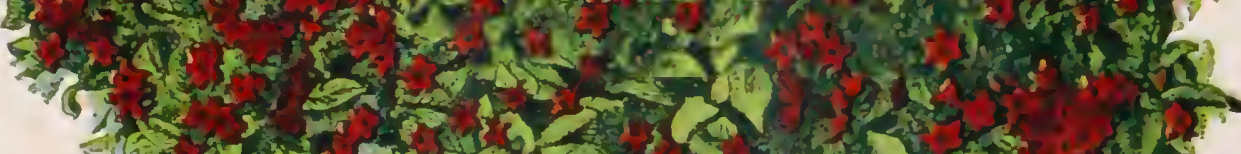

$$
\begin{aligned}
& \text { की }
\end{aligned}
$$

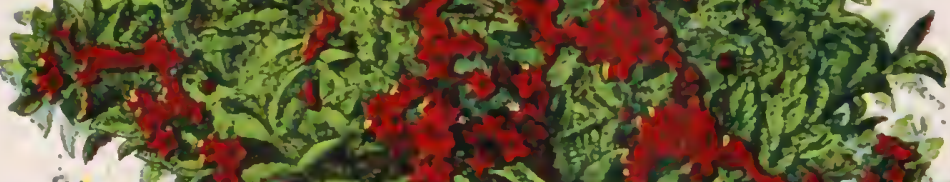

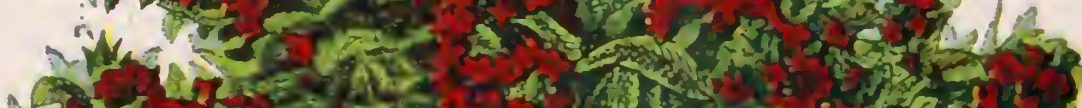

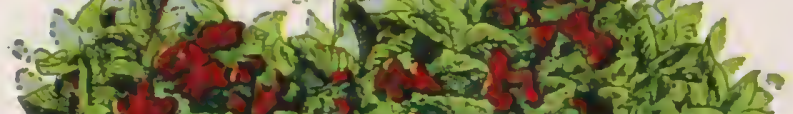

$$
\begin{aligned}
& 1+3 \text { an }
\end{aligned}
$$

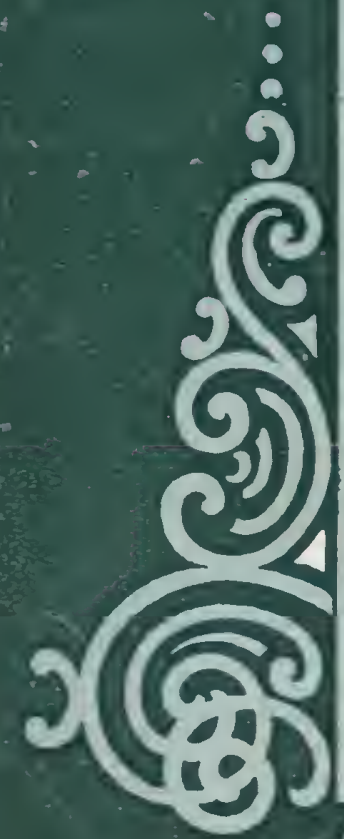

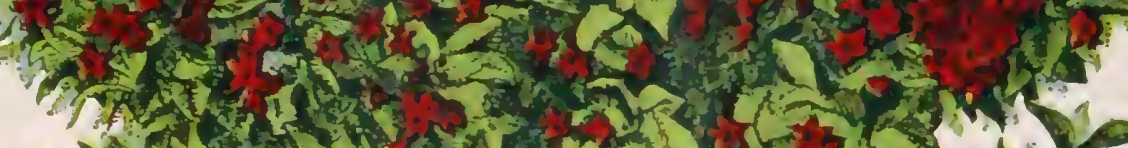

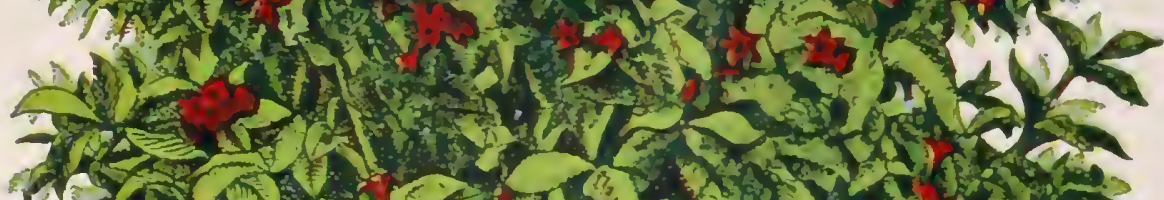

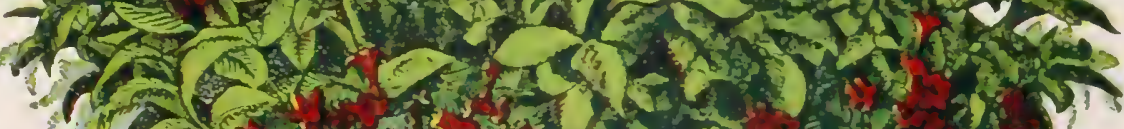

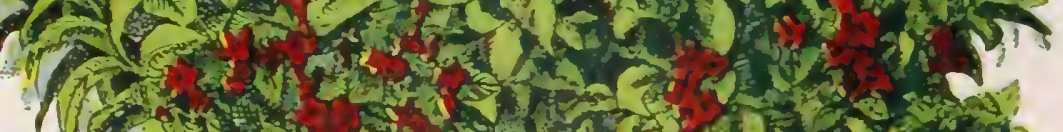

$$
\begin{aligned}
& \text { (f) }
\end{aligned}
$$

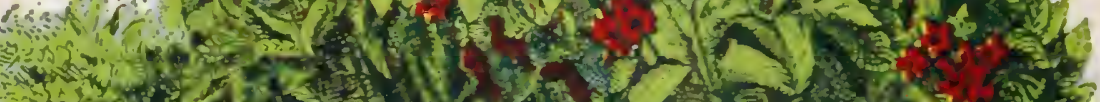

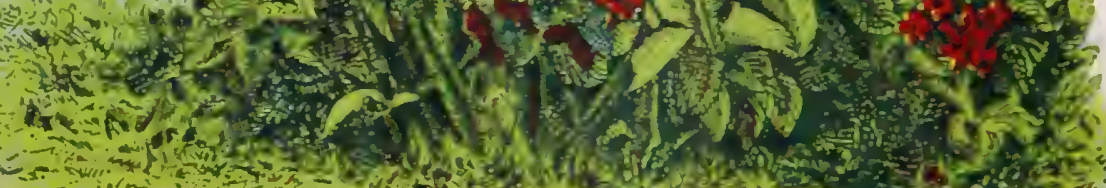

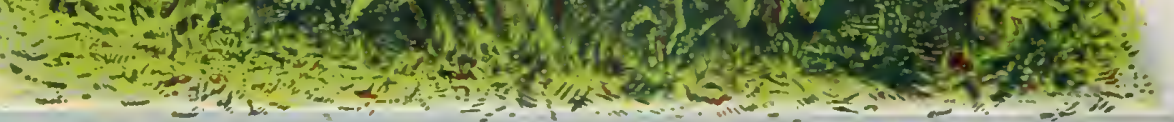

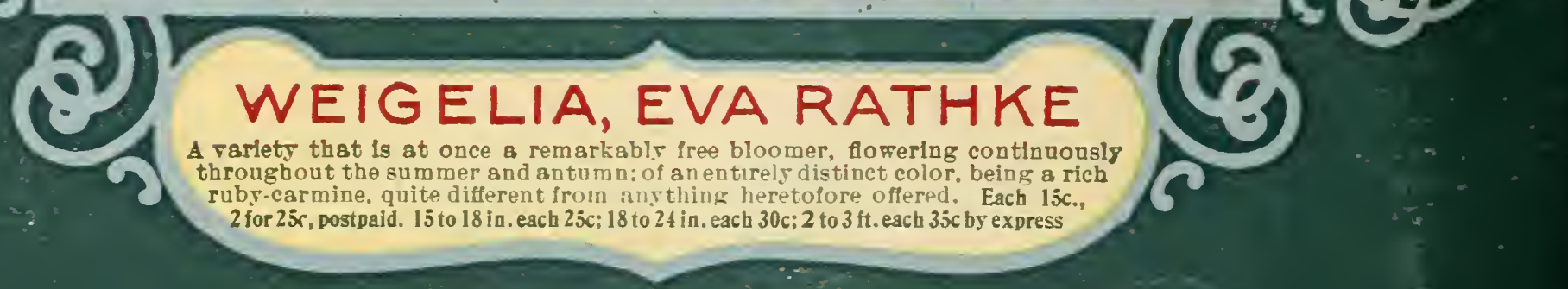

